Switzerland and Sub-Saharan Africa in the Cold War, 1967-1979 


\title{
New Perspectives on the Cold War
}

\author{
Series Editors \\ Jussi M. Hanhimäki (Graduate Institute Geneva) \\ Marco Wyss (Lancaster University)
}

Advisory Board

Nigel Ashton (The London School of Economics and Political Science)

Mark P. Bradley (The University of Chicago)

Anne Deighton (University of Oxford)

Mario del Pero (Centre d'histoire de Sciences Po, Paris)

Bernd Greiner (Berlin Center for Cold War Studies)

Tanya Harmer (London School of Economics and Political Science)

Hope M. Harrison (The George Washington University)

Wolfgang Mueller (University of Vienna)

Andrew Preston (University of Cambridge)

Sergey Radchenko (Cardiff University)

VOLUME 8

The titles published in this series are listed at brill.com/npcw 


\section{Switzerland and \\ Sub-Saharan Africa in the Cold War, 1967-1979}

Neutrality Meets Decolonisation

By

Sabina Widmer

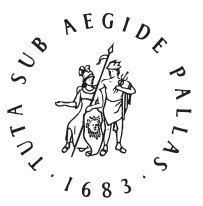

B R I L L

LEIDEN | BOSTON 
This is an open access title distributed under the terms of the CC BY-NC-ND 4.0 license, which permits any non-commercial use, distribution, and reproduction in any medium, provided no alterations are made and the original author(s) and source are credited. Further information and the complete license text can be found at https:// creativecommons.org/licenses/by-nc-nd/4.0/

The terms of the CC license apply only to the original material. The use of material from other sources (indicated by a reference) such as diagrams, illustrations, photos and text samples may require further permission from the respective copyright holder.

The Open Access publication of this book has been supported by the Swiss National Science Foundation.

Cover illustration: Swiss Federal Councillor Pierre Aubert and Nigerian Foreign Minister Major-General Henry E. O. Adefope sign a joint communiqué on 17 January 1979 in Lagos, image by Reto Hügin, courtesy of the Ringier Bildarchiv, Staatsarchiv Aargau, Aarau, Switzerland, (C) StAAG/RBA13-RCoo111-9_163.

A paragraph of the communiqué condemning Apartheid gave rise to controversy in Switzerland, as many observers considered it incompatible with Swiss neutrality. This led to an important debate on Switzerland's foreign policy at the crossroads of the Cold War and decolonisation.

Library of Congress Cataloging-in-Publication Data

Names: Widmer, Sabina, author.

Title: Switzerland and Sub-Saharan Africa in the Cold War, 1967-1979: neutrality meets decolonisation / by Sabina Widmer.

Description: Leiden, The Netherlands : Koninklijke Brill NV, [2021] |

Series: New perspectives on the Cold War, 2452-226o ; 8 | Includes

bibliographical references and index.

Identifiers: LCCN 2021035334 | ISBN 9789004464025 (hardback) | ISBN 9789004469617 (ebook)

Subjects: LCSH: Neutrality-Switzerland. | Colonies-Africa. | Cold War. | Switzerland-Foreign relations-Africa, Sub-Saharan. | Africa,

Sub-Saharan-Foreign relations-Switzerland. | Africa,

Sub-Saharan-History-196o-

Classification: LCC DQ76.A47 W53 2021 | DDC 327.49406709/047-dc23

LC record available at https://lccn.loc.gov/2021035334

Typeface for the Latin, Greek, and Cyrillic scripts: "Brill". See and download: brill.com/brill-typeface.

ISSN 2452-2260

ISBN 978-90-04-46402-5 (hardback)

ISBN 978-90-04-46961-7 (e-book)

Copyright 2021 by Sabina Widmer. Published by Koninklijke Brill nv, Leiden, The Netherlands. Koninklijke Brill NV incorporates the imprints Brill, Brill Nijhoff, Brill Hotei, Brill Schöningh, Brill Fink, Brill mentis, Vandenhoeck \& Ruprecht, Böhlau Verlag and V\&R Unipress.

Koninklijke Brill NV reserves the right to protect this publication against unauthorized use.

This book is printed on acid-free paper and produced in a sustainable manner. 
Für Isa \& Res

$\bullet$ 


\section{Contents}

Acknowledgements XI

Abbreviations XIII

Introduction 1

Linguistic Notes 27

1 A Non-colonial Power in Colonial and Postcolonial Africa 28

1 Four (Un-)Exceptional Cases: Relations with Angola, Mozambique, Ethiopia and Somalia 33

2 Swiss Business in Sub-Saharan Africa 50

\section{PART 1}

The Struggle for National Liberation during the Last Phase of European Colonialism, 1967-1974

Introduction to Part 168

2 Countering Criticism from the Third World: Switzerland's Stance on White Minority Rule 72

$1 \quad$ New York: Debates on Economic Collaboration at the 1967 UNGA $\quad 78$

2 Addis Ababa: OAU Diplomacy in Bern, $1972 \quad 83$

3 Geneva: The Status of Liberation Movements at the 1974 ICRC International Humanitarian Law Conference 95

3 Negotiating Foreign Policy on the Domestic Front: Non-state Actors and Portuguese Colonialism 109

1 Neutrality, National Defence, and Humanitarianism: Arms Exports to the Third World 113

2 Colonial Exploitation, Business Interests, and State Export Promotion: The Cabora Bassa Dam 119

3 A Question of (Non-)Interference: The Swiss Mission's Efforts to Free Mozambican Church Members 125

4 Economic Interests vs Human Rights: Portugal's Invitation to the 1973 Comptoir Suisse Trade Fair 133

Conclusion to Part 1144 
PART 2

A Shift in Cold War Alliances: Radical Regime Changes in

Sub-Saharan Africa, 1967-1979

Introduction to Part 2148

4 Attempting to Keep a Low Profile: The Revolutions in Somalia and Ethiopia 151

$1 \quad$ "Do We Actually Have Diplomatic Relations?" Swiss-Somali Links after the 1969 Coup d'État 154

2 "Eventful Times": Reactions to the 1974 Ethiopian Revolution 158

3 "Blood Money": Controversy over the Ethiopian Emperor's Swiss Bank Accounts 164

4 "The Situation Is Likely to Deteriorate Further": Economic and Humanitarian Relations with Pro-Soviet Ethiopia 176

5 Getting Out of a Foreign Policy Impasse: The Decolonisation of Angola and Mozambique 186

1 “The Coup in Portugal Has Set the Ball Rolling”: Internal Debates on Switzerland's Southern Africa Policy 188

2 Aid and Recognition: Preparations for the Independence of the Portuguese Colonies 197

3 "The Game Being Played Is Global": Attempts to Strengthen Relations with the Third World 212

6 Improving Switzerland's Image: Relations with Independent Mozambique 218

1 A Lesson for the 'Capitalists'? Swiss Diplomacy's Difficulties in Establishing Diplomatic Relations 220

2 "Considerable Political Interest in Showing Swiss 'Goodwill': The Beginning of a Development Cooperation Partnership 224

3 "Healthy Obstinacy Pays Off": Challenges of Economic Decolonisation 230

Conclusion to Part $2 \quad 241$ 
PART 3

Armed Conflicts in Africa and the Renewal of Cold War Tensions, 1975-1979

Introduction to Part 3244

7 Manoeuvring through the East-West and North-South Conflict: The Angolan War 247

1 The Political Benefits of a Humanitarian Image: Swiss-ICRC Cooperation during the Conflict $25^{2}$

2 African Influence vs US Pressure: Recognition of the People's Republic of Angola $\quad 256$

3 Unfulfilled Expectations: Relations with the MPLA Government 266

4 Towards a Swiss Policy Position on Southern Africa 274

8 Retaining Western Influence in Africa: The Ogaden War 284

$1 \quad$ Waiting and Aid: A Discreet Role during the Conflict 287

2 "Sources of Infection": Contributions to the Containment of Soviet Power in Sub-Saharan Africa 294

3 A Federal Councillor's Africa Trip, or the Limits of a More Active Foreign Policy 299

Conclusion to Part 3306

Conclusion 308

Bibliography 321

Index 349 


\section{Acknowledgements}

It is a great pleasure to extend my thanks to the people and institutions that supported me in various ways during the process of writing my thesis and publishing it in the form of this book. First and foremost, I would like to express my sincere gratitude to my supervisor, Janick Marina Schaufelbuehl, not only for her keen feedback, which has substantially elevated the quality of my work, but also for her continuous support and encouragement. I also wish to thank the other participants in the research project "Switzerland and the Cold War in the Third World. Switzerland's Political and Economic Role in the Main Armed Conflicts and Crises in Sub-Saharan Africa and the Middle East, 1973-1983", funded by the Swiss National Science Foundation. Sandra Bott and Marco Wyss have read and commented on my work at various stages and have always been ready to offer their advice. Conversation with Magnus Meister has been extremely stimulating. For their perceptive remarks on my thesis manuscript, I am profoundly indebted to the members of my thesis committee, Stéphanie Ginalski, Martin Lengwiler, Neville Wylie, and Marco Wyss.

During this research, I have benefited greatly from inspiring discussions with various scholars. For the exchange of ideas and their valuable advice on subjects as diverse as navigating different archives and the mysteries of academic publishing, I would like to thank Miguel Bandeira Jerónimo, Christoph Kalter, Ariane Knüsel, Matthieu Leimgruber, Joanna Lewis, Rui Lopes, N. Piers Ludlow, Pedro Aires Oliveira, Sue Onslow, Yves Steiner, and Sacha Zala. I am also grateful to Svetozar Rajak and the IDEAS team for welcoming me to the London School of Economics and Political Science (LSE) in 2016 and for making my stay such an enriching experience.

At the University of Lausanne, my gratitude is extended to the different people with whom I had the pleasure of sharing office 4540: Guillaume Beausire, Marion Beetschen, Hadrien Buclin, Virginie Fracheboud, Alix Heiniger, Michael Hutter, Yitang Lin, and Paul Turberg. Thanks for the long discussions about history and the pleasures of writing a PhD thesis, for emergency help with translations and proofreading, for stocking the office with food and coffee, and for putting up with my compulsion to share atrocious citations from my sources. The friendship and support of Cecilia Biancalana, Anne de Chastonay, Virginie Fracheboud, Yitang Lin, Iris Meyer, Céline Naef, and Johanna Schnabel have been invaluable. For the many inspiring discussions, I would also like to thank my other colleagues at the Institut d'Etudes Politiques, Historiques, et Internationales, in particular Maxime Bottel, Pierre Eichenberger, Steven Eichenberger, Isabelle Lucas, Nuno Pereira, Andrea Pilotti, and Simon 
Stückelberger. I have also benefited from discussion with other PhD students in the Groupe Guerre Froide: Morgane Bianco-Gay, Audrey Bonvin, Cyril Cordoba, Cyril Michaud, Quentin Tonnerre, and Tiphaine Robert.

This project would not have been possible without the help of numerous archivists, whose knowledge and professionalism have been extremely valuable, to access the collections at public and private archives in Switzerland, the United States, the United Kingdom, France, and Portugal. In particular, I would like to thank the staff of the Swiss Federal Archives in Bern for their friendly welcome during my frequent visits and the archivists at the Arquivo Histórico Diplomático for their efforts to declassify archival material during my stay in Lisbon. At the Archives Diplomatiques in La Courneuve, France, Agnes Moinet-Le Menn inventoried archival collections prior to my arrival, and she and Ariane Morais-Abreu made sure they were accessible during my visit. The Société Académique Vaudoise generously supported my research stay at the LSE. Archival research in France and Portugal was made possible thanks to a grant provided by the Fondation pour l'Université de Lausanne. For their hospitality during research stays in various cities, I would like to extend my thanks to Eva Bogaerds, Anne de Chastonay, Daniel Fahrni and Therese Rikli, Daniela Hettstedt, Yitang Lin and Dominique Auduon, and Carmen Zürcher.

Hadrien Buclin, Virginie Fracheboud, Laura Harder, Yitang Lin, Magnus Meister, and Johanna Schnabel have all read longer parts of the manuscript, and I am grateful for their helpful comments. A special thank you goes to Alma Widmer for checking abbreviations and references. I would like to thank Jussi Hanhimäki and Marco Wyss for including my book in the series New Perspectives on the Cold War. The anonymous reviewer's insightful comments helped improve the manuscript. It was a pleasure to work with Claire Chatterley, who did a great job copyediting the manuscript. I am grateful to Debbie de Wit and Wendel Scholma for guiding me through the publication process and the whole team at Brill for making it happen. The open access publication of this book was made possible thanks to a grant provided by the Swiss National Science Foundation. Lastly, I would like to thank my friends and family for providing a much-needed sense of perspective and for always having my back. 


\section{Abbreviations}

AAD

ACICR

$\mathrm{AD}$

ADM

AfZ

$\mathrm{AG}_{3} \mathrm{~W}$

AHD

ANTT

APAA

ASBA

ASNB

BAB

BBC

BIS

BPEAR

CAD

CADN

CCA

CETIM

CFPF

$\mathrm{CHF}$

CIA

CIEC

CISCOP

CSAD

CSCE

$\mathrm{CSH}$

DAM

Access to Archival Databases

ICRC archives

Administration Division (Switzerland)

Archives of the Département Missionnaire des Églises Protestantes de Suisse Romande (DM) (Switzerland)

Archiv für Zeitgeschichte (Archives for Contemporary History, Switzerland)

Arbeitsgruppe Dritte Welt (Working Group Third World, Switzerland)

Arquivo Histórico Diplomático (Diplomatic Archives, Portugal) Arquivo Nacional Torre o Tombo (National Archives, Portugal) Action Portugal et Afrique Australe (Operation Portugal and Southern Africa, Switzerland)

Archives of the Swiss Bankers Association

Archives of the Swiss National Bank

Basler Afrika Bibliographien. Namibia Resource Centre \&

Southern Africa Library (Switzerland)

Brown Boveri \& Cie (Switzerland)

Bank for International Settlements

Bureau for the Placement and Education of African Refugees (OAU)

Centre des Archives Diplomatiques, La Courneuve/Paris

(Diplomatic Archives, France)

Centre des Archives Diplomatiques, Nantes (Diplomatic Archives, Nantes, France)

Companhia de Culturas de Angoche (Mozambique)

Centre Europe-Tiers Monde (Switzerland)

Central Foreign Policy Files

Swiss Francs

Central Intelligence Agency (US)

Conference on International Economic Cooperation

Centre d'Investigation Sur le Colonialisme Portugais (Investigation

Centre on Portuguese Colonialism, Switzerland)

Central and Southern African Department (UK)

Conference on Security and Co-operation in Europe

Chambre Suisse de l'Horlogerie (Swiss Chamber of Watchmaking)

Direction des Affaires Africaines et Malgaches (Directorate for

African and Madagascan Affairs, France) 


\begin{tabular}{|c|c|}
\hline DFMA & Directorate of the Federal Military Administration (Switzerland) \\
\hline DGS & Directorate General of Security (Portugal) \\
\hline DIO & Directorate for International Organisations (Switzerland) \\
\hline \multirow[t]{2}{*}{$\mathrm{DM}$} & Département Missionnaire des Églises Protestantes de Suisse \\
\hline & $\begin{array}{l}\text { Romande (the mission wing of the Protestant churches of } \\
\text { French-speaking Switzerland) }\end{array}$ \\
\hline DPA & Directorate of Political Affairs (Switzerland) \\
\hline DPIL & Directorate of Public International Law (Switzerland) \\
\hline DPRA & Democratic People's Republic of Angola \\
\hline DTD & Defence Technology Division (Switzerland) \\
\hline EAD & East African Department (UK) \\
\hline EEC & European Economic Community \\
\hline EFTA & European Free Trade Association \\
\hline ERG & export risk guarantee \\
\hline EvB & Erklärung von Bern (Bern Declaration) \\
\hline FAO & Food and Agriculture Organization \\
\hline FCO & Foreign and Commonwealth Office (UK) \\
\hline FDEA & Federal Department of Economic Affairs (Switzerland) \\
\hline FDF & Federal Department of Finance (Switzerland) \\
\hline FDFA & Federal Department of Foreign Affairs (Switzerland) \\
\hline FDJP & Federal Department of Justice and Police (Switzerland) \\
\hline $\mathrm{FH}$ & Fédération Horlogère Suisse (Swiss Watchmakers' Federation) \\
\hline FLEC & $\begin{array}{l}\text { Frente para a Libertação do Enclave de Cabinda (Front for the } \\
\text { Liberation of the Enclave of Cabinda) }\end{array}$ \\
\hline FLN & Front de Libération Nationale (National Liberation Front, Algeria) \\
\hline FLNC & $\begin{array}{l}\text { Front de Libération Nationale Congolaise (Congolese National } \\
\text { Liberation Front) }\end{array}$ \\
\hline FMD & Federal Military Department (Switzerland) \\
\hline FNLA & $\begin{array}{l}\text { Frente Nacional para a Libertação de Angola (National Front for } \\
\text { the Liberation of Angola }\end{array}$ \\
\hline FPD & Federal Political Department (Switzerland) \\
\hline FRELIMO & $\begin{array}{l}\text { Frente de Libertação de Moçambique (Liberation Front of } \\
\text { Mozambique) }\end{array}$ \\
\hline FRG & Federal Republic of Germany \\
\hline FRUS & Foreign Relations of the United States \\
\hline GDR & German Democratic Republic \\
\hline GNP & $\begin{array}{l}\text { Gabinete dos Negócios Políticos (Office of Political Affairs, } \\
\text { Portugal) }\end{array}$ \\
\hline GRAE & $\begin{array}{l}\text { Governo Revolucionário de Angola no Exílio (Angolan } \\
\text { Revolutionary Government in Exile) }\end{array}$ \\
\hline
\end{tabular}


НААв $\quad$ Historical Archives Ав В (Switzerland)

HEKS Hilfswerk der Evangelischen Kirchen Schweiz (relief organisation of the Protestant churches of Switzerland)

HLS Historical Dictionary of Switzerland

Hsso Historical Statistics of Switzerland Online

ICM Instituto de Crédito de Moçambique (Mozambican Credit Institute)

ICRC International Committee of the Red Cross

IDA International Development Association

IEA International Energy Agency

IHL International Humanitarian Law

ILO International Labour Organization

IPM Igreja Presbiteriana de Moçambique (Presbyterian Church of Mozambique)

IRA Irish Republican Army

IRG investment risk guarantee

KGB Committee for State Security (USSR)

KSA Komitee Südliches Afrika (Southern Africa Committee, Switzerland)

MFA Movimento das Forças Armadas (Armed Forces Movement, Portugal)

MNE Ministério dos Negócios Estrangeiros (Ministry of Foreign Affairs, Portugal)

MNR Mozambican National Resistance, later known as Resistência Nacional Moçambicana (RENAMO)

MPla Movimento Popular de Libertação de Angola (Popular Movement for the Liberation of Angola)

NAM Non-Aligned Movement

NARA National Archives and Records Administration(US)

NATO North Atlantic Treaty Organization

NGO non-governmental organisation

NIEO New International Economic Order

OAU Organization of African Unity

OECD Organisation for Economic Co-operation and Development

OPEC Organization of the Petroleum Exporting Countries

PAIGC Partido Africano da Independência da Guiné e Cabo Verde (African Party for the Independence of Guinea and Cape Verde)

PCP Partido Comunista Português (Portuguese Communist Party)

PIDE International and State Defence Police (Portugal)

PLO Palestine Liberation Organization 


\begin{tabular}{|c|c|}
\hline PMAC & Provisional Military Administrative Council (Ethiopia) \\
\hline \multirow[t]{2}{*}{$\mathrm{POCH}$} & Progressive Organisationen der Schweiz (Progressive \\
\hline & Organisations of Switzerland) \\
\hline $\mathrm{PR}$ & Political report \\
\hline PRA & People's Republic of Angola \\
\hline PRC & People's Republic of China \\
\hline PRG & Provisional Revolutionary Government of South Vietnam \\
\hline PS & Partido Socialista (Socialist Party, Portugal) \\
\hline RENAMO & $\begin{array}{l}\text { Resistência Nacional Moçambicana (Mozambican National } \\
\text { Resistance) }\end{array}$ \\
\hline RG & Record Group \\
\hline SAFEP & $\begin{array}{l}\text { Schweizerische Arbeitsgruppen für Entwicklungspolitik (Swiss } \\
\text { Working Groups for Development Policy) }\end{array}$ \\
\hline SALF & Somali-Abo Liberation Front \\
\hline SALT & Strategic Arms Limitation Talks \\
\hline SBA & Swiss Bankers Association \\
\hline SCCIM & $\begin{array}{l}\text { Serviços de Centralização e Coordenação de Informações de } \\
\text { Moçambique (Mozambican Service for the Centralisation and } \\
\text { Coordination of Information) }\end{array}$ \\
\hline SEK & $\begin{array}{l}\text { Schweizerischer Evangelischer Kirchenbund (Federation of Swiss } \\
\text { Protestant Churches) }\end{array}$ \\
\hline SFA & Swiss Federal Archives \\
\hline SGI & $\begin{array}{l}\text { Société Générale pour l'Industrie (engineering consultant firm, } \\
\text { Switzerland) }\end{array}$ \\
\hline SIG & $\begin{array}{l}\text { Schweizerische Industriegesellschaft Neuhausen (arms } \\
\text { manufacturing company, Switzerland) }\end{array}$ \\
\hline SNB & Swiss National Bank \\
\hline SNF & Swiss National Science Foundation \\
\hline \multirow[t]{3}{*}{ SONEFE } & Sociedade Nacional de Estudos e Financiamentos de \\
\hline & Empreendimentos Ultramarinos S.A.R.L. (National Society for the \\
\hline & Study and Financing of Overseas Development, Portugal) \\
\hline SRC & Swiss Red Cross \\
\hline SSAA & Swiss-South African Association (Switzerland) \\
\hline STC & Service for Technical Cooperation (Switzerland) \\
\hline SWAPO & South West Africa People's Organisation \\
\hline SYL & Somali Youth League \\
\hline TNA & The National Archives (UK) \\
\hline UK & United Kingdom of Great Britain and Northern Ireland \\
\hline UN & United Nations \\
\hline UNCTAD & United Nations Conference on Trade and Development \\
\hline UNDP & United Nations Development Programme \\
\hline
\end{tabular}




$\begin{array}{ll}\text { UNGA } & \text { United Nations General Assembly } \\ \text { UNHCR } & \text { United Nations High Commissioner for Refugees } \\ \text { UNICEF } & \text { United Nations Children's Fund } \\ \text { UNITA } & \text { União Nacional para a Independência Total de Angola (National } \\ & \text { Union for the Total Liberation of Angola) } \\ \text { UPA } & \text { União dos Povos de Angola (Union of the Peoples of Angola) } \\ \text { US } & \text { United States of America } \\ \text { USSR } & \text { Union of Soviet Socialist Republics } \\ \text { Vorort } & \text { Swiss Federation of Commerce and Industry } \\ \text { VSFA } & \text { Verein Schweizer Freunde Angolas (Association of Swiss Friends of } \\ & \text { Angola) } \\ \text { VSM } & \text { Verein Schweizerischer Maschinen-Industrieller (Swiss Association } \\ & \text { of Machinery Manufacturers) } \\ \text { WCC } & \text { World Council of Churches } \\ \text { WEC } & \text { World Energy Conference } \\ \text { WHO } & \text { World Health Organization } \\ \text { WSLF } & \text { Western Somali Liberation Front } \\ \text { ZANU } & \text { Zimbabwe African National Union } \\ \text { ZAPU } & \text { Zimbabwe African People's Union }\end{array}$




\section{Introduction}

On 18 April 1972, some unusual guests arrived at Lohn, the Swiss government's luxurious country residence on the outskirts of Bern. A delegation of highranking representatives of the governments of Algeria, Cameroon, Kenya, Mali, Mauritania, and Zambia, headed by Moktar Ould Daddah, President of Mauritania and Chairman of the Assembly of Heads of State and Government of the Organization of African Unity (OAU), had flown in to discuss Switzerland's foreign policy in Africa. Specifically, the African diplomats wished to convince the Swiss government to take a stand against the white minority regimes in South Africa, Rhodesia, and the Portuguese colonies and to stop Swiss investment in these countries. During the reception at Lohn that preceded the official state dinner, the Swiss President, Nello Celio, expressed the Swiss people's sympathy for Africa and outlined the three principles that guided Switzerland's foreign policy in sub-Saharan Africa:

The first [principle] is that of non-interference in the affairs of another state; in our view, this principle is one of the pillars of the international legal order and, at the same time, a mandatory guideline for a country aspiring to a policy of neutrality. [...] [T] he second principle that guides us is our regard for the equality of all men and our condemnation of all forms of discrimination, be it political, racial, or religious, wherever it occurs. [...] There is a third principle that Switzerland has adhered to at all times. It is the principle of liberalism that secured the independence and liberty of its people. This also applies to the economic sphere; in accordance with this principle, the state cannot intervene at will in the economic sector. ${ }^{1}$

The OAU delegation's three-day visit to Bern was occasioned by fundamental differences over Switzerland's role in sub-Saharan Africa. In the late 196os, certain African nationalist movements and independent African governments started to criticise Switzerland's foreign policy concept, as sketched by

1 Address by Nello Celio, Swiss President, "Allocution prononcée par le Président de la Confédération, M. Nello Celio, à l'occasion du dîner offert en l'honneur de la délégation de l'OUA, le 18 avril 1972", no date, pp. 1-2, Swiss Federal Archives, Bern, Switzerland (SFA) E2001E-01\#1982/58\#440*. See also no author, "Programme pour la visite à Berne de la délégation de l'Organisation de l'Unité Africaine du 18 au 20 avril 1972", no date, ibid.

(C) SABINA WIDMER, 2021 | DOI:10.1163/9789004469617_002

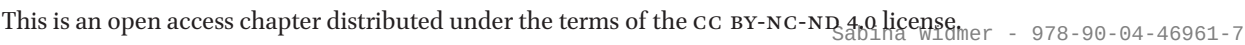


President Celio. By this time, the newly independent states of the Third World ${ }^{2}$ formed a majority in many international organisations and used this numerical advantage to demand a reorganisation of the global economic system. They also called for an end to the last bastions of white rule in the South of the African continent - the Portuguese colonies Angola and Mozambique, Apartheid South Africa which occupied Namibia, and the illegal settler regime in Rhodesia - and supported African movements fighting for national liberation. For Afro-Asian leaders, Bern's attempts to keep out of political debates about white minority rule and its refusal to consider cutting, or even reducing, its economic and financial ties with the white minority regimes in Southern Africa were incompatible with neutrality, as they amounted to taking a position on the racialised conflicts in this region. They refused to accept the Swiss government's strict differentiation between political principles and economic activities and were unimpressed by a verbal insistence on human rights that rarely went beyond abstract declarations. At the United Nations General Assembly (UNGA) and meetings of the OAU, they accused Swiss foreign policymakers of using neutrality as a smokescreen for economic interests and racism. The Bern visit was part of an extensive diplomatic offensive launched by the OAU in mid-1970 with trips to Washington, London, Paris, Bonn, and Rome aimed at convincing the Western bloc to take effective measures to end racial discrimination in Southern Africa. In a second step, the visiting programme was extended to the other member states of the North Atlantic Treaty Organization (NATO), neutral Sweden and Finland which were supportive of the liberation struggles in Southern Africa, and Switzerland and Japan, important trade partners of South Africa. Even though Switzerland was not the only target of criticism, this undermined its image in Third World states, which were important markets for the Swiss export industry. The credibility of Switzerland's neutrality was weakened not only by the country's political, economic, and ideological proximity to the Western bloc but also, and even more crucially, because it was part of the capitalist, industrialised North.

This book explores these disagreements over neutrality, economic interests, and human rights, which dominated Swiss foreign policymaking on sub-Saharan Africa in the late 196os and 1970s. They were shaped not only by

2 On the term "Third World" and its relation to the Cold War, see the discussion in Odd Arne Westad, The Global Cold War: Third World Interventions and the Making of Our Times, Cambridge: Cambridge University Press, 2005, pp. 2-3. Westad underlined that the term "indicates colonial and postcolonial processes of marginalization (and the struggle against these processes.)" This book follows his pragmatic definition of the Third World as "the former colonial or semicolonial countries in Africa, Asia, and Latin America that were subject to European (or rather pan-European, including American and Russian) economic or political domination." Ibid., p. 3 . 
the intensification of the North-South conflict that reached its apex in the mid-197os but also by the ramifications of the global Cold War. ${ }^{3}$ In this crucial period in international relations, variously called Détente, the "long 197os"4 or the "global 196os and 1970s", 5 bilateral superpower relations relaxed. At the same time, the intersections of decolonisation and the Cold War had their most striking and violent implications on the African continent, as newly independent African actors sought their place in a bilateral world and the United States of America (US) and the Union of Soviet Socialist Republics (USSR) attempted to control them. When local conflicts broke out, the superpowers and their allies provided the belligerents with training, supplies, and even troops. This exacerbated and frequently prolonged conflicts, with disastrous results for local populations. These interventions in local wars increased bilateral tension between the US and the Soviet Union. ${ }^{6}$ In turn, the collapse of Détente in the late 1970 s weakened the Third World's challenge to the global economic system and its demands for the end of racial discrimination in Southern Africa, ${ }^{7}$ calls that had been taken up by the global ' 1968 ' non-state protest movement. ${ }^{8}$

By analysing how Switzerland, a small, European, neutral state that had never been a colonial power, responded to the challenges arising from the intersection of Cold War dynamics and decolonisation in sub-Saharan Africa during this period of profound political, economic, and social change, this book contributes to the international history of the late 196os and 1970s. It focuses on Switzerland's foreign policy in Angola, Mozambique, Ethiopia, and Somalia. These four African states were not chosen for the importance of their bilateral relations with Switzerland, as political and economic exchanges were limited. Rather, the choice is explained by the special role of these states at the centre of global East-West and North-South confrontations in this period.

3 Westad coined this expression in his seminal study, The Global Cold War.

4 Poul Villaume, Rasmus Mariager, Helle Porsdam (eds.), The 'Long 197os'. Human Rights, EastWest Détente and Transnational Relations, Farnham: Ashgate, 2016.

5 This is the title of a new Routledge series in Cold War History: https://www.routledge.com/ The-Routledge-Global-196os-and-197os-Series/book-series/GLOBALSIXTIES (13 January 2021). See also Niall Ferguson et al., The Shock of the Global. The 197os in Perspective, Cambridge MA: The Belknap Press of Harvard University Press, 2010.

6 For an overview of these dynamics, see Jeffrey James Byrne, "Africa's Cold War", in Robert J. McMahon (ed.), The Cold War in the Third World, New York: Oxford University Press, 2013, pp. 101-123.

7 See notably Giuliano Garavini, After Empires. European Integration, Decolonization \& the Challenge from the Global South 1957-1986, Oxford: Oxford University Press, 2012; Mark Mazower, Governing the World. The History of an Idea, London: Allen Lane, 2012.

8 See notably Konrad J. Kuhn, "Liberation Struggle and Humanitarian Aid: International Solidarity Movements and the 'Third World' in the 196os", in Samantha Christiansen, Zachary A. Scarlett (eds.), The Third World in the Global rg6os, New York: Berghahn Books, 2013, pp. 69-85. 
Regime changes in Somalia (1969), Ethiopia (1974), Mozambique (1975), and Angola (1975-1976) led to a shift in superpower alliances on the African continent. The new governments of these four states were more overtly inspired by Marxism than the 'African Socialism' adopted by other governments in the late 195os and early 196os, and they concluded cooperation treaties with the USSR. These regime changes were accompanied by anti-Western rhetoric, the nationalisation of foreign property, and moves towards a more state-controlled economy. In addition, in all four countries, armed conflicts caused by internal events - the wars in Angola and Mozambique between the Portuguese colonial power and nationalists fighting for independence (1961-1974 and 1964-1974), in Angola between different liberation movements (1975-1976), and in the Ogaden region between neighbouring Ethiopia and Somalia (1977-1978) - were shaped and influenced by the various forms of support that the different belligerents received from both sides of the Cold War and by the North-South divide.

Based on extensive multi-archival research, this book demonstrates that between 1967 and 1979, the Swiss government's policy in sub-Saharan Africa was determined by the need to improve its international image and the credibility of its neutrality. Through the pragmatic use of diplomatic goodwill gestures and humanitarian and development aid, the Swiss government succeeded in maintaining its political and economic presence in Southern Africa and the Horn throughout armed conflicts, decolonisation, and regime changes. Moreover, it successfully fended off Afro-Asian criticism of its policy of neutrality while preserving close relations with the Western bloc. Moving beyond the Swiss case, the book exposes the limits of neutrality as a foreign policy guideline in North-South relations, reveals the growing marge de manoeuvre of small states in the international system during Détente, and highlights the role of non-state actors in the making of foreign policy.

Neutrality is at the core of this story. In its original form, neutrality began to emerge in seventeenth century Europe and only applied in times of war. It is enshrined in international law and was codified in the Fifth Hague Convention of 1907. The convention guarantees the inviolability of a neutral power's territory and requires it to prevent belligerents from moving troops or supplies across its land. If a neutral state decides to limit or prohibit the export of any goods that can be used in war, these restrictions must be impartially applied to all belligerents. ${ }^{9}$ During the Cold War, the law of neutrality did not apply, as

9 For history of the law of neutrality, see notably Stephen C. Neff, The Rights and Duties of Neutrals: A General History, Manchester: Manchester University Press, 20oo, here particularly pp. 129-130. 
this conflict was, from a legal perspective, not a war. However, neutrality also has a political dimension. This has no foundation in law but includes "all measures intended to strengthen and protect the law of neutrality". ${ }^{10}$ For a permanently neutral state like Switzerland, whose status was recognised by the Great Powers after the Congress of Vienna in 1815, a credible neutrality thus implied avoiding any policy that might undermine its ability to remain neutral in any future conflict, notably by not entering into peacetime alliances.

At the end of the Second World War, neutrality was discredited. It was either seen as ineffective, as the neutral Netherlands had been occupied by Nazi Germany and had subsequently abandoned neutrality, or morally reprehensible, as Switzerland and Sweden had collaborated with the axis powers. Swiss and Swedish foreign policymakers were therefore much concerned with recovering the credibility and respectability of their neutrality, the two main criteria, according to political scientist Harto Hakovirta, for the assessment of a policy of neutrality. ${ }^{11}$ Their efforts to convince other states of the usefulness of a neutral stance, notably by offering mediation or pursuing a humanitarian agenda, were even more important in the context of growing East-West polarisation. By the mid-1950s, both superpowers, which had been highly critical of neutrality at the end of the Second World War, had recognised its potential benefits and accepted the status of the five European neutrals: Switzerland, Sweden, Austria, Ireland, and Finland..$^{2}$

Jürg Martin Gabriel, The American Conception of Neutrality After 1941, Basingstoke: Palgrave Macmillan, 2002 (Updated and Revised Edition), p. 12.

11 Harto Hakovirta, East-West Conflict and European Neutrality, Oxford: Clarendon Press, 1988, pp. 26-29. On Switzerland's foreign policy during the Second World War, consult notably Hans Ulrich Jost, Politik und Wirtschaft im Krieg. Die Schweiz 1938-1948, Zürich: Chronos, 1998; Independent Commission of Experts Switzerland - Second World War (ed.), Switzerland, National Socialism and the Second World War. Final Report, Zurich: Pendo, 2002; Marc Perrenoud, "Léconomie suisse et la neutralité à géometrie variable", Matériaux pour l'histoire de notre temps 93 (2009), pp. 77-86; Neville Wylie, "Switzerland: a neutral of distinction?" In Neville Wylie (ed.), European Neutrals and Non-Belligerents during the Second World War, Cambridge: Cambridge University Press, 2002, pp. 331-354. For a brief overview, consult Marco Wyss, Jussi M. Hanhimäki, Sandra Bott, Janick Marina Schaufelbuehl, "Introduction. A Tightrope Walk - Neutrality and Neutralism in the Global Cold War", in Sandra Bott, Jussi M. Hanhimäki, Janick Marina Schaufelbuehl, Marco Wyss (eds.), Neutrality and Neutralism in the Global Cold War. Between or Within the Blocs? London: Routledge, 2016, pp. 1-14. On the attitude of the US, see notably Michael T. Ruddy, "European Integration, the Neutrals, and U.S. Security Interests: From the Marshall Plan to the Rome Treaties", in Michael Gehler, Rolf Steininger, (eds.), Die Neutralen und die europäische Integration 1945-1995, Wien: Böhlau, 2000, pp. 13-28; Gabriel, The American Conception of Neutrality After 1947; on that of the Soviet Union, Vladislav M. Zubok, "The Soviet Attitude towards the European Neutrals during the Cold War", in Gehler, Stein- 
Towards the end of the Second World War and during the early years of the Cold War, Switzerland's political leaders started to formulate a very restrictive foreign policy doctrine. It was based on a narrow, idealised conception of neutrality that began to take on an almost mythical importance and venerated Switzerland as a 'special case' in Europe and the world. In order to overcome Switzerland's international isolation and improve the image of its neutrality policy, this leading principle was complemented by the principles of solidarity and universality. While the first demanded commitment to good offices and humanitarian aid, the second called for the diplomatic recognition of all states, no matter the political couleur of their regimes. The willingness to offer good offices and mediation in international conflicts would, in the early 196os, be subsumed under the additional principle of availability. ${ }^{13}$

Although Switzerland did not formally join one of the Cold War blocs, several scholars have pointed out that its neutrality was compromised by the clear Western orientation of its foreign policy. The Swiss government and the majority of its population were strongly anti-Communist and had much closer economic, political, and military links to the US and Western Europe than to the USSR and the Eastern bloc. ${ }^{14}$ Neutrality was thus a flexible principle that was

inger, Die Neutralen und die europäische Integration, pp. 29-43; Wolfgang Mueller, "The US and Permanent Neutrality in the Cold War", Journal of Cold War Studies 18:4 (2016), pp. 148-179; Peter Ruggenthaler, The Concept of Neutrality in Stalin's Foreign Policy, Latham: Lexington Books, 2015 .

13 See notably Thomas Fischer, Daniel Möckli, "The Limits of Compensation: Swiss Neutrality Policy in the Cold War", Journal of Cold War Studies 18:4 (2016), pp. 12-35; Daniel Möckli, Neutralität, Solidarität, Sonderfall. Die Konzeptionierung der schweizerischen Aussenpolitik der Nachkriegszeit, 1943-1947, Zürich: Forschungsstelle für Sicherheitspolitik und Konfliktanalyse ETH, 2000; Daniel Trachsler, Neutral zwischen Ost und West? Infragestellung und Konsolidierung der schweizerischen Neutralitätspolitik durch den Beginn des Kalten Krieges, 1947-1952, Zürich: Forschungsstelle für Sicherheitspolitik und Konfliktanalyse EтH, 2002; Daniel Trachsler, Bundesrat Max Petitpierre. Schweizerische Aussenpolitik im Kalten Krieg 1945-1961, Zurich, NZZ, 2011.

14 On Swiss anti-Communism, consult Daniel Alexander Neval, 'Mit Atombomben bis nach Moskau'. Gegenseitige Wahrnehmung der Schweiz und des Ostblocks im Kalten Krieg 19451968, Zürich: Chronos, 2003; Luc van Dongen, "La Suisse dans les rets de l'anticommunisme transnational durant la Guerre froide: réflexions et jalons", in Sandra Bott, Janick Marina Schaufelbuehl, Sacha Zala (eds.), Itinera. Die internationale Schweiz in der Zeit des Kalten Krieges/Relations internationales de la Suisse durant la Guerre froide, Basel: Schwabe, 2011, pp. 17-30; several articles in Luc van Dongen, Stéphanie Roulin, Giles Scott-Smith (eds.), Transnational Anti-Communism and the Cold War. Agents, Activities, and Networks, Basingstoke: Palgrave Macmillan, 2014; Hadrien Buclin, "Swiss Intellectuals and the Cold War: Anti-Communist Policies in a Neutral Country", Journal of Cold War Studies 19:4 (2017), pp. 137-167. On Swiss pro-Western neutrality, which was nevertheless accepted by the UssR, see notably Hans Ulrich Jost, "Switzerland's Atlantic Perspectives", in Marko 
applied in a selective manner. The somewhat artificial differentiation between 'technical' and 'political' international organisations-adhesion to the former being compatible with neutrality and to the latter not-is only one example of how Bern managed to steer its foreign policy according to its national, mainly economic, interests. The ambiguous relationship between neutrality and economic interests has also been criticised. Historian Hans Ulrich Jost pointedly argued that Switzerland's "idealistic principle of neutrality, with its humanitarian connotation" has served as a shield to hide the sword of foreign trade, which "is wielded without moral reticence in the markets and business affairs of the world". ${ }^{15}$ This was exactly the accusation made by the African visitors to Bern in 1972.

Research on neutrality during the Cold War has mainly focused on the European theatres of the East-West conflict. By concentrating on the conflicts surrounding neutrality in sub-Saharan Africa and thereby extending the analysis to the global South, this book shows that neutrality was an even more malleable foreign policy concept in the Third World, where the danger of a neutral state being directly involved in armed conflict was much lower than in Europe. As a consequence of the decolonisation of most sub-Saharan African states in the late 1950s and early 196os, the concept of neutrality — developed in a European context - needed to prove its credibility and respectability to a new set of actors. During the tensions and wars of the late 196os and 1970s, where the lines of the East-West and North-South conflicts intersected, it became difficult to maintain a neutrality policy that was credible and respectable in the eyes of both unofficial Western allies and the rising Third World. Although this book does not adopt a truly comparative approach, it contrasts Switzerland's foreign policy in sub-Saharan Africa to that of other European neutrals, thereby contributing to a better understanding of the meaning of neutrality in the Third World during the Cold War.

Milivojevic, Pierre Maurer (eds.), Swiss Neutrality and Security: Armed Forces, National Defence and Foreign Policy, New York: Berg, 199o, pp. 110-121; Janick Marina Schaufelbuehl, Mario König (eds.) Traverse. Schweiz-USA im kalten Krieg/Suisse-USA dans la guerre froide, 16:2 (2009); and with regard to military and security policy, Mauro Mantovani, Schweizerische Sicherheitspolitik im Kalten Krieg (1947-1963). Zwischen angelsächsischem Containment und Neutralitäts-Doktrin, Zürich: Orell Füssli, 1999; André Schaller, Neutralität im West-Ost Handel: Das Hotz-Linder Agreement vom 23. Juli 1951, Bern: Haupt, 1987; Marco Wyss, "Neutrality in the Early Cold War: Swiss Arms Imports and Neutrality", Cold War History 12:1 (2012), pp. 25-49; Marco Wyss, Arms Transfers, Neutrality and Britain's Role in the Cold War: Anglo-Swiss Relations 1945-1958, Leiden: Brill, 2013.

15 Jost, "Switzerland's Atlantic Perspectives", p. 113. See also Hans Ulrich Jost, "Origines, interprétations et usages de la 'neutralité helvétique', Matériaux pour l'histoire de notre temps 93 (2009), pp. $5^{-12 .}$ 
Switzerland and Sweden, and, to a lesser extent, Austria, whose neutral status (declared in 1955) was based on the Swiss model, ${ }^{16}$ closely observed each other's policy decisions; as has been shown with regard to the recognition in the 1970s of the Communist halves of the divided states of Korea and Vietnam. ${ }^{17}$ This tension between cooperation and competition can also be observed in sub-Saharan Africa. Sweden was Switzerland's main competitor in this region, as the Austrian government was less exposed to criticism of its African policy and less interested in close relations with African states. The two other European neutrals, Finland and Ireland, were no reference for Swiss foreign policymaking in sub-Saharan Africa. ${ }^{18}$ Sweden was a de facto neutral state, whose conception of neutrality came closest to that of Switzerland. ${ }^{19}$ Yet, there were significant differences between the two states' foreign policy approaches, particularly when it came to relations with the Third World. Unlike Switzerland, Sweden joined the United Nations (UN) in 1946. Its active foreign policy, which emerged in the late 1950s and early 1960s, included taking a more independent stance from the superpower blocs and an outspoken position in international

16 Austrian neutrality is notably analysed by Günter Bischof, Austria in the First Cold War, 1945-1955. The Leverage of the Weak, Basingstoke: Palgrave Macmillan, 1999; Michael Gehler, "From Non-alignment to Neutrality: Austria's Transformation during the First East-West Détente, 1953-1958", Journal of Cold War Studies 7:4 (2005), pp. 104-136; Wolfgang Mueller, A Good Example of Peaceful Coexistence? The Soviet Union, Austria, and Neutrality, 1955-1991, Wien: Verlag der Österreichischen Akademie der Wissenschaften, 2011; Erwin A. Schmidl, "Lukewarm Neutrality in a Cold War? The Case of Austria",Journal of Cold War Studies 18:4 (2016), pp. 36-50.

Janick Marina Schaufelbuehl, Marco Wyss, Sandra Bott, "Choosing Sides in the Global Cold War: Switzerland, Neutrality, and the Divided States of Korea and Vietnam", The International History Review 37:5 (2015), pp. 1014-1036.

18 On Finnish neutrality, see Martti Häikiö, "Finland's Neutrality 1944-1994", in Gehler, Steininger, Die Neutralen und die europäische Integration, pp. 199-217; Kimmo Rentola, "From Half-Adversary to Half-Ally: Finland in Soviet Policy, 1953-1958", Cold War History 1:1 (2000), pp. 75-102. For a comparative analysis of European neutrality, see Hakovirta, East-West Conflict and European Neutrality; Efraim Karsh, Neutrality and Small States, London: Routledge, 1988.

19 For studies of Swedish neutrality in English, see, for example, Juhana Aunesluoma, Britain, Sweden and the Cold War, 1945-54. Understanding Neutrality, Basingstoke: Palgrave Macmillan, 2003; Robert Dalsjö, "The Hidden Rationality of Sweden's Policy of Neutrality during the Cold War", Cold War History 14:2 (2014), pp. 175-194; Birgit Karlsson, "Neutrality and Economy: The Redefining of Swedish Neutrality, 1946-52", Journal of Peace Research 32:1 (1995), pp. 37-48; Mikael af Malmborg, Neutrality and State-Building in Sweden, Basingstoke: Palgrave Macmillan, 20o1; Simon Moores, "'Neutral on our Side': US Policy towards Sweden during the Eisenhower Administration", Cold War History 2:3 (2002), pp. 29-62. 
affairs, an emphasis on human rights and development issues, and generally paying closer attention to the Third World. ${ }^{20}$

Building on Tor Sellström's meticulous reconstruction of Swedish diplomatic and humanitarian support for national liberation in Southern Africa, ${ }^{21}$ this book shows that there were different, competing models of a neutral foreign policy on the African continent. Switzerland's image problem on the African continent was compounded by the fact that African actors frequently compared its foreign policy to that of Sweden. The Swiss conception of neutrality-which insisted on the principle of non-interference in the internal affairs of other states and the separation of political and economic issueswas poorly adapted to a context where conflicts focused on the end of white minority rule and the reorganisation of global economic relations. Yet, while Switzerland's foreign policy in sub-Saharan Africa was criticised by Afro-Asian governments, Sweden's outspoken position created tension with the leaders of the Western bloc. One side's 'good neutrals' were the other's 'bad neutrals'. Considering these different interpretations of the flexible principle of neutrality, it follows that it was of limited use as a foreign policy guideline in NorthSouth relations.

The Swiss case is not only instructive to the study of neutrality but also to the analysis of the role and influence of small states in the international system during the global Cold War. In his classic comparative analysis of European small open economies, political scientist Peter Katzenstein briefly turned to the Third World policies of Sweden, Norway, Denmark, the Netherlands, Belgium,

20 For a historiographical overview on Swedish foreign policy during the Cold War, see Ulf Bjereld, Ann-Marie Ekengren, "Cold War Historiography in Sweden", in Thorsten B. Olesen (ed.), The Cold War - and the Nordic Countries: Historiography at Crossroads, Odense: University Press of Southern Denmark, 2004, pp. 143-175. Swedish Third World policy is analysed by Nikolas Glover, "Neutrality Unbound. Sweden, Foreign Aid and the Rise of the Non-Aligned Third World", in Bott et al., Neutrality and Neutralism in the Global Cold War, pp. 161-177. See also Magnus Jerneck, "Sitting on the Balcony: American Responses, Strategic Dilemmas, and Swedish Criticism of the Vietnam War", Diplomacy \& Statecraft 24:3, pp. 404-426; Aryo Makko, "Sweden, Europe, and the Cold War: A Reappraisal", Journal of Cold War Studies 14:2 (2012), pp. 68-97. Comparative studies of Switzerland's and Sweden's neutrality policies during the Cold War include Mikael Nilsson, Marco Wyss, "The Armed Neutrality Paradox: Sweden and Switzerland in US Cold War Armaments Policy", Journal of Contemporary History 51:2 (2016), pp. 335-363; John F. L. Ross, Neutrality and International Sanctions. Sweden, Switzerland and Collective Security, New York: Praeger, 1989. 
Austria, and Switzerland. He argued that these small European states, which relied on the smooth functioning of the international economic and political order, tended to be more accommodative of Third World states' demands than larger Western powers. Nevertheless, he also showed that in the late 196os and 1970s, there were two fundamentally different approaches to North-South relations among small states. These were exemplified by Sweden and Switzerland. While the first backed many Third World demands, tied Swedish foreign investment to a code of good conduct, and granted generous public aid, the latter opposed the preferential treatment of imports from developing countries. Switzerland was committed to the defence of market liberalism, even though its government was careful to adopt a discreet position so as not to offend Third World representatives. Its public aid commitment was modest, amounting to $0.19 \%$ of Switzerland's gross national product, considerably lower than the Organisation for Economic Co-operation and Development (OECD) average of $0.31 \%$ and the organisation's target of $0.7 \%$, which Sweden exceeded. ${ }^{22}$ Although Katzenstein's argument was made in very general terms, the analytical category of the small state, which in his study included three neutrals and four NATO members, is a useful reminder that geopolitical alliances—or the absence of such alliances - are not sufficient to explain foreign policy choices.

What these states had in common was their limited political and military clout on the international scene. This left them more exposed to the multiple and interconnected political, economic, military, and social challenges of the period and restricted their leeway to tackle them. These challenges were manifold: armed conflicts in the Third World, most famously in Vietnam; superpower Détente; growing distance in transatlantic relations; ${ }^{23}$ economic crises and the collapse of the Bretton Woods international monetary system; the rise of political and social protest movements; ${ }^{24}$ and the North-South conflict that culminated in the 1973 'Oil Shock' and the Third World political movement's demands for a New International Economic Order (N IEO) in $1974 .{ }^{25}$ The

22 Peter Katzenstein, Small States in World Markets. Industrial Policy in Europe, Ithaca: Cornell University Press, 1985, pp. 46, 121-122.

23 Jussi M. Hanhimäki, The Rise and Fall of Détente. American Foreign Policy and the Transformation of the Cold War, Washington, DC: Potomac Books, 2013; Poul Villaume, Odd Arne Westad (eds.), Perforating the Iron Curtain. European Détente, Transatlantic Relations, and the Cold War, 1965-1985, Copenhagen: Museum Tusculanum Press, 2010.

24 See, for example, Martin Klimke, Joachim Scharloth (eds.), 1968 in Europe. A History of Protest and Activism, New York: Palgrave Macmillan, 2008; Jeremy Suri, Power and Protest. Global Revolution and the Rise of Détente, Cambridge, MA: Harvard University Press, 2005. See notably Christopher R. W. Dietrich, Oil Revolution. Anticolonial Elites, Sovereign Rights, and the Economic Culture of Decolonization, Cambridge: Cambridge University Press, 2017; Garavini, After Empires. 
increasingly divergent opinions and strategies of the US, on the one hand, and its Western European allies, on the other, of how to confront these issues are a recurring theme in the scholarship on the 'global 196os and 197os'. Building on this, this study testifies to the increased marge de manoeuvre during Détente for small Western European states to lead foreign policy independently of superpower influence. As the image of the US suffered due to the retreat from Vietnam and the Watergate scandal, Swiss foreign policymakers grew disillusioned with Washington's policy on Africa in the mid-1970s. This book shows that Switzerland's foreign policy in sub-Saharan Africa owed more to Western European governments, in terms of both influence and coordination, than to the US. In addition to neutral Sweden and Austria, it stresses the importance of the European Economic Community (EEC), as a collective political actor, to Switzerland's foreign policy in sub-Saharan Africa. Thus, this study also provides insights into the history of European integration and European foreign policymaking during the Cold War. ${ }^{26}$

It would be misleading to underestimate the influence of small Western European states in international relations. The mere fact that the oAU included them in its delegation's itinerary proves that they were indeed actors to be reckoned with. This was particularly true for Switzerland, whose economic and financial interests in sub-Saharan Africa, and especially in South Africa, were considerable. Its relations with the Apartheid regime were particularly important to Swiss capital exports and imports of South African gold. Historian Sandra Bott notably showed that, between the 196os and the late 1980s, up to $80 \%$ of South Africa's gold production was commercialised by Swiss banks, which strengthened the international position of the Swiss financial centre. ${ }^{27}$ Thanks to Switzerland's economic and financial strength, some authors have argued that, in these fields, the country was, at the least, a middle power. They claim that its political and economic leaders employed what historian Sébastien Guex called a 'rhetoric of smallness' to discreetly protect and further their interests. ${ }^{28}$ This book shows that Switzerland's close economic relations

26 On the foreign policy efforts of the European Economic Community (EEC), see notably Lorenzo Ferrari, Sometimes Speaking with a Single Voice. The European Community as an International Actor, 1969-1979, Bruxelles: P.I.E. Peter Lang, 2016; Maria Găinar, Aux origines de la diplomatie européenne. Les neuf et la coopération politique européenne de 1973 à 1989, Bruxelles: P.I.E. Peter Lang, 2012; Garavini, After Empires; Daniel Möckli, European Foreign Policy during the Cold War. Heath, Brandt, Pompidou and the Dream of Political Unity, London: I.B. Tauris, 2009.

Sandra Bott, La Suisse et l'Afrique du Sud. Marché de l'or, finance et commerce durant l'apartheid, Zurich: Chronos, 2013, p. 377.

28 Sébastien Guex, "Introduction. De la Suisse comme petit État faible: jalons pour sortir d'une image en trompe-l'oeil", in Sébastien Guex (ed.), La Suisse et les Grandes puissances. 
with South Africa explain why foreign policymakers were less critical of white minority rule than those in other small Western European states.

Many traditional works in diplomatic history limit their analysis to the actions of governments and foreign ministries. This study goes further. It looks at the various state and non-state actors that participated in the formation of Switzerland's foreign policy and analyses their interactions with each other, but also with African governments, nationalist movements, and regional and international organisations such as the OAU and the UN. Particular attention is paid to the influence of Western governments on Swiss decision-making and to the interplay of domestic and foreign policy. While the domestic context always limits a government's freedom of action in matters of foreign policy, this is particularly marked in a direct democracy like Switzerland, where citizens can, through a popular vote, pronounce themselves on certain foreign policy issues. The rejection by a majority of voters of a loan of 200 million Swiss francs (CHF) to the International Development Association (IDA) in mid-1976 and of Switzerland's membership of the UN in March 1986 are two cases in point. The focus on a wide range of state and non-state actors and different levels of analysis is particularly instructive, as proven by Rui Lopes' similarly designed study of West German - Portuguese relations during the late independence wars in Portuguese Africa. ${ }^{29}$

The sub-Saharan African context presented a few particularities. Most Swiss individuals, organisations, and government services participating in foreign policymaking had only limited knowledge of this region. As a result, their positions were almost always coloured by some form of racial prejudice. In addition, developments in Angola, Mozambique, Ethiopia, and Somalia rarely drew high-level attention in Bern. Most policy decisions were made at the administrative level and were frequently influenced by individual actors and interests. The Swiss government's information deficit was compounded by the fact that, with the exception of Ethiopia, the Swiss government had no resident ambassador in the four states selected for this study. In addition, the diplomatic personnel that served in Africa was far removed from the ambassadors

1914-1945. Relations économiques avec les États-Unis, la Grande-Bretagne, l'Allemagne et la France/Switzerland and the Great Powers. 1914-1945. Economic Relations with the United States, Great Britain, Germany and France, Genève: Librairie Droz, 1999, pp. 7-29. See also Antoine Fleury, "La Suisse: petite ou moyenne puissance?" in Jean-Claude Allain (ed.), La moyenne puissance au XXème siècle: recherche d'une définition, Paris: FEDN-IHCC, 1989, pp. 217-230.

29 Rui Lopes, West Germany and the Portuguese Military Dictatorship, 1968-1974. Between Cold War and Colonialism, Basingstoke: Palgrave Macmillan, 2014 
appointed to the prestigious posts at the centres of power-in particular the US, the United Kingdom (UK), France, and the Federal Republic of Germany (FRG). ${ }^{30}$ These factors contributed to increasing the opportunities for nonstate actors to influence the government's foreign policy.

Although state actors certainly played a central role in the making of Switzerland's foreign policy in sub-Saharan Africa, different sets of non-state actorsbusiness leaders and firms, missionaries and religious organisations, Third World solidarity groups, and the International Committee of the Red Cross (ICRC) - contributed in various ways to determine the government's position in specific policy fields. Leaders of Swiss companies and economic associations wanted to tap into new African markets and lobbied their government not to give in to Third World pressure to restrict trade with and investments in Southern Africa. Swiss missionaries played a valued role in the implementation of the Swiss government's development policy on the African continent; in the period under consideration, they and their families formed almost half of all Swiss citizens living in the Portuguese colonies and the Horn of Africa. They were in close contact with African populations and had, in some cases, direct links to present and future political leaders. Thus, some missionaries acted as a bridge not only between African populations and Swiss religious circles but also between African elites and the Swiss government.

Afro-Asian criticism of the Swiss government and Swiss business elites' close relations with the white minority regimes in Southern Africa was taken up by an important and heterogeneous protest movement in Switzerland that developed out of the 1968 student movement and religious circles. ${ }^{31}$ As part of a transnational movement that criticised unequal North-South relations, Swiss students, peace activists, left-wing groups, and also a number of churches, missionary organisations, social democratic politicians, and academics demanded that the Federal Council take a firm stand against racial

30 See Florian Keller, Botschafterporträts. Schweizer Botschafter in den "Zentren der Macht" zwischen 1945 und 1975, Zürich: Chronos, 2017.

$31 \quad$ See notably René Holenstein, Was kümmert uns die Dritte Welt. Zur Geschichte der internationalen Solidarität in der Schweiz, Zürich: Chronos, 1998; Monica Kalt, Tiersmondismus in der Schweiz der 196oer und 197oer Jahre. Von der Barmherzigkeit zur Solidarität, Bern: Peter Lang, 2010; Konrad J. Kuhn, Entwicklungspolitische Solidarität: die Dritte-Welt-Bewegung in der Schweiz zwischen Kritik und Politik 1975-1992, Zürich: Chronos, 2011; Nuno Pereira, Anti-impérialisme et nouvelle gauche radicale dans la Suisse des années 1968, unpublished $\mathrm{PhD}$ thesis, University of Lausanne, 2015; and the contributions in Janick Marina Schaufelbuehl (ed.), 1968-1978. Ein bewegtes Jahrzehnt in der Schweiz, Zürich: Chronos, 2009. On the 1968 movement in general, see Damir Skenderovic, Christina Späti, Die 1968er-Jahre in der Schweiz. Aufbruch in Politik und Kultur, Baden: Hier + jetzt, 2012. 
discrimination, prevent Swiss firms from participating in exploitative practices in the Third World, and make a positive contribution to the development of African states. Thus, the stance of this solidarity movement was in direct opposition to that of many Swiss business leaders. The ICRC organised important relief missions during the Angolan and the Ogaden wars, which received financial and logistical support from the Swiss government. As a result of the high level of mobilisation within Swiss society, Bern's policy in sub-Saharan Africa was closely scrutinised. This study shows that, while economic interests had, on the whole, a very strong influence on Swiss foreign policymakers, the demands of the Third World solidarity movement did have an effect, too. The activists' petitions, parliamentary questions, and demonstrations forced the government to justify its policy and gave rise to debate within the Swiss federal administration. Since they were highly esteemed, helped implement Switzerland's development aid policy and thus contributed to the country's humanitarian image, churches and missionary organisations had more influence on the Swiss government than other solidarity actors. By examining the interests and interactions of the different state and non-state actors involved in foreign policymaking, this study bridges diplomatic, economic, and social history.

This book is part of a growing scholarship that focuses on the Cold War in the global South. Since at least the publication of Odd Arne Westad's seminal study, The Global Cold War, the Third World has become an important research topic in Cold War historiography. ${ }^{32}$ In Africa and Asia, the Cold War overlapped and interacted with the process of decolonisation. While many newly independent nations went through internal struggles as they built their states, the Eastern and Western blocs vied with each other to win their allegiance, offering support and intervening directly to change events for their own benefit. Despite their more limited agency, the global East-West rivalry also provided Third World leaders and independence movements with opportunities to play off the superpowers against each other in order to achieve their goals. ${ }^{33}$

32 See Robert J. McMahon, "Introduction", in McMahon, The Cold War in the Third World, pp. 1-10; Westad, The Global Cold War. Consult also Mark Philip Bradley, "Decolonization, the global South, and the Cold War, 1919-1962", in Melvyn P. Leffler, Odd Arne Westad (eds.), The Cambridge History of the Cold War. Volume I: Origins, Cambridge: Cambridge University Press, 2011, pp. 464-485; Michael E. Latham, "The Cold War in the Third World, 1963-1975" in Melvyn P. Leffler, Odd Arne Westad (eds.), The Cambridge History of the Cold War. Volume II: Crises and Détente, Cambridge: Cambridge University Press, 2011, pp. 258-280, and the corresponding bibliographic essays.

33 See notably Bradley, "Decolonization, the global South, and the Cold War"; Byrne, "Africa's Cold War". Particularly interesting for the agency of African actors is Matthew Connelly, 
Many Cold War crises and all the 'hot wars' of the period took place in the global South. From the late 196os, in particular, when the policy of Détente led to a decrease in tension between the superpowers and Western Europe experienced a period of relative peace and stability, despite facing an economic crisis, East-West confrontations in the global South turned increasingly violent. A significant number of these conflicts took place on the African continent, with devastating consequences for local populations. ${ }^{34}$

The armed conflicts and regime changes in Angola, Mozambique, Ethiopia, and Somalia that are at the centre of this study have been analysed in a number of recent publications. During the liberation struggles in Southern Africa that opposed, on one side, African nationalist movements in South Africa, Rhodesia, Namibia, and the Portuguese colonies and, on the other, the white minority regimes, the intersections of decolonisation and the Cold War emerged most strikingly. As the Portuguese, Rhodesian, and South African governments refused to grant, respectively, independence to their colonies and equal rights to their African populations, liberation movements found willing allies in the Eastern bloc. For many Western governments, the fiercely anti-Communist white minority regimes represented a bulwark against Soviet and Chinese influence on the continent, which resulted in a broad tolerance, although to varying degrees, of their racist policies. ${ }^{35}$ During the late independence wars in Angola and Mozambique, African liberation movements received political and military support from the UssR, the People's Republic of China (PRC)

"Rethinking the Cold War and Decolonization. The Grand Strategy of the Algerian War for Independence", Journal of Middle East Studies 33:2 (2001), pp. 221-245. The competition for the Third World was also played out between the USSR and the PRC, and between the US and the PRC: Gregg A. Brazinsky, Winning the Third World. Sino-American Rivalry during the Cold War, Chapel Hill: The University of North Carolina Press, 2017; Jeremy Friedman, Shadow Cold War. The Sino-Soviet Competition for the Third World, Chapel Hill: The University of North Carolina Press, 2015.

34 Byrne, "Africa's Cold War".

35 For a good introduction of these dynamics, see Sue Onslow, "The Cold War in Southern Africa. White Power, Black Nationalism and External Interventions", in Sue Onslow (ed.), Cold War in Southern Africa. White Power, Black Liberation, London: Routledge, 2009, pp. 9-34. With a focus on South Africa, see Gareth Evans, "The Great Simplifier: The Cold War and South Africa, 1948-1994", in Alan P. Dobson (ed.), Deconstructing and Reconstructing the Cold War, Aldershot: Ashgate, 1999. US tolerance towards Apartheid South Africa has notably been analysed by Thomas Borstelmann, Apartheid's Reluctant Uncle. The United States and Southern Africa in the Early Cold War, New York: Oxford University Press, 1993; Alex Thomson, U.S. Foreign Policy Towards Apartheid South Africa, 1948-1994. Conflict of Interests, New York: Palgrave Macmillan, 2008. For the dynamics between US foreign policy and domestic racism, see Thomas Borstelmann, The Cold War and the Color Line. American Race Relations in the Global Arena, Cambridge, MA: Harvard University Press, 2001. 
and other members of the Eastern bloc, as well as from the newly decolonised states of Africa and Asia. Although some governments and an important transnational solidarity movement in Western Europe also granted humanitarian aid to these movements, most Western states stood behind the authoritarian Portuguese regime that was a member of NATO. From the late 196os onwards, Western support for the three white minority regimes in Southern Africa was increasingly criticised by Afro-Asian governments that insisted the West adhere to its verbal commitment to the principle of self-determination. ${ }^{36}$

In 1974, a military coup d'état that was supported by large parts of the population toppled the Portuguese government and initiated the process of decolonisation. Mozambique experienced a relatively peaceful transition of power to a Marxist-inspired government. In Angola, however, rivalries between three competing liberation movements that were backed by various external powers escalated into an open, internationalised war. With the aid of a Cuban expeditionary force, the Movimento Popular de Libertação de Angola (Popular Movement for the Liberation of Angola, MPLA) repelled a South African invasion to win the Angolan $\operatorname{War}^{37}$ in early 1976, subsequently cementing its

$3^{6}$ On Soviet support to the Southern African liberation movements, see notably Roger E. Kanet, "The Superpower Quest for Empire: The Cold War and Soviet Support for 'Wars of National Liberation', Cold War History 6:3 (2006), pp. 331-352; Vladimir Shubin, “Unsung Heroes: The Soviet Military and the Liberation of Southern Africa", Cold War History 7:2 (2007), pp. 251-262; Vladimir Shubin, The Hot 'Cold War'. The UssR in Southern Africa, London: Pluto Press, 2008; Natalia Telepneva, Our Sacred Duty: The Soviet Union, the Liberation Movements in the Portuguese Colonies, and the Cold War, 1961-1975, PhD thesis, Open Access, The London School of Economics and Political Science, 2014. See also Maxim Matusevich (ed.), Africa in Russia, Russia in Africa. Three Centuries of Encounters, Trenton: Africa World Press, 2007; Christopher Andrew, Vasili Mitrokhin, The World Was Going Our Way. The KGB and the Battle for the Third World, New York: Basic Books, 2005. On China, see Steven F. Jackson, "China's Third World Foreign Policy: The Case of Angola and Mozambique, 1961-93", The China Quarterly 142 (1995), pp. 388-422. For the US, see Witney W. Schneidman, Engaging Africa. Washington and the Fall of Portugal's Colonial Empire, Dallas: University Press of America, 2004. See also the contributions in a recent special issue: Aurora Almada e Santos, Bernardo Capanga André, Corrado Tornimbeni, Iolanda Vasile (eds.), Afriche e Orienti. International Solidarities and the Liberation of the Portuguese Colonies 19:3 (2017).

37 I use the term Angolan War for the conflict in 1975-1976 that was shaped by the South African and Cuban interventions in order to distinguish it from the independence war against the Portuguese regime between 1961 and 1974 and the civil war between the Movimento Popular de Libertação de Angola (Popular Movement for the Liberation of Angola, M PLA) and the União Nacional para a Independência Total de Angola (National Union for the Total Liberation of Angola, UNITA) after the South African retreat in 1976. 
alliance with the USSR. ${ }^{38}$ Like the liberation movements that came into power in Angola and Mozambique, the military regimes that took over in Somalia in 1969 and Ethiopia in 1974 adopted an orthodox Communist rhetoric in order to strengthen their alliance with the USSR. ${ }^{39}$ While there is not much literature on the Somali coup d'état, the Ethiopian Revolution has been analysed in some detail. 40

The Ogaden War between Ethiopia and Somalia in 1977-1978 was the only conventional conflict between two African states during the Cold War. Desperate for increased external support for its ongoing invasion of the Ogaden region in south-eastern Ethiopia-an area whose possession had been a contentious issue for the two neighbouring states since Somalia's independence in 1960- the Somali government renounced its friendship treaty with the USSR in November 1977. Yet, as the Carter administration refused to intervene in a war of aggression, and the USSR and Cuba organised a massive military operation in aid of Ethiopia, the Somali troops were forced to withdraw in March 1978. The recent historiography of the Ogaden War has focused mainly on the role of the superpowers and the conflict's negative impact on East-West relations. ${ }^{41}$

38 In addition to the titles above, see Piero Gleijeses, Conflicting Missions. Havana, Washington, and Africa, 1959-1976, Chapel Hill: University of North Carolina Press, 2002; Piero Gleijeses, Visions of Freedom. Havana, Pretoria, and the Struggle for Southern Africa, 1976-1991, Chapel Hill: The University of North Carolina Press, 2013; Edward George, The Cuban Intervention in Angola, 1965-1991. From Che Guevara to Cuito Canavale, London: Cass, 2005; Jamie Miller, An African Volk. The Apartheid Regime and its Search for Survival, New York: Oxford University Press, 2016; Jamie Miller, "Yes, Minister. Reassessing South Africa's Intervention in the Angolan Civil War, 1975-1976", Journal of Cold War Studies 15:3 (2013), pp. 4-33; Westad, The Global Cold War, pp. 218-241; Geraint Hughes, "Soldiers of Misfortune: The Angolan War, the British Mercenary Intervention, and UK Policy towards Southern Africa, 1975-6", The International History Review 36:3 (2014), pp. 493-512. For an African perspective, see John A. Marcum, The Angolan Revolution. Volume II: Exile Politics and Guerrilla Warfare (1962-1976), Cambridge, MA: MIT Press, 1978.

39 Byrne, "Africa's Cold War", pp. 110-111.

40 For Somalia, see Gary D. Payton, "The Somali Coup of 1969: The Case for Soviet Complicity", The Journal of Modern African Studies 18:3 (1980), pp. 493-5o8; Robert G. Patman, The Soviet Union in the Horn of Africa. The Diplomacy of Intervention and Disengagement, Cambridge: Cambridge University Press, 2009 (1990); Radoslav A. Yordanov, The Soviet Union and the Horn of Africa during the Cold War. Between Ideology and Pragmatism, Lanham: Lexington Books, 2016. The Ethiopian Revolution has notably been analysed by Ethiopian scholars Andargachew Tiruneh, The Ethiopian Revolution 1974-1987. A Transformation from an Aristocratic to a Totalitarian Autocracy, Cambridge: Cambridge University Press, 1993; Gebru Tareke, The Ethiopian Revolution. War in the Horn of Africa, New Haven: Yale University Press, 2009.

41 On the UssR, see Patman, The Soviet Union in the Horn of Africa; Westad, The Global Cold War, pp. 250-287; Yordanov, The Soviet Union and the Horn of Africa. On the role of the 
Although it concentrates primarily on the Carter administration's policy in the Horn of Africa, historian Nancy Mitchell's detailed analysis also highlights the important role of Western European and Arab states. ${ }^{42}$ Gebru Tareke provides a useful military history of the conflict from an Ethiopian point of view. ${ }^{43}$

With the notable exception of Cuba, which played a pivotal role during the Angolan War, scholars have paid little attention to the role of small actors during the Cold War in sub-Saharan Africa in the late 196os and 1970s. Individual studies focus on support from North European governments and civil society for national liberation in Southern Africa, ${ }^{44}$ the German Democratic Republic (GDR)'s relations with the Soviet-allied regimes in Angola, Mozambique, and Ethiopia, ${ }^{45}$ and neutral Ireland's role in Africa. ${ }^{46}$ By exploring Switzerland's opportunities to influence the situation on the ground, notably through mediation, arms sales, diplomatic recognition, and humanitarian aid, this book will contribute to filling this gap.

The existing literature on Switzerland's role during the crises and regime changes in Angola, Mozambique, Ethiopia, and Somalia is sparse. It consists mainly of unpublished masters' theses of varying quality that analyse specific aspects of Swiss involvement in these four states. Authors have focused on the

Carter administration during the Ogaden War, see Donna R. Jackson, Jimmy Carter and the Horn of Africa. Cold War Policy in Ethiopia and Somalia, Jefferson, NC: McFarland, 2007; Donna R. Jackson, "The Carter Administration and Somalia", Diplomatic History 31:4 (2007), pp. 703-721; Donna R. Jackson, "The Ogaden War and the Demise of Détente", The Annals of the American Academy of Political and Social Science 632:1 (2010), pp. 26-40; Louise Woodroofe, 'Buried in the Sands of the Ogaden'. The United States, the Horn of Africa, and the Demise of Détente, Kent, Ohio: The Kent State University Press, 2013.

Nancy Mitchell, Jimmy Carter in Africa. Race and the Cold War, Washington DC: Woodrow Wilson Center Press, 2016.

43 Gebru Tareke, The Ethiopian Revolution; Gebru Tareke, "The Ethiopia-Domalia War of 1977 Revisited", The International Journal of African Historical Studies, 33:3 (2000), pp. 635-667.

44 See Tore Linné Eriksen (ed.), Norway and National Liberation in Southern Africa, Stockholm: Nordiska Afrikainstitutet, 2000; Christopher Munthe Morgenstierne, Denmark and National Liberation in Southern Africa. A Flexible Response, Uppsala: Nordiska Afrikainstitutet, 2003; Sellström, Sweden and National Liberation in Southern Africa. Volume I: Formation of a Popular Opinion; Sellström, Sweden and National Liberation in Southern Africa. Volume II: Solidarity and Assistance; Iina Soiri, Pekka Peltola, Finland and National Liberation in Southern Africa, Stockholm: Nordiska Afrikainstitutet, 1999.

45 Sara Lorenzini, "East-South Relations in the 1970s and the GDR Involvement in Africa: Between Bloc Loyalty and Self-interest", in Max Guderzo, Bruna Bagnato (eds.), The Globalization of the Cold War: Diplomacy and Local Confrontation, 1975-1985, London: Routledge, 2010, pp. 104-115; Klaus Storkmann, Geheime Solidarität: Militärbeziehungen und Militärhilfen der DDR in die 'Dritte Welt', Berlin: Ch. Links Verlag, 2012, pp. 243-384.

46 Kevin O'Sullivan, Ireland, Africa and the End of Empire. Small State Identity in the Cold War 1955-1975, Manchester: Manchester University Press, 2012. 
activities of the Swiss Mission in Mozambique, ${ }^{47}$ Swiss groups and individuals that expressed their solidarity with the independence struggles in Portuguese Africa, ${ }^{48}$ Swiss economic activities in colonial Angola and Mozambique, ${ }^{49}$ Angolan refugees in Switzerland, ${ }^{50}$ the view of the Swiss embassy in Addis Ababa on the Ethiopian Revolution of $1974,{ }^{51}$ and the controversy surrounding the Ethiopian Emperor's Swiss bank accounts in $1974-1975 .{ }^{52}$ The present book thus sheds light on the neglected field of Swiss bilateral relations with these four African states. It thereby also contributes to the growing but still small body of literature on Swiss political, economic, and humanitarian relations with sub-Saharan African countries during decolonisation. ${ }^{53}$ In recent years,

47 See notably Sérgio Inácio Chichava, "Unlike the Other Whites? The Swiss in Mozambique under Colonialism" in Eric Morier-Genoud, Michel Cahen (eds.), Imperial Migrations. Colonial Communities and Diaspora in the Portuguese World, Houndsmills: Palgrave Macmillan, 2012, pp. 149-167; Teresa Cruz e Silva, Protestant Churches and the Formation of Political Consciousness in Southern Mozambique (1930-1974), Basel: P. Schlettwein Publishing, 2001; Patrick Harries, Butterflies \& Barbarians. Swiss Missionaries \& Systems of Knowledge in South-East Africa, Oxford: James Currey, 2007; Caroline Jeannerat, Eric Morier-Genoud, Didier Péclard, Embroiled. Swiss Churches, South Africa and Apartheid, Münster: Lit-Verlag, 2011; Charles Rohrbasser, L'œuvre sociale de la Mission Suisse au Mozambique, unpublished Master thesis, University of Lausanne, 1991.

48 See notably Rahel Fischer, 'Die Solidarität in den Strukturen'. Entwicklungspolitische Konzepte, Aktionen und Lebenswelten der Arbeitsgruppe Dritte Welt Bern, 1968-1976, unpublished Master thesis, University of Bern, 2007; several contributions in Schaufelbuehl, 1968-1978; Andrea Steinemann, Medic'Angola und Komitee Südliches Afrika. Über das Entstehen, die Veränderung und das Verschwinden einer Schweizer Solidaritätsgruppe in den 197oer Jahren, unpublished Master thesis, University of Zurich, 2014.

49 Chichava, “Unlike the Other Whites?"; Adolphe Linder, Die Schweizer in Mosambik 1721199o, Capetown: Rondebosch, 1998; Tiago Ribeiro, L'attitude de la Confédération suisse visà-vis des mouvements indépendantistes angolais (1960-1975), unpublished Master thesis, University of Lausanne, 2011; Laure Schwager, La Suisse et ses liens politiques et économiques avec l'Angola pendant la Guerre froide (1974-1979), unpublished Master thesis, University of Lausanne, 2014.

$50 \quad$ Eliane Kurmann, 'Affaires angolaises'. Die angolanischen Studenten in der Schweiz während dem Unabhängigkeitskampf 1961-1975, unpublished Master thesis, University of Fribourg, 2008.

$5^{1} \quad$ Christian Scherer, Durch die tiefsten Tiefen des Wellentals. Die äthiopische Revolution in den Politischen Berichten der Schweizerischen Botschaft in Addis Abeba, 1970-1975, unpublished Master thesis, University of Bern, 2009.

$5^{2} \quad$ Sakina el Ammari, Les autorités politiques suisses face aux réclamations d'avoirs illicites deposes dans les banques suisses: le cas du 'blood money' de l'empereur éthiopien Haïlé Sélassié (1974), de Ferdinand Marcos aux Philippines (1986) et de Jean-Claude Duvalier en Haïti (1986), unpublished Master thesis, University of Lausanne, 2017.

53 Marisa Birri, "Der Kalte Krieg war in Afrika ein Heisser. Die Schweiz und der Kongokonflikt 196o-1963", in Bott, Schaufelbuehl, Zala, Die internationale Schweiz in der Zeit des Kalten Krieges, pp. 65-79; Philippe Boeglin, La coopération entre la Suisse et le Burkina 
an increasing number of scholars have started to analyse the unequal political, economic, financial, religious, social, and scientific relations of Switzerland, a small, export-oriented European state without colonies, and/or its citizens, with countries and actors in the Third World, both during and after colonialism. While some authors, mostly from the viewpoint of economic history, have sought to determine the existence of a specific form of 'Swiss imperialism', others, influenced by postcolonial studies, have looked at colonial discourses in Switzerland and studied forms of 'colonialism without colonies'.54 Thanks to

Faso. Continuité en régime révolutionnaire (1983-1987), unpublished Master thesis, University of Fribourg, 2010; Sandra Bott, Thomas David, Claude Lützelschwab, Janick Marina Schaufelbuehl (eds.), Suisse-Afrique (18e-20e siècles). De la traite des Noirs à la fin du régime d'apartheid, Münster: LIT Verlag, 2005; Alioune Dieng, A l'ombre de la France. Les relations entre le Sénégal et la Suisse au lendemain de l'indépendance (1960-1964), unpublished Master thesis, University of Neuchâtel, 20o8; Alioune Dieng, La Suisse et l'Afrique aux lendemains des indépendances: le cas de la Côte d'Ivoire, unpublished Master thesis, The Graduate Institute, Geneva, 2010; Ursin Hofmann, La politique d'aide au développement suisse pour le Tiers-monde. La relation entre la Confédération helvétique et la Banque africaine de développement entre intérêts propres et altruisme (1964-1975), unpublished Master thesis, University of Lausanne, 2011; Mathieu Humbert, "Une défense discrète et flexible des intérêts économiques suisses. Les cas du Ghana et du Congo au début de leur indépendance", Relations internationales 163:3 (2015), pp. 63-79; Lyonel Kaufmann, "Guillaume Tell au Congo. L'expansion suisse au Congo belge (1930-196o)", Les Annuelles 5 (1994), pp. 43-94; Lukas Meier, Swiss Science, African Decolonization and the Rise of Global Health, 1940-2010, Basel: Schwabe, 2014; Steve Page, La Suisse et le Ghana de Nkrumah: une présence économique et diplomatique à l'épreuve de la décolonisation (1950-1970), unpublished Master thesis, University of Fribourg, 2006; Steve Page, Le Nigeria et la Suisse, des affaires d'indépendance. Commerce, diplomatie et coopération 1930-1980, Bern: Peter Lang, 2016; Pascal Schmid, Medicine, Faith and Politics in Agogo. A History of Health Care Delivery in Rural Ghana, ca. 1925 to 1980, Zürich: LIT Verlag, 2018; Jérôme Schuwey, La Suisse et la Guinée de Sékou Touré. Les enjeux de la Coopération technique au lendemain de l'indépendance (1958-1974), unpublished Master thesis, University of Lausanne, 2011; Lukas Zürcher, “So fanden wir auf der Karte diesen kleinen Staat': Globale Positionierung und lokale Entwicklungsfantasien der Schweiz in Rwanda in den 196oer Jahren", in Hubertus Büschel, Daniel Speich (eds.), Entwicklungswelten. Globalgeschichte der Entwicklungszusammenarbeit, Frankfurt: Campus Verlag, 2009, pp. 275-309; Lukas Zürcher, Die Schweiz in Ruanda. Mission, Entwicklungshilfe und Nationale Selbstbestätigung (1900-1975), Zurich: Chronos, 2014.

54 For historiographical overviews, see notably Thomas David, Bouda Etemad, "Introduction", Les Annuelles 5 (1994), pp. 7-17; Thomas David, Bouda Etemad, "Un impérialisme suisse? Introduction", Traverse 5 (1998), pp. 7-16; Bouda Etemad, Mathieu Humbert, "La Suisse est-elle soluble dans sa 'postcolonialité'?" Schweizerische Zeitschrift für Geschichte 64:2 (2014), pp. 279-291; Patricia Purtschert, Harald Fischer-Tiné, "Introduction. The End of Innocence: Debating Colonialism in Switzerland”, in Patricia Purtschert, Harald Fischer-Tiné (eds.), Colonial Switzerland. Rethinking Colonialism from the Margins, Basingstoke: Palgrave Macmillan, 2015, pp. 1-25; Patricia Purtschert, Barbara Lüthi, Francesca 
a national research programme, mandated by the Swiss government in 2000 following public and parliamentary pressure concerning the issue of Switzerland's responsibility for the perpetuation of racial discrimination in South Africa, Swiss relations with the Apartheid regime have received particular attention. ${ }^{55}$ Although more research is still needed on Switzerland's relations with the Rhodesian settler regime that unilaterally declared its independence from the UK in 1965 , there are indications that firms domiciled in Switzerland played a central role in the evasion of the economic sanctions imposed on the country by the UN. ${ }^{56}$ Moving away from a purely bilateral view of such relations, this book shows that these economic links and the Swiss government's non-committal stance on racial discrimination loomed large over its relations with independent Afro-Asian governments in the 196os and 1970s and imperilled its image in the Third World.

The strategies adopted by Swiss foreign policymakers to deal with this contributed to and were influenced by a general reappraisal of Switzerland's foreign policy that started in the late 196os. This was prompted by a growing awareness that, in an international context marked by superpower Détente and the increasingly confident stance of newly decolonised states in the Third World, strict adherence to Switzerland's conception of neutrality might lead to the country's isolation. The Swiss government therefore decided to adopt a more active and outward-looking position to defend its interests in a changing global context. Research has focused, in particular, on Bern's decision to take

Falk, "Eine Bestandesaufnahme der postkolonialen Schweiz", in Patricia Purtschert, Barbara Lüthi, Francesca Falk (eds.), Postkoloniale Schweiz. Formen und Folgen eines Kolonialismus ohne Kolonien, Bielefeld: Transcript, 2012, pp. 13-63.

In 2000, the Swiss government charged the Swiss National Science Foundation (SNF) with carrying out a national research programme to study Switzerland's relations with the Apartheid regime. This project was not only hampered by the destruction of a number of relevant files but also by the government's April 2003 decision to block access to documents dated after 196o in the SFA. For background of research programme $42+$ and its political context, see its final report: Georg Kreis, Die Schweiz und Südafrika 1948-1994. Schlussbericht des im Auftrag des Bundesrates durchgeführten NFP 42+, Bern: Haupt, 2005, pp. 21-73. Other studies include Sandra Bott, Sébastien Guex, Bouda Etemad, Les relations économiques entre la Suisse et l'Afrique du Sud durant l'apartheid (1945-199o), Lausanne: Antipodes, 2005; Jeannerat, Morier-Genoud, Péclard, Embroiled.

56 On Swiss-Rhodesian economic relations, see Franziska Brunner, Die Beziehungen Schweiz-UNO im Kontext des Rhodesienkonflikts. Eine Neubewertung der multilateralen Zusammenarbeit, unpublished Master thesis, University of Bern, 2011; Jürg Martin Gabriel, "Switzerland and Economic Sanctions: The Dilemma of a Neutral", in Milivojevic, Maurer, Swiss Neutrality and Security, pp. 232-245; Rudolf Letsch, Rhodesien, die Vereinten Nationen und die Schweiz. Konzepte und Inkonsistenzen der Rhodesienpolitik, Herisau: Druck Schläpfer + Co. AG, 1983; Ross, Neutrality and International Sanctions. 
steps towards joining the UN (which was rejected in a popular vote in 1986), ${ }^{57}$ its active participation in the multilateral negotiations at the Conference on Security and Co-operation in Europe (CSCE) between 1972 and $1975,{ }^{58}$ its security policy, ${ }^{59}$ its policy on human rights, ${ }^{60}$ and its participation in international cooperation on counterterrorism. ${ }^{61}$

To date, Thomas Fischer's 2004 study remains the most detailed account of the turn towards a more active Swiss foreign policy in the late 1960s and the return to a foreign policy approach based on a restrictive and selective interpretation of neutrality in the late 1970 s and 1980s. Although his book focuses on the Northern hemisphere, like most works analysing this reorientation, Fischer underlines that the Third World played an integral part in the reconsideration of Swiss foreign policy. Relying exclusively on Swiss government sources and the private papers of foreign policymakers, he shows that, in the Third World, the Swiss authorities faced increasingly self-confident governments that demanded a greater say in international political and economic relations. Consequently, the Swiss government realised that, in order to protect its international standing, it needed to show more consideration to and intensify its relations with the recently decolonised countries in the global South. ${ }^{62}$ This point was subsequently developed in a number of recent works. ${ }^{63}$ The pre-

57 See Sandra Bott, Janick Marina Schaufelbuehl, "Switzerland and Détente: A Revised Foreign Policy Characterized by Distrust", in Martin Klimke, Reinhild Kreis, Christian F. Ostermann (eds.), Trust, but Verify. The Politics of Uncertainty and the Transformation of the Cold War Order, 1969-1991, Washington, DC: Woodrow Wilson Center Press, 2016, pp. 259-278; Thomas Fischer, Die Grenzen der Neutralität. Schweizerisches KSZE-Engagement und gescheiterte UNO-Beitrittspolitik im Kalten Krieg, 1969-1986, Zürich: Chronos, 2004.

$5^{8} \quad$ Fischer, Die Grenzen der Neutralität; Christoph Breitenmoser, Sicherheit für Europa. Die KSZE-Politik der Schweiz bis zur Unterzeichnung der Helsinki-Schlussakte zwischen Skepsis und aktivem Engagement, Zürich: ETH, 1996; Philip Rosin, Die Schweiz im KSZE-Prozess 1972-1983. Einfluss durch Neutralität, München: Oldenbourg Verlag, 2014. On the role of the European neutral countries, see Thomas Fischer, Neutral Power in the cscE. The $N+N$ States and the Making of the Helsinki Accords 1975, Baden-Baden: Nomos, 2009; Victor-Yves Ghebali, La diplomatie de la détente: La cscE, d'Helsinki à Vienne (1973-1989), Bruxelles: Emile Bruylant, 1989 .

59 Christoph Breitenmoser, Strategie ohne Aussenpolitik. Zur Entwicklung der schweizerischen Sicherheitspolitik im Kalten Krieg, Bern: Peter Lang, 2002.

6o Jon A. Fanzun, Die Grenzen der Solidarität:schweizerische Menschenrechtspolitik im Kalten Krieg, Zürich: NZZ, 2005.

61 Aviva Guttmann, The Origins of International Counterterrorism. Switzerland at the Forefront of Crisis Negotiations, Multilateral Diplomacy, and Intelligence Cooperation (19691977), Leiden: Brill, 2018.

62 Fischer, Die Grenzen der Neutralität.

63 See notably Magnus Meister, Swiss Economic and Political Relations with Israel, Egypt and Syria During the Arab-Israeli Conflicts (1967-1983), unpublished PhD thesis, University of 
sent study thus addresses a research deficit. Its key benefits are the multiple points of view and levels of analysis. It evaluates not only the impact of Swiss non-state actors on the formation of foreign policy but also the role and influence of Western governments, thereby placing Swiss foreign policy in both an international and transnational context. ${ }^{64}$

The extensive multi-archival research undertaken for this study reflects this approach. This book is based on a large and diverse body of primary documents from public and private archives in Switzerland, the US, the UK, France, and Portugal. The consultation of African archives was, however, outside of the scope of this book, for linguistic reasons as well as difficulties of access. Some printed African sources and secondary literature based on African archivessome of it written by African scholars - balance the predominantly Swiss and Western view of events in Southern Africa and the Horn of Africa. The bulk of archival research was conducted at the Swiss Federal Archives (SFA) in Bern. Research focused on the documents of different divisions within the Federal Political Department (FPD ) — Switzerland's foreign ministry: the Directorate of Political Affairs (DPA), the department's chief division and coordinating unit of Swiss foreign policy responsible for its operational aspects; the Directorate for International Organisations (DIO); the Service for Technical Cooperation (STC); the Political Secretariat; and the Swiss embassies in sub-Saharan Africa. The archives of the Federal Department of Economic Affairs' (FDEA) Trade Division were also consulted, as well as selected files of the Federal Department of Finance (FDF) and the Federal Military Department (FMD).

The vast array of different documents from the Swiss federal administration was complemented by papers from the archives of a number of economic, missionary, activist, and humanitarian groups and organisations in Switzerland. The minutes of governing body meetings of leading economic and financial associations were consulted, such as the Swiss Federation of Commerce and Industry (Vorort) at the Archiv für Zeitgeschichte (Archives for Contemporary History, AfZ) in Zurich and the Swiss Bankers Association (sBA) in Basel, as well as the Swiss National Bank (SNB) in Zurich. Archival research was also

Lausanne, 2019; Schaufelbuehl, Wyss, Bott, "Choosing Sides in the Global Cold War"; and the contributions in a special issue on Switzerland's role during the Cold War in the Third World. For an overview, see Sandra Bott, Jussi M. Hanhimäki, Janick Marina Schaufelbuehl, Marco Wyss, "Introduction. Le role international de la Suisse dans la Guerre froide globale: un équilibre précaire", Relations internationales 163:3 (2015), pp. 3-13.

64 Pierre Eichenberger, Thomas David, Lea Haller, Matthieu Leimgruber, Bernhard C. Schär, Christa Wirth, "Beyond Switzerland. Reframing the Swiss Historical Narrative in Light of Transnational History", Traverse 24:1 (2017), pp. 137-152. 
conducted at the company archives of two leading Swiss export firms whose archives are open to researchers: electro-technical company Brown, Boveri \& Cie (ввС, today Авв) and pharmaceutical group Ciba-Geigy (today Novartis). These firms represent the two most important Swiss export sectors to the African continent: chemicals and machines. To cover the perspective of other non-state actors, the archives of Swiss Maoist solidarity group Medic'Angola at the Basler Afrika Bibliographien. Namibia Resource Centre \& Southern Africa Library (ВАВ) and the Département missionnaire des églises protestantes de Suisse romande (the mission wing of the Protestant churches of French-speaking Switzerland, DM) in Lausanne provided fascinating insights. Finally, research was conducted at the ICRC archives in Geneva.

In order to situate Swiss foreign policy on sub-Saharan Africa in the broader context of the global Cold War, additional research was carried out at the foreign ministry archives of Western states that played an important role during the conflicts analysed in this book: the US and the three colonial powers, Portugal, France, and the UK. The documents gathered there shed new light on the major Western powers' view of Switzerland's foreign policy in the Third World during Détente. Archival research was complemented by the analysis of published sources and online collections, such as the diplomatic documents of Switzerland and the US, contemporary official publications, annual reports, and press reports.

Rather than following a strictly chronological approach, this study is divided into three thematic parts. They focus, respectively, on Switzerland's foreign policy during the late independence wars in Angola and Mozambique (19671974), the radical regime changes that occurred in Somalia, Ethiopia, Mozambique, and Angola (1969-1979), and Swiss actors' roles in and reactions to the wars in Angola and the Ogaden (1975-1979). Although the time frames do to some extent overlap, this structure allows a more in-depth analysis of the specific problems faced by Swiss foreign policymakers with regard to sub-Saharan Africa. A first, introductory chapter sketches Switzerland's foreign policy during decolonisation in sub-Saharan Africa from the late 1950s to the late 197os. It also situates its political, economic, and humanitarian interests in the four selected African states in this general context.

The analysis begins in 1967, when African governments, liberation movements, and a heterogeneous Swiss solidarity movement started to single out and condemn the Swiss government's cordial relations with the white minority regimes in South Africa, Rhodesia, and the Portuguese colonies, and the role of Swiss firms and banks in stabilising those regimes. Part 1 shows how the Swiss government dealt with this criticism during the late independence wars 
in Angola and Mozambique and how its strategy compared to that of other Western and neutral states. Chapter 2 focuses on criticism issued in the international arena. It argues that the Swiss government refused to take a stand on Portuguese colonialism out of fear that this would set a precedent for its relations with the Apartheid regime. Nevertheless, it undertook some limited efforts to show Swiss goodwill towards the African populations in Southern Africa through the supposedly non-political instrument of humanitarian aid. Chapter 3 opens the floor to the large and diverse Swiss movement for solidarity with the liberation struggles in Portuguese Africa. It demonstrates that, as a result of such protest, some members of the Swiss federal administration started to advocate a new foreign policy approach to Africa, which paid more attention to independent African governments. Although they remained in the minority, the Swiss government had, by 1974, come under considerable political pressure to improve its image, and that of its neutrality, on the African continent.

The three chapters in part 2 focus on the political transformations in Angola, Mozambique, Ethiopia, and Somalia that brought Marxist-inspired governments to power and were accompanied, to various extents, by anti-Western rhetoric and the nationalisation of foreign investments. Concentrating on the Horn of Africa, chapter 4 shows that the 1969 coup d'état in Somalia was met with little interest in Bern, as Swiss political, economic, or missionary interests were almost non-existent and the Socialist rhetoric of the new government was not considered unusual for an African state. The Ethiopian Revolution of 1974, however, was accompanied by virulent attacks against Swiss banks for harbouring the assets of the deposed Ethiopian Emperor. The Swiss government subsequently adopted a strategy of problem management and waited out the crisis. In chapter 5 , the narrative returns to Southern Africa, where the Portuguese Revolution of April 1974 heralded the decolonisation of Angola and Mozambique; Swiss foreign policymakers perceived this as an opportunity. The chapter demonstrates that in 1974-1975, the need to improve Switzerland's image in the Third World, due to its former association with the colonial power, spurred the government's efforts to establish cordial links with the future rulers of Angola and Mozambique by granting humanitarian aid and establishing diplomatic relations. As detailed in chapter 6, Bern was confronted with some difficulties in Mozambique. The new government that came into power in June 1975 prioritised political relations with those states that had supported its independence struggle, notably the Eastern bloc and neutral Sweden. The nationalisation of foreign property and the state's control of the import sector tested Swiss settlers and export firms. The conclusion of 
an economic and development cooperation agreement in 1979, however, put an end to the bilateral difficulties of the post-independence years. Part 2 shows that the Swiss government's response to the regime changes was largely pragmatic and influenced by the wish to maintain or increase Switzerland's political and economic presence and improve its image, irrespective of the new rulers' ideological orientations. The need to win favour with African and Third World states was more important than political and ideological ties to the US. During the political transformations in 1974 and 1975, Swiss policy decisions in sub-Saharan Africa were coordinated, in the first place, with the neutral governments of Sweden and Austria, and in the second place, with the capitals of the EEC. The increased importance of Western Europe was accompanied by signs of a growing Swiss disenchantment with the Ford administration's Africa policy and its ability to influence events on the African continent.

Part 3 turns to Swiss foreign policymakers' and humanitarian actors' roles in and perception of the wars in Angola (chapter 7) and the Ogaden (chapter 8), as well as the influence of these conflicts on Switzerland's foreign policy in Africa. When Angola became independent in November 1975 in the middle of an internationalised war, the Swiss government was confronted with the delicate issue of diplomatic recognition of the new state. Chapter 7 argues that the recognition of the Soviet-allied MPLA government by African states in February 1976, towards the end of the conflict, was decisive in the decision by Switzerland and other neutral and Western European states to follow suit, even though the Ford administration opposed this. Thanks to its considerable support for the ICRC relief mission during the Angolan War, the Swiss government quickly established cordial bilateral relations with the MPLA regime. In Bern, however, the Cuban military intervention in Angola—seen by many observers as a proxy force of the USSR - raised fears of further Soviet expansion in Southern Africa. As chapter 8 demonstrates, the Swiss government adopted a very passive attitude during the Ogaden War of 1977-1978. In the wake of the Angolan War, Swiss foreign policymakers perceived the conflict in the Horn to be further proof of the Soviet Union's expansionist designs and the US government's decreasing influence on the African continent. Although they felt the need to participate in the containment of Soviet influence on the African continent, their close relations with Apartheid South Africa restricted policy options. Even Bern's limited efforts to strengthen political and diplomatic ties with Africa met with domestic resistance. As global East-West tensions grew and the challenges to Switzerland's neutrality policy that had been issued by Afro-Asian governments and Swiss non-state actors lost momentum, the drive towards a more Third World oriented foreign policy stalled. The controversy raised in Switzerland by Foreign Minister Pierre Aubert's 1979 visit to Western 
Africa, which reveals the great scepticism, within parliament and public opinion, of the active foreign policy proposed by the Swiss government since the late 196os, therefore closes this study.

\section{Linguistic Notes}

For expressions, as well as personal and geographical names in Amharic and Arabic, the transliterations most frequently used in English-language literature have been followed.

Ethiopians are known by their first name. They do not have permanent family names, but add their father's first name to their own personal name. ${ }^{65} \mathrm{In}$ order to minimise confusion due to the irregular application of this convention in secondary literature, this book always uses an Ethiopian person's complete name, including in references, and lists Ethiopians by their first name. An exception is made for the Ethiopian leader Mengistu Haile Mariam, who is sufficiently well-known by his personal name alone-Mengistu.

65 Bahru Zewde, A History of Modern Ethiopia, 1855-1991, Oxford: James Currey, 2nd edition 2001, p. 280. 


\section{A Non-colonial Power in Colonial and Postcolonial Africa}

The connections between Switzerland and Africa are not immediately obvious. After all, this small, land-locked European country has never had colonies abroad. Nevertheless, there were and are numerous ties between Swiss and African people, organisations, and states. In the eighteenth and nineteenth centuries, some Swiss citizens and companies were involved in the triangular slave trade. ${ }^{1}$ In the wake of the European powers, which extended their control over the continent during the last third of the nineteenth century, Swiss missionaries, farmers, and entrepreneurs settled in Africa, benefiting from the structures put in place by the colonial authorities. ${ }^{2}$ Swiss geographical societies launched expeditions to Africa. ${ }^{3}$ Back in Switzerland, missionaries and explorers contributed to the dissemination of colonial imageries and racial

1 Thomas David, Bouda Etemad, Janick Marina Schaufelbuehl, La Suisse et l'esclavage des Noirs, Lausanne: Antipodes, 2005; Thomas David, Janick Marina Schaufelbuehl, "Swiss Conservatives and the Struggle for the Abolition of Slavery at the End of the Nineteenth Century", Itinerario 34:2 (2010), pp. 87-103; Hans Fässler, Reise in schwarz-weiss: Schweizer Ortstermine in Sachen Sklaverei, Zürich: Rotpunktverlag, 2005; Konrad J. Kuhn, Béatrice Ziegler, "Die Schweiz und die Sklaverei: Zum Spannungsfeld zwischen Geschichtspolitik und Wissenschaft", Traverse 16:1 (2009), pp. 116-130; Niklaus Stettler, Peter Haenger, Robert Labhardt, Baumwolle, Sklaven und Kredite: die Basler Welthandelsfirma Christoph Burckhardt \& Cie. In revolutionärer Zeit (1789-1815), Basel: Merian, 2004.

2 See notably Hans Werner Debrunner, Schweizer im kolonialen Afrika, Basel: Basler Afrika Bibliographien, 1991; Andrea Franc, Wie die Schweiz zur Schokolade kam: Der Kakaohandel der Basler Handelsgesellschaft mit der Kolonie Goldküste (1893-1960), Basel: Schwabe, 20o8; Mathieu Humbert, "L'expansionnisme suisse en Afrique sub-saharienne au cours du XIXe siècle. Un aperçu", Schweizerische Gesellschaft für Wirtschafts- und Sozialgeschichte/Société suisse d'histoire économique et sociale 29 (2015), pp. 145-161; René Lenzin, 'Afrika macht oder bricht einen Mann': Soziales Verhalten und politische Einschätzung einer Kolonialgesellschaft am Beispiel der Schweizer in Ghana (1945-1966), Basel: Basler Afrika Bibliographien, 1999; René Lenzin, "Schweizer im kolonialen und postkolonialen Afrika. Statistische Übersicht und zwei Fallbeispiele", Studien und Quellen 28 (2002), pp. 299-326; Claude Lützelschwab, La Compagnie Genevoise des Colonies Suisses de Sétif (1853-1956): Un cas de colonisation privée en Algérie, Bern: Lang, 2006.

3 Ruth Hagen, Expeditionen in den dunklen Kontinent: Die geografischen Gesellschaften der Schweiz und die wissenschaftliche Erforschung Afrikas, Saarbrücken: VDM, 20o9; Fabio Rossinelli, "Sociétés de géographie et impérialisme suisse au 19e siècle. Un tour d'horizon et deux exemples représentatifs", Schweizerische Zeitschrift für Geschichte 67:1 (2017), pp. 1-19. 
stereotypes. ${ }^{4}$ The gaining of independence by the formerly colonised territories and the departure of the European colonial powers, which started in the late 195os, coincided and interacted with the global East-West conflict. For that reason, and due to the existence of multiple Swiss-African entanglements, Swiss foreign policymakers observed the decolonisation of sub-Saharan Africa with great interest.

In 1957, Ghana was the first state in sub-Saharan Africa to gain independence from the UK. Three years later, in the 'Year of Africa' 1960, no less than 17 African states joined the UN. ${ }^{5}$ As the majority of the former British, French, and Belgian colonies gained independence in the late 1950s and early 196os in a predominantly peaceful process, the Swiss government adopted a low profile. It was careful not to be associated with the colonial powers and tried to maintain good relations with all parties in order to keep out of potential conflicts linked to decolonisation. Swiss foreign policymakers and business leaders hoped that the departure of the European colonial powers would result in increased export and investment opportunities for Swiss business, which would in turn contribute to Africa's economic development. The Swiss government therefore made efforts to establish cordial relations with the new African leaders, notably through the instrument of development aid, which was also intended to help counteract Communist influence in the Third World. Swiss diplomats believed that Switzerland was a particularly valued partner for independent African countries, as this small Western European neutral state with its reputation as a humanitarian actor was tainted neither by a past as a colonial power nor by adherence to one of the big geopolitical blocs. ${ }^{6}$ During the two major violent decolonisation conflicts in the early 196os-the Congo crisis and the independence war in Algeria-Bern played a more active role. Between 1960 and 1963, Switzerland participated in the UN peacekeeping mission in the former Belgian Congo by conducting supply and transport flights and by seconding Swiss experts to the mission. ${ }^{7}$ From 1960, Switzerland provided its good offices during the negotiations between France and the Algerian Front

4 Patrick Minder, La Suisse coloniale. Les représentations de l'Afrique et des Africains en Suisse au temps des colonies (1880-1939) Bern: Peter Lang, 2011.

5 United Nations (UN), "Growth in United Nations membership", https://www.un.org/en/ about-us/growth-in-un-membership (11 August 2021).

6 Marc Perrenoud, "Guerres, indépendances, neutralité et opportunités: quelques jalons historiques pour l'analyse des relations économiques de la Suisse avec l'Afrique (des années 1920 aux années 1960)", in Bott et al., Suisse - Afrique, pp. 85-104.

7 See Marisa Birri, Die Schweiz und der Kongo in den ersten Jahren der Unabhängigkeit 196o1963, unpublished Master thesis, University of Bern, 2007; Birri, "Der Kalte Krieg war in Afrika ein Heisser". 
de Libération Nationale (National Liberation Front, FLN), which culminated in the Evian Accords of March 1962 that confirmed Algeria's independence. ${ }^{8}$ In $1965,6,500$ Swiss nationals were recorded as living in sub-Saharan Africa, with a further 4,300 in South Africa. ${ }^{9}$

The foundation of the OAU in 1963 was a sign that African states intended to play a major role in the international arena and that they would not tolerate the Swiss government's complacent attitude towards colonialism and white minority rule forever. According to its charter, which was signed by 30 heads of state on 25 May 1963, as an organisation of independent African countries, the OAU aimed to promote African self-determination and cooperation between its member states and adhered to a policy of non-alignment in the Cold War. The liberation of the remaining territories under colonial rule was one of the main issues discussed at the OAu's founding conference in Addis Ababa. African leaders agreed to materially support liberation movements and exert diplomatic pressure on the colonial powers to induce them to grant their colonies independence. For this purpose, they set up a committee of nine members to coordinate aid for the liberation movements, the Coordinating Committee for the Liberation of Africa or Liberation Committee, with headquarters in Dar es Salaam. The OAU focused its activities on Portugal, the last European colonial power to resist decolonisation, and Apartheid South Africa. ${ }^{10}$

The institutionalisation of Switzerland's development cooperation policy was intricately linked to the decolonisation of Africa. In the context of the global East-West confrontation, both the Eastern and Western blocs used foreign aid as a tool in their competition for the Third World. Each side prescribed its own model of how states in the global South might be lifted out of poverty. The Swiss government's commitment to humanitarian aid and development cooperation is expressed in the principle of solidarity, and has thus formed an integral part of Switzerland's neutrality policy since the end of the Second World War. Federal Councillor Max Petitpierre, head of the FPD between 1945 and 1961, introduced the notion of 'neutrality and solidarity' in order to improve the image of Swiss neutrality—which had suffered due to its economic and financial relations with the axis powers-by underlining the

8 See Damien Carron, La Suisse et la guerre d'indépendance algérienne (1954-1962), Lausanne: Éditions Antipodes, 2013, pp. 373-419.

$9 \quad$ Lenzin, "Schweizer im kolonialen und postkolonialen Afrika", pp. 302-303.

10 C. O. C. Amate, Inside the OAU. Pan-Africanism in Practice, New York: St. Martin's Press, 1986, pp. 58-64, 211-214. More recent works on the OAU include Klaas van Walraven, Dreams of Power. The Role of the Organization of African Unity in the Politics of Africa, 1963-1993, Aldershot: Ashgate Publishing, 1999; Gaston-Jonas Kouvibidila, Histoire de la construction de l'Afrique, Paris: L'Harmattan, 2011. 
country's willingness to help face the political and economic challenges of the early Cold War. ${ }^{11}$ The Swiss government's solidarity policy initially focused on Europe, where it contributed to the Marshall Plan in aid of the reconstruction of Europe. The provision of Swiss aid to the Third World started in 1949-1950. The Federal Council decided to participate in the Expanded Programme of Technical Assistance, later the UN Development Programme (UNDP), launched by the UN on the proposal of US President Harry S. Truman. In the 195os, Swiss official aid consisted mainly of contributions to multilateral aid programmes, support for private Swiss charities, expert missions, and scholarships for foreign students. ${ }^{12}$

Between 1959 and 1961, when many sub-Saharan African states achieved their independence, the Swiss government's development aid policy was reorganised and its budget increased. In 1961, the Federal Council created the STC within the FPD, headed by the Delegate for Technical Cooperation. The term 'technical cooperation', used since 1961 instead of 'technical aid, ${ }_{13}^{13}$ underlines the supposedly apolitical character of Swiss development cooperation with the Third World. Yet, from its inception, Switzerland's development policy was politically motivated. On the one hand, it was aimed at containing Communist influence in the Third World. ${ }^{14}$ On the other hand, there was a merging of development cooperation and the promotion of Swiss exports. ${ }^{15}$ Within the FPD, the STC was responsible for Switzerland's bilateral development aid. Humanitarian aid and multilateral assistance were primarily the domain of the DIo. The Trade Division was in charge of different resources for aid for trade, such as capital exports, export risk guarantees (ERG), and financial agreements. The

11 Trachsler, Bundesrat Max Petitpierre, pp. 98-99, 110-115.

12 Daniele Waldburger, Lukas Zürcher, Urs Scheidegger, 'Im Dienst der Menschheit'. Meilensteine der Schweizer Entwicklungszusammenarbeit seit 1945, Bern: Haupt, 2012, pp. 20-30; René Holenstein, Wer langsam geht, kommt weit. Ein halbes Jahrhundert Schweizer Entwicklungshilfe, Zürich: Chronos, 2010, pp. 48-49.

13 See Marc Perrenoud, "Les relations de la Suisse avec l'Afrique lors de la décolonisation et des débuts de la coopération au développement", Revue internationale de politique de développement, 1 (2010), pp. 81-98, p. 88.

14 Daniel Trachsler, "Neutralität, Solidarität und Kalter Krieg: Die Entwicklungshilfe als aussenpolitisches Instrument in der Ära Petitpierre, 1945-1961" in Sara Elmer, Konrad J. Kuhn, Daniel Speich Chassé, Itinera. Handlungsfeld Entwicklung. Schweizer Erwartungen und Erfahrungen in der Geschichte der Entwicklungszusammenarbeit/Le champ d'action "développement". Attentes et expériences suisses dans le travail de développement, Basel: Schwabe, 2014, pp. 167-183.

15 Roger Graber, Entwicklungshilfe und Exportförderung im Kalten Krieg: Interessen, Motive und Strategien der Schweizer Exportindustrie in Entwicklungsländern (1955-1965), unpublished Master thesis, University of Zurich, 20o6. See also the contributions in Peter Hug, Beatrix Mesmer (eds.), Von der Entwicklungshilfe zur Entwicklungspolitik, Bern: SFA, 1993. 
division of competences was not always clear. In the 196os, bilateral project aid guided and financed by the STC was frequently executed by non-governmental organisations (NGO). According to guidelines established in 1964, development cooperation was subject to the approval of the receiving state and the bulk of aid was to be focused on a few key countries. The selection of these countries was somewhat arbitrary and based on ideological criteria, the presence of Swiss settlers or charities, or perceived similarities with Switzerland. ${ }^{16}$

Until the mid-196os, the Swiss government's development policy enjoyed broad domestic acceptance. This changed towards the end of the decade. With some delay, Swiss churches and solidarity groups took up the criticism of unequal North-South relations that had been issued by Third World governments a few years previously and demanded, in particular, the disconnection of aid from economic interests. Right-wing circles insisted that Swiss taxpayers' money should not be spent abroad and opposed the solidarity movement's demands for an increase in Switzerland's aid budget. Due to the growing politicisation of development cooperation, it took five years for a law on humanitarian aid and development cooperation to be adopted, in March $1976 .{ }^{17}$ The intense domestic debates surrounding Switzerland's development cooperation policy and the multitude of state and private actors involved in its implementation - charities, missionary societies, economic leaders-meant that the Swiss government's freedom of action in the field of aid was, to some extent, restricted.

Despite government efforts to increase Switzerland's commitment to development aid, the latter remained notoriously limited. In a comparative analysis of the aid policies of Austria, Denmark, Finland, Norway, Sweden, and Switzerland, economist Jacques Forster observed the emergence of two groups. Denmark, Sweden and Norway strongly increased their disbursements for development cooperation in the 1970s and exceeded the OECD target of $0.7 \%$ of gross national product at the end of the decade. The commitment of Austria, Finland and Switzerland hovered around $0.2 \%$ in 1979. In 1978, the Swedish government spent nearly 4.5 times as much as its Swiss counterpart on aid to the Third World. ${ }^{18}$ For this reason, some contemporaries criticised Switzerland

16 Waldburger, Zürcher, Scheidegger, 'Im Dienst der Menschheit', pp. 47-55. See also Zürcher, "So fanden wir auf der Karte diesen kleinen Staat".

17 See Samuel Misteli, "Der UnCTAD-Moment. Die Entstehung des Nord-Süd-Konflikts und die Politisierung des Schweizer Entwicklungsdiskurses”, in Elmer, Kuhn, Speich Chassé, Handlungsfeld Entwicklung, pp. 185-211; Holenstein, Wer langsam geht, pp. 62-66.

18 Jacques Forster, "Die öffentliche Entwicklungshilfe sechs kleiner europäischer Länder: Dänemark, Finnland, Norwegen, Oesterreich, Schweden, Schweiz. Grundlagen für eine vergleichende Analyse", Entwicklung/Développement 8 (1981), pp. 2-14. 
for not pulling its weight in the global South. Commenting on the disconnect between Switzerland's economic and financial strength and its unimpressive public foreign aid record, the US ambassador in Bern suggested in 1968 that Switzerland should be encouraged to "compare its performance with that of the 'big countries' rather than to let the Swiss indulge in their propensity for small-country thinking." 19

How do Switzerland's relations with Angola, Mozambique, Ethiopia, and Somalia fit the foreign policy pattern just sketched out? While Somalia was one of many states to achieve independence in 196o, the other three countries occupied exceptional positions during the decolonisation of sub-Saharan Africa. Ethiopia has never been colonised, whereas Angola and Mozambique were among the last colonies on the African continent because the authoritarian Portuguese government refused decolonisation until the mid-197os. This chapter first gives an overview of Switzerland's political and humanitarian relations with the four African countries under consideration prior to the regime changes, or, in the case of the Portuguese colonies, before the intensification of the national and international debate surrounding white minority rule in the late 196os. Secondly, it focuses on the development of commercial exchanges with and investments in the four countries and determines their relative importance compared to the whole continent. This reveals the overwhelming significance of Switzerland's political, economic, and financial interests in Apartheid South Africa to its foreign policy on the continent.

Four (Un-)Exceptional Cases: Relations with Angola, Mozambique, Ethiopia and Somalia

Somalia is the only one of the four selected African countries whose relations with Switzerland developed in line with the Swiss government's established policy during decolonisation. However, it held very little interest for Switzerland's political and economic elites and bilateral relations were extremely low-key. Scholars of Somali history underline the homogeneity of its population and culture and the strong nationalism of its people, which would determine its post-independence history. This clan-based, Muslim society of mostly pastoral nomads established trading cities on the coast of the Gulf of Aden

19 Airgram from John S. Hayes, US ambassador in Switzerland, to the Department of State, "Aid Club of Small Countries", 19.03.1968, p. 2, National Archives and Record Administration, College Park, Maryland, USA (NARA), Record Group (RG) 59, Subject-Numeric Files 1967-1969, AID (sWITZ), box 45o. 
and the Indian Ocean. In the second half of the nineteenth century, Britain, France, and Italy began to increase their control over the coast of the Horn of Africa, competing for colonial influence. At the same time, the Ethiopian Empire expanded its territory to include the Somali-inhabited Ogaden region in the hinterland. By 1897, a series of treaties completed Somalia's partition. French Somaliland (from 1967, French Territory of the Afars and Issas, Djibouti after independence in 1977) was bordered by the British Somaliland Protectorate on the Gulf of Aden. In the South, on the coast of the Indian Ocean, Italy established a colony. Until its defeat in 1920, the religious Derwish movement headed pan-Somali resistance against colonial domination. Somali territories were briefly unified by the Second World War. In August 1940, the Italian army captured British Somaliland, having already occupied Ethiopia, including the Ogaden, in 1936. In early 1941, the British reoccupied northern Somalia. They continued on and took control of Ethiopia for the Ethiopian Emperor as well as Italian Somaliland. For almost a decade, the Ogaden as well as British and Italian Somaliland were under British military administration. In this period, Somali nationalism grew. Among a number of Somali associations and movements, the Somali Youth Club opened in Mogadishu in May 1943. Later renamed the Somali Youth League (SYL), it turned into a political party that aimed to unite all Somalis and educate the youth. Although it was unable to prevent the UNGA 1949 decision to return Italian Somaliland to Italy for ten years as a UN trusteeship or the return of the Ogaden to Ethiopia that was completed in 1954, the SYL was instrumental in leading British and Italian Somaliland to independence and union. On 1 July 1960, the Republic of Somalia was created as a liberal democracy. While the SYL remained the most powerful political party, a multitude of other political parties echoed clan divisions and increased political fragmentation. The difficulties of incorporating the former British and Italian territories, with their different administrative structures and colonial languages, into a single state also contributed to this. ${ }^{20}$

After Somalia's independence, the Swiss Federal Council recognised the new state and sent the head of the DIO to attend the independence ceremonies in Mogadishu. ${ }^{21}$ As economic exchange between the two states was virtually nonexistent and only seven Swiss nationals lived in Somalia, the establishment of

20 For useful introductions to Somali history, see David D. Laitin, Said S. Samatar, Somalia. Nation in Search of a State, Boulder:Westview Press, 1987; Ioan M. Lewis, A Modern History of the Somali. Nation and State in the Horn of Africa, Oxford: James Currey, 4th edition, 2002.

21 Max Petitpierre, Federal Councillor and head of the FPD, proposal to the Federal Council, "Cérémonies d'indépendance de la Somalia. Nomination de M. le Ministre Jean de Rham, Chef de la Division des organisations internationales, en qualité d'Ambassadeur 
a diplomatic representation in this state was not considered a priority. ${ }^{22}$ From independence, Somalia's foreign policy was driven by the will to unite, under one banner, ethnic Somalis who were living in French Somaliland, Kenya's Northern Frontier District, and the Ethiopian Ogaden region. This led to tensions and armed conflicts with Somalia's neighbouring states. ${ }^{23}$ Therefore, the FPD's Administration Division (AD) decided in July 1967 to accredit the Swiss ambassador in Egypt to Somalia. ${ }^{24}$ A year later, Switzerland and Somalia finally established diplomatic relations. In November 1968, a consular agency under the guidance of Swiss businessman Robert Camenzind was opened in Mogadishu. ${ }^{25}$ Swiss development aid provided to Somalia was very limited and amounted to a total of CHF 270,00o for the period from 1961 to early $1967 .{ }^{26}$ The 1969 coup d'état by General Mohammad Siad Barre, who instituted a military regime and concluded a friendship treaty with the Soviet Union in July 1974, therefore had little impact on Swiss interests.

In Ethiopia, the situation was different. The history of modern Ethiopia is said to have begun with the coronation of Emperor Tewodros in 1855 . He started a process of unification and centralisation in the Horn of Africa by bringing a series of principalities and territories under the control of this multi-ethnic state headed by a Christian elite. Ethiopia's territorial expansion continued against the backdrop of European colonialist designs on the region. Emperor Menelik's 1896 victory against an invading Italian army at Adwa confirmed Ethiopia's independence. In a succession of treaties, the European colonial powers subsequently recognised Ethiopia's frontiers and the African state joined the League of Nations in $1922 .{ }^{27}$ Swiss contacts with the Ethiopian Empire date back to the arrival of the first Swiss missionaries in Ethiopia in the early nineteenth century. For 30 years from 1878 , Swiss engineer and railway pioneer Alfred Ilg acted as advisor to the Ethiopian court. These bilateral ties intensified in the twentieth century. In May 1933, Bern signed a Friendship and

extraordinaire en mission spéciale et Chef de la délégation suisse", 16.06.1960, SFA E2001E\#1980/83\#4044*.

22 Note from Raymond Probst, FPD, to Jean de Rham, head of the DIO, "Somalia", 15.06.196o, SFA E2OO1E\#1980/83\#4044*.

23 Laitin, Samatar, Somalia, pp. 129-138; Lewis, A Modern History of the Somali, pp. 178-195.

24 Letter from Fred Bieri, AD, to André Parodi, Swiss ambassador in Egypt, "Republik von Somalia", 12.07.1967, SFA E2004B\#199o/219\#615*.

25 Information and Press Service of the FPD, press release, "Aufnahme diplomatischer Beziehungen", 24.07.1968, SFA E2001E\#1980/83\#4044*; Ch. Glauser, AD, notice, "Agence consulaire de Suisse à Mogadiscio (Somalie)", 11.11.1968, sFA E2004B\#199o/219\#615*.

26 Letter from Jacques Rial, STC, to the Swiss embassy in Egypt, 25.07.1967, SFA E2005A\#1980/82\#798*.

27 See Bahru Zewde, $A$ History of Modern Ethiopia. 
Trade Treaty with the government of Emperor Haile Selassie, who came into power in 1930. Swiss firms like the arms manufacturers Oerlikon Bührle and Schweizerische Industriegesellschaft Neuhausen (SIG) established trade relations with Ethiopia. Between 1934 and 1936, industrialist Emil Bührle acted as Ethiopia's honorary consul in Zurich. ${ }^{28}$

The Italo-Ethiopian War of $1935^{-1936}$ and the subsequent Italian occupation of Ethiopia cast a shadow over these developing relations. On 3 October 1935, the Mussolini regime attacked Ethiopia, its fellow member of the League of Nations. As this constituted a breach of the League's Covenant, the organisation's General Assembly imposed sanctions on the attacker. The Swiss government, which had joined the League of Nations in 1920 after the organisation specifically acknowledged Switzerland's neutral status, voted with the majority. However, Bern's subsequent actions revealed its solidarity with its southern neighbour, with which it had very close cultural, economic, and political links. Keen to preserve cordial relations with Mussolini's fascist regime, and considering Ethiopia to be a backward, underdeveloped country with a government lacking state control, the Swiss authorities watered down the sanctions. They limited trade with Italy to the pre-attack level instead of interrupting it, and extended the embargo on arms exports to Ethiopia as well as its attacker. This position was criticised by other League members and damaged Switzerland's image within the organisation. When the Italo-Ethiopian War ended in May 1936 with the occupation of Addis Ababa, the Swiss authorities supported the early lifting of sanctions against Italy, refused permission to the Ethiopian emperor to live in his villa at Lake Geneva, and, in December 1936, formally recognised Italian sovereignty over Ethiopia. ${ }^{29}$

The end of the Second World War saw an important territorial reorganisation in the Horn of Africa, which would cause bitter struggles in the coming decades. In late 1941, British and Ethiopian troops liberated Ethiopia. In 1950, the UNGA joined together the former Italian colony of Eritrea in a federation with

28 Christoph Graf, "Die Schweiz und die Dritte Welt. Die Anerkennungspraxis und Beziehungsaufnahme der Schweiz gegenüber dekolonisierten aussereuropäischen Staaten sowie die Anfänge der schweizerischen Entwicklungshilfe nach 1945", Studien und Quellen 12 (1986), pp. 37-112, pp. 44-47; Marc Perrenoud, "Ethiopie", 15.10.2001, Historical Dictionary of Switzerland (HLS) Online, http://www.hls-dhs-dss.ch (13 January 2021); Beat de Fischer, Contributions à la connaissance des relations suisses-égyptiennes (d'environ 100 à 1949) suivies d'une esquisse des relations suisses-éthiopiennes (jusqu'en 1952), Lisbon: Ramos, Afonso \& Moita, Ltd, 1956, pp. 281-302.

29 See Neville Wylie, Marco Wyss, "Neutrality 'de jour': Switzerland and the Italo-Abyssinian War of 1935-6" in Frank McDonough (ed.), The Origins of the Second World War. An International Perspective, London: Continuum, 2011, pp. 278-293; Rainer Baudendistel, Between Bombs and Good Intentions. The Red Cross and the Italo-Ethiopian War, 1935-1936, New York: Berghahn Books, 2006, pp. 7-15. 
Ethiopia. The Ogaden area in the east of Ethiopia, which had been annexed by the UK during the War, was restored to Ethiopia in 1954. From the early 1950s onwards, US influence in Ethiopia increased. In 1953, the two states signed military agreements that guaranteed US access to Ethiopian military installations, notably the Kagnew base at Asmara, Eritrea, in exchange for extensive military assistance. The US also played an important role in the development of infrastructure and in education. ${ }^{30}$ Swiss-Ethiopian relations normalised soon after the Second World War. In June 1952, the Swiss Parliament agreed to the opening of a Swiss diplomatic representation in Addis Ababa. In November 1954, Haile Selassie made a state visit to Switzerland, which garnered much interest from the press and the Swiss population. ${ }^{31}$ After this visit, political relations between the two states deepened, although they were mostly focused on the person of the Emperor, who travelled regularly to Geneva and Lausanne. In 1970, 130 Swiss citizens lived in Ethiopia, working in business capacities, as employees of international organisations and aid projects, or as teachers, or missionaries. ${ }^{32}$ Since Addis Ababa hosted the headquarters of the OAU and offices of several international organisations, Heinz Langenbacher, Swiss ambassador to Ethiopia in the early 1970s, frequently underlined the city's importance as an international capital_-“'Africa's Geneva". ${ }^{33}$

In the 196os, Switzerland's development cooperation with Ethiopia, one of Africa's poorest states, was sparse. The sTC supported only a single project: the construction of a commercial college in Dire Dawa that was inaugurated in November 1967 and managed by the Swiss branch of an order of Franciscan nuns. ${ }^{34}$ Between 1961 and 1971, Switzerland's total aid to Ethiopia, including

30 Bahru Zewde, A History of Modern Ethiopia, pp. 179-189; Paul B. Henze, Layers of Time. A History of Ethiopia, London: Hurst \& Company, 200o, pp. 235-248. For Ethiopia's military relationship with the US until the 1970s, see Jeffrey A. Lefebvre, Arms for the Horn. U.S. Security Policy in Ethiopia and Somalia 1953-1991, Pittsburgh: University of Pittsburgh Press, 1991, pp. 55-172.

$31 \quad$ Graf, "Die Schweiz und die Dritte Welt", pp. 46-55; letter from Etienne Dennery, French ambassador in Switzerland, to the French foreign minister, "Visite du Négus en Suisse", 23.11.1954, Centre des Archives diplomatiques, Nantes, France (CADN) 89PO/2002021/424. Letter from Fernand Bernoulli, Swiss Ambassador in Ethiopia, to the AD, "Schlussbericht des Missionschefs von Addis Abeba”, confidential, 07.07.1970, pp. 1-5, 8, Diplomatic Documents of Switzerland 1848-1975 (Dodis) Online, https://www.dodis.ch/en (13 January 2021), dodis.ch/37162.

33 Scherer, Durch die tiefsten Tiefen des Wellentals, p. 120.

34 Note from Sigismond Marcuard, Delegate for Technical Cooperation, to Heinz Langenbacher, Swiss ambassador in Ethiopia, "Projets de coopération technique en Afrique", 13.08.1970, SFA E2OO5\#1983/8\#169*; note from Serge François Salvi, STC, to Anne de Riedmatten, DIO, "Note concernant l'Ecole 'Notre Dame' à Dire-Dawa, Ethiopie", 16.o9.1970, SFA E2005\#1983/8\#170*. 
scholarships, support for missionaries, and food aid, amounted to approximately CHF 1.6 million. This corresponds to $0.9 \%$ of the STC's framework budget of $\mathrm{CHF} 180$ million for 1970-1972. ${ }^{35}$

In the early 1970s, the Swiss government engaged in one of its most considerable aid projects in Africa at that time; the financing and partial running of the Duke of Harar Memorial Hospital in Addis Ababa. Designed to serve as a university hospital with 5 oo beds, it was built by a Yugoslav firm, financed by an Ethiopian foundation, and handed over to the Ethiopian government in $1971{ }^{36}$ Unable to finance the equipment and running of the hospital, the Ethiopian government asked the governments of the US, USSR, UK, FRG, the Scandinavian countries, and Yugoslavia to step in. While the governments contacted agreed that the construction of such a large hospital had been a mistake and the local representative of the World Health Organization (wHO) expressed his scepticism, the project aroused the interest of the medical faculty of the university hospital in Bern. Professor Maurice Müller, head of the faculty's orthopaedic department, who had briefly directed a hospital in Ethiopia in the 1940 and was a personal friend of Federal Councillor Nello Celio of the FDF, played a key role in persuading the Swiss government to take on the project. ${ }^{37}$ Thanks to this personal connection, the FDF was involved in the early stages. On 12 October 1971, Nello Celio accepted a letter from Haile Selassie, asking Switzerland to equip and take over the running of the hospital for three years. Ten days later, a delegation of hospital specialists accompanied by the ViceDirector of the FDF's Financial Administration travelled to Addis Ababa. The delegation considered the takeover of the hospital to be a great opportunity, highlighting in particular the chance to foster goodwill in Africa's capital and the possibility of strengthening the position of Switzerland's pharmaceutical industry in Ethiopia. ${ }^{38}$

35 Pierre Graber, Federal Councillor and head of the FPD, proposal to the Federal Council, "Technische Zusammenarbeit und humanitäre Hilfe mit Aethiopien. Teileröffnung des Duke of Harar-Spitals in Addis Abeba", 29.03.1973, pp. 2-3, SFA E2001E-o1\#1987/78\#2799*; Swiss Federal Council, Bericht des Bundesrates an die Bundesversammlung über seine Geschäftsführung im Jahre 1971, 23.02.1972, p. 35.

36 Pierre Graber, proposal to the Federal Council, "Technische Zusammenarbeit und humanitäre Hilfe mit Aethiopien. Teileröffnung des Duke of Harar-Spitals in Addis Abeba", 29.03.1973, p. 6, SFA E2OO1E-o1\#1987/78\#2799*.

Letter from Heinz Langenbacher to the sTc, "Prinz Makonnen-Spital, Addis Abeba", 11.10.1971, pp. 1-2, SFA E610oB-o2\#1986/168\#1720*; note from AL to René Keller, chief of DIO, "Prinz Makonnen-Spital in Addis-Abeba", 19.10.1971, ibid.

38 Note from Bernhard Müller, Vice-Director of the Financial Administration of the FDF, to Nello Celio, Federal Councillor and head of the FDF, "Duke of Harar Memorial Hospital Addis Abeba; Besichtigungsreise vom 20. bis 24. Oktober 1971”, o3.11.1971, SFA 
The STC, however, considered the project to be too ambitious and too expensive, arguing that only multilateral action could ensure the running of the hospital in the years to come. ${ }^{39}$ Although the majority of FPD leaders opposed the takeover of the Duke of Harar Hospital, Celio and Professor Müller informed the Ethiopian government that Switzerland would step in. The FPD was left in the dark and, in May 1972, presented with a fait accompli. ${ }^{40}$ Due to Switzerland's limited budget for foreign aid, the proposal submitted to the Swiss Federal Council in March 1973 was substantially reduced. The FPD suggested a partial opening of the hospital under Swiss direction. With a capacity of 150 beds and a polyclinic able to treat up to 300 patients a day, the hospital was to focus on the teaching and formation of Ethiopian health staff. The salaries of the 40 Swiss personnel were to be paid by the Swiss authorities, while the Ethiopian government assured the remuneration of the 15 othiopian employees. After three years, the running of the hospital was to be handed over to the Ethiopian counterparts. Switzerland's contribution to the project amounted to CHF 8 million, 2 million of which were to be covered by the medical faculty of the University of Bern, which was also responsible for managing the project. ${ }^{41}$

On 3 November 1973, Haile Selassie officially opened the Duke of Harar Memorial Hospital in the presence of many Ethiopian government members, the diplomatic corps, representatives of international organisations, and the press. Ambassador Langenbacher was optimistic about the project's success and professed himself happy "to have received, with this development project, a political instrument, which should considerably facilitate my work in other areas." ${ }^{22}$ Little did he know that within a year, during the Ethiopian Revolution,

E610oB-o2\#1986/168\#1720*; Prof. Maurice Müller, head of the orthopaedic department of the university hospital in Bern, Prof. Rudolf Preisig, dean of the medical faculty of the university of Bern, F. Althaus, head of technical services of the university hospital in Bern, Jakob Itten, architect, Walter Mamie, executive director of the Tiefenau hospital in Bern, report, "Duke of Harar Memorial Hospital Addis Abeba. Bericht der Informationsreise", 10.12.1971, pp. 1, 29, SFA E2001E-o1\#1987/78\#2799*.

39 Letter from Sigismond Marcuard to Maurice Müller, 18.11.1971, SFA E610oB-o2\#1986/ $168 \# 1720^{*}$.

40 Note from Bernhard Müller to the stc, "Prinz Makonnen-Spital Addis Abeba", 12.05.1972, SFA E2001E-o1\#1987/78\#2799*; letter from Heinz Langenbacher to the STC, "Prinz Makonnen-Spital Addis Abeba”, 27.04.1972, ibid.; note from Bernhard Müller to Nello Celio, "Prinz-Makonnen Spital Addis Abeba", o1.05.1972, SFA E610oB-o2\#1986/168\#1720*.

Pierre Graber, proposal to the Federal Council, "Technische Zusammenarbeit und humanitäre Hilfe mit Aethiopien. Teileröffnung des Duke of Harar-Spitals in Addis Abeba", 29.03.1973, pp. 8-14, SFA E2001E-o1\#1987/78\#2799*.

42 Letter from Heinz Langenbacher to Pierre Graber, "Eröffnung des 'Duke of Harrar Memorial Hospital', Addis Abeba”, o5.11.1973, p. 2, SFA E2001E-o1\#1987/78\#2799*. 
the hospital would become a liability. In early 1974, civil and military protest against Haile Selassie's autocratic regime escalated. After months of political turmoil, the Emperor was forced to step down in September 1974 and the military government that assumed power would subsequently turn towards the USSR.

With the exception of some internal disagreements about the Swiss engagement in the Duke of Harar project, Switzerland's bilateral relations with independent Somalia and Ethiopia were largely uncontroversial before the regime changes. As Angola and Mozambique remained under colonial rule and experienced violent independence wars, and African leaders and Swiss civil society actors strongly criticised white minority rule in Southern Africa from the late 196 os onwards, Switzerland's role in these two states was more contentious. Bern's political course, which would remain in place until Mozambique and Angola became independent in 1975, was set during the early phase of the independence wars, which started with the uprising of Angolan nationalists in 1961. At that time, Swiss foreign policymakers saw no need to deviate from their tried and tested low-key attitude and adopted a wait-and-see approach. The approach can be summed up as keeping the door open to both the colonisers and the colonised, while avoiding taking an official position. The Swiss government was careful to remain on good terms with Lisbon, its fellow member of the European Free Trade Association (EFTA), while not antagonising nationalist leaders that might later become part of independent African governments.

Portugal's presence in Africa dates back to the sixteenth century, when it established supply points on the sea routes to Asia on the islands of Cape Verde and São Tomé e Príncipe and on the coasts of Guinea-Bissau, Angola, and Mozambique. In the seventeenth and eighteenth centuries, its presence was motivated by the Atlantic slave trade. Angolans, in particular, were enslaved and transported to the plantations in the Portuguese colony of Brazil. Following Brazil's independence, in 1822, and the abolition of the slave trade, Portugal exercised scant control over its few coastal possessions in Africa. During the European imperial powers' 'scramble for Africa' in the late nineteenth century, Portugal started to extend its political, military, and economic control over its colonies. In Mozambique, concession companies that operated sugar and cotton plantations with foreign capital initially played an important role in the administration of the territory. In Angola, rubber and later cotton and coffee plantations were established. It was not until 1926 that forced labour was abolished in Portuguese Africa. Under the authoritarian Estado Novo regime in Portugal, which came into power in 1933, the administration of the colonies 
was further centralised. Compared to other African regions, anti-colonial protest was slow to emerge and was poorly coordinated until the 195 os. $^{43}$

In the early 1950s, Angolan nationalists started to manifest their discontent with Portugal's colonial rule and formed a variety of political groups to promote self-determination. Two rival movements each claimed to have started the armed uprising in Angola: the multiracial MPLA that was based in the area of the capital, Luanda, and included members of the Angolan Communist party, and the União dos Povos de Angola (Union of the Peoples of Angola, UPA). The UPA, which would become the Frente Nacional para a Libertação de Angola (National Front for the Liberation of Angola, FNLA) in 1962, was based on the common ethnic background of its members and had its strongholds in the north of Angola. Its leader, Holden Roberto, had close links to the elites of the neighbouring Congo. In February 1961, MPLA members attacked Luanda's main prison and other targets in the city. The Portuguese International and State Defence Police (PIDE), rechristened Directorate-General of Security (DGS) in 1969, immediately crushed their rebellion. Several hundred Angolans were killed in reprisals perpetrated by the police and white settlers. In March 1961, uprisings in the coffee-growing regions of northern Angola, reputedly organised by the UPA, caused the death of approximately 1,500 black Angolans and several hundred European settlers, while white reprisals and the belated reaction of the Portuguese military claimed tens of thousands of victims. As the Portuguese military presence increased dramatically over the following months, the conflict settled down into sporadic guerrilla warfare, in which the liberation movements fought both the Portuguese colonial army and each other. ${ }^{44}$

On 15 March 1961, the UN Security Council voted on a resolution put forward by Liberia that urged Portugal to introduce reforms in Angola. Although both the USSR and the US voted in favour of this resolution, it was defeated by six abstentions, including those of the UK, France, and the Republic of China. ${ }^{45}$ This breakdown of votes is indicative of the major Western powers' position during the early independence war in Angola. The Kennedy administration initially spoke out against Portugal's violent suppression of African nationalism.

43 Norrie MacQueen, The Decolonization of Portuguese Africa. Metropolitan Revolution and the Dissolution of Empire, London: Longman, 1997, pp. 1-15.

44 Ibid., pp. 18-20, 23-24. For a detailed overview of early Angolan nationalism and the outbreak of the independence war in Angola, see John A. Marcum, The Angolan Revolution. Volume I: The Anatomy of an Explosion (1950-1962), Cambridge, MA: MIT Press, 1969. Bruno Cardoso Reis, "Portugal and the UN: A Rogue State Resisting the Norm of Decolonization (1956-1974)", Portuguese Studies 29:2 (2013), pp. 251-276, pp. 262-263. 
In a radical break with his predecessor's policy, John F. Kennedy sought contact with moderate nationalist leaders in Portuguese Africa and supported several UN resolutions critical of Portuguese colonialism. From mid-1962, however, Washington's attitude changed, not least because the Kennedy administration wanted to ensure continued access to its strategically important military base on the Portuguese Azores. ${ }^{46}$ London's position was more cautious. Although the British Labour government was committed to the principle of self-determination and embarrassed about Lisbon's resistance to decolonisation, it refused to put too much pressure on its historical ally and fellow member of EFTA. The ongoing decolonisation process in British colonies was also a factor in London's discreet attitude. ${ }^{47}$ France and the FRG supported the authoritarian Estado Novo regime in Portugal, especially in the fields of military cooperation and arms sales. ${ }^{48}$

The outbreak of armed violence in Angola in 1961 quickly gained high-level attention in Switzerland. While Swiss foreign policymakers never doubted that the Portuguese territories would be decolonised in the foreseeable future, they had no inkling that the independence wars would drag on for more than fourteen years. Fearing that the situation might escalate, as it had in Algeria and the Congo, FPD leaders were concerned about the safety of Swiss citizens in Angola. More than fifty Swiss nationals left the colony between December 1960 and early July 1961. Out of the approximately 8 o people that stayed, more than half were members of Protestant or Catholic missionary societies. Many of the others worked as engineers, geologists, or mechanics. In July 1961, the FPD's Secretary General, Pierre Micheli, insisted that in order to better protect Swiss citizens and interests, Switzerland's consular agency should be transformed

46 For a recent overview of different states' positions during the early independence wars, see Luís Nuno Rodrigues, "The International Dimensions of Portuguese Colonial Crisis", in Miguel Bandeira Jerónimo, António Costa Pinto (eds.), The Ends of European Colonial Empires. Cases and Comparisons, Houndsmills: Palgrave Macmillan, 2015, pp. 243-267. On the Kennedy administration's policy on Portuguese colonialism and Africa in general, see Borstelmann, The Cold War and the Color Line, pp. 135-171; Philip E. Muehlenbeck, Betting on the Africans: John F. Kennedy's Courting of African Nationalist Leaders, Oxford: Oxford University Press, 2012; Luís Nuno Rodrigues, "The United States and Portuguese Decolonization”, Portuguese Studies 29:2 (2013), pp. 164-185; Schneidman, Engaging Africa, pp. $1-58$.

47 Pedro Aires Oliveira, "Live and Let Live: Britain and Portugal's Imperial Endgame (194575)", Portuguese Studies 29:2 (2013), pp. 186-208; Glyn Stone, "Britain and the Angolan Revolt of 1961", The Journal of Imperial and Commonwealth History 27:1 (1999), pp. 109-137; Glyn Stone, "Britain and Portuguese Africa, 1961-65", The Journal of Imperial and Commonwealth History 28:3 (2000), pp. 169-192.

48 Ana Mónica Fonseca, Daniel Marcos, "Cold War Constraints: France, West Germany and Portuguese Decolonization”, Portuguese Studies 29:2 (2013), pp. 209-226. 
into a consulate before the uprisings in Angola developed into all-out war. If the situation deteriorated, the establishment of a diplomatic representation might have unwelcome political or legal consequences, notably implying Switzerland's recognition of Angola as an independent state. Micheli wished to preserve Switzerland's cordial relations with the colonial power by avoiding "too big a snub to Portugal". The consulate in Luanda was established in January 1962 and was headed by a Swiss businessman as honorary consul. ${ }^{49}$

The year 1963 started with the first attacks made by the Partido Africano da Independência da Guiné e Cabo Verde (African Party for the Independence of Guinea and Cape Verde, the PAIGC) against the Portuguese colonial authorities. The PAIGC would soon control a significant part of the territory of Guinea-Bissau and prove a greater challenge to the Portuguese military than the liberation movements in both Angola and Mozambique..$^{50}$ In May of the same year, the newly founded OAU enhanced the legitimacy of the liberation struggles in Southern Africa by providing the nationalist movements with diplomatic and material support. The OAU also decided to proceed with "the breaking off of diplomatic and consular relations between all African States and [the] Governments of Portugal and South Africa so long as they persist in their present attitude towards decolonization". ${ }^{11}$ Two months later, the Swiss government was asked to act as Portugal's protecting power in Senegal. Lisbon's choice was probably motivated by Switzerland's long experience as a protecting power. During the Second World War, Bern had simultaneously represented the interests of 35 different states in over 200 mandates. During the Cold War, it continued to be asked to undertake such mandates, most famously by the US in Cuba in $1961 .{ }^{52}$ The language factor also played a role. As French

49 Note from Pierre Micheli, Secretary General of the FPD and head of the DPA, to the AD, "Vertretung in Angola", o6.o7.1961, SFA E2004B\#1974/53\#90*; see also the attached memorandum by Edouard Brügger, DPA, "Aktennotiz betreffend Schweizerkolonie und Lage in Angola. Lage in Angola", o6.07.1961. See also the excerpt of the minutes of the Federal Council's meeting on 10 January 1962, "Transformation de l'agence consulaire de Suisse à Luanda (Angola) en un consulat. - Nomination de M. Roland Gottraux, agent consulaire, en qualité de consul honoraire de Suisse à Luanda", pp. 1-2, ibid.

50 Norrie MacQueen, "Portugal's First Domino: 'Pluricontinentalism' and Colonial War in Guiné-Bissau, 1963-1974", Contemporary European History 8:2 (1999), pp. 209-23o, pp. 209, 212.

Resolution CIAS/Plen.2/Rev.2 adopted by the first conference of independent African heads of state and government from 22 to 25 May 1963, "Decolonization", https://au.int/ sites/default/files/decisions/32247-1963_cias_plen_2-3_cias_res_1-2_e.pdf (13 January 2021).

52 Thomas Fischer, "From Good Offices to an Active Policy of Peace: Switzerland's Contribution to International Conflict Resolution" in Jürg Martin Gabriel, Thomas Fischer (eds.), Swiss Foreign Policy, 1945-2002, Houndsmills: Palgrave Macmillan, 2003, pp. 74-104, p. 77. On Switzerland's representation of US interests in Cuba, see Virginie Fracheboud, "La 
is one of Switzerland's national languages, the Portuguese foreign ministry considered "that it would be very convenient if the Swiss government were to accept to take on the representation of Portuguese interests in some francophone African countries".53

The Portuguese request created a dilemma for the FPD. On the one hand, the willingness to represent the interests of third countries was part of Switzerland's active neutrality policy and helped to show the usefulness of a neutral stance. On the other hand, the department's leaders worried that acting as Portugal's protecting power might endanger Switzerland's own interests in Senegal and on the African continent. Still, the department's head concluded that there were insufficient reasons to refuse the mandate. ${ }^{54}$ Starting in mid-1963, Bern provided consular assistance to the 30,000 Portuguese nationals living in Senegal. ${ }^{55}$ Nevertheless, the FPD wanted to make it clear that representing Portugal's interests did not signify approval of its colonial policy. Accordingly, the Swiss ambassador in Senegal was ordered to mention Switzerland's readiness to defend Senegalese interests in Portugal to his host country's government. ${ }^{56}$ Such a double mandate would have minimised the risk of being perceived as the agent of a colonial power. But while Dakar gave its agreement to Switzerland representing Portuguese interests in Senegal, it showed no interest in conferring a mandate of its own. ${ }^{57}$ Egypt aside, where Franco's Spain acted as Portugal's protecting power and Brazil took on the corresponding mandate for the Nasser government, there were few Portuguese interests at stake in other African states that had severed their ties with Lisbon, and no further representation mandates were assigned. ${ }^{58}$

"In order to establish close ties of friendship with your country and government", representatives of Angolan and Mozambican nationalist movements

Suisse au service des intérêts américains à Cuba ou le succès de la politique de neutralité et solidarité (1961-1963)", Relations internationales 163:3 (2015), pp. 47-62.

Telegram no. 3 o from [?] Barreiros Martins, Portuguese Ministry of Foreign Affairs (MNE), to the Portuguese Embassy in Switzerland, 20.07.1963, Arquivo Histórico Diplomático, Lisbon, Portugal (AHD) PEA 1963, box 292.

Friedrich Traugott Wahlen, Federal Councillor and head of the FPD, proposal to the Federal Council, "Reprise éventuelle des intérêts du Portugal au Sénégal", 23.07.1963, p. 2, SFA E2OO1E\#1976/17\#4360*.

Letter from René Naville, Swiss Ambassador in Portugal, to the DPA, "Rupture de relations diplomatiques", 14.08.1963, SFA E2001E\#1976/17\#4352*.

56 Telegram no 25 from the FPD to the Swiss Embassy in Senegal, 25.07.1963, p. 1, SFA E2001E\#1976/17\#436o*.

57 Note from Raymond Probst, deputy head of the DPA, to Friedrich Traugott Wahlen, "Portugal im Verhältnis zu Drittstaaten”, 26.08.1963, p. 2, SFA E2001E\#1976/17\#4352*.

58 Letter from René Naville to the DPA, "Rupture de relations diplomatiques", 14.08.1963, SFA E2001E\#1976/17\#4352*. 
contacted the Swiss embassies in Algiers and Cairo in August 1963 in their quest for international recognition. ${ }^{59}$ Raymond Probst, the deputy head of the DPA, subsequently issued guidelines on Switzerland's attitude towards liberation movements and governments in exile that would remain valid for more than a decade. In a confidential note to Swiss diplomatic and consular posts in Africa, Probst warned them to take a suitably reserved approach towards these bodies and to react with caution to possible overtures, stating: "In fact, we have to avoid anything that might be interpreted as constituting an implicit recognition of these 'governments' or movements by Switzerland". At the same time, Swiss ambassadors were at liberty to have courteous relations with representatives of liberation movements if they should meet at diplomatic events. Conscious that some flexibility was needed, Probst left the manner of such contact to the good judgment of the ambassadors. ${ }^{60}$

When the armed struggle began in Mozambique in September 1964, there was little reaction from Bern. The war was launched by the Frente de Libertação de Moçambique (Liberation Front of Mozambique, FRELIMO), which was created in 1962 at the behest of Presidents Julius Nyerere of Tanzania and Kwame Nkrumah of Ghana and united three different regional and ethnically based liberation groups. However, the Portuguese military and secret service quickly countered FRELIMO's first attacks in northern Mozambique, while internal divisions initially occupied much of its leadership's attention. These continued after the assassination of FRELImo's first President, Eduardo Mondlane, in February 1969 and ended only when former military commander Samora Machel took over the presidency in May 1970. Under his leadership, FRELIM O's Marxist orientation was consolidated. In 1972 and 1973, the liberation movement intensified its guerrilla campaign. It extended its attacks to new regions in the centre of the country, away from its strongholds in the north where it had set up schools and administrative structures in the so-called liberated areas' ${ }^{61}$

In the mid-196os, however, FRELIMO did not pose much of a threat to the Portuguese army. By this time, the FPD's interest in the liberation wars in

59 Johnny Eduardo of the Angolan Revolutionary Government in Exile (GRAE)'s Algiers office, cited in the letter from Dietrich Kappeler, chargé d'affaires ad interim (a.i.) of the Swiss Embassy in Algeria, to the DPA, confidential, 23.08.1963, SFA E2001E\#1978/84\#5724*; see also the letter from Silvio Masnata, chargé d'affaires a.i. of the Swiss Embassy in Egypt, to the DPA, confidential, 27.08.1963, ibid.

6o Notification from Raymond Probst to Switzerland's diplomatic and consular posts in Africa, the Middle East, and the Far East, "Attitude à observer à l'égard des mouvements de libération et de gouvernements en exil”, confidential, 26.o9.1963, p. 1, SFA E2001E\#1976/17\#4375.

61 MacQueen, The Decolonization of Portuguese Africa, pp. 21; 25; 43-49. 
Portuguese Africa had waned, as the conflicts stagnated and there was little sign of a change in the status quo. The issue only reappeared when the Portuguese government occasionally criticised the anti-Portuguese activities of Angolan refugees in Switzerland or of Swiss missionaries in Angola and Mozambique. However, this never seriously harmed the friendly relations between the Swiss and Portuguese governments.

In the late nineteenth century, Protestant missionaries from the Frenchspeaking part of Switzerland had established missionary stations in Portuguese Africa. The Swiss Mission was active in Mozambique and South Africa, while the Mission philafricaine set up in Caluquembe, Angola. ${ }^{62}$ The Portuguese government and secret service suspected that the missionaries did not support their colonial policies and incited the local population to insubordination. As a consequence, some missionaries were refused return visas after a holiday in Switzerland in the early 1960s. US and British Protestant missions faced similar difficulties. ${ }^{63}$ In early 1965, the F PD's Secretary General urged the Swiss ambassador in Portugal to make every effort to help the missionaries. His support of the missions despite his awareness that the Portuguese suspicions might be justified testifies to the importance that the FPD attributed to religious missions. In particular, Pierre Micheli underlined the crucial role of religious missions for the Swiss government's development aid policy. ${ }^{64}$ Until the late 196os, the Swiss federal administration did not run its own development projects in the Third World, but provided financial support to private Swiss aid agencies or multilateral organisations that had experience in this field. ${ }^{65}$ Due to their long presence in Portuguese Africa, Swiss missions were valued partners of Switzerland's policy of solidarity with the developing world. A Swiss police investigation into the activities of the Mission philafricaine concluded in early 1965 that the Portuguese accusations were unfounded. ${ }^{66}$ In the case of the Swiss Mission in

62 On the establishment of Swiss missions in Angola and Mozambique, see Didier Péclard, Ethos missionnaire et esprit du capitalisme. La Mission philafricaine en Angola 1897-1907, Lausanne: Le Fait missionnaire, 1995; Harries, Butterflies \& Barbarians; Nicolas Monnier, Stratégie missionnaire et tactiques d'appropriation indigènes. La mission romande au Mozambique 1888-1896, Lausanne: Le Fait missionnaire, 1995.

63 Political letter from René Naville to Pierre Micheli, 27.01.1965, dodis.ch/30903; letter from J. J. Galabru, French consul general in Angola, to the French foreign minister, "Difficultés missionnaires protestants en Angola", o2.09.1964, CADN, 89PO/2002021/66o.

64 Letter from Pierre Micheli to René Naville, "Voyage en Angola et au Mozambique", 27.01.1965, confidential, SFA E2001E-01\#1987/78\#4643*.

65 Catherine Schümperli, La politique suisse de solidarité internationale. De la coopération au développement global, Lausanne: Presses polytechniques et universitaires romandes, 2007, pp. 28-29.

66 Report from Inspector René Gailloz, Federal Police, to the Chief of the Police Service of the Office of the Attorney General of Switzerland, 29.01.1965, p.3, SFA E2001E-01\#1987/78\#4643*. 
Mozambique, there were clearer grounds for suspicion. The mission had close links to leading members of FRELIMO, whose first President, Eduardo Mondlane, had been a pupil of one of its mission schools. ${ }^{67}$ In 1966, the Portuguese authorities suddenly resumed granting visas to Swiss missionaries, but not to those of other nationalities. This was seen as a sign of Lisbon's satisfaction with Bern's service as a protecting power in Senegal and with the refusal of Swiss delegations to international organisations to condemn Portuguese colonialism. ${ }^{68}$

The activities of Angolan refugees in Switzerland also periodically raised red flags in Lisbon. The Swiss authorities had considerable experience in dealing with the presence of foreign nationalists. In the early twentieth century, Switzerland, with its tradition of offering asylum to political refugees, became a site of anti-colonial mobilisation for South Asian activists. ${ }^{69}$ From the mid1950s onwards, during the independence war in Algeria, a number of Algerian refugees and nationalist leaders took up residence in Switzerland. They even established organisational structures of the FLN, which led to tensions with the French government. ${ }^{70}$ The Swiss authorities' attitude towards the Angolan refugees, who numbered at least 140 people, was characterised, on the one hand, by a certain tolerance for the possible future rulers of an African state and, on the other hand, by the repression of all political activities. These were considered harmful to the credibility of Switzerland's neutrality and to its relations with the colonial power. Although some Mozambican nationalists lived in Switzerland during the independence wars, too, ${ }^{71}$ their number was smaller and they were more discreet than their Angolan counterparts. Therefore, their presence did not give rise to the same concern.

In July 1961, a first group of 19 Angolans with different political affiliations arrived in Switzerland. They had studied in Portugal and fled to France after the outbreak of armed struggle in Angola. The Hilfswerk der Evangelischen Kirchen Schweiz (relief organisation of the Protestant churches of Switzerland, HEKS) took up their cause and petitioned the Swiss government to admit them. The FPD, the Division of Police of the Federal Department of Justice and Police

\footnotetext{
67 Cruz e Silva, Protestant Churches, pp. 101-119.

68 Ribeiro, L'attitude de la Confédération suisse, p. 53.

69 Harald Fischer-Tiné, "The Other Side of Internationalism. Switzerland as a Hub of Militant Anti-Colonialism, c. 1910-1920", in Purtschert, Fischer-Tiné, Colonial Switzerland, pp. 221-258.

70 On the presence and activities of Algerian nationalists in Switzerland, see Carron, La Suisse et la guerre d'indépendence algérienne, pp. 119-130; 220-238; 265-371.

71 In 1968, for example, the Portuguese secret services noted the presence of a Mozambican nationalist student group in Switzerland: report no 1486/68 by the Mozambican section of the Portuguese secret services, 11.og.1968, confidential, Arquivo Nacional Torre o Tombo (ANTT), Lisbon, Portugal, PIDE/DGS, Cl (2), no 4312, NT 7342.
} 
(FDJP), and the Immigration Police agreed, on condition that the refugees abstain from all political activities during their stay in Switzerland. ${ }^{72}$ In the following year, the anti-Communist Verein Schweizer Freunde Angolas (Association of Swiss Friends of Angola, vSFA) convinced the Swiss authorities to grant entry permits to several smaller groups of Angolan students. Founded in April 1961, the association supported the independence of Angola and aimed to counter Communist influence in Switzerland by awarding scholarships for a Western education to selected UPA members. The vSFA's president, Walter Artho, was a student leader at the University of Fribourg and was in close contact with Holden Roberto and with Jonas Savimbi, the secretary of the UPA and later one of Angola's principal nationalist leaders. Savimbi had arrived in Switzerland in 1959 or 1960 and studied in Fribourg and Lausanne. ${ }^{73}$

In early 1961, the Portuguese ambassador in Bern protested against the 'antiPortuguese' activities of "representatives of Angolan terrorist movements" in Switzerland. Federal Councillor and Foreign Minister Max Petitpierre replied that, while "we often grant hospitality to foreigners coming to us", the Office of the Attorney General of Switzerland was conducting an inquiry into the activities of Jonas Savimbi and the vsfa. ${ }^{74}$ As a consequence, Savimbi was interrogated by the police and cautioned to refrain from all political activities in Switzerland. ${ }^{75}$ This was not fully enforced. The Angolan refugees were systematically placed under surveillance. Due to his political role in the liberation struggle, Swiss police services monitored Savimbi particularly closely, but they were more lenient with him than with MPLA members. Up until his final departure from Switzerland after the completion of his studies in July 1965, they always agreed to extend his residence permit. In 1966, Savimbi launched his own liberation movement, the União Nacional para a Independência Total de Angola (National Union for the Total Liberation of Angola, UnITA) based in eastern Angola. Its formation completed the tripartite structure of Angolan nationalism. During the independence war, the MPLA, the FNLA, and UNITA attacked each other as well as the Portuguese and competed for foreign recognition and assistance. This probably contributed to the fact that the three liberation move-

72 Kurmann, 'Affaires angolaises', pp. 30-36, 46-47.

73 Ibid., pp. 37-43. Savimbi made contradictory statements about the time of his arrival in Switzerland. It was not until 1961 that his presence came to the attention of the Office of the Attorney General of Switzerland: Ibid., pp. 85-87.

Max Petitpierre, Federal Councillor and head of the FPD, "Entretien avec M. Guerra, Ambassadeur du Portugal, le mardi 23 mai 1961, à 15 h. 45”, no date, citations p. 1, 2, dodis. ch/15227. See also Edouard Brugger, DPA, memorandum, "Notiz über die Besprechung mit Herrn Walter Artho. Angola", confidential, 16.05.1961, dodis.ch/15225. 
ments never seriously threatened the colonial power. After the fall of the Portuguese colonial empire in 1974, their rivalry would escalate into the Angolan War of $1975^{-1976}$ that ended with the victory of the Soviet-allied MPLA. ${ }^{76}$

In the early 196os, the Angolan students were not granted official refugee status in Switzerland. As a consequence, their residence permits had to be renewed regularly and they were not entitled to state scholarships. Yet, they could count on an important support network. The financial aid and mentoring of the Angolan students was ensured to a large degree by national and international organisations such as the VSFA, the Catholic relief organisation Caritas, HEKs, the World Council of Churches (WCC), and the World University Service, as well as private companies and individuals. ${ }^{77}$ Thus, the Swiss government was able to show its support for Angola's potential future elites at minimal financial cost, while their uncertain legal status would have made it easy to expel them if Portuguese objections had become too vocal.

This changed in early 1968, when a number of Angolan refugees received political asylum in Switzerland. Hans Mumenthaler, head of the Division of Police's Welfare Section, was sympathetic to this request, as the Angolan refugees were persecuted by the Portuguese government and had de facto benefited from political asylum in Switzerland for years. He suggested, however, that the refugees should be encouraged to leave Switzerland as soon as conditions in Angola permitted or once they had the opportunity to live in a friendly African state. Partly, this was an expression of Bern's conviction that the admission and training of the refugees was a contribution to Angola's future development and that the students had important duties to fulfil in Africa. At the same time, this suggestion was also grounded in racism: "members of coloured races", Mumenthaler argued, would find it difficult to live permanently in a European country. ${ }^{78}$ In January 1968, 28 Angolans and their families made a collective application for political asylum in Switzerland; as long as "no overly bad elements are included", the Welfare Section was willing to look upon the cases with benevolence. ${ }^{79}$ Inspector René Gailloz of the Federal Police, who regularly checked up on the refugees, also recommended accepting the collective

76 Kurmann, 'Affaires angolaises', pp. 85-100. The most detailed analysis of the three Angolan liberation movements' rivalry between 1962 and 1976 is Marcum, Exile Politics and Guerrilla Warfare.

$77 \quad$ Kurmann, 'Affaires angolaises', pp. 32-33, 41, 52 .

78 Note from Hans Mumenthaler, head of the Division of Police's Welfare Section in the FDJP, to Ludwig von Moos, Federal Councillor and head of the FDJP, "Angolesische Flüchtlinge", o8.o1.1968, p. 2, SFA E428oA\#1998/296\#489*; see also Mumenthaler, memorandum, 19.12.1967, ibid.

79 Note from Hans Mumenthaler to Philippe Chappatte, FDJP, 24.01.1968, SFA E4280A\#1998/ $296 \# 489$ *. 
application, because "the political agitation in these milieus has fairly calmed down". ${ }^{80}$ Although several of the applicants had, in the past, been cautioned for being politically active, it was only in the cases of two members of the "little MPLA clan in Lausanne" that Gailloz spoke out against their recognition as political refugees. ${ }^{81}$ In April 1968, the Division of Police accepted 20 out of the 28 applications and a total of 32 Angolans were granted status as political refugees, including the two MPLA members that had raised Gailloz's suspicion. ${ }^{82} \mathrm{~A}$ further 20 applications were accepted up until $1975 .{ }^{83}$

As the independence wars in Angola and Mozambique dragged on, most other African colonies gained independence, and Portuguese colonialism was subsumed in the increasingly heated international debate on white minority rule in Southern Africa, the priorities of Swiss foreign policymakers changed. During the late independence wars between 1967 and 1974, they would focus less on preparing for decolonisation than on avoiding any action that might impair their political, economic, and financial relations with Portugal and, by extension, with South Africa and Rhodesia.

Swiss Business in Sub-Saharan Africa

Specialists in Swiss foreign relations have frequently underlined the crucial role of economic and financial interest in the shaping of Swiss foreign policy. They showed how commercial interests determined foreign policy decisions and underlined the strong influence of business leaders and industrial associations in Bern. ${ }^{84}$ Although the African continent made up less than $5 \%$ of Switzerland's

8o Cited in Philippe Chappatte, memorandum, 04.o3.1968, SFA E4280A\#1998/296\#489*.

81 Report by Inspector René Gailloz, Federal Police, to the head of the Police Service of the FDJP, "ANGOLAIS et autres Africains originaire des territoires portugais d'outre-mer. Demande d'asile politique en Suisse”, 29.03.1968, p. 3, SFA E4280A\#1998/296\#489*, see also pp. 7-8.

82 No author, table, "Personen, die von der Eidg. Polizeiabteilung mit Entscheid vom 11.4.1968 als Flüchtlinge anerkannt worden sind", no date, SFA E428०A\#1998/296\#489*; no author, table, "Personnes reconnues comme réfugiés par décision de la Division fédérale de police du 11 avril 1968", no date, ibid.

83 Kurmann, 'Affaires angolaises', p. 6o.

84 Dominique Dirlewanger, Sébastien Guex, Gian-Franco Pordenone, La politique commerciale de la Suisse de la Seconde Guerre mondiale à l'entrée du GATT (1945-1966), Zurich: Chronos, 2004, pp. 15-16. Notably, see also Cedric Humair, "Commerce extérieur et politique commerciale aux 19e et 2oe siècles”, Traverse 17:1 (2010), pp. 184-202; the articles in Hans Ulrich Jost, Monique Ceni, Matthieu Leimgruber (eds.), Relations internationales et affaires étrangères suisses après 1945, Lausanne: Éditions Antipodes, 2006; Marc Perrenoud, "Politique économique et relations extérieures", Traverse 17:1 (2010), pp. 171183; Janick Marina Schaufelbuehl, La France et la Suisse ou la force du petit. Évasion fiscale, relations commerciales et financières (1940-1954), Paris: Presses de Sciences Po, 2009. 
total foreign trade in the twentieth century, economic motives played an important role in determining its government's foreign policy during decolonisation. Swiss foreign policymakers sought to establish cordial relations with independent African governments in order to gain access to essential raw materials and expand into new markets. The departure of the colonial powers would, they hoped, open the way for Switzerland's export industry. The conclusion of bilateral investment protection agreements, intended to facilitate Swiss investments in developing countries, was an established part of Swiss policy in sub-Saharan Africa. ${ }^{85}$ Analysis of Switzerland's economic role in Southern Africa and the Horn therefore allows an evaluation of the importance of economic considerations on Swiss decision-making during the regime changes and armed conflicts in Angola, Mozambique, Ethiopia, and Somalia. This is even more important as Switzerland's economic and financial role in the global South was the main source of contention between Bern and Afro-Asian leaders in the late 196os and 1970s. As Swiss commercial exchanges with and investments in the Horn of Africa were very limited, this analysis focuses mostly on the Portuguese colonies, where relations with the colonial power were paramount.

Considering the dearth of official Swiss statistics, it is extremely difficult to get a reliable picture of the four African states' importance for Swiss economic circles. The trade statistics established by the Swiss customs authorities only include goods that physically crossed the Swiss border. These constitute only a small part of the total purchases and sales effected by Swiss firms and thus provide a partial picture of bilateral commercial exchanges. Information about Swiss foreign direct investment is even more vague due to a complete lack of statistical data for the period under consideration. The strong resistance of influential Swiss economic and financial elites ensured that it was not until the mid-1980s that the Swiss authorities started to publish statistics on Switzerland's balance of payments. Even then, information on foreign direct investment remained incomplete. ${ }^{86}$ In addition, it is difficult to disentangle Switzerland's economic relations with Angola and Mozambique from those with the Portuguese colonial power, as well as with neighbouring South Africa and Rhodesia. A rare diplomatic correspondence permits the assessment of the limits of bilateral trade statistics and the distorting effect of indirect trade; the Swiss ambassador in Ethiopia reported that in 1979, the food group Nestlé imported goods worth CHF 21 million from Angola and sold goods worth CHF 19 million there, while the trading firm André \& Cie had a turnover of CHF 309.7 million in the

85 Perrenoud, "Les relations de la Suisse avec l'Afrique".

86 Sébastien Guex, Janick Marina Schaufelbuehl, "Les vertus de l'ignorance. Enjeux et conflits autour des statistiques sociales et économiques en Suisse au XXe siècle", Économies et Sociétés 44:9 (2011), pp. 1555-1574, p. 1565. 
country. Thus, commercial exchanges with Angola by far exceeded the CHF 7.9 million (imports) and CHF 19 million (exports) indicated in the official Swiss trade statistics for that year. ${ }^{87}$ However, Swiss foreign policymakers rarely had detailed information about Swiss firms' activities in Africa at their disposal and based their policy decisions on the available approximate data.

Looking at Swiss trade with sub-Saharan Africa between 1961 and 1979, it seems clear that none of the four African states selected for this study was a major commercial partner for Switzerland. Table 1 shows that their combined weight in Switzerland's total trade with sub-Saharan Africa never reached $10 \%$, excepting the years immediately before the independence of Angola and Mozambique - when imports from Portuguese Africa made up $10.3 \%$. Of the four states, Angola had the biggest share of Switzerland's total trade with sub-Saharan Africa, while trade with Somalia was negligible. The shares of Angola, Mozambique, and Ethiopia in Switzerland's total imports from and exports to sub-Saharan Africa dropped after the regime changes in the mid-1970s. ${ }^{88}$ The limited information available suggests that Switzerland was not an important commercial partner for the African states, either. ${ }^{89}$ Table $1^{90}$

87 Letter from Fritz Bohnert, Swiss ambassador in Ethiopia, to the Trade Division, "Angola: Informationen über die Wirtschaft”, 21.10.1980, SFA E20o1E-o1\#1991/17_Bd.611, C.41. Angola.10o.o; Historical Statistics of Switzerland Online (HSSO) database, developed under the supervision of the Swiss Society for Economic and Social History in collaboration with the Universities of Zurich, Geneva and the Federal Institute of Technology Lausanne, https://hsso.ch/en (11 August 2021), tables L.20, "Einfuhrwerte nach Ursprungsländern 1920-1992 (in Millionen Franken): Afrika", L.24, "Ausfuhrwerte nach Verbrauchsländern 1920-1992 (in Millionen Franken): Afrika". The sum of US $\$ 120$ million has been converted to $\mathrm{CHF}$ using the exchange rates indicated in Lawrence H. Officer, "Exchange Rates Between the United States Dollar and Forty-one Currencies", Measuring Worth, 2018, https://www .measuringworth.com/datasets/exchangeglobal/ (13 January 2021).

88 HSso database, tables L.20, "Einfuhrwerte nach Ursprungsländern 1920-1992 (in Millionen Franken): Afrika", L.24, "Ausfuhrwerte nach Verbrauchsländern 1920-1992 (in Millionen Franken): Afrika".

89 From the 12 member states of the EEC and EFTA, Switzerland was, in 1968, the sixth most important buyer country of Angola, while it occupied the ninth place as a supplier: letter from René Naville to Pierre Micheli, 16.08.1968, p. 14, SFA E20o1E\#198o/83\#3788*. In 1973, imports from Switzerland constituted $2.4 \%$ of Mozambique's total imports, and the share of exports was with $0.1 \%$ even lower: Louis Chaney, Swiss consul in Mozambique, memorandum, "Mozambique", o1.11.1974, SFA E2004B\#1990/219\#373*. In 1966, Switzerland was the 17th most important provider of goods for Ethiopia and the 19th most important buyer: II, chargé d'affaires a.i. Swiss Embassy in Ethiopia, to the Trade Division, "Rapport économique", 03.08.1967, pp. 2-6, SFA 7110\#1978/50\#1358*.

90 Hsso Database, tables L.20, "Einfuhrwerte nach Ursprungsländern 1920-1992 (in Millionen Franken): Afrika", L.24, "Ausfuhrwerte nach Verbrauchsländern 1920-1992 (in Millionen Franken): Afrika" 


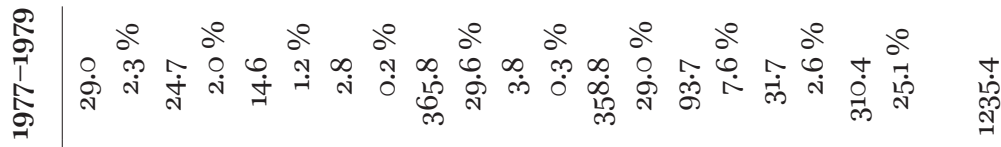

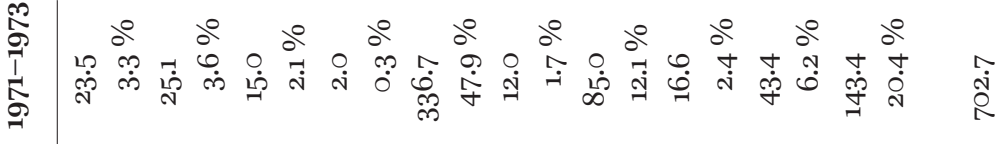

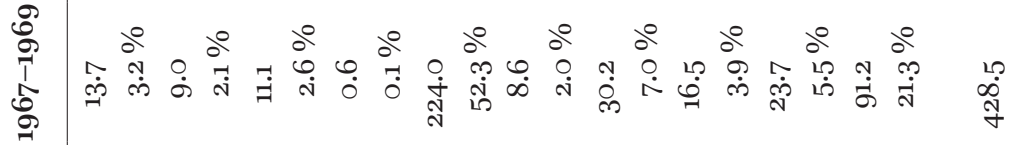

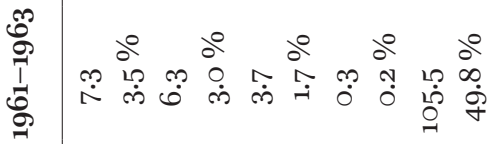

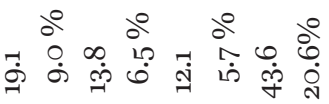

$\stackrel{\infty}{\text { กี }}$

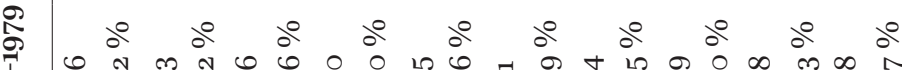
点

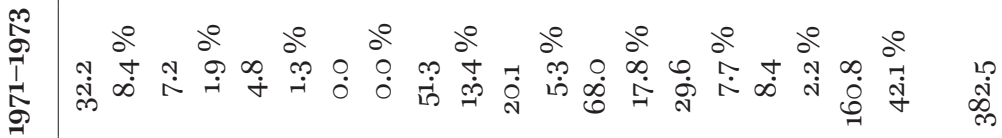


highlights the preponderance of South Africa in Switzerland's trade with subSaharan Africa, particularly with regard to exports. Between 1961 and 1973, South Africa absorbed about $50 \%$ of all Swiss exports to this part of the world. In the late 1970s, South Africa's share still amounted to almost 30\%, closely followed by Nigeria. In the late 196os and early 1970s, Swiss imports from Rhodesia amounted to $5 \%$ of Switzerland's total imports from sub-Saharan Africa, while Swiss exports to the Smith regime were not significant.

The importance of Switzerland's economic links with South Africa and Rhodesia was much greater than these countries' shares in its total trade with sub-Saharan Africa suggests. Bilateral relations with the Apartheid regime were particularly intense in the fields of capital exports to South Africa and imports of South African gold. Between 1968 and 1974, Swiss direct and indirect investment in South Africa constituted on average $7.6 \%$ of all foreign investment in the country and reached almost CHF 4,00o million in 1974. During the same period, more than $80 \%$ of South Africa's gold was commercialised through banks in Zurich. ${ }^{91}$ With the Swiss-South African Association (sSAA), which was founded in 1956 to promote and protect Swiss economic interests in South Africa and which included leading members of the major Swiss export firms and banks, the Apartheid regime had a strong lobby in Switzerland. ${ }^{92}$ Alongside its close economic, financial, and political relations with Pretoria, Switzerland's non-participation in the UN sanctions against Rhodesia also laid its government open to attacks from Third World leaders and Swiss civil society actors. After Rhodesian Prime Minister Ian Smith's white minority regime made a unilateral declaration of independence from the UK in November 1965 , Bern decided not to participate in UN economic sanctions against Rhodesia. Instead, future Swiss imports from Rhodesia were restricted to the levels of 1964-1965, the so-called courant normal. These allegedly autonomous measures were a result of direct British pressure and the Swiss government's

$91 \quad$ Bott, La Suisse et l'Afrique du Sud, pp. 276; 279; 373, and p. 386 for the exchange rates between rand and CHF. For an overview of Switzerland's relations with South Africa during the second half of the $20^{\text {th }}$ century, see also Kreis, Die Schweiz und Südafrika.

92 On this association, see David Gygax, La Suisse-South African Association (1956-200o). Un organe du capital helvétique en Afrique du Sud, Fribourg: Chaire d'histoire contemporaire de l'Université de Fribourg, 2001. A similar, but more low-key and less influential organisation existed to promote Swiss economic interests in Rhodesia: Rahel Stauffiger, 'Behind the Scenes'. Die Gesellschaft Schweiz-Rhodesien zwischen diskreter Beziehungspflege und offizieller Schweizer Rhodesienpolitik, unpublished Master thesis, University of Fribourg, 2018; Mathias Ulrich, 'Die Sache Rhodesiens in der Schweiz vertreten'. Funktion und Netzwerk der Gesellschaft Schweiz-Rhodesien, 1965-1980, unpublished Master thesis, University of Zurich, 2019. 
fear of negative Afro-Asian reactions if Switzerland were to be seen to benefit economically from other states' sanctions. ${ }^{93}$

Figure $1^{94}$ gives an overview of the development of Switzerland's commercial exchanges with Angola, Mozambique, Ethiopia, and Somalia between 196o and $1985 .{ }^{95}$ With the exception of Angola, Switzerland's trade balance with the four African countries was largely positive throughout this period. For a country forced to import a large part of the raw materials needed for its industry, this was important, as it helped to reduce its chronic foreign trade deficit.

The Angolan and Mozambican markets of the late 196os and early 1970s were very dynamic. Swiss imports from Angola grew steadily during the 196os and reached their highest level in 1973 with goods worth CHF 45.6 million being imported in that year. Swiss exports to both countries also increased steadily in the 196os. Between 1966 and 1973, exports to Mozambique quadrupled in real value, and almost tripled in the case of Angola. It could be argued that the independence wars had a positive effect on Switzerland's trade with the Portuguese colonies, as bilateral trade probably benefited from the colonial authorities' increased efforts to promote the industrialisation and economic development of Portuguese Africa. These efforts were part of a series of economic and social reforms destined to counter international criticism of Portugal's colonial rule and to win the 'hearts and minds' of the Angolan and Mozambican populations after the outbreak of armed struggle. ${ }^{96}$ After the Portuguese Revolution

93 FPD, FDEA, proposal to the Federal Council, "Rhodesien", urgent, 13.12.1965, attached to the Decree of the Federal Council, "Rhodesien", 17.12.1965, dodis.ch/31953. On Switzerland's policy of neutrality and its position towards the UN sanctions against Rhodesia, see Gabriel, "Switzerland and Economic Sanctions"; Letsch, Rhodesien, die Vereinten Nationen und die Schweiz"; Ross, Neutrality and International Sanctions, especially pp. 157-185.

94 Hsso Database, tables L.20, "Einfuhrwerte nach Ursprungsländern 1920-1992 (in Millionen Franken): Afrika", L.24, "Ausfuhrwerte nach Verbrauchsländern 1920-1992 (in Millionen Franken): Afrika". Data was adjusted to inflation $(1973=1)$ using the Swiss wholesale price index: table H.ga, "Grosshandelsindex nach Monaten Januar 1926 bis 1993 Mai (Juli 1914 = 100)".

95 Until 1975, the Swiss Foreign Trade Statistics only contain information about Switzerland's commercial exchanges with Portuguese West Africa, which includes Angola and GuineaBissau. However, the figures for the five following years show that Switzerland's imports from Angola were on average 13 times higher than those from Guinea-Bissau. With a ratio of 34:1, exports to Guinea-Bissau were even more negligible. Therefore, and for reason of comparability, I continue to use figures for Portuguese West Africa for the years of 1976 and later.

96 On economic and social reforms in the Portuguese colonies during the independence wars, see Gervase Clarence-Smith, The Third Portuguese Empire, 1825-1975. A Study in Economic Imperialism, Manchester: Manchester University Press, 1985, pp. 194-195, 214-217; Yonah N. Seleti, "The Development of Dependent Capitalism in Portuguese Africa", in Zbigniew A. Konczacki, Jane L. Parpart, Timothy Shaw (eds.), Studies in the Economic 


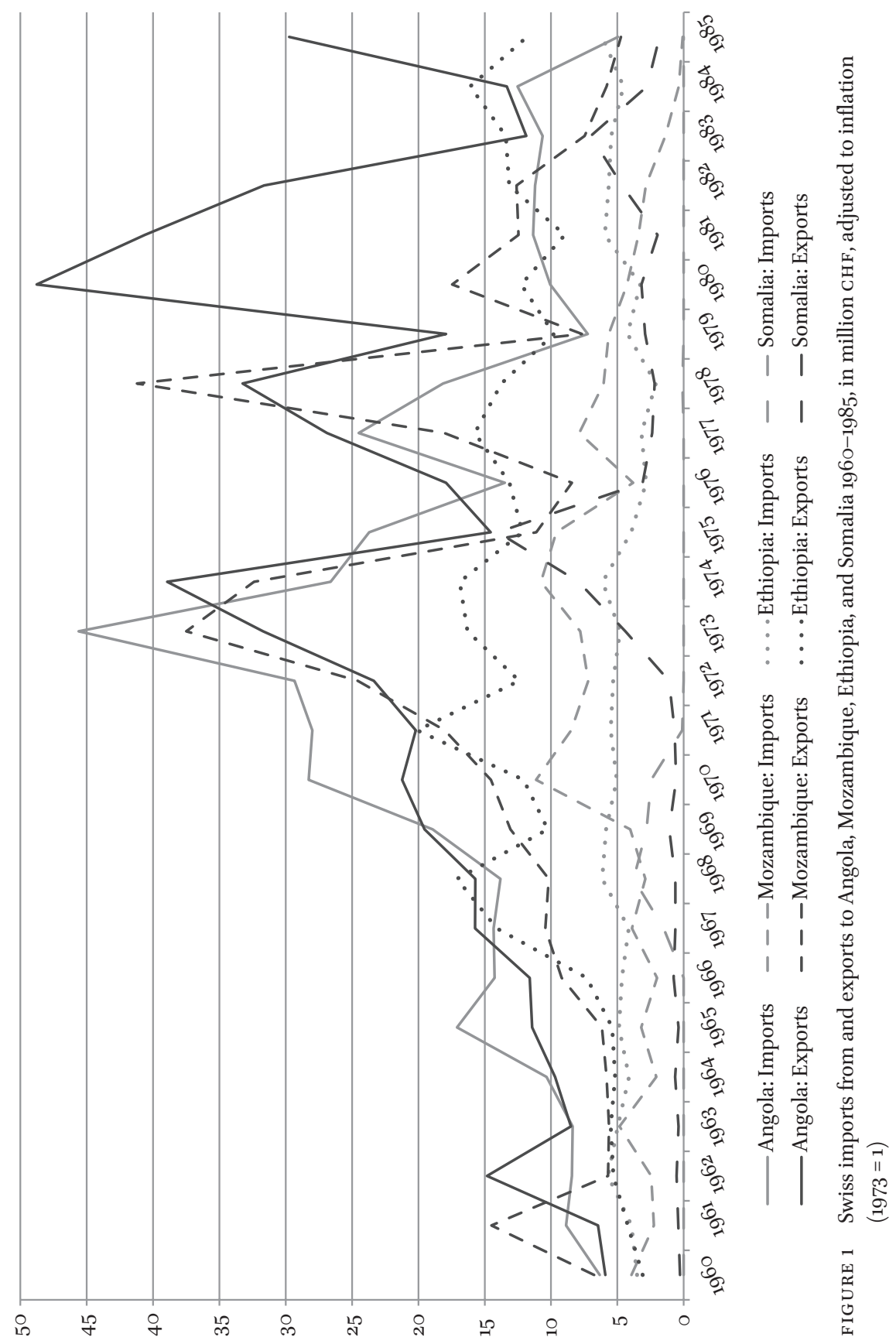


in 1974, Swiss imports and exports fell immediately. Uncertainty about the future of the colonies, which became independent in 1975, temporarily slowed trade. In 1977, exports to both countries grew again and reached their highest level a few years later, with goods worth CHF 45 million (in real value) exported to Mozambique in 1978 and CHF 58.1 million (in real value) to Angola in 1981. After this peak, Swiss exports to Mozambique fell sharply and by the mid1980 s, they had stagnated at a low level. By this time, Switzerland's imports from Mozambique had dwindled to less than CHF 0.4 million per year. This was due to armed conflicts, natural disasters, and radical economic reforms that crippled the young state's development and destabilised its economy. ${ }^{97}$

The low level of bilateral trade between Switzerland and Somalia and the correspondingly large influence of single deliveries in the trade statistics make it difficult to draw significant conclusions about the influence of the 1969 coup d'état on commercial relations. The rise in Swiss exports to Somalia in the early 1970s, which reached their highest level in 1975 with the export of goods worth CHF 15.9 million, is explained by particularly high levels of deliveries of machines as engineering company Sulzer equipped a textile firm in Somalia. The Swiss machine industry perhaps profited in a very small way from the limited economic growth that Somalia experienced in the first half of the $1970 s .{ }^{98}$ With regard to Ethiopia, it must first be noted that in the period under consideration, this state was one of Africa's least developed countries and was poorly industrialised. The productivity of the large agricultural sector was hindered by a lack of technology and infrastructure and, more importantly, the traditional system of land tenure and feudal mode of production. Despite widespread poverty, the aristocracy and the Orthodox Church had repeatedly resisted attempts at land reform. As a consequence, Ethiopia was heavily dependent on external loans and assistance. ${ }^{99}$ Nevertheless, Swiss exports to this state grew strongly in the late 196os. The political, social, and economic upheavals following the 1974 Ethiopian Revolution then led to a slight drop in

History of Southern Africa. Volume I: The Front-Line States, London: Frank Cass, 199o, pp. 30-74, pp. 63-70.

97 Malyn Newitt, "Mozambique", in Patrick Chabal, A History of Postcolonial Lusophone Africa, Bloomington: Indiana University Press, 2002, pp. 185-235, pp. 195-212.

98 Swiss Directorate General of Customs, Jahresstatistik des Aussenhandels der Schweiz, 1967-1979; see also RH, memorandum, "Téléphone le 27 février 1979 de M. Piottet de l'OSEC/Lausanne", o2.03.1979, SFA E2O25A\#1991/168\#1648*, Laitin, Samatar, Somalia, pp. $116-119$.

99 Shiferaw Jammo, "An Overview of the Economy 1941-74", in Shiferaw Bekele, An Economic History of Ethiopia, Vol. I: The Imperial Era 1941-74, Dakar: CODESRIA, 1995, pp. 1-71, mainly pp. 49, 54 . 
both imports and exports. Yet, by the early 1980s, Swiss imports from Ethiopia had again reached the levels of the 196os and early 1970s. This may be linked to the conclusion of a supply contract between the Ethiopian Minister for Coffee and André \& Cie in early 1979, which granted the Lausanne-based trading firm a right of first refusal for all coffee offered to a number of Western European states. ${ }^{100}$

Switzerland's main import commodities from the four African countries were raw materials, predominantly coffee, and its exports were primarily chemical products, followed by machines. Between 1967 and 1979, coffee accounted for $70-90 \%$ of all goods imported from Angola. In the period 1970-1974, Angola was Switzerland's fourth most important supplier of coffee, with annual average coffee imports worth CHF 24 million, which constituted 8.8\% of Switzerland's total coffee imports. Before the Ethiopian Revolution, almost $6 \circ \%$ of Switzerland's imports from this country consisted of coffee, Ethiopia's main export commodity. In 1977-1979, that figure rose to 93\%. Before Mozambique's independence, Swiss imports from this country were more varied, although cotton made up 50\% of imported goods in the early 1970s. By the end of the decade, coffee, which Switzerland had not imported from Mozambique prior to independence, made up more than $8 \circ \%$ of total imports from Mozambique or an average of CHF 6 million per year. ${ }^{101}$ Chemicals comprised almost $6 \circ \%$ of Swiss exports to both Mozambique and Angola in 1977-1979. In the boom years of 1972-1974, machines enjoyed a share of $50 \%$ in the former and $30 \%$ in the latter country. In the 1970s, chemicals made up more than $50 \%$ of Swiss exports to Ethiopia. In 1979, the Swiss multinational group Ciba-Geigy was responsible for a third of Ethiopia's imports of agrochemicals, which made it the biggest supplier. The share of watches grew during the observed period, reaching $20 \%$ of Swiss exports to Ethiopia in the late 1970s. In 1966, Swiss watches had a market share of $90 \%$ in Ethiopia. ${ }^{102}$

100 Letter from Fritz Bohnert, Swiss ambassador in Ethiopia, to the Trade Division, "Aethiopiens Export: nach dem Westen orientiert. André Lausanne”, 03.07.1979, p. 2, SFA E7115A\#1990/6o\#1351*.

101 HSSO database, table L.42a, "Einfuhrwerte einzelner Produkte nach den wichtigsten Ursprungsländern (in Millionen Franken): Mittel der Jahre 1970-1973”; Swiss Directorate General of Customs (ed.), Jahresstatistik des Aussenhandels der Schweiz, Bern, 1967-1979; Shiferaw Jammo, "An Overview of the Economy", p. 42.

Swiss Directorate General of Customs, Jahresstatistik des Aussenhandels der Schweiz, 1967-1979; II, charge d'affaires a.i. Swiss Embassy in Ethiopia, to the Trade Division, "Rapport économique", o3.08.1967, pp. 2-6, SFA 7110\#1978/50\#1358*; letter from Fritz Bohnert to the Trade Division and the STC, "Industrielle Vorhaben in Aethiopien", 19.11.1979, SFA E7115A\#1990/60\#1351*. 
The lack of statistical data makes it impossible to gain a clear picture of Swiss direct investment in Angola, Mozambique, Ethiopia, and Somalia. It was certainly not considerable in the Horn of Africa. Switzerland's financial and economic elites showed little interest in Ethiopia and almost none in Somalia. Jean Demaurex, a relative of Jean André whose family controlled one of the biggest Swiss trading firms, André \& Cie in Lausanne, founded several plantations in Ethiopia. Demaurex wholly owned the firm Cafex Private Ltd Co., established in 1956 in order to promote the sale of Ethiopian coffee in Europe. He later developed Tana Plantation Co., one of the biggest coffee plantations in Ethiopia, and in 1967, with the aid of several investors, Bilate Agricultural Estate. By 1975, André \& Cie held a majority participation of CHF 24 million in the latter two plantations. ${ }^{103}$ In 1969 , several Swiss firms were awarded contracts for the delivery of machines for the construction of hydroelectric power plants at the Awash and Fincha dams. ${ }^{104}$ Swiss insurance interests in Ethiopia thrived in the early 1970s. The reinsurance company Swiss Re alone had a yearly turnover in Ethiopia of about CHF 2 million. ${ }^{105}$ Even if few of the big Swiss banks, insurance companies, and major firms seemed interested in investing in Ethiopia, those investors present were eager to secure their assets through an investment protection agreement. In July 1970, the Trade Division therefore instructed the Swiss ambassador in Ethiopia to discuss this possibility with the Ethiopian authorities. Although the Ethiopian Foreign Minister verbally confirmed his country's interest in concluding such an agreement, periodical reminders from the Swiss embassy in Addis Ababa never received an official reply. It was not until 1998 that the two states would finally conclude a bilateral agreement to promote and protect investments. Negotiations initiated in 1971 on an aviation agreement also stalled and were disrupted by the Ethiopian Revolution. ${ }^{106}$

103 Letter from businessman Jean Demaurex to General Teferi Bante, chairman of the PMAC, 12.08.1975, attached to the letter from Jean Demaurex to Olivier Exchaquet, Swiss ambassador in Ethiopia, 12.08.1975, SFA E2001E-o1\#1987/78\#2798*; Claude Hugenin, DPA, memorandum "Garantie contre les risques de l'investissement: cas André / Ethiopie", 03.07.1975, SFA E2001E-o1\#1987/78\#2787*.

104 Letter from Fernand Bernoulli to the AD, "Schlussbericht des Missionschefs von Addis Abeba", confidential, 07.07.1970, p. 4, dodis.ch/37162; letter from Heinz Langenbacher to the STC, "Ethiopian Electric Light and Power Authority' (E ELPA): Finanzgesuch", 19.07.73, p. 1, SFA E2001E-o1\#1991/17_Bd.759, C.41.152.Eth.o.

105 Letter from Heinz Langenbacher to the STC, "Stipendium", 16.03.1972, SFA E2001E-o1\#1988/ $16 \# 3195^{*}$.

106 Letter from Fernand Bernoulli to the Trade Division, 28.05.1970, confidential, SFA E7110\#1981/41\#1188*; letter from Hans Bühler, Vice-Director of the Trade Division, to the Swiss embassy in Addis Ababa, "Investitionsschutzabkommen Äthiopien", o8.07.1970, ibid.; note 
Switzerland's economic role during the independence wars in Angola and Mozambique and its investments in the two colonies cannot be understood without looking briefly at its links with the colonising power. Switzerland's trade with and investments in Portugal increased after the two states became founding members of EFTA in 196o. At this time, Portugal had one of the least developed economies in Western Europe. Following its accession to EFTA, the Estado Novo regime relaxed its protectionist policy and Portugal's trade moved increasingly away from the colonies and towards the member states of EFTA and the EEC. At the same time, thanks to the independence wars, Portugal's military spending claimed about half of its budget. ${ }^{107}$ Bilateral commercial exchanges increased steadily between 1960 and 1974, with Swiss exports to Portugal always exceeding imports by a ratio of between 2:1 and 3:1. Between 1967 and 1974, exports to Portugal varied between 1.06\% and 1.38\% of Switzerland's total exports, imports never even reached $0.5 \%$. Although Portugal's market share of Switzerland's total foreign trade was small, it was still many times greater than that of its colonies. Swiss exports to Angola and to Mozambique only exceeded $0.1 \%$ of total Swiss exports in the years immediately before independence. The share of imports was even lower. ${ }^{108}$ Even bearing in mind that until 1974 at least part of Switzerland's imports from Portugal comprised colonial products, it is clear that the colonial power was a more important trading partner than either of its colonies.

In the early 1960s, the Portuguese government actively sought to strengthen its economic relations with Switzerland. But while Swiss industrial and banking circles were, in principle, favourably disposed towards increased economic and financial collaboration with Portugal, the latter's economic backwardness

from Sa to Hans Bühler, "Investitionsschutzabkommen Aethiopien, 22.05.1970, ibid.; letter from Fernand Bernoulli to the Trade Division, "Aethiopien: Investitionsschutzabkommen", 30.07.1970, ibid.; letter from Heinz Langenbacher to Bernhard Müller, "Investitionsschutzabkommen mit Aethiopien”, urgent, o1.11.1971, SFA E610oB-o2\#1986/168\#1720*; Langenbacher, report "Schlussbericht: Pendente Fragen und Hinweise", 14.04.1975, pp. 3-4, dodis.ch/39827; "Abkommen zwischen der Schweizerischen Eidgenossenschaft und der Demokratischen Bundesrepublik Äthiopien über die Förderung und den gegenseitigen Schutz von Investitionen", concluded on 26 June 1998 and in force since o7 December 1998, https://www .admin.ch/opc/de/classified-compilation/200106o6/index.html (13 January 2021). MacQueen, The Decolonization of Portuguese Africa, pp. 49-51.

108 Hsso database, tables L.3, "Bilanz des Aussenhandels und Zollerträgnisse nach Warenarten 1886-1992 (1)", L.18, "Einfuhrwerte nach Ursprungsländern 1920-1992 (in Millionen Franken): Europa", L.20, "Einfuhrwerte nach Ursprungsländern 1920-1992 (in Millionen Franken): Afrika", L.22, "Ausfuhrwerte nach Verbrauchsländern 1920-1992 (in Millionen Franken): Europa", L.24, "Ausfuhrwerte nach Verbrauchsländern 1920-1992 (in Millionen Franken): Afrika". 
and colonial wars were considered an obstacle to investment, whereas its lack of democratic government was apparently not. ${ }^{109}$ For its small size, Swiss direct investment in Portugal was considerable. While the UK was by far the largest foreign investor in the Southern European state in 1968, Switzerland was ranked seventh among US and Western European investors in the Portuguese industrial and commercial sectors. ${ }^{110}$ Portugal initiated negotiations, starting in 1968, which led to the establishment of a convention for the avoidance of double taxation in June 1973. The FDF insisted that Portugal was the principal beneficiary of this treaty, as it needed to attract Swiss investment to "help bring the country out of its industrial under-development".111 In November 1973, the Portuguese government sent a delegation to Bern to discuss the possibilities for increasing economic collaboration between Switzerland and Portugal. With the agreement of interested Swiss companies and trade associations in the chemicals and machines sectors, the two delegations agreed to pursue efforts to strengthen bilateral industrial cooperation. ${ }^{12}$ These efforts were interrupted by the April 1974 Carnation Revolution in Portugal and would only be resumed in late 1976 .

Moving from Europe to Africa, foreign investment in Angola and Mozambique increased rapidly after Portugal liberalised its economic policy in the early 196os. Historians Miguel Bandeira Jerónimo and António Costa Pinto underline the crucial role of foreign investment for the colonial economy during the independence wars and stress the need for further research on this subject. ${ }^{113} \mathrm{In}$

109 Paul Rudolf Jolles, Trade Division, memorandum, "Notiz über die Sitzung der schweizerischen Delegation vom 30. Oktober 1963 in Bern betreffend die wirtschaftliche Zusammenarbeit mit Portugal", no date, p. 2, dodis.ch/30691.

11 Letter from René Naville to the Trade Division, 29.07.1969, SFA E20o1E-o1\#1987/78\#4657*.

111 Due to the upheavals in Portugal following the coup d'état in April 1974, the treaty would not be signed until September 1974: "Botschaft des Bundesrates an die Bundesversammlung über ein Doppelbesteuerungsabkommen mit Portugal (vom 23. Oktober 1974)” Bundesblatt 2:46 (1974), pp. 1066-1092, pp. 1066-1067; Georges-André Chevallaz, Federal Councillor and head of the F DF, proposal to the Federal Council, "Double imposition avec le Portugal et la Belgique", 12.02.1974, p. 4, attached to the decree of the Federal Council, "Double imposition avec le Portugal et la Belgique. Signature de la convention par the Chef du département politique", 04.03.1974, dodis.ch/37677.

112 Jean Jacques Maeder, Trade Division, memorandum, "Coopération économique entre la Suisse et le Portugal. 14 novembre 1973, 10h15: Séance préparatoire à la visite officielle que le Ministre Vaz Pinto fera le 23 novembre à M. le Conseil fédéral Brugger", 16.11.1973, SFA E7110\#1984/70\#837* ; Maeder, draft minutes of the working meeting of Friday, 23 november 1973, "Coopération économique entre la Suisse et le Portugal”, 28.11.1973, ibid.

113 Miguel Bandeira Jerónimo, António Costa Pinto, "A Modernizing Empire? Politics, Culture, and Economy in Portuguese Late Colonialism", in Jerónimo, Pinto, The Ends of European Colonial Empires, pp. 51-8o, pp. 62-63. See also Clarence-Smith, Third Portuguese Empire, p. 204. 
general, Swiss investments in Angola and Mozambique increased in the 196os. Nevertheless, few Swiss companies were established in the colonies. Most firms conducted their business through branch offices and subsidiaries in Lisbon. Examples are ввс, Sulzer, and hydroelectric company Conrad Zschokke, which participated in the construction and equipping of dams and energy generating plants in the colonies. Ciba-Geigy and food company Nestlé had sales offices in Angola and Mozambique, although they also conducted part of their business through subsidiaries in South Africa and the Congo, respectively. ${ }^{114}$

In the 196os and 1970s, electrical engineering company ввс repeatedly obtained supply contracts in Angola and Mozambique, notably for thermal power stations II and III in Lourenço Marques (1959-1961 and 1967-1970). ${ }^{115}$ These and many other plants in the Portuguese colonies were built and controlled by SONEFE, a part-public company based in Lisbon that was largely dependent on the Portuguese state. The involvement of the Portuguese government meant that the Swiss Trade Division was favourably disposed towards ввC's March 1967 demand for an ERG cover amounting to CHF 12 million for deliveries destined for thermal power station III in Lourenço Marques. The possible damage to ввС's reputation if it did not receive the contract was considered more important than the risks associated with Mozambique's insecure political future. ${ }^{116}$ ВвС Baden also made deliveries for the construction of the Cabora Bassa dam in Mozambique. ${ }^{117}$

Two Swiss plantations in Mozambique were among the most important in the country. The Companhia de Boror in Macuse, founded in the 189os, grew coconut palms and sisal, kept cattle and produced salt. In the 1930s, Swiss shareholders obtained a majority interest in the plantation. With a turnover of CHF 63 million, the Boror group was the tenth largest company in Mozambique in the early 1970 s and employed tens of thousands of workers. ${ }^{118}$ The

114 Centre d'investigation sur le colonialisme portugais (CISCOP) in collaboration with the Centre Europe-Tiers Monde (CEтiм), Suisse-Portugal. De l'Europe à l'Afrique, Geneva: Editions CETIM, 1973, pp. 77, 98-100.

115 T.-V. Huber, ввс Baden, Aide-mémoire, "Activités MAGUE - Brown Boveri au Portugal dans le domaine des centrales thermiques", 31.10.1973, pp. 1-2, attached to the letter to the Trade Division, "Portugal", 31.10.1973, SFA E7110\#1984/70\#847".

116 Note from Ernst Henri Léchot, responsible for relations with Portugal within the Trade Division, to Hans Bühler, "Mozambique - Kraftwerkbau in Lourenço Marques; GA 7.49, ввс, Baden; 12 Mio Fr." 18.03.1967, SFA E7110\#1978|50\#1682*; Clarence-Smith, Third Portuguese Empire, p. 170.

117 See chapter 3 .

118 Georges E. Mourgue d'Algue, Boror, memorandum, "Note à l'intention du département politique, à Berne. Concerne: Companhia do Boror, siège à Macuse/Mozambique. Boror Comercial, siège à Lourenço Marques/Mozambique", o1.10.1974, p. 1, attached to the note from Georges E. Mourgue d'Algue, Comptoir de Représentations d'Etreprises Commerciales 
fifteenth largest company at that time, the Companhia de Culturas de Angoche (CCA), had a turnover of CHF 47 million in the early 1970s. Initially, the company mainly produced sisal and opened a cashew factory in the 196os. In 1974, the Compagnie Commerciale et Agricole S.A. in Glarus, Switzerland, held 97.5\% of the companies' share capital. ${ }^{119}$ Boror and CCA employed Swiss citizens as engineers, technicians, agronomists, and accountants. Smaller retail businesses like Bridler \& Co, Abegg Pharma, Beira Trading Co. Ltd, and City Stores Ltd in Beira were sales agents for important Swiss brands in Mozambique. ${ }^{120}$ By comparison, Swiss interests in Angola during the independence war were less visible. There were few Swiss commercial agencies, as most companies conducted their business through subsidiaries in Lisbon. ${ }^{121}$ On the whole, Swiss economic activities in the colonies were little affected by the independence wars. ${ }^{122}$

Details of Switzerland's overall financial role in the Portuguese colonies and the credit offered by Swiss banks are hard to come by. Part of the difficulty lies in the fact that Swiss credit left few traces in public archives. Only credit arrangements exceeding $\mathrm{CHF} 10$ million or with a term of more than 12 months were subject to the veto of the SNB, which usually also submitted such cases to the federal authorities. ${ }^{123}$ Consequently, the number of credit arrangements mentioned below is almost certainly underestimated. Additionally, some credit granted to institutions in Portugal was used for investment in the colonies. In 1969, a Swiss group led by Lavoro Bank AG, Zurich, subscribed approximately CHF 21.9 million to a bond of CHF 120.8 million of the state-

et Diverses, to Michael Gelzer, deputy chief of the DPA, "Companhia do Boror S.A. Boror Comecial S.A. - Mozambique”, o1.10.1974, SFA E2001E-o1\#1987/78\#4182*; cIscop, SuissePortugal, p. 75; Linder, Die Schweizer in Mosambik, pp. 49-54. The ciscop study published in September 1973 indicates the turnover of the CCA of escudos 442 million without mentioning the year of reference. This amount has been converted to CHF using the average exchange rates between January 1970 and August 1973 (escudos $100=$ CHF 14.3): Data Portal of the SNB, Interest Rates, Yields and Foreign Exchange Market, Historical Exchange Rates of Selected Euro Member Countries, https://data.snb.ch/en/topics/ziredev\#!/cube/ devkuhism (13 January 2021).

119 Memorandum by CCA in preparation of a meeting with the DPA on 3 October 1974, "Companhia de Culturas de Angoche (CCA) S.A.R.L. Antonio Enes", no date, SFA E2001E-01\#1987/78\#4182*; CISCop, Suisse-Portugal, p. 75; Linder, Die Schweizer in Mozambique, pp. 103-109. For the conversion of cCA's turnover of escudos 330 million into Swiss francs, see the preceeding footnote.

120 Jean Pierre Adrien Bertrand, Swiss consul in Mozambique, to the AD, "Mon voyage de service dans le nord de la province du Mozambique du 26 mai au 29 juin 1969", 10.07.1969, p. 2, SFA E2001E\#1980/83\#3788*; Linder, Die Schweizer in Mozambique, pp. 133-150.

121 Letter from René Naville to Pierre Micheli, 16.o8.1968, p. 14, SFA E2001E\#1980/83\#3788*.

122 Letter from the Swiss consul in Mozambique, Jakob Etter, to the DPA, 24.04.1968, p. 2, SFA E2001E\#1980/83\#3788*.

Bott, La Suisse et l'Afrique du Sud, p. 106. 
owned Companhia Mineira do Lobito, a major iron exporter in Angola. ${ }^{124}$ In the early 1970s, five Swiss credit arrangements issued to clients in the Portuguese colonies can be identified, worth a total of CHF 46 million. The issuing institutions were all smaller banks, such as the Swiss group Alpina Investments AG, Xelor Invest AG in Baden, and the Geneva branch of First National City Bank. ${ }^{125}$ The majority of these funds went to Mozambique. The Instituto de Crédito de Moçambique (Mozambican Credit Institute, ICM), founded by the Portuguese government in 1969 to centralise public funds for credit and finance operations for the development of the colony, was partly responsible for this. In the first half of 1972, its administrator, António de Almeida, met with sBA President Alfred Sarasin in Basel. Although there is no record of this meeting, the ICM was very satisfied with the results, as one of its leaders wrote to Sarasin in July 1972: "The contacts you so kindly suggested to us were of great value and interest and we are very pleased to let you know that we already openned [sic] accounts with several renown swiss [sic] banks and are negotiating our first external operations."126

124 CISCOP, Suisse-Portugal, p. 79. The amounts indicated in escudos (escudos 145 million of a bond of escudos 800 million) have been converted to CHF using the average exchange rates for 1970 (escudos $100=$ CHF 15.1 million), the first year that these exchange rates are available on the website of the SNB: Data Portal of the SNB, Interest Rates, Yields and Foreign Exchange Market, Historical Exchange Rates of Selected Euro Member Countries, https://data.snb.ch/en/topics/ziredev\#!/cube/devkuhism (13 January 2021).

125 In 1971, the Swiss financial authorities authorised a credit of US\$ 3.5 million from the First National City Bank, Geneva, to the Sociedade Technica de Equipamentos Industriais \& Agricolas Lda., in Mozambique, this sum was increased by a further US\$ 2 million in 1974. In 1972, Alpina Investment AG granted a first credit of CHF 25 million to the ICM, and a second of Deutschmark 12.5 million to SONEFE in Lourenço Marques. Finally, a credit of Deutschmark 4.95 million from Xelor Invest AG, Baden, to the Instituto dos Cereais de Moçambique was authorised in 1974. The sums have been converted to CHF using the exchange rates indicated in table O.22a of the Hsso database, "Wechselkurse für Sichtdevisen in der Schweiz 1875-1907 und 1913-1992 (in Franken)". Letter from Nello Celio to the SNB, "Kapitalexport", 30.08.1971, SFA E20o1E-o1\#1991/17_Bd. 986, C.41. Moz.152.o; letter from Leutwiler, Lademann, SNB, to the First National City Bank, Geneva, "Kredit an die Firma Sociedade Tecnica de Equipamentos Indistriais e Agricolas, Lda, Lourenço Marques. Erhöhung von US\$ 2'оoo'ooo.-- auf 5'500'000.--", 04.01.1974, attached to the letter from the SNB to the FDF, the FPD, and the FDEA, "Bewilligung von Kapitalexportgeschäften sowie Kotierungen ausländischer Wertpapiere - Schreiben EFD vom 16.8.1968", ibid.; FP, "Moçambique recebe um crédito de 170 mil contos", Jornal o Seculo, 24.05.1972, SFA E2200.54-03\#1984/100\#172*; letter from Louis Chaney to the Financial and Economic Service of the FPD, 29.08.1972, SFA E2200.54-O3\#1984/100\#172*; letter from Georges-André Chevallaz to the SNB, "Kapitalexport", 18.05.1974, SFA E2001E-o1\#1991/17_ Bd. 986, C.41.Moz.152.o.

126 Letter from Domingos Guimarães Teixeira, chairman of the ICM, to the SBA, attention to Alfred Sarasin, 18.07.1972, Archives of the Swiss Bankers Association, Basel, Switzerland 
Analysis of Switzerland's economic and financial relations in sub-Saharan Africa raises two final questions: that of Switzerland's role and responsibility during the independence wars in Angola and Mozambique; and that of the weight of economic considerations on Swiss foreign policymaking in subSaharan Africa. With regard to the first question, political scientist Sérgio Inácio Chichava argued that, through their economic activities, Swiss citizens contributed to the stabilisation of the Portuguese empire and the exploitation of the Mozambican population. ${ }^{127}$ Swiss trade with and investment in Portugal and its two largest African colonies increased after the two European states joined EFTA in 196o. It accelerated in the late 196os and early 1970s and was not visibly slowed by the independence wars. The conflicts had no direct economic benefits for Switzerland, such as an increase in Swiss arms sales. Nevertheless, Swiss business circles benefited from the economic boom in the colonies that resulted in part from reforms introduced by the colonial authorities as a response to the outbreak of armed violence. In addition, Switzerland's growing economic presence in Angola and Mozambique increased the risks associated with a transfer of power in the colonies. For these reasons, it must be concluded that from a business point of view, there was little incentive for Switzerland's political and economic elites to advocate a change in the colonies' status quo.

The Swiss government was keen to separate political and economic affairs. It refused to accept the view, frequently advanced by Afro-Asian leaders and Swiss civil society actors from the late 196os onwards, that tolerating the economic and financial activities of Swiss citizens and companies in Angola and Mozambique implied official support for Portuguese colonialism. During the independence wars, the leaders of the FPD and the FDEA never spoke out against economic relations with Portugal and its colonies. In some cases, the Swiss state promoted exports to Portuguese Africa by granting an ERG cover. However, it must be stated that the Swiss state's commitments in the two colonies were very small. On 1 January 1972, they amounted to CHF 10 million, more or less evenly distributed, which constituted 3.1\% of all ERG's in Africa and $0.27 \%$ worldwide. ${ }^{128}$ There is only one known case where the FPD's Secretary General expressed his reservations about a credit arrangement issued to the Portuguese colonies. Referring to the harsh criticism by the UNGA and

(ASBA), folder L. 182 Afrique 5.1.71 au 14.7.75. See also the letter from António de Almeida, ICM, to the SBA, 10.04.1972, ibid.

128 ERGs granted to Angola and Mozambique amounted to CHF 4.77 million and CHF 5.22 million, respectively: FDAE, memorandum, "Engagements de la Confédération dans le domaine des garanties contre les risques à l'exportation et de l'investissement en faveur des Etats africains", [January 1972], dodis.ch/36377. 
independent African states of Western financial cooperation with the white minority regimes in Southern Africa, he expressed doubt as to whether the authorisation of a CHF 19.8 million credit arrangement issued by the Zurich branch of Dow Banking Corporation to SONEFE in Angola would be in Switzerland's interest, especially as the issuing institution was foreign-owned. ${ }^{129}$ Due to Portugal's need to develop its economy and attract foreign investment, Swiss-Portuguese economic relations were unequal. Therefore, Swiss delegations could have used their leverage in economic negotiations to express a wish for the decolonisation of Angola and Mozambique. There is no sign that they ever did so.

The second question refers to the role of economic interests in Swiss foreign policymaking in Southern Africa and the Horn. As Somalia's and Ethiopia's poverty limited trade and investments, economic interests were not a driving force of Swiss foreign policy in the Horn of Africa. In Angola and Mozambique, the situation was slightly different. Although Switzerland had more substantial trade with and investments in the Portuguese colonies, the overall importance of Portugal and its colonies to the Swiss economy remained small. Economic considerations are not sufficient to explain why the Swiss government privileged the status quo and relations with Portugal over those with Angola's and Mozambique's potential future rulers. Economic and financial relations with South Africa and, to a lesser extent, with Rhodesia were of paramount importance for Swiss foreign policy in Southern Africa and on the whole African continent. The Swiss government was hesitant to take any steps that might have limited Swiss business in South Africa. It refused to cut its links with the Portuguese colonial power out of fear that it might then be forced to adopt similar measures with regard to the other white minority regimes in the region. At the same time, Switzerland's economic role in South Africa and Rhodesia became a political handicap in the late 1960s, as condemnation of Apartheid and white minority rule was one of the main issues that united independent African governments of all political couleurs. On the whole, Somalia, Ethiopia, Mozambique, and Angola were minor economic and development cooperation partners for Switzerland. For the Swiss government, these countries mattered mainly because of the armed conflicts and regime changes that placed them at the centre of the global East-West and North-South confrontations.

129 Letter from Ernesto Thalmann, Secretary General of the FPD and head of the DPA, to the SNB, "Exportation de capitaux à destination de l'Angola", 16.08.1972, p. 1, SFA E2001E-o1\#1987/78\#4656*. The credit does not seem to have been authorised: Letter from Pierre André Nussbaumer, chief of the Financial and Economic Service of the FPD, to the Office of the Permanent Observer of Switzerland to the United Nations, "Résolution no 2979 (XXVII) du 14.12.1972 / Investissements étrangers en Angola", 16.01.1973, SFA E2001E-01\#1987/78\#4656*. 
PART 1

The Struggle for National Liberation during the Last Phase of European Colonialism, 1967-1974 


\section{Introduction to Part 1}

Even though, in general, our conception of permanent neutrality is scarcely understood by delegations of the Third World to the UN, we have so far enjoyed a favourable bias, based, on the one hand, on the humanitarian tradition of our country, and, on the other, on the international role played by Geneva. It is to be feared that this image might deteriorate in the future and that our neutrality might be accused of being a hypocritical screen for making good investments and doing good business with the 'racists' of Pretoria. ${ }^{1}$

The words of Bernard Turrettini, ambassador at the Office of the Permanent Observer of Switzerland to the UN, in February 1968 anticipated a change in the international perception of Switzerland's foreign policy in sub-Saharan Africa. As most former colonies had achieved independence and East-West tensions had started to relax in the late 196os, the independence wars in the Portuguese colonies were increasingly in the national and international spotlight. The fight against colonialism and white minority rule was the main issue uniting different African regimes. Most of the newly independent African and Asian states supported the struggle of African liberation movements politically, and in some cases materially. From the late 196os onwards, Afro-Asian criticism of white minority rule, voiced mainly at the UNGA and the OAU, became increasingly forceful. It also began to target Western states that were accused of collaborating with the racist regimes in Southern Africa.

While the political leaders of the Soviet Union, the PRC, and member states of the Eastern bloc spoke out for national liberation and provided Southern African liberation movements with arms and military training, the Western bloc's position was less clear-cut. Although there was widespread agreement that the days of colonialism and racist oppression were over, Cold War considerations prevented many governments from paying more than lip service to the principle of self-determination. The South African regime's insistence on its function as a bulwark against Communist liberation movements in the region, the strategic importance of the Cape Route, and its production of essential mineral resources helped to contain criticism of its Apartheid policy. ${ }^{2}$

1 Letter from Bernard Turrettini, ambassador at the Office of the Permanent Observer of Switzerland to the United Nations, to Federal Councillor Willy Spühler, 20.02.1968, p. 3, SFA E2003A\#1980/85\#1971*.

2 Evans, "The Great Simplifier", pp. 140-146. 
Portugal was a founding member of NATO and considered important for the protection of the organisation's southern flank and for stability in Southern Africa. Strong economic and military ties, most importantly the US Lajes airbase on the Portuguese Azores, prevented the US, British, French, and West German governments from publicly criticising the Portuguese regime. The governments of some small Western European states, notably those of Norway, Denmark, and the Netherlands, were more critical and in the 1970s advocated pressuring Portugal, through NATO, to change its colonial policy. However, on the whole, the Estado Novo regime remained well integrated in the Western alliance until the Carnation Revolution in April $1974 .^{3}$

Minority rule in Southern Africa and many Western governments' tolerance of it mobilised numerous civil society actors. As a part of the global protest movement after 1968, student groups, Third World activists, members of labour movements and Social Democratic parties, and religious organisations, such as the ecumenical WCC, supported the struggle of Southern African liberation movements and called for an end to racial oppression in the region. At the same time, they challenged their own governments to take a stand against white minority rule and to stop economic and military collaboration with regimes engaged in armed conflicts. ${ }^{4}$ As the debate about national liberation in Southern Africa became increasingly heated, Switzerland's economic role in the region drew much critical attention. This started to undermine the credibility and respectability of the country's policy of neutrality and put Swiss foreign policymakers on the defensive.

The intensification of the conflict over national liberation in Southern Africa in the late 196os and early 1970s was part of much bigger changes in international relations along East-West and North-South lines that challenged Switzerland's foreign policy. The late 196os marked the beginning of a transformation in East-West relations. The Cold War crises in Berlin and Cuba in the early 196os had brought home the dangers of an escalation of the superpower conflict in the nuclear age. As a result, Western European states took a series of steps to decrease international tensions and improve their relations with the USSR. In 1966, French President Charles de Gaulle withdrew from NATO's unified military command and visited Moscow. More importantly, Willy Brandt's Social Democratic government, which came into power in the FRG in late 1969, intensified the country's new Ostpolitik (policy towards the East). This would

3 See notably Rui Lopes, "Accommodating and Confronting the Portuguese Dictatorship within NATO, 1970-4", The International History Review 38:3 (2016), pp. 305-326.

4 See notably Kuhn, "Liberation Struggle and Humanitarian Aid"; Klimke, Scharloth, 1968 in Europe; Suri, Power and Protest. 
lead to the recognition of West Germany's territorial borders as inherited from the Second World War and to the mutual recognition of the two German states in late 1972. The Western European challenges to US dominance were mirrored in the Eastern bloc, although to a lesser degree. In March 1969, the Warsaw Pact renewed its call for a Pan-European security conference that, for the first time, did not exclude the US, and thereby launched the CSCE negotiations that would begin in 1972. The administration of Republican Richard Nixon, who entered office in early 1969, had the job of reacting to the relative decline of US power as the Soviet Union's strategic military forces approached those of the US, and to European wishes for reduced political tensions and increased economic cooperation with the Eastern bloc. Nixon and his National Security Advisor, Henry Kissinger, initiated direct back channel contact with the UssR. The two superpowers opened negotiations on arms controls, notably at the Strategic Arms Limitation Talks (SALT), and signed an interim agreement, known as SALT I, in May 1972 in Moscow. This first summit meeting between Nixon and Leonid Brezhnev was followed by a second conference in Washington in June 1973. The US administration also made efforts to improve relations with the PRC, which culminated in Nixon's China visit in February 1972. ${ }^{5}$

In parallel to the establishment of Détente, changes were underway in North-South relations. As decolonisation accelerated after the Second World War, the newly independent states in the global South began to organise themselves and create a common front to further their interests. In 1955, Asian and other Third World leaders met in Bandung, Indonesia, where they emphasised Third World cooperation, the liberation of colonial territories, and a neutralist foreign policy removed from superpower dominance. On these principles, the Non-Aligned Movement (NAM) was officially founded in 1961. In the economic sphere, during the first UN Conference on Trade and Development (UNCTAD) in 1964, developing countries formed the $\mathrm{G}_{77}$ group, whose membership overlapped with that of the NAM. They demanded more equality in North-South economic relations. By the early 1970s, Third World states formed a bloc that acted confidently on the international stage. ${ }^{6}$

5 See Raymond L. Garthoff, Détente and Confrontation. American-Soviet Relations from Nixon to Reagan, Washington, DC: The Brookings Institution, revised edition 1994; Jussi M. Hanhimäki, "Détente in Europe, 1962-1975", in Leffler, Westad, The Cambridge History of the Cold War. Volume II: Crises and Détente, pp. 198-218; Robert D. Schulzinger, "Détente in the NixonFord Years, 1969-1976", in Leffler, Westad, The Cambridge History of the Cold War. Volume II: Crises and Détente, pp. 373-394.

6 See notably Garavini, After Empires; Mazower, Governing the World; Jürgen Dinkel, "Third World Begins to Flex its Muscles'. The Non-Aligned Movement and the North-South Conflict during the 1970s", in Bott et al., Neutrality and Neutralism in the Global Cold War, pp. 108-123. 
In order to prevent international isolation in a context of East-West rapprochement, growing Third World political power, and European integration, Swiss foreign policymakers recognised the need for a more outward-looking position and adopted a more active approach to foreign policy. The experience of terrorism by left-wing Palestinian and Brazilian organisations, respectively, during the 1969-1970 attacks on an El Al plane at Zürich airport and the explosion of one and hijacking of another Swissair plane, and the kidnapping of the Swiss ambassador in Rio in 1970-1971, also contributed to the awareness that neutrality alone was not sufficient to protect Switzerland's standing in the Third World. This realisation resulted in a number of limited steps in some areas-notably Switzerland's active participation in the CSCE negotiations, the government's 1971 decision to join the UN, and the recognition of North Vietnam and North Korea in 1971 and 1974, respectively. ${ }^{7}$ Yet, despite the considerable political pressure exercised by Afro-Asian leaders (chapter 2) and part of Switzerland's civil society (chapter 3), the Swiss government resisted similar openings in Southern Africa, as it was unwilling to compromise its economic relations with Portugal and South Africa. This significantly impaired the image of Switzerland's neutrality in sub-Saharan Africa, especially as neutral Sweden presented an alternative model of a neutrality policy that was more attuned to Third World issues.

7 See Bott, Schaufelbuehl, "Switzerland and Détente"; Guttmann, The Origins of International Counterterrorism. 


\section{Countering Criticism from the Third World: Switzerland's Stance on White Minority Rule}

In the late 1960 s and early 1970s, the Swiss government's position towards Portuguese colonialism and the independence wars in Angola, Mozambique, and Guinea-Bissau was not fundamentally different from during the early years of the conflict. The Swiss authorities still preferred to avoid taking a stand and tried to keep the door open to both the coloniser and the colonised. This was increasingly difficult, however, as Portugal became the last European colonial power to resist decolonisation. For the authoritarian Estado Novo regime led by António de Oliveira Salazar, the colonies of Angola, Mozambique, Guinea-Bissau, Cape Verde, and São Tomé e Príncipe were an integral part of the Portuguese empire. Since the early 196os, the Portuguese authorities had been involved in costly counter-insurgency wars against African liberation movements fighting for independence. ${ }^{1}$ Initial hopes for change after Marcello Caetano took over from a hospitalised Salazar in September 1968 were soon dashed. ${ }^{2}$ As Portuguese colonialism became an anachronism, it was subsumed under the general problem of systematic racial discrimination in Southern Africa. Together with the white settler regime in Rhodesia that had, in 1965, unilaterally declared its independence from the UK, and an Apartheid South Africa that occupied Namibia, the Portuguese colonies formed part of a bastion of white minority rule in Southern Africa. The three minority regimes cooperated militarily to combat the challenge of African nationalism, notably negotiating a secret, informal military agreement called Exercise Alcora in the latter half of 1970. Although Pretoria provided some military support to Lisbon and Salisbury, each government was critical of the others' different, but always discriminatory, way of organising their multiracial societies. ${ }^{3}$

1 MacQueen, The Decolonization of Portuguese Africa.

2 Lopes, West Germany and the Portuguese Military Dictatorship, p. 7.

3 See Miller, An African Volk, pp. 95-10o; Paulo Correia, Grietjie Verhoef, "Portugal and South Africa: Close Allies or Unwilling Partners in Southern Africa during the Cold War?" Scientia Militaria: South African Journal of Military Studies 37:1 (2009), pp. 50-72; Filipe Ribeiro de Meneses, Robert McNamara, "The Origins of Exercise ALCORA, 1960-71", The International History Review 35:5 (2013), pp. 1113-1134; Filipe Ribeiro de Meneses, Robert McNamara, "Exercise ALCORA: Expansion and Demise, 1971-4”, The International History Review 36:1 (2014), pp. 89-111. 
In international settings, the white minority regimes in Southern Africa were frequently discussed as a single issue. This was problematic for Switzerland's foreign policy during the late independence wars in the Portuguese colonies. Switzerland was not a former colonial power like the UK and France, did not cooperate militarily with the Estado Novo regime like the Nixon administration, France, and the FRG, and its economic relations with Portugal and its colonies remained limited. Nevertheless, its prominent economic position in South Africa and its government's independent stance on the UN sanctions against Rhodesia ensured it considerable negative attention from Third World governments. Fearing that its political and economic relations with these states might otherwise suffer, the Swiss government felt compelled to react to their challenges.

Up until the Carnation Revolution in April 1974, the Swiss government never publicly took a stand against Portugal's colonial rule or the manner in which the Estado Novo regime oppressed the African liberation movements. Its distanced attitude towards Portuguese colonialism was reinforced by a legalistic view of decolonisation. "Legally, Portugal's sovereignty over the territories in question, which has been established for centuries, is hardly disputable", argued Ambassador Ernesto Thalmann of the DIO in April 1968. ${ }^{4}$ Thus, Bern refused to discuss the issue of colonialism in moral terms and considered decolonisation an internal affair of the Portuguese regime. At the same time, there was widespread awareness that the movement towards decolonisation was inevitable and that something had to be done to show Switzerland's interest in the colonies' African populations in order to facilitate the future establishment of political relations with independent states.

The Swiss government's position during the independence wars in Portuguese Africa was determined on a case-by-case basis and influenced by its selective understanding of neutrality, which was characterised by the emphasis on non-interference, as well as by its political and economic interests. Fierce debates about colonialism and white minority rule at the UN and other international organisations meant that the Swiss government could no longer rely solely on its position of neutrality and abstention to protect itself from criticism. In order to improve Switzerland's image and dispel the impression of being allied to the colonial power, Swiss foreign policymakers made use of two policy instruments that allowed them to make a positive contribution: granting humanitarian and development aid to the African populations and proposing its good offices to the belligerents.

4 Ernesto Thalmann, head of the Dio, "Instructions aux délégations suisses dans les conférences internationales au sujet de l'admission et de l'exclusion de certains pays", 10.04.1968, pp. 4-5, dodis.ch/33555. 
The granting of aid was in accordance with the principle of solidarity that had been part of Switzerland's conception of neutrality since the Second World War. However, Swiss government aid to the Portuguese colonies was small-scale. In 1967, the STC began to financially support the humanitarian work of Swiss missions in Angola, Mozambique, and South Africa, despite the fact that the latter was not considered a developing country and that the STC did not usually grant aid to dependent territories. This change in policy was justified, inter alia, with the argument that the people living in these countries should not be punished for the omissions of their governments. ${ }^{5}$ Until the end of 1969, the STC granted a total of CHF 400,000 to support the deployment of volunteers to Swiss missions that worked in the fields of education, medicine, and religion in Mozambique (22 people) and Angola (6 people). ${ }^{6}$ In 1969, the Federal Government also collaborated with the Swiss Mission in Mozambique on a donation of 10 tons of powdered milk that was distributed in the country by missionaries. ${ }^{7}$ Nevertheless, compared to the contributions to Rwanda and India - the main beneficiaries of Swiss aid that had received more than CHF 18 million each by the end of $1968^{8}$ — Switzerland's bilateral aid to the Portuguese colonies was negligible and could not be counted upon to foster much political goodwill.

The instrument of granting scholarships to shape the future cadres of independent states looked promising, but was not handled flexibly enough to produce the desired outcome. Swiss foreign policymakers hoped that the beneficiaries of scholarships to study in Switzerland would later be well disposed towards the country. In their view, admitting such students also protected the beneficiaries from Communist influence. ${ }^{9}$ However, scholarships in Switzerland are granted on an intergovernmental basis; African students' applications had to go through the Portuguese bureaucracy, which preferred to reserve the scholarships for metropolitan students. In mid-1972, the DPA and the DIO

5 Note from Sigismond Marcuard, Delegate for Technical Cooperation, to the DIO, 26.02.1968, p. 2, SFA E2OO3A\#1980/85\#1971*.

6 Note from Richard Pestalozzi, deputy head of the sTc, to Ernst Henri Léchot, responsible for relations with Portugal within the Trade Division, "Technische Zusammenarbeit mit Portugal", 29.12.1969, SFA E2005A\#1980/82\#707*.

7 Report from Jean-Pierre Bertrand, Swiss consul in Mozambique, to the FPD, "Geschäftsbericht des schweizerischen Konsulats in Lourenço Marques 1969", 29.01.1971, p. 13, SFA E2400\#1991/232\#22*.

8 Theodor Kunz, sTC, memorandum, "Liste der Entwicklungsländer, für welche die Schweiz Verpflichtungen eingegangen ist (inkl. Auszahlungen per 31.12.1968)", 15.01.1969, p. 1, dodis. $\mathrm{ch} / 32947$.

9 Trachsler argues that from its inception, Switzerland's development aid programme had strongly anti-Communist intentions and was aimed at containing Communist influence in the Third World: Trachsler, "Neutralität, Solidarität und Kalter Krieg". 
considered it inappropriate to interfere in Portugal's choice and to reserve one of the two scholarships offered to Portugal for a student of African origin. The two services feared a negative reaction from Lisbon. ${ }^{10}$

For African nationalists, obtaining scholarships and other forms of humanitarian aid was about more than material support for their struggle. In September 1972, Pedro Gadimpovi, responsible for national education in the Angolan Revolutionary Government in Exile (GRAE), contacted the STC. He wished to open "a channel of cooperation between your organisation and my department" and asked the STC to create opportunities for young Angolans to study in Switzerland. ${ }^{11}$ The wording of his request underlines the GRAE's aspiration to establish itself as a legitimate counterpart of the Swiss authorities-and the true representative of the Angolan people. The STC, however, insisted that Swiss scholarships were only attributed to governments, thereby thwarting the GRAE's attempt at gaining international recognition. ${ }^{12}$ FPD officials' unwillingness to risk offending Portugal by giving the impression of politically supporting African nationalists undermined the fiction of non-political aid. It also limited the effectiveness of this policy instrument to improve the image of Switzerland's neutrality and to create good preconditions for the Portuguese colonies' independence.

The principle of availability, which underlines Switzerland's willingness to offer mediation and good offices during armed conflicts, has been part of the country's conception of neutrality since the early $1960{ }^{13}{ }^{13}$ Yet, by the end of the decade, Switzerland's neutrality was no longer seen as a sufficient guarantee for its impartiality, as Albert Natural of the DPA stated at the annual conference of Swiss ambassadors in 1967: "In the second half of the 2oth century, conflicts usually take place between states of different ideologies or races. Consequently, the fact that Switzerland is liberal and white can cause [...] totalitarian regimes and coloured peoples to distrust us." Natural underlined that African actors in particular preferred to look for regional mediators. ${ }^{14}$ Indeed, there were few opportunities for Switzerland's good offices during the independence wars in Portuguese Africa. The Estado Novo regime had little interest in negotiations

10 Note from Jean-Jacques Indermühle, DPA, to the DIO, "Bourses fédérales pour le Portugal", 14.07.1972, SFA E2001E-01\#1982/58\#6126*; see also note from FR, DIO, to Lukas Burckhardt, DIO, "Stipendiengesuche von Angehörigen portugiesischer Provinzen", 11.07.1972, attached to the note from Lukas Burckhardt to the DPA, "Bundesstipendien für Portugal", 12.07.1972, SFA E2OO1E-o1\#1982/58\#6126*.

11 Letter from Pedro Gadimpovi, GRAE, to the STC, 04.09.1972, SFA E2OO5A\#1983/18\#183*.

12 Letter from Benoît Frochaux, STC, to the GRAE, 19.09.1972, SFA E2OO5A\#1983/18\#183.

13 Möckli, Neutralität, Solidarität, Sonderfall, p. 28o.

14 Albert Natural, DPA, draft speech, "Note en vue de la conférence des Ambassadeurs (30.8.1.9.1967). Les bons offices”, 21.08.1967, p. 2, dodis.ch/33674. 
with the liberation movements. African nationalists were unlikely to ask the Swiss government to mediate, as they considered it to be too closely linked to the colonial power.

Switzerland's mandate to represent Portugal's interests in Senegal gave the Swiss authorities some openings to help appease the tensions in Guinea-Bissau, where the PAIGC fought the Portuguese military. Since the outbreak of this independence war in 1963, Senegalese President Léopold Sédar Senghor had tried to mediate between the PAIGC and the Portuguese government. ${ }^{15} \mathrm{He}$ repeatedly used the Swiss embassy in Dakar to contact Lisbon. Swiss diplomats were generally willing to go a little further than their mandate warranted and to serve as a two-way channel of communication between Lisbon and Dakar, as long as this did not endanger their own relations with Portugal. ${ }^{16}$ Switzerland's most important contribution to the search for a solution to the conflict in Guinea-Bissau was the organisation of a meeting between the Senegalese and Portuguese authorities in February 1970, where the possibility of ending the war was discussed. ${ }^{17}$ The initiative for this meeting came from Senghor. He asked the Swiss embassy in Dakar in late 1968 to use Switzerland's good relations with Portugal to convince the new Portuguese leader, Marcello Caetano, to meet with a Senegalese delegation. ${ }^{18}$ Preparations for the bilateral meeting were well advanced by late January 1970 when the Swiss ambassador in Senegal, Jean Richard, learned-from his American and French colleagues- that he was not only expected to host the Portuguese delegation but also to chair the discussions. Senghor had approached the US ambassador in Senegal in the hope of convincing the Nixon administration to pave the way for the prospective meeting's success. ${ }^{19}$ The French government, which represented Senegal's interests in Portugal, expected little to come of the meeting and preferred to sit back. ${ }^{20}$ The FPD empowered its ambassador to take an active role during this

15 MacQueen, "Portugal's First Domino", p. 217.

16 See notably the letter from Lucien Mossaz, head of the section responsible for the representation of foreign interest in the FPD, to the Swiss Embassy in Senegal, confidential, 10.10.1967, p. 2, SFA E2003-o6\#1979/15\#240*.

17 The Dakar meeting organised by the Swiss embassy is mentioned by MacQueen, but the author mistakenly places it in early 1971: MacQueen, "Portugal's First Domino", p. 218.

18 Letter from Pascal Frochaux, Swiss ambassador in Senegal, to Pierre Micheli, Secretary General of the FPD and head of the DPA, 11.12.1968, secret and urgent, p. 3, SFA E20o1E\#1980/83\#3769*.

19 Telegram no 231 from Lewis Dean Brown, US Ambassador in Senegal, to the Secretary of State, confidential, p. 2, 23.01.1970, NARA RG 59, Subject-Numeric Files 1970-1973, POL PORT-SENEG 1/1/70, box 2557 .

20 Telegram no 251 from Lewis Dean Brown to the Secretary of State, confidential, 26.01.1970, NARA RG 59, Subject-Numeric Files 1970-1973, POL PORT-SENEG 1/1/70, box 2557. 
meeting: "The request for good offices should, in principle, be met favourably. Provided that this is the wish of both parties, our role is thus to be interpreted as broadly as possible and to assist as much as possible—obviously avoiding any partisanship." 21

Ambassador Richard was the only foreign diplomat present at the meetings between the Portuguese envoy Alexandre Ribeiro da Cunha and a Senegalese delegation headed by Foreign Minister Karim Gaye on 9-11 February 1970. During the discussions, the two sides agreed that their dialogue, which had also centred on the possibility of self-determination in Guinea-Bissau, might be continued. Afterwards, Richard was carefully optimistic that a real exchange might take place. ${ }^{22}$ However, attitudes soon hardened again and in late 1970, Gonçalo Caldeira Coelho of the Portuguese Foreign Ministry told the Swiss ambassador in Portugal that the dialogue could only be reopened if it was limited to the discussion of purely bilateral issues. ${ }^{23}$ While there are no indications of Switzerland's further implication in the search for a resolution of the conflict in Guinea-Bissau, negotiations between Lisbon and Dakar did not break off completely. Other bilateral meetings were organised by France in 1971 and by the UK just weeks before the Portuguese revolution in $1974 .{ }^{24}$ The episode of the Senegalese-Portuguese meeting in early 1970 demonstrates the limits of the Swiss government's influence to contribute to the peaceful resolution of the liberation wars in sub-Saharan Africa. While the Senegalese government was happy to delegate the logistics of the meeting to Portugal's protecting power, the US and French ambassadors in Dakar seem, at times, to have been better informed about the proceedings than their Swiss colleague. In addition, Senghor asked the US and the UK, not Switzerland, to induce Lisbon to agree to a negotiated solution to the independence war in Guinea-Bissau.

Clearly, the Swiss government's policies of aid and good offices neither influenced the course of the independence wars in the Portuguese colonies, nor were they able to diffuse the criticism of Switzerland's political and economic role in Southern Africa. The protection mandate in Senegal might have satisfied the Portuguese authorities, but it did not dispel the impression that Switzerland was on the side of the white minority regimes. In a similar vein,

\footnotetext{
21 Telegram no 8 from the FPD to the Swiss embassy in Senegal, 02.02.1970, SFA E2001E\#1980/83\#3769*. See also telegram no 6 from the Swiss embassy in Senegal to the FPD, 28.01.1970, ibid.

Telegram no 12 from the Swiss embassy in Senegal to the FPD, 12.02.1970, urgent, SFA E2001E\#1980/83\#3769*.

23 Letter from René Naville, Swiss ambassador in Portugal, to the DPA, confidential, O3.11.1970, p. 1, SFA E2OO1E\#1980/83\#3769*.

24 MacQueen, "Portugal's First Domino", pp. 219; 226-227.
} 
Bern's aid to the colonies' African populations was too limited to leave a lasting impression on the liberation movements. In a context of growing politicisation of white minority rule, the Swiss government's preparations for the independence of Angola and Mozambique were increasingly sidelined. Instead, Swiss foreign policymakers focused on countering Third World criticism. Between 1967 and 1974, Switzerland's stance on Portuguese colonialism and white minority rule was discussed at three centres of international diplomacy: the UN in New York, OAU headquarters in Addis Ababa, and at the seat of international organisations and the ICRC in Geneva. The question of how to deal with African criticism-Swiss diplomats rarely differentiated between the positions of individual governments and usually lumped them all togethercaused some friction within the Swiss federal administration. Instead of taking a clear stand on Portuguese colonialism and curbing its economic relations with Southern Africa to appease the African critics, Bern focused on the granting of limited humanitarian aid to the victims of the independence wars and took steps to improve its relations with the OAU. This, it was hoped, would enable Switzerland to compensate for its close relations with the white minority regimes, without prejudicing its economic interests.

\section{New York: Debates on Economic Collaboration at the 1967 U NGA}

Anti-colonialism was already an issue at the UNGA when Portugal was admitted to the international organisation in 1955. Yet, it was the independence of 17 African states in 196o that shifted the balance of power in the UN and paved the way, in December of the same year, for UNGA resolutions 1514 and 1542. In resolution 1514, the UNGA called for the decolonisation of all territories that had not yet attained independence. Resolution 1542 explicitly mentioned the Portuguese colonies, thereby refuting the colonial power's claim that these territories were overseas provinces. ${ }^{25}$ In the years that followed the outbreak of armed violence in the Portuguese colonies, the Afro-Asian bloc at the UN repeatedly raised the subject of Portuguese colonialism. It was instrumental to the adoption of increasingly strong resolutions against the Estado Novo regime by the Special Committee on Decolonisation and the UNGA. Nevertheless, the Salazar government could usually count on the support of the three Western

25 Reis, "Portugal and the UN", pp. 255-26o; see also Aurora Almada e Santos, "The Role of the Decolonization Committee of the United Nations Organization in the Struggle Against Portuguese Colonialism in Africa: 1961-1974", The Journal of Pan-African Studies 4:10 (2012), pp. 248-26o. 
permanent members of the Security Council. ${ }^{26}$ The Afro-Asian bloc was similarly vocal in condemning white minority rule in South Africa and Rhodesia.

Switzerland's close relations with South Africa and Portugal initially escaped the attention of the newly independent countries in Africa and the rest of the Third World. As Switzerland was a relatively small international player, had never been a colonial power, and had not joined the UN, this is perhaps not surprising. After the Rhodesian white minority government's unilateral declaration of independence from the UK in 1965, Bern also seemed to comply with the UN's Rhodesia policy in its own way. The Swiss government did not recognise Rhodesia, embargoed the export of arms to the country, and blocked the assets of the Reserve Bank of Rhodesia that were deposited at the SNB. At the same time, without referring directly to the UN call for sanctions, the Federal Council introduced the 'autonomous' and not very far-reaching measures to reduce trade with Rhodesia that were briefly outlined in the preceding chapter. $^{27}$

In 1967, however, Afro-Asian states increasingly focused on the role that trade and foreign investment played in stabilising the minority regimes and preventing the independence of dominated territories. Switzerland could no longer hide behind the great powers. In late September 1967, Bernard Turrettini, ambassador at the Office of the Permanent Observer of Switzerland to the United Nations in New York, warned the Dio that Swiss firms were likely to figure on a list of firms active in Southern Africa that a sub-committee of the Decolonisation Committee, composed of Socialist, Third World, and Finnish representatives, had just compiled. ${ }^{28}$

At the twenty-second session of the UNGA, held in 1967 , the problem of white minority rule was one of the main topics discussed. No less than seven points on the subject figured on the agenda. In the general debate, where Liberia's representative criticised the growing exports from EEC and EFTA countries to Rhodesia, Switzerland was not mentioned by name. But during discussions in different UN commissions, Swiss trade with South Africa and Rhodesia was mentioned six times. Talking about the "major Western powers"

26 Reis, "Portugal and the UN", p. 265; Lopes, West Germany and the Portuguese Military Dictatorship, pp. 15-16.

27 FPD, FDEA, proposal to the Federal Council, "Rhodesien", urgent, 13.12.1965, attached to the decree of the Federal Council, "Rhodesien", 17.12.1965, dodis.ch/31953; Ross, Neutrality and International Sanctions, pp. 165-166.

28 Letter from Bernard Turrettini, ambassador at the Office of the Permanent Observer of Switzerland to the United Nations, to the Dio, "Intérêts économiques étrangers dans les territoires coloniaux de l'Afrique australe”, 28.og.1967, SFA E2003A\#1980/85\#1971*. 
that continued to trade with South Africa in the UN's Special Political Commission, the Kenyan representative stated:

These countries include the UK, France, the US, West Germany, Japan, and Switzerland. These countries are each among the most powerful in the world and, as a group, they could certainly be a decisive factor in an issue such as apartheid. These countries not only chose not to respond to the hopes of millions of Africans, but they preferred to continue cashing in the profits from the ruthless exploitation of these same poor people. ${ }^{29}$

African delegates did not explicitly mention Switzerland's economic role in the Portuguese colonies. However, the situations in South Africa, Rhodesia, Namibia, and the Portuguese colonies were discussed interchangeably within UN frameworks. As a member of the DIO underlined in an internal note in November 1967, "[a]ll these problems being more or less interdependent, an amalgamation has progressively taken place, so that one can observe today, at the United Nations, a global approach to Southern Africa." ${ }^{30}$ Even though Switzerland's economic role in the Portuguese colonies was negligible, there was no guarantee that its links to Portugal would not be singled out in the future. Indeed, when the blacklist of firms doing business with the white minority regimes in Southern Africa was published in November 1967, it included two Swiss plantations in Mozambique. ${ }^{31}$

The criticism raised at the UNGA had an immediate effect in Bern. Concerned about Switzerland's image in Africa, the DIO organised a meeting of high-ranking members of different services of the FPD and the Trade Division on 29 November 1967. Ernesto Thalmann, at the time chief of the DIO, chaired the meeting, which he opened by stating that, although he did not want to dramatise the attacks, it was possible that they were "the prelude to a wider campaign" that might affect Switzerland's standing in different international organisations. Therefore, it was important to be proactive and to think about

29 Emphasis in original. Cited in François Pictet, chief of the DIo's United Nations and International Organisations Section, memorandum, "Nations Unies. Questions relatives à l'Afrique australe. Critiques envers la Suisse", 17.11.1967, p. 4, attached to the note from Pictet to the Secretary General of the FPD, 17.11.1967, SFA E2003A\#1980/85\#1971*.

$30 \quad$ Ibid., p. 1.

31 The firms in questions were the CCA and Copra and Cashew Nut Factories (probably Boror): letter from François de Ziegler, Office of the Permanent Observer of Switzerland to the United Nations, to the DIO, "Documentation concernant la Décolonisation", 17.11.1967, p. 2, SFA E2OO3A\#1980/85\#1971*. 
the steps to be taken in order to ward off the criticism. ${ }^{32}$ The ensuing discussion focused almost exclusively on Switzerland's economic relations with South Africa and Rhodesia, which were both more exceptional in international comparison and more heavily criticised by the Afro-Asian bloc than relations with Portugal. While all participants agreed that the African criticism voiced at the UNGA was problematic, there was a gulf in opinion between the members of the FPD and the representative of the Trade Division-Vice-Director Hans Bühler. The latter clearly prioritised Switzerland's economic and political relations with South Africa and was hostile to any measure that might impinge on these ties. Bühler refused to consider the argument of the African lobby that economic relations with white minority regimes might contribute to their stabilisation: "By trading with or investing in these regions, Switzerland has no political motive and no intention of assisting the governments in power." ${ }^{33}$ The members of the FPD, however, argued that the accusations should be taken seriously, as Third World criticism was likely to increase. Nevertheless, although some participants hinted at the possibility of a more reticent government position towards South Africa, no real change in policy was decided. Instead, the leaders of the FPD services agreed to prepare a file on Swiss policy in Southern Africa that would help Swiss ambassadors abroad respond to further allegations. Lastly, the participants returned to their standard panacea whenever relations with Africa were concerned; they discussed the granting of humanitarian aid in order to foster political goodwill towards Switzerland. ${ }^{34}$

The question of aid for Southern Africa was the focus of intense debate between the different sections of the FPD responsible for aid. As a result of the accusations levelled against Switzerland at the UN, the STC prepared to increase its activities in the independent states of Southern Africa: Lesotho, Zambia, Malawi, and Tanzania. ${ }^{35}$ Multilateral aid in the form of a Swiss contribution to different UN programmes in favour of the victims of racial oppression, such as the UN Trust Fund for South Africa or the UN Training Programme for South Africans, was more controversial than bilateral aid. Despite

32 Statement of Ernesto Thalmann, in François Pictet, memorandum, "Relations de la Suisse avec l'Afrique australe. Réunion inter-départementale du 29 novembre", 13.12.1967, p. 1, SFA E2005A\#1980/82\#132*; see also the note from Pictet to the STC, "Afrique australe", 14.11.1967, ibid.

Statement of Hans Bühler, Vice-Director of the Trade Division, in François Pictet, memorandum, "Relations de la Suisse avec l'Afrique australe. Réunion inter-départementale du 29 novembre", 13.12.1967, p. 1, SFA E2005A\#1980/82\#132*.

34 Ibid., pp. $2-3$.

35 Note from Richard Pestalozzi to the Dio, "Fonds betreffend Südafrika'. Ihre Notiz vom 15. Januar 1968”, 19.01.1968, dodis.ch/33771. 
Ambassador Turrettini's frequent insistence that such donations might compensate for Switzerland's close relations with the white minority regimes and the fact that other Western states had already made financial contributions, the DPA was opposed to these programmes because of their political nature. ${ }^{36}$ This scepticism was shared by the STC, which was, in any case, doubtful that a financial contribution would really allow the Swiss government to buy its way out of criticism. ${ }^{37}$ The reluctance to contribute to the UN funds was probably also a reflection of a general aversion to multilateral aid, which reduces individual donors' control over aid and its political benefits. The DIO, most closely concerned with UN affairs, also had some doubts about the special funds, but advocated an additional contribution to the Office of the United Nations High Commissioner for Refugees (UNHCR) in favour of South African refugees: "This form of aid, granted to a virtually apolitical organisation which endeavours at all times to make the humanitarian aspect predominate in the examination of problems, would meet our agreement, as we would like to depoliticise potential aid as much as possible." ${ }^{38}$ The Swiss authorities' concern about avoiding programmes that were perceived to be politically motivated to make a donation for political reasons appears more than a little paradoxical. It is indeed striking how FPD officials underlined the non-political nature of humanitarian aid at the same time that they justified this aid with political motives. However, for the time being, no such Swiss contribution was made.

The criticism of Switzerland's role in Southern Africa voiced at the 1967 UNGA was no one-time occurrence that could easily be put aside. The insistence on decolonisation and opposition to white minority rule were positions that were, at least verbally, supported by all African leaders. Bernard Turrettini warned the head of the department in February 1968 that African states were convinced that this cause was just and would not give up. He feared that Switzerland's economic relations with the minority regimes in Southern Africa might endanger the credibility of its neutrality. ${ }^{39}$ As a consequence, Federal Councillor Willy Spühler expressed his concern about growing Swiss investment in South Africa to the SNB in March 1968. He was, however, firmly

36 Gérard Fonjallaz, Dio, memorandum, "Aide aux victimes de l'apartheid", o9.10.1967, SFA E2003A\#1980/85\#1970*.

37 Note from Richard Pestalozzi to the Dio, "'Fonds betreffend Südafrika'. Ihre Notiz vom 15. Januar 1968", 19.01.1968, dodis.ch/33771.

38 Note from Ernesto Thalmann to the DPA, "Aide aux victimes de l'apartheid - Participation éventuelle de la Suisse à un Fonds des Nations Unies", 25.11.1967, p. 4, SFA E2003A\#1980/85\#1970*.

39 Letter from Bernard Turrettini to Federal Councillor Willy Spühler, 20.02.1968, p. 3, SFA E2003A\#1980/85\#1971*. 
rebuffed. Two months later, Ambassador August Lindt made a statement condemning Apartheid at the UN International Conference on Human Rights in Tehran.$^{40}$ While the impact of African criticism on the FPD's approach towards South Africa was admittedly very modest, no such change occurred with regard to Portuguese colonialism. Still, in April 1968, the Dio did instruct Swiss delegations to abstain from all votes on the exclusion of Portugal from intergovernmental organisations and conferences. Although Bern recognised Portuguese sovereignty in Africa, publicly defending Portugal's legal right to its colonies would have made Switzerland a supporter of the colonial regime in the eyes of the Third World. This was deemed too risky. ${ }^{41}$ "De facto, we are only a 'moral great power' in Europe, in Africa we still have to prove this", Swiss ambassador Hans Karl Frey, stationed in Kenya, warned his colleagues in September $1969 .{ }^{42}$ Later the same month, the Tanzanian representative to the UN, while highlighting Western collaboration with the white minority regimes during a plenary meeting of the UNGA, mentioned Swiss interests in the construction of the Cabora Bassa dam in Mozambique, Nestlé's activities in Angola, and Switzerland's non-compliance with the UN sanctions policy towards Rhodesia. ${ }^{43}$ The Swiss government had to face even more pressure when the OAU emerged as a new collective actor in the international discussion about Switzerland's role in Southern Africa.

\section{Addis Ababa: OAU Diplomacy in Bern, 1972}

In the early 1970s, African censure of Portuguese colonialism and white minority rule in Southern Africa reached a new intensity. Addis Ababa, the headquarters of the OAU, became a second centre of African criticism of Switzerland's political and economic relations with the white minority regimes. In April 1969, thirteen leaders of east and central African states had published the Lusaka Manifesto, which called on the help of all governments to convince the

$40 \quad$ Kreis, Die Schweiz und Südafrika, p. 80; on the background of Lindt's apartheid declaration, see Thomas Widmer, Christian Hirschi, Stabilität im Wandel. Gestaltung der schweizerischen Südafrikapolitik von 1968 bis 1994, Zürich: Verlag Rüegger, 2005, pp. 76-94. Ernesto Thalmann, "Instructions aux délégations suisses dans les conférences internationales au sujet de l'admission et de l'exclusion de certains pays", 10.04.1968, pp. 4-5, dodis.ch/33555.

42 Statement of Hans Karl Frey, Swiss ambassador in Kenya, minutes of the Annual Conference of Swiss Ambassadors 03.09.1969-05.o9.1969, 10.10.1969, p. 15, dodis.ch/30859.

43 Telegram no 187 from the Permanent Observer of Switzerland to the United Nations to the FPD, 24.09.1969, SFA E2003A\#1980/85\#1971*. 
Portuguese, South African, and Rhodesian regimes to end racial discrimination and minority rule. The OAU and the UN ratified this manifesto in that very year. It was the expression of a moderate strand of African discourse on liberation, which focused on peaceful change and dialogue with the racist regimes. It contrasted with a more militant strand calling for violent action that gained increasing influence in the following years. Subsequently, the October 1971 Mogadishu Declaration of east and central African states concluded that there was no solution left, other than to support the armed struggle. ${ }^{44}$ In parallel with continued pressure through various UN bodies, independent African governments increased their lobbying through the OAU; delegations from Africa's continental organisation toured NATO members and other Western European states in order to convince their governments to stop collaborating with the white minority regimes.

When the OAU started to criticise Switzerland's role in Southern Africa in 1970, FPD leaders in Bern were not pleased to have to justify their position to a second organisation and showed a certain distrust of their African interlocutors. In November 1970, the OAU's secretary, Guinean Boubacar Diallo Telli, approached the Swiss ambassador in Ethiopia, Heinz Langenbacher, and asked to discuss Switzerland's "sins" in Southern Africa with him. ${ }^{45}$ The ambassador's superiors warned him "to exercise the greatest possible restraint" towards Diallo Telli, as "there is little doubt that all he cares about is denouncing Switzerland to the OAU member states and others as a 'collaborator." 46 Yet, due to the numeric weight of independent African states in international organisations and their combined economic importance for Switzerland, Bern could ill afford to simply ignore the OAU. African pressure and especially the threat of negative economic consequences, had already been decisive in Switzerland's closure of its consulate in Rhodesia in March 1970. Switzerland was the last state, aside from South Africa, Portugal, and the Greek military dictatorship, to close its consulate in Salisbury ${ }^{47}$ This, together with Switzerland's

44 Lopes, West Germany and the Portuguese Military Dictatorship, pp. 17-30.

45 Telegram no 44 from the Swiss Embassy in Ethiopia to the FPD, 17.11.1970, SFA E2003A\#1984/84\#672*.

46 Letter from Michael Gelzer, Deputy Chief of the DPA, to the Swiss Embassy in Ethiopia, "Dokumentation über die Beziehungen der Schweiz mit Australafrika", 27.11.1970, confidential, p. 2, SFA E2003A\#1984/84\#1748*.

47 In its proposal to the Federal Council to close the consulate, the FPD mentioned notably the call for sanctions against Western states entertaining diplomatic relations with the Rhodesian regime voiced at the OAU Council of Ministers in early March: FPD, proposal to the Federal Council, "Schweizerisches Konsulat in Rhodesien", 13.03.1970, SFA E2001E\#1980/83\#3819*. According to a member of the British embassy in Bern, the 
non-participation in the UN sanctions against Rhodesia, caused quite a stir. In Addis Ababa, Langenbacher was regularly confronted with new allegations against Switzerland. In April 1971, for example, Diallo Telli warned him that Switzerland's image in Africa was waning because its principles of neutrality and humanitarianism were not applied in Southern Africa. Langenbacher, who liked and respected Diallo Telli, closed his report of this conversation with a passionate appeal to take the OAU and its position seriously. ${ }^{48}$ Like his colleague Turrettini in New York, he became a spokesman for a more active Swiss policy in this region that was more attentive to the demands of independent African governments.

In June 1971, the announcement that the OAU intended to visit Switzerland, Japan, and several NATO members to discuss these states' relations with the white minority regimes galvanised the Swiss federal administration. The planned visits were a continuation of the tour of Washington, London, Paris, Bonn, and Rome undertaken the preceding year by Zambian President Kenneth Kaunda, who had become chairman of both the OAU and NAM in mid$1970^{49}$ For the head of the FPD's newly founded Political Secretariat, Albert Natural, the visit was an occasion to re-examine Switzerland's relations with Southern Africa and its policies on the main problems in this region: Apartheid, Namibia and Rhodesia, and the Cabora Bassa dam in Mozambique. ${ }^{50}$

Preparations for the visit began immediately. Ambassador Langenbacher reported to the DPA that the OAU delegates had been disappointed by their visits to Washington, London, and Bonn. They had praised their reception in Paris and Rome: "This impression was determined less by factual concessions than by the cordial atmosphere that Rome and Paris knew to create and to which the African responds particularly well." ${ }^{51}$ This racist and patronising comment was reproduced in a memorandum on the Kaunda visits in other Western

closure was a result of direct threats of the governments of the Congo and Cameroon to abrogate air service agreements with the Swiss national airline, Swissair, if the Swiss government maintained its consulate in Salisbury: Letter from G. V. Britten, Chancery of the British Embassy in Switzerland, to the Rhodesia Political Department, o3.04.1970, The National Archives, Kew, UK (TNA) FCO $36 / 726$.

48 Political Report (PR) no 10 from Heinz Langenbacher, Swiss ambassador in Ethiopia, "Africa und die Schweiz", 02.04.1971, p. 4, SFA E2300-01\#1977/29\#3*.

49 Lopes, West Germany and the Portuguese Military Dictatorship, p. 22.

50 Note from Albert Louis Natural, head of the newly formed Political Secretariat, to the heads of division in the FPD and the Trade Division, "Visite d'une délégation de l'OUA en Suisse: relations avec l'Afrique australe", 02.07.1971, confidential, p. 2, SFA E2001E-O1\#1982/58\#440*.

$5^{1}$ Letter from Heinz Langenbacher to the DPA, "Besuch einer OAU-Delegation in Bern", o8.07.1971, confidential, p. 2, SFA E2OO1E-o1\#1982/58\#440*. 
capitals and would set the tone for the whole organisation of the visit. ${ }^{52}$ The guidelines for the first interdepartmental meeting on preparing for the OAU visit, held on 24 August 1971, are typical of the condescending way in which the Swiss authorities regarded the OAU delegates and their lack of consciousness that Switzerland's position in Southern Africa might be perceived as problematic. As Edouard Brunner, deputy chief of the Political Secretariat, stated early in the meeting, "[t]he important thing is not so much what is said to the Africans, but how it is said."53 He asserted that there was no need to justify Switzerland's role in Southern Africa. The FPD's Secretary General repeatedly stressed the importance of Switzerland's economic exchanges with South Africa and insisted that nothing be said or done during the OAU representatives' visit that might offend the Portuguese or South African governments. ${ }^{54}$ In order to improve Switzerland's relations with the OAU, it was decided to receive the delegates as honoured guests and to focus on creating a good atmosphere during the visit. A working group of FPD and FDEA members was tasked with compiling an information file for the attention of the visitors, which explained Swiss policies in areas that might be criticised by the OAU. ${ }^{55}$

The decision to welcome the African visitors with all honours stemmed from serious concerns about the possible negative effects of ignoring the OAU and its demands. The question of white minority rule united African governments of all political couleurs. On the one hand, their persistent criticism of Switzerland's position in Southern Africa might impair the country's image in the Third World and endanger the credibility of its neutrality. On the other hand, the newly independent African states also held some economic power and concerted action by them could potentially damage Switzerland's economic interests in those states. The OAU's written report following its first round of visits to NATO capitals in mid-1970 had envisaged the possibility of imposing economic and political sanctions on states that refused to break off relations

52 Memorandum by Jean-Jacques Indermühle, DPA, "Résumé des visites que la Délégation de l'OUA a faites en automne 1970 auprès des Gouvernements américain, anglais, allemand, français et italien", 19.07.1971, p. 4, SFA E2001E-o1\#1982/58\#439*.

53 Emphasis in original. Statement of Edouard Brunner, deputy chief of the Political Secretariat, in Jean-Jacques Indermühle and Hansrudolf Hoffmann, FPD, "Vorbereitende Sitzung vom 24.8.1971 bezüglich Besuchs der OAU-Delegation in der Schweiz”, no date, p. 1, attached to the note from Albert Louis Natural to the heads of division in the FPD and the Trade Division, "Visite d'une délégation de l'OUA en Suisse: relations avec l'Afrique australe", 07.09.1971, SFA E2001E-01\#1982/58\#440*.

54 Statements of Ernesto Thalmann, Secretary General of the FPD, ibid., pp. 2, 13.

55 Note from Ernst Henri Léchot to Hans Bühler, "Mission OUA", 31.08.1971, SFA E2001E-o1\#1982/58\#440*. See also the section on the Cabora Bassa dam in chapter 3. 
with the white minority regimes. During a preliminary visit to Bern in December 1971, OAU Secretary Diallo Telli warned that the OAU would draw its conclusions after the completion of the second round of visits planned for 1972. These might include the boycott of states that continued to trade with South Africa, Rhodesia, and Portugal. Nevertheless, in their dealings with Switzerland, OAU leaders focused on dialogue rather than confrontation. Prior to the Portuguese Revolution, OAU resolutions criticising Western states' policies on Southern Africa never mentioned Switzerland. During his talk with the FPD's Secretary General in December 1971, Diallo Telli insisted that the visit was "a mission of goodwill, friendship" and stated its goals in moderate terms: "it is important that the countries we visit become aware of the problem, that they reflect, that they weigh up the pros and cons of their current policies, not only in terms of international morality but also in terms of their economic and commercial interests in the medium and long term." 56

During the preparatory phase, FPD officials hardly ever referred to the foreign policies of the European neutral states, particularly Sweden and Austria. While the latter was not on the OAU delegation's itinerary, the former's position on national liberation was very different from that of Switzerland. In Sweden, the liberation struggles in Southern Africa received great popular and governmental support. Following initial contact between the Swedish authorities and Portuguese African nationalists in the 196os, the Swedish parliament endorsed official humanitarian aid for the Southern African liberation movements in May 1969. Non-military support was extended to the PAIGC in Guinea-Bissau from mid-1969 and, in decreasing importance, to FRELIMO and the MPLA, from 1971. Together with the USSR, Sweden was one of the most generous donors to the PAIGC. Although the Swedish government did not formally recognise these liberation movements, it treated them increasingly like governments-in-waiting. ${ }^{57}$ Unlike their Swiss counterparts, the Swedish authorities did not consider their policy of neutrality to be incompatible with taking a clear position against colonialism and white minority rule. Well informed of the course of the OAU's visit to Sweden in October 1971, DPA leaders realised

$5^{6} \quad$ BRE, "Entretiens du jeudi 23 décembre 1971 de Monsieur l'Ambassadeur Thalmann avec le Secrétaire général de l'OUA Monsieur Diallo Telli (DT)", 27.12.1971, p. 3, attached to the note from Jean-Jacques Indermühle to to the heads of division in the FPD and the Trade Division, "Visite d'une délégation de l'OUA", 28.12.1971, SFA E2001E-o1\#1982/58\#440*. See also the letter from Heinz Langenbacher to the DPA, "Besuch einer OAU-Delegation in Bern", o8.o7.1971, confidential, p. 1-2, ibid.

57 See Sellström, Sweden and National Liberation in Southern Africa. Volume II: Solidarity and Assistance, pp. 32-125, particularly p. 64. 
that the Swedish example could not serve as inspiration for Switzerland. ${ }^{58}$ This opposing model of a neutral foreign policy on Southern Africa increasingly turned into a liability for Switzerland. Reporting on the UN Security Council's first meeting on the African continent in Addis Ababa in January and February 1972, Heinz Langenbacher noted that Sweden "repeatedly received a good Africa-mark (also by liberation movements)". ${ }^{59}$

The OAU delegation, presided over by the new OAU chairman, Mauretanian President Moktar Ould Daddah, and comprising high-ranking members of the OAU and the governments of Algeria, Cameroon, Kenya, Mali, Mauritania, and Zambia arrived in Bern on 18 April 1972. In his welcome speech, Swiss President Nello Celio explained Switzerland's foreign policy on Southern Africa. This was guided by three principles: First, the principle of non-interference in the internal affairs of other states, which was an important part of the Swiss conception of neutrality. Secondly, the President underlined Switzerland's commitment to the equality of all people and its rejection of all forms of discrimination. Finally, Celio mentioned the principle of liberalism to explain that the Swiss government could not intervene in the economic sector as it saw fit. ${ }^{60}$ Commenting mockingly on Switzerland's "African policy (or absence of policy)", Eduardo Manuel Fernandes Bugalho, the Portuguese ambassador in Bern, observed the contradictions inherent in the compilation of these principles when reporting back to his government a few days later: "It is certainly curious how the moral reference, with which they [the Swiss] wanted to a certain extent to satisfy the African interlocutor, was squeezed between the two political principles, which themselves exclude any action that could be justified by the acceptance of the other [moral principle]."61

On the following day, talks were held in a pleasant and friendly atmosphere, according to Swiss observers. In his introductory speech, Ould Daddah stated clearly what the OAU expected from Switzerland: "We would like to see the Swiss Government try to limit the activities of its nationals in the countries of concern to us." After explaining that economic collaboration with the white minority regimes in Southern Africa was short-sighted and that the Swiss

$5^{8}$ See the letter from René Faessler, Swiss Ambassador in Sweden, to the DPA, "Visite à Stockholm de la délégation OUA", 28.10.1971, p. 1, SFA E2001E-o1\#1982/58\#440*.

59 PR no 3 from Heinz Langenbacher, "Die Grenzen der Uno: Die Afrika-Debatte des Sicherheitsrates in Addis Abeba (28.1.-4.2.1972)", 05.02.1972, p. 11, SFA E2300-o1\#1977/29\#3*.

6o Address by Nello Celio, Swiss President, "Allocution prononcée par le Président de la Confédération, M. Nello Celio, à l'occasion du dîner offert en l'honneur de la délégation de l'OUA, le 18 avril 1972", no date, pp. 1-2, SFA E2001E-o1\#1982/58\#440*.

61 Telegram no $9(10,11)$ from Eduardo Manuel Fernandes Bugalho, Portuguese ambassador in Switzerland, to the MNE, 22.04.1972, pp. 1-2, AHD, PEA, Pr. 320.8o, box 712. 
business sector should be encouraged to redirect its investments to independent African states, he turned to his second subject: "I come back to the humanitarian issue. Switzerland has distinguished itself through its humanitarian action. It is not by chance that it is the birthplace of the Red Cross [...]. That is why we have come to ask Switzerland to help the liberation movements on a humanitarian and social level." 62

The head of the Swiss delegation, Federal Councillor Pierre Graber, once again underlined the Swiss government's limited influence in economic affairs. The discussion soon centred on different options for direct Swiss support for the liberation movements and the refugees of the independence wars. The OAU delegation was well prepared. The Executive Secretary of its Liberation Committee presented different aid projects organised by the OAU and the liberation movements, specifying their needs. Graber argued that as a longstanding permanent neutral state, Switzerland had to adhere more strictly to the principles of neutrality than the other European neutrals. This constrained the Swiss government's scope for action. Nevertheless, he informed the OAU delegation that the Swiss government had decided to contribute CHF 75, OOO to the UN Trust Fund for South Africa. The Federal Councillor also promised that this humanitarian action would be continued and that the DPA would examine in what way direct Swiss aid would be possible. ${ }^{63}$ The news of Switzerland's contribution to the Trust Fund was well received by the OAU delegation and Ould Daddah personally announced it at a press conference during the visit. ${ }^{64}$

After the departure of the OAU delegation on 20 April, FPD leaders declared themselves satisfied. They particularly highlighted the moderate and reasonable stance of the African delegates. ${ }^{65}$ According to Heinz Langenbacher, the African delegates also gave the visit a positive verdict. The ambassador reported that the Swiss government's willingness to consider granting humanitarian aid to the victims of the liberation struggle, the friendly reception of the delegation, and the honest and realistic discussions both with the Swiss

62 Statement of Moktar Ould Daddah, Mauritanian president and chairman of the OAU, in Jean-Jacques Indermühle, Hanspeter Strauch, "Procès-verbal des entretiens du 19 avril 1972 avec une délégation de l'OUA dirigée par M. Ould Daddah, Président en exercice de l'OUA et Chef d'Etat mauritanien", no date, pp. 4-5, SFA E2001E-o1\#1982/58\#440*.

63 Ibid., pp. 6-16.

64 Letter from Gaspard Bodmer, DIO, to the Permanent Observer of Switzerland to the UN, "Beiträge an verschiedene Institute der Vereinten Nationen (UNITAR, UNRISD, Institut de recherches des Nations Unies pour la défense sociale, Fonds d'affectation spéciale des Nations Unies pour l'Afrique du Sud)", 02.05.1972, SFA E2001E-01\#1982/58\#440*.

65 Telegram from the FPD to the Swiss embassies in Africa and to the Office of the Permanent Observer of Switzerland to the UN, 24.04.1972, p. 2, SFA E2001E-o1\#1982/58\#440*. 
authorities and with business people were appreciated. Consequently, it seemed that Switzerland's image in Addis Ababa had improved—at least for the time being. ${ }^{66}$ The Swiss press showed little interest in the visit, especially in German-speaking Switzerland. ${ }^{67}$ Press reports from French-speaking Switzerland that mentioned a Swiss promise of humanitarian aid for African liberation movements did, however, lead to complaints from the South African and the Portuguese embassies in Bern. In order to prevent further controversy, the FPD warned its own ambassadors in South Africa and Portugal to be careful when mentioning possible Swiss aid. ${ }^{68}$

The Swiss government's strategy of focusing on low-cost political goodwill gestures such as the warm reception given to the delegation and the granting of humanitarian aid to draw attention away from their unwillingness to change their Southern Africa policy was successful. Although Bern made very few concessions, the April 1972 visit was a small turning point in Switzerland's Southern Africa policy. It increased the government's awareness of the risks to its image of its non-committal stance on white minority rule and encouraged it to be even more careful to keep a low profile. The visit also spurred a renewed effort to aid the Southern African populations. As in 1967-1968 after the UNGA criticism of Switzerland, Swiss foreign policymakers considered humanitarian aid a suitable instrument to improve the image of their neutrality in Africa.

While preparing for the OAU visit, the DIO had re-examined the matter of a possible Swiss contribution to UN programmes in favour of Southern African refugees that had been shelved in 1968. As the forthcoming visit placed Switzerland in the limelight, the service judged a goodwill gesture opportune. The Swiss Anti-Apartheid Movement and Ambassador Langenbacher in Addis Ababa also endorsed a Swiss contribution to the UN Trust Fund for Africa. The Federal Council approved this in February 1972. The announcement of the decision was delayed until the visit of the OAU in April in order to boost its impact. ${ }^{69}$ Despite Pierre Graber's promise of further aid, little happened after

66 Letter from Heinz Langenbacher to the Political Secretariat, "OAU-Delegation", 07.06.1972, SFA E2OO1E-O1\#1982/58\#440*.

67 Gregor Kündig, FPD, memorandum, "Berichte und Kommentare in der Schweizer Presse zum Besuch einer Delegation der OAU-Staaten in der Schweiz am 18. und 19.4.1972", June 1972, dodis.ch $/ 36362$.

68 Telegram from the FPD to the Swiss embassies in South Africa and Portugal, 21.04.72, urgent, p. 1, SFA E2001E-o1\#1982/58\#440*. See also telegram no 9 (10, 11) from Eduardo Manuel Fernandes Bugalho to the MNE, 22.04.1972, p. 3-5, AHD, PEA, pr. 321.80, box 712.

69 Peter Friedrich, Dio, memorandum "Fonds d'affectation spéciale des Nations Unies pour l'Afrique du Sud - Contribution éventuelle de la Suisse", 13.10.1971, SFA E2001E-ol\#1982/58\#440*; letter from Gaspard Bodmer to the Permanent Observer of 
the OAU delegation left Bern. The DIO was hardly proactive and seemed content to wait for the OAU to provide further information on its humanitarian programme. ${ }^{70}$ At the same time, Bern continued to be torn between the wish to grant aid in order to appease the African critics of its policy in Southern Africa, and concern that aid might be equated to support for national liberation.

The personal initiative of ambassador Heinz Langenbacher was mainly responsible for the only further action in favour of Southern African refugees before the Carnation Revolution. In February 1973, he proposed that the Swiss government finance a seminar on refugees in Africa that the OAU's Bureau for the Placement and Education of African Refugees (BPEAR) planned to hold in the second half of 1973. The event would bring together representatives of African governments, liberation movements, and international and regional organisations. ${ }^{71}$ FPD staff members worried that sponsoring this seminar might make it look as if Switzerland supported the liberation struggle in Southern Africa. To avoid possible criticism by the white minority regimes and the part of the Swiss population that was well disposed to South Africa, they asked the UNHCR to serve as an intermediary for Switzerland's contribution. "By proceeding in this manner, this operation could be listed, in our statistics and reports, as a completely unproblematic donation to the HCR", a department member wired to Langenbacher in May $1973 \cdot{ }^{72}$ With the consent of the UNHCR, the FPD agreed to cover the total cost of the seminar, \$25, OOO (CHF $78,900) \cdot{ }^{73}$ Discussions during the seminar were highly political, justifying the

Switzerland to the UN, "Beiträge an verschiedene Institute der Vereinten Nationen (UNITAR, UNRISD, Institut de recherches des Nations Unies pour la défense sociale, Fonds d'affectation spéciale des Nations Unies pour l'Afrique du Sud)", 02.05.1972, ibid.

70 Letter from René Keller, chief of the DIO, to the Swiss embassy in Ethiopia, "Aide humanitaire éventuelle aux mouvements africains de libération", 27.06.1972, SFA E2001E-o1\#1982/58\#439*; letter from Heinz Langenbacher to the DIO, "Ev. Humanitäre Hilfe für Befreiungsbewegungen”, 24.11.1972, SFA E2003A\#1984/84\#672*; letter from Langenbacher to the DIO, "Ev. Humanitäre Hilfe für Befreiungsbewegungen", 01.02.1973, SFA E2003A\#1988/15\#573* and handwritten notes on this document.

71 Letter from Heinz Langenbacher to the DIO, "OAU: Flüchtlingshilfe", 10.02.1973, SFA E2003A\#1988/15\#570*; letter from Langenbacher to the DIO, "OAU-Flüchtlingshilfe", 27.02.1973, ibid.

72 Telegram no. 28 from the FPD to the Swiss embassy in Ethiopia, 22.03.1973, SFA E2003A\#1988/15\#570*.

73 The Swiss contribution was later reduced to $\$ 15^{\prime}$ OOO ( $\mathrm{CHF} 47^{\prime} 3 \mathrm{OO}$ ), as the OAU covered the rest through its own budget: note from François Pictet to the chief of the DiO, "Séminaire de l'ouA sur les réfugiés", 27.03.1973, SFA E2003A\#1988/15\#570*; telegram no. 38 from the FPD to the Swiss embassy in Ethiopia, 04.04.1973, ibid. The sums have been converted to CHF using the exchange rates indicated in Officer, "Exchange Rates Between the United States Dollar and Forty-one Currencies". 
FPD's earlier reluctance. Accordingly, the Swiss embassy in Ethiopia recommended that Switzerland keep its distance from the BPEAR in the future and collaborate rather with the UNHCR in the matter of refugees. ${ }^{74}$ Thus, Swiss aid to Southern Africa remained limited.

The opening of the Executive Secretariat of the OAU in Europe in Geneva in late 1973, first discussed between the OAU and the Swiss government during the 1972 Bern visit, was the most significant result of this diplomatic effort. In the second half of 1971, the DIO had read in a UN document that the OAU wished to establish an office in Western Europe, "so that liaison can be maintained with the Specialised Agencies, anti-apartheid movements and other organisations with regard to action against apartheid." 75 The DIo considered it to be in Switzerland's interest for this mission to be located in Geneva. It was a sign of courtesy towards the OAU, as it would facilitate the organisation's contact with the numerous international organisations established in the city. In addition, it would allow an intensification of Switzerland's contact with the OAU and potentially boost Swiss-African economic relations. At the same time, DIO officials wished to control the principal political organisation on the African continent, as they noted in August 1972: "such an information office would be easier for us to control and to 'hem in' than an information office without official status, which could indulge in disagreeable propaganda without us having the means to intervene. ${ }^{76}$ The OAU bureau was granted the same official status and resulting privileges as any other liaising mission in Geneva. Consequently, its delegation was bound by international diplomatic law and prohibited from undertaking "any activity which may be qualified as interference in the internal affairs of the host country, or directed against a third state in such a way as to damage the interests of the host country itself."77 In June 1974, the OAU's Council of Ministers was satisfied with the positive results the Executive Secretariat of the OAU in Europe had achieved in its first year. It encouraged Afri-

74 Marcus Kaiser, Swiss embassy in Ethiopia, report, "Bericht über das Zweite Flüchtlingsseminar des OAU Bureau for Placement and Education of African Refugees (BPEAR) vom 26.11. - 1.12.1973 in Addis Ababa", confidential, no date, attached to the letter from Heinz Langenbacher to the DIO, "Flüchtlingsseminar OAU", o6.12.1973, SFA E2OO3A\#1988/ $15 \# 570^{*}$.

Emphasis in original. Cited in the note from Gaspard Bodmer to the chief of the DIO, "Ouverture d'une mission ouA à Genève", 11.08.1972, p. 1, SFA E2003A\#1984/84\#672*.

76 Ibid., p. 2. See also Gaspard Bodmer, memorandum, "Visite à Berne d'une délégation de l'OUA et établissement d'une mission permanente de l'OUA à Genève", 14.10.1971, dodis.ch/36376; decree of the Federal Council, "Statut de la délégation permanente de l'Organisation de l'Unité Africaine”, 05.09.1973, dodis.ch/39298.

77 Hanspeter Strauch, aide-mémoire, "Ouverture, par l'OAU, d'une Mission permanente à Genève", no date [12.02.1973], p. 2, dodis.ch/39296. 
can ambassadors in Europe to collaborate with the Executive Secretariat and requested the latter to "follow its political action with European Governments on questions of decolonization and the struggle against apartheid and racial discrimination" and to "strengthen its information activities and its cooperation with the non-governmental organizations engaged in the struggle against colonialism and apartheid."78

With regard to Switzerland's policy in the Portuguese colonies, FPD leaders were even more careful to keep a low profile after the OAU visit. Thus, Michael Gelzer, the deputy chief of the DPA, decided in March 1972 not to appoint a career consul to Angola, although Switzerland's economic interests and the number of Swiss residents in the country would have justified this. Since the OAU and the UN might interpret the upgrading of Switzerland's diplomatic representation as a sign of support for the Portuguese colonial regime, Gelzer preferred discretion to practicalities. ${ }^{79}$ For the same reason, in January 1973, he cancelled two official trips by the Swiss ambassador in Lisbon, one to Angola and one to Mozambique, that had already been approved by the AD: "Because of the agitation against Portugal's colonial policy, which is, as is well known, one of the main subjects of UN debates, it is my opinion that we should avoid any gesture which could be interpreted as a recognition of Portugal's colonial territorial claims." 80 On this issue, the FPD adopted the same line as the Nordic countries, which prevented their representatives in Lisbon from accepting the Portuguese authorities' customary open invitation to every newly-arrived ambassador to visit the African colonies. While the French, British, and US ambassadors, as well as those from several Latin American states, had visited Angola and Mozambique by the middle of 1973, and their Austrian and Belgian colleagues accepted the invitation, the Dutch, Norwegian, and Danish governments refused. Considering the Social-Democratic Swedish government's open condemnation of Portuguese colonialism, it is not surprising that the Swedish ambassador does not seem to have received an invitation. ${ }^{81}$

78 Resolution CM/Res 345 (XXIII) of the OAU Council of Ministers' 23rd Ordinary Session from 6 to 11 June 1974, "Resolution Executive Secretariat of the OAU in Europe (Geneva)", https://au.int/sites/default/files/decisions/9582-council_en_6_15_june_1974_council_ ministers_twenty_third_ordinary_session.pdf (13 January 2021).

79 Note from Michael Gelzer to Antonino Janner, head of the AD, "Schweizerisches Konsulat in Luanda (Angola)", 15.03.1972, SFA E2001E-o1\#1982/58\#6127*.

8o Note from Michael Gelzer to the AD, 11.01.1973, p. 1, SFA E2001E-o1\#1987/78\#4648*.

81 Letter from S. F. St. C. Duncan, British Embassy in Portugal, to Barbara Richards, Central and Southern African Department (CSAD) of the FCO, "Tours of Heads of Missions of Portuguese Africa", 27.06.1973, pp. 1-2, TNA FCO 45/1316. 
Swiss foreign policymakers continued to be faithful to the 1963 instructions to keep their distance from representatives of African liberation movements. In early June 1973, Federal Councillor Pierre Graber refused to meet an MPLA member on the basis that the Swiss government could not have official relations with a liberation movement as long as it had normal diplomatic ties to Portugal. ${ }^{82}$ Later in the same month, the DIO issued guidelines that Swiss delegations to international organisations should abstain from any votes aimed at granting observer status to liberation movements. ${ }^{83}$ The dilemma between Bern's selective interpretation of neutrality, which resulted in a pro-Portuguese position, on one hand, and the realisation that decolonisation was inevitable and public support of Portugal might endanger relations with the colonies' future rulers and independent Third World governments, on the other hand, did not make for easy policy choices. Consequently, the DPA was engaged in a careful balancing act, which occasionally interfered with the efficient running of its foreign services.

The positive evaluation of the OAU visit to Bern should not obscure the fact that the Swiss government did little more than "to listen and utter fine words", as a French observer noted. ${ }^{84}$ Instead of serving as an opportunity to set out a more coherent Swiss policy on Southern Africa, one that gave more emphasis to the people oppressed by white minority rule, the visit confirmed Bern's unwillingness to reconsider Switzerland's economic relations in this region. In this sense, the meetings with OAU delegates were a missed chance to adapt Switzerland's position and prepare for decolonisation. The continued neglect of the African liberation movements, in particular, would have negative consequences after the independence of Angola and Mozambique. In the short term, however, the Swiss government successfully used the promise of humanitarian aid to improve relations with the OAU. The fact that the OAU delegates themselves focused on aid by appealing to Switzerland's humanitarian tradition and did not request a fundamental change in the country's economic role in Southern Africa suggests that they knew their interlocutors well enough to be able to form realistic expectations of the possible outcome of the visit.

82 Letter from Alfred Reinhard Hohl, DPA, to the Schweizerische Arbeitsgruppen für Entwicklungspolitik (Swiss Working Groups for Development Policy, SAFEP), 07.06.1973, SFA E2001E-01\#1987/78\#4648*.

83 Note from François Pictet to René Keller "Participation des mouvements de libération aux activités des organisations internationales", 21.06.1973, dodis.ch/38891, and handwritten comments indicating agreement.

84 Letter from Bernard Dufournier, French ambassador in Switzerland, to Maurice Schumann, French Foreign Minister, "Mission de l'OUA à Berne", 26.04.1972, p. 2, Centre des Archives diplomatiques, La Courneuve/Paris, France (CAD) 206QO/169. 


\section{Geneva: The Status of Liberation Movements at the 1974 ICRC International Humanitarian Law Conference}

In 1973 and 1974, a new front in the struggle for national liberation in Southern Africa opened in Geneva, at the headquarters of the ICRC, in the field of international humanitarian law ( $\mathrm{IHL}$ ). In the late 196os, a movement advocating the revision of international law applicable in armed conflict had gained momentum. New forms of conflict, such as independence wars and guerrilla warfare, and the use of new weapons, such as napalm, had exposed the limits of the Geneva Conventions. First established in 1864, and revised and updated in 1949 under the auspices of the ICRC, these conventions regulate the conduct of armed conflict and protect its victims. The formerly colonised states of the Third World, which had not been involved in drawing them up, were a driving force behind the call for a revision of IHL that was taken up by the ICRC and various UN bodies. The questions of whether so-called freedom fighters should be legally protected, and if, and in what form, they should be able to participate in the development of international law were some of the most controversial issues. This debate primarily pitted Third World governments against the leaders of the Western bloc. ${ }^{85}$ The Swiss government played a major role in this regard. In early 1974, as depository state of the Geneva Conventions, it convened a diplomatic conference to reaffirm and develop IHL applicable in armed conflicts. The demand that liberation movements be invited to participate in this conference, voiced by African leaders and fiercely opposed by the UK and the US, therefore placed Bern in a difficult position.

The story of the Swiss government's relations with the ICRC and the latter's role in Swiss foreign policy is a long and complex one. ${ }^{86}$ The ICRC was founded

85 Some indications about these dynamics can be found in David P. Forsythe, The Humanitarians. The International Committee of the Red Cross, Cambridge: Cambridge University Press, 2005, pp. 261-263.

86 A complete account of the relations between the Swiss government and the ICRC still needs to be written, although several authors have treated this question. See notably Baudendistel, Between Bombs and Good Intentions, pp. 7-49; Thomas Brückner, Hilfe schenken. Die Beziehung zwischen dem IKRK und der Schweiz, 1919-1939, Zürich: NZZ Libro, 2017; François Bugnion, Le Comité international de la Croix-Rouge et la protection des victimes de la guerre, 2nd ed., Geneva: Comité international de la Croix-Rouge, 200o, pp. 1156-1175; Forsythe, The Humanitarians, pp. 183-92; Hans Peter Gasser, "The International Committee of the Red Cross and its Development since 1945", in Gabriel, Fischer, Swiss Foreign Policy, pp. 105-126; Hans Haug, "Die Schweiz, die Rotkreuz- und Rothalbmondbewegung und das Internationale Komitee vom Roten Kreuz", in Alois Riklin, Hans Haug, Raymond Probst (eds.) Neues Handbuch der schweizerischen Aussenpolitik, Bern: Haupt, 1992, pp. 677-691; Isabelle Vonèche Cardia, Neutralité et engagement. Les relations entre le Comité 
in 1863 in Geneva and is, on a legal level, a private association incorporated under Swiss law. There are, however, strong ties between the ICRC and its host country, which are most visibly represented by the organisation's emblem, which is an inversion of Switzerland's national flag. Both the ICRC and the Swiss government are neutral, but their conceptions of neutrality differ. While Switzerland's neutrality is anchored in international law, that of the ICRC is based on its standing practice and was confirmed by the International Conferences of the Red Cross of 1965 and 1986. The organisation generally abstains from participating in political controversies and in principle treats all belligerents equally in order to aid all victims of conflict. Its freedom of action is more restricted than that of the Swiss government. ${ }^{87}$ The two bodies mutually reinforce each other's neutral standing; while the ICRC's seat in a neutral state is deemed to guarantee its impartial humanitarian action, the Swiss authorities consider the ICRC a pillar of Switzerland's humanitarian image that improves the international reputation of its neutrality, and a foreign policy asset. Following criticism of the ICRC's silence on the holocaust, which some scholars have attributed to Swiss government influence, ${ }^{88}$ efforts were made to increase the organisation's independence. In 1993, the ICRC and the Swiss government signed a headquarters agreement, making the ICRC's premises off-limits to Swiss authorities. Although the members of the organisation's governing board are still exclusively Swiss, the professional staff has been internationalised since the early 1990s. In the late 1960s, however, many former Swiss diplomats and politicians sat on the Committee. Finally, Switzerland is also the ICRC's main financial contributor. In 1975, the Swiss government covered more than one third of the cost of the Geneva headquarters and slightly less than one ninth of field operation expenses. ${ }^{89}$ Thanks to these close links between the Swiss government and the humanitarian organisation, which frequently blurred the distinctions between them in the eyes of international observers, the former was particularly interested in the revision of humanitarian law.

In the late 196os, the broad question of human rights during armed conflicts and the revision of the Geneva Conventions and the 1907 Hague Conventions on the laws of war was on the agenda of the UN. Resolution XxiII of the Tehran

international de la Croix-Rouge (CICR) et le Gouvernement suisse 1938-1945, Lausanne: SHSR, 2012; Albert Wirz, "Die humanitäre Schweiz im Spannungsfeld zwischen Philanthropie und Kolonialismus: Gustave Moynier, Afrika und das IKRK", Traverse 5 (1998), pp. 95-110.

87 Bugnion, Le Comité international de la Croix-Rouge, pp. 1159-63.

88 An overview of this debate can be found in Vonèche Cardia, Neutralité et engagement, pp. 24-26.

89 Wirz, "Die humanitäre Schweiz", p. 100. 
International Conference on Human Rights, held in April and May 1968, invited the UN Secretary General to study means to ensure the better application of existing humanitarian law and the need for additional conventions to better protect civilians and combatants in armed conflicts. His report was later analysed by several UN commissions and discussed at the UNGA..$^{90}$ The ICRC's mandate to address these problems was a result of Swiss and Western lobbying. For the Swiss government, the reaffirmation and development of IHL was an opportunity to play a role in international humanitarian diplomacy, but only if it took place under the auspices of the ICRC. As a non-member of the UN, Switzerland was excluded from negotiations at the UNGA. Prior to the Tehran conference, FPD leaders were concerned about the "risk of seeing the United Nations, as a result of their role in the protection of human rights, gradually assume competence in areas which have always been the responsibility of the ICRC" ${ }^{91}$ The Swiss authorities feared that their humanitarian image would suffer if the ICRC's status were to diminish. Discussions between the two bodies in mid-1969 show clearly that the initiative to press for the ICRC to take on the revision of IHL came from Bern. ICRC delegates underlined repeatedly that their main goal was the revision of humanitarian law, even if this was to take place within UN frameworks. However, Ernesto Thalmann, the head of the DIO, argued that the revision could only succeed if directed by the ICRC. Discussions at the UN, he feared, would be politicised, especially with regard to the status of members of liberation movements. This would lead to the distortion of international law. For this reason, he was even hesitant to include independent Third World governments too heavily in the revision of humanitarian law. ${ }^{92}$ At the 21st International Conference of the Red Cross, in Istanbul in Sep-

$90 \quad$ No author, "Brief for the United Kingdom Delegation to the Twenty-Fifth Session of the United Nations General Assembly. Item 47: Respect for Human Rights in Armed Conflicts", no date, p. 1, attached to the note from the FCO to the UK Steering Committee on International Organisations, 16.11.1970, TNA FCO 61/68o.

91 FPD, proposal to the Federal Council, "Conférence internationale des droits de l'homme, Téhéran, 22 avril - 13 mai 1968, o1.03.1968”, p. 4, attached to the decree of the Federal Council, "Conférence internationale des droits de l'homme, Téhéran, 22 avril - 13 mai 1968", 20.03.1968, dodis.ch/34271.

92 Jean Pictet, Director General of the ICRC, memorandum of conversation with Ernesto Thalmann, head of the DIo, and Denise Werner, chief of the Dio's International Aid Organisations Section, on 5 August 1969, "Restauration du droit de la guerre", no date, confidential, especially p. 3, ICRC archives, Geneva, Switzerland (ACICR) B AG o59-073; see also Jean Pictet, memorandum of conversation with Ernesto Thalmann, Friedrich Traugott Wahlen, Federal Councillor and head of the FPD, Pierre Micheli, Secretary General of the FPD and head of the DPA, Jean Cuendet, DPIL, and Denise Werner on 19 August 1969, no date, confidential, ibid. 
tember 1969, the head of the Swiss delegation therefore proposed a resolution that mandated the ICRC to continue the examination of the problem together with governmental experts, which was unanimously adopted. ${ }^{93}$

Many Western governments shared the wish to have the ICRC deal with the revision of IHL. They hoped that this would depoliticise the issue and that they would have a greater say than if the matter were dealt with by the UNGA, where the Afro-Asian majority could impose its views. The British government was particularly active in this regard. Members of the Foreign and Commonwealth Office (FCO), realising in mid-1970 that the movement to revise international law was too strong to be ignored, decided instead to take an active role in influencing the development of humanitarian law. In a meeting with Claude Pilloud of the ICRC Directorate in July 1970, they encouraged the Geneva organisation to draft new IHL instruments. ${ }^{94}$ They also undertook considerable efforts to ensure that the controversial issue of liberation movements be kept out of UN debates as much as possible and lobbied their NATO allies and other friendly governments to support the ICRC initiative. ${ }^{95}$ The US State Department was more restrained and hesitated to support a revision of international law in armed conflict as long as American soldiers were engaged in Vietnam. ${ }^{96}$

This Swiss and Western lobbying proved fruitful. The ICRC, which had received an official mandate from the Istanbul Red Cross conference in late 1969, developed drafts for additional humanitarian legislation. These were subsequently discussed during conferences of the National Red Cross and Crescent Societies and at two meetings of governmental experts. At the last session, in June 1972, 400 specialists from 77 states reached broad agreement on the texts for two additional protocols to the Geneva Conventions. Therefore,

93 See Pierre Graber, Federal Councillor and head of the FPD, proposal to the Federal Council, "Conférence diplomatique sur le droit humanitaire", 20.08.1972, p. 1, attached to the decree of the Federal Council, "Conférence diplomatique sur le droit humanitaire", 18.09.1972, SFA E2OO3A\#1984/84\#1390*.

94 Claude Pilloud, member of the ICRC Directorate, "Entretien au Foreign Office à Londres", 28.07.1970, ACICR B AG 059-120; no author, "Record of a meeting held at the Foreign and Commonwealth Office on Tuesday, 28 July, 1970, at 2.00 p.m. [with Claude Pilloud]", 12.08.1970, TNA FCO 61/678. See also note from Merrick S. Baker-Bates, FCO, to Hilary W. King, United Nations (Economic and Social) Department of the FCO, "Human Rights in Armed Conflict", 26.06.1970, TNA FCO 61/679.

95 Letter from Hilary W. King to Tessa A. H. Solesby, UK Mission in New York, "Respect for Human Rights in Armed Conflict", 21.08.1970, TNA FCO 61/678.

96 Letter from Tessa A. H. Solesby to John A. Wilberforce, United Nations (Economic and Social) Department of the FCO, "Human Rights in Armed Conflict", 16.o9.1970, p. 1, TNA FCO $61 / 678$. 
the Federal Council agreed in September of that year to convene a diplomatic conference in Geneva in early 1974, which would discuss and eventually adopt the two additional protocols. ${ }^{97}$

The hope that moving the revision of IHL from New York to Geneva would depoliticise the debate proved to be in vain. African liberation movements wanted wars of national liberation to be recognised as international conflicts. On the one hand, this would ensure a better protection of their fighters when taken prisoner. On the other hand, it would elevate them to belligerents on a par with the colonial authorities and thereby enhance their legitimacy and that of their cause. During a discussion with ICRC representatives in August 1970 in Algiers, delegates of liberation movements expressed their wish to collaborate with the ICRC on the revision of IHL, as well as in the conflict zones. They noted indiscriminate bombings and the use of prohibited chemical weapons by the Portuguese army and contrasted it to their own adherence to humanitarian principles. FRELIMo delegate José Oscar Monteiro, in particular, highlighted his movement's humanitarian policy and willingness to free Portuguese prisoners of war. ${ }^{98}$ Independent African governments supported the liberation movements' concerns. In June 1971, The OAU's Council of Ministers called for a worldwide campaign "to apply to freedom fighters the relevant articles of [the] Geneva Convention of 1949 on the treatment of prisoners of war and to ensure participation of liberation movements in the drafting and application of international humanitarian law applicable to the so-called internal conflicts". 99

For the Swiss government, the difficulties began in early 1973, when the Norwegian government demanded that African liberation movements be admitted to the diplomatic conference in Geneva. Since the early 1970s, NATO member Norway had spoken out strongly in favour of the application of the Geneva Conventions to wars of national liberation. British and US delegates in particular resented this. Oslo was subsequently excluded from meetings of

97 Decree of the Federal Council, "Conférence diplomatique sur le droit humanitaire", 18.09.1972, SFA E2003A\#1984/84\#1390*; see also Pierre Graber, proposal to the Federal Council, "Conférence diplomatique sur le droit humanitaire", 20.08.1972, attached to this document.

98 Michel Veuthey, ICRC Legal Department, memorandum, "Consultations sur le droit humanitaire international applicable dans les conflits non internationaux et la guérilla. Entretiens à Alger, dans les locaux du Croissant-rouge algérien, les 5, 6 et 7 août 1970", pp. 3-4, 13.08.1970, ACICR B AG 059-203.01.

99 Resolution CM/Res. 242 (XVII) of the OAU Council of Ministers' $17^{\text {th }}$ Ordinary Session from 15 to 19 June 1971, "Resolution on Apartheid and Racial Discrimination", https:// au.int/sites/default/files/decisions/9586-council_en_15_19_june_1971_council_ministers_ seventeenth_ordinary_session.pdf (13 January 2021). 
a Western working group that first met in London in September 1972 to coordinate a common approach to the Geneva conference. In April 1973, the Norwegian government hosted the UN-OAU International Conference of Experts for the Support of Victims of Colonialism and Apartheid in Southern Africa. ${ }^{100}$ On his return from this conference, an ICRC representative informed the FPD in confidence that the Norwegian government planned to request the invitation of African liberation movements to the diplomatic conference. François Pictet, deputy chief of the DiO, suggested that Oslo be discreetly told that Switzerland did not approve of this demand. Thereby, he hoped to avoid having to publicly refuse an invitation. ${ }^{101}$ The outright rejection of the liberation movements' participation illustrates the FPD leaders' distrust of these non-state actors. Unlike the ICRC, which had consulted African nationalists during the elaboration of the additional protocols in Algiers in 1970 and in Algiers and Cairo in 1972-1973, the FPD did not even discuss the possibility of inviting them to Geneva. ${ }^{102}$ Swiss foreign policymakers underestimated the strength of the liberation movements' cause. Unimpressed by the Swiss protests, in May 1973 the Norwegian embassy in Bern formally invited the Federal Council to inform the parties to the Geneva Conventions of the liberation movements' wish to participate in the humanitarian law conference. ${ }^{103}$ In June 1973, the OAU added weight to this demand. Following a resolution by its Council of Ministers, the General Secretariat sent a note to the Swiss embassy in Ethiopia, asking the

100 See notably Harold Beeley, UK Mission in Geneva, to Sir Vincent Evans, Legal Advisor at the FCO, "ICRC Conference on Humanitarian Law", o1.o6.1971, p. 1, TNA FCO 61/810; letter from I. K. C. Ellison, UN Department, to C. J. Makins, UK embassy in the US, "ICRC Conference on Humanitarian Law in Armed Conflict”, 16.o6.1972, pp. 1-2, TNA FCO 61/957; telegram from Sir Alec Douglas-Home, Foreign Secretary, to UK embassies in Canada, France, FRG, US, Denmark, Belgium, Australia, The Netherlands, Italy, Turkey, New Zealand, and to the mission in Geneva, "Western Working Group Consultations on Humanitarian Law in Armed Conflicts", 11.08.1972, TNA FCO 61/957. On the 1974 Oslo conference, see Tore Linné Eriksen, "The Origins of a Special Relationship: Norway and Southern Africa 196o-1975", in Eriksen, Norway and National Liberation in Southern Africa, pp. 9-89, pp. $5^{6-73}$.

101 Note from François Pictet, deputy chief of the Dio, to the chief of the DiO, "Conférence diplomatique sur le droit humanitaire. Mouvements de libération nationale”, 25.04.1973, p. 2, SFA E2OO3A\#1988/15\#1140*.

102 Michel Veuthey, memorandum, "Consultations sur le droit humanitaire international applicable dans les conflits non internationaux et la guérilla. Entretiens à Alger, dans les locaux du Croissant-rouge algérien, les 5, 6 et 7 août 1970", 13.08.1970, ACICR B AG 059203.01; Veuthey, memorandum, "Mission en Algérie du 5 au 10 octobre 1972", 18.10.1972, ACICR B AG 059-396.o5; note no 1936 from Marcel A. Boisard, ICRC office in Egypt, to Jean-Pierre Hocké, Delegate General, "Entretiens avec les mouvements de résistance", 24.02.1973, ACICR B AG 059-396.05.

Royal Norwegian Embassy in Bern, aide-mémoire, 21.05.1973, SFA E2003A\#1988/15\#1140*. 
Swiss government to take all necessary steps to "ensure the effective participation of the liberation movements recognised by the OAU at this diplomatic conference". 104

Although the conference was competent to decide on admissions by plenary vote, the DIO and the ICRC agreed that a solution ought to be found discreetly in advance to avoid political debates. Independently, they concluded that the OAU, which had observer status, should represent the liberation movements. On 22 June 1973, during a regular meeting of ICRC delegates, FPD officials, and the Secretary General of the conference, Swiss ambassador Jean Humbert, it was agreed that broad participation in the Geneva conference was desirable, so that all belligerents would feel bound by the resulting protocols. However, concessions to the liberation movements must not result in the withdrawal of the Portuguese and South African delegations. The DIo therefore suggested trying what was later called the 'Swiss compromise' - the representation of liberation movements by the OAU - on the US, British, and French governments that were hostile to the presence of the liberation movements. ${ }^{105}$ Trying to garner support for this compromise solution, the Swiss government was caught between fronts.

The British authorities, which closely followed the organisation of the diplomatic conference and continually lobbied the Swiss government and the ICRC, would have preferred the liberation movements to be absent from Geneva and were firmly opposed to granting them observer status. British interest in this area is explained by the concern that the additional protocols would be applied to the conflict between the British authorities and the Irish Republican Army (IRA) that fought for the independence of Northern Ireland. Nevertheless, the FCO agreed that the Swiss compromise was the best that could be expected. ${ }^{106}$

104 Letter from the OAU Secretariat to the Swiss embassy in Ethiopia, 13.06.1973, attached to the letter from Hans Schärer, chargé d'affaires a.i. of the Swiss embassy in Ethiopia, to the DIO, "'Conférence diplomatique sur le droit humanitaire'. Teilnahme afrikanischer Befreiungsbewegungen", 19.06.1973, SFA E2003A\#1988/15\#1140*; see also resolution CM/ Res. 307 (Xx) of the OAU Council of Ministers' 21st Ordinary Session from 17 to 24 May 1973, "Resolution sur la conférence diplomatique sur le droit humanitaire", attached.

105 Note from François Pictet to the chief of the DiO, "Participation des mouvements de libération nationale à la Conférence diplomatique sur le droit humanitaire", 26.o6.1973, SFA E2003A\#1988/15\#1140*; see also the note from François Pictet to the chief of the DIO, "Participation des mouvements de libération nationale à la Conférence diplomatique sur le droit humanitaire", 19.06.1973, ibid; A. Martin, ICRC, memorandum of conversation with representatives of the FPD, "Conférence diplomatique de 1974", 25.06.1973, pp. 1-2, ACICR B AG 152-045.

106 Note from R. J. A. Martin, UN Department, FCo, to R. C. Cox, Northern Ireland Office, "Draft protocol to article 3 of the Geneva Conventions and Northern Ireland, 21.05.1973, TNA FCO 61/109o; letter from M. A. Arthur, UN Department, FCO, to Gillian G. Brown, 
While this solution was just about acceptable to most Western governments, OAU representatives told Jean Humbert during a meeting in Addis Ababa in October 1973 that the liberation movements would find it difficult to accept being represented by the OAU, considering that they had already achieved observer status at the Fourth Committee of the UNGA and at the International Labour Organization (ILO).107 In a press communiqué, the OAU insisted on the necessity for "the independent states of Africa to review the agreements concluded on their behalf by their former colonial administrators." The invitation of the liberation movements would avoid the need for further revision of IHL once colonialism was truly over. ${ }^{108}$ Because of the liberation movements' resistance to the Swiss compromise, the DIO started to modify its proposal, granting them extensive rights if they would accept being part of the OAU delegation, including the right to be present at all times and a right to speak.109

In December 1973, the US authorities, which had been content until the twenty-eighth session of the UNGA to let the British take the lead in Western lobbying efforts, took a more active interest in the Geneva conference. George W. Aldrich, the deputy legal advisor of the State Department and intended head of the US delegation to the Geneva conference, was concerned about what he considered to be the resigned attitude of the Western delegations regarding the presence of the liberation movements. He informed the Swiss embassy in Washington that the US government might reconsider its presence if the liberation movements were to be invited in their own name and urged the Swiss to find a solution before the beginning of the conference. ${ }^{110}$ The new US attention to the issue was linked to the ratification by the Provisional Revolutionary Government of South Vietnam (PRG) of the Geneva Conventions shortly before the conference; this step allowed the PRG to demand an invitation. ${ }^{111}$ In January

UK Embassy in Switzerland, "Diplomatic Conference on Humanitarian Law in Armed Conflict", 20.07.1973, p. 1, ibid.; Gaspard Bodmer, memorandum, "Conférence sur le droit humanitaire; participation des mouvements de libération nationale africains”, 25.07.1973, p. 1, SFA E2OO3A\#1988/15\#1140*.

107 Report no 6 from Ambassador Jean Humbert, General Commissioner for the Diplomatic Conference on International Humanitarian Law, to the Dio, "Participation des mouvements africains de libération nationale à la Conférence sur le droit humanitaire. Voyage du Commissaire général à Addis Abeba", 23.10.1973, pp. 4-5, SFA E2003A\#1988/15\#1140*.

108 OAU press communiqué, 13.10.1973, SFA E2003A\#1988/15\#1140*.

109 François Pictet, memorandum, "Participation des mouvements de libération nationale à la Conférence diplomatique”, 11.12.1973, pp. 1, 4-5, SFA E2003A\#1988/15\#1140*.

110 Telegram no 633 from Felix Schnyder, Swiss ambassador in the US, to the FPD, 12.12.1973, p. 1, SFA E2OO3A\#1988/15\#1140*.

111 No author, memorandum, "Humanitarian Law in Armed Conflict. US/UK Bilateral Consultations, 30 January 1974, Foreign and Commonwealth Office", no date, p. 2, TNA FCO 61/1238. 
1974, the US State Department instructed its representations in selected African states to support the Swiss compromise. ${ }^{12}$ Fearing that these US lobbying attempts might be counterproductive, François Pictet of the DIO expressed his hope that they "were made with great tact to avoid creating the impression that the Swiss proposal was inspired by America."113 Indeed, the deputy Secretary General of the OAU told Ambassador Heinz Langenbacher that the US initiative had rendered some OAU members more distrustful of the Swiss compromise. ${ }^{114}$

In January 1974, the OAU organised an IHL seminar for African liberation movements in Dar es Salaam. At this event, Jean Humbert was unable to convince the liberation movements to accept the Swiss compromise. The African nationalists suggested instead that the Swiss government officially invite the liberation movements that were recognised by the OAU and that the conference should then decide on the terms of their presence. ${ }^{115}$ Since they considered that the extension of official invitations exceeded their authority as convening power, the Swiss authorities rejected this counterproposal. They agreed, however, to issue visas to the nationalist representatives so that they could be present in Geneva. ${ }^{116}$ On this point, the head of the Dio, René Keller, overruled his deputy, who preferred to use the visas as leverage and only grant them if the diplomatic conference decided to invite the liberation movements. Keller feared that many states would accuse Switzerland of "playing into the hands of colonialism and imperialism" if the visas were not issued and thus made a concession to the political power of Third World countries. ${ }^{117}$ As a

112 Telegram from Kenneth Rush, Deputy Secretary of State, to the US embassies in the Ivory Coast, Ghana, Ethiopia, Nigeria, Liberia, Kenya, 15.01.1974, NARA, RG 59, Access to Archival Databases (AAD), https://aad.archives.gov/aad/index.jsp (13 January 2021), Central Forł eign Policy Files (CFPF), Electronic Telegrams 1974, 1974STATEoo8939.

113 Telegram no 11 from François Pictet to the Swiss embassy in the US, 15.01.1974, SFA E2003A\#1988/15\#1140*.

114 Letter from Heinz Langenbacher to the DIo, "Rotkreuzkonferenz: Befreiungsbewegungen”, 22.01.1974, confidential, p. 2, SFA E2003A\#1988/15\#1140*.

115 OAU Liberation Committee, minutes, "Compte-rendu du séminaire de l'OUA sur le droit humanitaire. Tenue à Dar-es-Salaam du 21 au 25 janvier 1974", no date, SFA E2003A\#1988/15\#1140*. See also report no 9 from Jean Humbert to the DIO, "Voyage à Dar es-Salaam - Séminaire pour les mouvements africains de libération nationale", 28.01.1974, SFA E2003A\#1988/15\#573*; Michel Veuthey, memorandum, "Séminaire organisé par l'OUA pour les mouvements de libération africaine en vue de la Conférence diplomatique sur le droit humanitaire - Dar es-Salaam, 21 - 25 janvier 1974", o8.02.1974, ACICR B AG 152-046.o3.

116 Telegram no 8 from Ernesto Thalmann, Secretary General of the FPD, to the Swiss embassy in Tanzania, 24.01.1974, SFA E2003A\#1988/15\#1140*.

117 Note from René Keller to the Secretary General of the FPD, "Participation des mouvements de libération nationale à la Conférence diplomatique", 23.01.1974, urgent, p. 2, SFA E2003A\#1988/15\#1140*. 
consequence of the African liberation movements' decision to reject the Swiss compromise, the Arab League demanded that the Palestine Liberation Organization (PLO) also be invited in its own name. Although the PLO had already agreed that its representative be included in the delegation of the Arab League, PLO representatives expressed their solidarity with the OAU decision in Dar es Salaam and went back on the earlier agreement. ${ }^{118}$

The memorandum of a meeting held between DIO members and two ICRC delegates less than two weeks before the start of the conference reveals the two bodies' different attitudes towards the invitation issue. The former insisted on the importance of the participation of liberation movements and provisional governments like the PRG in the conference and urged Bern to find some kind of solution before negotiations began. François Pictet of the DIO admitted that the FPD had long underestimated the determination of the liberation movements' supporters and was only now addressing the issue properly. Nevertheless, he insisted that his division did not have the time and manpower necessary to enter into negotiations with African delegations. After this meeting, JeanPierre Hocké, Director of the ICRC's Operations Department, expressed his satisfaction that the Swiss government was now more open to the liberation movements: "the FPD realises that it will be very difficult, if not impossible, to take refuge behind the rather legal position that it has adopted so far".119

All efforts to arrange a compromise solution for the participation of African liberation movements before the start of the conference failed. Negotiations in committees and regional groups continued in Geneva. The status of these movements, as well as the PRG and the PAIGC government in Guinea-Bissau, which had unilaterally declared its independence from Portugal in September 1973 and deposited instruments of accession to the Geneva Conventions on 21 February 1974, dominated the first part of the conference. ${ }^{120}$ Finally, a consensus was reached on admitting Guinea-Bissau to the conference with full rights and the liberation movements as observers with all rights except the right to vote. ${ }^{21}$ The US delegation accepted this compromise without a vote in order to separate the status of the African movements from that of the PRG, whose

118 Telegram no 39 from Yves André Berthoud, Swiss embassy in Egypt, to the FPD, 14.02.1974, p. 1, SFA E2OO3A\#1988/15\#1140*.

119 Jean-Pierre Hocké, memorandum, "Participation des mouvements africains, du GRP et du GRUNC à la Conférence diplomatique”, p. 2, 12.02.1974, ACICR B AG 059-397.02. Telegram from Francis Lykins Dale, US Mission in Geneva, to the Secretary of State, "Laws of War Conference - Current Status", p. 2, NARA, RG 59, AAD, CF PF, Electronic Telegrams 1974, 1974GENEVAo1188.

121 Second circular letter from René Keller to all Swiss embassies, "Conférence diplomatique sur le droit humanitaire”, 04.03.1974, p. 1, SFA E2003A\#1988/15\#1140*. 
invitation to the conference was defeated in an extremely tight vote. ${ }^{122}$ This decision disappointed the Executive Council of the ICRC, whose members had wanted participation in the conference to be as universal as possible. ${ }^{123}$

The admission of African liberation movements to the 1974 ICRC Diplomatic Conference on the Reaffirmation and Development of IHL Applicable in Armed Conflicts represented an important diplomatic victory for themselves and their supporters. FRELIMO heralded it as "a great victory for the Mozambican people and for all other peoples fighting for their freedom." In the English-language periodical Mozambique Revolution, edited by its Department of Information and aimed at an international audience, FRELIMO demanded that Portugal apply and respect the Geneva Conventions, concluding that, "the best and most effective way of putting an end to the suffering inflicted on our people by the war is to eliminate the very causes of war as soon as possible, in other words, to put an end to Portuguese colonialism and imperialism."124 Many Western delegations were frustrated by the lack of substantive results and the omnipresence of what they perceived as tiresome political debates during the conference. According to Jean Humbert, the lack of contact between the Non-Aligned bloc and those Western delegations that defended a traditional interpretation of $\mathrm{IHL}$, and the latter's obstinacy and refusal to propose compromise-based solutions, allowed the former to benefit from their numerical weight. Thus, they managed to push through an amendment to elevate liberation wars to the level of international conflicts, which significantly improved the status of liberation movements. ${ }^{125}$ The conference report of the British

122 George W. Aldrich, chairman of the US delegation, "Classified Report of the United States Delegation to the Diplomatic Conference on the Reaffirmation and Development of International Humanitarian Law Applicable in Armed Conflicts", 10.06.1974, Foreign Relations of the United States (FRUS) Online, https://history.state.gov/historicaldocuments (13 January 2021), 1969-1976, vol. E-3, doc. 235. The admission of the PRG was defeated with 38 against 37 votes, with 33 abstentions: no author, "Vote sur l'admission ou la non admission du Gouvernement révolutionnaire provisoire du Vietnam du Sud", 28.o2.1974, attached to the second circular letter from René Keller to all Swiss embassies, "Conférence diplomatique sur le droit humanitaire”, 04.03.1974, p. 1, SFA E2003A\#1988/15\#1140*.

123 J. Ott, ICRC, memorandum of conversation between Roger Gallopin, President of the ICRC's Executive Council, and ambassador Nguyen Van Luu, head of the Department of International Organisations and International Law of the Ministry of Foreign Affairs of the Democratic Republic of Vietnam and deputy head of delegation, 12.02.1974, p. 1, ACICR B AG 152-046.02.

124 No author, "FRELIMO in world events", Mozambique Revolution $5^{8}$ (January-March 1974), pp. 10-11, p. 11.

125 Report no 11 from Jean Humbert to the Dio, "Considérations de caractère général sur les travaux de la Conférence qui a eu lieu du 20 février au 29 mars 1974”, 10.04.1974, p. 5, SFA E2003A\#1988/15\#1140*. 
delegation, written in June 1974, was unequivocal about the results of the conference: "To the extent that there were any, they were lamentable." According to the delegation, the lack of progress was due to the political agenda of Third World countries and the tug of war between the Communist bloc and the US regarding the PRG - and the Swiss organisers' lack of leadership. ${ }^{126}$ George W. Aldrich, the leader of the US delegation, heartily concurred with this assessment and explained it by the "unfamiliarity of the Swiss Government with the rough and tumble of United Nations politics."127

As political debates stalled the work of the 1974 conference, three more diplomatic conferences and numerous formal and informal meetings took place until the two additional protocols aimed at improving the protection of the civilian population and codifying the norms applicable to non-international armed conflicts were finally adopted in $1977 .{ }^{128}$ Even then, many states either did not sign or never ratified Protocol I that dealt with international war, notably the US and the Ussr. The UK and France only did so after the end of the Cold War. ${ }^{129}$

For the Swiss government, the Geneva conference of February and March 1974 was an opportunity to secure the ICRC's and its own influence in the debate on the revision of IHL in armed conflicts, play a role on the international stage, and strengthen its image as a neutral, humanitarian actor. However, due to the conference's strong polarisation along North-South lines, it was only partly successful. The issue of the African liberation movements' admission highlights Bern's disregard for these actors and their goals. The DiO was convinced that African nationalists had no legal claim to representation, and underestimated both their determination to be present in their own name and the support they could rely on from the Afro-Asian bloc and some Western states, notably NATO member Norway. Given the Swiss authorities' interpretation of their position as convenors of the Geneva conference as a passive role, they refrained from taking initiatives and making more substantial concessions

126 Report of the British delegation, "Diplomatic Conference on Humanitarian Law in Armed Conflict. Geneva 20 February - 29 March 1974: First Session”, 17.06.1974, citation p. 1, TNA FCO 61/1233.

127 George W. Aldrich, "Classified Report of the United States Delegation to the Diplomatic Conference on the Reaffirmation and Development of International Humanitarian Law Applicable in Armed Conflicts", 10.o6.1974, FRUS Online, 1969-1976, vol. E-3, doc. 235. Yves Sandoz, "La Suisse et le droit international humanitaire, en particulier les conventions de Genève pour la protection des victimes des conflits armés", in Riklin, Haug, Probst, Neues Handbuch der schweizerischen Aussenpolitik, pp. 247-263, p. $25^{2}$.

129 Amanda Alexander, "A Short History of International Humanitarian Law", The European Journal of International Law 26:1 (2015), pp. 109-138, p. 126. 
that might have allowed the issue to be resolved before the beginning of the conference. At the same time, their leeway was limited, as although the British and US administrations repeatedly pressured the FPD to achieve a solution in advance, it is doubtful that they would have agreed to grant the liberation movements far-reaching privileges.

In this context, the Swiss government, as convenor of the conference, did not make a good impression. While Western delegations criticised its passivity and lack of clear direction, representatives from the Third World expressed their incomprehension that the liberation movements had not been invited. In a conversation with members of the DIO during the conference, FRELIMO delegate José Oscar Monteiro, the spokesman for the liberation movements in Geneva, criticised the Swiss government for its one-sided stance during the independence wars in Southern Africa. Neutrality, according to Monteiro, was no excuse for not taking a stand for the liberation movements, especially as neutral Sweden and NATO-member Norway had already done just that. ${ }^{130}$ Uttered barely a month before the Carnation Revolution, these words were indicative of the gulf between the Swiss authorities and the liberation movements, which would complicate relations after the independence of Mozambique and Angola.

Starting in 1967, Afro-Asian leaders criticised Switzerland's interpretation of a neutral foreign policy as one that refused to acknowledge the political consequences of economic activities at the $\mathrm{UN}$, the OAU, and international organisations in Geneva. The Swedish counterexample strengthened this criticism. However, in the eyes of the major Western powers, whose political line in Southern Africa Swiss foreign policymakers followed and towards whom their neutrality policy had traditionally been oriented, it was clear who the 'good neutrals' were. Western observers underlined the Swiss government's 'sensible' approach to Third World issues - an approach that did not undermine their position as Sweden and Norway did. They therefore welcomed its more active foreign policy, as the British ambassador in Bern eloquently put it in mid-1973:

It seems to me that we can only gain if Switzerland does take a more relaxed view of its neutrality, if it does, for example, finally take the plunge and join the UN. [...] [T]here is no doubt where Switzerland's sympathies lie (for what it is worth, within 10 minutes of my meeting M. Celio, the Minister of Finance, he remarked [...] that no former British

130 Letter from François Pictet to the Swiss embassies in Ethiopia and Tanzania and the Office of the Permanent Observer of Switzerland to the UN, "Possibilité d'une aide suisse en Afrique australe”, 29.04.1974, SFA E2005A\#1985/101\#547*. 
colony was now better off than it had been under British rule). Switzerland may be small and often narrow in its outlook, but its assets as a stable, democratic and wealthy State, with solid views on world affairs, more solid one might say than any of the other European neutrals, are not to be underrated. ${ }^{131}$

131 Diplomatic report no 252/73 from John Richard Wraight, British ambassador in Switzerland, to the British Secretary of State, "First Impressions of Switzerland", 01.05.1973, p. 6, TNA FCO 33/2279. 


\section{Negotiating Foreign Policy on the Domestic Front: Non-state Actors and Portuguese Colonialism}

In the late 196os, as African governments began to single out Switzerland's connections with the white minority regimes of Southern Africa, protest also grew on the domestic front. Activist groups that developed out of the ' 1968 ' student movement and religious circles started to raise their voices against Portuguese colonialism and what was perceived as the Swiss government's complicity with a racist regime involved in a violent colonial war. These actors were part of a transnational protest network. In the late 196os, student movements in Western Europe and the US took up the issue of the unequal relations between the global North and the global South, proclaiming their solidarity with the peoples of the Third World. At the same time, some churches and religious actors, inspired by liberation theology, were increasingly engaged in political issues and started to criticise contemporary paternalistic approaches to development aid. Students, peace activists, intellectuals, radical leftist groups, and religious organisations formed a variety of solidarity movements with the Third World. The armed struggles of liberation movements in the global South motivated and sometimes radicalised these solidarity groups, and served as inspiration for a more general resistance against the capitalist system. ${ }^{1}$ In this context of growing mobilisation for Third World issues, the authoritarian Estado Novo regime, at the head of a colonial empire, was an ideal target.

Influenced by student protests against the wars in Vietnam and Biafra, numerous activist groups were created in Switzerland between 1967 and 1970. Although their aims and activities differed, they were united by their moral protest against injustice in the world. In their search for the causes of the unequal development of the North and the South, most activists focused on the responsibility of their own society. They aimed to inform people in Switzerland about the situation in the Third World and convince them of the need to break with the contemporary policies of industrialised countries that created structures of dependency in the global South. ${ }^{2}$ The Swiss government's role in the stabilisation of the Portuguese colonial empire was discussed as part of the broader critical analysis of North-South relations. This included

1 Kuhn, "Liberation Struggle and Humanitarian Aid", pp. 70-71.

2 Holenstein, Was kümmert uns die Dritte Welt, pp. 177-178. 
the reappraisal of aid and development policies and condemnation of the Third World's exploitation by the First World. As a result of this mobilisation, a wide range of non-state actors with very different motives joined with Swiss churches and missionary organisations, banks, and export firms in trying to influence the Swiss government's foreign policy in Southern Africa in parliament, through direct lobbying, and on the street. ${ }^{3}$

Although some Swiss activists had criticised the repressive nature of the Portuguese regime since the early 196os and an Anti-Apartheid Movement was founded in Geneva in 1964, it was not until the end of the decade that protest started to focus on Portugal's African colonies. In April 1968, the performance of a play that denounced Portuguese colonial rule and the complicity of Western countries and NATO caused a stir in Geneva and raised public awareness of the situation in Portugal and its colonies. The play enjoyed considerable success in Switzerland and abroad. ${ }^{4}$ In the following years, various Swiss individuals and groups showed much solidarity with the liberation struggles in Angola, Mozambique, and Guinea-Bissau and formed a heterogeneous protest landscape.

The solidarity group Medic'Angola, for example, initially focused exclusively on the liberation struggle in Angola and was based mainly in Zurich. Founded in 1970 or 1971 following contact between Swiss activists and MPLA members in Algiers, the group edited and sold a journal to inform the Swiss public about the situation in Angola. At the same time, its 10-25 members collected clothes, medicines, and money to be sent to the MPLA. In 1972, Medic'Angola drew closer to the Maoist inspired Swiss Communist Party and devoted itself to the anti-imperialist struggle and the class struggle in Switzerland. As a result of this radicalisation, several members left the group in late 1972 to found another movement, the Komitee Südliches Afrika (Southern Africa Committee, KSA). After Angola's independence, Medic'Angola changed its name to Kämpfendes Afrika (Fighting Africa), swapped its allegiance to UNITA to protest against the growing Soviet influence on the MPLA, and turned towards liberation movements in Rhodesia and South Africa. ${ }^{5}$ The group was in direct contact with

3 Some sections of this chapter are derived in part from Sabina Widmer, "Switzerland's Neutrality Policy in Southern Africa on the Defensive: The Swiss Government's Reactions to Non-State Actors' Solidarity with the Independence Struggles in the Portuguese Colonies, 1968-1974", Afriche e Orienti 19:3 (2017), pp. 101-114.

4 Nuno Pereira, "Le mouvement suisse de 1968 et le Portugal: de la dictature à la révolution (1962-1975)", in Schaufelbuehl, 1968-1978, pp. 147-16o, p. 151.

5 On Medic'Angola, see Marcel Dreier, "Afrikanische Befreiungsbewegungen und die antiimperialistische Solidaritätsbewegung in der Schweiz" in Schaufelbuehl, 1968-1978, pp. 161-176; Dag Henrichson, Registratur AA.5. The Archive of the Solidarity Group Medic'Angola / Kämpfendes Afrika (Zurich, 1971 - 1988), Basel: Basler Afrika Bibliographien. Namibia Resource Centre \& Southern Africa Library, 2002, pp. xix-xxv; Steinemann, Medic'Angola. 
African liberation movements and other European solidarity groups. In February 1974, for example, an MPLA representative visited the group to inform them about the independence struggle in Angola. ${ }^{6}$ A few weeks later, members of Medic'Angola participated in an international conference organised by a British solidarity group, together with activists from Austria, West Germany, Italy, and Denmark. On this occasion, the group held discussions with representatives of liberation movements, coordinated its activities with other movements, exchanged information and propaganda material, and visited the embassy of the PRC in London. ${ }^{7}$

The Anti-Apartheid Movement in Geneva, which became the Swiss AntiApartheid Movement in 1971 and created a branch in German-speaking Switzerland in 1975, also had international links. It exchanged pamphlets and information with the British Anti-Apartheid Movement. ${ }^{8}$ The Swiss AntiApartheid Movement, whose activities extended to all white minority regimes in Southern Africa, focused on information and lobbying in Switzerland. Its members grew from 450 in 1968 to 1,200 in 1975 . They included politicians, priests, and scientists. ${ }^{9}$ In Bern, Third World solidarity groups such as the Erklärung von Bern (Bern Declaration, EvB) and the Arbeitsgruppe Dritte Welt (Working Group Third World, $\mathrm{AG}_{3} \mathrm{~W}$ ), founded in 1968 by Protestant theologians and in 1969 by religious student groups, respectively, focused on Portuguese Africa within the framework of their general criticism of North-South relations. Both groups concentrated on activities in Switzerland and were key players in the Swiss campaign against the Cabora Bassa dam in Mozambique. ${ }^{10}$ $\mathrm{AG}_{3} \mathrm{~W}$ became the coordinating body of the Schweizerische Arbeitsgruppen für

No author [Medic'Angola], minutes, 26.o2.1974, Basler Afrika Bibliographien. Namibia Resource Centre \& Southern Africa Library (BAB), Basel, Switzerland, AA5.II.6.1o.

7 No author, "Bericht über die Osterkonferenz, Besuche in London und Paris", no date [between Easter 1974 and the Carnation Revolution], BAB AA5.II.I.I.1o.

8 See the correspondence between the British and the Swiss Anti-Apartheid Movements in the Bodleian Library in Oxford. In 1971, for example, two groups decided to exchange their journals: letter from Ethel de Keyser, Executive Secretary of the British Anti-Apartheid Movement, to C. Thommen, Geneva Anti-Apartheid Movement, 29.09.1971, and the attached letter from C. Thommen to the British Anti-Apartheid Movement, 15.09.1971, Bodleian Library, Oxford, UK, MSS AAM 1352.

9 Pereira, Anti-impérialisme et nouvelle gauche radicale, p. 42.

10 On the Erklärung von Bern (Bern Declaration, EvB), see Fischer, 'Die Solidarität in den Strukturen'; Anne-Marie Holenstein, Regula Renschler, Rudolf Strahm, Entwicklung heisst Befreiung. Erinnerungen an die Pionierzeit der Erklärung von Bern (1968-1985), Zürich: Chronos, 2008; Konrad Kuhn, "'Der Kampf der Entrechteten dort ist unser Kampf hier!' Entwicklungspolitisches Engagement und internationale Solidarität in der Schweiz", in Schaufelbuehl, 1968-1978, pp. 113-123; Manuel Schär, "Wie entwickeln wir die 'Dritte Welt'? Kontinuitäten und Brüche im Entwicklungsverständnis um 1968 in der Schweiz", in Schaufelbuehl, 1968-1978, pp. 99-111. 
Entwicklungspolitik (Swiss Working Groups for Development Policy, SAFEP), an umbrella organisation of about 30 Swiss groups that was officially constituted in January 1973 and focused on development policies. ${ }^{11}$ Churches, religiously motivated charities, trade unions, and members of parliament were also part of the Swiss protest landscape.

Their activities did not pass unobserved by either the Swiss or the Portuguese authorities. The files on different Swiss movements in the archives of the Portuguese secret service PIDE/DGS contain numerous pamphlets and Swiss newspaper articles. They show how closely the Estado Novo regime monitored 'anti-Portuguese' activities abroad. ${ }^{12}$ Swiss solidarity groups caused some irritation in Lisbon and sporadically led to complaints from Portugal. For example, in a discussion with the Swiss ambassador to Portugal in September 1968, the head of political affairs at the Portuguese foreign ministry, Gonçalo Caldeira Coelho, expressed his surprise that neutral Switzerland tolerated political debates concerning the internal affairs of third states and cited the doings of several solidarity groups in some detail. ${ }^{13}$ In response, the head of the Swiss Federal Police, André Amstein, briefed the DPA on these movements, commenting on their links to Angolan refugees living in Switzerland and to other radical organisations. Although he downplayed the influence of Swiss solidarity groups on public opinion, he mentioned repeatedly that the activists were part of the extreme left, thereby attempting to delegitimise their claims. As they were mostly Swiss, Amstein professed to be unable to intervene, but he promised to continue to monitor them. ${ }^{14}$ His response is symptomatic of the

11 Holenstein, Was kümmert uns die Dritte Welt, pp. 192-193; Fischer, "Die Solidarität in den Strukturen", pp. 35-37.

The Portuguese authorities reported, for example, on the formation of a Mouvement de soutien aux peuples de l'Angola et des autres colonies portugaises (support movement for the people of Angola and the other Portuguese colonies) in Geneva in July 1968 and on a solidarity pamphlet distributed by activists before Christmas 1970: PIDE Angola, report, "Informação no 784 - SC/CI (2). Movimento de apoio aos povos de Angola e das outras colónias portuguesas", 19.07.1968, ANTT, PIDE/DGS, Cl (2), no 4312, NT 7342; José de Vilhena Ramires Ramos, Serviços de Centralização e Coordenação de Informações de Moçambique (Mozambican Service for the Centralisation and Coordination of Information, SCCIM), report, "S.D.I. Apoios aos movimentos subversivos suiça; 'Action Noel 70", 20.05.1971, ANTT, SCCIM, no 648. The files on many Swiss activist groups such as the Afrika Komitee Basel (Africa Committee Basel) or the Groupe de travail Afrique australe et Portugal (Working Group Southern Africa and Portugal), Geneva, in the archives of the Portuguese secret service PIDE/DGS in the ANTT have not yet been declassified. of Police, "Umtriebe gegen Portugal in der Schweiz", 24.o9.1968, dodis.ch/32136. 
Swiss authorities' perception of a leftist threat to the state from within and provides some evidence of their comprehensive surveillance of unorthodox activities during the Cold War. ${ }^{15}$

In the late 196os and early 1970s, a number of key issues and events linked to Portugal's colonial policy polarised Swiss society and sparked conflict over foreign policy priorities between the Swiss government, civil society actors, and economic elites: arms exports to Portugal; the participation of Swiss firms and banks in the construction of the Cabora Bassa dam in Mozambique; the imprisonment of Mozambican Christians linked to the Swiss Mission; and Portugal's invitation as a guest of honour to the 1973 Comptoir Suisse trade fair.

\section{Neutrality, National Defence, and Humanitarianism: Arms Exports to the Third World}

Arms exports are a particularly sensitive issue for a neutral state. ${ }^{16}$ The Fifth Hague Convention of 1907 that determines the rights and duties of neutrals in war on land asserts that neutral states are not obliged to restrict arms exports to belligerents. If they do decide to impose restrictions or prohibitions, these must be impartially applied to all warring parties. ${ }^{17}$ Although Swiss arms exports to a belligerent are not prohibited by international law, there is a risk that the credibility and respectability of its neutrality would suffer if Switzerland were perceived to indirectly contribute to or even benefit from armed violence. In the late 1960s and early 1970s, arms sales to Third World countries not only had important ramifications on Switzerland's image as a neutral but the issue also divided Swiss society. The Swiss government was forced to juggle

15 On Swiss surveillance activities in the 2oth century, see Georg Kreis (ed.), Staatsschutz in der Schweiz. Die Entwicklung von 1935-1990. Eine multidisziplinäre Untersuchung im Auftrage des schweizerischen Bundesrates, Bern et al.: Paul Haupt, 1993.

16 On the tension between Swiss neutrality and arms exports, see notably Walther L. Bernecker, Thomas Fischer (eds.), Unheimliche Geschäfte. Schweizer Rüstungsexporte nach Lateinamerika im 20. Jahrhundert, Zurich: Chronos, 1991; Reto Moosmann, "Die Verwässerung des 'generellen Ausfuhrverbots' im Dienste von Armee und Rüstungsindustrie. Zur Kriegsmaterialausfuhrpolitik des Bundesrates in den 195oer und 6oer Jahren", Schweizerische Zeitschrift für Geschichte 56:2 (2006), pp. 152-167; Jean-Marie Pellaux, L'affaire Pilatus. Les milieux engagés et la Suisse officielle face aux exportations d'armes (1978-1985), Fribourg: Université de Fribourg, 2008.

17 "Laws of War: Rights and Duties of Neutral Powers and Persons in Case of War on Land (Hague V)", 18.10.1907, Yale Law School, The Avalon Project, Documents in Law, History and Diplomacy, http://avalon.law.yale.edu/2oth_century/hagueo5.asp (13 January 2021). 
the export and defence interests of Switzerland's arms industry, and the protest of religious and Third World organisations that considered arms exports incompatible with the country's humanitarian policy.

Until 1972, Swiss arms exports were regulated by the Decree of the Federal Council of 28 March 1949. This Decree confirmed the already existing general ban on the export of weapons and other so-called war materials. However, the Defence Technology Division (DTD) of the FMD, could, after consultation with the FPD, exceptionally grant export permits. Behind the scenes, the general ban on arms exports was softened almost immediately. The Swiss arms industry lobbied the Federal Council to liberalise its policy, arguing that exports were necessary to maintain the independent and technologically advanced armament industry that was essential for Switzerland's national defence. Many FMD members shared this view. ${ }^{18}$ In practice, a procedure was established whereby companies had to request permits both for the fabrication of specific war materials and for their export. Applications for export to countries where armed conflicts were taking place or threatened to break out were not to be granted. However, this restriction was treated rather flexibly. Thus, exports to warring parties might be authorised if there was a written guarantee that the arms delivered by Swiss firms would not be used in the conflict. ${ }^{19}$ Nevertheless, the Federal Council introduced export bans or restrictions for specific states and regions, notably Israel and the Arab countries in 1955, South Africa in 1963, and Rhodesia in $1965 .^{20}$

Applications for arms exports to Portugal presented a particular dilemma. On the one hand, the supply of arms to a NATO member country for its defence needs in Europe posed no political problems. It was in the interest of Switzerland's armament industry and considered essential for its national security. On the other, Portugal was undeniably an actor in the armed conflicts in its African colonies. From this angle, arms sales to Portugal were also contrary to UN policy. In the early 196os, both the UNGA and the Security Council requested its members and those of its specialised agencies to prevent the sale and supply to Portugal of arms and military equipment that might be used in the colonies. ${ }^{21}$ Although Switzerland was not a member of the UN, it was a member of the UN's specialised agencies. As it was politically inopportune to counter-

\footnotetext{
18 Moosmann, "Verwässerung des 'generellen Ausfuhrverbots", pp. 154-160.

19 David Gaffino, Autorités et entreprises suisses face à la guerre du Viêt Nam, 1960-1975, Neuchâtel: Alphil, 20o6, pp. 8o-81.

$20 \quad$ Moosmann, "Verwässerung des 'generellen Ausfuhrverbots", p. 162.

21 Resolution 1742 (XVI) of the UN General Assembly, "The situation in Angola", 11onnd plenary meeting, 30.01.1962, http://www.un.org/en/ga/search/view_doc.asp?symbol=A/ RES/1742(XVI) (13 January 2021); Resolution 180 (1963) of the UN Security Council, "Ques-
} 
act these resolutions and appear to benefit from armed conflicts in Southern Africa, the Swiss authorities wished to prevent Swiss-made arms from being used during the independence wars. The decision on whether to grant a permit to export arms to Portugal therefore hinged on whether the materials in question were likely to be used in Portuguese Africa.

This was often difficult to determine. The Swiss authorities did not always show uniform rigour when judging export applications. In 1964, the Federal Council refused arms manufacturer sig's project to supply rifles and guns to Portugal worth about CHF 20 million, as it would have been difficult to monitor their use. The Swiss authorities were also somewhat sceptical about the sudden Portuguese interest in the Swiss armament industry, as Portugal was not one of its traditional clients. Moreover, they suspected that the Portuguese government had turned to Switzerland since it had become more difficult to buy arms from NATO countries. ${ }^{22}$ When, five years later, the metal processing company Schweizerische Metallwerke Selve \& Co requested a permit for the fabrication of 65 tons of parts for the production of munitions destined for Portugal, the FPD insisted on a declaration by the Portuguese government that those munitions would not be used in the colonies. ${ }^{23}$ The department was not swayed by the argument that the opportunity to export their goods was essential to the Swiss company's survival. ${ }^{24}$ This demand proved too much for Selve's Portuguese business partner. It withdrew from the planned deal in mid-1969, stating that no Portuguese authority would be willing to meet such an unreasonable demand. ${ }^{25}$ In the same year, the export to Portugal of ten encryption units was authorised. In this case, the Portuguese Defence Department had signed a declaration that these units would not be re-exported. As their use in

tion relating to territories under Portuguese administration",31.07.1963, http://www.un.org/ en/ga/search/view_doc.asp?symbol=S/RES/18o(1963) (13 January 2021). eral Councillor and head of the FPD, "Kriegsmateriallieferungen nach Portugal", 31.01.1964, p. 3, dodis.ch/31455.

23 Letter from Jacques-Bernard Rüedi to the Directorate of the Federal Military Administration (DFMA), "Ausfuhr von Kriegsmaterial nach Portugal", 31.03.1969, SFA E20o1E\#1980/ $83^{\#} 3784^{*}$.

24 Letter from the firm Schweizerische Metallwerke Selve \& Co to the DFMA, "Ausfuhr von Kriegsmaterial nach Portugal", 23.01.1969, p. 1, SFA E2001E\#1980/83\#3784*.

25 Cited in the letter from the Schweizerische Metallwerke Selve \& Co to the Board of Control for Trade in War Materials of the DFMA, "Ausfuhr von Kriegsmaterial nach Portugal", 02.07.1969, attached to the letter from Jean-Louis Grognuz, Board of Control for Trade in War Materials, to the DPA, "Ausfuhr von Näpfchen nach Portugal", 04.07.1969, SFA E2001E\#1980/83\#3784*. 
the colonies was therefore "although not excluded, at least unlikely", the FPD granted the export permit. ${ }^{26}$

While the federal administration's control over the final destination of arms exports to Portugal was not watertight, sales of war materials authorised by the FPD did not reach significant amounts. An overview of Swiss arms exports to Portugal between 196o and 1970 shows that they hardly ever exceeded CHF 0.3 million per year and consisted mainly of encryption units. Exceptionally, in 1961 and 1972 , they reached CHF 0.6 million. ${ }^{27}$ It is possible that subsidiaries of Swiss firms in other European countries might have delivered arms to Portugal, but such deals left no traces.

There are no signs that Swiss arms were exported to the liberation movements in Angola and Mozambique. The FPD stood firm when it came to arms sales to states bordering the Portuguese colonies. In August 1968, the department refused the export of a cannon to Zambia because of the country's tense relations with neighbouring Rhodesia, which was on Switzerland's embargo list, and the activities of Zambia-based Rhodesian and Mozambican liberation movements. ${ }^{28}$ Through the Swiss embassies in London and Nairobi, Zambian officials unsuccessfully urged Bern to reconsider. ${ }^{29}$ While Bern was at least in some cases willing to give the authoritarian Estado Novo regime the benefit of the doubt and allow limited arms sales to Portugal in the hope that the material would not be used in the colonies, it did not extend the same courtesy to the Zambian government in the middle of 1968.

In the late 196os, a case of illegal arms sales to Third World states caused the so-called Bührle scandal and led to the reorganisation of Swiss legislation on arms exports. In late 1968, it was made public that the Swiss arms manufacturer Oerlikon Bührle had deliberately sold arms to seven embargoed countries, including South Africa, by supplying falsified end user certificates to the Swiss authorities. This affair caused a huge public outcry. The use of Bührle air defence guns by the Nigerian government during the civil war, at the same time as the ICRC, supported by the Federal Council, coordinated an important

26 Note from Michael Gelzer, deputy chief of the DPA, to Willy Spühler, Federal Councillor and head of the FPD, "Ausfuhr von Kriegsmaterial nach Portugal", 29.08.1969, and notes attached to this document, SFA E2001E\#1980/83\#3784*. Jean-Louis Grognuz, table, "Exportations de matériel de guerre en francs, Portugal 19601970", 25.08.1971, SFA E2001E-o1\#1982/58\#6106*; Grognuz, table, "Entwicklungsländer. Export von Kriegsmaterial 1972", 07.04.1973, SFA E5001G\#1985/220\#1110*.

28 Letter from Michael Gelzer to Oerlikon Bührle, "Ausfuhr einer 20 mm-Kanone und von Munition dazu nach Zambia", 16.08.1968, SFA E5001G\#1982/18\#2738*.

29 Letter from Michael Gelzer to the Swiss Embassy in Kenya, "Waffenausfuhr nach Zambia", 07.02.1969, SFA E5001G\#1982/18\#2738*. 
relief mission and the Swiss population made large donations in support of the starving population of the secessionist province of Biafra, outraged many people. The scandal provoked several parliamentary questions and led to the criminal prosecution of the director and high-ranking employees of Oerlikon Bührle and their conviction in November 1970. In the second half of 1968, Swiss peace activists launched a popular initiative to prohibit all arms exports with the exception of those to neutral European states. Members of Swiss churches, charities, development organisations, trade unions, and radical youth groups rallied behind the initiative. ${ }^{30}$

In the aftermath of the Bührle scandal, the federal administration also started to review Switzerland's policy on arms exports. The Federal Council even considered imposing an embargo on arms exports to the entire African continent. The government set up an interdepartmental working group to discuss the issue. Considering that Swiss exports to African countries were limited and the major potential sales markets South Africa and the Arab countries were already embargoed, the working group judged that an extension of the embargo to the whole African continent would not have serious consequences for the Swiss armament industry. A total embargo, such as that practised by Sweden, could also be justified from a political point of view, as Federal Councillor Willy Spühler explained in his proposal to the Federal Council in May 1969: "Indeed, the problem of deliveries of war materials to countries that benefit from development aid and that periodically need humanitarian assistance is in no part of the world as severe as in Africa. The example of Nigeria/Biafra shows this very clearly."31 However, the working group feared that an embargo on a whole continent might create an unwelcome precedent. The public might then argue that embargoes should also be introduced on Asia and Latin America, "where upheavals and revolutions also tend to happen periodically" and where an embargo would have "much more serious consequences for our

30 On the Bührle scandal, see Kalt, Tiersmondismus in der Schweiz, pp. 354-40o; Ruedi Tobler, "Wenn Schweizer Kanonen auf IKRK-Flugzeuge schiessen. Der Bührle Skandal", in Heinz Looser et al. (eds)., Die Schweiz und ihre Skandale, Zürich: Limmat Verlag, 1995, pp. 93-106; with a focus on the Biafra conflict, Dominik Matter, "'sos Biafra.'Die Schweizerischen Aussenbeziehungen im Spannungsfeld des nigerianischen Bürgerkriegs 19671970", Bern: Diplomatische Dokumente der Schweiz (DDS), 2015, pp. 46-49; 90-95; Gian-Luca Stössel, Kriegsmaterial und Solidarität - Die Schweiz und der Biafrakrieg. Die Bemühungen der Schweiz um Linderung der humanitären Auswirkungen des Biafrakriegs und die Bührle-Affäre, Saarbrücken: vDM Verlag Dr. Müller, 2011.

Willy Spühler, proposal to the Federal Council, "Kriegsmaterialausfuhr nach Afrika, Indien und Pakistan", confidential, 22.05.1969, p. 2, attached to the excerpt of the minutes of the Federal Council's meeting on 2 June 1969, "Kriegsmaterialausfuhr nach Afrika, Indien und Pakistan", SFA E5001G\#1982/19\#2509*. 
industry". ${ }^{32}$ In the end, this economic argument won the day. In June 1969, the Federal Council only prohibited the export of arms to specific African countries. Included in the embargo were the Portuguese colonies and neighbouring states: Tanzania, Zambia, Zaire, and Guinea. ${ }^{33}$

While the Swiss government embargoed Angola, Mozambique, GuineaBissau, and their bordering countries to prevent Swiss-made arms from reaching the liberation movements, it continued to allow limited arms exports to Portugal despite the remaining risk that the material might be used in its colonies. Although there was no absolute guarantee that arms sold to Portugal would not end up in the colonies, the Swiss government was willing to take the risk of selling to only one warring party and thus to violate Switzerland's neutrality.

In June 1972, the Swiss parliament adopted a new federal law on war materials. It prohibited arms exports to certain countries if they compromised Switzerland's policy on human rights and its humanitarian and development aid. Three months later, the Swiss people rejected the initiative for the ban of arms exports in an extremely tight vote. ${ }^{34}$ The FPD and the FMD subsequently reviewed a number of applications for export permits to Portugal. Due to the Estado Novo regime's colonial policy and the violation of human rights in Portuguese Africa, the two departments demanded, in a proposal to the Federal Council, stricter control of the Portuguese written guarantees that the arms would not be used in the colonies. They were well aware that this position was not consistent: "An export ban would be more correct."35 But, as Portugal was a fellow EFTA member and close trading partner of Switzerland, the departments suggested granting export permits for arms that had already been commissioned, but refusing all new requests for the production of war materials for Portugal. The Federal Council finally decided to end the unequal treatment of the belligerents in the independence wars in Portuguese Africa by agreeing to gradually phase out arms exports to Portugal in November $1972 .{ }^{36}$ The

$32 \quad$ Ibid., p. 3 .

33 Excerpt of the minutes of the Federal Council's meeting on 2 June 1969, "Kriegsmaterialausfuhr nach Afrika, Indien und Pakistan", confidential, SFA E5001G\#1982/19\#2509*.

34 Walter Kälin, "Schweizerische Kriegsmaterialausfuhr im Spannungsfeld von Menschenrechten und Entwicklungszusammenarbeit", in Bernecker, Fischer, Unheimliche Geschäfte, pp. 73-91, p. 74 .

FMD, FPD, proposal to the Federal Council, "Richtlinien für die Behandlung von Fabrikations- und Ausfuhrgesuchen für Kriegsmaterial im Anschluss an die Volksabstimmung vom 24. September 1972", 29.11.1972, p. 16, SFA E2001E-o1\#1982/58\#6106*.

36 Decree of the Federal Council, "Richtlinien für die Behandlung von Fabrikations- und Ausfuhrgesuchen für Kriegsmaterial im Anschluss an die Volksabstimmung vom 24. September 1972", 15.11.1972, SFA E2OO1E-o1\#1982/58\#6106*. 
Swiss government hoped that this would discreetly stop future arms sales to the Estado Novo regime. The introduction of an embargo was to be avoided, as it might have been construed as a public condemnation of Portugal's colonial policy, which could have irritated Lisbon and threatened Swiss trade with the country.

The Bührle scandal mobilised a heterogeneous coalition of Swiss non-state actors sympathetic to Third World issues. It launched a debate on weapons sales to Third World countries that led to a tightening of Switzerland's legislation on arms exports in 1972. The possible participation of Swiss firms in the construction of the Cabora Bassa dam in Mozambique was another mobilising factor for Switzerland's civil movement for solidarity with the Portuguese colonies.

\section{Colonial Exploitation, Business Interests, and State Export Promotion: The Cabora Bassa Dam}

For the people of Mozambique, it does not matter whether the dam is to be built by British and Swiss, by Americans and French or by West Germans, Swedes and South Africans. [...] The involvement of foreign capital in Cahora Bassa and any other scheme in Mozambique is a hostile act against the people of Mozambique. ${ }^{37}$

Ever since the beginning of the construction of the huge Cabora Bassa dam and hydroelectric power plant on the Zambezi River in Mozambique in 1969, the Mozambican liberation movement FRELIMo had denounced the project as a means of perpetuating white minority rule in Southern Africa and it had attacked the construction site. The fact that the electricity generated in this power plant was mainly intended for South Africa supported FRELIMO's claims. It was also argued that the dam would be used to attract large numbers of white settlers. Independent African governments, the OAU, and the WCC supported FRELIMO's struggle against Cabora Bassa. Several UN resolutions also condemned the project. Cabora Bassa was an important focal point for groups opposed to Portuguese colonialism in many Western European states. The dam was planned by Portuguese engineers, financed to a large degree by South Africa, and slated for construction by a consortium of West German, French, Italian, Swedish, South African, and Portuguese firms. It was to be

37 Emphasis in original. No author, "Caetano, Capitalism, Cahora Bassa", Mozambique Revolution 40 (September 1969), pp. 4-12, p. 11. 
the largest in Africa and the fifth largest in the world at that time. Numerous solidarity and Third World movements in Western Europe took up the issue, criticising the firms participating in the dam's construction for supporting the Portuguese Empire. ${ }^{38}$

Although in 1966 the Swiss trade authorities had hoped that the Cabora Bassa dam would provide good opportunities for Switzerland's export industry, by early 1968 big firms, such as Sulzer and Escher Wyss, had withdrawn from the project for technical reasons. ${ }^{39}$ However, one of the German participants in the Zamco consortium charged with the construction of the dam, в вс Mannheim, was a subsidiary of ввс Baden. ${ }^{40}$ ввс Baden acted as a subcontractor of its subsidiary and delivered electrical supplies destined for Cabora Bassa. There are indications of other Swiss firms' or banks' involvement in the Cabora Bassa project, but no accurate information is available. ${ }^{41}$ As ввС Baden's deliveries destined for a project that was seen by many as a symbol of Portuguese colonial oppression were known at the time, the firm was an obvious target for protest. The emerging Swiss protest movement focusing on Portuguese colonialism rallied round the Cabora Bassa campaign, ${ }^{42}$ thereby answering the OAU Council of Ministers' call of early 1970, "on all progressive people the world

38 For a detailed contemporary analysis of the Cabora Bassa project, see Keith Middlemas, Cabora Bassa. Engineering and Politics in Southern Africa, London: Weidenfeld and Nicolson, 1975. See also Kuhn, "Liberation Struggle and Humanitarian Aid"; Lopes, West Germany and the Portuguese Military Dictatorship, pp. 74-76; Sellström, Sweden and National Liberation in Southern Africa. Volume I: Formation of a Popular Opinion, pp. 484-503.

39 See the letter from the Trade Division to the Vorort and the Verein Schweizerischer Maschinen-Industrieller (Swiss Association of Machinery Manufacturers, vSM), "Moçambique - Zambesi-Projekt", o6.04.1966, Archiv für Zeitgeschichte (Archives for Contemporary History, AfZ), Zurich, Switzerland, Ів Vorort-Archiv, 377.20.1; letter from the Trade Division to the Vorort and the vsm, "Mozambique - Zambesi-Projekt", 12.10.1966, ibid., and the attached letter from Jakob Etter, Swiss consul in Mozambique, to the Trade Division, "Moçambique - Zambesi-Projekt", 30.o9.1966; letter from René Naville, Swiss ambassador in Portugal, to the Trade Division, 15.03.1968, pp. 2-3, SFA E7110\#1979/14\#1638*.

4 в вс Baden participated to $56.6 \%$ in its German daughter: Kuhn, "Kampf der Entrechteten", p. 117 .

41 In 1970, the Swiss embassy in Lisbon reported that the Zurich firm Holding Rodio indirectly participated in the Cabora Bassa project. Three years later, activists cited a newspaper report according to which big Swiss banks had, in summer 1971, covered a CHF 50 million bond of the South African government destined for the construction of the dam: telegram no 12 from the Swiss embassy in Lisbon to the FPD, 22.06.1970, SFA E2001E\#1980/83\#3430*; ciscop, Suisse-Portugal, p. 78.

42 This point is made by Fischer, 'Die Solidarität in den Strukturen'; Holenstein, Was kümmert uns die Dritte Welt, pp. 188-189; Holenstein, Renschler, Strahm, Entwicklung heisst Befreiung; pp. 50-52; Kuhn, “Kampf der Entrechteten”, pp. 118-121. 
over to rise and condemn the actions of the governments of their countries involved in the execution of this diabolical project."43

Swiss opposition to Cabora Bassa emerged in June 1970. Private visits by the South African Prime Minister to Geneva and the Minister of Finance to Bern and Zurich led solidarity groups to suspect that Swiss capital would participate in the construction of the dam. ${ }^{44}$ On 10 June 1970, Jean Ziegler, a social democratic member of the Swiss National Council and Professor of Sociology at the University of Geneva, addressed a parliamentary question to the Federal Council. He asked the government to prevent Swiss firms from participating in the construction of the dam. ${ }^{45}$ In the following weeks and months, numerous organisations, including student groups, the Christian Peace Service, and the Anti-Apartheid Movement in Geneva, took up the call. They insisted that the government should, at the very least, refrain from supporting the construction of the dam by granting ERGs to Swiss firms. ${ }^{46}$ As two student movements at the University of Bern wrote to the Federal Council in June 1970, "a Swiss intervention at this point would appear in a bad light, coming across as unscrupulous stop-gapping. We urge you to do everything in your power to prevent capital interests, rather than humanitarian principles, from determining Swiss foreign policy again." ${ }^{47}$ The Schweizerische Evangelische Kirchenbund (Federation of Swiss Protestant Churches, SEK), which could scarcely be accused of

43 Declaration CM/St. 3 (XIV) of the OAU Council of Ministers' 14th Ordinary Session from 27 February to 6 March 1970, "Declaration on the Cabora Bassa Hydro-Electric Dam by the Fourteenth Ordinary Session of the OAU Council of Ministers", https://au.int/sites/ default/files/decisions/9596-council_en_27_february_6_march_1970_council_ministers_ fourteenth_ordinary_session.pdf (13 January 2021).

44 Kuhn, "Kampf der Entrechteten", p. 117.

45 National Council, "Petite question Ziegler du 10 juin 1970. Barrage de Cabora Bassa - Participation suisse", attached to the excerpt of the minutes of the Federal Council's meeting on 9 September 1970, SFA E2001E\#1980/83\#3430*.

46 See, for example, the open letter from the Arbeitsgruppe Angola (Angola Working Group) and the Arbeitsgruppe für Kirche und Gesellschaft der Unversitätsgemeinden Bern (Church and Society Working Group of the University of Bern), to the Federal Council, 13.06.1970, SFA E7110\#1981/41\#1776*; letter from Hedwig Meyer-Schneeberger, Christian Peace Service and Fonds für Entwicklung und Partnerschaft in Afrika (Fund for Development and Partnership in Africa), to the Federal Council, "Besuch von Ministerpräsident Vorster und schweizerische Beteiligung am Projekt von Cabora Bassa”, 23.06.1970, pp. 3-4, dodis. $\mathrm{ch} / 35939$; letter from the Committee of the Anti-Apartheid Movement in Geneva to the Federal Council, 25.06.1970, SFA E2001E\#1980/83\#3430*; open letter from the Tagelöhner für die Dritte Welt (Day Labourers for the Third World) to the Federal Council, 17.10.1970, ibid.

47 Open letter from the Angola Working Group and the Church and Society Working Group of the University of Bern to the Federal Council, 13.06.1970, SFA E7110\#1981/41\#1776*. 
left-wing tendencies, also urged the Swiss government to consider political and developmental aspects when taking a position on Cabora Bassa. ${ }^{48}$

The question of whether or not an ERG should be granted for deliveries destined for Cabora Bassa is particularly salient, as it highlights the conflicts between Third World solidarity, economic interests, and foreign policy. The issue had first arisen in October 1969. Representatives of ввС Baden met with the Vice-Director of the Trade Division, Hans Bühler, to enquire about the possibility of obtaining an ERG cover amounting to Deutschmark 6o million (CHF 70.2 million). Bühler informed the firm that this demand could only be considered if the sum was considerably reduced. Switzerland's limited annual exports to Mozambique did not justify such a significant financial engagement. ${ }^{49} \mathrm{He}$ did not comment on the legitimacy of the Cabora Bassa project. The DPA was not consulted at this stage. According to an internal document of ввс Baden dated January 1971, the parent company's deliveries to its German subsidiary amounted to CHF 25 million, CHF 11 million of which were covered by the German Hermes insurance. ${ }^{50}$ Historian Konrad Kuhn argued that this partial cover, coupled with the fear of additional negative publicity, explains why в ВС Baden never officially applied for an ERG cover in Switzerland. ${ }^{51}$ The absence of such a demand saved the Swiss authorities from a trade-off between the wish to support Switzerland's economy, and the risk to the country's image if the Swiss government was perceived to actively support firms that contributed to the stabilisation of colonial rule in Mozambique.

Confronted with Ziegler's parliamentary question and protest letters from solidarity movements, the DPA's first priority was to gain more information about the issue. The directorate therefore requested Swiss embassies in states where firms were or had been involved in the construction of Cabora Bassa to report on their host governments' and the local populations' attitude towards the project. ${ }^{52}$ The replies showed that, while the Swedish firm

48 Letter from W. Sigrist and W. Probst, sEK, to the Federal Council, "Cabora Bassa-Projekt", o8.07.1970, SFA E2001E\#1980/83\#3430*.

49 Note from AE to Ernst Henri Léchot, responsible for relations with Portugal within the Trade Division, "Anfrage von Herrn Nationalrat Jean Ziegler vom 10.6.1970 wegen allfälliger schweizerischer Lieferungen für den Bau des Staudammes von Cabora Bassa (Mozambique)", 17.06.1970, p. 1, SFA E7110\#1981/41\#1776*. The sum has been converted to CHF using the exchange rates indicated in table O.22a of the Hsso database, "Wechselkurse für Sichtdevisen in der Schweiz 1875-1907 und 1913-1992 (in Franken)”.

5 [?] Bernhardt, [?] Rinderknecht, ввс, memorandum, "Information über Cabora Bassa", p. 11, 07.01.1971, SFA E2001E-01\#1982/58\#440*.

$5^{1} \quad$ Kuhn, “Kampf der Entrechteten”, p. 118.

52 Telegram from the FPD to the Swiss embassies in the FRG and France, 18.06.1970, p. 2, SFA E2001E\#1980/83\#3430*; telegram from the FPD to the Swiss embassies in the UK, Sweden 
ASEA had renounced its participation in the Zamco consortium because of parliamentary and governmental pressure, the positions of British and Italian firms were less clear-cut. Although Rome kept its distance from Cabora Bassa, an Italian firm participated in the project. According to the FCO, British nonparticipation was entirely due to commercial factors. ${ }^{53}$ Reassured that governmental condemnation of the project was the exception in Western Europe, different offices in the FPD and the FDEA collaborated to edit the Federal Council's reply to Ziegler's question. This was published in September 1970. The reply did not enter into moral or political considerations. It hinted that the project would be beneficial for the African population and independent Malawi, not only for European settlers. It contained the same arguments that had already been advanced in reply to different solidarity groups: the eventual participation of Swiss firms or banks would not be decisive for the realisation of the project; the federal authorities had no legal means to prevent Swiss firms from participating; and if an ERG cover were to be solicited, the Federal Council would examine the application with care. ${ }^{54}$

It is impossible to know how BBC Baden's directors would have reacted if the Swiss government had insisted on the firm's withdrawal from the Cabora Bassa project. It is true that a few years later, in early 1974, ввС abandoned its plans to tender for a contract to build a power station in Rhodesia after considerable pressure from the Swiss trade authorities. ${ }^{55}$ But in the Rhodesian case, the firm's activities would have been much more exposed than in the case of Cabora Bassa, where ввс's contribution was small and the Portuguese government still enjoyed a certain degree of international legitimacy.

In reaction to the mounting pressure from grassroots activists and some church publications, ввС's leaders prepared to justify their participation in the construction of the dam. In late 1970, BвC representatives participated in

and Italy, 18.o6.1970, p. 2, ibid.; telegram from the FPD to the Swiss embassies in Portugal and South Africa, 18.06.1970, p. 2, ibid.

53 Telegram no 85 from the Swiss embassy in Sweden to the FPD, 19.06.1970, SFA E2001E\#1980/83\#3430*; telegram no 57 from the Swiss embassy in Portugal to the FPD, 23.06.1970, p. 2, ibid.; telegram no 157 from the Swiss embassy in Italy to the FPD, 23.06.1970, ibid.; letter from René Keller, Swiss ambassador in the UK, to the DPA, "Cabora Bassa", 24.06.1970, p. 2, ibid.; note from Philippa Drew, CSAD, to [?] Budgen, FCo, "Cabora Bassa", 23.06.1970, TNA FCO 45/523.

54 "Réponse du Conseil federal", attached to the excerpt of the minutes of the Federal Council's meeting on 9 September 1970, SFA E2001E\#1980/83\#3430*.

55 Note from Fritz Rothenbühler, Delegate of the Federal Council for Trade Agreements, to Ernst Brugger, Federal Councillor and head of the FDEA, "Rhodesien - Kraftwerkprojekt der ввс. Schreiben von Herrn A. Schärer, Greifensee, vom 5. Februar 1974”, 14.03.1974, SFA E7110\#1985/97\#1755*. 
panel discussions with solidarity groups. In January 1971, the firm prepared a long document for their own staff to help them refute frequently advanced criticisms. The document focused mainly on the civilising merit of the dam project. It also aimed to discredit the activists by emphasising their Communist sympathies. ${ }^{56}$ Finally, в вС publicly downplayed its involvement in the project; the firm only mentioned the part of its deliveries covered by the German Hermes insurance. ${ }^{57}$

In the following years, student, religious, and Third World groups continued to organise information events, publish articles, distribute pamphlets, and lobby the Federal Council. They exchanged materials with activists in other countries and maintained contact with representatives of African liberation movements. Despite the significance of the campaign against Cabora Bassa, Swiss protest remained limited when compared to the situation in the FRG. In a meeting in February 1972, ввС Baden's directorate noted that agitation against Cabora Bassa had reached such levels in West Germany that the firms involved in the dam's construction had had to take coordinated countermeasures. There was no mention of further steps to be taken in Switzerland. ${ }^{58}$ In the FRG, demonstrations were attended by up to 1,00o people and there were clashes with the police. Some German activists even acquired shares in the companies involved in the building of Cabora Bassa and condemned the project at shareholder meetings. In response, German companies employed public relations firms to defend their actions, collaborated with economic associations, and lobbied the Brandt government to maintain its commitment to the project..$^{59}$ The Swiss campaign against Cabora Bassa lost its momentum in early 1973, when the invitation of Portugal to the Comptoir Suisse trade fair provided the solidarity movements with a new target. After the Carnation Revolution and Mozambique's independence, work on the dam continued without much interruption. It was finally completed in $1979 .{ }^{60}$

The French ambassador in Switzerland, Jacques Roux, had noted in June 1970 that the nascent controversy surrounding Cabora Bassa was a sign that "some Swiss minorities are starting to realise that their country's image in the

56 [?] Bernhardt, [?] Rinderknecht, ввс, memorandum, "Information über Cabora Bassa", 07.01.1971, SFA E2OO1E-o1\#1982/58\#440*.

57 Kuhn, "Kampf der Entrechteten", pp. 117-118; see also Hans Bühler, Vice-Director of the Trade Division, memorandum, "Caborah Bassa", 19.01.1971, SFA E7110\#1982/108\#1341".

$5^{8}$ [?] Dietrich, ввC Baden, minutes of the 21 meeting of the directorate (DS-CH) of 24 February 1972, no date, p. 3, Historical Archives Авв (НААвв ), Baden, Switzerland, file 6о5610.

59 Lopes, West Germany and the Portuguese Military Dictatorship, pp. 67, 75-76.

6o Minutes of the meeting of ввс's Board of Directors on 18 November 1975 in Baden, no date, p. 19, НААвв, folder 253689, file 6о5626; Kuhn, “'Kampf der Entrechteten”, p. 120. 
world depends less on generous but vague declarations of intent than on the specific attitude it adopts towards certain problems that international conscience has to face." He was convinced, however, that the protest would have no noticeable effect on the Swiss government and business elites. ${ }^{61}$ Roux was partially right. Grassroots protest against the Cabora Bassa project did not lead ввС Baden to withdraw from delivering electrical supplies to its subsidiary, nor did it change the Swiss government's position. It did, however, raise public awareness of Western firms' activities in colonial Mozambique. The campaign also provided a rallying point for protest movements and probably strengthened their international networks.

A Question of (Non-)Interference: The Swiss Mission's Efforts to Free Mozambican Church Members

While the construction of the Cabora Bassa dam mobilised activists and churches in many Western European states, in Switzerland solidarity with arrested Mozambican Christians was mostly limited to Protestant circles in the French-speaking part of the country. In June 1972, the Portuguese secret service PIDE/DGS arrested over 1,500 Mozambicans suspected of being members of FRELIMO. Among the detained were approximately 30 members of the African sister church of the Swiss Mission. In the following years, Swiss missionaries made significant efforts to secure the release of their African church members and to allay Portuguese suspicions that they were collaborating with FRELIMO. This issue sheds light on the role of churches and missionary organisations in colonial Mozambique and underlines their importance to the Swiss government's foreign policy in sub-Saharan Africa.

In colonial Mozambique, the Catholic Church was an important pillar of the Portuguese regime. In return for stabilising the colonial system through the evangelisation and education of the African population, the Catholic hierarchy and missions benefited from state subsidies and tax advantages. Compared to Protestant missionary societies, they enjoyed a privileged situation. In the 196os, and especially after Pope Paul Vi received leaders of frelimo, the MPLA, and the PAIGC in July 1970, divisions opened up within the Portuguese Catholic Church. Some Catholic priests in Mozambique took a stand

61 Letter from Jacques Roux, French ambassador in Switzerland, to the French foreign minister, "Du passage du Premier Ministre de la République d'Afrique du Sud", 3o.o6.1970, p. 4, CADN 89PO/2002021/66o. 
against the colonial regime. ${ }^{62}$ Unlike their Catholic counterparts, Protestant missions - and the Swiss Mission in particular — have often been described as supporters of Mozambican independence. Teresa Cruz e Silva, for example, underlined the Swiss Mission's important contribution to shaping the political consciousness of its African church members and educating Mozambique's future elites ${ }^{63}$ However, Eric Morier-Genoud and Sérgio Inácio Chichava criticised this dominant view of the Swiss Mission's exceptionalism. They underlined the contributions of other Protestant and Catholic missionary societies in the formation of Mozambican nationalism and the diversity of positions within the Catholic Church. ${ }^{64}$

Swiss Protestant missionaries first arrived in Mozambique in the late nineteenth century. After the Second World War, the Swiss Mission, which was also active in South Africa, was increasingly Africanised. In 1962, the Swiss missionaries concluded an accord with the Igreja Presbiteriana de Moçambique (Presbyterian Church of Mozambique, IPM) signing over to the latter the responsibility for the missionary, educational, and humanitarian works of the former Swiss Mission. Protestant churches in French-speaking Switzerland created the DM, which continued to provide funding and aid to the IPM and remained the only interlocutor recognised by the Portuguese authorities. ${ }^{65}$ The DM had close relations with the African population and with members of FRELIMO. The founder and first president of FRELIMO, Eduardo Mondlane, was a former pupil of a Swiss missionary school and remained in friendly contact with some missionaries until his assassination in $1969 .{ }^{66}$ Ever since the outbreak of the independence war in 1964, the Catholic colonial authorities were wary of these contacts. The suspicion that Protestants were inciting the Mozambican people to insurrection was also fuelled by the Programme to Combat Racism that the ecumenical wcc launched in 1970 after two years of planning. The programme focused on Southern Africa and distributed funds to liberation movements, including FRELIMO. ${ }^{67}$

62 See Amélia Neves de Souto, Caetano e o Ocaso do 'Império'. Administração e Guerra Colonial em Moçambique durante o Marcelismo (1968-1974), Porto: Edições Afrontamento, 2007, pp. 383-413.

63 Cruz e Silva, Protestant Churches, p. 154. For a critical discussion of the literature on the church in Mozambique, see Chichava, "Unlike the Other Whites?"; Eric Morier-Genoud, The Catholic Church, Religious Orders and the Making of Politics in Colonial Mozambique: The Case of the Diocese of Beira, 1940-1974, Ann Arbor: Um I, 2006, pp. 29-36.

64 Chichava, "Unlike the Other Whites?"; Morier-Genoud, The Catholic Church, pp. 316-317.

65 Cruz e Silva, Protestant Churches, p. 135.

66 On the relations between Eduardo Mondlane and the Swiss Mission, see ibid., pp. 101-119.

67 The Programme to Combat Racism started a bitter controversy in Switzerland and led to the first public discussion of the country's position towards South Africa and Apartheid: Jeannerat, Morier-Genoud, Péclard, Embroiled, pp. 214-215. 
Prompted by Portuguese suspicions of their subversive role in Mozambique, the colonial regime's increasing repression against the African population, and the announcement of the Programme to Combat Racism, in the late 196os the DM started to reconsider its presence in Mozambique. The emerging Third World solidarity movement in Switzerland probably also contributed to this reconsideration. At the missionary Synod in June 1969, some delegates called for the withdrawal of Swiss missionaries from Mozambique and South Africa in order to avoid being associated with the white minority regimes. However, the Synod finally voted for the DM to continue activity in Southern Africa in support of its local sister churches. ${ }^{68}$ The WCC's decision, in August 1970, to support FRELIMO financially sparked further discussions. In October of the same year, in an internal position paper, the DM stated its opposition to racism and colonial oppression. The authors expressed their desire for Swiss churches to take a clear and courageous stand and incite the Swiss population to oppose racism in Southern Africa. With regard to their own role, however, they argued for discretion, so as not to endanger African church members and Swiss missionaries: "Our responsibilities and direct relations with the South African and Mozambican churches sometimes require the DM to be silent here about what we know and do, in order to still be able to speak and act there."69

When forty members of the Catholic order of the White Fathers decided to leave Mozambique in May 1971 as a sign of protest against the Portuguese colonial regime, Philip A. Potter of the WCC questioned the DM's discreet public attitude. ${ }^{70}$ In his reply, Georges Andrié, secretary of the DM, insisted that no discussion about the position of Protestant churches in Mozambique should be held without the presence of African church members, thereby showing his regard for the IPM's opinion. ${ }^{71}$ In September, the DM's Council set up a study group to define the DM's position and strategy in Southern Africa. In a draft letter to Potter in early 1972, Andrié summarised the results of the study group's reflections; although the DM considered the independence struggle to be justified, its tactics were determined by the need to avoid any action that could lead to retaliation against the IPM and the expulsion of Swiss missionaries from Mozambique. Nevertheless, Andrié considered that direct contacts with

68 Ibid., p. 221.

69 DM position paper, dated October 1970 and entitled, by hand, "racisme", p. 2, Archives of the DM (ADM), Lausanne, Switzerland, ${ }_{1653}$ B, box 182.

70 Letter from Philip A. Potter, wCC, to Juel Nordby, United Methodist Church, and Georges Andrié, Secretary of the DM, 30.07.1971, p. 2, ADM 1829B, box 255; see also Andrié, "Groupe d'étude Afrique australe, Bref historique de la question en ce qui concerne le Mozambique", 19.10.1971, ADM 1653B, box 182. On the role of the White Fathers in late colonial Mozambique, see de Souto, Caetano e o Ocaso do 'Império', pp. 398-402.

Letter from Georges Andrié to Philip A. Potter, 07.08.1971, p. 2, ADM 1829B, box 255. 
FRELIMO members should be cultivated and that humanitarian aid could be granted to the movement. ${ }^{72}$ The archives of the DM do indeed contain proof of material humanitarian support provided by DM members to FRELIMO, but the scope of this assistance is difficult to determine..$^{73}$

While DM leaders in Switzerland reflected on their mission in Southern Africa and Third World solidarity groups protested against the construction of the Cabora Bassa dam, events in Mozambique took a drastic turn. In June 1972, the DM's fears of violent action against African church members were proved to be well-founded when the PIDE/DGS rounded up more than 1,500 Mozambicans suspected of being members of FRELIMO. Around 30 African priests and employees of the Swiss Mission were also detained. Swiss missionaries in Mozambique immediately tried to obtain more information. Although the head of the DGS in Lourenço Marques did not inform them of the actual charges against the arrested men, he assured them that the operation was not directed against the mission itself or against European missionaries. ${ }^{74}$ During a trip to Lourenço Marques in September 1972, two DM representatives were able to visit the majority of the detained IPM members. Several present and former leaders of the IPM were among the prisoners, most famously the sitting President of the Synodal Council, Zedequias Manganhela. He was accused, inter alia, of having met a FRELIMO leader in Switzerland 6 years previously. ${ }^{75}$ The fact that a meeting between Eduardo Mondlane and Manganhela had indeed taken place in July 1966 through the somewhat reluctant intermediary of the DM testifies to the efficiency of Portuguese surveillance. ${ }^{76}$

72 Draft letter from Georges Andrié to Philip A. Potter, o8.02.1972, p. 7, ADM 1829C, Box 255.

73 In 1966, for example, the DM reacted positively to the request of Janet Mondlane, wife of FRELIMo leader Eduardo Mondlane, for primary school books that were to be used in schools set up by the liberation movement: Letter from F. Ouwehand to Janet Mondlane, 07.04.1966, ADM 793E, box 72. In 1973, a DM member sent medications to FRELIMO: Letter from Samuel Rodrigues Dhlakama, head of FRELIMO's health services, to Jean-Paul A. Widmer, DM, 04.07.1973, ADM 1821D, box 254.

74 Letter from Louis Chaney, Swiss consul in Mozambique, to the DPA, "Mission Suisse. Arrestations d'Africains", 27.06.1972, confidential, pp. 1-2, SFA E2200.167\#1991/284\#21*. On the arrests of IPM members, see also Cruz e Silva, Protestant Churches, pp. 138-149; Alf Helgesson, Church, State and People in Mozambique. An Historical Study with Special Emphasis on Methodist Developments in the Inhambane region, Uppsala: Swedish Institute of Missionary Research, 1994, pp. 368-374. On the role of the Portuguese secret service in the colonial war, see Dalila Cabrita Mateus, A PIDE/DGS na Guerra Colonial (1961-1974), Lisbon: Terramar, 2004.

75 Georges Andrié, memorandum, "Communication au Synode missionnaire sur la situation au Mozambique”, 30.11.1972, pp. 1-3, ADM 1862B, box 262.

76 Charles Périer, memorandum, "Entrevue Manganhela - Edwardo Mondlane, en l'absence de M. Ouwehand et M. Vittos, mercredi 13 juillet 1966", no date, ADM $793 \mathrm{E}$, box 72 . 
The colonial authorities' fear of the IPM's and the DM's subversive potential is expressed in a report by the Mozambican DGS written in early November 1972 after the DM members' visit: "There are therefore no doubts as to the danger posed, in the political situation of this state, by the subversive action that is being developed by elements of the Swiss Mission, given the great mass of believers that it guides, and given the prestige in which it is held by the natives" ${ }^{77}$ In the second half of 1972, the DM tried ceaselessly to obtain the liberation of its fellow church members. The organisation informed the Swiss public about the fate of the detainees, met with the Swiss ambassador in Lisbon and with Portuguese clerics and members of the DGS in Mozambique, and collaborated with the International Commission of Jurists and Amnesty International. ${ }^{78}$

On 11 December 1972, Manganhela died in prison. The official cause of death was reported to be suicide. Shortly afterwards, the death of another detained IPM member became public. Most of the arrested IPM members were subsequently released, probably on orders from Lisbon. However, the risk to the IPM, the DM, and their members was far from over. Prior to their release, the detainees had been coerced into signing declarations stating that IPM meetings were in truth meetings of FRELIMO and that the church sent money to the liberation movement's headquarters in Dar es Salaam through the intermediary of the DM. Swiss missionaries feared that the DGS would use these declarations to take further action against the IPM and the DM. ${ }^{79}$ In February 1973, missionary Marcel Vonnez, stationed in Beira, reported on the Portuguese accusations: "Each of our services ends with 'Viva o Frelimo!" Manganhela, so rumour had it, had been designated to become the future president of independent Mozambique, and the Swiss Mission his government. At the same time, Vonnez was sure that the Portuguese authorities did not believe in these charges but would use them as a pretext to expel Swiss missionaries, if desired: "What annoys people is the influence of the Swiss Mission on the population." 80

In order to protest the innocence of the liberated prisoners and to refute the accusations made against the DM, the missionary organisation's leadership

77 DGS Mozambique (signature not legible), report, "Prisões efectuadas por esta delegação de segurança de elementos da missão suiça, desta cidade, quando da - operação 'vendaval", o3.11.1972, p. 6, ANTT, PIDE/DGS, CI(2), no 19639.

78 Georges Andrié, memorandum, "Communication au Synode missionnaire sur la situation au Mozambique”, 30.11.1972, pp. 1-4, ADM 1862B, box 262.

79 George Andrié, memorandum, "Situation de l'église presbytérienne au Mozambique", 10.01.1973, strictement confidentiel, p. 2, ADM 1862B, box 262.

8o Letter from Marcel Vonnez, DM missionary in Mozambique, to Georges Andrié, o3.02.1973, p. 2, ADM 1825 D, box 255 . 
intensified its use of diplomatic channels in early 1973. In January, DM members called on the Portuguese ambassador in Bern, Eduardo Bugalho. They were hoping to explain the impact that Manganhela's death had had in Switzerland. ${ }^{81}$ The Portuguese embassy received dozens of identical cards from residents of the French-speaking part of Switzerland protesting against the treatment of IPM members. Lisbon did not find out who was behind this campaign; the DM protesting its innocence. ${ }^{82}$ During a meeting with Federal Councillor Pierre Graber and other FPD leaders in the same month, representatives of the missionary society explained their difficulties in Mozambique. Graber expressed his gratitude for the DM's missionary and humanitarian activities in Mozambique and promised the FPD's support in rejecting the false accusations made against the missionaries. At the same time, he warned the DM, "in view of the tensions prevailing in this Portuguese overseas territory, to avoid, by means of the necessary restraint both in dealing with the authorities and the indigenous population, anything that might appear to be interference in the political confrontation or even partisanship." ${ }^{83}$ In April, Georges Andrié continued the campaign to clear the DM's name with a call on the US consul in Mozambique, probably in the hope of enlisting his aid in case of the expulsion of Swiss missionaries from the Portuguese colony. ${ }^{84}$

The DM-F PD meeting in Bern reveals that the leading Swiss foreign policymakers held the missionary organisation in great esteem and deemed its educational and medical activities a boost to Switzerland's humanitarian image. They relied on missionary organisations such as the DM for their development aid policy and to present Switzerland in a positive light. Thus, in February 1973 the FPD's Secretary General asked Jean-Louis Pahud, Swiss ambassador in Portugal, to discuss the DM's situation informally with the Portuguese authorities

81 Letter from Eduardo Bugalho, Portuguese ambassador in Switzerland, to the Portuguese Minister of Foreign Affairs, "Missão suíça de Moçambique", 23.01.1973, pp. 2-5, ANTT, SSCIM, no 432 .

82 Letter from Angelo Ferreira, director of the Gabinete dos Negócios Políticos (Office of Political Affairs, GNP) in the Portuguese Overseas Ministry, to the Governor-General of Mozambique, 23.02.1973, ANTT, SSCIM, no 432.

83 Hermann Grob, DPA, Michael Gelzer, memorandum, "Notiz über die Besprechung mit der Delegation des "Département missionaire des églises protestantes de Suisse romande" vom 18. Januar 1973", no date, p. 4, attached to the letter from Ernesto Thalmann, Secretary General of the FPD, to Jean-Louis Pahud, Swiss ambassador in Portugal, "Schwierigkeiten der 'Mission Suisse' in Mozambique”, o9.02.1973, confidential, SFA E2200.167\#1991/284\#21*.

84 Telegramme no 244 from [?] van Oss, US consulate in Mozambique, to the Secretary of State, 12.04.1973, p. 2, NARA, RG 59, AAD, CFPF, Electronic Telegrams 1973, 1973LOURENoo244. 
and to refute categorically all accusations made against this organisation. ${ }^{85}$ Pahud, who was generally very uncritical of the Estado Novo regime's colonial policy and a staunch supporter of the official Swiss line of non-intervention in the internal affairs of other states, thought less highly of the DM. While he was willing to believe DM's assurance that it had not supported FRELIMO, he wondered if the organisation could really guarantee that its contributions to the IPM had not ended up in the hands of the liberation movement. Convinced that the missionaries' problems were at least partly of their own making, he did not think it advisable to approach the Portuguese authorities on their behalf: "the DM plays with fire in Mozambique and now, suddenly worried, it asks the Political Department for protection against the risk of burns or even flames". ${ }^{86}$ Yet, Pahud was requested in no uncertain terms to do as he was told. ${ }^{87}$ High-ranking members of the Portuguese administration later assured the Swiss ambassador that the missionaries would be allowed to continue their work in Mozambique, if they did not take a political stand. 88

In October 1973, the Council of the DM decided to accede to an appeal from the IPM to request an audience with Marcello Gaetano in order to clear the released Presbyterians' names and free some IPM members that were still imprisoned. ${ }^{89}$ While Michael Gelzer, the deputy chief of the DPA, was not very optimistic about the DM's chances of obtaining an audience, he nevertheless agreed to support the request. At the same time, several lawyers worked on the indictments against the released IPM prisoners in Mozambique. ${ }^{90}$ On 14 November 1973, the Portuguese authorities promulgated an act of amnesty. The charges against the 33 IPM members freed in 1972 were dropped and a further 19 members were freed. ${ }^{91}$ Against the advice of the DPA, whose leaders feared that such an approach would only further antagonise the Portuguese

85 Letter from Ernesto Thalmann to Jean-Louis Pahud, "Schwierigkeiten der 'Mission Suisse' in Mozambique", o9.02.1973, SFA E2200.167\#1991/284\#21*.

86 Letter from Jean-Louis Pahud to the DPA, "Difficultés de la 'Mission Suisse au Mozambique", 05.03.1973, p. 3, SFA E2001E-01\#1987/78\#4610*.

87 Telegram no 17 from the DPA to the Swiss embassy in Portugal, 19.03.1973, SFA E2001E-o1\#1987/78\#4610*.

88 Letter from the Jean-Louis Pahud to the DPA, "Difficultés de la 'Mission Suisse' au Mozambique", 30.03.1973, strictly confidential, SFA E2200.167\#1991/284\#21*.

89 Minutes of the $100^{\text {th }}$ meeting of the DM's Council on 04.10.1973, no date, confidential, pp. 6-7, ADM, folder Conseil 1973-1978.

90 Letter from Michael Gelzer to the Swiss Ambassador in Portugal, "Mission Suisse' in Mozambique", confidential, 17.10.1973, pp. 2-3, SFA E2200.167\#1991/284\#21; letter from Gelzer to the DM, 15.11.1973, confidential, ibid.

91 Letter from Louis Chaney to the DPA, "Mission suisse au Mozambique (Eglise presbytérienne)", 04.12.1973, p. 1, SFA E2200.167\#1991/284\#21*. 
government, the DM persisted in its efforts to meet with Caetano, with success. On 7 February 1974, the Portuguese president received three DM leaders. Caetano assured the delegation that the DM need not worry about its future in Mozambique and that the freed prisoners were safe from further prosecution. Nevertheless, the delegates were frustrated that they were not able to clear Manganhela's name. ${ }^{92}$

For the Swiss government, the activities of the DM missionaries were a potential source of both political goodwill and of tension. Their ambivalent attitude towards Swiss citizens in Portuguese Africa was not restricted to missionaries, as demonstrated by an episode involving a Swiss businessman in Mozambique. In early 1968, a South African entrepreneur living in Lourenço Marques created a so-called 'Goodwill Fund' to support the Portuguese troops fighting in this colony. He appealed to members of the foreign business community in Mozambique to make donations for the purchase of two air ambulances, after an initial plan to buy war materials gave rise to reservations. The director of Swiss import firm Bridler \& Co. was one of the deputy chairmen of the fund's committee, and thereby openly sided with the colonial army. The Swiss consul cautioned the businessman to minimise his involvement and to ensure that the donations were used for purely humanitarian purposes, warning that FRELIMO might otherwise take retaliatory measures against the committee members. The DPA, which endorsed this recommendation, feared that Switzerland's image might be damaged if it became associated with an organisation that was supportive of Portugal's colonial wars. ${ }^{93}$ Bern's attitude corresponded to that of the US government; the American consul voiced similar reservations with regard to the engagement of American citizens in the Goodwill Fund. ${ }^{94}$ The DPA preferred Swiss citizens living in Africa to keep a low profile, cause no embarrassment, and boost Switzerland's image by doing their work well, be it business or missionary activity.

92 Georges Andrié, memorandum, “Compte-rendu approximatif de l'entrevue accordée par le Prof. Marcello Caetano, Premier ministre à MM. G. Guinand, G. Morier-Genoud, G. Andrié, au palais de Sao Bento - à 17 heures", 07.02.1974, ADM 1862C, box 262; letter from Jean-Louis Pahud to the DPA, "Mission Suisse au Mozambique", o8.o2.1974, confidential, SFA E2001E-01\#1987/78\#4610*.

93 Letter from Jakob Etter, Swiss consul in Mozambique, to the DPA, "Gründung eines 'Goodwill Fund' der hiesigen ausländischen Kolonie zu Gunsten der in Moçambique eingesetzten Soldaten", 22.05.1968, SFA E2001E\#1980/83\#3788*; see also the letter from Jacques-Bernard Rüedi to the Swiss consulate in Mozambique, "Goodwill Fund", 04.06.1968, ibid.

94 Airgram from J. G. Gossett, US Consul-General in Mozambique, to the Department of State, "Goodwill Fund of Mozambique's Foreign Communities, 04.06.1968, NARA, RG 59, Subject-Numeric Files 1967-1969, POL 15 MOZ, box 2353. 
In Angola, there was no such trouble. Protestant Swiss missionaries seem to have come to an arrangement with the Estado Novo regime. In July 1973, Marcello Caetano most courteously received the leader of the Mission philafricaine, Dr. Rodolphe Bréchet. ${ }^{95}$ Bréchet assured the DPA in early 1974 that the work of his mission proceeded unhindered and in fact received much support from the Portuguese authorities. This he explained by his organisation's abstention from all political activities and the fact that the missionaries were mindful of the Portuguese colonial authorities in Angola, which they considered their hosts. ${ }^{96}$ There are no signs that the Mission philafricaine ever criticised Portugal's colonial policy.

Thanks to the DM's incessant lobbying for the liberation of the members of its African sister church, religious circles in French-speaking Switzerland were well informed about the arrests, and Manganhela's death in late 1972 caused a wave of indignation. This explains why churches were some of the first actors to mobilise against Portugal's invitation to a major Swiss trade fair in 1973 as a guest of honour.

\section{Economic Interests vs Human Rights: Portugal's Invitation to the 1973 Comptoir Suisse Trade Fair}

The year 1973 marked the high point of Swiss protests against Portuguese colonialism and Switzerland's role in the independence wars in Angola, Mozambique, and Guinea-Bissau. In September, several thousand people marched in Lausanne to express their objection to Portugal's colonial policy. Demonstrators stormed the exhibition grounds of the Comptoir Suisse, a major Swiss trade fair to which Portugal was invited as a guest of honour. Violent clashes with the police led to the arrest and charging of many demonstrators. Observers considered this demonstration to be atypical of Switzerland's political scene. It was preceded by several months of intensive lobbying by a broad coalition of religious and solidarity actors that urged the fair's organisers and the Swiss government to rescind the invitation to Portugal. This was one of the few instances in the late 196os and 1970 s where the Federal Council as a whole discussed Switzerland's position on Portuguese colonialism.

95 Letter from Michael Gelzer to the DM, 15.11.1973, confidential, p. 3, SFA E2200.167\#1991/ $284 \# 21^{*}$.

96 Alfred Hohl, DPA, memorandum, "Vorsprache Dr. Bréchet bei Botschafter Thalmann", 18.02.1974, p. 2, SFA E2001E-o1\#1987/78\#4650*. 
Portugal's invitation to the Comptoir Suisse initially mobilised religious circles. In early 1973, the EvB and the Africa Institute in Geneva contacted the organisers of the fair and expressed their reservations about the invitation. In April, an article in the Protestant weekly journal La Vie Protestante taking up the same point compelled the fair's organisers to take a stand. Marc-Antoine Muret, General Secretary of the Comptoir Suisse, explained to the daily newspaper 24 Heures that the invitation had been extended in consultation with the federal authorities and that ideological considerations did not influence the choice of guests. Several Swiss newspapers recounted this exchange.${ }^{97}$ It is likely that the DM, which was at that time busy trying to obtain the liberation of Mozambican Christians, initiated this first controversy. In March 1973, the missionary organisation's Council had decided to inform other churches of French-speaking Switzerland about Portugal's invitation to the Comptoir Suisse and urge them to take a stand. ${ }^{98}$

As the appeal to the fair's organisers did not achieve the desired results, several churches and religious groups addressed their concern to the Swiss government in May and June 1973. They criticised the Estado Novo regime's colonial policy, especially its treatment of the IPM members, and warned of possible demonstrations if the invitation were upheld. ${ }^{99}$ It may seem surprising that these groups asked the Federal Council to intervene in a privately organised economic event. However, the Swiss authorities and the fair's organisers collaborated closely; the Swiss government was officially represented at the Comptoir Suisse and the DPF was consulted about the choice of the three

97 See the letter from Eduardo Bugalho to the Portuguese Foreign Minister, "Comptoir de Lausanne", 16.04.1973, AHD, PAA, pr. 922, box 1226, and attached newspaper articles: MS, "Portugal bleibt Ehrengast des 'Comptoir", Tages-Anzeiger, 11.04.1973; PLR, "Proteste gegen Ehrengast Portugal am Comptoir Suisse. 'Keine ideologische Rücksicht”, National Zeitung, 11.04.1973; letter from Bugalho to the Foreign Minister, "Comptoir de Lausanne", 24.04.1973, ibid., and attached news items: ATs-ssp, "Au Comptoir de Lausanne. Etait-il opportune d'inviter le Portugal?” La Suisse, 11.04.1973; ATs, “Quels hôtes pour le Comptoir? L'invitation faite au Portugal soulève la polémique”, Gazette de Lausanne, 11.04.1973.

98 Minutes of the $95^{\text {th }}$ meeting of the DM's Council on 24 March 1973, confidential, p. 2, ADM, folder Council 1973-1978.

99 Letter from Guy-Olivier Segond and Jean-Pierre Jornod, Protestant Church of Geneva, to Pierre Graber, Federal Councillor and head of the FPD, 18.05.1973, SFA E2001E-o1\#1987/78\#884*, see also the attached letter from Segond and Jornod to the director of the Comptoir Suisse, 08.05.1973; Hermann Grob, "Notiz über die Besprechung mit der Delegation des 'Département missionnaire des églises protestantes de la Suisse romande' (D.m.) vom 6. Juni 1973", o8.o6.1973, confidential, p. 3, ibid.; W. Sigrist, President of the SEK, to Pierre Graber, "Portugal am Comptoir Suisse", o8.o6.1973, ibid. 
annual guests of honour. ${ }^{100}$ Although this did not become public at the time, the invitation to Portugal had even been extended by a Swiss diplomat and was linked to bilateral commercial negotiations. In early 1971, the Fédération Horlogère Suisse (Swiss Watchmakers' Federation, FH) had suggested Portugal's invitation as a sign of Swiss goodwill after the Portuguese government ceded to Swiss demands to abolish tariffs on watches and their components. ${ }^{101}$ In reply to the churches, FPD leaders underlined that Portugal's invitation was justified on economic grounds and that this commercial fair was not the right occasion to discuss political problems. ${ }^{102}$ In June 1973, National Councillor Jean Ziegler also took up the issue and asked the Federal Council to withdraw its official support of the fair. ${ }^{103}$ Shortly afterwards, an international scandal provided further fuel for the protest.

In July 1973, newspaper reports about a massacre committed by Portuguese troops in the Mozambican village of Wiriyamu caused a surge of national and international protest. On 10 July, a few days before Marcello Caetano was scheduled to travel to London for a state visit, The Times published an article by missionary Adrian Hastings about the brutal murder of 400 villagers the previous December. Although Lisbon immediately denied the allegations, the reports of Portuguese atrocities confirmed to many the brutality of the colonial power's repression of Mozambicans suspected of nationalist sympathies. ${ }^{104}$

100 See Ernesto Thalmann, memorandum, "Entretien du 3 août 1973 à Berne entre le Secrétaire général du Département et M. Marc-Antoine Muret, Directeur général du Comptoir Suisse", o6.o8.1973, p. 3, SFA E2001E-01\#1987/78\#884*.

101 Letter from Gerard Bauer, FH President, and René Retornaz, FH Director, to Pierre Languetin, Delegate of the Federal Council for Trade Agreements, "Portugal: importation en suisse de vins fins", 19.04.1971, SFA E7110\#1982/108\#912*. See also the letter from Languetin to Ch. M. Wittwer, General Manager of the Chambre suisse de l'horlogerie (Swiss Chamber of Watchmaking, CSH), and René Retornaz, "Portugal - Problème horloger", 23.03.1971, SFA E7110\#1982/108\#909*, letter from Jean-Louis Pahud to the Trade Division, "Portugal Affaire des vins de qualité", o9.08.1971, p. 2, SFA E7110\#1982/108\#912*.

102 Letter from Jean Zwahlen, head of the FPD's Financial and Economic Service, to the Protestant Church of Geneva, "Participation du Portugal au Comptoir Suisse 1973", 12.06.1973, SFA E20o1E-o1\#1987/78\#884*; letter from Ernesto Thalmann to the SEK, "Teilnahme Portugals am Comptoir 1973", 11.07.1973, ibid.

103 "Petite question Ziegler du 27 juin 1973. Schweizer Comptoir - Comptoir Suisse 1973", Amtliches Bulletin der Bundesverfassung 1973, Herbstsession Nationalrat, o3.10.1973, p. 1391 .

104 Although most scholars agree now that the massacre took place, there is still some debate about its extent. See Bruno Cardoso Reis, Pedro Aires Oliveira, "Cutting Heads or Winning Hearts: Late Colonial Portuguese Counterinsugency and the Wiriyamu Massacre of 1972", Civil Wars 14:1 (2012), pp. 80-103; Mustafah Dhada, "The Wiriyamu Massacre of 1972: Its 
In Switzerland, Hastings's article had an immediate effect. Only a day after its publication, representatives of the Christian Peace Service, the EvB, Action Portugal et Afrique Australe (Operation Portugal and Southern Africa, APAA), the Swiss Human Rights League, the KSA, and the $\mathrm{AG}_{3} \mathrm{~W}$ addressed a telegram to Federal Councillor Pierre Graber. They urged him to convince the organisers of the Comptoir Suisse to withdraw the invitation to "Portugal, which is charged with war crimes", stating: "we consider that Switzerland's image is harmed if a state involved in a colonial war is welcomed to Switzerland as a guest of honour". ${ }^{105}$ According to Gillian G. Brown of the British embassy in Bern, the signatories were "basically respectable organisations though containing individual communists among their members." ${ }^{106}$ In the middle of 1973, the embassy closely observed the activities of Swiss solidarity groups, probably because the British authorities had themselves been confronted with considerable public protest against Caetano's state visit. ${ }^{107}$

A few days after the Wiriyamu massacre became public, the Dutch ambassador in Bern asked the DPA if Bern would be willing to participate in a joint proposal to the Portuguese government to accept an international enquiry into the allegations. DPA leaders decided, however, that Switzerland could not participate in such a step because of the principle of non-interference. ${ }^{108}$ The Swedish government was more outspoken. It heavily criticised the Portuguese government, intended to raise the issue at the UNGA and at a meeting of Nordic

Context, Genesis, and Revelation", History in Africa 40 (2013), pp. 45-75; Mustafah Dhada, "The Wiriyamu Massacre of 1972: Response to Reis and Oliveira, Civil Wars 15:4 (2013), pp. 551-558; Bruno Cardoso Reis, Pedro Aires Oliveira, "Reply to Mustafah Dhada", Civil Wars 15:4 (2013), pp. 559-562; Mustafah Dhada, The Portuguese Massacre of Wiriyamu in Colonial Mozambique, 1964-2013, London et al.: Bloomsbury, 2016. On Caetano's state visit to London, see Norrie MacQueen, Pedro Aires Oliveira, “'Grocer meets Butcher': Marcello Caetano's London Visit of 1973 and the Last Days of Portugal's Estado Novo", Cold War History 10:1 (2010), pp. 29-50.

105 Telegram from the Christian Peace Service (Hansjürg Braunschweig, Peter Rüegg), EvB (Georges Rossier, Annemarie Holenstein, François de Vargas), APAA (Dyons Gerard, Jacky Corthay), Swiss Human Rights League (Joan Chicherio), KsA (Daniel Kohn), AG3W (Andres Anderli) to Pierre Graber, 11.07.1973, SFA E2001E-o1\#1987/78\#4651*.

106 Letter from Gillian G. Brown, British Embassy in Bern, to the CSAD, "Mozambique", 16.07.1973, TNA FCO 45/1311.

107 Letter from C.K. Woodfield, UK embassy in Bern, to the CSAD, "Mozambique", o3.08.1973, TNA FCO 45/1313; letter from C.K. Woodfield to the CSAD, "Mozambique", 13.08.1973, ibid.

108 Handwritten notes by Jean-Jacques Indermühle, DPA, dated 17.07.1973 about his discussion with Ernesto Thalmann and Michael Gelzer, on Jean-Jacques Indermühle, memorandum, "Entretien téléphonique avec M. Kist, Conseiller de l'Ambassade des Pays-Bas", 16.o7.1973, p. 1, SFA E2001E-01\#1987/78\#4651*. 
Ministers, and doubled its aid to FRELIMO. ${ }^{109}$ The Danish government also vocally condemned the massacres and seconded the Swedish UN initiative.110

Faced with renewed demands to rescind Portugal's invitation to the Comptoir Suisse, the Swiss government prevaricated. DPA members asked Switzerland's diplomatic posts in Lisbon and Lourenço Marques for more information. Consul Louis Chaney in Mozambique was quite objective. He underlined that, as long as the Portuguese authorities refused an international enquiry, there was not sufficient information available to conclusively prove or disprove the massacre claims. ${ }^{111}$ Ambassador Jean-Louis Pahud in Lisbon was staunchly pro-Portuguese. He argued that withdrawing the invitation "would amount to bringing the Government of Lisbon to trial on the basis of accusations made without any proof by a media outlet in the context of an internal policy manoeuvre of a third state" and warned that the Portuguese government would react strongly to such interference. ${ }^{112}$ The Portuguese authorities indeed observed the events in Switzerland closely for any sign of a change in attitude from the Federal Council or the organisers of the fair. But in mid-July 1973, the latter only suggested that, in order to mitigate possible attacks during the Comptoir Suisse, the Portuguese authorities should limit their exposition to commercial issues and avoid any political aspects liable to give rise to controversy. ${ }^{113}$

Protest against Portugal's presence at the trade fair did not die down. The extreme Left picked up the issue and a number of small solidarity movements were created in this context. ${ }^{114}$ In late July 1973, 118 Swiss citizens sent an appeal to the Federal Council, expressing their outrage at the massacres and urging the government to take a stand. Among the signatories were several parliamentarians, professors, and priests, as well as leaders of solidarity movements

109 PR no 6 from Claude Ochsenbein, chargé a.i. Swiss Embassy in Sweden, "Massacres au Portugal - Réactions de la Suède", 17.07.1973, p. 1, SFA E20o1E-o1\#1987/78\#4651*.

110 Letter from Walter Jäggi, Swiss ambassador in Denmark, to the DPA, "Tensions entre le Danemark et le Portugal", 24.07.1973, p. 1, SFA E2001E-o1\#1987/78\#4651*.

111 Letter from Louis Chaney to the DPA, "Manifestation contre les allégations de Massacre au Mozambique", 17.07.1973, confidential, SFA E20o1E-o1\#1987/78\#4651*; letter from Chaney to the DPA, "Situation au Mozambique à la suite des allégations de massacre par l'armée portugaise", 26.07.1973, confidential, ibid., letter from Chaney to the DPA, "Ironie de la guerre et chronique des allégations de massacre par l'armée portugaise au Mozambique", 14.08.1973, ibid.

112 Letter from Jean-Louis Pahud to the DPA, "Massacre au Mozambique?" 23.07.1973, confidential, p. 3, SFA E2001E-01\#1987/78\#4651*.

113 Telegram no. 32 from [?] Lopes Vieira, Portuguese embassy in Switzerland, to the MNE, 20.07.1973, AHD, PAA, pr. 922, box 1226.

114 Pereira, Anti-impérialisme et nouvelle gauche radicale, pp. 77-78. 
and labour unions. ${ }^{115}$ Members of the Christian Peace Service expressed their discontent about the delay in the government's reply to Ziegler's parliamentary question in a letter to the FPD in early August. If the official silence was not broken soon, they argued:

this could not be justified with Swiss neutrality, but would have to be considered a statement in favour of the Portuguese colonial regime. In the case of Portugal at the Comptoir Suisse, the competent authorities in Bern and Lausanne cannot avoid choosing between the colonial power Portugal and the liberation movement FRELIMO, which means, from a political and economic point of view, choosing between the present and the future. ${ }^{116}$

Unknown to the protesting civil society actors, the decision to uphold the invitation to Portugal had already been taken at the highest political level on 3 August 1973. Two weeks earlier, Georges-André Chevallaz, the liberal mayor of Lausanne and future Federal Councillor, had suggested that the FPD should contact Lisbon and explain the problems that the Portuguese presence at the trade fair might cause, notably the risk of violent demonstrations. ${ }^{117}$ As the event was fast approaching and he considered it inadvisable for the FPD to take sole responsibility, the department's Secretary General, Ernesto Thalmann, suggested that Chevallaz's and Ziegler's requests be submitted to the Federal Council. ${ }^{118}$ The draft proposal that he presented to Pierre Graber for approval reflected the shared opinion of the FPD and the Trade Division that the invitation to Portugal should be honoured, as a matter of principle, as well as for reasons of foreign policy: "the cancellation of the invitation at the last moment would be even more detrimental to our international image and our relations with Portugal than the demonstrations that might take place."119 Pierre Graber, however, did not agree with his department. To him, the position of different churches and religious bodies was crucial:

115 Appeal by 118 citizens to the Federal Council, no date, but receipt stamp 30.07.1973, SFA E2001E-o1\#1987/78\#4651*.

116 Letter from Hansjörg Braunschweig and Peter Rüegg, Christian Peace Service, on behalf of the signatories of the telegram of 11 July to Ernesto Thalmann, 08.08.1973, p. 2, SFA E2001E-o1\#1987/78\#884*.

117 Letter from Georges-André Chevallaz, mayor of Lausanne, to Pierre Graber, 19.07.1973, p. 1-2, SFA E2OO1E-01\#1987/78\#884*.

118 Letter from Ernesto Thalmann to Pierre Graber, 20.07.1973, p. 1, dodis.ch/3839o.

119 FPD, draft proposal to the Federal Council, "Portugal, hôte d'honneur du Comptoir Suisse 1973", no date, attached to the note from Ernesto Thalmann to the Federal Council, 27.07.1973, SFA E2OO1E-01\#1987/78\#884*. 
while I attach little importance to most of the organisations that signed the joint telegram to the Political Department, I would consider it very unfortunate to ignore the position of organisations such as the Federation of Swiss Protestant Churches, the Protestant Church of Geneva, and the DM in Lausanne. I cannot help thinking that we badly need the active support of these institutions, and others like them, to back our humanitarian policy in general and development cooperation in particular. ${ }^{120}$

In this, Graber was isolated in the Federal Council. In a telephone meeting on 3 August 1973, the Swiss government decided not to withdraw the invitation. Even the liberal Nello Celio, who had been greatly impressed by the international campaign following the massacre in Mozambique, rallied behind the majority. ${ }^{121}$

Marc-Antoine Muret of the Comptoir Suisse was satisfied with the Federal Council's decision. During a meeting with FPD representatives in Bern, he agreed to cover up the fact that a Swiss diplomat had extended the invitation to Portugal and to publicly declare that it had been made by the organisers of the fair themselves. ${ }^{122}$ The Swiss government's long silence had created tensions with the Portuguese ambassador in Bern. On the day before the Federal Council's decision, Ernesto Thalmann had summoned Eduardo Bugalho at the request of several Federal Councillors. The Secretary General informed Bugalho of the complaints against Portugal's presence at the trade fair, stating clearly, however, that he did not want to exert any pressure on Lisbon to withdraw. ${ }^{23}$ Bugalho was more unsettled than reassured by this conversation, uncertain whether the summons was a veiled attempt at discouraging Portugal's participation. ${ }^{124}$

On 10 August 1973, the Swiss government finally took an official stand and prioritised economic interests over human rights. In its published reply to Ziegler's question, the Federal Council argued that Portugal had been invited, by

120 Letter from Pierre Graber to Ernesto Thalmann, 24.07.1973, pp. 1-2, attached to the note from Thalmann to the members of the Federal Council, 27.07.1973, SFA E2001E-o1\#1987/ $78 \# 884^{*}$.

121 Excerpt of the minutes of the 5 th extraordinary meeting of the Federal Council on 3 August 1973, "Portugal als Ehrengast am Comptoir Suisse", 03.08.1973, p. 2, dodis.ch/30305.

122 Ernesto Thalmann, memorandum, "Entretien du 3 août 1973 à Berne entre le Secrétaire général du Département et M. Marc-Antoine Muret, Directeur général du Comptoir Suisse", o6.08.1973, p. 3, SFA E2001E-o1\#1987/78\#884*.

123 Note from Ernesto Thalmann to the members of the Federal Council, 02.08.1973, SFA E2001E-o1\#1987/78\#884*.

124 Telegram no. 36 from Eduardo Bugalho to the MNE, O2.08.1973, urgent, confidential, AHD, PAA, pr. 922, box 1226; see also telegram no. 38 from Eduardo Bugalho to the MNE, 07.08.1973, ibid. 
the Comptoir Suisse, for entirely economic reasons and that it would be premature to rescind the invitation in the absence of objective information about the massacre allegations. Finally, the Federal Council underlined its firm intention to be officially represented at the fair due to the event's importance for the Swiss economy and the fact that Switzerland enjoyed normal diplomatic relations with its fellow EFTA member. ${ }^{125}$ This reply reassured Swiss business people in Lisbon, who had feared that anti-Portuguese sentiments in Switzerland might endanger their interests. ${ }^{126}$

On the evening before the publication of the Federal Council's reply, Chevallaz's letter was mentioned on television. Speculation about the mayor's take on Portugal's invitation created a sensation in the press and almost caused a diplomatic incident. After receiving a worried early morning phone call from Eduardo Bugalho, Charles Müller, deputy chief of the DPA and head of its European Division, invited the Portuguese ambassador to the FPD to inform him personally of the Federal Council's reply to Ziegler's question. ${ }^{127}$ Bugalho, who was still not sure of the Swiss authorities' real intentions, let himself finally be persuaded that the Federal Council did not intend to hint that the Portuguese should reconsider coming to Switzerland. ${ }^{28}$ The head of the Trade Division, Paul Rudolf Jolles, also tried to reassure the ambassador and to dispel any ill feeling that might be caused by the Federal Council's reply.129

With the publication of the Federal Council's reply to Ziegler's question, Portugal's presence at the Comptoir Suisse was confirmed. A number of Protestant and Catholic organisations continued to lobby the government. ${ }^{130}$ Other, more radical groups came together to form a joint committee in order to coordinate a campaign that focused on the fight against Portuguese colonialism and support for liberation movements, the denunciation of Portuguese oppression in the metropolis, and the complicity of Swiss political and economic elites with

125 "Petite question Ziegler du 27 juin 1973. Schweizer Comptoir - Comptoir Suisse 1973. Réponse du Conseil federal du 10 août 1973", Amtliches Bulletin der Bundesverfassung 1973, Herbstsession Nationalrat, 03.10.1973, p. 1391.

126 See telegram no 32 from Jean-Louis Pahud to the DPF, 10.08.1973, SFA E20o1E-o1\#1987/ $78 \# 4651^{*}$.

127 Charles Müller, Deputy Chief of the DPA, memorandum, "Beteiligung Portugals am Comptoir Suisse 1973", 10.08.1973, SFA E2001E-01\#1987/78\#884*.

128 Telegram no 43 from Eduardo Bugalho to the MNE, 13.08.1973, AHD, PEA, pr. 331.80, box 756.

129 Telegram no 41 (42) from Eduardo Bugalho to the MNE, 13.08.1973, p. 2, AHD, PEA, pr. 331.80 , box 756 .

130 Letter from W. Sigrist and W. Probst to Pierre Graber, "Teilnahme Portugals am Comptoir 1973", 20.08.1973, SFA E2001E-o1\#1987/78\#883*; letter from André Gachet, on behalf of Protestant and Catholic working groups in Geneva, to Swiss President Roger Bonvin, 04.o9.1973, p. 1, SFA E2001E-o1\#1987/78\#884*. 
the Estado Novo regime. They prepared leaflets to be distributed at the entrance to the trade fair, organised counter-expositions in many cities in French-speaking Switzerland, and called for a demonstration in Lausanne against Portugal's presence at the Comptoir. The APAA, a religiously motivated Third World solidarity group founded in the run-up of the trade fair, seems to have played a particularly important role. ${ }^{131}$ The day before the opening of the fair, the Bishop of Fribourg, Lausanne, and Geneva further increased tensions by officially refusing to accept an invitation to the Comptoir Suisse. As he wrote in a communiqué, he feared that participating in this event, "could, in the present context, be interpreted as an act of solidarity with the injustices committed in certain Portuguese colonies against the indigenous population as well as against Catholic and Protestant missionaries".132

On 8 September 1973, the opening day of the Comptoir Suisse, several thousand people participated in a protest march towards the exhibition grounds, making it, according to historian Nuno Pereira, one of the most spectacular events of the post-1968 protest cycle in Switzerland. ${ }^{133}$ When demonstrators tried to occupy the Portuguese exhibition, there were violent clashes with the police; many people were arrested and about fifty charged with rioting. The demonstrators were not discouraged and continued their activities two days later, on Portugal's official day at the fair. Pamphlets distributed on this occasion by the APAA claimed that, "[ $t$ ]he Comptoir is not neutral: it does not invite the Portuguese people, but the Portugal of dictatorship and colonial terror", 134 and condemned repression by the Swiss government and police:

We do not want this democracy, where a minority is in power, which seeks to muzzle the protesters in order to maintain silence about the exploitation that the Portuguese people and the African peoples are fighting and to deflect attention away from the fact that large Swiss companies benefit

See D. Muller, Gerard Dyens, APAA, (eds.), pamphlet, "Contre le terrorisme portugais: soutien aux mouvements de libération", no date [before 8 September 1973], p. 2, attached to the letter from the director of the GNP to the General Director of Security, 22.11.1973, ANTT, PIDE/DGs, Cl(2), no 129o/73, NT 7872. On the APAA, see Pereira, Anti-impérialisme et nouvelle gauche radicale, pp. 169-170.

132 Chancellery of the diocese of Fribourg, 07.09.1973, cited in telegram no 56 from Eduardo Bugalho to the MNE, 07.09.1973, AHD, PEA, pr. 331.80, box $75^{6}$.

133 Pereira, "Le mouvement suisse de 1968", pp. 152-153.

134 D. Muller, Gerard Dyens, APAA, (eds.), pamphlet, "Contre le terrorisme portugais: soutien aux mouvements de libération", no date [before 8 September 1973], p. 5, attached to the letter from the director of the GNP to the General Director of Security, 22.11.1973, ANTT, PIDE/DGS, Cl(2), no 129o/73, NT 7872 . 
from this exploitation, by building their factories in Portugal and paying a pittance to the workers. ${ }^{135}$

This proved to be the high point of Swiss protest against Portugal at the Comptoir Suisse. On 11 September 1973, the Chilean coup d'état made international headlines and diverted the attention of many Swiss solidarity movements away from the trade fair in Lausanne.

The demonstration and lobbying against Portugal's presence at the Comptoir Suisse was noted and commented upon by the ambassadors of several other countries. The Finnish ambassador to Switzerland and Portugal told his US colleague in Lisbon that the incident was "particularly noteworthy as indicating that anti-Portuguese sentiment [was] spreading even among generally politically apathetic Swiss."136 The US ambassador in Bern, however, thought that Portugal had simply been a "convenient target" for the "very well-organized but small radical-Left minority movement in Switzerland which, deprived of VietNam as an issue, has needed some sort of focal point around which to rally its followers and keep them motivated"137 and that it should not be considered an indication of the feeling of the general Swiss public. The account of the demonstration by the British embassy in Bern was more factual, underlining that opposition to Portugal's presence in Lausanne was mainly concentrated in leftist circles. ${ }^{138}$

On a bilateral level, the demonstrations did not disturb diplomatic relations between Switzerland and Portugal. As was customary, the Swiss president and high-ranking FPD representatives visited the Portuguese exhibition, and conversations with the Portuguese ambassador at the official dinner focused on economic affairs. ${ }^{139}$ Switzerland's representatives in Portugal and Mozambique confirmed that the events in Lausanne had not led to a deterioration of rela-

135 J. M. Cruchet (ed.) for the joint committee against Portugal's presence at the Comptoir and the schoolchildren's committee against Portugal's presence at the Comptoir, "Laction contre la présence du Portugal au Comptoir se poursuit", [10.09.1973], p. 1, attached to the letter from the director of the GNP to the General Director of Security, 22.11.1973, ANTT, PIDE/DGS, Cl(2), no 129o/73, NT 7872 .

136 Cited in the telegram from [?] Post, US Embassy in Portugal, to the US Embassy in Switzerland, o3.10.1973, NARA, RG 59, AAD, CFPF, Electronic Telegrams 1973, 1973LISBONo3637.

137 Telegram from Shelby Cullom Davis, US ambassador in Switzerland, to the US Embassy in Portugal, 11.10.1973, NARA RG 59, Subject-Numeric Files 1970-1973, POL 23-8 switz, box 2612.

138 Letter from C.K. Woodfield, UK embassy in Bern, to the CSAD, "Mozambique", 19.o9.1973, TNA FCO $45 / 1314$.

139 Telegram no 57 from Eduardo Bugalho to the MNE, 14.09.1973, AHD, PEA, pr. 331.80, box 756 . 
tions with the Estado Novo regime. ${ }^{140}$ While solidarity movements continued to sporadically demand that the Swiss authorities take a stand on Portugal's colonial policy and the massacre claims up until the Carnation Revolution, public attention died down after the Comptoir Suisse closed its doors.

The demonstration against the Portuguese presence at the Comptoir Suisse was the culmination of several years of Swiss protest against Portuguese colonial rule and what was considered to be the Swiss government's complicity with this imperialist regime. The high level of protest activities in Switzerland was down to the interplay of national and international factors. The Bührle scandal of 1968 exposed the contradictions between humanitarian aid and arms exports to the Third World. The use of Swiss-made guns during the Biafra War appalled large parts of the Swiss population and drew their attention to the country's Africa policy. The transnational campaign against the Cabora Bassa dam in Mozambique in the early 1970 s was another important focal point for Swiss civil society actors. They took up the criticism of Western collaboration with the Portuguese colonial regime voiced by FRELIMO and solidarity movements in other European states and applied it to the national context, in particular to ввС's indirect participation in the dam's construction. The imprisonment and death of IPM members in Mozambique in 1972 alarmed religious circles in Switzerland and convinced them of the oppressive nature of the Portuguese colonial regime. Then, reports of the Wiriyamu massacre in the international press in July 1973 further fuelled Swiss protests. Finally, and most importantly, the invitation of Portugal as a guest of honour to a Swiss trade fair provided an ideal rallying point, as it exposed the cordial relations of Swiss business elites and the government with the Estado Novo regime.

Swiss non-state actors' material assistance of liberation movements in Angola and Mozambique seems to have been limited. There are few signs that solidarity movements prevented Swiss firms from trading with and investing in the Portuguese colonies and they did not succeed in convincing the Swiss government to publicly take a stand against Portuguese colonialism. Nevertheless, the heterogeneous Swiss solidarity movement was a political force in the late 196os and early 1970s. It helped delegitimise Portuguese colonialism, made economic collaboration a subject of discussion, and forced firms like ввС Baden to publicly justify their position. Swiss non-state actors closely scrutinised their government's Africa policy and their frequent appeals put Bern on the defensive. The criticism of churches and missionary organisations was particularly difficult to rebut.

140 Letter from Louis Chaney to the DPA, 17.09.1973, SFA E2001E-01\#1987/78\#884*; letter from Bruno Stöckli, chargé d'affaires a.i. of the Swiss Embassy in Portugal, "Demonstration gegen Portugal anlässlich des Comptoir Suisse", 20.o9.1973, ibid. 


\section{Conclusion to Part 1}

As you know, it is not the habit of the Federal Council to bring charges through public statements, or rather to criticise policies and practices of third states. We are aware that this restraint of our authorities may nowadays contrast with the behaviour of other states-also neutral onesand that it is not understood everywhere. ${ }^{1}$

In a letter to the Christian Peace Service in October 1973, the deputy chief of the DPA reiterated the Swiss government's habitual unwillingness to take a stand on Portuguese colonialism. Despite the double challenge issued by AfroAsian leaders and Swiss civil society actors since the late 196os, the majority of Swiss foreign policymakers saw no need to deviate from their policy of noninterference. On the issue of national liberation in Southern Africa, their position contrasted markedly to that of other small Western European states. The governments of Sweden, Norway, Finland, Denmark, Ireland, and the Netherlands showed more openness on Third World issues and repeatedly criticised Portugal's colonial policy and white minority rule, although to varying extents.

How to explain these different foreign policy choices? Swiss foreign policymakers frequently referred to their economic relations with Portugal to justify Switzerland's non-committal stance. When it came to policymaking on Portuguese colonialism, the importance of Switzerland's EFTA ties went beyond bilateral economic interests. Bern set great store by these ties as they were an expression of Western European cooperation and solidarity. Apart from the Swiss government's unwillingness to affront a fellow EFTA member, its reluctance to consider adapting its foreign policy also stemmed from the fear that, once it responded to demands to take a stand on colonialism and cut its limited economic investments in Portuguese Africa, it would be forced to make similar concessions in Rhodesia and especially South Africa, where Swiss economic and financial interests were much more substantial. As the other small European states did not have significant economic interests in sub-Saharan Africa that might be endangered by tensions with the white minority regimes or by decolonisation, they had a relatively wide marge de manoeuvre and decided they could afford to be more outspoken. ${ }^{2}$

1 Letter from Michael Gelzer, deputy chief of the DPA, to the Christian Peace Service, 04.10.1973, SFA E2001E-01\#1987/78\#4651*.

2 Lorenzo Ferrari, "The European Community as an Opposer of the Portuguese Colonial Rule: Debates and Initiatives, 1970-1974" Afriche e Orienti 19:3 (2017), pp. 69-84, p. 77. 
The Swiss government's reluctance to risk annoying Lisbon and Pretoria with which it had enjoyed close relations for decades, also stemmed from a deep, often unacknowledged, distrust of the less well-known and thus more unpredictable African actors that wanted to change the way international relations worked. Most FPD officials were hesitant to recognise African liberation movements as belligerents on a par with the Portuguese colonial authorities. Their reluctance to adapt their foreign policy to a new form of conflict was strengthened by the widespread low opinion of Africans, and the apprehension, hardly ever voiced but nevertheless present, that Angola and Mozambique's future rulers might turn towards the Soviet Union. Bern's unease in dealing with African non-state actors was echoed, although to a lesser degree, in its relations with newly independent African governments. Swiss foreign policymakers were displeased with the latter's criticism of Swiss foreign policy, and, more generally, with the Third World political movement's demands to reorganise global economic and political relations, and downplayed them as a needless politicisation of technical issues.

The national and international debates surrounding Switzerland's foreign policy in Southern Africa boiled down to questions of racial equality and justice in North-South relations and were therefore increasingly discussed in moral terms. Against this background, the Swiss government's insistence on its special role as a neutral state that was not part of the UN was met with decreasing sympathy, especially as neutral Sweden was one of Western Europe's foremost champions of national liberation in Southern Africa. For many Afro-Asian leaders and Swiss civil society actors, Switzerland's political and economic elites were part of the imperialist North exploiting the global South. This criticism impaired the credibility and respectability of Switzerland's neutrality in the Third World and built up significant pressure on the Swiss government to improve its image in the global South. Its established instruments of good offices and humanitarian and development aid were of limited use to silence critical voices. In the highly politicised context of Southern Africa, aid, in particular, automatically appeared to either support the African populations and potentially undermine the settler regimes, or legitimise white minority rule and thereby weaken African nationalism. This ran contrary to the supposedly non-political nature of Switzerland's aid policy. Swiss foreign policymakers had no coherent strategy to deal with these challenges to their foreign policy in Southern Africa. Instead, they clung to their position, attempted to deflect criticism, and hoped that their problems in the region would somehow disappear. On the whole, ambassador Felix Schnyder's selfdeprecating statement during a courtesy call at the US Department of State in 
early 1974 that, "the Swiss traditionally avoid problems instead of solving them" was most apt. ${ }^{3}$

Even though domestic and international criticism did not lead to substantial Swiss policy changes in sub-Saharan Africa between 1967 and 1974, the debate about Switzerland's role in North-South relations in the international arena and within Swiss society caused some friction within the Swiss government and federal administration. A small number of diplomats and foreign policymakers were willing to take heed of the criticism and suggested adapting the country's foreign policy, while a majority focused on keeping the door closed and refusing all concessions that might impair Switzerland's political and financial relations with the white minority regimes. Disagreements arose mainly between the FPD and the Trade Division, and between the diplomatic representations in New York and Addis Ababa, and headquarters in Bern. While Swiss ambassadors in New York and Addis Ababa were attuned to Third World opinion and insisted that the disapproval of African governments needed to be taken seriously, representatives of the Trade Division and the Swiss embassy in Portugal claimed that it was essential not to antagonise Switzerland's EFTA partner. In Bern, the head of the FPD put great emphasis on the opinion of Swiss churches critical of racial oppression, while most DPA members were unwilling to reconsider Switzerland's policy in Southern Africa, and the DIO advocated some small gestures towards the population of the region.

In the end, the Swiss government was able to resist the pressure to change its Southern African policy because the major Western powers also refused to cut their political, economic, and military links with Portugal and South Africa. Although Afro-Asian states and a transnational solidarity network confronted the US, the UK, and the FRG with their perceived failure to support national liberation in Southern Africa, and differences over how to deal with Portuguese colonialism were debated at organisations such as the EEC and NATO, there was enough 'respectable company'4 for Bern to hold out. That is, until the April 1974 Carnation Revolution in Portugal initiated the process of decolonisation in Angola and Mozambique and solved some of the problems.

3 Cited in David Pfotenhauer, memorandum of conversation between Swiss ambassador Felix Schnyder accompanied by Olivier Exchaquet of the Swiss embassy in Washington, with Arthur A. Hartman, Assistant Secretary of European Affairs, 26.o2.1974, p. 1, NARA, RG 59,

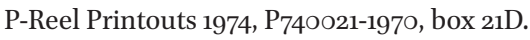

4 This term is borrowed from Norrie MacQueen, "Belated Decolonisation and UN Politics against the Backdrop of the Cold War. Portugal, Britain, and Guinea-Bissau's Proclamation of Independence", Journal of Cold War Studies 8:4 (2006), pp. 29-56. 


\section{PART 2}

\section{A Shift in Cold War Alliances: Radical Regime}

Changes in Sub-Saharan Africa, 1967-1979 


\section{Introduction to Part 2}

Western influence in sub-Saharan Africa - and if I say Western, I include Switzerland, as we are in the same boat-Western influence that was considerable immediately after decolonisation decreases constantly. First and foremost, African self-reliance grows. The influence of [...] the Communists increases, it has, however, limitations. But only if the West adopts a far-sighted Africa policy and sticks to it despite all tribulations. ${ }^{1}$

At the annual conference of Swiss ambassadors in Bern in September 1975, Richard Pestalozzi commented on a shift in superpower alliances on the African continent that had started in 1974. Early in 1974, civil and military unrest broke out in Ethiopia. This would lead, in September, to the installation of a military regime and the deposition of the Ethiopian Emperor. The new government adopted an anti-Western rhetoric and sought an alliance with the UssR. In April 1974, the Portuguese Estado Novo regime was toppled, which opened the way for the decolonisation of Mozambique and Angola. In both countries, Marxist-inspired regimes would take over. The coming to power of FRELIMO in June 1975 was largely peaceful. The MPLA, however, only consolidated its rule after a Cuban military intervention assured it victory in the Angolan War in February 1976. In July 1974, the Somali military government, which had come to power in a coup in 1969, formalised its alliance with the Soviet Union by concluding a friendship treaty. These four regimes were more overtly Marxistinspired than other African states that had adopted different, more autonomous forms of 'African Socialism' in the late 1950s and early 196os. ${ }^{2}$ In all four cases, their takeover was accompanied by the nationalisation of foreign property and by efforts to push the economic system towards a more state-controlled model.

During and after these regime changes, the Swiss government was faced with a number of challenges and policy decisions that made it impossible to avoid taking a position. In Ethiopia, Angola, and Mozambique, Swiss investments were nationalised. The Ethiopian Revolution was accompanied by a press campaign that accused Swiss banks of harbouring public funds that had been deposited abroad by the former Emperor. The new Mozambican

1 Speech by Richard Pestalozzi, Swiss ambassador in Kenya, at the Annual Conference of Swiss Ambassadors, "Konfrontation oder Kooperation zwischen Industriestaaten und Entwicklungsländern, aus der Sicht Schwarzafrikas", 04.09.1975, p. 4, dodis.ch/48225.

2 Byrne, "Africa's Cold War", pp. 109-111. 
government also directly targeted Switzerland, criticising its pro-Portuguese position during the independence wars. Switzerland's political, economic, and financial elites were accused of having participated in the exploitation of poor African states. Consequently, the political debates surrounding Switzerland's foreign policy in sub-Saharan Africa reached their peak in the mid-197os.

International relations were similarly tumultuous. In January 1973, the US and the government of North Vietnam signed a ceasefire agreement, which led to the withdrawal of US troops from Vietnam. Half a year later, Leonid Brezhnev visited the US and the two superpowers concluded the Agreement on the Prevention of Nuclear War, as well as accords on several other economic, scientific and cultural bilateral issues. Yet, tensions soon grew again. The superpowers found themselves on opposing sides in the 1973 October War between Israel - supported by the US - and Egypt and Syria — backed by the USSR. Although Moscow and Washington both got their respective allies to respect a ceasefire at the end of the month, the war did start to undermine Détente. In parallel, President Richard Nixon's domestic position was weakened by his involvement in the Watergate break-in of June 1972, and he was forced to step down in August 1974. His successor, Gerald Ford, continued negotiations with the USSR, but the fall of the South Vietnamese government in April 1975 and Vietnam's unification under a Communist government undermined confidence in the ability of the US to defend its allies. In Europe, however, Détente culminated in mid-1975 in the signing of the CSCE Final Act in Helsinki. ${ }^{3}$

The mid-197os also represented the apex of the Third World's political power and cooperation. The fourth NAM summit in Algiers in September 1973 focused on the redistribution of global economic resources. Delegates from 75 countries demanded greater involvement of the global South in decisionmaking on economic matters. Only a few weeks later, during the October War, the Arab members of the Organization of the Petroleum Exporting Countries (OPEC) increased the price of crude oil, lowered production, and introduced an oil embargo on states that were supporting Israel, notably the US. To Western states, this brought home their dependency on raw materials produced in the global South and forced them to participate in the North-South dialogue with the Third World. The oil shock also contributed to the economic crisis that hit Western Europe in the mid-1970s. Third World states used their majority in international organisations to influence the agenda of the UN, notably

3 See Garthoff, Détente and Confrontation, pp. 36o-486; Douglas Little, "The Cold War in the Middle East: Suez Crisis to Camp David Accords" in Leffler, Westad, The Cambridge History of the Cold War. Volume II: Crises and Détente, pp. 305-326; Schulzinger, "Détente in the NixonFord Years". 
convening the sixth special session of the UNGA on raw materials and development. In April 1974, this special session approved the Declaration on the Establishment of a NIEO. This challenge from Third World states caused industrialised states to strengthen coordination in order to present a united front. In February 1974, Washington brought together 13 major oil-consuming countries at a World Energy Conference (WEC) to discuss a joint response to the oil crisis. The creation of the G6 (later $\mathrm{G} 7$ ) group in late 1975 was also a result of the chief industrial societies' attempts to deal with the economic challenges presented by Third World states. ${ }^{4}$

As a reaction to the assertive stance of Third World governments and the experience of dependency caused, inter alia, by the 1973 oil crisis, Swiss foreign policymakers adopted a more active position in North-South debates. ${ }^{5}$ Some of them also questioned the utility of neutrality as a guideline for foreign policy on the Third World. In Africa, the reputational damage caused by Switzerland's selective policy of neutrality in Southern Africa continued to grow, and with it the danger that political and economic interests on the continent might suffer. At a time when Switzerland was facing its biggest economic crisis since the Second World War, which culminated in 1975-1976 and was accompanied by increased government efforts to promote foreign trade, this was particularly unwelcome. ${ }^{6}$ Consequently, the need to boost Switzerland's image and that of its neutrality dominated Swiss decision-making during the regime changes in the Horn of Africa (chapter 4), the decolonisation of the Portuguese colonies (chapter 5), and the establishment of bilateral relations with postcolonial Mozambique (chapter 6). In this context, the ideological orientation of the four new regimes was certainly noted and commented upon in Bern, but it had no decisive impact on Switzerland's foreign policy.

4 See Dinkel, “Third World Begins to Flex its Muscles"; Garavini, After Empires, p. 175; Giuliano Garavini, "Completing Decolonization: The 1973 'Oil Shock' and the Struggle for Economic Rights", The International History Review 33:3 (2011), pp. 473-487; Giuliano Garavini, "The Colonies Strike Back: The Impact of the Third World on Western Europe, 1968-1975", Contemporary European History 16:3 (2007), pp. 299-319; Möckli, European Foreign Policy during the Cold War, pp. $253^{-} 315$.

5 Fischer, Die Grenzen der Neutralität, pp. 131-132.

6 See Magnus Meister, Les Trente Glorieuses et la crise des années 1970 en Suisse. Une politique conjoncturelle et économique au service de l'internationalisation de l'économie suisse, unpublished Master thesis, University of Geneva, 2013; Patrick Halbeisen, Tobias Straumann, "Die Wirtschaftspolitik im internationalen Vergleich", in Patrick Halbeisen, Margrit Müller, Béatrice Veyrassat, Wirtschaftsgeschichte der Schweiz im 20. Jahrhundert, Basel: Schwabe, 2012, pp. 983-1075, pp. 1051-1058. 


\section{Attempting to Keep a Low Profile: The Revolutions in Somalia and Ethiopia}

In the mid-1970s, the military regimes that took power in Somalia in 1969 and in Ethiopia in 1974 sought to strengthen their links to the Soviet Union. Subsequently, the Horn of Africa turned into a second trouble spot for Switzerland's foreign policy on the African continent, after Southern Africa. The 1969 military coup in Somalia had domestic causes. From 1967 onwards, Prime Minister Mohammad Egal had taken a more conciliatory, less aggressive approach to the nationalist goal of adding neighbouring territories inhabited by ethnic Somalis to the Somali state. His attempt to resolve the issue by diplomatic means caused public dissatisfaction and left the army without a raison d'être. During the March 1969 elections, violent clashes erupted between different political parties and there were widespread accusations of corruption. This further undermined confidence in the government. On 15 October 1969, while Prime Minister Egal was on a visit to the US, President Ali Shermarke was shot by one of his police guards. Six days later, the army took power in a bloodless coup. The Supreme Revolutionary Council under General Mohammad Siad Barre arrested government officials, including the returned Egal, suspended the constitution, abolished the Supreme Court, closed parliament, and renamed the state the Somali Democratic Republic. The new regime promised to fight corruption, continue the struggle for the unification of all Somali people, and work for the improvement of economic and social conditions. ${ }^{1}$ In the months after the coup, Soviet military and economic delegations visited Mogadishu. ${ }^{2}$ Nevertheless, Soviet involvement in Somalia increased moderately at first. It was only after Egypt's President Anwar Sadat expelled all Soviet military and technical advisors in July 1972 that Somalia and its ports gained great strate-

1 Laitin, Samatar, Somalia, pp. 76-79; Lewis, A Modern History of the Somali, pp. 203-207.

2 Therefore, many contemporary Western observers concluded that the Soviet Union was involved in the events of 21 October. The two most detailed historical analyses of the Soviet Union's role in the Horn of Africa nuance this view. Robert Patman argues that the Kremlin did not orchestrate the coup, although it anticipated and probably encouraged it. Based on extensive archival research, Radoslav Yordanov concludes that while the Soviet Committee for State Security (KGB) was informed in advance about the coup, there is no evidence of direct Soviet involvement: Patman, The Soviet Union in the Horn of Africa, pp. 95-97; Yordanov, The Soviet Union and the Horn of Africa, pp. 89-91. 
gic importance for the Kremlin. Consequently, the Soviet presence in Somalia grew markedly, particularly in the military field. Yet, although the two states concluded a friendship treaty in July 1974, Siad Barre was not Moscow's puppet. Introducing socialism in a strongly clan-based Muslim society with a large nomadic population called for pragmatic policies that were not always in line with Soviet prescriptions for socialist development. Siad Barre also guarded his independence in the field of foreign policy, where he adopted a neutralist approach. ${ }^{3}$

In 1974, Ethiopian leaders also started to turn towards the USSR. Early in the year, the dissatisfaction with Ethiopia's feudal regime and the long reign of Haile Selassie that had been growing since 196o erupted. Ethiopian scholars underline the importance of an abortive coup in 196o, instigated by members of the Imperial Bodyguard, which heralded more than a decade of open political protest. In several rural areas, peasants rose up against heavy taxation and exploitation by a landholding elite. In Eritrea, whose autonomy in the UN-decreed federation with Ethiopia had been steadily eroded, liberation movements started to fight for independence in 1961. The Ethiopian student movement also became more outspoken after 1960, and became the dominant force of opposition until the end of the regime. Increasingly radicalised from the mid-196os onwards, Ethiopian students were part of the international student protest movement and had associations in Europe and the US. Student groups challenged the authority of the regime, demanding land reforms and civic liberties, and declaring the right of nationalities to self-determination. ${ }^{4}$ A devastating famine that mainly hit the provinces of Wollo and Tigre in 19731974, costing the lives of an estimated 100,000-200,000 people in 1973, also contributed to the erosion of the regime's legitimacy. Haile Selassie's government was criticised for its lack of action when failing rains in 1972 brought drought, the official cover-up of the situation, and the continuation of grain exports during the famine. ${ }^{5}$

The Ethiopian Revolution began in mid-January 1974 with the mutiny of an army brigade in southern Ethiopia over salaries and social issues, which ended only when the Emperor sent a letter promising to look into the demands. The incident created unrest within the army, where coordinating committees were set up to manage the armed forces' claims. In mid-February, a civilian uprising

3 See Yordanov, The Soviet Union and the Horn of Africa, pp. 85-102.

4 Bahru Zewde, A History of Modern Ethiopia, pp. 209-226; Gebru Tareke, The Ethiopian Revolution, pp. 11-14, 24-34.

5 Edmond J. Keller, Revolutionary Ethiopia: From Empire to People's Republic, Bloomington: Indiana University Press, 1991, pp. 166-167. 
started in Addis Ababa and soon spread to neighbouring towns and provincial capitals. Taxi drivers, teachers, and students went on strike and organised demonstrations against educational reform programmes and rising petrol prices caused by the international oil crisis, and were quickly joined by the city's unemployed. The government's reaction was contradictory: on the one hand, security forces were authorised to use force against demonstrators and looters; on the other hand, Haile Selassie publicly promised that many of their demands would be met. A few days later, the Ethiopian Prime Minister, who had occupied his post since 1961, was forced to resign. The appointment of a new cabinet did little to calm public protests, however, and did not prevent the Confederation of Ethiopian Labour Unions from joining the fight and organising a general strike that lasted for four days and ended with all demands being met. ${ }^{6}$ Nevertheless, discontent within the population and the army continued.

In late June 1974, the Coordinating Committee of the Armed Forces, Police, and Territorial Army was established, later called variously the Armed Forces Committee, the Provisional Military Administrative Council (PMAC) or the Derg (committee in Amharic). Over the following months, the committee gradually took over the functions of the government. Its policies were summarised in a policy statement called 'Ethiopia First' and published on 10 July. They included loyalty to the Emperor, constitutional reform and the prosecution of corrupt officials, and more rights and improved living conditions for the people. ${ }^{7}$ On 12 September 1974, Haile Selassie was arrested and detained, and the PMAC assumed power. Its chairman, Lieutenant General Aman Mikael Andom, acted as the new head of state. The Derg suspended the constitution, dissolved parliament, and prohibited strikes and demonstrations, thereby alienating many of the groups that had been instrumental to the popular uprisings of the first half of $1974 .{ }^{8}$ Over the following months and years, the PMAC would enact a series of radical reforms, strengthen its links to the USSR, and turn away from the US - which had supported the old regime. Haile Selassie would be killed sometime in 1975 .

The radical regime changes in the Horn of Africa drew the attention of the Swiss government to an area of the world where Switzerland's political and economic interests were few, and in the case of Somalia practically non-existent. In neighbouring Ethiopia, Switzerland's commercial relations were limited due to the African country's poverty and lack of agricultural and industrial development. Bern had cordial but low-key relations with the ruling Emperor

6 Andargachew Tiruneh, The Ethiopian Revolution, pp. 37-44.

7 Ibid., pp. 61-71.

8 Bahru Zewde, A History of Modern Ethiopia, p. 236. 
Haile Selassie and increased its development cooperation in this state in the early 1970s. The presence of the superpowers in the Horn of Africa ensured that events in this region were closely scrutinized in Bern. The progressively Marxist turn of Mohammad Siad Barre's regime preoccupied the anti-Communist Swiss government. The increasing radicalisation of Ethiopia's new elites, together with FRELIMO coming to power in Mozambique in June 1975 and the MPLA's victory in the Angolan War in early 1976, sparked fears of rapidly increasing Soviet influence on the African continent. At the same time, Ethiopia hosted the headquarters of the OAU and numerous international and regional organisations, and was therefore frequently referred to as 'Africa's capital'. The strong diplomatic presence in Addis Ababa as well as Haile Selassie's renown as one of Africa's most distinguished elderly statesmen ensured that the events in Ethiopia were observed with particular interest, both in Switzerland and around the world. The OAU had, in the early 1970s, increased its pressure on the Swiss government to change its one-sided policy on Southern Africa, and discussed the introduction of sanctions against foreign firms dealing with the white minority regimes. The new Ethiopian regime's appeals, starting in September 1974, for the restitution of public funds that the deposed Emperor had allegedly deposited in Swiss bank accounts were therefore particularly damaging to Switzerland's image in sub-Saharan Africa. Once again, it was Switzerland's economic - in this case financial—role in the Horn of Africa that sparked controversy and induced its political leaders to try to keep a low profile.

\section{“Do We Actually Have Diplomatic Relations?" Swiss-Somali Links after the 1969 Coup d'État}

In August 1975, the Somali ambassador to Tanzania asked his Swiss counterpart in Dar es Salaam whether the two states had diplomatic relations. ${ }^{9}$ His question was symptomatic of the mutual indifference that marked SwissSomali relations. There was little that bound the two states together. Economic exchanges were close to zero and aid extremely limited, even by Swiss standards. Only the Somali Democratic Republic's tightening links to the USSR after the 1969 coup d'état sporadically attracted Bern's attention.

The October 1969 military coup in Somalia did not provoke a strong reaction in Switzerland. André Parodi, Swiss ambassador to Egypt who was also

9 Cited in Claude Huguenin, DPA, memorandum, "Visite de l'Ambassadeur Jaccaud auprès du Chef de la Division II, le 13 août 1975”, 25.08.1975, p. 3, SFA E20o1E-o1\#1987/78\#4651*. 
accredited to Somalia, noted a few weeks after the coup that the new regime turned increasingly Marxist and multiplied its contacts with the Communist bloc. From this, he concluded that no intensification in economic exchange between Switzerland and Somalia was to be expected. ${ }^{10}$ In mid-December, Parodi forwarded a confidential report from the West German Embassy in Mogadishu, which was studied with great attention by several FPD officials. According to the heavy underlining, interest focused mainly on the new regime's ideological background and its contacts with the Soviet Union. ${ }^{11}$ Bilateral relations were scarcely affected in the immediate aftermath of the coup. The sTC's planning for the grant of scholarships to twelve Somali teachers to study in the Italian-speaking part of Switzerland, begun in 1969, continued in spite of the regime change and was abandoned in July 1970 by mutual consent. ${ }^{12}$ The new regime's nationalisations of banks and power stations in February 1970 did not touch Swiss interests. ${ }^{13}$

In the early 1970s, issues linked to Switzerland's diplomatic representation in Somalia occasionally drew the FPD's attention to this state. In late June 1970, the Swiss honorary consul, Robert Camenzind, was forced to leave the country within 24 hours, ostensibly for subversive activities. Ambassador Parodi speculated, however, that Camenzind's links to the old regime as well as his frequent travels, which included trips to Somalia's enemy-Ethiopia, had raised the Somali government's suspicions. Both Parodi and the DPA concluded that the consul's expulsion should not be considered an unfriendly act towards Switzerland and that bilateral relations should be upheld. ${ }^{14}$ The expulsion of another Swiss citizen who worked for the UNDP a few months later was explained by Parodi as due to the intrigues of the Soviet head of the organisation in Somalia: "This episode is mainly remarkable because it shows, once again, how the Communist states take every opportunity to increase their influence in devel-

10 Letter from André Parodi, Swiss ambassador in Egypt, to the Protocol Service of the FPD, "Relations avec le Soudan et la Somalie", confidential, o2.12.1969, p. 2, SFA E20o1E-o1\#1991/ 17_Bd.1096, B.15.21.

11 Letter from André Parodi to Pierre Micheli, Secretary-General of the FPD, "Situation en Somalie après le putsch militaire", 12.12.1969, SFA E20o1E\#1980/83\#4051* and the attached report by the German embassy in Somalia, "Lage in Somalia", no author, no date. It was mainly due to a change in the Somali curriculum which rendered Italian-speaking teachers superfluous: letter from André Parodi to the STC, "Instruction publique - Cours pour enseignants somaliens", pp. 1-2, 06.07.1970, SFA E2005A\#1983/18\#794*.

See, for example, the letter from André Parodi to the sтc, "Technische Zusammenarbeit mit Somaliland", 19.10.1970, SFA E2005A\#1983/18\#794*.

14 Letter from André Parodi to the DPA, confidential, 08.07.1970, SFA E2O04B\#199o/219\#615*; note from Michael Gelzer, deputy chief of the DPA, to the AD, "Beziehungen mit Somalia und Konsularagentur in Mogadiscio", 20.07.1970, ibid. 
oping states. They do not hesitate to use international organisations for their own purposes and at the expense of Western member states."15 A year later, Parodi warned the Swiss export promotion agency not to be too hopeful with regard to economic opportunities for Swiss pharmaceutical firms in Somalia because of the regime's "socialist tendencies" ${ }^{16}$ After Parodi left his post in August 1971, the Swiss government transferred responsibility for diplomatic relations with Somalia from the Swiss embassy in Egypt to that in Tanzania, mainly for organisational reasons. Yet, in the words of the FPD's proposal to the Federal Council in May 1971, the greater geographical proximity of Dar es Salaam and Mogadishu was echoed in ideological affinities, as both governments "share equally progressive political views."17 The comparison of Siad Barre's policies with Julius Nyerere's vision of an African Socialism based on the development of rural villages shows that the Somali regime's ideological outlook was not initially considered unusual for an African state. ${ }^{18}$

In late 1974, in the midst of the Ethiopian Revolution and at a time when the independence of Mozambique and Angola was certain, the Swiss authorities decided to close their consulate in Mogadishu and forego the accreditation of a Swiss ambassador to Somalia. This amounted to an unofficial severance of diplomatic relations between the two states. The decision was triggered by the recommendation of the Somali ambassador in Tanzania that his Swiss counterpart, Lucien A. Mossaz, in October 1974, should skip his farewell visit to Mogadishu because the Somali authorities had no time for him. As this was the second time in one year that Mossaz was discouraged from travelling to Somalia, the FPD decided in December to definitively close the Swiss consular agency in Mogadishu, which had been temporarily shut since Camenzind's expulsion..$^{19}$ Given Somalia's marginal importance for and unfriendly attitude towards Switzerland, the FPD also decided that the accreditation of another

15 Letter from André Parodi to the STC, "PNUD-Delegationen in unterentwickelten Ländern", p. 2, 17.12.1970, SFA E2005A\#1983/18\#794*.

16 Letter from André Parodi to the oSEC, 23.08.1971, p. 2, SFA E2001E-o1\#1982/58\#66o3*

17 Pierre Graber, Federal Councillor and head of the FPD, proposal to the Federal Council, "Modification de la competence juridictionnelle des ambassades du Caire et de Dar es Salaam" (inter alia), 24.05.1971, secret, p. 3, SFA E2004B\#1982/69\#122*. On Nyerere's vision of Socialism, see Vijay Prasad, The Darker Nations. A People's History of the Third World, New York: The New Press, 2007, pp. 191-203.

19 Letter from Lucien A. Mossaz, Swiss ambassador in Tanzania, to Antonino Janner, head of the AD, "Visite d'adieu en Somalie", o8.10.1974, confidential, SFA E2004B\#199o/219\#615* and handwritten comments on this document; letter from Alfred Glesti, AD, to the Swiss embassy in Tanzania, "Agence consulaire à Mogadiscio", o8.01.1975, SFA E2004B\#199o/ $219 \# 615^{*}$. 
Swiss ambassador to this country was not necessary for the time being. ${ }^{20}$ The Swiss government's tacit decision to let matters rest met with little interest and caused no rupture between the two states.

This decision was only criticised once. In late 1976, after the Soviet-allied MPLA had won the Angolan War, Richard Pestalozzi, Swiss ambassador to Kenya and one of the FPD's foremost advocates for a more active policy towards the Third World, urged his superiors to take up diplomatic relations with Somalia again. Pestalozzi argued that, even if the Somali regime's treatment of Camenzind and Mossaz had been unfriendly, the Swiss authorities should be more tolerant of Third World states. He underlined that the lack of a diplomatic representation in Somalia was not only contrary to the principle of universality in foreign relations, but also facilitated Soviet influence in the country. Finally, Pestalozzi insisted that a consulate was also of practical importance, as Switzerland had, through charitable organisations such as the Swiss Red Cross (SRC), repeatedly granted humanitarian aid to the droughtand famine-stricken country. ${ }^{21}$ Bern did not comment on the argument that Switzerland had a share in the Western bloc's responsibility to contain Soviet influence in the Third World. The deputy head of the DPA's African, Asian, Middle Eastern and Latin American Division, Hansjakob Kaufmann, simply replied that the decision not to accredit an ambassador to Somalia was due to budget constraints. ${ }^{22}$

Thus, in late 1976, diplomatic relations between Switzerland and Somalia were de facto suspended. Somalia's limited political and economic importance for Switzerland, its unfriendly attitude towards Swiss representatives to the country, and the troubled state of federal finances certainly explain why the FPD decided to ignore the principle of universality in the case of Somalia. However, the question of the extent to which the ideological orientation of Siad Barre's regime influenced this decision needs to be addressed. The Somali government's links with the Soviet Union were never mentioned in discussions about the state of bilateral relations from late 1974 onwards. To conclude that they did not play a role, or that a socialist Somalia was not considered a danger to overall Swiss interests would be too simple, especially considering the Swiss authorities'

20 Bernard Freymond, FPD, minutes of the 1oth meeting of Commission I (representations) of the 'Florian' working group on 5 December 1974, 09.12.1974, p. 3, SFA E2004B\#1996/399\#12*. Letter from Richard Pestalozzi, Swiss ambassador in Kenya, to the DPA, "Diplomatische Vertretung in Somalia", 11.10.1976, SFA E2004B\#199o/219\#381*; see also letter from Pestalozzi to the DPA and the AD, "Diplomatische Vertretung in Somalia", 20.08.1976, ibid. ern and Latin American Division, to the Swiss embassy in Kenya, "Diplomatische Vertretung in Somalia", 22.11.1976, SFA E2004B\#1990/219\#381*. 
generally anti-Communist position. It seems more probable that, unlike Ambassador Pestalozzi, most FPD leaders did not feel responsible for maintaining relations with Somalia and thereby trying to influence its government's ideological orientation. They appear to have been content to delegate this responsibility to the bigger members of the Western bloc, first and foremost the US.

\section{2 "Eventful Times": Reactions to the 1974 Ethiopian Revolution}

The Ethiopian Revolution was not entirely unexpected to the Swiss authorities, as Haile Selassie's reign had long been disputed. However, the radical turn it would take caught them off guard. The Somali coup d'état five years previously had certainly not prepared them for the profound effects that the revolution would have on Swiss-Ethiopian relations. The military and civilian uprisings that broke out in Ethiopia in early 1974 and led gradually to the deposition of Emperor Haile Selassie and the takeover by a military regime in September of the same year, did not immediately raise concern in Bern. Kept abreast of the sweeping political changes in Ethiopia through the reports of Ambassador Heinz Langenbacher, the FPD continued its humanitarian and development activities. Later, however, Swiss interests, notably the Duke of Harar Memorial Hospital, were directly targeted. The deposition of the Emperor, which was accompanied by rumours about his assets in Swiss banks, was a turning point for Swiss-Ethiopian relations and soured Bern's links with the new regime. In late 1974, the execution of about 6o high-ranking former dignitaries provoked the Swiss government's first, albeit extremely cautious, public statement on the situation in Ethiopia.

During the early phase of the Ethiopian Revolution, the Swiss authorities observed the situation without taking a stand and were careful not to get involved. Heinz Langenbacher's initial reports on what he considered to be the fiercest incidents of public opposition in the last few years focused on the safety of Swiss citizens and interests in Ethiopia in these "eventful times". ${ }^{23}$ Langenbacher's reports contain no hint of possible Communist activities behind the uprisings. This tallies with a report from the Swiss embassy in Washington from early March, that a State Department official categorically excluded any foreign influence in the revolution. ${ }^{24}$ The majority of foreign diplomats in

23 PR no 8 from Heinz Langenbacher, Swiss ambassador in Ethiopia, "Aethiopien in Bewegung”, 05.03.1974, p. 3, SFA E2300-01\#1977/30\#3*. See also PR no 6 from Langenbacher, "Aethiopien: Erste Bilanz der Unruhen", 25.02.1974, ibid.

24 Telegram no 131 from Felix Schnyder, Swiss ambassador in the USA, "la crise ethiopienne vue de Washington”, o7.03.1974, p. 1, SFA E2001E-o1\#1987/78\#2801*. 
Addis Ababa agreed that the new government appointed as a result of the public protest should be cautiously supported, as divisions within the armed forces made the alternative-a military regime-unattractive. ${ }^{25}$ DPA members were relieved that the Swiss embassy in Ethiopia did not have a radio connection to Geneva and that they could therefore refuse, in mid-March, the imperial family's request to send encoded messages through its diplomatic channels to the Ethiopian Crown Prince, who lived in Geneva for medical reasons. ${ }^{26}$ Despite the uprisings, Bern continued planning an intervention by the newly-founded Swiss Disaster Relief Corps in the famine-affected areas of Ethiopia. ${ }^{27}$

In April 1974, the situation became more alarming from the Swiss government's point of view. Langenbacher reported that both the US, through its stake in the university in Addis Ababa, and the UssR, through the trade unions, now tried to influence events in Ethiopia. ${ }^{28}$ However, Moscow's reaction to the Ethiopian uprisings was cautious. Soviet and Eastern bloc embassy personnel in Addis Ababa observed the events with great interest, but were careful not to give rise to suspicions that they were supporting leftist extremists. ${ }^{29}$ The civil uprisings in Addis Ababa were also felt in the Duke of Harar Memorial Hospital, which had been opened just a few months before political unrest began to spread and was one of the most important Swiss development cooperation projects on the African continent. In mid-March 1974, a delegation of Ethiopian nursing staff had made a number of complaints to the Ministry of Health. They protested discrimination against Ethiopian staff members and the overly demanding attitude of the Swiss staff and requested more privileges. The Swiss hospital management entered into drawn-out negotiations with the protesters and finally managed to calm the situation..$^{30}$ The Ethiopian press increasingly attacked the hospital, as well as foreign firms and investments. In mid-April,

25 PR no 9 from Heinz Langenbacher, "Kontrolliertes Abwarten in Aethiopien", 12.03.1974, SFA E2300-01\#1977/30\#3*.

26 Letter from Heinz Langenbacher to the DPA, "Unrast in Aethiopien", 19.03.1974, strictly confidential, SFA E2001E-01\#1987/78\#2801*, and handwritten comments on this document.

27 No author (STC), information document, "Informations-Unterlagen zu einer Antwort des Bundesrates an der Sitzung der Sektion 'Politisches Departement' der GPK des NR vom 29. April 1974", 25.03.1974, dodis.ch/39676. PR no 17 from Heinz Langenbacher, "Aethiopien: Agitation und Unrast gehen weiter", 16.04.1974, p. 2, SFA E2300-01\#1977/30\#3*.

29 Yordanov, The Soviet Union and the Horn of Africa, pp. 124-128.

30 Letter from Dr. Johannes Bircher, Swiss hospital management, to the project management in Bern, 01.04.1974, attached to the letter from Heinz Langenbacher to the STC, "Duke of Harrar Spital", 01.04.1974, SFA E2O05A\#1985/101\#216*. 
the Council of Ministers considered the introduction of a state monopoly on the import of pharmaceutical products. ${ }^{31}$

From that time onwards, the spectre of nationalisations and other economic measures that threatened Swiss interests in Ethiopia was ever present. The approximately 1,00o workers on the Swiss Bilate cotton plantation went on strike, supported by the union in Addis Ababa. After his negotiations with union representatives and workers failed, the manager contacted the Minister of Interior and had the leaders of the strike arrested. It was not until midMay that work on the plantation resumed. ${ }^{32}$ In late April 1974, a committee of various Ethiopian army and security forces took matters into its own hands and started arresting officials and other representatives of the old regime. Although the committee expressed its allegiance to Haile Selassie's government and soon stopped its activities, Heinz Langenbacher interpreted this as one step further towards military dictatorship. As criticism of the Emperor increased, the ambassador also linked the army's assertiveness to the Portuguese military coup on 25 April that might have served as a model for the Ethiopian army. ${ }^{33}$

On 12 September 1974, Emperor Haile Selassie was arrested and the PMAC officially took power. For Bern, the regime change's most worrying consequence was the accusation made in Ethiopian newspapers, starting in midSeptember, that the deposed Emperor had deposited public funds in Swiss banks. The ensuing bilateral difficulties are discussed later in this chapter. On a legal level, the regime change did not necessitate a direct Swiss reaction. Like France and other Western European states, Switzerland recognises states, not governments. Thus, no official acknowledgement of the regime change was needed. The UK, which does recognise governments, did so in a note one week

PR no 14 from Heinz Langenbacher to Pierre Graber "Weiterhin unruhiges Aethiopien”, 02.04.1974, SFA E2300-O1\#1977/30\#3*; letter from Langenbacher to the Trade Division, "Einfuhr von pharmazeutischen Produkten in Aethiopien", 23.04.1974, SFA E7110\#1985/97\#1850*, letter from Langenbacher to Marcel Heimo, Delegate for Technical Cooperation, "Duke of Harrar Spital in der aethiopischen Presse unter Beschuss", 29.04.1974, SFA E2OO1E-O1\#1987/78\#2799*.

Letter from Heinz Langenbacher to the DPA, "Gefährdung der Plantage unseres Landsmanns Demaurex", 23.04.1974, SFA E2OO1E-o1\#1987/78\#2798*; letter from Langenbacher to the DPA, "Schliessung der Schweizer Plantage Demaurex", 26.04.1974, ibid., letter from Langenbacher to the DPA, "Schliessung der Schweizer Plantage Demaurex", 07.05.1974, ibid., letter from Langenbacher to the DPA, "Schweizer Plantage in Bilate", 14.05.1974, ibid. PR no 19 from Heinz Langenbacher, “Aethiopien: Die Armee greift ein", 29.04.1974, SFA E2300-01\#1977/30\#3*. See also Andargachew Tiruneh, The Ethiopian Revolution, p. 5 ०. 
after the arrest of the Emperor. The US government argued that the question of recognition did not arise, and that relations should continue as before. ${ }^{34}$

The Ford Administration's laissez-faire approach to the Ethiopian Revolution disconcerted Swiss policymakers. A few days after the deposition of the Emperor, the Swiss chargé d'affaires in Washington, Olivier Exchaquet, reported that the US government viewed the political changes in Ethiopia in a rather positive light, although the dangers of radicalisation and increased Soviet and Chinese influence were not yet averted. Edward William Mulcahy, Deputy Assistant Secretary of State for African Affairs, told Exchaquet he found it surprising that "the US, whose military and economic assistance of Ethiopia is extremely important, has never been mentioned since the beginning of the slow military revolution; even the CIA, which is readily and often for good reason the target of leftist elements, has never been attacked so far." 35 Although the Derg tried, from its takeover, to enter into an alliance with the Soviet Union, Moscow was, at first, reluctant to improve relations with Ethiopia to an extent that would endanger its ties with Somalia. As long as military assistance from the Soviet Union was not forthcoming, the Derg made sure not to break with the US in order to ensure continued arms supplies. ${ }^{36}$ Mulcahy's positive evaluation of the Ethiopian situation did not reassure Exchaquet. The Swiss chargé d'affaires concluded that the US State Department was so puzzled by the machinations of the Ethiopian generals that it did not even try to understand events that he himself considered to be rather disconcerting. ${ }^{37}$ This is a sign of the progressive lack of confidence of Swiss diplomats in the US government's interpretation of events in Africa and its policies on that continent that would increase over the following years.

On 23 November 1974, the military regime's increasingly harsh treatment of the opposition culminated in the execution without trial of about 6 o former dignitaries of Haile Selassie's government and members of the armed forces. The Derg's chairman, General Aman Andom, was also killed. There was a strong international reaction to these executions, which damaged the Derg's image in many states. On the morning of 26 November, Heinz Langenbacher wired to the FPD that the Derg was planning another series of executions and

34 Note from R. A. Neilson, East African Department (EAD) of the British FCO, to Norman Aspin, Assistant Under-Secretary of State, FCO, "Ethiopia: Recognition of the new military administration", 17.09.1974, TNA FCO 31/1681, and handwritten notes on the document. PR no 85 from Olivier Exchaquet, chargé d'affaires of the Swiss embassy in the US, "Les événements d'Ethiopie vus de Washington", 18.o9.1974, p. 2, SFA E2001-o9\#1984/68\#49*.

36 Westad, The Global Cold War, pp. 262-265.

37 PR no 85 from Olivier Exchaquet, "Les événements d'Ethiopie vus de Washington", 18.og.1974, p. 3, SFA E2001-o9\#1984/68\#49*. 
that the ambassadors of the EEC member states and an ICRC delegate present in Addis Ababa had suggested that their headquarters should send an appeal to the PMAC to respect humanitarian principles. ${ }^{38}$ Fearing for the lives of the imprisoned Ethiopian imperial family, the British, French, and Italian ambassadors in Addis Ababa had indeed taken the initiative to encourage a common EEC appeal to the Derg. London suggested that several African governments should make use of their influence on the Ethiopian regime. The ICRC was first to intervene directly on 26 November, with a telegram to the Derg. The following day, an EEC protest note was handed over. Covered by the EEC petition, the US State Department authorised its chargé d'affaires in Ethiopia to deliver a low-key message to the military government, even though the US was in a vulnerable position due to its long-standing military relationship with Haile Selassie's government. The UN Secretary-General and the President of the UNGA also appealed for clemency. ${ }^{39}$

Before deciding on its own course of action, the FPD requested detailed information about the EEC's plans. The department's secretary general telephoned the neutral governments in Vienna and Stockholm, learning that, while the Austrian government had not yet considered taking a stand, the Swedish authorities planned to join with the other ambassadors in Addis Ababa, support UN appeals, and announce all these actions publicly. ${ }^{40}$ The EEC appeal and the Swedish position figured prominently in the FPD's proposal to the Federal Council that the Swiss government comment briefly on the events in Ethiopia. ${ }^{41}$ This testifies to the department's Western European frame of reference when it came to foreign policymaking on Africa. On 2 December 1974, the

38 Telegram no 342 from Heinz Langenbacher to the FPD, 26.11.1974, SFA E2Oo1E-o1\#1987/ $78 \# 2801^{*}$.

39 Telegram no 578 from Willie Morris, British ambassador in Ethiopia, to the FCO, 26.11.1974, TNA FCO 31/1677; telegram no 574 from Morris to the FCO, 25.11.1974, ibid.; telegram no 575 from Morris to the FCO, 26.11.1974, ibid.; note from M. K. Ewans, EAD, to Norman Aspin, "Ethiopia", 25.11.1974, ibid.; telegram no 702 from James Callaghan, Foreign Secretary, to the British embassies in Kenya, Sudan, Nigeria, Zambia, Ghana, and Tanzania, "Ethiopia", 25.11.1974, ibid.; telegram from Robert Stephen Ingersoll, Deputy Secretary of State, to the US embassy in Ethiopia, 26.11.1974, NARA, RG 59, AAD, CFPF, Electronic Telegrams 1974, 1974STATE261115; telegram from Ingersoll to all US diplomatic posts in Africa, 27.11.1974, ibid., 1974STATE261727; telegram no 21050 from Roger Gallopin, President of the ICRC's Executive Council, to the Provisional Military Government of Ethiopia, 26.11.1974, AICRC B AG 225 072-0o8.

Telegram from Michael Gelzer to the Swiss embassies in the E EC member states, 27.11.1974, urgent, SFA E2OO1E-o1\#1987/78\#2801*; note from Ernesto Thalmann, secretary-general of the FPD, to Gelzer, "Aufruf des Bundesrates an äthiopische Machthaber", 27.11.1974, ibid. Georges-André Chevallaz, Federal Councillor and deputy head of the FPD, proposal to the Federal Council, "Exécutions à Addis-Ababa”, 29.11.1974, SFA E20o1E-o1\#1987/78\#2801". 
Federal Council broke its official silence about the events in Ethiopia and the policies of the Derg. It published a short statement, expressing its dismay at the loss of life and its hope "that justice and humanity would prevail in Ethiopia and peace return to this country."42 The cautious wording of the statement, which was couched in humanitarian terms, highlights the Swiss authorities' unwillingness to give the impression of interfering in Ethiopia's internal affairs. That they nevertheless decided to go public can be explained, on the one hand, by the interventions of other states that served as examples. On the other hand, and more decisively, the Swiss government was, in early December, under pressure to reveal the state of its diplomatic exchanges with the PMAC concerning the Emperor's assets in Switzerland. Making a public statement about SwissEthiopian relations without mentioning the widely publicised executions in this country would have raised questions, especially as the executions could be used to delegitimise the Derg and its appeals for the repatriation of the Emperor's assets. ${ }^{43}$

The executions of 23 November were a turning point for Ethiopia's foreign relations, and alienated Western and African governments. The press and public opinion in many African states condemned the PMAC's violent policies. According to the US chargé d'affaires, the reactions of African diplomats in Addis Ababa and of OAU officials varied "from revulsion and disgust [...] to regret but cautious hope 'dirg' will now be able to make compromises necessary to unify country." 44 Conscious of Haile Selassie's prestige and worried that the violent events in Ethiopia might tarnish Africa's global image, African diplomats even debated relocating the OAU's headquarters, from where the mass graves of the executed were clearly visible. ${ }^{45}$ The Derg's violent treatment of the opposition also influenced relations with Switzerland. Members of the Ethiopian Foreign Ministry assured Heinz Langenbacher that the PMAC was aware of its humanitarian obligations, that political prisoners would receive a proper trial, and that no more executions would take place. ${ }^{46}$ But while the

42 Information Service of the Federal Chancery, press statement, "Erklärung des Bundesrates", 02.12.1974, SFA E2001E-o1\#1987/78\#2801*.

43 See telegram no 398-40o from Bernard Dufournier, French ambassador in Switzerland, to the French Foreign Ministry, 03.12.1974, CAD 206QO/169.

44 Telegram from [?] Wyman, US embassy in Ethiopia, to the Secretary of State, o2.10.1974, p. 1, NARA, RG 59, AAD, CFPF, Electronic Telegrams 1974, 1974ADDIS14234.

45 Diplomatic report no 402/74 from Willie Morris to the FCO, "Ethiopia's bloodless revolution turns bloody: the massacre of 23 November", 03.12.1974, p. 4, TNA FCO 31/1677; PR no 49 from Heinz Langenbacher, "Militär-Diktatur Aethiopien", o3.12.1974, pp. 2-3, SFA SFA E2300-01\#1977/30\#3*.

46 Letter from Heinz Langenbacher to the DPA, "Der Bundesrat zur Lage in Aethiopien", 03.12.1974, SFA E2OO1E-O1\#1987/78\#2801*. 
Armed Forces Committee adopted a more conciliatory approach after the executions, the Swiss government was, from December 1974 onwards, far less willing to compromise with the Derg, especially when it came to the issue of Haile Selassie's assets in Switzerland.

\section{"Blood Money": Controversy over the Ethiopian Emperor's Swiss Bank Accounts}

After the deposition of Haile Selassie in September 1974, accusations made by the Ethiopian press, and immediately taken up by the public and the Derg, that Swiss banks were harbouring several billion francs that the former Emperor had transferred out of Ethiopia seriously impaired Swiss-Ethiopian relations. The PMAC and the Ethiopian Foreign Ministry subsequently made serious, but ultimately unsuccessful, efforts to gain the Swiss authorities' cooperation to repatriate the Emperor's assets. ${ }^{47}$ The controversy surrounding Haile Selassie's Swiss bank accounts was not unique. Based on documents from the SFA, historian Christophe Farquet identified more than twenty disputes concerning capital flight from Third World countries to Switzerland between the 195os and the $1970{ }^{48}{ }^{4}$ A detailed analysis of how the Swiss political and financial elites collaborated to rebut the Ethiopian accusations and preserve Switzerland's image in that country therefore holds relevance beyond the study of SwissEthiopian relations after the revolution. It also deepens our understanding of Bern's general strategies to protect the banking secret in the Third World. The

A first contribution to the study of this affair has recently been made by El Ammari, Les autorités politiques suisses face aux réclamations d'avoirs illicites.

48 Christophe Farquet, "Au-delà des affaires, de la corruption et de la spéculation. Analyse de la fuite de capitaux vers le nord au temps de la décolonisation au travers des sources diplomatiques suisses", Economic History Working Papers 4 (2017), especially p. 17. On the Swiss banking secret and the role of Swiss banks in the country's foreign policy, see notably Sébastien Guex, "The Origins of the Swiss Banking Secrecy Law and its Repercussion for Swiss Federal Policy", Business History Review 74 (2000), pp. 237-266; Christophe Farquet, La défense du paradis fiscal suisse avant la Seconde Guerre mondiale: une histoire internationale. Analyse de la politique helvétique dans les négociations sur la double imposition et l'évasion fiscale durant l'entre-deux-guerres, Neuchâtel: Éditions Alphil-Presses universitaires, 2016; Peter Hug, "Steuerflucht und die Legende vom antinazistischen Ursprung des Bankgeheimnisses. Funktion und Risiko der moralischen Überhöhung des Finanzplatzes Schweiz", in Jakob Tanner, Sigrid Weigel (eds.), Gedächnis, Geld und Gesetz. Vom Umgang mit der Vergangenheit des Zweiten Weltkrieges, Zürich: vdf Hochschulverlag AG an der ETH Zürich, 2002, pp. 269-321; Marc Perrenoud, "La place financière suisse en tant qu'instrument de la politique étrangère helvétique", Relations internationales 121 (2005), pp. 25-42; Schaufelbuehl, La France et la Suisse. 
analysis remains, however, limited by the lack of sources from the Ethiopian government and from Swiss banks. Although the SBA was an important actor in this controversy, its archives are fragmented and only a single reference to this affair could be found. The study is therefore based almost entirely on Swiss and Western diplomatic sources.

The Emperor's Swiss bank accounts were at the heart of Ethiopian propaganda against Haile Selassie. Immediately before and after his deposition, press reports linked Haile Selassie's investments abroad with the famine in Ethiopia. Switzerland was first explicitly targeted on 15 September 1974, three days after the Emperor was forced to step down. An article published in the English-language newspaper Ethiopian Herald accused the country of having attained its prosperity by benefiting from a poor Third World country:

As for the billions of dollars, it is blood money! Let tiny Switzerland triple its living standards by it, and come back to Africa to help us, a poor underdeveloped country, and modernize our hospitals and selflessly participate in Red Cross and welfare programs because they love us! We don't beg for their aid, we demand our legitimate but stolen money which they kept in their banks with mutual and criminal consent. ${ }^{49}$

The allusion to Switzerland's humanitarian image and especially its support for the Duke of Harar Memorial Hospital rendered the accusation particularly serious. Over the following days, the press continued to promote this connection between Switzerland's financial policies and the suffering of the Ethiopian people, which caused public outrage. The extent to which this press campaign was instigated by the Derg remains unclear.

Swiss embassy personnel in Addis Ababa viewed these press reports with concern and prepared to deal with public demonstrations against Switzerland. ${ }^{50}$ Hans Schärer, in charge of the embassy while Ambassador Langenbacher was on holiday, requested a meeting with Ethiopia's new leader, General Aman Andom, to seek reassurance that the safety of Swiss citizens and interests would be guaranteed. During this meeting, on 23 September 1974, the general told Schärer that he had solid evidence that the Emperor's assets of $\$ 15$ billion

49 Cited in the Letter from Hans Schärer, chargé d'affaires ad interim at the Swiss embassy in Ethiopia, to the DPA, "Aethiopische Geldanlagen in der Schweiz", 16.og.1974, p. 2, SFA E2001E-o1\#1987/78\#1001*.

50 Telegram no 262 from Hans Schärer, Paolo Brogini, and [?] Markstaller to the FPD, 13.09.1974, SFA E2OO1E-O1\#1987/78\#2801*. 
(CHF 45 billion) were invested almost exclusively in Switzerland. ${ }^{51}$ That the Ethiopian head of state was willing to take the time to receive the Swiss chargé d'affaires himself, less than two weeks after the takeover by the Derg and at a time of great political turmoil, testifies to the importance of the issue for the new government. Widespread poverty and famine in Ethiopia meant that the PMAC had great need of additional funds. This episode also refutes the assertion frequently advanced by Western observers critical of the Derg that the accusations against Switzerland served solely to destroy the image of Haile Selassie. Although the vilification of the Emperor certainly served the PMAC's interests, the regime initially had real hope of repatriating the Emperor's funds.

Why was Switzerland singled out in this brazen manner? It could be advanced that this was because the Emperor really did transfer significant sums to Swiss banks, and only Swiss banks. This answer, however, is not sufficient. Although Haile Selassie did indeed have assets in Switzerland, the Derg was never able to prove this, and the sums claimed seem to have been exaggerated. Furthermore, the Derg had access to information that the Ethiopian imperial family had also transferred some capital to other countries, notably the UK and the US. Other additional factors explain why Switzerland was targeted. As the Emperor and his family had close links to Switzerland and it was a known fact that Haile Selassie owned a villa in the country, it was not far-fetched to suspect that he also possessed Swiss bank accounts. From a propaganda point of view, allegations against Switzerland were immediately credible due to the reputation of Swiss banks with their strict interpretation of the banking secret and international headlines about several cases of capital flight from African countries to Switzerland since the early 196os. ${ }^{52}$ Finally, Ethiopian decision-makers certainly preferred to focus the press campaign on a small country with limited political influence, rather than affront the US and the UK at a time when the new regime was still trying to preserve good relations with the Western bloc.

The Derg's hope that the Swiss government would help to repatriate the Emperor's funds proved to be false. Heinz Langenbacher, who broke off his holiday to deal with the affair, was instructed by the deputy chief of the DPA in late September to "draw his Ethiopian interlocutors' attention, in a suitable manner, to the counterproductive effects that the continuation of the unfriendly press campaign against our country might have on all Swiss aid to

Letter from Hans Schärer to the DPA, "Aethiopische Geldanlagen in der Schweiz", 24.09.1974, SFA E2OO1E-O1\#1987/78\#1001*. The sum has been converted to CHF using the exchange rates indicated in Officer, "Exchange Rates Between the United States Dollar and Forty-one Currencies".

Farquet, "Au-delà des affaires", pp. 5-6. 
Ethiopia". ${ }^{33}$ The Swiss government was not above using aid as diplomatic leverage to obtain its priority objective; containment of the rumours. It showed no interest in investigating what truth lay in them. This reaction is representative of what Christophe Farquet called the Swiss "strategy of suppressing and managing crises" when faced with allegations of capital flight. ${ }^{54}$

Ambassador Langenbacher immediately set to work. He met with Ethiopian officials, sent a letter to the approximately 200 Swiss citizens living in Ethiopia in order to reassure them, and planned to publish statements and give interviews to counteract the Derg's propaganda. In early October, he met with Ethiopia's Acting Foreign Minister and the Minister of Information to try and calm the situation. Underlining the damaging effects of the rumours on relations between the two states, Langenbacher handed them a memorandum that explained Switzerland's banking secret and its government's limited means of intervention. While his interlocutors promised to placate the public and the press, they nevertheless insisted on the gravity of the accusations, which the government intended to pursue. ${ }^{55}$ Although the head of the FPD and other high-ranking members of the department were regularly briefed on developments in this affair, ${ }^{56}$ the Swiss ambassador to Ethiopia was largely given free rein to deal with the situation as he saw fit.

While media reports died down after Langenbacher's meeting at the Foreign Ministry, public outrage in Ethiopia continued. Members of the Swiss embassy were verbally and physically attacked. The Swiss team at the Duke of Harar Memorial Hospital experienced increasing hostility from their Ethiopian counterparts. ${ }^{57}$ According to Langenbacher, the Swiss were, in early October 1974, part "of Addis Ababa's most hated foreigners", which was grist to the mill for some OAU diplomats: "They refer to the conduct of Swiss economic circles with regard to Rhodesia and South Africa and assert that Switzerland shows once more its true colours as 'cynical profiteers and hypocrites". 58 In November, the Ethiopian security police interrogated a Swiss businessman, suspect-

53 Michael Gelzer, memorandum, "Aethiopische Geldanlagen in der Schweiz", 30.09.1974, SFA E2OO1E-o1\#1987/78\#1001*.

54 Farquet, "Au-delà des affaires", p. 10.

55 Letter from Heinz Langenbacher to the DPA, "Vermögen des ex-Kaisers bei Schweizerbanken?", 07.10.1974, SFA E7110\#1985/97\#456*; telegram no 296 from Langenbacher to the FPD, 08.10.1974, SFA E2001E-o1\#1987/78\#1001*.

56 Michael Gelzer, handwritten memorandum, 10.10.1974, SFA E2001E-o1\#1987/78\#1001*.

57 Letter from Heinz Langenbacher to the DPA, "Lage in Aethiopien", 15.10.1974, SFA E2001E-01\#1987/78\#2801*.

58 Letter from Heinz Langenbacher to the DPA, "Vermögen des ex-Kaisers bei Schweizerbanken?", o7.10.1974, p. 5, SFA E7110\#1985/97\#456*. 
ing that he had helped an arrested Ethiopian princess, who was an associate in one of his plantations, to transfer funds to Switzerland. ${ }^{59}$ Aside from the immediate danger to Swiss citizens, the controversy also damaged Switzerland's image, not only in Ethiopia but also on the African continent as a whole.

Reports about the scale of the Emperor's assets in Switzerland were contradictory from the start. The $\$ 15$ billion that Aman Andom had mentioned to Schärer in September 1974 later became 15 billion Ethiopian birr (about CHF 21 billion), several billion birr, or simply a considerable sum. There were also rumours about Haile Selassie's alleged investments in the President Hotel in Geneva and firms like Omega watches and Oerlikon Bührle. In October, Langenbacher heard from a trusted Ethiopian source that the maximum amount the Emperor might have transferred to third countries was CHF 14O-200 million, a sum he seems to have considered plausible. ${ }^{60}$ While the ambassador generally insisted that the amounts mentioned were greatly exaggerated, it is noticeable that he never questioned the basic allegation of capital flight to Switzerland. This is even more striking as the Derg could produce almost no evidence for its claim. After a meeting with General Aman Andom on 10 October, Langenbacher reported that the Derg possessed only a single document attesting to assets of the Emperor in the Industrie- und Handelsbank Zürich. This private bank was founded by industrialist Emil Bührle, Ethiopia's former honorary consul in Zurich. ${ }^{61}$

After this meeting with the chairman of the Derg, Heinz Langenbacher became increasingly pessimistic about the future of Swiss-Ethiopian relations. Fearful of the consequences once the PMAC realised how limited the Swiss government's means - or rather willingness - to intervene really were, the Swiss embassy in Addis Ababa adopted a low profile. In this, Langenbacher enjoyed the moral support of his Western colleagues. They mostly agreed that the Ethiopian claims were exaggerated and purely political, serving to discredit the former Emperor. According to them, the choice of Switzerland, a "traditional country of investments", as a scapegoat served to increase the credibility

59 Letter from Heinz Langenbacher to the DPA, "Feindselige Haltung Schweizern gegenüber", 11.11.1974, SFA E2Oo1E-o1\#1987/78\#2798*; letter from Langenbacher to the DPA, "Jean Demaurex, General Manager der Cafex: Ausreise-Visum", 11.02.1975, ibid.

6o Letter from Heinz Langenbacher to the DPA, "Vermögen des Kaisers in der Schweiz? 14.10.1974, confidential, pp. 1-2, SFA E2OO1E-01\#1987/78\#2799*; letter from Langenbacher to the DPA, "Vermögen des Kaisers", 24.10.1974, p. 1, SFA E7110\#1985/97\#456*.

61 Letter from Heinz Langenbacher to the DPA, "Vermögen des Kaisers in der Schweiz? 14.10.1974, confidential, p. 1, SFA E2001E-o1\#1987/78\#2799*. 
of the allegations. ${ }^{62}$ Although Aman Andom had mentioned to Langenbacher that Haile Selassie also had assets in British and US banks, the Derg never contacted these states' embassies in Ethiopia. This suggests that the Ethiopian regime did not want to antagonise these powerful countries. As Langenbacher wrote to the DPA, the US chargé d'affaires showed much sympathy for Switzerland's difficulties - and disdain for Third World criticism of unlawful Northern practices in the global South: "Incidentally, the American remarked kindly: 'Switzerland and the States have nearly the same problem between myths and emotionalism. You: your banks; we: the CIA!" 63

In mid-October 1974, the Derg raised the stakes and announced that it would send a delegation to Switzerland to discuss the political and legal problems regarding the Emperor's assets. The delegation sought talks with high-ranking members of the FPD and with the president of the SBA. ${ }^{64}$ Fearing retaliatory action against Swiss citizens in Ethiopia, FPD officials tried to convince the SBA to cooperate with the Derg. In a letter to the president of the SBA, Alfred E. Sarasin, the Secretary General of the department underlined the gravity of the situation in Ethiopia and the danger it posed to the security of Swiss nationals living there. Since the presence of the OAU headquarters in Addis Ababa meant that events there had great influence on other African states, he argued that it was in the SBA's own interest to save the reputation of Swiss banks on the African continent. More significantly, he underlined that a show of goodwill was particularly important because the Swiss authorities were, on legal grounds, unable to give information to the delegation, an argument that might be difficult to understand for the Ethiopians. ${ }^{65}$ The Swiss government planned to deal with the Ethiopian delegation in a similar manner to the OAU delegation that had visited Bern in April 1972; to receive it with all honours, but ultimately make no substantial concessions. ${ }^{66}$ During a meeting on 29 October 1974 between the SBA president and high-ranking FPD officials in Bern, a legal

\footnotetext{
$62 \quad$ Ibid., p. 2.

63 Letter from Heinz Langenbacher to the DPA, "Kaiserliches Vermögen in der Schweiz? 18.10.1974, SFA E711O\#1985/97\#456*.

64 Telegram no 300 from Heinz Langenbacher to the FPD, 16.10.1974, SFA E2001E-o1\#1987/ 78\#1001*.

65 Letter from Ernesto Thalmann to Alfred E. Sarasin, President of the SBA, "Relations avec l'Ethiopie concernant les avoirs du Négus en Suisse", 21.10.1974, SFA E2001E-o1\#1987/ $78 \# 1001^{*}$.

66 This link was explicitly made by Ambassador Langenbacher, who argued that the red carpet-treatment had worked very well with the OAU delegation: letter from Heinz Langenbacher to the DPA, "Kaiserliches Vermögen in der Schweiz? 04.11.1974, SFA E711O\#1985/ $97 \# 456$.
} 
approach to the problem prevailed. The majority of those present agreed that the Ethiopian delegation had to prove its claims and take legal action in order to repatriate possible assets. Alfred Sarasin refused to see the delegation that was scheduled to arrive in mid-November. ${ }^{67}$

Even within the Swiss federal administration, this legalistic interpretation of the Swiss banking secret was not uncontroversial. Two attendees at the meeting advocated a more accommodating position, mainly due to the potential political fallout if Swiss citizens were to suffer because of the activities of the banks. Curt Alfred Markees of the FDJP therefore suggested that the Swiss authorities should make enquiries about the Emperor's accounts in Swiss banks. ${ }^{68}$ The head of the Financial and Economic Service of the FPD, Jean Zwahlen, went even further and called the Swiss banking secret into question. As attacks against Swiss banks for harbouring the assets of politically exposed persons were increasingly frequent and Third World countries critical of Switzerland's banking system had great political weight in international organisations, he argued that the Swiss authorities were constricted by the banking secret. This institution prevented Bern from obtaining the information necessary to deal adroitly with such accusations. As public opinion in Switzerland was also increasingly critical of the banking secret, Zwahlen maintained that banks should be forced to behave more responsibly. He closed his memorandum of the conversation with the sBA delegation by querying whether the Swiss banking secret should really be fully maintained, or whether the revision of Swiss banking law should be considered. ${ }^{69}$ No response to this suggestion is recorded.

In the meantime, the Ethiopian authorities continued to search for proof of the Emperor's assets in Switzerland. The governor of the National Bank of Ethiopia met the imprisoned Haile Selassie several times and went over his books. However, Aman Andom and the Derg were unwilling to accept the banker's

67 Alfred E. Sarasin, W. E. Flückiger, minutes of the 142nd meeting of the Committee of the SBA on 6 November 1974, p. 10, ASBA VRA142Prot_VB; Jean Zwahlen, head of the FPD's Financial and Economic Service, memorandum of conversation, "Avoirs bancaires en Suisse de l'ex-empereur d'Ethiopie. Préparation de la visite d'une délégation éthiopienne, 13.11.1974, SFA E2001E-o1\#1987/78\#1001*; note from Curt Alfred Markees, FDJP, to Kurt Furgler, Federal Councillor and head of the FDJP, "Angeblich in der Schweiz liegendes Vermögen des äthiopischen Kaisers”, urgent, 12.11.1974, SFA E426oC-o1\#1993/9\#411*.

68 Note from Curt Alfred Markees, to Kurt Furgler, "Angeblich in der Schweiz liegendes Vermögen des äthiopischen Kaisers", urgent, 12.11.1974, p. 2, SFA E426oC-o1\#1993/9\#411*.

69 Jean Zwahlen, memorandum of conversation, "Avoirs bancaires en Suisse de l'exempereur d'Ethiopie. Préparation de la visite d'une delegation éthiopienne, 13.11.1974, pp. 2-4, SFA E2OO1E-01\#1987/78\#1001*. 
conclusion that "only a relatively modest amount of money exists", as the British ambassador wrote to the FC ${ }^{70}$ On 15 November 1974, Langenbacher learned from Aman Andom that the former Emperor had signed a power of attorney for the repatriation of his assets and his children had agreed to close their bank accounts in favour of the Ethiopian people. Foreign diplomats in Addis Ababa observed this development with interest. ${ }^{71}$ Yet, doubts soon arose about the existence of this power of attorney. Mohammed Hamid, legal advisor, head of the US desk at the Ethiopian Foreign Ministry, and leader of the Ethiopian delegation scheduled to travel to Switzerland, told Heinz Langenbacher that he had never seen it. Mohammed Hamid, who had just returned from the UNGA, considered the files on the Emperor's assets to be too incomplete to warrant a trip to Bern and therefore postponed it. ${ }^{72}$ The head of the FPD's Directorate of Public International Law (DPIL) was quite content with this postponement. In a personal letter to Heinz Langenbacher, Emanuel Diez explained why the delegation's visit would be fruitless:

We and especially the banks will have to beware of handing over the money, provided that it belongs to the Ethiopian state, to people that might after a short time disappear from the political stage, and the money with them. Because of this fact alone we need to be extraordinarily cautious, also with regard to possible recommendations to the banks, as the Confederation might otherwise later be made directly liable for damages. ${ }^{73}$

The execution of about 60 political prisoners on 23 November 1974 and the subsequent international outcry delegitimised the Derg and weakened its position in the diplomatic exchanges about Haile Selassie's Swiss assets. On the one hand, the Swiss authorities' willingness to collaborate to a certain extent with the PMAC decreased significantly. During a meeting in the presence of Federal

70 Telegram no 536 from Willie Morris to the FCO, 13.11.1974, TNA FCO 31/1676.

71 Letter from Heinz Langenbacher to the DPA, "Vermögen des Kaisers in der Schweiz", 15.11.1974, SFA E711O\#1985/97\#456*; telegram no 541 from Willie Morris to the FCO, 15.11.1974, TNA FCO 31/1676; telegram no 1249 from [?] Treca, French embassy in Ethiopia, to the Foreign Ministry, 15.11.1974, CAD 206QO/169; telegram from [?] Wyman, US embassy in Ethiopia, to the State Department, 15.11.1974, NARA, RG 59, AAD, CFPF, Electronic Telegrams 1974, 1974ADDIS13655.

72 Letter from Heinz Langenbacher to the DPIL, "Kaiserliches Vermögen in der Schweiz?" 18.11.1974, SFA E711O\#1985/97\#456*.

73 Letter from Emanuel Diez, head of the DPIL, to Heinz Langenbacher, 22.11.1974, personal and confidential, SFA E2001E-o1\#1987/78\#1001*. 
Councillor Pierre Graber a few days after the executions, DPA leaders decided that it was not opportune to receive an Ethiopian delegation as long as the situation in Addis Ababa was "troubled, confused, and chaotic" and as long as the emissaries' mandates and their duration was called into doubt because of the government's fragility. ${ }^{74}$ While the executions served as a welcome pretext to those voices within the FPD that had never wanted to enter into negotiations with the Ethiopian authorities, they also silenced internal calls for some degree of collaboration and a more flexible approach to the banking secret. Meanwhile, possibly as a result of statements made by London-based members of the Ethiopian imperial family after the executions, information about the proposed visit of the delegation leaked to the international press. ${ }^{75}$ This increased the pressure on the Derg to be able to show some positive results from the affair of the former Emperor's assets.

During a press conference on the same day as the publication of the Federal Council's statement on the executions in Ethiopia, the Swiss Vice Chancellor announced the planned visit of the Ethiopian delegation. ${ }^{76}$ As a result of the ensuing publicity, National Councillor Jean Ziegler (Social Democratic Party) asked the government in a parliamentary interpellation to insist that Swiss banks return the Emperor's assets to the Ethiopian people, as the affair risked harming Switzerland's relations with OAU member states. ${ }^{77} \mathrm{He}$ was not heeded. On the contrary, the FPD's attitude had hardened considerably. In a telegram to Langenbacher, Emanuel Diez no longer mentioned political factors, such as the possibility of reprisals against Swiss citizens in Ethiopia, but argued firmly, using legal phraseology. He insisted that the Derg needed to give precise information about the sums concerned and the banks involved if it wanted to have any chance of recovering the assets. Diez suggested that the PMAC engage a Swiss lawyer to follow up on its claims. This was even more advisable, since, as he put it, the Swiss legal system was difficult to grasp for non-European legal experts. ${ }^{78}$

74 Telegram no 256 from Michael Gelzer to the Swiss embassy in Ethiopia, 26.11.1974, SFA E2001E-o1\#1987/78\#1001*.

75 Telegram no 347 from Heinz Langenbacher to the FPD, 27.11.1974, SFA E20o1E-o1\#1987/ $78 \#_{1001}{ }^{*}$; letter from Langenbacher to the Information and Press Service of the FPD, "Vermögen des Kaisers", 28.11.1974, confidential, SFA E7110\#1985/97\#456*.

76 Telegram no 273 from Peter Erni, head of the F PD's Information and Press Service, to the Swiss embassy in Ethiopia, o2.12.1974, SFA E2001E-o1\#1987/78\#2801*.

77 "Interpellation Ziegler-Genève. Gelder aus Aethiopien. Wortlaut der Interpellation vom 4 Dezember 1974", Amtliches Bulletin der Bundesversammlung 1975, Wintersession Nationalrat, 01.12.1975, p. 1545 .

78 Telegram no 285 from Emanuel Diez to the Swiss embassy in Ethiopia, 06.12.1974, SFA E2001E-o1\#1987/78\#1001*. 
After the killing of General Aman Andom in Ethiopia, the alleged power of attorney signed by Haile Selassie could not be found. Both Mohammed Hamid of the Foreign Ministry and Major Mengistu Haile Mariam, the Derg's "strongman", to use Langenbacher's words, and future Ethiopian head of state, independently asked the Swiss ambassador to visit the former Emperor in prison and witness his signature on a new document. ${ }^{79}$ This was the first, albeit indirect, contact between the Swiss authorities and Mengistu. DPA leaders did not approve of this idea, as Langenbacher's presence was no guarantee that the prisoner was not signing under duress and it was doubtful that the banks would accept the legitimacy of the document. Out of concern for the safety of Swiss citizens in Ethiopia, they did not reject the proposal outright, but ordered Langenbacher to do his best to avoid being mixed up personally in the affair. ${ }^{80}$ The Ethiopian authorities' somewhat rash proposal was probably a result of their dismay at the international protests following the executions. In any case, it was not followed up. On 30 November 1974, the Derg publicly announced that the Emperor had agreed to transfer his own and his family's assets to Ethiopia in favour of the famine-stricken areas. The Emperor's letter, which was dated 18 October 1974, no longer singled out Switzerland, but rather mentioned transfers to banks outside of Ethiopia more generally. ${ }^{81}$

In mid-December 1974, the rumours about Haile Selassie's Swiss bank accounts died down and the Derg stopped making demands. In the following months, the Ethiopian authorities hardly ever mentioned the affair. Two factors explain the PMAC's silence: on the one hand, the Derg was busy with the conflict in Eritrea-after the violent death of General Aman Andom, himself Eritrean, hostilities between government troops and liberation movements escalated in this province; on the other hand, a copy of a Swiss Federal Court verdict in a similar case of capital flight had opened the Ethiopian authorities' eyes to the difficulties they faced in seeking repatriation of the funds. In July 1974, the Federal Court had, in fact, set aside an earlier cantonal judgment in favour of the restitution to the Algerian government of funds deposited in

79 Heinz Langenbacher, memorandum, "Vermögen des Kaisers", 28.11.1974, attached to the letter from Langenbacher to the DPIL, "Kaiserliches Vermögen", 28.11.1974, confidential, SFA E711O\#1985/97\#456*.

8o Telegram no 272 from Ernesto Thalmann to the Swiss embassy in Addis Ababa, 29.11.1974, SFA E2001E-o1\#1987/78\#1001*; telegram no 329 from Thalmann to the Swiss embassy in Paris, for the attention of Pierre Graber, 29.11.1974, urgent, ibid.

81 Cited in the letter from Heinz Langenbacher to the DPIL, "Vermögen des Kaisers", o9.12.1974, confidential, p. 1, SFA E7110\#1985/97\#456*; see also letter from Langenbacher to the DPIL, "Vermögen des Kaisers", o3.12.1974, confidential, ibid. 
Swiss banks by the former Secretary General of the FLN ${ }^{82}$ Although the governor of the National Bank of Ethiopia seems to have been in contact with a bank in Zurich, ${ }^{83}$ it appears that the Derg had given up hope that Swiss banks would agree to repatriate the former Emperor's assets.

By the time Heinz Langenbacher took his leave from the Ethiopian government in mid-May 1975, a slow normalisation of bilateral relations had taken place. The ambassador was optimistic that, with suitable Swiss humanitarian and development aid, the issue of the Emperor's assets in Switzerland might be laid to rest. ${ }^{84}$ Half a year later, the governor of the National Bank of Ethiopia confirmed in a discussion with Langenbacher's successor, Olivier Exchaquet, that the affair was now forgotten. ${ }^{85}$ In Switzerland, Federal Councillor Georges-André Chevallaz's verbal reply to Jean Ziegler's request concluded the discussion about this issue in early December 1975. The head of the FDF refused to intervene in the affairs of third states by determining whether a head of state's assets in Switzerland were legally acquired. Alluding to the portrayal of the Swiss banking secret in popular films and books, Chevallaz expressed his unwillingness to be the "James Bond' of international justice", thereby dismissing calls for the Swiss government to take a more active role with regard to capital flight. ${ }^{86}$

What was the truth behind the allegations about the Ethiopian Emperor's assets in Swiss banks? Historian Christophe Farquet qualifies the evidence for capital flight from Ethiopia to Switzerland as adequate. ${ }^{87}$ Although it is impossible, in the absence of data from the concerned banks, to determine the precise sums that Haile Selassie or his family deposited in Swiss banks, there is

82 Letter from Heinz Langenbacher to the DPIL, "Kaiserliches Vermögen", confidential, 03.02.1975, SFA E2001E-01\#1987/78\#1001*. See also the letter from Langenbacher to the DPIL, “Kaiserliches Vermögen”, confidential, 10.01.1975, ibid.; Bahru Zewde, A History of Modern Ethiopia, p. 257, Farquet, "Au-delà des affaires", p. 12.

83 Letter from Heinz Langenbacher to the DPIL, "Kaiserliches Vermögen", confidential, O3.03.1975, p. 1, SFA E2OO1E-01\#1987/78\#1001*.

84 Letter from Heinz Langenbacher to Pierre Graber, "Unsere Beziehungen zu Äthiopien”, 20.05.1975, SFA E2001E-01\#1987/78\#1001*.

85 Letter from Olivier Exchaquet, Swiss ambassador in Ethiopia, to the DPA, "Besuch Gouverneur Staatsbank", o6.11.1975, SFA E2001E-o1\#1987/78\#2787*.

86 Statement by Georges-André Chevallaz, Federal Councillor and head of the F DF, "Interpellation Ziegler-Genève. Gelder aus Aethiopien", Amtliches Bulletin der Bundesversammlung 1975, Wintersession Nationalrat, 01.12.1975, p. 1547. On this subject, see Sébastien Guex, Gianni Haver, "James Bond contre - ou pour? - les gnomes de Zurich. L'image de la place financière suisse dans da série oo7", in Françoise Hache-Bissette, Fabien Boully, Vincent Chenille (eds.), James Bond (2)oo7. Anatomie d'un mythe populaire, Paris: Bélin, 2007, pp. 330-338.

87 Farquet, "Au-delà des affaires", p. 17. 
no reason to doubt that the imperial family had indeed transferred money to Switzerland before the deposition of the Emperor. The Swiss authorities never questioned this. On the contrary, when the Ethiopian court had asked Langenbacher in the early days of the revolution about a secure radio connection to Geneva, observers in Bern immediately concluded that the imperial family wished to transfer its assets to Switzerland. ${ }^{8}$ They did not, however, envisage taking any steps to prevent this. Two sources offer more positive proof. In May 1975, the deputy chief of the DPA heard from reliable Swiss sources connected to the imperial family that, although several major and private banks in Geneva and Zurich had denied the existence of bank accounts in Haile Selassie's name, the Industrie- und Handelsbank Zürich administrated "relatively small assets of the Emperor".89 This tallies with the report of a luncheon conversation between the US ambassador in Switzerland and several prominent Geneva bankers in early December 1974. During this discussion, the bankers acknowledged that the former Emperor certainly had assets in Switzerland, although they were not nearly as substantial as reported in the press. Having met Haile Selassie in the 1930s, the senior manager of the Geneva branch of "one of the largest Swiss banks" reportedly "expressed doubt that he [the Emperor] had financial sophistication personally to make wide use of possibilities offered in Switzerland," as a member of the US embassy in Switzerland reported to the State Department. ${ }^{90}$

Whatever the scale of the imperial family's assets in Switzerland, the allegations made by the Ethiopian press and authorities were based in fact. Confronted by accusations of benefiting economically from the pillage of a poor Third World country, the Swiss authorities fell back on their standard reaction when confronted with cases of capital flight: they focused on smoothing things over and hid behind the legal framework by demanding exact proof and stressing their independence from, and lack of influence on, Swiss banks.

Why did the controversy die down? The fall and eventual end of Ethiopian demands for the restitution of Haile Selassie's assets was not a result of political or economic pressure from the Swiss government. Switzerland's economic interests in Ethiopia were few and the Swiss involvement in the Duke of Harar Memorial Hospital provided limited leverage over the Derg. It is more probable

88 Handwritten comment on the letter from Heinz Langenbacher to the DPA, "Unrast in Aethiopien", 19.03.1974, strictly confidential, SFA E2001E-o1\#1987/78\#2801*.

89 Jürg Andreas Iselin, deputy chief of DPA and chief of its African, Asian, Middle Eastern and Latin American Division, memorandum, "Aethiopien, kaiserliches Vermögen", 28.05.1975, p. 2, SFA E2001E-o1\#1987/78\#1001*.

9o Telegram from [?] Percival, US embassy in Switzerland, to the State Department, 05.12.1974, p. 2, NARA, RG 59, AAD, CFPF, Electronic Telegrams 1974, 1974BERNo4556. 
that the controversy abated because the Derg, once its leaders realised that it would be difficult to recover Haile Selassie's assets through the Swiss courts due to the lack of both evidence and Swiss government cooperation, decided to focus its attention on more immediate problems: the widespread internal opposition to its regime, the escalating conflict in Eritrea, and the transformation of Ethiopia's economy. Nonetheless, the issue of the former Emperor's Swiss bank accounts continued to overshadow all aspects of Swiss-Ethiopian relations in the following years.

"The Situation Is Likely to Deteriorate Further": Economic and Humanitarian Relations with Pro-Soviet Ethiopia

Ambassador Heinz Langenbacher's belief that the political and economic situation in Ethiopia was likely to deteriorate after his departure in May 1975 was correct. ${ }^{91}$ As soon as Haile Selassie's Swiss bank accounts disappeared from the political agenda, two new issues cast a shadow over Swiss-Ethiopian relations: the nationalisation of Swiss assets in Ethiopia and Switzerland's gradual withdrawal from the Duke of Harar Memorial Hospital. The Swiss embassy in Addis Ababa and the authorities in Bern continued to keep a low profile. The issue of the Emperor's assets in Switzerland was frequently mentioned in discussions about how to obtain compensation for nationalised Swiss property and whether development aid to Ethiopia should be continued, and care was taken not to further alienate the Ethiopian authorities. As the controversy might flare up again at any moment, Bern had limited leverage to protect the interests of Swiss citizens. Between 1974 and 1976, as the PMAC strengthened its links with the USSR, Switzerland's economic and humanitarian presence in Ethiopia dwindled.

The Ethiopian Revolution cut short the country's nascent development cooperation partnership with Switzerland. Given the size of the Swiss engagement, it was the hospital project that was most affected by the political and military turmoil. After the deposition of Haile Selassie in September 1974, the latent tensions between the European and Ethiopian staff of the hospital flared up again. The leader of the Swiss medical delegation feared that Swiss team members might be kidnapped to force Bern to cooperate in the repatriation of the Emperor's holdings in Switzerland. The Swiss team faced increasing

91 Heinz Langenbacher, final report, "Schlussbericht: Pendente Fragen und Hinweise", 14.04.1975, p. 3, attached to the letter from Langenbacher to the AD, "Schlussbericht", 14.04.1975, SFA E2OO1E-o1\#1988/16\#3164*. 
resentment from Ethiopian staff and patients. In early December, the hospital even had to be briefly evacuated after a bomb alert. As a consequence, morale was low. ${ }^{92}$ Members of the Derg criticised the hospital project for not being adapted to local conditions, since they considered it more important to train a large number of basic health operators for the countryside rather than a few highly skilled specialists. The Duke of Harar Memorial Hospital, it was declared, should become a real 'hospital for the people. ${ }^{93}$

The members of the Swiss project management team at the University of Bern were disheartened by this growing hostility and advocated the accelerated handover of the hospital; Swiss staff should be gradually replaced with Ethiopian staff and responsibilities handed to the Ethiopian side. ${ }^{94}$ In early December 1974, the dean of the medical faculty of the University of Bern announced the project management's intention to terminate its participation in the hospital project by 30 June 1975. This decision was justified by the faculty's conviction that, due to the changes in Ethiopia, the main objectives of the project - especially the teaching of Ethiopian healthcare specialistswere unattainable..$^{95}$ The withdrawal of the Swiss project management team forced the FPD to decide if and how Swiss support for the hospital should be continued. The sTC, which had initially had the biggest reservations about the project, advocated the continuation of Switzerland's engagement. As the biggest personnel and financial contributions that the Swiss authorities had ever made to a single project phase were at stake, and premature discontinuation might renew the controversy over the Emperor's assets in Switzerland, the new Delegate for Technical Cooperation argued that the project should not be abandoned completely. ${ }^{96}$ During an interdepartmental meeting on the future of the hospital in late January 1975, domestic arguments to continue were decisive. Federal Councillor Pierre Graber insisted that, although the initial deci-

92 Letter from Johannes Bircher to the STC, 23.09.1974, confidential, SFA E2001E-o1\#1987/ $78 \# 2798^{*}$; letter from Heinz Langenbacher to the DPA, "Vermögen des Kaisers in der Schweiz? 14.10.1974, confidential, SFA E20o1E-o1\#1987/78\#2799*; telegram no 365 from Langenbacher to the FPD, 03.12.1974, ibid.

93 Letter from Heinz Langenbacher to the sтc, "Konzept des Duke of Harrar Spitals", 24.10.1974, SFA E2005A\#1985/101\#216*.

94 Letter from Walter Mamie, Swiss project management, to the STC, "Projekt Duke of Harrar Memorial Hospital, Addis Ababa", 16.10.1974, SFA E2005A\#1985/101\#216*.

95 Letter from Jürg Hodler, dean of the medical faculty of the University of Bern, to Pierre Graber, "Projet Duke of Harrar Memorial Hospital Addis Ababa", 05.12.1974, SFA E2001E-01\#1987/78\#2799*.

96 Note from Rolf Wilhelm, Vice-Director of the sтc, to Pierre Graber, "Duke of Harrar-Spital Addis Abeba. Kündigung des Regievertrages durch die medizinische Fakultät der Universität Bern vom 17. Januar 1975", 23.01.1975, p. 1, SFA E2001E-o1\#1987/78\#2799*. 
sion to support the project had been a mistake, it was now crucial to save face at a time when development aid was much criticised by politicians and the general public. ${ }^{97}$ Graber's words alluded to a draft law on humanitarian and development aid that had been debated in the Swiss parliament since 1971. Newspaper headlines about the waste of taxpayers' money in Ethiopia were liable to reduce the likelihood of the law being passed. ${ }^{98}$

While the FPD prepared to shoulder responsibility for the hospital on its own, it also had to deal with the nationalisation of Swiss assets in Ethiopia. On 6 December 1974, two weeks after the widely publicised executions, the new chairman of the Derg, Teferi Bante, had outlined the policy guidelines of his government to a delegation of the diplomatic corps. Apart from the Derg's commitment to human rights, which Heinz Langenbacher received with some scepticism, Teferi Bante's promise that the PMAC did not envisage the nationalisation of foreign property and, on the contrary, welcomed foreign investment in Ethiopia, drew his attention. This contradicted reports that nationalisations were imminent in Eritrea. ${ }^{99}$ Indeed, the chairman's promise proved to be short-lived. On 1 January 1975, the Derg enacted a first wave of nationalisation, taking over all banks, financial, and insurance companies. One month later, 72 more firms were nationalised, followed by farmland in March. ${ }^{100}$ Historian Andargachew Tiruneh argues that the Derg made these decisions less in the hope of economic gain for the Ethiopian state than in an attempt to appear progressive and win over the civilian left by carrying out the reforms demanded during the popular uprisings in early $1974 .{ }^{101}$ The most important nationalisations of Swiss property occurred in the insurance and agricultural sectors. The

97 Noa Zanolli, sTC, memorandum, "Zusammenfassung der Besprechung mit Bundespräsident Graber. Fortführung Duke of Harrar-Spital", 30.01.1975, SFA E2001E-o1\#1987/78\#2799*; telegram no 26 from Marcel Heimo to the Swiss embassy in Ethiopia, 04.02.1974, SFA E2005A\#1985/101\#216*.

98 Because both leftist and conservative factions contested it vigorously, this law was only adopted in 1976: Waldburger, Zürcher, Scheidegger, 'Im Dienst der Menschheit', pp. 85-87.

99 Letter from Heinz Langenbacher to the DPA, "Erster Besuch beim neuen Staatschef", o9.12.1974, confidential, SFA E2Oo1E-o1\#1987/78\#2801*; PR no 51 from Langenbacher, "Erste Erklärung des neuen Chairman Teferi", 16.12.1974, SFA E230o-o1\#1977/30\#3* and the attached document, "Statement of H.E. Brigadier General Teferi Banti to deans of the diplomatic corps on Dec. 6, 1974".

100 Letter from Heinz Langenbacher to the DPIL, "Nationalisierungsmassnahmen der aethiopischen Militär-Regierung”, o6.o1.1974, SFA E2001E-o1\#1987/78\#2787*; letter from Langenbacher to the DPA, "Weitere Nationalisierungen in Aethiopien", 04.02.1974, ibid.; letter from Henning Rieder, chargé d'affaires ad interim in the Swiss embassy in Ethiopia, to the DPA, "Nationalisierung des Ackerlandes", 10.03.1974, ibid.

Andargachew Tiruneh, The Ethiopian Revolution, p. 96. 
re-insurance company Swiss Re held $16.5 \%$ of the share capital of the nationalised African Solidarity Insurance Co., worth CHF 680,0oo, and had concluded reinsurance contracts with several other Ethiopian insurance companies. ${ }^{102} \mathrm{~A}$ number of plantations, as well as some smaller interests, were also affected. Compared to other states, Swiss damages were limited. With 3.4\% of all nationalised foreign interests, Switzerland occupied the fifth rung of affected states, after Italy $(55 \%)$, the Netherlands $(20 \%)$, the US $(7 \%)$, and the UK $(5 \%) .{ }^{103}$

The DPA, which was responsible for dealing with nationalisations, immediately charged the Swiss ambassador in Addis Ababa with documenting every case of Swiss interests affected by the actions of the Derg. ${ }^{104}$ Like his EEC colleagues, Heinz Langenbacher sent a protest note to the Derg in mid-February, insisting on fair compensation for nationalised Swiss interests. However, the Ethiopian authorities had only just established a commission to draft the law that would serve as the legal basis for nationalisations. Since there was much uncertainty about the country's future economic policy, the DPA decided to wait until the situation in Ethiopia had calmed down. ${ }^{105}$ Langenbacher's demarches to the Ethiopian authorities were somewhat isolated. In early 1975, the ambassadors of EEC member states in Addis Ababa met frequently to coordinate their action. In a collective note to and during meetings with members of the Ethiopian government, they insisted on prompt, adequate, and effective compensation. There was also some coordination with the Japanese, Indian, and Greek ambassadors, as well as the US chargé d'affaires. Heinz Langenbacher was not included in meetings open to non-EEC members. In a despatch to the FCO in May 1975, the British ambassador underlined the benefits of this cooperation: "I am in no doubt that this demonstration that we work together-and the implicit reminder of our collective importance to Ethiopia - strengthens our position." ${ }^{106}$ If the Ethiopian authorities had, in the

102 Letter from P. Gmeiner, secretary of the Swiss Insurance Association, to the Financial and Economic Service of the FPD, "Nationalisierung in Aethiopien", 23.01.1975, p. 1, SFA E2001E-o1\#1987/78\#2787*.

103 Andargachew Tiruneh, The Ethiopian Revolution, p. 94. This is based on data from the Ethiopian Compensation Commission for nationalisations, which does not, however, indicate the value of assets nationalised.

104 Letter from Alfred Reinhard Hohl, DPA, to the Swiss embassy in Ethiopia, 10.01.1975, SFA E2001E-o1\#1987/78\#2787*.

105 Letter from Heinz Langenbacher to the DPA, "Nationalisierungen in Aethiopien", 26.02.1975, SFA E2001E-o1\#1987/78\#2787*.

106 Despatch from Willie Morris, British ambassador in Ethiopia, to James Callaghan, Foreign Secretary, "Nationalisations in Ethiopia", 19.05.1975, confidential, p. 11, TNA FCO 31/1845; see also the letter from Morris to Richard A. Neilson, EAD, "Nationalisations", 27.02.1975, TNA FCO 31/1844. 
1970s, started to pay compensation for nationalised interests, it is possible that collective action would have brought about speedier results. As this was not the case, the question of whether Switzerland's non-membership of the EEC was, in this instance, a disadvantage remains open.

Ethiopia's political instability and nationalisation policy discouraged foreign investors. In order to stop the brain drain that increased after the nationalisations of early 1975, the Derg refused to grant exit visas to thousands of foreign citizens. This affected very few Swiss citizens. While a missionary was allowed to depart if he promised not to return, two businessmen later left the country illegally. ${ }^{107}$ As the Ethiopian authorities did not have the manpower necessary to effectively take over control of nationalised firms, many of them continued to muddle along under their old management and save what could be saved. By September 1975, neutral and Western governments had still not received any reply to their various demarches to the Derg but agreed to wait and see. For domestic reasons, the US State Department was particularly patient. As the Hickenlooper amendment allowed the discontinuation of economic and military aid programmes to states that had nationalised US interests without offering due compensation, the US embassy kept a low profile in order to keep Congress from stopping arms deliveries to Ethiopia. ${ }^{108}$

Swiss firms and individuals affected by nationalisations in Ethiopia adopted various strategies. Large companies with interests in many states could afford to be patient and seem to have preferred to deal directly with the local authorities. Conversely, the owners of small firms whose economic existence was threatened by the nationalisation of their investment relied heavily on the DPA's support. The heads of the re-insurance company Swiss Re took matters into their own hands. After a first, unsuccessful, attempt to negotiate with the Ethiopian authorities in Addis Ababa in early 1975, they appealed to the regime for compensation in December of that year, requiring no help from the DPA. ${ }^{109}$

107 Letter from Heinz Langenbacher to the DPA, "Ausreise- und Visa-Verweigerung", 28.02.1975, SFA E2OO1E-o1\#1987/78\#2789*; note from Langenbacher to the Swiss embassy in Ethiopia, "ввС Baden in Aethiopien", о2.06.1975, confidential, attached to the letter from Rolf Heinis, DPA, to the Swiss embassy in Addis Ababa, "ввС Baden in Aethiopien", 10.06.1975, SFA E2001E-o1\#1987/78\#2778*.

108 Letter from Olivier Exchaquet, Swiss ambassador in Ethiopia, "Nationalisations", 17.09.1975, SFA E2Oo1E-o1\#1987/78\#2787*; see also airgram from [?] Hummel, US embassy in Ethiopia, “American Firms Nationalized by Ethiopian Government", 05.09.1975, NARA, RG 59, P-Reel Printouts 1975, P750148-o928, box 148B.

109 Letter from Swiss Re to the FPD, "Nationalisierung in Aethiopien - African Solidarity Ins. Co., Addis Abeba", 05.12.1975, SFA E7110\#1986/24\#1248*, and the attached letter from Swiss Re to the Ethiopian Ministry of Commerce and Industry, "The African Solidarity Insurance Co. Ltd., Addis Ababa", 05.12.1975. 
The pharmaceutical firm Ciba-Geigy also took quick, preventive action. In the light of the danger that its Ethiopian agent, foreign controlled Ageca, might be nationalised, the group's executive committee agreed in March 1975 to open a technical advisory office in Addis Ababa. This allowed technicians stationed in Ethiopia to continue promoting Ciba-Geigy products. In the following years, the technical advisory office, which was not formally registered in Ethiopia, operated from Ageca's premises, while its employees were contracted by CibaGeigy's regional office in Nairobi. ${ }^{110}$

The DPA was much more closely involved in the case of the nationalised plantations and firms managed by Swiss businessman Jean Demaurex. He had founded three businesses in Ethiopia, two of which, Tana Plantation Co. and Bilate Agricultural Estate, were controlled by André \& Cie, which held a majority interest of CHF 24 million. These two plantations were nationalised in March $1975 .{ }^{111}$ For investments in Bilate plantation amounting to $\mathrm{CHF}$ 4.2 million and resulting interest revenues, Jean André had obtained, in June 1973, an investment risk guarantee (IRG) with a risk coverage of $70 \%$. After the nationalisation of his two plantations, André demanded his dues from the Swiss state. ${ }^{112}$ In July 1976, the IRG Commission and the head of the FDEA decided to disburse the guaranteed amount to Jean André. ${ }^{13}$ This meant that the DPA was now responsible for recuperating the losses engendered by the

110 A. Baumgartner, minutes no 12/75 of the Ciba Geigy Group Executive Committee meeting on 25 March 1975, Novartis archives, Basel, Switzerland, Ciba-Geigy company archives, minutes: minutes of the Group Executive Committee, box KL.1; note from H. Schwarb, Region 5 (Africa), to M. Wertenschlag and B. Sygfrid, "Aethiopien / Registrierung TAO CGTMS", 25.10.1978, ibid., regional services, box RD 07.2, and the attached letter from P. J. Wanner, W. F. Grieder, regional office Nairobi of Ciba-Geigy Trading and Marketing Services Co., Ltd., to M. Werdenschlag, Ciba-Geigy Ltd., Basel, “T.A.O. Ethiopia”, 16.10.1978.

111 Letter from Heinz Langenbacher to the DPA, "Nationalisierungen", 20.03.1975, SFA E7110\#1986/24\#1248*; letter from Langenbacher to the DPA, "Nationalisierungen: Billate Plantation", 27.03.1975, ibid.

112 Claude Hugenin, DPA, memorandum "Garantie contre les risques de l'investissement: cas André / Ethiopie", 03.07.1975, SFA E2001E-01\#1987/78\#2787*; M. Heini, audit expert in the Swiss Federal Audit Office, report, "Bericht über die Aktenprüfung im Zusammenhang mit dem IRG-Schadenfall Nr. 73.2.1, Aethiopien; Billate Agricultural Estate”, og.01.1976, SFA E7110\#1987/2O\#1202*. The IRG, introduced in 1970, aims to promote Swiss investments in developing countries. Although its introduction was frequently justified with development objectives, its main beneficiaries were Swiss investors: see Chantal Magnin, "Entwicklungshilfe für die Schweizer Wirtschaft. Der lange Weg zur Investitionsrisikogarantie, 196o-197o”, in Hug, Mesmer, Von der Entwicklungshilfe zur Entwicklungspolitik, pp. 363-379.

113 Letter from Ernst Brugger, Federal Councillor and head of the FDEA, to the IRG Commission, "Investitionsrisikogarantie / Schadenfall auf Verfügung Nr. 73.2.1 Aethiopien, André, Lausanne", o1.07.1976, SFA E7001C\#1987/101\#539*. 
plantations' nationalisation and recovering the disbursed sum from the Ethiopian authorities. Demaurex' own firm, Cafex, was taken over by the PMAC after its owner illegally left Ethiopia in August 1975, having waited almost a year for an exit visa. However, as he did not have an IRG cover, the DPA argued that responsibility for obtaining compensation remained with the owner. ${ }^{114}$

Swiss-Ethiopian cooperation in the humanitarian field was no more satisfactory than in the economic sphere. In mid-1975, the Swiss and Ethiopian authorities agreed on a limited continuation of the hospital development project. While the running of the hospital was handed over to the Ethiopians, the STC agreed to recruit and pay six medical specialists that would work and teach in Addis Ababa for another 18 months. The suggestion, made by a member of the Ethiopian Ministry of Health, that the Swiss authorities should put the sum remaining in its project budget at the disposal of the ministry — which could recruit two doctors from the Eastern bloc for the salary of one Swiss specialist-received a non-committal response. ${ }^{115}$ By late November 1975, the reminder of Ethiopia's imperial past had disappeared from the name of the hospital, now known as Black Lion Hospital. However, collaboration with the Ethiopian authorities did not become any easier. The STC struggled to obtain replies to its repeated queries and conditions did not permit the doctors it had recruited to fulfil their teaching duties. In April 1976, the Derg sent all the newly-trained anaesthetists and 15 anaesthesia machines paid for by the STC to aid the war effort in Eritrea. The Swiss authorities reacted by withdrawing one of its doctors from the hospital. As the main objective of the three remaining doctors' expert mission in Addis Ababa - teaching — had become almost impossible, the STC decided in November 1976 not to continue its limited involvement in Ethiopia. ${ }^{116}$ This was the end of Switzerland's support for the former Duke of Harar Memorial Hospital. Collaboration with Ethiopia would,

114 ATS/DPA, “Un Lausannois arrêté en Éthiopie", Tribune - Le Matin, o9.08.1975, p. 7; telegram no 181 from the Swiss embassy in Addis Ababa to the FPD, SFA E2Oo1E-o1\#1987/78\#2798*; Claude Huguenin, memorandum, "Visite de M. et Mme Jean Demaurex, le 22 août 1975", 22.08.1975, SFA E2OO1E-o1\#1987/78\#2798*.

115 Noa Zanolli, memorandum of conversation with Dr. Assefa Tekle, Permanent Secretary of the Ethiopian Ministry of Public Health, and Ato Mengesha, head of the ministry's planning department, 05.06.1975, SFA E2005A\#1985/101\#216*; Letter from Marcel Heimo to the Swiss Embassy in Ethiopia, "Fortsetzung der Schweizer Hilfe. Unsere beiden Noten vom 1. April 1975", 17.07.1975, ibid.

116 Noa Zanolli, report, "Bericht über Dienstreise vom 17.10.75-16.11.75 nach Tansania und Aethiopien von N. Zanolli”, 26.11.1975, p. 44, E2005A\#1985/101\#216*; letter from Olivier Exchaquet, Swiss ambassador in Ethiopia, to the Delegate for Technical Cooperation, 26.04.1976, p. 2, SFA E2005A\#1991/16\#523*; letter from Exchaquet to the sTC, "Black Lion Hospital”, 17.05.1976, p. 1, SFA E2005A\#1991/16\#523*; letter from Jean-Maurice Délèze, STC, 
in any case, have come to an end in 1977, when the Derg forced all Western doctors and medical personnel to leave the country.117

The results of almost six years of development cooperation with the Ethiopian authorities were mixed. Pressured into taking on a project that did not meet its criteria for medical aid, the STC was often forced to improvise. While some of the problems that arose at the hospital might have been avoided through better planning that took Ethiopian needs into account, the project can reasonably be called a victim of the Ethiopian Revolution. Although Swiss involvement in the hospital provided medical equipment and care to a country that lacked both, anti-Western and especially anti-Swiss sentiments in Ethiopia had a disruptive effect on work in the hospital. The resulting frustration explains why, in mid-1981, the Vice-Director of the STC reacted very firmly to an Ethiopian demand for renewed aid. In a letter to the Swiss embassy in Ethiopia, he made it clear that the STC had no interest whatsoever in repeating the experience of the hospital project, which he qualified as "a failure, at least partly."118

A similar conclusion can be drawn with regard to the nationalisation of Swiss assets in Ethiopia. In January 1976, the PMAC set up a commission to deal with compensations for nationalised assets and foreign ambassadors regularly reminded the government of its obligations. Yet, by the middle of 1978, its rules of procedure had still not been established. ${ }^{119}$ In the meantime, the Derg had strengthened its alliance with the USSR and had, thanks to major SovietCuban military intervention, defeated Somalia during the Ogaden War. As all attempts by the Carter administration to reach an agreement on compensation for US interests failed, the US government decided in October 1979 to close its Aid Mission in Ethiopia. By mid-1981, a single US firm had been compensated, probably in order that Ethiopia might again benefit from US bilateral and multilateral aid. Consequently, the Swiss authorities were pessimistic about their

to Dr. P. Nadelhaft and Dr. P. Riedl, doctors in the hospital, "Black Lion Hospital", 12.11.1976, SFA E2005A\#1991/16\#523*.

117 Letter from Fritz Bohnert, Swiss ambassador in Ethiopia, to the STC, "Spital in Addis Abeba. Ein Fehlobjekt unserer Hilfe? Und warum?” 21.11.1980, SFA E2025A\#1991/168\#657*.

118 Letter from Rolf Wilhelm to the Swiss embassy in Ethiopia, "Un appui suisse à l'Hôpitel du Lion Noir est à nouveau souhaité", 07.05.1981, SFA E2O25A\#1991/168\#657*.

119 Letter from Olivier Exchaquet to the DPA, "Nationalisierungen", 13.01.1976, SFA E2001E-o1\#1991/17_Bd. 758, B.34.66; letter from Hansjakob Kaufmann to the Trade Division, the Financial and Economic Service, and the DPIL, "Verstaatlichungen in Aethiopien", o7.o9.1976, ibid.; letter from Fritz Bohnert to the Trade Division and the DPA, "Gespräche des neuen amerikanischen Botschafters mit den äthiopischen Behörden", 21.08.1978, SFA E711O\#1989/32\#1361*. 
citizens' chances of obtaining any compensation for their losses, which were estimated at a total of $\mathrm{CHF} 22.5$ million by Bern. ${ }^{120}$

The example of the Duke of Harar Memorial Hospital underlined the limits of development cooperation as a political instrument. While the Swiss government's takeover of this project was explicitly requested by the Ethiopian Emperor and seems to have strengthened cordial relations with the old regime, it did not protect Switzerland from the criticism of the new rulers. It may even have accentuated bilateral tensions, as it drew the attention to the contrast between Bern's humanitarian engagement, and Swiss banks' welcome of misappropriated capital. From this viewpoint, the juxtaposition of CHF 140 million, the lowest amount mentioned for Ethiopian funds in foreign, mainly Swiss banks, and the CHF 8 million that the Swiss government and the University of Bern spent on the hospital, made it clear to Ethiopian observers which side benefited from bilateral relations.

The controversy surrounding the Ethiopian Emperor's Swiss bank accounts highlighted Switzerland's problematic role in North-South relations. Although there was a brief moment in late 1974 when a few members of the Swiss federal administration advocated relaxing Switzerland's banking secret and a parliamentary interpellation demanded the same, the issue never gained anywhere near as much sympathy in Switzerland as, for example, national liberation in Southern Africa. This is probably explained by the fact that the period of sustained pressure on the Swiss government and Swiss banks was very short. The debate flared up in mid-September 1974; in November, the Derg lost much of its international standing due to the widely publicized execution of opponents, and by the end of the year, the issue had died down. Thus, there was not much time for Swiss non-state actors to mobilise around this issue, especially as there was no pre-existing movement of solidarity with the Ethiopian population. Despite the autocratic character of the old regime and its shortcomings during the 1973-1974 famine, Haile Selassie was still widely regarded as a distinguished African statesman, which may have acted as a further deterrent to expressing solidarity with the new government.

By late 1976, the Swiss government's interest in the Horn of Africa was much diminished. Diplomatic relations with Somalia were unofficially suspended

120 Letter from Fritz Bohnert to the DPA, "Aethiopien: Kompensationsfrage. Regierungserklärung”, 08.10.1979, SFA E20o1E-o1\#1991/17_Bd. 759, B.34.66; letter from Edouard Brunner, DPA, to the Swiss embassy in Ethiopia, "Aethiopien: Entschädigung für verstaatlichte Vermögenswerte", 17.10.1979, ibid.; Serge François Salvi, DPA, memorandum, "Verstaatlichungen Aethiopien", o1.07.1981, ibid.; Arnold Hugentobler, DPA, memorandum, "Visite de l'Ambassadeur Bohnert, 6 août 1981”, 10.08.1981, SFA E20o1E-o1\#1991/17_Bd. 759, B.73.o. 
and, despite this country's formal alliance with the USSR, Bern mostly ignored it. Swiss-Ethiopian relations had normalised. In his final reports to Bern, Ambassador Olivier Exchaquet underlined that Haile Selassie's assets in Switzerland were no longer an issue in Ethiopia. While he had little hope of seeing commercial exchange increase in the foreseeable future because of the African country's poverty and its elites' focus on subsistence farming, the Derg's nationalisations rendered investment in Ethiopia unattractive. ${ }^{21}$ Although Exchaquet noted "Ethiopia's real slide to the Left", he was reassured that the country was still firmly anchored in the Western bloc from the point of view of military alliances, as it received most of its military supplies from the US.122 This would soon change. Only a year later, an unprecedented reversal of superpower alliances in the Horn of Africa would take place. Hoping to obtain US military support for its invasion of the Ogaden that caused the war of the same name between Somalia and Ethiopia, Siad Barre's regime broke with the USSR in November 1977 and Moscow subsequently began to officially support Ethiopia.

121 Final report from Olivier Exchaquet to the AD, 01.11.1976, pp. 2-6, SFA E2001E-o1\#1988/ $16 \# 3164$.

122 PR no 8 from Olivier Exchaquet, "L'Ethiopie à fin 1976 (Rapport final)", 12.11.1976, p. 5, SFA E2300-01\#1988/91\#3*. 


\section{Getting Out of a Foreign Policy Impasse: The Decolonisation of Angola and Mozambique}

On 25 April 1974, a military coup d'état in Portugal, supported by large parts of the population, changed the dynamics of the independence wars in Southern Africa. Almost without bloodshed, the Movimento das Forças Armadas (Armed Forces Movement, MFA), constituted mainly of junior officers, toppled the Estado Novo regime. Although the coup came as a surprise to both the Portuguese leaders and international observers, growing discontent within the military had been evident for some time. At its root were the independence wars in Africa. After more than a decade of war, Portuguese defeat in Guinea-Bissau, whose independence the liberation movement PAIGC had unilaterally declared in September 1973, became increasingly likely. In February 1974, General António de Spínola, former Portuguese commander-in-chief in Guinea-Bissau, published a book in which he called for reforms in Portugal. He also argued that the solution to the wars in Africa had to be political, not military. The book quickly became a bestseller and undermined the position of Prime Minister Marcello Caetano. The junior career officers who comprised the majority of the MFA were motivated mainly by their perceived loss of status after a series of reforms improved the situation of conscripted officers. Yet, their dissent was also an expression of wide-ranging dissatisfaction with the organisational problems of the Portuguese army linked to the extensive troop demands of the African wars. ${ }^{1}$ Faced with this discontent, the Caetano regime failed to act decisively. There was next to no resistance when the MFA took control of Lisbon on 25 April 1974. General Spínola was chosen to head the Junta of National Salvation that assumed power in Portugal and later became the first provisional president. The secret police and censorship were abolished, political prisoners liberated, the army reorganised and civil governors dismissed. The MFA's programme was deliberately vague on the question of the future of Portugal's African colonies, in order to appeal to as great a number of people as possible. Its final version contained no commitment to the principle of selfdetermination. Instead, it argued that a negotiated solution was needed to the

1 Kenneth Maxwell, The Making of Portuguese Democracy, Cambridge: Cambridge University Press, 1995, pp. 30-38; MacQueen, The Decolonization of Portuguese Africa, pp. 68-77.

(C) SABINA WIDMER, 2021 | DOI:10.1163/9789004469617_010

This is an open access chapter distributed under the terms of the CC BY-NC-ND 4 40 license 
independence wars, that an open, national debate about the overseas problem should take place, and that steps should be taken to adopt an overseas policy that would lead to peace. ${ }^{2}$

The Carnation Revolution introduced a period of profound political, economic, and social transformation in Portugal, where no less than six provisional governments followed in rapid succession before a democratically elected president took office in June 1976, at the head of a constitutional democracy. In Africa, the fall of the Estado Novo regime marked the beginning of the decolonisation of Angola, Mozambique, Guinea-Bissau, Cape Verde, and São Tomé e Príncipe. Unwilling to continue the financial and military commitment necessary to fight the liberation movements in the colonies, the new Portuguese authorities were, by July 1974, ready to negotiate the transfer of power. The approaching end of Portuguese colonial rule increased the pressure on the white minority regimes in Rhodesia and South Africa and intensified the liberation struggle in Southern Africa.

The period between early 1974 and mid-1975, when Mozambique became independent and the struggle between the Angolan liberation movements escalated into all-out war, with interventions from both sides of the global East-West conflict, was crucial for Switzerland's foreign policy in sub-Saharan Africa. In the first months after the Carnation Revolution, there was great uncertainty about the future of the Portuguese colonies. In Bern, Switzerland's role in Southern Africa was hotly debated. The Portuguese coup offered a way out of the impasse created by the Swiss government's selective interpretation of neutrality. As soon as Portugal's new leaders were willing to grant independence to the former colonies and the independence wars in Mozambique and Angola were drawing to a close, the need to make a trade-off between relations with the coloniser and the colonised disappeared. Like the US, France, the FRG, and the UK, the Swiss government strove to overcome its past association with the Portuguese colonial regime. To silence the ever-mounting national and international criticism of Switzerland's economic and financial role in Southern Africa, protect Swiss interests in Angola and Mozambique, and develop economic exchanges with the new states, Bern undertook great efforts to establish cordial relations with the Portuguese territories' future rulers, despite their Soviet ties. These efforts were also part of a general Swiss attempt to strengthen its relations with Third World governments in the context of the North-South conflict.

2 Maxwell, The Making of Portuguese Democracy, pp. 56-6o; MacQueen, The Decolonization of Portuguese Africa, pp. 79-87. 


\section{"The Coup in Portugal Has Set the Ball Rolling": Internal Debates on Switzerland's Southern Africa Policy}

Exactly one month after the Carnation Revolution, Swiss Ambassador Richard Pestalozzi, who was stationed in Kenya, reported how the political and military situation started to move after the Portuguese coup d'état. ${ }^{3}$ Although his words referred to events in Mozambique, they applied to the whole of Southern Africa. The anticipated withdrawal of the Portuguese colonial power strengthened the calls for national liberation in the region. Afro-Asian pressure on the Federal Council to take decisive action to prevent Swiss firms and banks from collaborating with and investing in the region continued to mount. In April 1974, the publicity given to numerous complaints to the UN about Swiss firms or individuals breaking the economic sanctions had reached the point that FPD leaders agreed to take steps to restrict the export of Swiss goods and capital to Rhodesia. ${ }^{4}$ In late May, the UN Unit on Apartheid (later Centre against Apartheid) published a critical report on Switzerland's relations with South Africa. Its author was Gilbert Rist, director of the Geneva-based Centre EuropeTiers Monde (Europe-Third World Centre, CEтіM), a member of the Swiss Anti-Apartheid Movement and member of the Advisory Commission on Switzerland's Relations with the UN. ${ }^{5}$ In late June, the OAU's Council of Ministers urged its member states "to blacklist those persons, companies and institutions in their countries which in pursuance of colonial and racial interest continue to have dealings or business with the illegal regime in southern Rhodesia". African leaders even considered using access to raw materials as leverage to force states to comply with the UN sanctions, as the OPEC states had done during the 1973 oil embargo. 6 Thus, behind the scenes, Switzerland's foreign policy in Southern Africa was the subject of intense debate in 1974.

3 PR no 4 by Richard Pestalozzi, Swiss ambassador in Kenya, "Die Lage in Malawi", 24.05.1974, p. 3, SFA E2300-O1\#1977/30\#59*.

4 SLR, memorandum, "Aktennotiz zum Vorbereitungsgespräch für die Sitzung vom 10. April 1974 mit den Vertretern des EVD", 08.04.1974, SFA E2001E-o1\#1987/78\#4773*; Claude Huguenin, DPA, memorandum, "Sanctions rhodésiennes: séance interdépartementale du 10 avril 1974", o6.o5.1974, SFA E7110\#1985/97\#1755*.

5 See the letter from René Keller, chief of the Dio, to the main federal offices and Swiss embassies in Africa and New York, "Beziehungen zwischen der Schweiz und Südafrika. UNO-Dokument”, 15.07.1974, SFA E2OO3A\#1988/15\#1508*.

6 Resolution CM/Res 347 (XXIII) of the OAU Council of Ministers' 23rd Ordinary Session from 6 to 11 June 1974, "Resolution on Sanctions against Rhodesia", https://au.int/sites/default/ files/decisions/9582-council_en_6_15_june_1974_council_ministers_twenty_third_ordinary _session.pdf (13 January 2021); telegram no 197 from Heinz Langenbacher, Swiss ambassador in Ethiopia, to the FPD, 27.06.1974, SFA E2O01E-01\#1987/78\#4329*. 
Despite the MFA programme's non-committal stance on self-determination in Portuguese Africa, it was evident to most Swiss observers that the Carnation Revolution would have far-reaching consequences for the colonies' future. In Bern, the view of the Swiss ambassador in Portugal, Jean-Louis Pahud, expressed in early May 1974, that any solution to the colonial problem other than the complete independence of Portugal's African colonies was unlikely, was widely shared. ${ }^{7}$ How much control the new Portuguese authorities would have over the decolonisation process, in particular over its timing, and what this would mean for Swiss interests and policies in Southern Africa, was less certain.

FPD leaders had no intention of getting mixed up in what Federal Councillor Pierre Graber considered to be a complex and potentially violent decolonisation process. In a meeting with the Foreign Policy Committee of the Council of States in late May 1974, he presented Southern Africa as one of the most alarming trouble spots worldwide. Failed peace negotiations due to factionalism in Portugal and Angola, a unilateral declaration of independence by white settlers in Mozambique, and a South African military intervention in Portuguese Africa to prevent the spread of African nationalism were some of the risks he outlined. From a global perspective, the presence of the US and the USSR in Southern Africa due to the region's strategic importance and natural resources, rendered the situation even more volatile. ${ }^{8}$ Referring to Switzerland's role in this context, Graber hinted that the intermediary of Swiss missionaries, who were known to have shown sympathy for the liberation movements, and the granting of humanitarian aid would help Switzerland protect its interests in Angola and Mozambique. ${ }^{9}$ Despite some concern that the political changes in Angola and Mozambique might have negative consequences for trade relations, ${ }^{10}$ the Swiss government intended to follow its old strategy for dealing with the decolonisation of former colonies: adopt a low profile, keep out of all conflicts, and later win over the future rulers with the offer of humanitarian and development aid. As yet, Bern made no special efforts to enter into contact with the liberation movements in Portuguese Africa in order to get on good terms with these territories' probable future elites. ${ }^{11}$

PR no 9 by Jean-Louis Pahud, Swiss ambassador in Portugal, "Le problème de l'Outre-mer portugais après le coup d'Etat du 25 avril”, 10.05.1974, p. 2, SFA E230o-01\#1977/3O\#49*. Statement of Pierre Graber, Federal Councillor and head of the FPD, in the minutes of the meeting of the Foreign Policy Committee of the Council of States on 27 May 1974, 31.05.1974, pp. 13-14, SFA E1050.12\#1995/512\#8*.

9 Ibid., p. 18.

10 Letter from Ernst Henri Léchot, responsible for relations with Portugal within the Trade Division, to the Swiss consulates in Angola and Mozambique, "Mozambique und Angola - Einfuhrregime", 05.06.1974, SFA E7110\#1985/97\#1259*. 
For Swiss citizens living in the Portuguese colonies, the consequences of the regime change in Portugal were immediate. In Mozambique, the Portuguese Governor-General was recalled, censorship abolished and the secret services (PIDE/DGS) reorganised. Nevertheless, Swiss consul Louis Chaney reported a few days after the Carnation Revolution that daily life as well as the war between FRELIMO and the Portuguese army continued almost unchanged. The traders and planters that comprised almost half of the 200 Swiss residents in Mozambique expressed some fear about their long-term future in Mozambique. The missionaries, who made up the other half, welcomed the political changes. ${ }^{12}$ In Angola, several liberation movements and political parties started to compete for power, rendering the general insecurity even greater than in Mozambique. ${ }^{13}$ Swiss solidarity movements that had protested for years against Portuguese colonialism rejoiced at the new freedoms enjoyed in Portugal after the coup. However, in a letter accompanying a petition to the Federal Council to recognise Guinea-Bissau that had obtained about 5,000 signatures, a solidarity group, the Collectif Europe-Afrique, insisted on the continuing need to press for the MFA to commit to decolonisation. After all, "the numerous imperialist interests, both strategic and economic, that developed and made profits under the Portuguese regime might well support a neo-colonialist solution."14 The activists therefore demanded, in vain, that the Swiss authorities should support the liberation movements' quest for complete independence.

The Swiss government's cautious attitude during the first months following the Portuguese coup and their confidence in their ability to buy the goodwill of Angola's and Mozambique's future rulers may seem surprising. After all, Swiss foreign policymakers were well aware of the damage caused to their image by their close relations with the white minority regimes in Southern Africa. In late May 1974, a member of the Swiss Anti-Apartheid Movement who had recently travelled to Tanzania and Mozambique warned the DPA that Switzerland's

Letter from Walter Jaeggi, Swiss ambassador in Denmark, to the DPA, "Besuch des MPLA (Angola)-Leiters Agostinho NETo in Kopenhagen und sozialdemokratische Beziehungen Dänemark-Portugal", o8.05.1974, SFA E2001E-o1\#1987/78\#4650*.

Letter from Louis Chaney, Swiss consul in Mozambique, to the DPA, 29.04.1974, p. 1, SFA E20o1E-o1\#1987/78\#4651*; letter from Chaney to the DPA, "Situation au Mozambique (dès le 1er mai) sous le regime de la Junta de Salut National”, o6.05.1974, pp. 2-3, ibid. See also the letter from missionary Marcel Vonnez to Georges Andrié, DM, 21.06.1974, ADM 3056G. I am indebted to the late Patrick Harries for drawing my attention to the Vonnez correspondence.

13 Letter from Roland Gottraux, Swiss honorary consul in Angola, to the Swiss Embassy in Lisbon, 26.05.1974, SFA E2200.54-O3\#1992/228\#252*.

14 Letter from the Collectif Europe-Afrique to the Federal Council, 29.05.1974, p. 2, SFA E2001E-o1\#1987/78\#3234*. 
“image was not very good among FRELIMO's leaders, who criticise its abstaining neutrality". ${ }^{15}$ His words echoed the disapproval of the Swiss authorities' selective interpretation of neutrality uttered by a FRELIMO representative during the international humanitarian law conference in Geneva in early $1974 .{ }^{16}$

Only four days after the events of 25 April, the deputy chief of the DIO, whose directorate was more attuned to the ramifications of the Third World's condemnation of Swiss neutrality than other FPD services, took up the FRELIMO member's criticism of Swiss partiality during the independence wars. He asked Swiss ambassadors in sub-Saharan Africa if the moment had come to grant humanitarian aid to the liberation movements in Portuguese Africa. ${ }^{17}$ The replies reveal that there was no agreement on strategy. Despite his misgivings about FRELIMO's Eastern bloc connections and violent strategies, Richard Pestalozzi reasoned that the quick granting of aid to the Portuguese colonies' future rulers might prevent Switzerland from being considered part of the "camp of the reactionaries and racists". ${ }^{18}$ His colleague in Ethiopia, Heinz Langenbacher, was more enthusiastic about support for the liberation movements. He even argued that the government should go further and limit Swiss investment in Southern Africa. ${ }^{19}$ However, the view that won the day in Bern was that of Lucien Mossaz in Tanzania, who argued that it was contrary to Switzerland's policy of neutrality to support dissident movements that were still engaged in armed conflict. ${ }^{20}$

In the light of Afro-Asian leaders' growing determination to bring white minority rule to an end, Pestalozzi and Langenbacher increased their calls for a new Swiss Southern Africa policy. Their demand for the restriction of the activities of Swiss firms and banks in this region placed them at one extreme of the split that divided the Swiss government and federal administration. Commenting on the minutes of the first interdepartmental meeting on Switzerland's

15 Statement by Pierre Bungener, President of the Swiss Anti-Apartheid Movement, cited in Claude Huguenin, memorandum, "Entrevue avec M. Bungener, Président du Mouvement Anti-Apartheid de Suisse, le 29.5.1974”, 31.05.1974, SFA E2001E-01\#1987/78\#4651*.

16 Cited in the letter from François Pictet, deputy chief of the Dio, to the Swiss embassies in Ethiopia and Tanzania and the Office of the Permanent Observer of Switzerland to the UN, "Possibilité d'une aide suisse en Afrique australe", 29.04.1974, pp. 1-2, SFA E2005A\#1985/101\#547*.

17 Ibid.

18 Letter from Richard Pestalozzi to the Dio, "Schweizerische Unterstützung der Befreiungsbewegungen im südlichen Afrika”, o6.o6.1974, p. 3, SFA E2001E-o1\#1987/78\#4651*.

19 Letter from Heinz Langenbacher to the DIo, "Hilfe für afrikanische Befreiungsbewegungen", 24.06.1974, p. 3, SFA E2200.185-O2\#1987/123\#42*.

20 Letter from Lucien Mossaz, Swiss ambassador in Tanzania, to the Dio, "Possibilité d'une aide suisse en Afrique australe", o8.05.1974, SFA E2OO3A\#1988/15\#573*. 
Rhodesia policy in early April 1974, Pestalozzi got the "impression of a retarding Trade Division and a pressing Political Department. It is the old question of whether trade interests precede political interests in the formation of Swiss foreign policy or vice versa." ${ }^{21}$ Indeed, in the frequent meetings taking place over the following months, the Trade Division resisted the FPD leaders' efforts to restrict Swiss exports to Rhodesia by trying to minimise the problem and gain time. ${ }^{22}$ Langenbacher saw it as his duty, as he wrote to the DIO in July 1974, to provide the necessary facts "that permit you to counterbalance the power of trade and industry, which, as I know from my time at the head office, maintain strong pressure on our Africa policy and frequently neglect long-term, general Swiss interests." 23

Faced with strong resistance from Swiss economic and financial circles, FPD officials were in a quandary. Their efforts to comply with African demands to curtail Switzerland's economic relations with Rhodesia were constantly thwarted. Similarly, the majority of the Federal Council refused to limit Swiss collaboration with South Africa. ${ }^{24}$ The decolonisation of Angola and Mozambique provided Swiss decision makers with a far less controversial opportunity to counterbalance their close relations with white minority regimes by supporting the leadership and populations of independent black African states. Thus, Switzerland's close political and economic relations with South Africa and Rhodesia continued to loom large over its foreign policy in the region.

What influence did Swiss-Portuguese relations have on Bern's foreign policy during the decolonisation of Angola and Mozambique? During the first few months after the MFA coup, the Swiss government was attentive to the position of the coloniser. FPD leaders waited for an official Portuguese commitment to decolonisation before seeking to contact the future rulers of Angola

21 Letter from Richard Pestalozzi to the DPA, “Sanktionen gegen Rhodesien”, 30.05.1974, p. 4, SFA E2200.185-02\#1987/123\#44*.

22 Claude Huguenin, memorandum, "Sanctions rhodésiennes. Discussion dans le bureau de M. l'Ambassadeur Rothenbühler le 29.4.1974", 30.04.1974, SFA E2001E-01\#1987/78\#4765*; see also Ross, Neutrality and International Sanctions, pp. 174-177.

23 Letter from Heinz Langenbacher to the Dio, "Beziehungen Schweiz - Südafrika; UNoDokument", 29.07.1974, p. 2, SFA E2003A\#1988/15\#1508*.

24 In July 1974, for example, the Federal Council agreed to grant an ERG cover to BBC for deliveries to South Africa amounting to $\mathrm{CHF} 327$ million despite the opposition of the FPD, which feared that this deal might become public and damage Switzerland's image in Africa: Decree of the Federal Council, "Exportrisikogarantie an die Firma AG Brown Boveri \& Cie, Baden im Wert von 327 Mio. Franken für die Lieferung von drei Dampfturbinengruppen nach der Republik Südafrika", o9.07.1974, and the attached report from Pierre Graber to the Federal Council, "Afrique du Sud. Garantie contre le risque d'exportation", 24.06.1974, dodis.ch/40342. 
and Mozambique and taking steps to establish cordial relations with the soonto-be independent states. Once the Portuguese provisional government agreed to the independence of its former colonies, Bern was no longer bound by its solidarity with a fellow EFTA member. The major social, political, and economic transformations that followed the Carnation Revolution and continued until early $1976 \mathrm{kept}$ the different Portuguese transitional governments fully occupied. Consequently, the colonial power played a rather weak and passive role during the decolonisation of its African colonies. Switzerland and other Western and neutral states viewed developments in Portugal separately from those in Portuguese Africa.

Initially, they focused on the European theatre. Between 1974 and 1976, different political parties and sections of the Portuguese military and the population competed for the power to determine the country's orientation in the East-West conflict. The leaders of the Western bloc were preoccupied by the growing influence of left-wing officers of the MFA and of the Partido Comunista Português (Portuguese Communist Party, PCP), which participated in the Portuguese government. Blinded by 'a Cold War lens', Secretary of State Henry Kissinger focused on the Communist threat within nato. Fearing a domino effect in other European states, he aimed to exclude Portugal from sensitive NATO information and even considered covert operations in the Southern European state. In contrast, Western European governments and Social Democratic leaders in the UK, France, the FRG, Sweden, Norway, and the Netherlands supported the moderate forces in Portugal, especially the Partido Socialista (Socialist Party, PS). At a time when democratic transitions were also under way in Greece after the fall of the colonels' regime in July 1974 and in Spain after Franco's death in November 1975, they sought to bind Portugal politically and economically to Western Europe. ${ }^{25}$

25 On international reactions to the Portuguese Revolution, see David Castaño, "'A Practical Test in the Détente': International Support for the Socialist Party in the Portuguese Revolution (1974-1975)", Cold War History 15:1 (2015), pp. 1-26; Ana Mónica Fonseca, "The Federal Republic of Germany and the Portuguese Transition to Democracy (1974-1976)", Journal of European Integration History 15 (2009), pp. 35-56; Oscar Jose Martin Garcia, "The End of the Carnival': The UK and the Carnation Revolution in Portugal", Contemporary British History 29:2 (2015), pp. 199-221; Bernardino Gomes, Tiago Moreira de Sá, Carlucci vs. Kissinger. The US and the Portuguese Revolution, Lanham: Lexington Books, 2011; Mario del Pero, "A European Solution for a European Crisis. The International Implications of Portugal's Revolution" Journal of European Integration History 1 (2009), pp. 15-34; Mario del Pero, "Which Chile, Allende?' Henry Kissinger and the Portuguese Revolution", Cold War History 11:4 (2011), pp. 625-657; Pedro Aires Oliveira, "O Flanco Sul sob Tensão. A NATo e a Revolução Portuguesa, 1974-1975”, Relações Internacionais 21 (2013), pp. 61-78; Schneidman, Engaging Africa, pp. 139-185; Antonio Varsori, "Crisis and Stabilization in 
Up until mid-July 1974, Swiss diplomats in Washington had twice discussed the situation in Portugal with State Department officials. This attests to a more immediate preoccupation with the situation in Europe than with that in the African colonies. ${ }^{26}$ Nevertheless, Bern preferred to keep its distance from the ever-changing Portuguese governments, especially after the takeover by radical MFA officers close to the PCP, following a failed anti-Communist putsch in mid-March 1975. These officers immediately nationalised banks and insurance companies. At the same time, an increasingly assertive popular movement of farm labourers, industrial workers, and inhabitants of poor urban neighbourhoods occupied houses and agricultural estates, demanding better wages and living conditions. ${ }^{27}$ In early 1975, a number of Swiss business people were expelled from their workplaces, while workers committees occupied some Swiss-owned firms. ${ }^{28}$

In order to support moderate forces in Portugal, the FRG, France, and the US granted bilateral credit arrangements to Portugal amounting to CHF 73.6 million, CHF 17 million, and CHF 38.7 million, respectively. Both the EEC and EFTA agreed on the principle of aid to Portugal. In this context, the Swiss government found it increasingly difficult to dissociate itself from international attempts to stabilise the Portuguese economy. In early July 1975, the FPD and the FDEA underlined Switzerland's shared responsibility to prevent extremist forces from taking power in Portugal. ${ }^{29}$ Three months later, representatives of the Trade Division, the FPD, Switzerland's representation to EFTA, and the Vorort decided to respond positively to Portuguese requests for aid from EFTA. Thereby, they wished to avoid, both being the scapegoat if multilateral pro-

Southern Europe during the 1970s: Western Strategy, European Instruments", Journal of European Integration History 1 (2009), pp. 5-14; Tilo Wagner, "Portugal and the German Democratic Republic during the Carnation Revolution", Portuguese Journal of Social Science 7:1 (2008), pp. 37-47.

26 PR no 45 from the Swiss embassy in the US, "Portugal nach dem Militaerputsch, von Washington aus gesehen”, 24.05.1974, SFA E2300-O1\#1977/3O\#88*; PR no 62 from Felix Schnyder, Swiss ambassador in the US, "Portugal - Spanien, von Washington aus gesehen", 15.07.1974, ibid.

27 Maxwell, The Making of Portuguese Democracy, pp. 86-89; 108-112; 117-120;

28 Henri Cuennet, FPD, memorandum, "Protection des personnes et des intérêts suisses au Portugal", 12.06.1975, attached to the letter from Charles Müller, Deputy Chief of the DPA, to the Swiss embassy in Portugal, "Intérêts suisses au Portugal", 12.06.1975, SFA E2200.54o3\#1992/228\#367*.

EPD and FDEA, proposal to the Federal Council, "Relations avec le Portugal", 04.07.1975, SFA E70o1C\#1985/232\# $522 *$. The credits of Deutschmark 70 million and US\$ 15 million have been converted to CHF using the exchange rates indicated in Officer, "Exchange Rates Between the United States Dollar and Forty-one Currencies". 
grammes should fail, and letting the Scandinavian governments enjoy the benefits of a successful action alone. ${ }^{30}$ Consequently, the Swiss delegation agreed during the EFTA Ministerial Meeting of 6 November 1975 in Geneva to contribute to the $\$ 100$ million EFTA development fund for Portugal. ${ }^{31}$ Nearly a year later, in October 1976, the Swiss parliament approved participation in the fund amounting to about CHF 63 million (one quarter of the total fund). Barely four months after a majority of Swiss voters had rejected a loan of CHF 200 million to the IDA, the Swiss parliament's approval of a contribution to the EFTA fund was, to observers, somewhat surprising. The French ambassador in Switzerland concluded that the catchwords of European solidarity and the fight against Communism in Portugal had been responsible for this result. ${ }^{32}$ But it also appears that aid for a European country was easier to sell in Switzerland than aid for Third World states.

In the latter half of 1975 , Swiss banks started to negotiate credit arrangements with Portugal. In late November 1975, the SNB granted a loan of $\$ 50$ million to the Banco de Portugal. The FPD welcomed this as a sign of Swiss goodwill towards Portugal and considered the timing of the decision to be extremely favourable. ${ }^{33}$ By the latter half of 1975 , the PCP had lost much support, as a civilian anti-Communist opposition formed around the PS and moderate officers gained influence within the MFA. A sixth provisional government, formed in early September, included the democratic parties and benefited from substantial US and Western European financial aid. With the failure of a coup staged by left-wing military forces on 25 November 1975, the

30 Claudio Caratsch, DPA, memorandum, "Assistance technique et économique au Portugal", o6.10.1975, dodis.ch/3906o; Jean-Jacques Maeder, Trade Division, memorandum, "Portuv gal: assistance économique. Réunion du 3 octobre 1975 avec MM. Ambassadeur Languetin; Jagmetti; Caratsch; Wiesmann; Streuli; Jetzer; Bru; Jg; Lo; Ae; Mr", o7.10.1975, dodis. $\mathrm{ch} / 39886$.

Jean-Jacques Maeder, memorandum, “AE LE: assistance financière au Portugal”, 29.10.1975, SFA E711O\#1986/24\#1024*; EFTA, Economic and Development Committee, "Essai de définition des modalités d'un fonds de l'AELE en faveur du Portugal. Note de la Délégation Suisse", 04.12.1975, ibid.; decree of the Federal Council, "AELE: Réunion ministérielle du 6 novembre 1975 à Genève. Instructions et delegation”, 05.11.1975, and attached proposals and reports by the FPD and the FDEA, dodis.ch/39898.

32 Letter from Claude Lebel, French ambassador in Switzerland, to Louis de Guiringaud, French Foreign Minister, "Participation de la Suisse au Fonds de développement institué par l'A.E.L.E. en faveur du Portugal", 05.10.1976, CAD 1929INVA/4683.

Minutes of the meeting of the SNB's directorate on 27 November 1975, "No. 1311. Kredit an Portugal", pp. 1908-1909, Archives of the Swiss National Bank, Zurich, Switzerland (ASNB); note from Ernesto Thalmann, secretary-general of the FPD, to Pierre Graber, strictly confidential, 28.11.1975, SFA E2Oo1E-o1\#1987/78\#4656*. See also the minutes of the meeting of the SNB's directorate on 30 October 1975, "No. 1187. Kredit an Portugal”, pp. 1729-1730, ASNB. 
prospect of a Communist takeover in Portugal had vanished. ${ }^{34}$ The SNB had a $10 \%$ participation in a $\$ 25$ o million ( $\mathrm{CHF} 645.3$ million) loan that the Bank for International Settlements (BIS) in Basel granted to Portugal in November 1975. In mid-1976, it contributed $\$ 55$ million to a loan of $\$ 25$ o million granted to Portugal by eight European central banks. ${ }^{35}$

Switzerland's provision of bilateral and multilateral financial aid to Portugal only took off once Portugal was set on a non-Communist path and a political and economic return on the investment might reasonably be expected. In the parliamentary elections of April 1976, the Ps won the most votes $(35 \%)$ and subsequently formed a minority government. General António Ramalho Eanes won the presidential elections and took office in June 1976 at the head of a constitutional democracy. ${ }^{36}$ In 1976, Swiss-Portuguese relations started to improve. Exports to Portugal, which had dropped by over $40 \%$ in 1975 compared to 1974, were growing once more. In September 1976, bilateral negotiations on economic collaboration and technical aid were resumed. ${ }^{37}$ The visit of the Portuguese Foreign Minister to Bern in January 1977 symbolised the normalisation of political relations between the two states. ${ }^{38}$ The cooling of bilateral relations that began in the second half of 1974 and the Portuguese leadership's preoccupation with domestic turmoil explain why the Portuguese government's position was rarely cited in Swiss decision-making during the decolonisation of Angola and Mozambique.

34 Maxwell, The Making of Portuguese Democracy, pp. 149-157.

35 Minutes of the meeting of the SNB's directorate on 17 November 1975, "No. 1262/6. Kredit an Portugal", pp. 1832-1833, ASNB; minutes of the meeting of the SNB's directorate on 8 January 1976, "No. 3/4. Kredit der BIZ an Portugal", p. 6, ibid.; minutes of the meeting of the SNB's directorate on 26 February 1976, "No. 197/2.1. Kredit der BIZ", p. 311, ibid.; minutes of the meeting of the SNB's directorate on 8 July 1976, "No. 620. Kredit der BIZ an Portugal", p. 987 , ibid.; minutes of the meeting of the SNB's directorate on 22 July 1976 , "No. 653 b. Zentralbankkredit an Portugal”, p. 1038, ibid. The sum has been converted to CHF using the exchange rates indicated in Officer, "Exchange Rates Between the United States Dollar and Forty-one Currencies".

36 Maxwell, The Making of Portuguese Democracy, pp. 16o-165.

37 Jean-Jacques Maeder, memorandum, "Commission mixte suisse-portugaise. 21-23 septembre 1976", late September 1976, dodis.ch/48598.

38 Letter from Claude Lebel to Louis de Guiringaud, "Visite du Ministre portugais des Affaires Etrangères à Berne”, 18.01.1977, p. 2, CADN 370PO/B/749; see also François Nordmann, FPD, minutes, "Visite officielle à Berne du Ministre des affaires étrangères du Portugal, M. José Manuel de Medeiros Ferreira, les 13 et 14 janvier 1977”, 07.02.1977, dodis.ch/48124. 


\section{Aid and Recognition: Preparations for the Independence of the Portuguese Colonies}

In late July 1974, the Portuguese government promulgated a law recognising the right to self-determination of the African colonies. It expressed the new regime's commitment to decolonisation and opened the way for bilateral agreements on the transition of power to the PAIGC in Guinea-Bissau and FRELIMO in Mozambique. ${ }^{39}$ There was, as yet, no indication as to which liberation movement would come into power in Angola. The Swiss political and business elites started to prepare for the establishment of diplomatic and economic relations with independent Angola and Mozambique. This was all the more urgent as Switzerland's image problem in sub-Saharan Africa continued to grow. Heinz Langenbacher, Swiss ambassador in Ethiopia, warned his colleagues during the annual meeting of Swiss ambassadors in Bern in early September 1974 that economic collaboration with the white minority regimes in Southern Africa had started to undermine the credibility of Switzerland's neutrality policy. Members of the OAU accused the country of leading a "cynical, interest-driven policy that uses humanitarian actions as a smokescreen", which compared unfavourably with Sweden's "more idealistic policy". 40

Cold War considerations were noticeably less important to Bern's analysis of the situation after the Carnation Revolution in the Portuguese colonies than in Portugal. FPD officials rarely cited FRELIMO's and the PAIGC's links to the Eastern bloc or the possibility that the Marxist-inspired MPLA might take over in Angola to justify their position. At least until the internationalisation of the Angolan War in late 1975, Switzerland's Western ties played only a small role in the department's decision-making. This was certainly due to a lessening of international tensions in the context of Détente between the superpowers. Yet, the Swiss diplomats' greater political flexibility in Southern Africa can also be explained by the US government's comparatively passive role in this region. After Richard Nixon's resignation on 9 August 1974, due to his involvement in the Watergate scandal, the Ford administration had other priorities. Policy conflicts within the State Department, between the African Bureau attentive to the tenets of African nationalism and Secretary of State Henry Kissinger who focused on geopolitical aims, also contributed to this. ${ }^{41}$

\footnotetext{
39 MacQueen, The Decolonization of Portuguese Africa, pp. 88-92.

40 Statement of Heinz Langenbacher, minutes of the Annual Conference of Ambassadors 04.09.1974-06.o9.1974, 30.09.1974, p. 75, dodis.ch/35118.

41

Schneidman, Engaging Africa, pp. 191-195.
} 
In order to prepare for the decolonisation of Angola and Mozambique, the Swiss government focused on two foreign policy instruments: the granting of humanitarian and development aid and diplomatic recognition of the soonto-be independent states. The recognition of a newly decolonised state is a prerequisite for the establishment of diplomatic relations. Since the Second World War, the Swiss government has recognised states, not governments. ${ }^{42}$ Its policy in this matter was guided by the principle of universality, which called for the diplomatic recognition of all states, no matter the political couleur of their regime. In actual fact, the decision of whether or not to recognise a state was always influenced by political considerations. This was particularly evident in the case of the divided states of Germany, Vietnam, and Korea. In all three cases, the Swiss government first recognised the pro-Western governments, and only in the early 1970s their Communist counterparts. ${ }^{43}$ In the context of decolonisation, the question of whether a colony achieved its independence in agreement with the colonising power was a decisive element in the Swiss government's recognition policy.

The Swiss government's position on the recognition of Guinea-Bissau after the PAIGC declared its independence on 24 September 1973 set a precedent for Swiss decision-making during the decolonisation of Angola and Mozambique. The PAIGC's unilateral declaration of independence was immediately recognised by many African governments. In early November 1973, the AfroAsian majority in the UNGA carried a resolution welcoming Guinea-Bissau's independence, in the face of opposition from Portugal, the US, the UK, Spain, Greece, Brazil, and South Africa. All other Western European states abstained. ${ }^{44}$ Two weeks later, Guinea-Bissau entered the OAU. ${ }^{45}$ In Bern, Swiss solidarity groups' demands for the recognition of the new state went unheeded. Reply-

42 Heinz Klarer, Die schweizerische Praxis der völkerrechtlichen Anerkennung, Zürich: Schulthess Polygraphischer Verlag, 1981, p. 294. See also Urban Kaufmann, "Nicht die ersten sein, aber vor den letzten handeln'. Grundsätze und Praxis der Anerkennung von Staaten und Regierungen durch die Schweiz (1945-1961)", in Antoine Fleury, Horst Möller, Hans-Peter Schwarz (eds.), Die Schweiz und Deutschland 1945-1961, Munich: R. Oldenbourg, 2004, pp. 69-87.

43 Switzerland finally recognised North Vietnam in September 1971, the GDR in December 1972, and North Korea in December 1974. On this subject, see Schaufelbuehl, Wyss, Bott, "Choosing Sides in the Global Cold War".

44 Letter from Bernard Turrettini, Ambassador at the Office of the Permanent Observer of Switzerland to the United Nations, to the Dio, "UNo: Republik Guinea-Bissau. Resolution 3061 (XVIII)", 05.11.1973, SFA E2001E-o1\#1987/78\#4649*. See also MacQueen, "Belated Decolonisation and UN Politics against the Backdrop of the Cold War".

45 Letter from Heinz Langenbacher to the DIO, "OAU: Guinea-Bissau", 19.11.1973, SFA E20o1Eol\#1987/78\#4649*. 
ing to a parliamentary question by Jean Vincent, National Councillor and member of the Swiss Workers' Party, the Federal Council argued in February 1974 that Guinea-Bissau did not meet the criteria required of a sovereign state under international law; there was no government that sovereignly and permanently exercised public authority over the population and territory, as the independence war was still ongoing. ${ }^{46}$ At the time, even the Swedish government, which had been the largest external donor to the PAIGC apart from the Soviet Union, did not yet plan to recognise Guinea-Bissau. ${ }^{47}$

The Portuguese coup d'état changed the situation. As the Scandinavian countries and the Netherlands considered recognising Guinea-Bissau even if the new Portuguese regime should continue to refuse negotiating with the PAIGC, FPD leaders started to contemplate doing the same. Given that Switzerland's economic interests in Guinea-Bissau were almost non-existent, their new willingness to recognise the new state was entirely political; they did not want Switzerland to be one of the last states to recognise Guinea-Bissau. ${ }^{48}$ As in the cases of the recognition of North Vietnam and North Korea, the Swiss government coordinated this step with its fellow European neutrals. While Sweden was one of the main advocates of the speedy recognition of GuineaBissau, the Austrian government saw no need to hurry, as there was hardly any public pressure to do so in Austria. ${ }^{49}$ In June 1974, the DiO decided to provide 10 tons of powdered milk to the population in Guinea-Bissau that the ICRC was to distribute, aid that it was hoped would make a favourable impression on the country's future rulers. ${ }^{50}$

46 Decree of the Federal Council, "(No 572) Petite question Vincent du 28 janvier 1974 concernant reconnaissance de la Guinée-Bissau", 13.02.1974, SFA E20o1E-o1\#1987/78\#3234*. See also the telegram from the KSA to Pierre Graber, 26.o9.1973, SFA E2001E-o1\#1987/78\#4649*; petition by numerous Swiss solidarity movements to the Federal Council, received on 16.01.1974, SFA E2001E-o1\#1987/78\#4649*.

47 Letter from Claude Ochsenbein, chargé d'affaires a.i. of the Swiss embassy in Sweden, to the DPA, "Relations Suède-Guinea-Bissau", 04.03.1974, SFA E2001E-o1\#1987/78\#3234*; Sellström, Sweden and National Liberation in Southern Africa. Volume II: Solidarity and Assistance, p. 64.

48 No author, memorandum, "3. Guinea-Bissau", 24.04.1975, attached to the note from the FPD to Federal Councillor Pierre Graber, 25.04.1975, SFA E20o1E-o1\#1987/78\#1683*; HN, memorandum, "Visite Kirchschläger. Guinée-Bissau: remarques introductives”, 02.05.1974, SFA E2001E-o1\#1987/78\#3234*.

49 No author, excerpt of minutes, "Extrait du procès-verbal des entretiens avec M. Kirchschläger du 3 mai 1974", no date, SFA E20o1E-ol\#1987/78\#3234*; Karl Fritschi, DPA, memorandum, "Anerkennung von Guinea-Bissau. Schwedens Haltung", 07.06.1974, ibid.

50 Letter from René Keller to the Swiss embassy in Guinea, 20.06.1974, SFA E20o1Eol\#1987/78\#3234*; letter from Benoît Frochaux, chargé d'affaires a.i. of the Swiss embassy in Guinea, to the DIO, 01.07.1974, ibid. 
On 9 August 1974, the Portuguese authorities concluded an agreement in principle on decolonisation with the PAIGC. Sweden and Finland immediately recognised Guinea-Bissau. Ceding to international pressure, the Portuguese Foreign Minister invited the ambassadors of states that had not yet recognised Guinea-Bissau to a meeting, hinting that Lisbon was no longer opposed to such a step. ${ }^{51}$ As the EEC member states and Austria, a member of the UN Security Council, recognised Guinea-Bissau, on 12 August the Secretary General of the FPD suggested that the Federal Council should not hesitate any longer: "Otherwise, we will finally be among the last to maintain the fiction of the colonial status." ${ }^{52}$ The Federal Council recognised Guinea-Bissau the following day, before this territory's formal independence. On 10 September, Guinea-Bissau was the first Portuguese colony to be officially granted independence. A week later, it joined the UN. ${ }^{53}$

The case of Guinea-Bissau indicates some of the factors that would influence Swiss decision-making when it came to the recognition of Mozambique and Angola; the granting of humanitarian aid, close attention to the position of the colonial power, the desire to be neither the first nor the last to recognise a new state, and attempts to coordinate decisions with the other European neutrals and the EEC. Yet, Swiss recognition of Guinea-Bissau, like that of other Western states, can also be read as a sign of Third World power. In a context of mounting Afro-Asian criticism of Western collaboration with the white minority regimes in Southern Africa, Western governments were under pressure to show their support for African nationalism. In the case of the recognition of Guinea-Bissau, this could be done at minimal political and financial cost.

After the Western recognition of Guinea-Bissau, international attention turned to Mozambique. In mid-August 1974, for the first time since the Carnation Revolution, Swiss embassy officials in Washington discussed the situation in Portuguese Africa with the US Deputy Assistant Secretary of State for African Affairs, Edward William Mulcahy. The latter underlined that, although developments in this region were not a priority of Washington's foreign policy, they did receive high-level attention. In a report to Bern, Olivier Exchaquet, the chargé d'affaires of the Swiss embassy, commented that the Ford

$5^{1} \quad$ Telegram no 7 o from Jean-Louis Pahud to the DPA, 10.08.1974, SFA E2Oo1E-o1\#1987/78\#3234*; telegram no 50 from Charles Müller to the Swiss embassy in Lisbon, 07.08.1974, ibid.; telegram no 85 from Peter Friederich, Swiss embassy in Finland, o9.08.1974, ibid.; letter from Claude Ochsenbein to the DPA, "Reconnaissance de la Guinée-Bissau", 12.08.1974, ibid. SFA E2001E-o1\#1987/78\#3234*.

53 Telegram no 12 from Alfred Reinhard Hohl, DPA, to the Swiss embassy in Guinea, 13.08.1973, SFA E20o1E-o1\#1987/78\#3234*; MacQueen, The Decolonization of Portuguese Africa, p. 109. 
administration's Africa policy lacked direction: "One gets the impression that $\mathrm{X}$ [Mulcahy] is preoccupied with the consequences of Mozambique's independence, but that the State Department has no plan at all to cope with possible troubles. ${ }^{54}$ Exchaquet would come to a similar conclusion regarding the Ethiopian Revolution only a month later. Consequently, Switzerland's Africa policy was, in the following years, more closely coordinated with the other neutral and Western European states than with the US.

On 7 September 1974, the Portuguese authorities and FRELimo concluded the Lusaka Agreement, which established the legal framework for the decolonisation of Mozambique. The agreement introduced an official ceasefire after 11 years of war and set the terms for FRELIMO to take over without holding elections. A transitional government consisting of FRELIMO members and Portuguese representatives took over the running of Mozambique until its independence, set for 25 June 1975 . The Portuguese military quickly put down an attempted coup in Lourenço Marques staged by groups of white settlers and Africans hostile to FRELIMO.$^{55}$ In early October 1974, two delegations of Swiss citizens living in Mozambique visited Bern to demand governmental support during decolonisation. A group of DM and IPM members requested financial aid to continue their humanitarian efforts. The missionaries also hinted that early recognition of Mozambique might compensate for Switzerland's former lack of support for African liberation movements. ${ }^{56}$ Representatives of the major Swiss companies in Mozambique raised the spectre of nationalisations. The risk that FRELIMO might introduce a Soviet-style system of economic development or Tanzanian-style nationalisations and collective agriculture schemes was mentioned in numerous reports by Swiss diplomats in Portugal, Tanzania, and Mozambique. ${ }^{57}$ Convinced of the importance of establishing, at

54 PR no 78 from Olivier Exchaquet, chargé d'affaires a.i. of the Swiss embassy in the US, "Le désengagement portugais en Afrique vu de Washington", 16.08.1974, p. 5, SFA E230oo1\#1977/30\#88*.

55 Newitt, "Mozambique", p. 193; MacQueen, The Decolonization of Portuguese Africa, pp. 146-148.

56 Claude Huguenin, memorandum, "Visite de membres du Département missionnaire de Lausanne et de l'Eglise presbytérienne du Mozambique", 14.10.1974, p. 2, SFA E2200.167\#1991/284\#21*.

Letter from Jean-Louis Pahud to the DPA, 27.09.1974, very urgent, SFA E20o1E-o1\#1987/ 78\#4651*; PR no. 8 from Lucien Mossaz, "Prévisions sur la politique du Mozambique", o1.10.1974, SFA E2OO1-09\#1984/68\#85*; letter from Mossaz to the Trade Division, "La politique économique du Mozambique indépendant”, o3.10.1974, SFA E 7110\#1985/97\#500*; see also telegram no 11 from the Swiss consulate in Mozambique to the FPD, 27.09.1974, SFA E20o1E-o1\#1987/78\#4651*; telegram no 6o from Alfred Reinhard Hohl to the Swiss embassy in Portugal, 26.o9.1974, SFA E2001E-o1\#1987/78\#4651*; letter from Louis Rochat, 
the very least, informal contact with FRELIMO as soon as possible, the deputy chief of the DPA, Michael Gelzer, requested these diplomats to report on the plans of the Scandinavian states, the EEC, and Austria. ${ }^{58}$ On 30 October 1974, while these strategic clarifications were ongoing, the Federal Council decided to recognise Mozambique after full independence and authorised the FPD to determine the date of official recognition. ${ }^{59}$

The FPD leaders' wish to get on good terms with Mozambique's future rulers was part of their growing efforts to show more openness towards the Third World. Symptomatic of this was an increasing awareness that Switzerland's negative attitude towards liberation movements had been short-sighted, as the chief of the DIO's section for the UN and international organisations, Franz Muheim, stated in a note to his supervisor in late October 1974:

We probably neglected to take into account that today's leaders of liberation movements are often the same people that will be responsible for the government of independent states tomorrow, states we will recognise and establish diplomatic relations with, but also states on whose goodwill we will depend to some degree, because they host Swiss colonies, Swiss investments, and other Swiss economic interests. ${ }^{60}$

The lack of Western support had, according to him, forced these movements to seek aid elsewhere and had subjected them to the influence of the Eastern bloc. ${ }^{61}$ Richard Pestalozzi's criticism of the official Swiss policy on Southern Africa was even more explicit. Referring to the Ethiopian attacks against Switzerland linked to the controversy surrounding the Emperor's Swiss bank accounts, he warned that the country's good name might suffer if its government did not take a stand and use all its means to limit economic exchanges

Financial and Economic Service of the FPD, to the SNB, the SBA, and the Federation of Swiss Industrial Holding Companies, "La politique économique du Mozambique indépendant", o9.10.1974, ASBA, folder L. 182 Afrique 5.1.71 au 14.7.75.

$5^{8}$ Letter from Michael Gelzer, Deputy Chief of the DPA, to the Swiss embassies in Portugal and Tanzania and the consulate in Mozambique, "Schweizerische Interessen in Mozambique", o3.10.1974, SFA E2001E-o1\#1987/78\#4651*.

59 Decree of the Federal Council, "Anerkennung von Mozambique durch die Schweiz", 30.10.1974, SFA E2001E-o1\#1987/78\#4178*.

6o Note from Franz Muheim, chief of the Dio's section for the UN and international organisations, to René Keller, "OLP - Afrikanische Befreiungsbewegungen; Stellung der Schweiz", 29.10.1974, p. 3, SFA E2003A\#1988/15\#573*.

$61 \quad$ Ibid., p. 4. 
with South Africa. ${ }^{62}$ However, since the majority of the Federal Council was unwilling to curtail Switzerland's economic relations with South Africa, and the development of legal measures to limit trade with Rhodesia advanced only slowly, the sole remaining means to improve Switzerland's image in Southern Africa was the granting of humanitarian aid to the liberation movements in this region. ${ }^{63}$

Consequently, in reply to a request from a committee of Portuguese, Swiss, and Dutch religious organisations for aid to support famine-stricken provinces in Mozambique, the Swiss authorities granted food aid amounting to $\mathrm{CHF}$ 140,000. ${ }^{64}$ Many FPD officials agreed that a gesture of goodwill towards the Mozambican population was "politically desirable" as a sign of a Swiss presence in Mozambique "beyond purely mercantile motives", as Michael Gelzer put it in late November. ${ }^{65}$ This was all the more important as, in mid-October, European and African newspapers had started to spread rumours about a Swiss millionaire attempting to recruit mercenaries to prevent FRELIMO's takeover. Investigations by the Office of the Attorney-General of Switzerland concluded, in December 1974, that the rumours were untrue and that the millionaire, a rather ambivalent character who had a profitable business helping people escape from the GDR, had only been drawing attention to himself. Nevertheless, this affair was embarrassing for the Swiss government, which continued to be confronted by these rumours until early $1975 \cdot{ }^{66}$

62 PR by Richard Pestalozzi, "Die Schweiz und der Konflikt um die weissen Regime in Südafrika", 14.11.1974, SFA E2003A\#1988/15\#1508*.

63 Letter from Michael Gelzer to the Swiss embassy in Kenya, 23.12.1974, SFA E2001E-o1\#1987/ 78\#4329*.

64 Note from Denise Werner, chief of the Dio's International Aid Organisations Section, to the DPA, "Aide humanitaire sollicité au faveur du Mozambique", 20.11.1974, SFA E2001E-o1\#1987/78\#4651*; letter from René Keller to the KSA, 12.12.1974, SFA E2200.54○ß $1992 / 228 \# 38^{*}$.

65 Note from Michael Gelzer to the International Aid Organisations Section of the DIo, "Humanitäre Hilfe an Moçambique", 26.11.1974, SFA E2001E-o1\#1987/78\#4651*. See also the note from Denise Werner to the DPA, "Aide humanitaire sollicité au faveur du Mozambique", 20.11.1974, ibid.; letter from Jean-Louis Pahud to the DPA, "Schweizerische Interessen in Mozambique", 21.11.1974, ibid.

66 Telegram no 81 from Richard Pestalozzi to the FPD, 23.10.1974, SFA E2001E-o1\#1987/78\#4651*; letter from Bernard Torrione, Swiss Consul-General in Milano, Italy, to the DPA, 24.10.1974, ibid.; letter from Alfred Reinhard Hohl to the Office of the Attorney-General of Switzerland, 30.10.1974, ibid.; letter from Louis Chaney, Swiss consul in Mozambique, to the DPA, "Mercenaires pour le Mozambique", 07.11.1974, ibid.; letter from Etienne Vallotton, Swiss ambassador in Algeria, to the DPA and the Information and Press Service of the FPD, 26.11.1974, ibid.; letter from Rudolf Gerber, Attorney-General, to the FPD, 16.12.1974, ibid., and the attached report from [?] Lörtscher, Zurich City Police, to the Office of the Attor- 
In late 1974, FPD leaders observed the tense situation in Angola with great interest and ordered the Swiss honorary consul in Luanda to write regular reports. ${ }^{67}$ However, for several reasons, they did not yet take any steps to establish political contact with the country's future rulers. First, the Portuguese authorities had not yet concluded a decolonisation agreement with the rivalling Angolan liberation movements. Second, the Swiss authorities had no information about significant Swiss investments in this state that would have justified a proactive stance. Finally, anti-Communism might also have played a role. In a letter to the Swiss ambassador to Zaire in mid-November, Alfred Hohl of the DPA expressed his worry that forces might gain influence in Angola that "are closer to Brazzaville or Dar es Salaam and might thus obtain their schoolbooks from Moscow rather than from the West". ${ }^{68}$

In mid-January 1975, the Portuguese government and the three Angolan liberation movements, which had been pressured by the OAU and independent African governments to present a common front in the negotiations with the colonial power, concluded the Alvor Agreement. It set the terms for Angola's accession to independence on 11 October 1975 and created a transitional government consisting of a Portuguese High Commissioner and a presidential council with a representative of each movement. The twelve ministries were divided equally between the three movements and Portugal. 69 As a consequence, the DPA started to make detailed plans for Switzerland's future relations with Mozambique and Angola. The establishment of diplomatic relations with these two states was judged important for two reasons: first, it would counterbalance Switzerland's close links with South Africa; second, it would make it easier for Swiss firms to benefit from the economic potential of Angola and Mozambique. Hydroelectric projects in these territories, their deepwater

ney-General of Switzerland, 13.11.1974; letter from Heinz Langenbacher to the DPA, "OAU", 20.01.1975, ibid.; letter from [?] Ritter, Swiss embassy in Libya, to the DPA, "Neutralität der Schweiz. Söldner für Mozambique”, 05.04.1975, ibid. See also Stefan Hohler, Hans Ulrich Lenzlinger. Fluchthelfer, Abenteurer und Lebemann, Bern: Stämpfli, 2013.

67 Letter from Alfred Reinhard Hohl to Roland Gottraux, O2.10.1974, SFA E2200.54-O3\#1992/ $228 \# 252^{*}$, see also letter from Gottraux to the FPD, 22.09.1974, SFA E2200.54-03\#1992/ $228 \# 252^{*}$.

68 Letter from Alfred Reinhard Hohl to the Swiss Embassy in Zaire, 12.11.1974, SFA E2001E-o1\#1987/78\#4650*. See also the letter from Hohl to the Trade Division, 22.11.1974, ibid.; letter from Jean-Louis Pahud to the DPA, "Schweizerische Interessen in ANGOLA", 03.12.1974, SFA E2001E-o1\#1987/78\#4651*; letter from Hans Lüthi, Trade Division, to the DPA, "Wirtschaftsbeziehungen mit Angola", og.12.1974, SFA E7110\#1985/97\#457*.

69 Gleijeses, Conflicting Missions, p. 242; MacQueen, The Decolonization of Portuguese Africa, pp. 174-176; Marcum, Exile Politics and Guerrilla Warfare, p. 255. 
ports, and their natural resources, especially Angola's oil, were considered to be of particular interest to Swiss companies and investors. ${ }^{70}$

In parallel, the STC decided to grant development aid to Mozambique and Guinea-Bissau. Angola was excluded from these plans because of its political instability. The Soviet ties of FRELIMO and the PAIGC were not seen as an obstacle. The Delegate for Technical Cooperation even considered that the two states' socio-economic policies favouring the rural population would facilitate the selection of suitable cooperation projects. ${ }^{71}$ However, because of difficulties in identifying projects that met the STC's criteria, the service decided, in July 1975, to wait before taking up direct bilateral cooperation with Mozambique. Instead it made financial contributions to projects carried out by the Food and Agriculture Organization (FAO), the United Nations Children's Fund (UNICEF), and the DM. ${ }^{72}$

During the first half of 1975, the continuing conflict between the three Angolan liberation movements made it very uncertain who the country's future rulers would be. Clashes between the FNLA and the MPLA turned increasingly violent, while Portuguese troops proved unwilling to enforce the Alvor Agreement. UNITA kept out of the fighting and consolidated its political and military support. ${ }^{73}$ In this context, the DPA was careful not to favour one liberation movement over another, in order to keep its diplomatic options open, and cited its policy of neutrality to justify its non-committal stance. For example, when two representatives of UNITA approached a Swiss diplomat in Geneva in early February 1975 to convey their leader's wish to establish relations with Switzerland, the diplomat replied with what would become a standard phrase during the following months: "Switzerland cannot take position in favour of one of the three liberation movements, this would represent an interference into the internal affairs of Angola". ${ }^{74}$

$70 \quad$ FPD, memorandum, "Angola \& Mozambique", no author, no date, attached to a note from Alfred Reinhard Hohl to Charles Glauser, FPD, 03.02.1975, SFA E2004B\#199o/219\#344*.

71 Note from Marcel Heimo, Delegate for Technical Cooperation, to the DPA, "Coopération technique avec le Mozambique, l'Angola et la Guinée-Bissau”, 10.02.1975, p. 3, SFA E2005A\#1985/101\#547*.

72 Note from Marcel Heimo to the DPA, "Technische Zusammenarbeit mit Mozambique", 08.07.1975, SFA E2005A\#1985/101\#547*; see also the note from Serge François Salvi, head of the STC's Africa section, to Claude Huguenin, "Coopération avec le Mozambique", o3.06.1975, ibid.

73 Gleijeses, Conflicting Missions, pp. 251-253.

74 Note from Jean Schneeberger, Permanent Mission of Switzerland to the United Nations Office and the other international Organisations in Geneva, to André Dominicé, chief of the Permanent Mission, 07.02.1975, SFA E2001E-o1\#1987/78\#4650*. 
Unofficial contacts were a different matter. After the fall of the Estado Novo regime, the fact that the Swiss authorities had, in the 196os, granted political asylum to a number of Angolan refugees offered a potential diplomatic opportunity. Two members of the Angolan transitional government and three state secretaries, all but one members of UNITA, had lived in Switzerland during the liberation war. Other former refugees occupied high positions within the liberation movements. The most prominent of these were José N'Delé, UNITA's representative in the presidential council, and Jonas Savimbi, the movement's leader, both of whom were married to Swiss citizens. ${ }^{75}$ FPD officials considered the Swiss ties of these influential Angolans to be an advantage for the establishment of good relations with an independent Angolan government. Thus, in early 1975, they unofficially cultivated their relations with former Angolan refugees. On the one hand, this enabled them to obtain privileged information about the situation in Angola and the plans of the liberation movements. On the other hand, with an eye on the long term, they hoped that possible future leaders of this country would be well disposed towards Switzerland.

In early March 1975, for example, a D PA representative met with FNLA member Albert Tanda before the latter's departure from Switzerland to take on a high-level post in Luanda. During their discussion, Tanda made it clear that the FNLA was unwilling to share power and wanted to establish a military government in Angola. ${ }^{76}$ While this prospect did not appeal to the Swiss authorities much more than the MPLA's ideological leanings, the Swiss authorities' perception of UNITA and its leader was overwhelmingly positive. In a report to Bern in March 1975, the Swiss consul in Angola described Jonas Savimbi as an "intelligent leader", "non-racist", commanding a well-disciplined army and having the least "leftist" political programme of the three Angolan movements. ${ }^{77}$ Inspector René Gailloz of the Federal Police, who had been in regular contact with N'Delé and Savimbi during their time in Switzerland, insisted that Savimbi was a "very moderate politician and well-disposed towards our

75 René Gailloz, inspector of the Federal Police, memorandum, "Gouvernement de transition angolais et anciens réfugiés angolais en Suisse”, 30.04.1975, SFA E2001E-o1\#1987/78\#4650*. See also Giovanni E. Bucher, Swiss ambassador in Portugal, to the AD, "Démission de M. R.P Gottraux, Consul hon. de Suisse à Luanda", 12.02.1975, SFA E2200.54-03\#1992/228\#252*.

76 Claude Huguenin, memorandum, "Visite du ressortissant angolais M. Albert TANDA", 13.03.1975, p. 2, SFA E2001E-01\#1987/78\#4650*.

77 Marcel Guélat, Swiss consul in Angola, to the AD, confidential, 24.03.1975, pp. 4-5, SFA E2001E-01\#1987/78\#4650*. 
country",78 and that his movement was not steered from outside, "unlike the protégés of President Mobutu of Zaire (FNLA) or of the Soviet bloc (MPLA)."79

Despite this positive reading of UNITA, the Swiss authorities remained careful not to openly favour the movement. They took greater care to appear impartial during the early stages of the Angolan conflict than their Swedish counterparts. In February 1975, Sweden's Social Democratic government, which had close and long-standing links with the MPLA, decided to honour a bilateral aid agreement concluded with the movement the year before. Despite some domestic criticism that this constituted undue interference in Angola's internal affairs, Swedish representatives continued their consultations with the MPLA and their initial, very limited, humanitarian aid was disbursed just before the independence of Angola in November 1975. This aid relationship amounted to a de facto recognition of the MPLA as Angola's legitimate future government, which was clearly understood both by the MPLA and its two opponents..$^{80}$

The clashes between the liberation movements rendered it more difficult for the FPD to make its humanitarian aid appear neutral and disinterested. In early 1975, for example, the FNLA requested urgent Swiss help to train nurses. Jean-Pierre Weber, Swiss ambassador to Zaire, argued in late March that "[o]bviously, our attitude must be to win the future leaders without moving away from our traditional position or taking position in the conflict". ${ }^{81}$ Caught between the political potential of granting humanitarian aid to the Angolan population, and a certain reluctance to support a potential future warring party, the DPA decided that this request could only be considered if it was channelled through the provisional government. ${ }^{82}$ With the intensification of the Angolan conflict from mid-1975 onwards, members of the FPD insisted that every Swiss aid project had to benefit all three warring parties equally, ${ }^{83}$ so as not to endanger Switzerland's policy of neutrality.

78 Cited in Alfred Reinhard Hohl, memorandum, 10.04.1975, SFA E20o1E-o1\#1987/78\#4650*.

79 René Gailloz, memorandum, "Gouvernement de transition angolais et anciens réfugiés angolais en Suisse”, 30.04.1975, p. 3, SFA E2Oo1E-o1\#1987/78\#4650*.

8o Sellström, Sweden and National Liberation in Southern Africa. Volume II: Solidarity and Assistance, pp. 129-131.

81 Jean-Pierre Weber, Swiss ambassador in Zaire, to the DPA, confidential, 27.03.1975, p. 2, SFA E2005A\#1985/101\#230*.

82 Note from Alfred Reinhard Hohl to the DIO and the Delegate for Technical Cooperation, "Angolesisches Gesuch um Ausbildung von Krankenschwestern", 08.04.1975, pp. 1-2, SFA E2005A\#1985/101\#230*. It seems that this project was never realised.

83 See, for example, Renata Carugo, sTc, to the Delegate for Technical Cooperation, "Entrée en matière", 26.o6.1975, p. 2, SFA E2005A\#1985/101\#114*. 
Due to the growing political instability, the FPD intensified its preparations for Angola's independence. In March 1975, the department sent career diplomat Marcel Guélat to take over the consulate in Luanda. The new consul soon concluded that a continuing official presence in the country was essential in order to show Switzerland's interest in Angola and ensure the evacuation of the approximately 100 Swiss citizens living in the country if the situation should deteriorate. A representative on the spot would also allow the Swiss authorities to quickly establish contact with the future government in order to ensure Switzerland's place in the future industrialisation of Angola. ${ }^{84}$ The Federal Council shared this view and decided, in June 1975, to recognise Angola after it achieved 'full independence'. ${ }^{85}$ It was left to the FPD to determine when this would be.

In Mozambique, meanwhile, the FPD sought to establish good relations with the country's new elite. This proved to be much more difficult than its members imagined. In early 1975, FRELIMo's leadership adopted a confident stance and showed great reticence towards the US and those Western European states it considered to have been allied to the Portuguese colonial power. Thanks to its selective interpretation of neutrality, Switzerland was seen as part of this camp. The Swiss embassy in Tanzania and consul Bruno Stöckli, who took on his post in Lourenço Marques at the beginning of February, attempted to make contact with FRELIMO in order to prepare for the establishment of official relations after Mozambique's independence. Two developments added urgency to their advances: first, the danger of nationalisations became real. In mid-February, the transitional government enacted a law permitting the nationalisation of empty buildings that targeted mainly the property of foreigners who had left the country in the preceding year. Second, FRELIMO's leaders made it known that they were unwilling to establish relations with diplomats that had received their accreditation from the colonial authorities and would not automatically accept the transformation of consulates, established under Portuguese rule, into embassies. ${ }^{86}$ Yet, all Swiss attempts to obtain an audience with FRELIMo's Vice-President, Marcelino dos Santos, who was

\footnotetext{
84 Marcel Guélat to the AD, "Mission en Angola - Rapport", o8.04.1975, pp. 8, 11-12, SFA E2200.54-O3\#1992/228\#252*.

85 Decree of the Federal Council, "Anerkennung von Angola durch die Schweiz", confidential, 16.06.1975, SFA E2001E-o1\#1987/78\#1683*.

86 Letter from Bruno Stöckli, Swiss consul in Mozambique, to the AD, very urgent and confidential, 21.02.1975, SFA E2001E-o1\#1987/78\#4178*; letter from Stöckli to the DPA, "Mozambique. Wahrung von schweizerischen Interessen", 14.03.1975, SFA E2001E-o1\#1987/78\#4182*.
} 
responsible for the movements' external relations at its headquarters in Dar es Salaam, were unsuccessful. ${ }^{87}$

This was not, in itself, extraordinary. Other Western states were facing similar dismissal. FRELIMo's leadership greatly distrusted the US government. In order to dispel suspicions of imperialist US designs, the American consul general, Peter C. Walker, recommended in late March 1975 that the Ford administration should recognise Mozambique immediately after its independence and be open to aid requests, but otherwise adopt a low profile. Walker insisted that FRELIMO wished to have diplomatic contact with both blocs. According to him, there was no reason to think that US interests should be affected any worse than "in the many other militantly 'non-aligned' African countries". 88 Thanks to their common interest in introducing majority rule in Rhodesia, and thanks to a generous British aid offer of $£_{15}$ million (CHF 83.7 million), the UK managed to get in touch with FRELIMO more quickly. A meeting between Samora Machel, the movement's leader, and the British Minister of Overseas Development was held on 10 May 1975 in Dar es Salaam, where they discussed future bilateral relations. ${ }^{89}$

A breakthrough in Swiss-Mozambican relations occurred on 22 May 1975. Through the intermediary of Hanna Sahlfeld-Singer, Social Democratic member of the National Council and Vice-President of the Südafrika Mission (South Africa Mission), two FRELIMO representatives who were passing through Switzerland were received by the DPA in Bern. This meeting proved that the alliances made during the independence war were still crucial for the liberation movement. The two Mozambicans compared Switzerland's selective interpretation of neutrality to Sweden's policy of neutrality, and judged its position

$87 \quad$ PR no 2 by Bruno Stöckli, "Mozambique. Entkolonialisierung und ihre Nebenerscheinungen”, 20.03.1975, p. 3, SFA E2300-01\#1977/30\#51*. Letter from Raymond Berberat, chargé d'affaires a.i. of the Swiss embassy in Tanzania, to the DPA, "Kontakte mit FRELIMO-Führung", 16.05.1975, SFA E2001E-o1\#1987/78\#4651.

88 Airgram from Peter C. Walker, US Consul General in Mozambique, to the Department of State, “Annual U.S. Policy Assessment - Mozambique", 25.03.1975, p. 9, see also 10; NARA, RG 59, Records Relating to Portuguese Guinea, Mozambique 1975, box 6 .

89 H.M.S. Reid, head of the CSAD, draft memorandum, no date, attached to the note from Reid to several department heads, 05.03.1975, TNA FCO 45/1732; no author, "Record of a meeting between President Samora Machel and other frelimo leaders and the Rt Hon Judith Hart MP, Minister of Overseas Development, in State House Dar es Salaam on 10 May 1975", no date, TNA FCO 45/1734; see also H.M.S. Reid to Norman Aspin, Assistant Under-Secretary of State, FCO, "Proposal for Samora Machel to visit London", 08.04.1975, TNA FCO 45/1732; Reid to Aspin, "Samora Machel”, 15.04.1975, ibid. The sum of $£_{15}$ million has been converted to CHF using the exchange rates indicated in Officer, "Exchange Rates Between the United States Dollar and Forty-one Currencies". 
during the conflict against that of Norway, Denmark, and the Netherlands, which had supported FRELIMO's independence struggle, and that of the UK. They also criticised the Swiss authorities for waiting too long before contacting FRELIMO. DPA leaders tried to deflect these accusations with information about possible humanitarian and development aid. ${ }^{90}$ They did not take up the suggestion to publish a communiqué on Switzerland's willingness to establish relations with Mozambique, considering it impossible to draft a text that satisfied both sides. ${ }^{91}$ Instead, they tried to obtain an official invitation to the Mozambican independence celebrations on 25 June 1975, in order to publicly show their support for independent Mozambique.

Invitations to the independence festivities were selective and reflected FRELIMO's priorities in foreign relations. While African and Eastern bloc states were welcomed to Mozambique, only Portugal, the UK, the Scandinavian countries, and the Netherlands received formal invitations. Unofficial groups from the US, the FRG, and Italy were also present. ${ }^{92}$ While the Ford administration does not seem to have been overly concerned about such treatment, the French authorities were particularly piqued and feared that it might damage their standing in Africa..$^{93}$ Their attempts to convince the other EEC member states to aim for a collective representation at the ceremonies failed and the French ambassador to Tanzania was explicitly told by a FRELIMO official to stay away from the festivities. ${ }^{94}$

In this context, the Swiss authorities again benefited from the connections of Swiss missionary circles. Thanks to the good offices of a DM member, who had been personally invited by Samora Machel to head up a delegation of Swiss churches, the FPD learned, four days before Mozambique's independence, that

$90 \quad$ Claude Huguenin, memorandum, "Premiers contacts à Berne avec les représentants du Frelimo", 26.05.1975, SFA E2001E-o1\#1987/78\#4651. See also the letter from National Councillor Hanna Sahlfeld-Singer to Pierre Graber, 30.04.1975, SFA E2001E-o1\#1991/17_Bd. 985, B.55.40.

91 Telegram no 36 from Jürg Andreas Iselin, deputy chief of DPA and chief of its African, Asian, Middle Eastern and Latin American Division, to the Swiss embassy in Tanzania, 20.06.1975, SFA E2001E-o1\#1987/78\#4178*.

92 Report from Stanley F. St. C. Duncan to James Callaghan, British Foreign Secretary, "Moçambique independence: visits by Minister of State, the Rt Hon Mr. David Ennals, MP, 24-26 June 1975", 30.06.1975, pp. 1-2, TNA FCO 45/1735.

Telegram from Peter C. Walker to the US Secretary of State, o9.05.1975, NARA, RG 59, AAD, CFPF, Electronic Telegrams 1975LOURENoo474; MC, Direction des affaires africaines et malgaches (DAM), memorandum, "Indépendance du Mozambique", 26.05.1975, p. 1, CAD 342QONT/6.

94 Telegram no 159-161 from Georges Denizeau, French ambassador in Tanzania, to the French Foreign Ministry, 18.06.1975, CAD 342QONT/12. 
its delegate would be welcome in Mozambique. ${ }^{95}$ Switzerland's role as a host of numerous international organisations may also have helped to soften FRELIMO's leadership. ${ }^{96}$ Despite the unorthodox way in which the Swiss delegate Paul Etienne Jaccaud, the new Swiss ambassador to Tanzania, had received his invitation to the independence ceremonies, he was received with all honours. Only Marcelino dos Santos showed hostility to the delegation of "capitalist Switzerland". Dos Santos' criticism of the lack of Swiss support for the Mozambican independence struggle was compounded by a personal grievance; during a trip to Switzerland in December 1974, where he gave a press conference and interviews organised by the DM, he was apparently refused an audience by the Swiss authorities. DPA leaders, however, did not recall this incident. ${ }^{97}$

On 25 June 1975, the day of Mozambique's independence, Pierre Graber sent a congratulatory telegram to Samora Machel, which equated to official recognition of the new state. ${ }^{98}$ Ten days earlier, the Swiss government had decided to recognise Angola after its independence. However, the situation escalated rapidly. In July, after heavy fighting, the MPLA expelled the FNLA from Luanda and the transitional government collapsed. FNLA leader Holden Roberto left Zaire and led his movement's march towards Luanda, while unita fought MPLA troops in central and southern Angola. That same month, President Ford approved covert CIA support for the FNLA and UNITA, and South Africa increased its aid to those two movements, while Cuba sent a mission to Angola to determine the MPLA's need for aid. ${ }^{99}$

At least until the Angolan War, which is discussed in chapter 7, the political necessity of establishing cordial contact with the governments of independent

95 Letter from Bruno Stöckli to the DPA, "VR Mozambique. Schweizerische Teilnahme an den Unabhängigkeitsfeierlichkeiten”, o9.o7.1975, p. 1, SFA E2001E-o1\#1987/78\#4178*; JeanPaul A. Widmer, DM, memorandum, "Note concernant les contacts entre le Département Politique Fédéral et les envoyés du gouvernement de la République Populaire du Mozambique, précédemment Frelimo", 30.09.1975, pp. 3-4, SFA E2001E-o1\#1987/78\#4651.

96 Telegram from Peter C. Walker to the Secretary of State, 03.07.1975, NARA, RG 59, AAD, CF PF, Electronic Telegrams 1975, 1975LOURENoo717.

97 Letter from Paul Etienne Jaccaud, Swiss ambassador in Tanzania, to the DPA, the AD, and the Trade Division, "Indépendance du Mozambique", o3.07.1975, p. 2, E2001E-o1\#1987/ $78 \# 4178^{*}$. This episode is mentioned in several SFA documents, but FPD members were at a loss to know if it had really taken place and if yes, who had refused to see dos Santos: see notably the handwritten comments on telegram no 23 from Bruno Stöckli to the FPD, urgent, 08.o3.1976, SFA E2OO1E-o1\#1988/16\#46o2*.

98 Telegram from Pierre Graber to Samora Machel, President of Mozambique, 25.06.1975, SFA E2Oo1E-o1\#1987/78\#4178*.

99 Gleijeses, Conflicting Missions, pp. 254, 257-258; Marcum, Exile Politics and Guerrilla Warfare, pp. 26o-262; Miller, "Yes, Minister", p. 17. 
Angola and Mozambique was undisputed, both within the Swiss federal administration and in civil society. The danger that existing Swiss interests in the Portuguese colonies might be nationalised and Swiss economic actors' wish to benefit from the two states' economic potential after the departure of the colonial authorities spurred Bern's efforts to get on good terms with the potential future rulers. Yet, as there were few commercial exchanges and Swiss investments, economic aspects were not decisive. The will to improve Switzerland's image and the credibility of its neutrality in Africa was key to its foreign policy during the decolonisation of Angola and Mozambique. The establishment of cordial relations with the countries' new rulers, which was supported by Swiss business circles and solidarity movements, was a low-cost means to counterbalance relations with the minority regimes. It also showed Third World observers that Switzerland was not racist and was supportive of newly independent black governments.

\section{"The Game Being Played Is Global": Attempts to Strengthen} Relations with the Third World

In mid-December 1974, foreign policy expert Walther Hofer, National Councillor for the conservative centre-right Swiss People's Party and a history professor at the University of Bern specialising in totalitarian systems and ideologies, requested the government to comment on Switzerland's position in what he termed a "new kind of Cold War" - a time when the Western world was under pressure not only from the USSR but also from the newly decolonised states of the Third World that engaged in "economic blackmail" at the UN and its specialised agencies. ${ }^{100}$ When replying to Hofer's query six months later, shortly before Mozambique became independent and the Angolan War escalated, Federal Councillor Pierre Graber took the opportunity to speak at length about Switzerland's place in the international system. In front of the Swiss National Council, Graber agreed that, since the October 1973 Arab-Israeli War, international relations, and particularly North-South relations, had changed. At a time when Third World leaders were trying to force the reorganisation of the international order, he insisted that Switzerland could not remain iso-

100 Interpellation by National Councillor Walther Hofer on 13 December 1974, "Interpellation Hofer-Bern. Internationale Lage - Situation internationale”, Amtliches Bulletin der Bundesversammlung 1975, Sommersession Nationalrat, 16.06.1975, pp. 842-849, p. 842; Peter Stettler, "Walther Hofer", 11.03.2014, HLS Online. 
lated. The economic interdependence of developing and industrialised states required Bern to participate actively in multilateral negotiations: "[t]he game being played is global; no one can avoid it." In order to improve its image and defend its political and economic interests, Graber asserted that the Swiss government needed to strengthen its relations with Third World states. ${ }^{101}$

The decolonisation of Angola and Mozambique occurred at a time when both North-South relations and Switzerland's foreign policy underwent a period of change. The 1973 oil shock, Third World demands for a NIEO, the assertive behaviour of Afro-Asian states at the 1974 ICRC IHL conference and other international organisations, OAU threats to blacklist firms trading with Rhodesia, and the scandal over the Ethiopian Emperor's Swiss bank accounts all contributed to a growing realisation that Switzerland's position in NorthSouth relations needed a rethink. By mid-1975, FPD leaders recognised the need to extend their efforts to lead a more active foreign policy on the Third World. When it came to East-West relations in Europe, similar steps had already been taken. At the CSCE negotiations in Geneva between September 1973 and July 1975, the Swiss delegation played an unusually energetic role, which led historian Thomas Fischer to talk about a "successful activation" of Switzerland's foreign policy in this sphere of international relations. ${ }^{102}$ Western observers highlighted the possibility of a positive Swiss contribution to the relaxation in East-West relations:

Switzerland may be small in the scheme of things and may still cling to her neutrality. But she is politically and socially one of the stablest countries in Europe, with a strong regard for liberty and a firmly democratic system of government [...]. She is an important trading partner with one of the highest standards of living and one of the strongest currencies in the world; financially Switzerland is in many ways a major Power. She is, moreover, situated in a key position along the NATO defence line across the continent. ${ }^{103}$

101 Statement by Federal Councillor Pierre Graber, "Interpellation Hofer-Bern. Internationale Lage - Situation internationale", Amtliches Bulletin der Bundesversammlung 1975, Sommersession Nationalrat, 16.06.1975, pp. 842-849, citation p. 847; see also Fischer, Die Grenzen der Neutralität, pp. 131-132.

102 Fischer, Die Grenzen der Neutralität, p. 157.

103 Diplomatic report no 12/75 from John Richard Wraight, British ambassador in Switzerland, to the British Secretary of State, "Switzerland and Europe", 17.12.1974, p. 7, TNA FCO $33 / 2575$. 
In the Third World, Swiss foreign policymakers were more hesitant. Their policy choices in Southern Africa both contributed to and were profoundly influenced by the realisation that more openness towards developing countries was needed. Like almost no other region in the world, Southern Africa demonstrated the damage to the image of Switzerland's neutrality caused by the focus on the pursuit of economic and financial gain at the expense of equality and human rights. At the same time, the Swiss government's efforts to get on good terms with Angola's and Mozambique's potential future rulers were reinforced by the need to respect Afro-Asian leaders' demands that the independence of the former colonies should finally be supported.

Between 1974 and mid-1975, FPD leaders' attitudes towards a number of actors - whose participation in international diplomacy they had formerly viewed with distrust and attempted to minimise-slowly, hesitantly, started to shift. These included non-state actors, such as liberation movements, and organisations such as the NAM. As late as 1973, Swiss foreign policymakers were wary of these new actors that challenged the rules of international relations. After the fourth NAM summit in Algiers in September 1973, Michael Gelzer, deputy chief of the DPA, still insisted on the need for Switzerland to keep its distance from the "wasps' nest", as he disparagingly labelled the NAM. This distrust was not only due to the political and economic demands of Third World leaders that 'politicised' non-political organisations and conferences; Swiss political leaders also wanted to clearly distinguish Switzerland's neutrality from other forms of non-alignment, fearing that the image of the former might suffer if the country was too closely associated with the NAM. ${ }^{104}$ This last point explains why the Swiss government not only did not participate but even actively avoided being invited to the NAM summit in Algiers, even though neutral Sweden, Austria, and Finland attended as observers. ${ }^{105}$

However, FPD leaders soon realised that the Third World political movements' demands could not be ignored. At a meeting of the Foreign Policy Committee of the National Council in mid-April 1974, Pierre Graber insisted that the demands for fair commodity prices were "difficult to contest". He sought to reassure the foreign policy specialists that, despite radical rhetoric that was mainly destined for their own citizens, most non-aligned governments

104 Letter from Michael Gelzer to the Swiss embassy in Kenya, 14.09.1973, SFA E20o1E-o1\#1987/ 78\#706*.

105 Pierre Luciri, DPA, memorandum, "Conférence au sommet des non-alignés (Alger, septembre 1973). Présence de l'Autriche, de la Suède et de la Finlande. Absence de la Suisse”, 19.08.1975, attached to the note from Jürg Andreas Iselin to the head of the FPD, "La Suisse et les non-alignés", 20.08.1975, SFA E2001E-o1\#1987/78\#706*. 
pursued a "reasonable, nuanced" foreign policy. ${ }^{106}$ In late October 1974, a slight softening can be observed in Switzerland's position with regard to the participation of African liberation movements and the PLO in international organisations. Franz Muheim, chief of the DIO's section for the UN and international organisations, remained opposed to the full admission of these movements, which would constitute their de facto recognition as legitimate international actors, and wanted Swiss delegations to continue abstaining from such votes. He suggested, however, that they should use their right to explain Switzerland's position. This would lessen Switzerland's political distance from other small European states, like Sweden and the Netherlands, that had frequently voted in favour of the liberation movements' participation. ${ }^{107}$

In a position paper written in February 1975, members of the DPA and the DIo explicitly linked the Swiss government's policy on decolonisation and white minority rule with Afro-Asian states' condemnation of the 'neo-colonialist' activities of Western powers and the role of foreign investments and multinational firms in the pillaging of the Third World's resources. ${ }^{108}$ This position paper is the first time that FPD leaders spelled out Switzerland's long-standing policy on decolonisation: "In accordance with its policy of neutrality and, consequently, the principle of non-interference in the internal affairs of other states, Switzerland abstains from interfering in any decolonisation process as a matter of principle." 109 That they did so at a time when the problem of decolonisation was, with a few exceptions, restricted to Southern Africa testifies to the growing pressure that the Swiss government faced from the Third World political movement. With an economy strongly oriented towards foreign markets, Swiss policymakers felt particularly threatened by, and were sensitive to, Third World criticism. Thus, they were anxious to make use of opportunities to improve political relations with Afro-Asian states in order to protect economic interests. Yet, the paper highlights Bern's unwillingness to change its position on white minority rule in Southern Africa. Focusing on a selective interpretation of neutrality, the authors explained their restrained policy on South Africa, Rhodesia, and Namibia. As the decolonisation of Portuguese Africa was well

106 Pierre Graber's speech at the meeting of the Foreign Policy Committee of the National Council on 24 April 1974, "Tour d'horizon", no date, p. 17, SFA E1050.12\#1995/512\#8*.

107 Note from Franz Muheim, chief of the DIo's section for the UN and international organisations, to René Keller "OLP - Afrikanische Befreiungsbewegungen; Stellung der Schweiz", 29.10.1974, pp. 3-4, SFA E2003A\#1988/15\#573*.

108 Claude Huguenin, DPA; Armin Kamer, Franz Muheim, Marianne von Grünigen, DIo, memorandum, "Note sur la décolonisation. (Aspects multilatéraux et bilateraux intéressant la Suisse)", 28.02.1975, pp. 3-4, SFA E2003A\#1988/15\#573*.

Ibid., p. 9 . 
under way, they underlined their willingness to grant humanitarian aid to and establish contact with the future governments of Angola and Mozambique. Nevertheless, in July 1975, Switzerland was explicitly mentioned in a resolution by the OAU Council of Ministers that urged "the Western Powers, particularly the United States of America, Great Britain, France, the Federal Republic of Germany, Switzerland and Japan to end immediately all cooperation with the regimes in Pretoria and Salisbury".110

In mid-1975, the increasing polarisation in North-South relations led to a reconsideration of Switzerland's relations with the NAM. The issue was raised by Pierre Luciri, a young diplomatic officer at the DPA's African, Asian, Middle Eastern and Latin American Division who would obtain his $\mathrm{PhD}$ in political science at the Graduate Institute of International and Development Studies in 1976 for a thesis on Swiss foreign policy during the First World War. In a note to his supervisor in late May 1975, Luciri suggested that Switzerland seek to participate at NAM meetings as an observer. This would allow Bern to be rapidly informed of the evolution of this political force, win sympathies, and neutralise criticism. Luciri argued that, as Switzerland had been a founding member of the OECD's International Energy Agency (IEA) in November 1974, observer status at the NAM was consistent with Switzerland's neutrality:

As soon as our material interests are concerned, our neutrality scruples hardly count any more. In contrast, it is traditionally more difficult for us to discern our immaterial interests and to seek to evoke sympathies if the game does not appear to be commercially or financially profitable. Thereby, we identify ourselves more and more with the group of rich countries at the OECD. ${ }^{111}$

Although FPD leaders decided that it would be precipitate to send a representative to the NAM's conference of foreign ministers in Lima in late August 1975, many of them shared Luciri's opinion. "If neutrality allows us to participate fully in the politics of the rich countries, it will also allow us to simply go and

110 Resolution CM/Res 422 (XXV) of the OAU Council of Ministers' $25^{\text {th }}$ Ordinary Session from 18 to 25 July 1975, "Resolution on Sanctions against the White Minority Regimes in Southern Africa", https://au.int/sites/default/files/decisions/9588-council_en_18_25_july_1975 _council_ministers_twenty_fifth_ordinary_session.pdf (13 January 2021).

111 Note from Pierre Luciri to Jürg Andreas Iselin, "La Suisse et les non-alignés", 28.05.1975, p. 2, SFA E2001E-o1\#1987/78\#706*.On Luciri, see Jacques Rial, Le bicorne et la plume. Les publications de diplomates suisses de 1848 à nos jours. Un essai de bibliographie, Malta and Geneva: DiploFoundation, Graduate Institute of International and Development Studies, 2008, pp. 156-157. 
listen to the debates of the poorer countries", Jürg Andreas Iselin, deputy chief of DPA and chief of its African, Asian, Middle Eastern and Latin American Division, argued in a note to Pierre Graber, demanding his boss' authorisation to pursue a rapprochement with the NAM. ${ }^{112}$ This realisation would bear fruit the following year, and Switzerland would, for the first time, be present at an NAM summit.

Despite Bern's growing openness towards liberation movements and the NAM and its participation in the North-South dialogue, policy changes remained restricted to the diplomatic level. Pierre Graber and some of his team's attempts to strengthen Switzerland's relations with the Third World faced domestic opposition. This was particularly visible in the debates of the Advisory Commission on Switzerland's Relations with the UN. This commission was created in August 1973 to discuss Switzerland's accession to the world organisation and included representatives of the Swiss parliament, political parties, universities, trade associations, labour unions, legal experts, and the press. The polarisation in North-South relations, and the Arab states' attempt to isolate Israel and the 1974 UNGA decision to withhold South Africa's voting rights, in particular, increased scepticism of the UN. Although the commission's final report in May 1975 recommended that Switzerland join the UN, an important minority rejected it. ${ }^{113}$ While the Trade Division agreed to a rapprochement with the NAM in order to gain a source of information about the North-South dialogue, Jürg Andreas Iselin admitted in August 1975 that the FPD could not readily count on the Swiss people's support for this step. ${ }^{114}$ In the face of this resistance to a more active Third World policy and the escalation of the Angolan War, Swiss foreign policymakers concentrated on the establishment of cordial political relations with independent Mozambique.

112 Note from Jürg Andreas Iselin to the head of the FPD, "La Suisse et les non-alignés", 20.08.1975, p. 2, SFA E2001E-01\#1987/78\#706*.

113 Fischer, Die Grenzen der Neutralität, pp. 158-186.

114 Note from Jürg Andreas Iselin to the head of the FPD, "La Suisse et les non-alignés", 20.08.1975, p. 2, SFA E2OO1E-01\#1987/78\#706*. 


\section{Improving Switzerland's Image: Relations with Independent Mozambique}

When Mozambique became independent in June 1975, Swiss-Mozambican relations were tense. Confidently looking forward to a bright future, FRELIMo's leadership criticised Switzerland's selective interpretation of neutrality during the independence wars and its cordial relations with the white minority regimes in South Africa and Rhodesia. The new government nationalised Swiss assets in Mozambique and numerous Swiss business people and missionaries left the country, together with many Portuguese and foreign citizens. Four years later, the situation had changed. Natural disasters, the departure of skilled workers, the loss of remittances from Mozambican mine workers in South Africa due to a change in the Rand mines' recruitment policies, and the ruling party's moves towards a planned economy drastically reduced Mozambique's economic output. The security situation had also deteriorated. In retaliation for FRELIMO's support of Rhodesian nationalist movements, the Rhodesian army started to attack targets in Mozambique. Its secret services were instrumental in the creation of the Mozambican National Resistance (MNR). While this movement did not represent a serious military challenge to the Mozambican government in the late 1970s, its guerrilla activities had a destabilising effect. In the 1980s, it became known under the name Resistência Nacional Moçambicana (Mozambican National Resistance, RENAMO) and its equipment and training were taken over by South Africa. ${ }^{1}$ Yet, by early 1979 , political relations between Switzerland and FRELIMO were cordial and the two governments even planned for a courtesy visit by the Mozambican president to Bern. In October 1979, the two governments signed a bilateral trade and economic cooperation agreement.

In the mid- to late 1970s, Mozambique was the only one of the four radical states in sub-Saharan Africa whose government developed a close bilateral relationship with Switzerland. This was mainly a result of the Swiss government's efforts to improve its image in the former Portuguese colonies and, at the same time, strengthen links with a newly decolonised Third World state. In Bern, Mozambique mattered for several reasons. First, there were Swiss

1 See Newitt, "Mozambique”. 
citizens living in this state whose interests the FPD had to protect during the political, economic, and social transformations of the first years of independence. Second, as one of the Frontline States committed to the struggle against white minority rule in Rhodesia and South Africa, the Mozambican government was an important actor in regional politics. Third, despite Rhodesian cross-border raids and the increasing activity of the MNR, Mozambique was relatively stable and peaceful, and thus offered opportunities for bilateral cooperation. Unlike Angola, Ethiopia, and Somalia, Mozambique was not the arena of a major conflict that influenced the shape of the Cold War. Consequently, neutrality considerations and East-West tensions weighed less on Swiss decision-making. In the context of growing North-South polarisation, most Western European governments and even the US State Department were eager to get on the Mozambican government's good side. In Bern, the officers tasked with handling relations with Mozambique at an administrative level treated it, for the most part, like any other developing state and paid little attention to its Soviet ties.

The FRELIMO government was, initially, more hesitant to develop its bilateral relations with Switzerland. After Mozambique's independence, the new rulers were welcomed by Third World states, supported by the Eastern bloc, and courted by most Western European governments. Establishing diplomatic relations with a state that had consistently kept its distance during the independence wars and refused to support national liberation was not a foreign policy priority for the new government. Growing economic and military difficulties towards the end of the 1970s changed this. Bern's willingness to focus its development cooperation policy on Mozambique and hopes of benefiting from close economic relations explain why the FRELIMO government responded to Swiss overtures.

Against the backdrop of the Cold War in Africa, regional conflict, and North-South tensions, the Swiss government's image improvement campaign in Mozambique between 1975 and 1979 focused on three aspects: the establishment of diplomatic relations, the creation of a bilateral aid relationship (that continues to the present day), and the protection of economic interests. Although these policy fields were interconnected, it is useful to consider them separately, as they involved different strategies and actors, both within the Swiss federal administration and in civil society. Nevertheless, the conclusion of the bilateral trade and economic cooperation agreement in late 1979 brings these various interests together. 


\section{A Lesson for the 'Capitalists'? Swiss Diplomacy's Difficulties in Establishing Diplomatic Relations}

While open war broke out between the Angolan liberation movements, FRELIMO's rise to power on 25 June 1975 was uncontested. The Swiss government recognised Mozambique on the same day. Intent on improving the country's image in Southern Africa and protecting the interests of Swiss business people and missionaries in Mozambique, the FPD subsequently sought to establish diplomatic relations. However, at that time, Swiss foreign policymakers were confronted with the consequences of their selective interpretation of neutrality during the independence war. ${ }^{2}$ FRELIMO was assertive and made a clear distinction between states that had supported its struggle and those that had not. Switzerland was clearly in the latter category. Unused to such confident behaviour from a newly decolonised state, most Western European governments and even the US State Department scrambled to get into FRELIMo's good books. The ambassadors of Sweden, Norway, Denmark, and Portugal were among the first to formally present their credentials to the Mozambican government a few days after independence, together with the representatives of selected African, Asian, and Eastern bloc states. ${ }^{3}$ However, those Western states that had established consulates during the colonial period were forced to close them down. FRELIMO ignored or rejected their repeated attempts to establish diplomatic relations. According to consul Bruno Stöckli, who had no official standing after the closure of the Swiss consulate, the Mozambican government wanted to "teach a lesson to the 'capitalists". 4

This antagonism also affected Swiss missionaries. In a public speech a month after Mozambique's independence, President Samora Machel attacked the Catholic Church and Swiss and US Protestant missions as well as their 'imperialist' countries of origin. Religious organisations were accused of being enemies of the people and all privately owned hospitals and schools were nationalised. This public hostility caused much consternation, although the DM's leadership realised that it was mainly intended to unify the country. In fact, the former IPM hospitals and schools continued to run smoothly

2 This section is derived in part from Sabina Widmer, "D'une "neutralité abstentionniste" à une solidarité instrumentalisée: L'établissement de relations diplomatiques entre la Suisse et le Mozambique", Relations internationales 163:3 (2015), pp. 81-94.

3 List attached to the letter from Bruno Stöckli, Swiss consul in Mozambique, to the DPA, "VR Mozambique. Bilaterale und multilaterale Beziehungen”, 29.08.1975, SFA E2001E-01\#1987/ $78 \# 4178^{*}$.

4 Letter from Bruno Stöckli to the DPA, "VR Mozambique. Beziehungen zur westlichen Welt", confidential, p. 2, SFA E2001E-o1\#1987/78\#4178*. 
and the Mozambican government even expressed its wish to collaborate with the DM in the healthcare sector. Nevertheless, due to the political and economic transformations in Mozambique, especially the nationalisations and continuing public criticism of churches, the Swiss missionary presence fell by almost two-thirds between mid-1974 and June 1976. Of the 16 people that remained, more than half signed work contracts with the Mozambican government. ${ }^{5}$

Since the Swiss parliament had decided, on 20 June 1975, to open embassies in Angola and Mozambique, FPD leaders decided not to push for the establishment of diplomatic relations with Mozambique before the expiry of the threemonths referendum period in late September. ${ }^{6}$ In hindsight, Bern's passive role over these months was a miscalculation. By the time Swiss diplomats in Dar es Salaam and New York took up the issue in mid-September, the UK and the US had formalised their links with FRELIMO. ${ }^{7}$ FRELIMO attached great importance to following the correct procedures for the establishment of diplomatic relations. Nevertheless, the Mozambican Foreign Minister, Joaquim Chissano, finally promised the Swiss Permanent Representative to the UN to make an exception and deal with this issue after his return from the UNGA in midOctober. ${ }^{8}$ This positive sign was all the more important as the FPD was facing domestic criticism of the way it had handled relations with Mozambique. A DM member claimed that the department had been discourteous to the two FRELIMO members that visited Bern in May 1975, and insisted that the choice of Swiss diplomats in Mozambique revealed a lack of judgment; both consul Bruno Stöckli and Paul Etienne Jaccaud—who was Swiss ambassador to Tan-

5 Circular letter by Marcel Vonnez, Swiss missionary in Mozambique, 28.07.1975, ADM, 3057G; minutes of the $119^{\text {th }}$ meeting of the DM's Council on 04.09.1975, no date, confidential, p. 5 , ADM, folder Conseil 1973-1978; Albert Rotach, DM, memorandum, "Noté au 7e Colloque, 14 avril 76", 15.04.1976, ADM, 1851B, box 26o.

6 Letter from Jürg Andreas Iselin, deputy chief of DPA and chief of its African, Asian, Middle Eastern and Latin American Division, to the Swiss consulate in Lourenço Marques, 28.07.1975, confidential, SFA E2001E-o1\#1987/78\#4178*.

7 On 16 September 1975, it was announced that diplomatic relations between the UK and Mozambique were established as from 22 August. US-Mozambican relations were established on 23 September 1975: J. H. Lewen, British ambassador in Mozambique, report, "Mozambique: Annual Review for 1975. The Year of Independence", 02.01.1976, p. 7, TNA FCO $45 / 1898$.

8 Letter from Sigismond Marcuard, Ambassador at the Office of the Permanent Observer of Switzerland to the United Nations, to the DPA, "Etablissement des relations diplomatiques avec le Mozambique", 26.o9.1975, SFA E2001E-o1\#1987/78\#4178*; letter from Marcuard to the DPA, "Etablissement de relations diplomatiques avec la République populaire du Mozambique", 10.10.1975, ibid. 
zania and designated representative to Mozambique- had formerly acted as representatives to the Portuguese regime. ${ }^{9}$

On 4 November 1975, Western consulates in Lourenço Marques were informed that all personnel that had taken up their posts before independence had to leave the country within a week, on pain of expulsion. It soon transpired that only those states that had not yet established diplomatic relations with Mozambique were affected. ${ }^{10}$ To the leaders of the FPD, the expulsion of Stöckli was a radical change of attitude after the cordial talks in New York. The only foreign consul to have taken up his post during the transitional period, Stöckli was in a singular position. Although the severing of all links with the colonial period was a matter of principle for the Mozambican leadership, its foreign ministry relented after the FPD's Secretary General asked it to reconsider Stöckli's expulsion. The Mozambican authorities insisted, however, that Bern conform to the suggested manner of establishing diplomatic relations through a formal exchange of notes. ${ }^{11}$ Consequently, on 25 November 1975, Pierre Graber sent an official telegram to Joaquim Chissano to enquire about a date for the establishment of diplomatic relations. ${ }^{12}$ As the deadline given to foreign consulate personnel, 11 November 1975, was also the date of Angola's independence, the matter of a possible connection needs to be addressed. It is likely that the approach of Angolan independence spurred the Mozambican authorities to cut all ties with the colonial period. Although this could give rise to speculation that they attempted to put pressure on Western governments to recognise the allied MPLA government in Angola, there is no proof of such activity.

Jean-Paul A. Widmer, DM, memorandum, "Note concernant les contacts entre le Département Politique Fédéral et les envoyés du gouvernement de la République Populaire du Mozambique, précédemment Frelimo", 30.o9.1975, SFA E2001E-o1\#1987/78\#4651.

The personnel of the US, UK, Italian, and Dutch diplomatic representations were exempt from expulsion: Telegram from [?] Arenales, US consulate in Mozambique, to the Secretary of State, 04.11.1975, NARA, RG 59, AAD, CFPF, Electronic Telegrams 1975, 1975LOURENo1176; see also telegram from Arenales to the Secretary of State, 05.11.1975, NARA, RG 59, AAD, CFPF, Electronic Telegrams 1975, 1975LOURENo1180.

11 Telegram no 285 from Alfred Glesti, AD, to the Office of the Permanent Observer of Switzerland to the United Nations, 04.11.1975, SFA E20o1E-01\#1987/78\#4178*; telegram no 307 from Sigismond Marcuard to the FPD, 04.11.1975, ibid; Telegram from Ernesto Thalmann, Secretary-General of the FPD, to the Secretary-General of the Mozambican Foreign Ministry, 06.11.1975, SFA E2001E-o1\#1987/78\#4178*; letter from the Mozambican Foreign Ministry to Thalmann, 17.11.1975, ibid.; telegram from the Secretary-General of the Mozambican Foreign Ministry to Thalmann, 20.11.1975, ibid. 
As international outrage against the South African intervention in the Angolan War increased and the MPLA gained ground militarily, the Swiss authorities continued their increasingly solitary efforts to formalise their links with Mozambique. In early February 1976, the FRG, which had granted a large loan to Mozambique, established diplomatic relations with the FRELIMO government. ${ }^{13}$ France achieved the breakthrough on 19 February, two days after leading the Western European states' recognition of the People's Republic of Angola (PRA). Bruno Stöckli was convinced that it was the early recognition of Angola that made the Mozambican authorities overlook France's heavily criticised colonial policy. ${ }^{14}$ In late February 1976, Switzerland was the last state with a consulate in the Mozambican capital —now renamed Maputo—-that had not yet established diplomatic relations with Mozambique. As the Angolan War wound down and the PRA gained international, including Swiss, recognition, the Swiss government finally received encouraging signs from its Mozambican counterpart. On 12 April 1976, the two states established diplomatic relations. ${ }^{15}$ As the Mozambican government did not react to Bern's request for accreditation of Paul Jaccaud and the Swiss embassy in Tanzania was already responsible for Swiss relations with several other African states, the AD decided to accredit the Swiss ambassador to Ethiopia, Olivier Exchaquet, to both Mozambique and Angola. It can be assumed that this decision, which was certainly not made for reasons of geographical proximity, was partly based on the three states' similar ideological orientation. ${ }^{16}$

Why did it take the Swiss authorities more than nine months to establish diplomatic relations with Mozambique? Did FRELIMo deliberately snub Switzerland? In the absence of Mozambican sources, it is impossible to answer these questions conclusively. FPD officials struggled to understand the Mozambican leaders' assertive attitude. In a speech to Swiss ambassadors posted to sub-Saharan Africa in September 1976, Jürg Andreas Iselin of the DPA placed the fault squarely with the Mozambican authorities. According to him, their

13 Telegram from Johnnie Carson, chargé d'affaires a.i. of the US embassy in Mozambique, to the Secretary of State, 04.02.1976, NARA, RG 59, AAD, CFPF, Electronic Telegrams 1976, 1976LOURENoo112, see also the telegram from Carson to the Secretary of State, 15.01.1976, NARA, RG 59, AAD, CF PF, Electronic Telegrams 1976, 1976LOURENooo44. from Bruno Stöckli to the FPD, 19.02.1976, SFA E2OO1E-o1\#1988/16\#46o2**. Telegram no 13 from Bruno Stöckli to the FPD, 08.o3.1976, SFA E20o1E-o1\#1988/16\#46o2*; telegram from Pierre Graber to Joaquim Chissano, 12.04.1976, ibid.

16 Excerpt of the minutes of the Federal Council's meeting on 25 May 1976, pp. 3-4, SFA E2004B\#199o/219\#373; letter from Fritz Bohnert, Swiss ambassador in Ethiopia, to the AD, "Addis Abeba: Parallelakkreditionen", 24.10.1980, SFA E2024A\#1990/221\#68*. 
formalism, lack of administrative experience, rudimentary bureaucracy, communication deficits, and personal grudges were responsible for the delays. ${ }^{17}$ Consul Bruno Stöckli was convinced that Marcelino dos Santos had personally blocked Switzerland's file at the Foreign Ministry. ${ }^{18}$ More likely than sinister machinations by the Mozambican Vice President is the explanation advanced by an Undersecretary of the South African Foreign Ministry in February 1976; the establishment of diplomatic relations with Switzerland was "hardly at the top of the collective leadership's priority list".19

The severely short-staffed Mozambican administration faced major political, economic, and social challenges after independence. At the same time, FRELIMO was in a position of power and could afford to be selective in its foreign relations. For the Mozambican authorities, Switzerland was a member of the capitalist camp. Its government's insistence on a selective interpretation of neutrality must have rung hollow to FRELIMO's leaders during the independence war. In the context of the racial conflicts in Southern Africa, neutrality per se was no recommendation in the eyes of African nationalists. Neutral Sweden's support for national liberation granted it a place among FRELIMO's allies, while Austria formalised its links with FRELIMO even later than Switzerland, in mid-October. This delay seems to have been due mainly to Vienna's lack of interest in forcing the issue. ${ }^{20}$ If the Mozambican leaders intended to show their displeasure with Portugal's former allies, this carried less political risks in the case of a small state with limited geopolitical influence.

2

\section{"Considerable Political Interest in Showing Swiss 'Goodwill”: The Beginning of a Development Cooperation Partnership}

Ever since the late 196os, the possibility of granting aid to the African populations in the Portuguese colonies as a means of improving the image of Switzerland's neutrality had been discussed within the Swiss federal administration. gen der Schweiz zum Südlichen Afrika”, p. 7, appendix no 20 of the minutes of the Annual Conference of Ambassadors, 01.09.1976-03.09.1976, no date, SFA E2O1O-O1A\#199o/5\#9*.

18 Telegram no 13 from Bruno Stöckli to the FPD, o8.o3.1976, SFA E2Oo1E-o1\#1988/16\#46o2*.

19 Cited in the letter from Théodore Curchod, Swiss ambassador in South Africa, to the Secretary-General of the FPD, "Mosambik, Rhodesien aus der Sicht Pretorias", pp. 2-3, 10.02.1976, SFA E2OO1E-o1\#1988/16\#4616.

20 Airgram from Wiley Thomas Buchanan Jr., US ambassador in Austria, to the Department of State, “Austria and Mozambique Establish Diplomatic Relations", 19.10.1976, NARA, RG 59, P-Reel Printouts 1976, $\mathrm{P}_{7} 6 \mathrm{o164}_{4}-2241$, box 164D. 
Although the STC was not usually active in dependent territories, it had granted financial support to DM missionaries in Mozambique. The end of the anticolonial war and Mozambique's approaching independence removed the main obstacle to Swiss development aid in this country. While planning its future bilateral relations with Portugal's former colonies in early 1975, the DPA underlined the "considerable political interest in showing Swiss 'goodwill" by granting aid to these territories. ${ }^{21}$ Independent Mozambique, a champion of national liberation whose government would play an important role in the negotiations for an end to minority rule in Rhodesia, was an ideal candidate to implement this strategy. Consequently, the FPD embarked on a policy that would turn this country into a key state for Swiss development cooperation up to the present day. ${ }^{22}$

Switzerland's image problems in Southern Africa ensured that the attention of the FPD services responsible for foreign aid was already on Mozambique before the new state achieved independence. In September 1975, the STC's Eastern Africa Group, whose responsibility included the countries in Southern Africa, decided to extend its activities to two further countries in addition to its four selected key states of Rwanda, Kenya, Madagascar, and Tanzania. Its recent independence and its leaders' clear development priorities meant that Mozambique was the only state singled out for future development cooperation. ${ }^{23}$ The growing intensity of the liberation wars in Southern Africa after the end of the Angolan War in early 1976 increased the FPD's political interest in strengthening its humanitarian role in the region. As most other states in the area were either judged politically unstable or were under white minority rule and thus not eligible to host STC projects, Mozambique and Lesotho were the only candidates for more substantial Swiss aid. ${ }^{24}$ Subsequently, the STC

21 Note from Alfred Reinhard Hohl, DPA, to the stc, "Guinea-Bissau. Angola. Mozambique", 17.02.1975, SFA E2OO5A\#1985/101\#547*.

22 STC, Trade Division (eds.), Schweiz-Mozambique. 30 Jahre bilaterale Zusammenarbeit von 1979 bis 2009, Bern: STC, 2009. See also Federal Council, press release, "Switzerland and Mozambique discuss peace and sign an international cooperation agreement", 28.02.2018, https://www.admin.ch/gov/en/start/documentation/media-releases.msg-id-69945.html (13 January 2021).

23 Rudolf Dannecker, head of the sTc's Eastern Africa Section, work programme, "TechnischeZusammenarbeit Ostafrikagruppe. Programmund Richtlinien für die technische Hilfe in der Ostafrikagruppe, 1975-1979", September 1975, pp. 3-4, SFA E2005A\#1985/101\#225*.

24 Note from Thomas Raeber, deputy head of the STC, to the Political Secretariat, "Die schweizerische technische Zusammenarbeit und das südliche Afrika. Ihre Anfrage vom 11. Mai 1976", 04.06.1976, SFA E2005A\#1991/16\#541*. 
examined the possibility of contributing to an agricultural project organised by the FAO, with a view to gaining experience in an unfamiliar country. ${ }^{25}$

In parallel to this slow start to a bilateral development cooperation relationship, the Dio continued to grant humanitarian aid to Mozambique through the intermediary of Swiss and international charities. Donations mounted from CHF 275, OOO in 1976 to CHF 880,000 in 1977, but dropped to CHF 370,000 in $1978 .{ }^{26}$ Part of this aid was destined for Rhodesian refugees. After Mozambique's independence, the liberation movement Zimbabwe African National Union (ZANU), which was supported by the FRELIMO government, used the new state as a base for its attacks against the Smith regime. The ensuing repression by the Rhodesian authorities caused more than 250,00o black Zimbabweans to flee to neighbouring countries until the Lancaster House peace agreement of late 1979 put an end to the white minority regime in Rhodesia. Overall, 160,00o of these refugees made their way to Mozambique, which burdened the young state's economy. ${ }^{27}$

Switzerland's humanitarian and development aid was instrumental to improving bilateral relations with FRELIMO from mid-1976 onwards. Before leaving Switzerland to take charge of the newly opened Swiss embassy in Maputo in early 1977, Claude-Louis Piachaud was asked to keep the DIO informed of all possibilities for granting further aid to Mozambique. The correspondence between the DIO and Piachaud shows a preoccupation with making Swiss aid as visible as possible, which testifies to the Swiss authorities' intent of providing FRELIMO with tangible proof of Switzerland's goodwill. This strategy undoubtedly paid off: when Piachaud enquired about Mozambique's need for international aid in February 1977, he was cordially received by Marcelino dos Santos, whose hostility towards Switzerland had been frequently cited as a reason for the FPD's difficulties in establishing diplomatic relations with Mozambique. ${ }^{28}$ As the young state was facing increasing economic and

25 Letter from Rudolf Dannecker to the Swiss embassy in Ethiopia, "Coopération technique avec le Mozambique”, o3.o9.1976, p. 1, SFA E2001E-o1\#1991/17_Bd.985, B.55.40; letter from Dannecker to the Swiss embassy in Ethiopia, "Projet d'aide associée avec la FAO au Mozambique”, 12.08.1976, SFA E2005A\#1991/16\#1029*.

26 Note from LV to Philippe de Rham, stc, "Aide humanitaire en faveur du Mozambique", 02.05.1979, SFA E2O25A\#1991/168\#1259*.

27 Nathaniel Kinsey Powell, "The UNHCR and Zimbabwean Refugees in Mozambique, 19751980", Refugee Survey Quarterly 32:4 (2013), pp. 41-65, pp. 42-45.

28 See notably the letter from Claude-Louis Piachaud to the DIO, "Section de secours en cas de catastrophe à l'étranger", 19.02.1977, SFA E2001E-o1\#1991/17_Bd.985, B.55.4O; letter from Piachaud to the DIO, "Section des oeuvres d'entraide internationale", 22.03.1977, SFA E2003A\#1990/3/633*; letter from Piachaud to the DIO, "Aide au Mozambique du 
political difficulties, due notably to natural calamities and the intensification of the conflict in Rhodesia, it was in great need of foreign aid. FRELIMO could therefore no longer afford to differentiate between friends and foes from colonial times.

Private Swiss actors played a singular role in bilateral development cooperation. The FRELIMO government adopted a unique policy of recruiting and hiring independent foreign experts. These experts, numbering about 2,00o in the early 1980s, were remunerated by the Mozambican authorities and occupied important positions in FRELIMO's administration. ${ }^{29}$ Although their number varied, about 25 Swiss volunteers worked in Mozambique in the late 197os. Most of them belonged to one of two categories: first, some former members of the DM continued their humanitarian work after the nationalisation of missionary hospitals and schools as employees of the Mozambican state. Despite FRELIMO's public hostility towards religious organisations, the DM continued to collaborate closely with the IPM and to grant financial and material support to the young state. Its leaders no longer sent medical or teaching staff to independent Mozambique. Instead, they encouraged volunteers to contact the Mozambican authorities directly. Continuing close interest in the fate of the young republic was also fuelled by personal contact with the president and the ministers of health and development. The DM supported the Swiss authorities' plans to start development cooperation with independent Mozambique and continued to be a valued source of information for Swiss diplomats. ${ }^{30}$ Second, a number of people, usually young and left-wing, left Switzerland to help build a postcolonial socialist state. ${ }^{31}$

The attitudes of FPD officials towards these private volunteers were ambivalent, as shown by internal discussions of whether the Swiss government should

Gouvernement suisse et de la Croix-Rouge Suisse après les inondations de janvier 1977", 12.07.1977, SFA E2001E-o1\#1991/17_Bd.985, B.55.40.

29 Georges Capt, sTC, report, "Rapport de mission au Mozambique février 1981", 25.03.1981, p. 2, SFA E2O25A\#1991/168\#1261*.

30 Letter from Georges Guinand, President of the Council of the DM, and Georges Morier-Genoud, Secretary General of the DM, to Jürg Andreas Iselin, 07.09.1977, SFA E2001E-o1\#1991/17_Bd. 984; B.15.21; letter from Rudolf Dannecker to the Council of the DM, 25.09.1977, SFA E2005A\#1991/16\#1029*; minutes of the 140th meeting of the DM's Council on 10.09.1977, no date, confidential, p. 9, ADM, folder Conseil 1973-1978; minutes of the 151th meeting of the DM's Council on 21.10.1978, no date, confidential, pp. 6-7, ibid. On FRELIMo's attitude towards churches after Mozambique's independence, see Eric Morier-Genoud, Of God and Caesar. The Relation Between Christian Churches and the State in Post-Colonial Mozambique, 1974-1981, Lausanne: Le Fait Missionnaire, 1996.

$31 \quad$ Letter from Olivier Exchaquet, Swiss ambassador in Ethiopia, to the AD, "Opportunité d'ouvrirunerepresentation permanenteà Maputo", o2.08.1976, SFA E2004B\#199o/219\#373*. 
top up their salaries. In August 1976, Olivier Exchaquet, the Swiss ambassador accredited to Mozambique, insisted that these "young people who came to aid Mozambique out of idealism (frequently Marxist)" were nevertheless "good patriots" and suggested that the STC might grant them some financial support. ${ }^{32}$ His successor, Fritz Bohnert, was less open-minded. Fearing for the image of Switzerland's neutrality, he pointed out the political risk of paying volunteers over whose recruitment and activities Bern had no control. ${ }^{33} \mathrm{He}$ must have felt vindicated in late October 1979, when some private Swiss development workers made a small gift of $\mathrm{CHF} 4,300$ to the Mozambican government to aid its defence capacities against Rhodesian attacks. The STC, which was in favour of topping up their salaries, subsequently felt compelled to insist that these volunteers had no official mission from the Swiss authorities and did excellent work for a small Mozambican salary. ${ }^{34}$ Although Swiss policymakers frequently noted that the private development workers improved Switzerland's image in Mozambique, the latter's importance should not be overestimated. Their number was insignificant compared to the 25 o Swedish nationals working for FRELIMO in late 1979, whose salaries were paid from a special Swedish grant to the Mozambican government. ${ }^{35}$

The STC continued its plans to start a long-term cooperation partnership with Mozambique, despite the increasing military insecurity in the state. After exploratory talks in February 1978, an initial agreement for a small Swiss aid programme was reached three months later. Shortly afterwards, foreign development workers were explicitly targeted by anti-FRELIMo forces. In June 1978, a Belgian couple working for the FAO were assassinated in the province of Manica and in the following month, a bomb exploded in a café in Maputo that was frequented by Portuguese development workers. ${ }^{36}$ These events

$32 \quad$ Ibid., p. 4 .

33 Letter from Fritz Bohnert to the DPA, the STC, and the Trade Division, "Mosambik: bilaterale Beziehungen - Handelsvertrag - ERG - Projekte TZ”, pp. 6-8, SFA E2Oo1E-o1\#1991/17_ Bd. 984 ; B.15.21.

34 Henri-Philippe Cart, head of the stc's Eastern Africa Section, memorandum, "Don de coopérants suisses à la République du Mozambique”, 22.10.1979, SFA SFA E20o1E-o1\#1991/ 17_Bd.985, B.55.4O; see also the letter from Claude-Louis Piachaud to the FPD's Information and Press Service, "Don de coopérants suisses à la RPM", 04.10.1979, SFA E2025A\#1991/ $168{ }_{1259 *}$.

35 Letter from Fritz Bohnert to the stc, “Die 'spontanten Kooperanten' in Mosambik. Topping-up. Politische Funktionen”, 29.10.1979, SFA E2O25A\#1991/168\#1259*.

36 Jean-Maurice Délèze, report, "Mission au Mozambique. 23-26 février 1978", March 1978, SFA E2005A\#1991/16\#1030*; letter from Claude-Louis Piachaud to the Political Secretariat, “'Terrorisme' au Mozambique", 28.07.1978, SFA E2010-o1A\#199o/5\#97*. 
do not seem to have had any effect on the STC's cooperation policy. In January 1979, the service approved the Eastern Africa Group's proposal for an aid programme for Mozambique amounting to $\mathrm{CHF} 4$ million. It included projects in the fields of water supply, health centres, rural development, food safety, the topping up of the salaries of private development workers, and land surveying, mostly in the north-eastern province of Cabo Delgado. ${ }^{37}$ The proposal was curiously silent about the political situation in Mozambique and made no reference to the activities of the MNR at all. The strong and enduring political will to make a positive humanitarian contribution in Southern Africa explained why the STC was dedicated to following a course set in 1975, when the intensifying civil war in Mozambique could not have been predicted. An element of international competition probably also played a role. In addition to unquantifiable Eastern bloc aid, Mozambique had received Western and UN financial and technical aid amounting to $\$ 95$ million in 1977. Sweden, Norway, Finland, Denmark, and Iceland had concluded a global agreement for aid amounting to $\$ 50$ million over three years. ${ }^{38}$ For these reasons, the sTC downplayed the risks associated with a long-term engagement in a state suffering from considerable civil unrest. At least in the decision to concentrate on the comparatively safe regions of Maputo and Cabo Delgado, the service took the military situation into account. ${ }^{39}$

With the launching of an STC aid programme in early 1979, development cooperation took off. The Southern African state was about to become the fifth key country for Swiss development aid. ${ }^{40}$ In the 198 os, the sTC continued its activities despite the escalation of the war between the government and RENAMO. Due to this long-term engagement in Mozambique, the Swiss authorities were able to play an important role in the peace process between FRELIMO and RENAMO in the early 199os, notably with regard to the demobilisation and reintegration of former soldiers. ${ }^{41}$

37 Rudolf Dannecker, proposal to the head of the STC, "Programme d'appui à l'effort de développement Mozambicain”, 16.01.1979, SFA E2200.70\#1993/404\#8*. See also telegram no 18 from [?] Voegele, FPD, to the Swiss embassy in Madagascar, 31.01.1979, SFA E2025A\#1991/168\#1259*.

38 Jean-Maurice Délèze, Philippe de Rham, "Mission d'identification de projets au Mozambique", October 1978, p. 5, attached to the note from Délèze to the STC, "Rapport de mission au Mozambique", 18.02.1978, SFA E2005A\#1991/16\#1030*.

39 STC, Trade Division, Schweiz-Mozambique, p. 22.

40 Henri-Philippe Cart, "Programme de coopération au développement 1980 de la Section Afrique orientale", February 1980, p. 1, SFA E2O25A\#1991/168\#670*.

41 STC, Trade Division, Schweiz-Mozambique, pp. 43-47. 


\section{"Healthy Obstinacy Pays Off": Challenges of Economic Decolonisation}

Mozambique's independence profoundly influenced Swiss trade with and investments in this territory. Insecurity about the colony's future after the Carnation Revolution and later the coming to power of an African government unsettled European business people and caused many colonists to leave the country between 1974 and 1976 . This had a disruptive impact on the economic development of the newly independent state. After the departure of the Portuguese colonial authorities, the FRELIMO government took over banks, statecontrolled companies, and ports formerly held by the colonial power. Swiss business people had to deal with new African leaders who were intent on breaking the links with the colonial economy and nationalising foreign property. ${ }^{42}$ As FRELImo consolidated its power in the second half of the 197os, economic actors had to find their place in the increasingly state-controlled economy. However, the changes introduced after Mozambique's independence also presented new opportunities, particularly for Switzerland's export industry. For the pharmaceuticals company Ciba-Geigy, for example, its good sales in Mozambique were, in early 1978, "proof that a healthy obstinacy pays off, especially during times of crisis". ${ }^{43}$ As the Swiss government and firms faced similar challenges in Mozambique and Angola, they often discussed the situation in the two former colonies interchangeably and adopted common strategies. Consequently, there is some overlap here with the next chapter.

The Carnation Revolution interrupted the general upwards trend in Switzerland's commercial exchanges with Mozambique. On average, they were on a lower level during the second half of the 1970s than they had been in the years before 1974, although Swiss exports picked up towards the end of the decade. In the late 1970s, Mozambique and Angola remained interesting export markets for Swiss machines and pharmaceutical companies. Ciba-Geigy, в вС, and Bühler were active in both countries, while Sulzer and Saurer equipped textile factories in Mozambique. ${ }^{44}$

42 Letter from Bruno Stöckli to the FPD's Financial and Economic Service and the Trade Division, "Mozambique. Portugiesisch/mozambikanische Zusammenarbeit", 17.04.1975, SFA E20o1E-o1\#1987/78\#4651; M. Anne Pitcher, Transforming Mozambique. The Politics of Privatization, 1975-2000, Cambridge: Cambridge University Press, 2002, p. 42. Ciba-Geigy SA, Rapport de gestion de CIBA-GEIGY SA 1977, Basel: Schwabe, [1978], p. 25.

44 Note from Hermann Jossen, DPA, to the designated Swiss ambassador in Angola, "ANG O LA. Schweizerkolonie”, 01.10.1976, SFA E2004B\#1990/219\#344*; letter from Giovanni Enrico Bucher, Swiss ambassador in Portugal, to the DPA, "Quelques renseignements sur la situation en Angola", 10.11.1976, SFA E2001E-o1\#1988/16\#1920*; Claude Louis Piachaud, chargé 
The Mozambican government's takeover of shares in the Cabora Bassa dam had little effect on ввС, which had been heavily criticised by African governments and Swiss solidarity movements during the independence war for the deliveries it had made to its German subsidiary. At a board meeting in November 1975, a few months after Mozambique's independence, it was reported that construction of the dam continued without disruption, "because FRELIMO is obviously interested in selling electricity." ${ }^{25}$ During the economic crisis of the mid-197os, Third World markets were important for Switzerland's export industry. In February 1976, ввС delegates observed at a board meeting that the growth of the group's business with African and Asian states had compensated for the lack of orders from its traditional markets caused by the recession in Europe and the strong Swiss franc. They agreed, however, that this boom was unlikely to continue, as the new markets already showed signs of saturation and the collaboration with state-trading countries presented further challenges ${ }^{46}$ Despite additional administrative burdens, the big Swiss export firms and multinational groups that were well-established on the Angolan and Mozambican markets were content with their affairs in these states in the late 1970 and qualified their collaboration with the state-controlled import organisations as satisfactory. ${ }^{47}$

These companies were little inconvenienced by the fact that the Swiss government no longer granted ERG covers once the risks associated with deliveries to Portuguese Africa became Mozambican and Angolan. The continuing instability and the difficult economic situation following the two states' independence in 1975 meant that Bern considered these risks too high to cover. The lack of a state guarantee was particularly disadvantageous for smaller firms. Whereas bigger companies like Sulzer, Saurer, and Ciba-Geigy obtained

d'affaires of the Swiss embassy in Maputo, memorandum, "Intérêts suisses. Représentations, firmes d'exportation", 17.04.1979, SFA E2001E-o1\#1991/17_Bd.984, B.15.50.4. For the development of Swiss trade with Mozambique, see chapter 1.

45 Cited in Dietrich, ввс Baden, minutes of the meeting of the Board of Directors on 18 November 1975 in Baden, no date, p. 19, НААвв, folder 253689, file 605626. See also Dietrich, ввC Baden, minutes of the 7 th meeting of the directorate (DS-CH) of 3 April 1975, 07.04.1975, p. 2, НAABB; Dietrich, minutes of the $6^{\text {th }}$ meeting of the directorate (DSCH), 20 March 1975, no date, p. 5, НАAв B.

46 Dietrich, ввс Baden, minutes of the meeting of the Board of Directors on 23 February 1976 in Baden, no date, pp. 15-16, HAABB, folder 253689, file 6o5626.

47 Cited in Hans Freiburghaus, chargé d'affaires of the Swiss embassy in Luanda, report, "Schlussbericht Schweizerische Botschaft Luanda", 25.10.1979, p. 3, SFA E2001E-01\#1991/17_ Bd.610, B.15.21; note from Jean Zwahlen, head of the FPD's Financial and Economic Service, to the DPA, "Visite du Président Machel en Suisse", 27.04.1979, SFA E20o1E-o1\#1991/17_ Bd.984, B.15.21. 
credit letters from banks. ${ }^{48}$ Switzerland's restrictive ERG policy was not only criticised by representatives of the African governments but also by Swiss export firms and banks, who pointed out that Angola and Mozambique had reliably honoured their financial obligations. In the case of Mozambique, this pressure had some effect. By 1979, ERG covers were again granted for shortterm contracts. ${ }^{49}$

After independence, Swiss banks collaborated closely with the Mozambican national bank, although it is difficult to obtain detailed information on this. In August 1978, a UBS delegation travelled to Maputo. This visit was probably linked to a revolving loan of CHF 20 million that UBS seems to have granted to the Mozambican government in the late 197os. Consequently, in October 1979, the Vice Director of the Mozambican national bank told the Swiss ambassador to Mozambique: "Switzerland is our best financial centre."50

Decolonisation and the takeover by Marxist-inspired FRELIMo had a negative impact on Swiss traders and business people established in Mozambique. Within a few years after the Carnation Revolution, most Swiss investments were under state control. Barring a number of smaller Swiss-owned trading firms and properties, the most significant case was that of the Companhia de Boror, the biggest copra producer in the country, which was nationalised in

48 Letter from Claude Louis Piachaud to the Trade Division, "Garantie contre les risques à l'exportation - Mozambique", 04.03.1977, SFA E7110\#1988/12\#1481*. See also the letter from Ernst Henri Léchot, responsible for relations with Portugal within the Trade Division, to the Swiss embassy in Maputo, "Mozambique: Garantie contre les risques à l'exportation", 16.03.1977, ibid.; note from Hermann Hofer, Vice-Director of the Trade Division and president of the commission for the ERG, to Léchot, "Exportrisikogarantie GA 4.39 Angola/ввс", 20.08.1974, SFA E7110\#1985/97\#1468*, and the attached memorandum, "Exportrisikogarantie", no author, 16.08.1974; letter from Léchot to the office for the ERG, "Portugal - ERG GA 4.39 Angola/BBC", 4.10.1974, SFA E7110\#1985/97\#1468*.

49 Letter from Ernst Henri Léchot to the Swiss embassies in Ethiopia and Mozambique, "Mozambique: Garantie contre les risques à l'exportation", 01.06.1979, SFA E2001E-o1\#1991/17_987, C.41.111.o, and attached notes; letter from Léchot to the Swiss embassy in Mozambique, "Mozambique: Garantie contre les risques à l'exportation", 21.06.1979, SFA E7114A\#1990/6o\#1533*.

50 Cited in Claude-Louis Piachaud, minutes, "Procès-verbal des principaux points de l'entretien entre Monsieur l'Ambassadeur Bohnert et le Vice-Gouverneur de la Banque du Mozambique, Prakash Ratilal, le 22 octobre 1979, au sujet plus particulièrement de la CCA ANGOCHE (AGAVA ZUG)", 22.10.1979, p. 1, attached to the letter from Piachaud to the Trade Division, "Mozambique: CCA ANGOCHE et développement des relations commerciales", 23.10.1979, SFA E7115A\#199o/6o\#1537*. See also the letter from Piachaud to the Financial and Economic Service of the FPD, "Délégation UBS au Mozambique", 25.08.1978, SFA E2001E-o1\#1991/17_987, C.41.111.o; Piachaud, report, "Mozambique - Rapport de synthèse", o3.10.1980, p. 7, SFA E7115A\#1990/142\#1585*. 
May 1976. The loss was put at CHF 65.5 million, $70 \%$ of which concerned Swiss investments. ${ }^{51}$ This nationalisation without compensation was justified on the grounds of economic sabotage; before leaving Mozambique, the company's managers had smuggled money and copra out of the country, sabotaged equipment, and failed to pay employees. ${ }^{52}$ The other major Swiss plantation, CCA, valued at CHF 27 million in 1974, was able to continue operations after Mozambique's independence. Its productivity suffered due to problems recruiting qualified personnel and workers, scarcity of material and spare parts, and difficulties obtaining permits. Losses were increasingly heavy. In August 1981, the Swiss investors decided to withdraw and hand the company over to local investors. ${ }^{53}$

In attempting to obtain compensation for nationalised Swiss assets, the DPA faced challenges similar to those it faced in Ethiopia, as nationalisations occurred before guidelines for compensation were issued. In Mozambique, the situation was compounded by the fact that Switzerland did not formalise its relations with the new rulers until spring 1976 . From June 1975 until early 1977 there was no functioning Swiss consulate in Maputo that might have acted as an intermediary. Therefore in June 1976, FPD leaders sent a note to the Mozambican foreign ministry, asking for more information about the nationalisation decrees issued in February 1975 and early $1976 .{ }^{54}$ Further interventions were not deemed useful. At the Third Frelimo Congress in February 1977, the Mozambican government officially adopted Marxism-Leninism. FRELIMO's economic interventions became more frequent and were now part of an ideological programme. A decree on compensation was enacted after the congress classified proprietors that had left Mozambique as enemies of the state. As such, they were not entitled to compensation. This was the case for most Swiss

$51 \quad$ Note from Hermann Jossen to the DPA and the DPIL, "Nationalisierungen in Angola und Mozambique - Geltendmachung schweizerischer Ansprüche”, 02.06.1976, SFA E2200.167\#1991/284\#51*; letter from Fritz Bohnert to the DPIL, "Mosambik: Ueberführung ausländischen Eigentums in die Verwaltung oder das Eigentum des Staates", 22.07.1977, SFA E2001E-o1\#1988/16\#4611*.

52 Pitcher, Transforming Mozambique, p. 39.

53 Claude Louis Piachaud, memorandum, "Données sur entreprises suisses au Mozambique", 17.04.1979, attached to the letter from Piachaud to the DPA, "Voyage Président du Mozambique en Suisse", 20.04.1979, SFA E7115A\#199o/60\#1542*; letter from Hanspeter Ammann, managing director of Agava Trading Ltd, to Georges Peyraud, chargé d'affaires of the Swiss embassy in Mozambique, 04.08.1981, attached to the letter from Arnold Hugentobler, DPA, to Agava Trading Ltd, "CCA Angoche", 10.08.1981, SFA E7115A\#1991/189\#1422*.

54 Note from Hermann Jossen to the DPA and the DPIL, "Nationalisierungen in Angola und Mozambique - Geltendmachung schweizerischer Ansprüche", 02.06.1976, SFA E2200.167\#1991/284\#51*. 
owners. ${ }^{55}$ The Swiss representative's frequent interventions were unsuccessful and by the early 1980s, there was still no sign that FRELIMO might be willing to start negotiating compensation. ${ }^{56}$

The example of the chemicals and pharmaceutical firm Ciba-Geigy, today Novartis, provides a fascinating inside view of how a Swiss multinational group adapted its strategy to the changing local context and managed to uphold and even increase its business volume in the first years after the independence of Mozambique and Angola. With a turnover of CHF 6,950 million in 1970, the Ciba-Geigy group headquartered in Basel was the second largest in Switzerland and would soon become one of the leading pharmaceutical companies worldwide. It was one of the main Swiss exporters to Angola and Mozambique after the fall of the Portuguese colonial empire, with chemicals and pharmaceuticals making up almost $6 \circ \%$ of Switzerland's exports to both states in the period $1977-1979 \cdot{ }^{57}$

In the 1950s and 196os, the export-oriented chemical and pharmaceutical firms Ciba and Geigy became increasingly multinational, creating sales organisations as well as production and research facilities on multiple continents. In 1970, the year in which the two companies merged, less than $5 \%$ of the group's total turnover was generated in Africa. ${ }^{58}$ As the bonds between the colonial powers and their African colonies had started to loosen in the late 1950s, Ciba had reorganised its sales policies in preparation for decolonisation. Until then, sales to African countries had been handled through offices in Paris, Lisbon, and Horsham (UK), and through headquarters in Basel. In view of the African continent's future importance, Ciba planned to open information and scientific offices in Leopoldville-renamed Kinshasa in 1966 - and Nairobi. It was hoped that these offices would handle sales with African states more effectively. ${ }^{59}$ Convinced of the continent's fast-growing potential, Ciba-Geigy's

55 Note from Hansjakob Kaufmann, deputy chief of the DPA's African, Asian, Middle Eastern and Latin American Division, to the DPIL, 29.07.1977, SFA E20o1E-o1\#1988/16\#4611*; see also letter from Fritz Bohnert to the DPIL, "Mosambik: Ueberführung ausländischen Eigentums in die Verwaltung oder das Eigentum des Staates", 22.07.1977, ibid.; Pitcher, Transforming Mozambique, pp. 38-40.

56 Swiss embassy in Mozambique, memorandum, "Intérêts suisses", 06.10.1980, SFA E2200.307A\#1994/370\#19*.

57 Bernhard Degen, "Ciba", 30.03.2021, HLs Online; Christian Zeller, Globalisierungsstrategien - Der Weg von Novartis, Berlin: Springer, 2001, pp. 157-159; Swiss Directorate General of Customs, Jahresstatistik des Aussenhandels der Schweiz, 1967-1979.

$5^{8}$ Zeller, Globalisierungsstrategien, pp. 144-150, 158. See also Paul Erni, Mariage à la bâloise. Histoire de la fusion Ciba-Geigy, Zürich: NZz Verlag, 1979.

59 [?] Faraquier, sales department of country group III in Ciba's pharmaceuticals section, to the members of the Ph.G.A, "Zukünftige Organisation in den Gebieten Afrikas mit 
executive board charged its regional committee for Africa in late 1972 with developing a plan to improve the group's position in the recently decolonised African states. ${ }^{60}$ The training of local employees and their gradual promotion to senior management positions in order to limit the danger of expulsion and safeguard the group's position in Africa was an important part of Ciba-Geigy's strategy. In 1974, Ciba-Geigy's sales budget for Africa (excluding South Africa, Rhodesia, Egypt, Sudan, and Libya) reached CHF 200 million and its position on the continent was qualified as excellent. ${ }^{61}$ In early 1976 , the continent's share in total group sales was growing. Attendees at a meeting of the Regional Committee for Africa explained that this was due to the activities of branch offices in the different African countries. ${ }^{62}$

The Carnation Revolution initially had a negative impact on Ciba-Geigy's business in Angola and Mozambique. Sales figures in 1976 were significantly lower than they had been during the colonial period. In Angola, they dropped from CHF 10 million in the record year of 1974 to CHF 3.1 million in 1976, in Mozambique from CHF 5.3 million to CHF 3.5 million. ${ }^{63}$ Despite decreasing sales and the difficulties linked to regime changes and the war in Angola, the group maintained its branch offices in Luanda and Lourenço Marques. In November 1975, Ciba-Geigy's regional services prepared for possible nationalisations in Mozambique. They centralised their different offices in a new location, fearing that business might be impaired if the Boror company, on whose premises some of their offices had formerly been located, was nationalised. Thus, the group's leadership adopted a similar strategy to the one employed after the Ethiopian Revolution, when it chose to distance itself from its former

Negerbevölkerung (Afrique noire)", 19.08.1958, citation p. 2, Novartis archives, Ciba company archives, box KG K2, Kon 3 .

6o Minutes no 26/72 of the Ciba Geigy Group Executive Committee meeting on 14 November 1972, Novartis archives, Ciba-Geigy company archives, minutes: minutes of the Group Executive Committee, box KL.1.

$61 \quad$ Minutes of the meeting of the Ciba-Geigy Regional Committee for Africa on 21 January 1975, "Behandlung des Budgets 1975 Schwarzafrika", Novartis archives, Ciba-Geigy company archives, regional management, minutes of the regional committees, box RD $7-8$, Afrika: RD 7.2.

62 H. Schwarb, minutes of the meeting of the Ciba-Geigy Regional Committee for Africa on 29 January 1976, pp. 3, 9, Novartis archives, Ciba-Geigy company archives, regional management, minutes of the regional committees, box RD 7-8, Afrika: RD 7.2.

63 H. Schwarb, report, "Bericht über meinen Aufenthalt in Angola / Mosambik vom 1.-10.3.77", 15.03.1977, Novartis archives, Ciba-Geigy company archives, minutes: various documents, box KL 1.o1, Aug 1976 - Dez 1979. 
agent that was threatened by nationalisation. This decision proved shrewd, as Boror was indeed nationalised in mid-1976. ${ }^{64}$

In September 1976, for the first time since the independence of Mozambique and Angola, a member of Ciba-Geigy's management travelled to the former Portuguese territories. H. Schwarb's detailed reports highlight the challenges the group faced during the consolidation of the rule of FRELIMO and the MPLA. The new governments' plans to control foreign trade, the possible nationalisation of further economic sectors, and, in Angola, the insecure military situation that reduced demand for agricultural and agrochemical products required strategic adjustments. Nevertheless, the author was optimistic about future business chances. He judged it important to maintain Ciba-Geigy's presence in order to keep a finger on the pulse and to help clients with bureaucratic problems. This would also contain the influence of the Eastern bloc: "I believe that the financial sacrifices necessary for $c G$ [Ciba-Geigy] are absolutely acceptable in order to make a modest contribution to the continuation of the economic presence of the West." 65 In Mozambique, "in a strong stranglehold of Eastern infiltrators", Schwarb judged Ciba-Geigy to be in a good position, as many competitors had reduced their activities. Despite the country's lack of foreign currency, Ciba-Geigy's products were of national interest and likely to be prioritised in the allocation of currency. ${ }^{66} \mathrm{~A}$ second journey to the two former colonies in early 1977 convinced Schwarb of Ciba-Geigy's favourable prospects, particularly in Mozambique. As this state's economy was based on agriculture, there would always be a need for agrochemical products, no matter how the political situation developed. He concluded that decolonisation had had a positive impact on the group's business: "Remaining foreigners confirm that the business of those firms whose structures are intact is not going worse, but rather better than before independence." ${ }^{n 7}$

64 R. Pargätzi, minutes no 9/75 of the Regional Services meeting on 21 November 1975, p. 4, Novartis archives, Ciba-Geigy company archives, Regional Services, minutes, box RD 1, 14/72-9/77; R. Pargätzi, minutes no 5/76 of the Regional Services meeting on 14 May 1976, p. 11, ibid.

65 Emphasis in original. H. Schwarb, report to the Executive Committee, "Bericht über meinen Aufenthalt in Luanda / Angola vom 16.-22.9.76”, o6.10.1976, p. 4, Novartis archives, CibaGeigy company archives, minutes: various documents, box KL 1.01, Aug 1976 - Dez 1979.

66 H. Schwarb, report to the Executive Committee, "Bericht über meinen Aufenthalt in Maputo, Mosambik vom 23-28.9.76", o7.10.1976, citation p. 1, Novartis archives, Ciba-Geigy company archives, minutes: various documents, box KL 1.01, Aug 1976 - Dez 1979; see also R. Pargätzi, minutes no $11 / 76$ of the Regional Services meeting on 22 October 1976, p. 5, Novartis archives, Ciba-Geigy company archives, Regional Services, minutes, box RD 1, 14/72-9/77.

67 H. Schwarb, report, "Bericht über meinen Aufenthalt in Angola / Mosambik vom 1.-10.3.77", 15.03.1977, p. 6, Novartis archives, Ciba-Geigy company archives, minutes: various documents, box KL 1.O1, Aug 1976 - Dez 1979. 
Ciba-Geigy's export figures for Mozambique between 1977 and 1979 back his assumption. Although they were subject to irregularities (1977: CHF 14.3 million, 1978: CH F 22.3 million, 1979: CHF 6.8 million), exports to Mozambique were significantly higher than in $1974{ }^{68}$ In 1980 , Ciba-Geigy achieved peak annual sales of more than CHF 20 million in both Angola and Mozambique. According to regional services in Basel, stability of staffing, both with regard to headquarters and expatriates working in Africa, was a prerequisite of success in these instable markets, as frequent personnel changes unsettled clients and local staff and hampered success. ${ }^{69}$

On the whole, Ciba-Geigy weathered the political and economic transformations in Mozambique during the late 1970s rather well. The group had the necessary financial backing to tide it over in the difficult years of 1975 and 1976. The strategic choice to maintain a minimal presence by keeping the Maputo branch office open paid off, as the group was later able to rely on a functioning infrastructure and established contact with clients to promote its sales. As chemicals and pharmaceuticals were of national interest, demand for CibaGeigy's products continued in spite of the great economic difficulties of independent Mozambique. Despite increasing competition from the Eastern bloc, the same was true for other well-established and well-known big Swiss export firms, mostly in the machine sector. The increasing administrative burdens they faced when dealing with state-controlled importers might even have been an advantage, as they eliminated less well-connected competitors.

In 1975, the Swiss government set greater store in developing bilateral relations than its Mozambican counterpart. Four years later, the situation was reversed. The FRELIMO administration undertook efforts to deepen bilateral relations that culminated in the conclusion of a bilateral Trade and Economic Cooperation Agreement in October 1979. In late January 1979, the Mozambican Foreign Minister, Joaquim Chissano, informed the Swiss embassy in Maputo that President Samora Machel wished to make a courtesy visit to Switzerland during a trip to Europe in the first half of the year. ${ }^{70}$ Maputo's diplomatic community explained that the choice of Switzerland, certainly not one of FRELIMo's sup-

68 No author, “Umsatzübersicht für ZIмвавWE und umliegende Länder", 12.09.1980, p. 1, attached to the minutes of the Regional Committee for Sub-Saharan Africa on 10 September 1980, 12.09.1980, Novartis archives, Ciba-Geigy company archives, regional management, minutes of the regional committees, box RD 7-8, Afrika: RD 7.2.

69 R. Pargätzi, minutes no 12/8o of the Regional Services meeting on 12 December 198o, p. 7, Novartis archives, Ciba-Geigy company archives, Regional Services, minutes, box RD 1, 10/77-12/80. Präsidenten der Volksrepublik Mosambik”, 24.01.1979, SFA E2200.307A\#1991/285\#24*. 
porters during the independence war, was due to the Mozambican authorities' wish to increase economic and especially financial cooperation. ${ }^{71}$ Three months after this initial contact, the FRELIMO government suddenly insisted on the official character of the visit with the corresponding protocol for 45 delegates. To Bern's further consternation, the Swiss chargé d'affaires in Maputo, ClaudeLouis Piachaud, heard on 5 May, ten days before Machel's scheduled arrival in Switzerland, that the Mozambican government had ambitious goals for the visit. It not only wished to deepen relations with Swiss firms and banks and to convince the Swiss government to grant ERG covers for deliveries to Mozambique but also wanted to sign bilateral treaties on economic, technical, and scientific cooperation. ${ }^{72}$ In Bern, this came as a surprise. The sTC had only just launched an aid programme for Mozambique a few months previously and had no intention of concluding a bilateral framework accord. ${ }^{73}$ During a preparatory meeting in Bern on 9 May 1979, FPD officials and a Mozambican delegation headed by Sergio Vieira, the Governor of the Mozambican national bank, failed to reach an agreement on the publication of a joint communiqué. Vieira therefore cancelled, or in his words, postponed, his head of state's visit. Nevertheless, the talks remained cordial and the Swiss authorities promised to study the drafts of a trade agreement and a general agreement of cooperation presented by Vieira. ${ }^{74}$

The Mozambican delegation's understanding attitude led Swiss diplomats in Maputo and Addis Ababa to suspect that FRELImo had abandoned the plans for Machel's trip beforehand. Two other scheduled visits had already been cancelled by May and internal difficulties rendered the absence of the head of state difficult. ${ }^{75}$ If they, indeed, engineered a last-minute cancellation in order to put pressure on the Swiss government to increase economic col-

71 Letter from Claude-Louis Piachaud to the Political Secretariat, "Voyage du Président Samora Machel en Suisse", 10.05.1979, very urgent and confidential, SFA E2200.307A\#1991/285\#24*; letter from John F. Doble, UK embassy in Mozambique, to K.J. Baudains, FCO, confidential, "Visits by Machel", 11.06.1979, TNA FCO 106/83.

Telegram no 19 from Claude-Louis Piachaud to the FPD, 05.05.1979, SFA E2200.307A\#1991/ $285^{\# 24}$; note from Hansjakob Kaufmann, head of the FPD's Protocol Service, to Federal Councillor Pierre Aubert, "Séance du Conseil federal du 2 mai 1979, 'Aussprache", 01.05.1979, SFA E2001E-o1\#1991/17_Bd. 984, B.15.50.4; letter from Piachaud to the Political Secretariat, "Voyage du Président Samora Machel en Suisse", 10.05.1979, very urgent and confidential, SFA E2200.307A\#1991/285\#24*.

73 Philippe de Rham, stc, memorandum, "Coopération au développement du Mozambique”, 03.05.1979, p. 4, SFA E2025A\#1991/168\#1259*.

74 Alfred Rüegg, DPA, memorandum, "Besuch Samora Machels", 11.05.1979, SFA E2001E -o1\#1991/17_Bd. 985, B.73.Moz.o.

75 Letter from Claude-Louis Piachaud to Fritz Bohnert, 17.05.1979, confidential, SFA E2200 .70\#1993/403\#3*; letter from Bohnert to the DPA, "Besuchsreise des mosambikanischen Präsidenten: ein Rückblick und ein Ausblick”, 29.10.1979, SFA E2200.307A\#1991/285\#24*. 
laboration, the Mozambican authorities certainly played their Swiss counterparts well. The national and international press explained the cancellation by citing Bern's unwillingness to receive more than one visit of state per year. This provoked a parliamentary question and aroused indignation in Swiss religious and Third World circles, which interpreted it as a sign of Bern's lack of respect towards the head of a Third World state. ${ }^{76}$

Thanks to the controversies surrounding Machel's cancelled visit to Bern, Switzerland's political and economic elites reacted quickly and favourably to the Mozambican wish to conclude economic agreements. Three weeks after the cancelled visits, the Swiss trade authorities had incorporated the two Mozambican draft agreements into a single Swiss counterproposal that was submitted to FRELIMO. Negotiations were speedy and constructive. On 22 October 1979, the two governments signed the Swiss-Mozambican Trade and Economic Cooperation Agreement. It covered the intensification of trade, the granting of most-favoured nation treatment, the protection of intellectual property, and the encouragement of cooperation in the economic, industrial, technical, agricultural, tourist, services, and healthcare sectors. As Switzerland's trade with and investments in Mozambique were limited, the Swiss government's willingness to negotiate an agreement with FRELIMO is explained by political motives. Most importantly, Bern hoped that the conclusion of a cooperation agreement would prove that bilateral relations between the two states were cordial and thereby calm critical voices in Switzerland. From a more long-term perspective, in early October, shortly before the signature of the agreement, the FDEA argued that Switzerland had a political interest in increasing its contact with the Southern African state bordering South Africa and Zimbabwe Rhodesia, and that the Mozambican government's wish to diversify its foreign economic relations should be encouraged. ${ }^{77}$

While the Mozambican government hesitated to establish diplomatic relations with Switzerland in 1975, humanitarian and development aid played a

76 "Question ordinaire Grobet du 21 juin (79.727). Abgesagter Besuch des Präsidenten von Mosambik. Visite annullée du Président du Mozambique", Amtliches Bulletin der Bundesversammlung 1979, Herbstsession Nationalrat, 05.10.1979, p. 1379; BJ, "Visite du Président de la République Populaire du Mozambique, M. Samora Machel - Succession des faits", o8.10.1979, SFA E2001E-o1\#1991/17_Bd. 984, B.15.50.4.

77 Letter from Ernst Henri Léchot to the Vorort, 28.05.1979, SFA E2001E-o1\#1991/17_Bd. 984, C.41.Moz.111.o; Jean-Jacques Maeder, Trade Division, to Paul Jolles, head of the Trade Division, "Handelsabkommen mit Mozambik", 29.10.1979, p. 2, SFA E7115A\#199o/6o\#1529*; proposal from the FDAE to the Federal Council, "Mozambik - Abkommen über Handel und wirtschaftliche Zusammenarbeit", o3.10.1979, attached to the decree of the Federal Council, "Mozambik - Abkommen über Handel und wirtschaftliche Zusammenarbeit, Fortsetzung von Verhandlungen", 24.10.1979, SFA E1004.1\#1000/9\#872*. 
crucial role in the normalisation of bilateral relations between the two states in the late 1970s. Aid calmed FRELIMo's criticism of Swiss foreign policy in sub-Saharan Africa. In the words of an STC officer, it "was used to buy the Swiss authorities a good conscience". ${ }^{78}$ Switzerland's development cooperation programme for Mozambique convinced the latter's government of Bern's willingness to engage in a long-term commitment to the Southern African state. At the same time, the strength of Switzerland's economy and the activities of well-known Swiss export companies and banks in Mozambique probably raised FRELIMO's hopes of benefiting from growing economic cooperation and motivated its push for the conclusion of bilateral trade and cooperation agreements. Mozambique's growing economic difficulties and the escalating conflict between FRELIMO and RENAMO in the 1980s dashed these hopes.

78 Letter from Philippe de Rham to Jean-Maurice Délèze, "'Pneumatologie mozambicaine”, o6.o6.1979, p. 3, SFA E2O25A\#1991/168\#1259*. 


\section{Conclusion to Part 2}

We have two possible strategies in the Southern Africa conflict. One matches our current policy: to wait and see, placate, lie low, limit damages as far as possible, cede only under the pressure of events. Apparently, people think that this policy allows us to come off best and that it corresponds with public opinion. The other possibility is an Africa policy worthy of its name, that takes our long-term interests into account and does not push us into the camp of the white minority regimes in Southern Africa, but creates an image that allows us to establish good relations with sub-Saharan Africa, whose political and economic importance grows, even if this requires steps that break fresh ground and do not conform to our foreign policy traditions. ${ }^{1}$

Ambassador Richard Pestalozzi made no secret about which of the two strategies he preferred. Like a number of his colleagues, he advocated a break with the Swiss government's selective interpretation of neutrality in sub-Saharan Africa. Yet, the strategy adopted during the regime changes in Southern Africa and the Horn corresponded to the first - with efforts being made to improve Switzerland's image, but none that can be qualified as ground-breaking. In both regions, Switzerland's foreign policy was mainly driven by the will to improve the country's image in Africa and in the Third World in general. The Swiss government adopted a pragmatic policy that focused on maintaining a political presence and protecting economic interests. Both in Ethiopia and in Mozambique, the Swiss government managed to overcome the new governments' criticism of its foreign policy in sub-Saharan Africa. Bern waited out the controversy surrounding the Ethiopian Emperor's Swiss bank accounts until the Derg's human rights abuses discredited it in the eyes of foreign observers and Ethiopian leaders focused their attention on other problems. After a phase of Swiss-Mozambican tension following FRELIMo's rise to power, Bern quickly found a modus vivendi with Mozambique's new government, despite the latter's radical economic reforms. Humanitarian and development aid played a key role in this regard. By establishing cordial relations with a black Southern African state that promised to be politically stable, Swiss foreign policymakers hoped to dissociate themselves, in the eyes of Afro-Asian leaders, from the past association with the colonial power. Economically speaking, this

1 Letter from Richard Pestalozzi, Swiss ambassador in Kenya, to the DPA, "OAU-Konferenz der Staatschefs in Kampala”, 24.06.1975, p. 4, SFA E2200.185-02\#1987/123\#44*. 
was also less costly than stopping trade with and investments in South Africa and enforcing compliance with the UN sanctions on Rhodesia.

In this context, the new rulers' Soviet ties were of secondary importance. During the decolonisation of Angola and Mozambique, Swiss foreign policymakers concentrated on counterbalancing their relations with South Africa and rarely mentioned the Cold War alliances of FRELIMO and the Angolan liberation movements. The image of Switzerland's neutrality, its stance in the region, and the protection of citizens and economic interests were primordial. In the Horn of Africa, where Swiss material interests were few, the new leaders' ideological orientation more strongly influenced the Swiss government's assessment of the regime changes; these leaders' socialist tendencies and the presence or absence of Soviet and Chinese influence on events were frequently remarked upon in diplomatic reports. Nevertheless, on the whole, Bern treated the four new regimes like any other Third World governments. At a time when the North-South conflict was intensifying and senior decision-makers in Bern recognised the need to improve Switzerland's relations with the Third World, it was the North-South rather than the East-West dimension that determined Switzerland's foreign policy during the regime changes in sub-Saharan Africa.

Most Western and neutral states viewed the events in Southern Africa and the Horn in a similar light. When considering whether or not to recognise the Portuguese colonies, or make a public statement on the November 1974 executions in Ethiopia, Bern's policy decisions were coordinated first, with the neutral governments of Sweden and Austria and second, with the EEC capitals. The increased importance of Western Europe as a frame of reference for Switzerland's foreign policy in sub-Saharan Africa was accompanied by a growing disenchantment with the Ford administration's Africa policy and its ability to influence events on the continent. This would come to a head during the Angolan War. 


\section{PART 3}

Armed Conflicts in Africa and the Renewal of Cold War Tensions, 1975-1979 


\section{Introduction to Part 3}

"[B]lack Africa [is] turning increasingly red", the president of the Foreign Policy Committee of the Swiss Council of States was concerned to note in February 1976, as the Angolan War was about to end with the victory of the Marxistinspired MPLA. ${ }^{1}$ Between 1975 and 1978, developments in sub-Saharan Africa had their most direct impact on superpower relations during the Cold War. The wars in Angola and in the Ogaden brought Africa to the forefront of the East-West confrontation. In mid-1975, armed conflict broke out between the three Angolan liberation movements that wished to take over government of the soon-to-be independent state. In October 1975, a few weeks before Angola's scheduled date of independence, South Africa invaded the country to prevent an MPLA victory, probably with the tacit acceptance of the US. This South African invasion was repelled by Cuban troops that started to arrive in early November 1975. The war between Ethiopia and Somalia, in mid-1977, started as a conflict between two Soviet allies for possession of the Ethiopian Ogaden desert. In a bid to gain increased external support, the Somali government renounced its ties to the USSR in November. However, as the Carter administration refused to openly aid this regime and the USSR and Cuba carried out large-scale interventions in favour of their remaining ally, Somali troops were forced to withdraw in March 1978.

The link between the wars in Angola and the Ogaden and the demise of superpower Détente has been highlighted by a number of scholars. Raymond Garthoff argued that the US and the UssR had different ideas of what a policy of Détente entailed. For the US, Détente was a strategy to manage and check growing Soviet power. For the USSR, however, Détente was a means of bringing about a transition in the international role of the US, away from a position of superiority towards a more modest role in world politics. As these differences were not clearly understood, misunderstandings arose that created increased distrust and suspicion. ${ }^{2}$ Soviet leaders viewed their Third World policies as separate from the bilateral relationship with the US, and felt entitled to support and defend local revolutions. To the Ford and Carter administrations, however, the Cuban and Soviet interventions in Angola and in the Ogaden were proof

\footnotetext{
1 Statement of Raymond Broger, President of the Foreign Policy Committee of the Council of States (Christian Democrat), in the minutes of the meeting of the Foreign Policy Committee of the Council of States on 12 February 1976, no date, p. 20, SFA E1050.12\#1995/512\#10*.

2 Garthoff, Détente and Confrontation, notably pp. $27-73$.
}

(C) SABINA WIDMER, 2021 | DOI:10.1163/9789004469617_013

This is an open access chapter distributed under the terms of the CC BY-NC-ND 4 a license 
of Soviet aggression and expansionism that violated Détente. ${ }^{3}$ Although it is probably exaggerated to claim, as the US National Security Advisor Zbigniew Brzezinski did in his memoirs, Détente "lies buried in the sands of the Ogaden", the conflict did increase tensions between the superpowers and undermine Détente. ${ }^{4}$

With the launching of the North-South dialogue in 1975 and the erosion of Third World political and economic power by the late 1970s, the second half of this decade was also a crucial period in North-South relations. The Conference on International Economic Cooperation (CIEC) opened in Paris in December 1975 and brought together developing and developed states to discuss the demands of the Third World for a NIEO. Yet, as a result of concerted opposition to these demands from the North, the growing fragmentation of Third World unity, and the increasing debt crisis, the Third World's political power had started to wane by the end of the decade. ${ }^{5}$ Nevertheless, considering their still significant political weight, the position of independent African states during the Angolan and Ogaden wars was a crucial factor for Western policymakers to take into account. This was particularly important in Angola. As rejection of the Apartheid regime was one of the main issues uniting Third World states, the association with the invading South African army severely tarnished the image of the US in the global South. In the case of the Ogaden War, the Somali invasion broke the fundamental OAU principle of the inviolability of the borders inherited from colonialism. This made it difficult for Western states to openly support Somalia against Soviet-allied Ethiopia.

In many parts of the globe, the wars in Angola and in the Ogaden confirmed a general impression of US weakness. In the 1970s, several factors contributed to undermining the image of US political, military, and economic power. There was the crisis of the US-led world economic system; in the early 1970s, declining domestic productivity resulted in a US trade deficit. Inflation and unemployment grew. To prevent the outflow of dollars, the Nixon administration suspended the convertibility of the US dollar to gold in August 1971, which led to the abandonment of fixed exchange rates and the breakdown of the Bretton Woods international monetary system in 1973. The 1973-1974 oil crisis reinforced these economic difficulties and increased the power of oil producers in the Third World in international economic relations. The Vietnam War

3 See notably ibid., pp. 732-745; Westad, The Global Cold War, pp. 241-249, 279-287.

4 Cited in Westad, The Global Cold War, p. 282. On the Ogaden War and Détente, see Jackson, Jimmy Carter and the Horn of Africa; Jackson, "The Ogaden War and the Demise of Détente"; and Woodroofe, 'Buried in the Sands of the Ogaden'.

5 See notably Mazower, Governing the World, pp. 311-317; Garavini, After Empires; pp. 201-249. 
also undermined the US's international standing. It deeply divided US society, and the expenditures linked to the war were an important element in the country's balance of payments difficulties. The fall of Saigon in April 1975, after more than a decade of direct US military engagement in Vietnam, constituted a humiliating defeat, which would overshadow Washington's foreign policy for years to come. ${ }^{6}$

During the wars in Angola (chapter 7) and in the Ogaden (chapter 8), the Swiss government adopted a wait-and-see approach. Partly thanks to the granting of humanitarian aid through the ICRC, Bern succeeded in manoeuvring through the conflicts without further damaging its image in Africa or impairing its relations with the Western superpower. However, the victories of the MPLA and Soviet-backed Ethiopia in the two major 'hot wars' of the period contributed to an increased perception of a 'Communist threat' in Africa. This sparked policy initiatives within the FPD that aimed to reconsider Switzerland's foreign policy in sub-Saharan Africa. Yet, the Swiss government's limited attempts to strengthen its engagement in this region were hampered by the resistance of a significant part of the Swiss population.

6 See notably Daniel J. Sargent, "The United States and Globalization in the 197os", in Ferguson, The Shock of the Global, pp. 49-64; Lien-Hang T. Nguyen, "The Vietnam Decade: The Global Shock of the War", in Ferguson, The Shock of the Global, pp. 159-172. 


\section{Manoeuvring through the East-West and North-South Conflict: The Angolan War}

The roots of the Angolan War are difficult to determine, as knowledge of the belligerents and their background remains limited due to the lack of internal sources. The rivalry between the three Angolan liberation movements, with their different ideological outlooks and visions for the development of Angola, was based, at least initially, on their different ethnic groups and regional strongholds. They were each led by an ambitious authoritarian leader and had entered into different international alliances, all of which had prevented the formation of a common anti-colonial front during the independence wars. Pressured by the OAU and independent African governments, the FNLA, the MPLA, and UNITA had briefly set aside their differences in early 1975 to conclude the Alvor Agreement on decolonisation with the Portuguese government. After repeated clashes in the first half of 1975, the shaky truce between the three Angolan liberation movements was shattered in July. The MPLA expelled FNLA troops from Luanda and the transitional government collapsed. FNLA leader Holden Roberto left his exile in Zaire and led his troops' march towards Luanda. Meanwhile, UNITA fought the MPLA in central and southern Angola. Occupied with the political, economic, and social upheaval in Portugal, the colonial authorities were unable to control the decolonisation process in Angola, despite their ongoing military presence. At the same time, the three movements' external allies stepped up their support. In midJuly 1975, the South African Prime Minister decided to support the FNLA and UNITA with weapons and equipment amounting to CHF 76 million (US\$ 27.4 million). On 18 July, the US government, which had already granted limited support to the FNLA in January 1975, authorised the disbursement of US\$ 6 million for IAFEATURE, a covert CIA operation aimed at preventing an MPLA victory by strengthening its two opponents. Until August, this was followed by two further payments of US\$ 8 million and US\$ 10.7 million. In early August, a Cuban mission arrived in Angola to determine the MPLA's need for aid. ${ }^{1}$ The extent of Soviet and Chinese involvement in the Angolan War is less clear. The

1 Gleijeses, Conflicting Missions, pp. 235-242, 254-258, 292-293; Marcum, Exile Politics and Guerrilla Warfare, pp. 26o-262; Miller, "Yes, Minister", pp. 17-18; Schneidman, Engaging Africa, pp. 208-209. The value of South African military aid (rand 20 million) has been 
USSR had decided to supply the MPLA with heavy weapons in late 1974. Out of rivalry with the Soviet Union, the PRC put its weight behind the FNLA and UNITA. ${ }^{2}$ These two movements also received support from Zaire and France, and, it seems, from the UK, the FRG, and Rumania. Yugoslavia was the MPLA's main supplier of weapons during the first half of 1975, but the GDR also sent military aid. ${ }^{3}$ Foreign interventions shortly before Angola's scheduled independence on 11 November 1975 further internationalised the conflict and increased tension between the superpowers. In October, South Africa invaded Angola in order to prevent the MPLA from seizing power, presumably with US approval. On 7 November, Cuban troops arrived in support of Agostinho Neto's MPLA. In March 1976, the Angolan War ended with the victory of the MPLA.

For the Swiss government, the Angolan War represented the most crucial test of its foreign policy in sub-Saharan Africa between 1967 and $1979 .{ }^{4}$ In a speech before the Foreign Policy Committees of the two houses of parliament in late August 1975, Federal Councillor Pierre Graber considered the events in Angola to be one of the biggest dangers to peace in Africa. ${ }^{5}$ During this conflict at the intersection of decolonisation and East-West dynamics, Swiss foreign policymakers pursued a number of conflicting goals. Their first and major preoccupation was maintaining their neutrality during an armed conflict. This implied the equal treatment of all belligerents. In late 1974, the Swiss government had decided to uphold the prohibition on the export of arms to Angola and its neighbouring countries, particularly Zaire, a decision that was confirmed in December $1975 .{ }^{6}$ As far as could be ascertained, the export ban on war materials was largely respected during the Angolan War. Rumours about

converted to CHF and US\$ using the exchange rates indicated in tables III and IV in Bott, $L a$ Suisse et l'Afrique du Sud, pp. 386-387.

2 Westad, The Global Cold War, pp. 224-227; Shubin, The Hot 'Cold War', pp. 40-44; Jackson, "China's Third World Foreign Policy", pp. 405-410.

3 See Gleijeses, Conflicting Missions, pp. 347-351. On the role of the UK, see Hughes, "Soldiers of Misfortune".

4 The first sections of this chapter are derived in part from Sabina Widmer, "Neutrality challenged in a Cold War Conflict: Switzerland, the International Committee of the Red Cross, and the Angolan War", Cold War History 18:2 (2018), pp. 203-220, copyright Taylor \& Francis.

5 Pierre Graber, Federal Councillor and head of the FPD, speech held at the meetings of the Foreign Policy Committees of the Council of States on 21 August 1975 and the National Council on 28 August 1975, "Tour d'horizon", no date, p. 14, SFA E1050.12\#1995/512\#9*.

6 Note from Michael Gelzer, deputy chief of the DPA, to Pierre Graber, "Exportation de materiel de guerre vers le Zaïre”, 12.12.1974, dodis.ch/40643; note from Hannes Vogt, DPA, to Jürg Andreas Iselin, deputy chief of the DPA and chief of its African, Asian, Middle Eastern and Latin American Division, "Bundesratsbeschluss vom 2. Juni 1969, der ein Kriegsmaterial-Embargo für verschiedene afrikanische Länder verhängt hat”, o8.12.1975, dodis .ch/39365. 
Swiss weapons deliveries made to UNITA in late 1975 were not substantiated. ${ }^{7}$ In the final stages of the conflict, the demand for an export permit for two Pilatus Porter aircraft destined for Luanda put the Swiss authorities in a quandary, as they had no legal means to prevent the export of these dual use planes. Worried about the possibility that "in press reports of the civil war in Angola, Swiss Pilatus-Porter might be mentioned at the same time as Soviet arms and Cuban troops", a DPA official asked the Federal Air Office in mid-February to convince the Swiss firm to delay delivery of the planes until the end of the conflict. ${ }^{8}$

Second, the Swiss government was hard-pressed to improve its image in Southern Africa and in the Third World more generally. For this reason, it sought cordial relations with Angola's future rulers-which would be determined by the outcome of the war. As Switzerland had been accused of caring little for the African populations of Southern Africa, it was politically important to make a positive contribution in favour of soon-to-be independent Angola. This rendered it difficult for FPD leaders to adopt a distanced and disinterested attitude and wait out the end of the conflict before establishing relations with the winners.

The arrival of the Cold War on the African continent, as Swiss foreign policymakers read the events in Angola, raised the stakes further still. In this context, their third goal was maintaining close relations with the US. During the early stages of the Angolan War, this was not difficult. During a meeting with Edward William Mulcahy, Deputy Assistant Secretary of State for African Affairs, in April 1975, the Swiss ambassador to the US had learnt that "State Department officials find it difficult to interest their boss in this continent."9 Swiss diplomats were aware that Washington's eyes were not turned to Africa, but rather focused on the collapse of the South Vietnamese regime. As they

7 Letter from Richard Pestalozzi, Swiss ambassador in Kenya, to the DPA, "Schweizerische Waffenlieferungen nach Angola?", 16.12.1975, confidential, SFA E2200.185-02\#1987/123\#45*; letter from Hansjakob Kaufmann, deputy chief of the DPA's African, Asian, Middle Eastern and Latin American Division, to the Swiss embassy in Kenya, "Livraison d'armement suisse à l'Angola?", o8.01.1976, ibid.

8 Letter from Jürg Andreas Iselin to the Federal Air Office, "Export von Pilatus-Porter Flugzeugen nach Angola”, 13.02.1976, SFA E2001E-o1\#1991/17_Bd. 611, B.51.14.21.20.Ang.

9 PR no 27 by Felix Schnyder, Swiss ambassador in the US, "Lévolution en Afrique australe vue de Washington”, 23.04.1975, p. 4, SFA E230o-o1\#1977/3O\#88*. On Secretary of State Henry Kissinger's lack of interest for Angola until late spring 1975, see notably Jussi Hanhimäki, The Flawed Architect: Henry Kissinger and American Foreign Policy, Oxford: Oxford University Press, 2004, pp. 406-413; Schneidman, Engaging Africa, pp. 202-211; Gleijeses, Conflicting Missions, pp. 356-357. See also the letter from Steven McDonald, Country Officer for Angola and Mozambique in the US State Department, to Thomas F. Killoran, US Consul-General in Angola, o9.05.1975, NARA, RG 59, Records Relating to Angola 1974-1975, box 1. 
had no knowledge of the July 1975 decision to launch a CIA operation in Angola, the Swiss authorities felt at liberty to determine their policy without superpower interference. However, the intervention of South African and Cuban troops shortly before the country's independence on 11 November 1975 transformed Angola into a Cold War battleground. Fearing that the Marxistinspired MPLA might prevail, thanks to Soviet and Cuban backing, the Ford administration exerted considerable political pressure to prevent other states from recognising Angola. Consequently, the Swiss government's policy during the Angolan War focused, above all, on maintaining a political (and economic) presence without alienating any one of the belligerents, the US, or independent African governments.

The outbreak of open war in Angola did not come as a surprise to the FPD. Civil war had been viewed as a possibility since the Carnation Revolution and had spurred its leaders' cautious and low-key policy in this country. As the fighting between the three liberation movements escalated in July 1975, the Swiss authorities adopted a wait-and-see approach. Their most immediate concern was the evacuation of Swiss citizens living in Angola. Due to the hostilities, more than half of the 100 Swiss citizens registered in Angola in early 1975 had left the country by September. Those remaining were mainly missionaries working in the south of the country, along with a few Swiss employees of the Luanda office of Ciba-Geigy. ${ }^{10}$

The FPD's preoccupation with remaining on good terms with all contenders for power affected its evacuation policy. In late June 1975, the wife of a highranking member of UNITA, who was a member of the transitional government's Presidential Council, contacted the Swiss consul to enquire if, as a Swiss citizen, she and her son might participate in the evacuation programme. Due to her husband's political office, the department had decided, in April 1975, that Theresia N'Delé was not eligible for Swiss consular protection. In mid-July, this decision was revoked. Hansjakob Kaufmann, deputy chief of the DPA's African, Asian, Middle Eastern and Latin American Division, argued that, as UNITA was a real contender for power in Angola, it was not in the Swiss government's interest to offend a prominent representative of the movement by refusing protection to his wife. Nevertheless, Kaufmann warned the FPD's Consular Section of the need for maximum discretion: "If the political group that N'Dele belongs to were to be eliminated or forced into exile during the current domestic disputes in Angola and our support of Mrs. N'Dele-even though schweizerischen Hochseeschiffes m/s St-Cergue", 13.o9.1975, SFA E20o1E-o1\#1987/78\#1686*. See also Jossen, memorandum, „Angola. Evakuierung der Landsleute”, 22.09.1975, ibid. 
it was strictly humanitarian-became known, the victorious political group might interpret it as an attempt to interfere in the domestic dispute."11

In mid-1975, Swiss foreign policymakers held on to the principle of treating all belligerents equally by not fulfilling requests - for aid or recognitionmade by any movement. ${ }^{12}$ Nevertheless, they had a clear preference for UNITA. In a tour d'horizon established by the FPD for the Foreign Policy Committees of the two houses of parliament in late August 1975, the MPLA was characterised as a "Communist organisation linked to the Soviet Union", similar to FRELIMO in Mozambique. ${ }^{13}$ While the FNLA's links to Zaire, the US, and the PRC were mentioned, the report was curiously silent on the foreign ties of UNITA. Social Democrat Jean Ziegler challenged this at a committee meeting of the National Council. He described UNITA as a creation of the Portuguese secret services that was currently supported by the US, and accused the Swiss government of being biased in favour of its leader, Jonas Savimbi. Federal Councillor Pierre Graber emphatically rejected this notion and insisted that the Swiss authorities were impartial. ${ }^{14}$ Yet, the repeated insistence in the tour d'horizon on the MPLA's Communist orientation and Soviet ties was certainly not accidental.

Since the war in Angola derailed preparations for the establishment of cordial relations with the country's future government, FPD leaders sought opportunities to show Swiss support for the Angolan population without taking a stand in the conflict. Despite Switzerland's maxim of availability and longstanding reputation as a mediator, they never considered extending its good offices to the conflicting parties in Angola. This is explained, in part, by a certain unwillingness to get involved in this multifaceted conflict, taking place in a region where Switzerland's image was not the best. More importantly, the OAU insisted that the resolution of the Angolan conflict was an African affair and its own responsibility. The majority of independent African governments did not

Note from Hansjakob Kaufmann to Rolf Heinis, Consular Section, 15.07.1975, confidential, SFA E2001E-o1\#1987/78\#1686*. See also Alfred Reinhard Hohl, DPA, memorandum, 10.04.1975, SFA E2OO1E-01\#1987/78\#4650*; letter from Hansruedi Karlen, Swiss consul in Angola, to the AD, "Frau Theresia Agnes N'DELE: Frage der Gewährung des konsularischen Schutzes", 24.06.1975, attached to the note from Heinis to Kaufmann, 14.07.1975, SFA E2001E-o1\#1987/78\#1686*.

Note from Ernesto Thalmann, Secretary General of the FPD, to the Swiss President, "Relations avec le Portugal", 20.08.1975, p. 3, SFA E2001E-o1\#1987/78\#4656*.

Pierre Graber's speech at the meetings of the Foreign Policy Committees of the Council of States on 21 August 1975 and the National Council on 28 August 1975, "Tour d'horizon", no date, p. 15, SFA E1050.12\#1995/512\#9*.

14 Minutes of the meeting of the Foreign Policy Committee of the National Council on 28 August 1975, September 1975, pp. 15, 18, SFA E1050.12\#1995/511\#19*. 
even want the Angolan War to be discussed at UN level. ${ }^{15}$ The negative reactions to Switzerland's attempts to mediate during the Biafra War had taught Swiss diplomats that the OAU did not take kindly to outside interference. ${ }^{16}$ As a consequence, they were wary when an FNLA member living in Switzerland suggested Swiss mediation in the Angolan War in mid-December 1975 and were glad to drop the matter when it turned out that the movement's leadership had not signed off on the proposal. ${ }^{17}$ Switzerland's mandate to protect US interests in Cuba did not involve it in the Angolan conflict, either. In mid-December, the State Department charged the Swiss Embassy in Washington with transmitting a note to the Cuban government, warning that the Cuban intervention in Angola endangered the normalisation of its relations with Western states. Yet, before the embassy could deliver it, US-Cuban relations deteriorated to such a point that the embassy was requested to destroy it. ${ }^{18}$ Humanitarian aid offered a better chance of improving Switzerland's image.

\section{The Political Benefits of a Humanitarian Image: Swiss-ICRC Cooperation during the Conflict}

During the Angolan War, the Swiss government's humanitarian aid was channelled through the ICRC. In early June 1975, the ICRC opened an official delegation in Luanda and set out an action plan. It aimed to ensure respect for the Geneva Conventions, visit prisoners of war, and provide urgent medical assistance to victims of the conflict by sending three medical teams to Angola. A limited distribution of food to particularly vulnerable sections of the population was also planned. On 1 July 1975, the ICRC launched a restricted appeal for funding from 17 National Red Cross Societies and ten days later, a first medical-surgical team left Geneva for Luanda. ${ }^{19}$ The Swiss government imme-

15 Telegram no 381 from Sigismond Marcuard, Ambassador at the Office of the Permanent Observer of Switzerland to the United Nations, to the FPD, 10.12.1975, SFA E2001E-o1\#1987/78\#1687*; see also telegram no 374 from Marcuard to the FPD, 08.12.1975, SFA E2OO1-O9\#1984/68\#16*.

16 See letter from Fernand Bernoulli, Swiss ambassador in Ethiopia, to the AD, "Schlussbericht des Missionschefs von Addis Abeba", 07.07.1970, pp. 3-4, dodis.ch/37162. Claude Huguenin, DPA, memorandum, "Médiation dans le conflit angolais?", 16.12.1975, SFA E2001E-01\#1991/17_Bd.610, B.15.21.

18 PR no 74 from Alfred Hohl to the FPD, “Angola”, 24.12.1975, p. 2, SFA E2001E-o1\#1987/78\#1687*.

19 Jeanne-Marie Egger, ICRC delegate, Frank Schmidt, delegate-general for Africa and head of the ICRC's Relief Division, “Action CICR en Angola. Plan opérationnel”, 23.06.1975, pp. 1-2, ACICR B AG 200013 004; no author, ICRC memorandum, "Action du CICR en Angola", o6.08.1975, pp. 1-2, SFA E2003A\#1988/15\#650*. 
diately decided to support this mission, both directly and through the intermediary of the SRC. Hence, the FPD covered the cost for a medical team recruited by the SRC to go on a six-month mission to Angola and financed foodstuffs to be distributed by the ICRC. Instead of collaborating with international organisations, such as the WHO, Bern preferred to work with the ICRC and the SRC, Switzerland's "traditional partners". ${ }^{20}$ The Swiss government's contributions to the ICRC mission were justified by its close identification with the humanitarian organisation, which strengthened Switzerland's humanitarian image and international standing.

In the case of Angola, collaboration with the ICRC also had direct political benefits. It allowed the FPD to ignore demands for help coming from the different warring parties without appearing unsympathetic. In mid-August 1975, for example, an FNLA representative asked the FPD to grant humanitarian aid to his movement. His two interlocutors at the DIO deflected this demand by listing the Swiss government's different contributions to the ICRC, which totalled more than CHF 1 million. Although he would have preferred it to be in the FNLA's favour only, the Angolan expressed his gratitude for Switzerland's generous aid. ${ }^{21}$ As humanitarian aid for only one of the liberation movements might have been interpreted as solidarity with this movement's cause, the Swiss government's support for the ICRC relief mission was an opportunity to demonstrate its sympathy for the Angolan population without having to take a stand.

In early September 1975, the ICRC rented an airplane to facilitate the transport of goods and people. Following the precedent of earlier ICRC relief missions, the Federal Council agreed to cover the lion's share of the cost, provided that the plane would benefit all warring parties. The Swiss state also took on the war risk insurance, which could have cost it up to CHF 3 million. ${ }^{22}$ This was the only direct Swiss government attempt to influence the relief opera-

20 Note from Pierre Barbey, chief of the Dio's section for international aid organisations, to Franz Muheim, chief of the DIo's section for the UN and international organisations, "Aide à l'Angola (sur le plan médical)", 21.07.1975, SFA E2003A\#1988/15\#650*; see also Hans Schindler, Anton Wenger, both SRC, to René Keller, chief of the Dio, "Medizinische Hilfe an Angola", 04.07.1975, SFA E2003A\#1988/15\#650*.

21 Pierre Barbey, memorandum, "Aide à l'Angola", 15.08.1975, SFA E2003A\#1988/15\#650*.

22 Note from Pierre Barbey to René Keller, "Demande du CICR tendant à une participation de la Confédération à l'affrètement d'un avion pour l'Angola”, 27.08.1975 and handwritten notes on the same document, SFA E2003A\#1988/15\#650*; Pierre Graber, proposal to the Federal Council, "Kriegsrisiko-Garantie", 28.o8.1975, urgent, attached to the decree of the Federal Council, "Kriegsrisiko-Garantie für Hilfsflüge der BALAIR in Angola. Chartervertrag zwischen dem IKRK und der BALAIR. Bundesbeiträge", o3.o9.1975, dodis.ch/38571. 
tions. Its insistence on equal treatment of the belligerents is explained by its negative experience in the Biafra War. During this conflict, Bern had feared that the credibility of its neutrality and its relations with the Nigerian government might suffer because the latter had accused the ICRC of partiality for the secessionist province of Biafra. ${ }^{23}$ As the ICRC had learned its lesson and was careful to remain impartial towards the Angolan liberation movements, Bern's condition was largely redundant.

The interdependence between the Swiss state and the ICRC is illustrated in operational and personnel links. During the Angolan mission, the FPD issued diplomatic passports to some ICRC delegates. ${ }^{24}$ In late September 1975, the department placed two of its own employees at the organisation's disposal. This offer was initially met with scepticism, as the ICRC worried that deploying FPD personnel might undermine its independence. An ICRC official was particularly concerned about being associated with Switzerland's close relations with Portugal during the independence war, as one of the FPD employees had formerly worked at the Swiss embassy in Lisbon: "Wouldn't this give the impression that the ICRC is somewhat subordinate to Swiss diplomacy?" ${ }^{25} \mathrm{Nev}-$ ertheless, the ICRC accepted the two officials into its ranks. The FPD continued to pay their salaries, as it believed their stay in Angola to be in the department's own interest. ${ }^{26}$ There is no sign that the two F PD officials reported back to Bern during their mission, but the department did receive some privileged information from ICRC headquarters in Geneva. ${ }^{27}$

The collaboration between the Swiss government and the ICRC was mutually beneficial. Apart from operational and personnel support, the ICRC benefited from the Swiss government's significant financial contributions. Until 25 October 1975, the organisation received or was promised cash, services, and material amounting to $\mathrm{CHF} 4.27$ million, mostly made up of governmental contributions. At CHF 1.3 million, the Swiss government's share was more

23 Matter, 'sos Biafra', especially pp. 54, 57.

24 SB, minutes of the ICRC Task Force Angola's meeting no 15 on 22 October 1975, 05.11.1975, p. 3, ACICR B AG 200 013-005.03.

25 Paul Reynard, ICRC, minutes of a telephone conversation with Erik Lang, AD, on 26 September 1975, 29.09.1975, ACICR B AG 252 O13-009.

26 [?] Meier, $\mathrm{AD}$, decree, "Affectation de M. Jürg STREULI à une mission de délégué du CICR à Carmona (Angola)", o6.10.1975, SFA E2003A\#1988/15\#766*; Erik Lang, decree, "Affectation de M. Peter vogLER à une mission de délégué du CICR à Luanda (Angola)”, o8.10.1975, ibid.

27 See, for example, Pierre Barbey's questions during a visit to the ICRC: SB, minutes of the ICRC Task Force Angola's meeting no 15 on 22 October 1975, 05.11.1975, p. 3, ACICR B AG $200013-005.03$. 
than twice as high as those of the next generous governments- the US and the Netherlands. Keeping in mind that part of the SRC's contribution of almost CHF 250,000 - about one-fourth of all donations by National Red Cross Societies - was funded by the FPD, the Swiss government was the biggest single contributor to the ICRC action in Angola. Until October 1975, it shouldered about one-third of the mission's total expenses. ${ }^{28}$

Bern was able to profit from the ICRC's good standing and its privileged access to the three liberation movements. Before leaving Angola in early October 1975, the Swiss consul in Luanda noted that the ICRC's rental plane had improved Switzerland's image in Angola. ${ }^{29}$ The airplane was rented from the Swiss company Balair and marked with the Swiss flag. This blurred the distinction between the ICRC and Switzerland and may have given the impression that all supplies transported by this airplane were donated by the Swiss government. Switzerland's contribution to the ICRC relief mission was highly visible, perceived to be non-political, and appreciated by all belligerents. The ICRC delegates also took over some consular responsibilities. After the departure of the Swiss consul, Switzerland had no diplomatic presence in Angola. Swiss citizens remaining in this country were referred to ICRC delegates and other designated contact persons in case of need..$^{30}$ Bern relied on reports from ICRC delegates and Swiss diplomats stationed in neighbouring African states for information on the political and military situation.

By mid-October 1975, the MPLA had control of key areas of Angola and was continuing to gain ground. Fearing that a victorious MPLA would provide a safe haven for the South West Africa People's Organisation (swAPO) that struggled against South Africa's occupation of Namibia, Pretoria escalated its involvement in the Angolan War. On 14 October, the South African government sent regular troops to bolster the FNLA and UNITA. Together with Angolan soldiers, they advanced rapidly towards Luanda. Although the extent of US connivance is still unknown, it is unlikely that the South African decision to engage in direct intervention was made without consultation. After learning of South Africa's intervention, the Cuban government decided to send troops to Angola,

28 Telegram from Roger Gallopin, President of the ICRC's Executive Council, "rapport de situation no 5", 24.10.1975, p. 1, SFA E2003A\#1988/15\#650*.

29 [Hansruedi Karlen], memorandum, "Angola: Tätigkeit des IKRK. Einsatz der swissair und BALAIR", 02.10.1975, attached to the letter from Karlen to the AD, "Mission in Angola: Schlussbericht", O2.10.1975, SFA E2001E-01\#1987/78\#4650*; see also the note from Jürg Andreas Iselin to the DIO, "Aide à l'Angola", 20.10.1975, ibid.

30 Telegram no 36 from Rolf Heinis to the Swiss consulate in Luanda, 24.og.1975, SFA E2001E-o1\#1987/78\#1686*; telegram no 36 from Antonino Janner, chief of the AD, to the Swiss consulate in Luanda, 25.o9.1975, ibid. 
without consulting the UsSR. On 7 November, the first Cuban soldiers reached Angola and joined the ranks of the MPLA. ${ }^{31}$ Just as Angola was about to gain independence, these foreign interventions turned the country into a hotspot of the global Cold War.

Angola's independence changed the legal basis of the ICRC mission and drastically altered the organisation's working conditions. Supply flights had to be stopped, as the ICRC was unable to reach agreement on their continuation with the three movements. ${ }^{32}$ International tensions following the Cuban and South African interventions blocked donations. Owing to lack of funding, the ICRC had to operate with minimal staff. ${ }^{33}$ In late February 1976, once hostilities had almost ceased and the MPLA had achieved widespread international recognition, the ICRC submitted a six-month aid programme to the Angolan government in order to give it time to establish healthcare infrastructure. In April 1976, however, the MPLA decided that the country's reconstruction should be taken over by national institutions, notably the Angolan Red Cross, which had become independent of the Portuguese Red Cross and with which the ICRC maintained close contact during the war. Although the ICRC planned to continue collaboration with the Angolan Red Cross, this marked the end of its relief mission to the country. ${ }^{34}$ Nevertheless, the Swiss government's support for the ICRC mission continued to be a valuable diplomatic resource in the establishment of cordial relations with Angola's new leaders.

\section{African Influence vs US Pressure: Recognition of the People's Republic of Angola}

On 11 November 1975, the Portuguese government transferred sovereignty to the 'Angolan people' and ended almost 5 oo years of colonial rule. In the midst of the Angolan War, sovereignty was highly disputed. In Luanda, the MPLA announced the formation of the PRA, which was immediately recognised by the Eastern bloc and some African and Third World governments. The FNLA

\footnotetext{
$31 \quad$ Miller, "Yes, Minister", p. 29; Gleijeses, Conflicting Missions, pp. 269-270; 298-308.

$32 \mathrm{JME} / \mathrm{CCz}$, ICRC, minutes of the ICRC Task Force Angola's meeting no 20.1 on 10.12.1975, no date, p. 1, ACICR B AG 200 013-005.03.

33 Peter von Graffenried, DIO, memorandum, "Visite de M. J.-P. Hocké, CICR. Tour d'horizon des activités opérationnelles du CICR 14 janvier 1976”, 20.01.1976, SFA E2003A\#1990/ $3^{\# 6} 77^{*}$.

34 Telegram from Roger Gallopin to Arthur Bill, the Federal Council's Delegate for Disaster Relief Abroad, Herrmann Jossen, and René Keller, "report no 9", 26.04.1976, sFA E2003A\#1990/3\#633*.
} 
and UNITA, in a temporary alliance, proclaimed the Democratic People's Republic of Angola (DPRA), with its capital in Huambo (formerly Nova Lisboa), but won no international recognition whatsoever. ${ }^{35}$ The question of whether or not to recognise the new state was a high-stakes decision that dominated Switzerland's foreign policymaking after Angola's independence. Recognition was called for under the principle of universality, and by the Federal Council's June 1975 decree to recognise the new state, and Bern's wish to improve Switzerland's image in Southern Africa. Although Switzerland recognises states and not regimes, the creation of two rivalling governments during an internationalised conflict rendered the issue of Angola's recognition highly political. There was no question of whom to recognise, as the FPD never considered recognising the DPRA. Recognition of the PRA, however, implied acceptance of the MPLA as the legitimate representation of the Angolan population, for the simple reason that the Swiss government usually communicated the act of recognition in a telegram addressed to the government of a newly recognised country. Since the US lobbied hard to prevent other states from recognising the PRA, an early Swiss recognition might have exposed its government to criticism. Confronted with this dilemma, the Swiss government initially decided to wait and see.

As Angola's independence approached, attempts to influence the Swiss and other Western European states' stance on recognition of the new state increased. The MPLA launched a diplomatic campaign and sent official delegations to various European capitals. Despite their disapproval of the MPLA's ideological orientation, a high-ranking group of FPD officials welcomed a delegation on 7 November 1975. Again, the Swiss authorities' insistence on their humanitarian aid paid off, as the MPLA representatives expressed their gratitude for the substantial aid and important role of the ICRC in Angola. To the great relief of their interlocutors, they were assured that there was no expectation of an immediate Swiss recognition of the government that the MPLA intended to form. Suitably reassured, Claude Huguenin of the DPA pointed out that the visitors "made an effort to present a reassuring image of a popular, solid, decisive, and moderate MPLA by refraining from any reference to its Marxist ideology" 36 The FNLA also vied for recognition and invited the Swiss ambassador in Zaire to participate in independence celebrations in Kinshasa.

35 Gleijeses, Conflicting Missions, p. 311; MacQueen, The Decolonization of Portuguese Africa, pp. 197-198.

36 Claude Huguenin, memorandum, "Visite d'une délégation du MPLA le 7 novembre 1975", 11.11.1975, p. 4, SFA E2Oo1E-01\#1987/78\#1683*. 
Bern, still not wishing to enter into official relations with any of the movements, ordered the ambassador to decline this invitation. ${ }^{37}$

A few days before Angola's independence, Secretary of State Henry Kissinger instructed all US embassies abroad to warn their host governments against "making any hasty move toward recognizing MPLA as government of Angola". ${ }^{38}$ When a diplomat of the US embassy in Bern duly approached Hansjakob Kaufmann, the deputy head of the DPA's African, Asian, Middle Eastern and Latin American Division, he was assured that Switzerland would not imminently recognise Angola. However, Kaufmann stated that this might change should the OAU unexpectedly convince the three movements to form a coalition government. ${ }^{39}$ By referring to the OAU, Kaufmann hinted that the Swiss government's position on Angola's recognition would not be guided by the US alone. This allowed him to keep all options open and to justify a possible future recognition of an Angolan state in which the MPLA formed part of the government. From this time onwards, the Swiss authorities sought regular briefings on the situation in Angola from the US administration. ${ }^{40}$

There was also pressure to recognise the PRA on the domestic front. On the day of Angola's independence, the Progressive Organisationen der Schweiz (Progressive Organisations of Switzerland, РОСн), a party of the New Left, demanded immediate recognition. This forced the Swiss government to comment publicly on the issue. In an evasive one-sentence statement, it argued that the political and military situation in Angola was too unstable to determine whether the criteria applicable in international law for the recognition of a state had been fulfilled. ${ }^{41} \mathrm{~A}$ few days later, Federal Councillor Pierre Graber expanded on this statement in a speech to a cantonal congress of the Social Democratic Party. The Federal Councillor deplored the civil war and warned

37 Telegram no 95 from Jürg Andreas Iselin to the Swiss embassy in Zaire, 10.11.1975, SFA E2001E-o1\#1987/78\#1684*.

38 Telegram from Henry Kissinger, US Secretary of State, to all US diplomatic posts, "Angolan Recognition", o8.11.1975, FRUS Online, vol. XXVIII, Southern Africa, doc. 135.

39 Telegram from Odell, US Embassy Bern, to the Secretary of State, 10.11.1975, NARA, RG 59, AAD, CFPF, Electronic Telegrams 1975, 1975BERNo4636.

40 See notably PR no 70 by Alfred Reinhard Hohl, Swiss Embassy in Washington, "La situation en Angola vue de Washington”, o3.12.1975, SFA E230o-o1\#1977/30\#88*; telegram no 775 from Hohl to the FPD, 16.12.1975, SFA E2200.36\#1996/251\#393*.

41 Ernst Andres, head of the Information and Press Service of the FPD, "Sprachregelung. Unabhängigkeit Angolas", 11.11.1975, SFA E2001E-o1\#1987/78\#1683*; see also the telegram no $346-35^{\circ}$ by Bernard Dufournier, French ambassador in Switzerland, to the French foreign ministry, 11.11.1975, CAD 206QO/169; telegram no $5^{2}$ from Eduardo Manuel Fernandes Bugalho, Portuguese ambassador in Bern, to the MNE, 12.11.1975, AHD, PEA, 1975, Pr. 320.80, box 29 . 
of the dangers of foreign intervention. He went on to express his hope that Angola's territorial unity would be preserved and that the OAU would be able to find a compromise solution to the conflict. Finally, he explained that the Federal Council could not recognise the new state, as it was impossible to determine that any of the three movements exercised the prerogatives of state power. ${ }^{42}$ By using legal criteria, Graber sought to hide the fact that Switzerland's non-recognition of Angola was mainly justified by political reasons. In the following months, Swiss solidarity movements continued to demand Swiss recognition of the PRA and organised meetings to express their solidarity with the M PLA..$^{43}$ Although a majority of Swiss solidarity groups supported the MPLA, others, like Medic'Angola, which later swapped its allegiance to UNITA, favoured a government of national unity. ${ }^{44}$

Although no government in Western Europe recognised Angola in late 1975, their positions during the war varied. Neutral Sweden continued its support of the MPLA and, less than two weeks before independence, decided to proceed with the disbursement of humanitarian aid to this movement, amounting to CHF 3.7 million in the financial year $1975^{-1976.45}$ The Danish government also continued to support existing humanitarian aid projects to the MPLA. Conversely, the Dutch and Norwegian authorities did not grant additional means to this movement, so as not to support a warring party. ${ }^{46}$ The British and French governments publicly adopted an impartial attitude to the three bellig-

42 Information telegram from the FPD to all its diplomatic posts and divisions and to the Trade Division, "extrait de l'exposé de M. Pierre Graber, Président de la Confédération au Congrès d'automne du parti socialiste neuchâtelois, les Brenets, le 15 novembre 1975", 17.11.1975, SFA E2005A\#1985/101\#230*.

43 Letter from M. Briod, Groupe Afrique Lausanne, to Pierre Graber, Federal Councillor and Swiss President in 1975, "Résolution", 16.11.1975, SFA E2001E-o1\#1987/78\#1683*; letter from [?] Braun, Afrikakomitee Basel, to the Federal Council, "Resolution an den Bundesrat", 11.12.1975, ibid.; letter from Irène Lichtenstein, Comité Unitaire de Soutien à la République Populaire d'Angola (United Support Committee for the People's Republic of Angola), to Graber, “Résolution", 13.12.1975, ibid; Kurmann, 'Affaires angolaises', pp. 162-163.

44 No author [Medic'Angola], minutes, "Veranstaltung vom 10.12.1975 mit José Luis Cambinos, Vertreter des MPLA und des SAM", no date, BAB AA5 II.1 1.10; Henrichson, Registratur $A A .5$, p. xii.

45 Sellström, Sweden and National Liberation in Southern Africa. Volume II: Solidarity and Assistance, pp. 129-131. The sum of 5.4 million Swedish krona has been converted to CHF using the exchange rates indicated in Officer, "Exchange Rates Between the United States Dollar and Forty-one Currencies".

46 Swiss embassy in Copenhague, translation of an article in the Kristeligt Dagblad, 19 September 1975, "Dänemark setzt seine Unterstützung der MPLA fort", attached to the letter from Walter Jaeggi, Swiss ambassador in Denmark, to the DPA, the DIO, and the STC, "Weiterführung der dänischen finanziellen Unterstützung der MPLA", 30.09.1975, SFA E2001E-01\#1987/78\#4650*. 
erents. British officials advised against taking any formal action to shore up the FNLA and UNITA in order to avoid African accusations of meddling in Angolan affairs. Considering an M PLA victory inevitable, British policymakers preferred not to prolong the conflict. They wanted a clean slate on which to establish relations with a movement whose Soviet ties would be counterbalanced by the moderating influence of other African states. ${ }^{47}$ Yet, British companies supported UNITA and the extent of official tolerance for the private recruitment of more than one hundred British mercenaries to the FNLA in January 1976 is still debated. ${ }^{48}$ France provided arms to UNITA and, through Zaire, to the FNLA. In addition, French mercenaries were active in the ranks of the FNLA. ${ }^{49}$ Although the EEC member states had decided, in late October 1975, to coordinate their policy on Angola, the differing positions of European governments rendered collective diplomatic action difficult. ${ }^{50}$

In the weeks and months following Angola's independence, the Ford administration continued lobbying to convince African states and the OAU as a whole to deny the MPLA regime recognition. The Cuban intervention was denounced as a Soviet incursion into Africa and a danger to Détente. Initially, African governments were deeply divided about whom to support in the Angolan War. This, together with the liberation movements' unwillingness to cooperate with each other led to the failure of all OAU attempts at brokering a peaceful solution to the conflict. However, once the international press started to report on the South African intervention in late November 1975, African support for the MPLA grew. ${ }^{51}$

In early December 1975, FPD leaders started to reconcile themselves with the prospect of an MPLA government in Angola for several reasons. First, a military victory by the MPLA appeared more and more likely. The MPLA and a growing number of Cuban troops halted the South African advance, which, like UNITA and the FNLA, continued to lose ground. There are contradictory interpretations of the Soviet Union's military role in the conflict, but it definitely

47 Note from Martin Reith, CSAD, to H.M.S. Reid, head of CSAD, "Angola", secret, p. 4, TNA FCO 45/1685; letter from P. M. H. Young, CSAD, to P. I. V. Mallet, UK embassy in Stockholm, "M PLA Representative in Scandinavia", 18.o9.1975, TNA FCO 45/1682; no author, memorandum, "Angola", confidential, attached to the note from Reid, to Miss Rycroft, Planning Section, 19.09.1975, TNA FCO 45/1685; see also Hughes, "Soldiers of Misfortune", pp. 499-50o.

48 Hughes, "Soldiers of Misfortune"; Gleijeses, Conflicting Missions, p. 293.

49 Gleijeses, Conflicting Missions, pp. 293, 312; note from JPC, DAM, to the minister [?], "Position de la France vis-à-vis du problème angolais", 28.10.1975, CAD 310QONT/6.

50 Memorandum from Edward F. Fugit, African Bureau, to Edward William Mulcahy, Deputy Assistant Secretary of State for African Affairs, "EC Nine Intentions on Angola", 20.11.1975, NARA, RG 59, Records Relating to Angola 1974-1975, box 1.

$5^{1} \quad$ Schneidman, Engaging Africa, pp. 212-217; Garthoff, Détente and Confrontation, pp. 576-580; Gleijeses, Conflicting Missions, pp. 321-327. 
stepped up aid to the MPLA after Angola's independence and, in January 1976 at the latest, airlifted Cuban troops to the Southern African state..$^{52}$ Second, the battle for international recognition and the condemnation of foreign interventions also started to turn against the FNLA and UNITA. The Swiss ambassadors to Kenya and South Africa warned that South Africa's intervention, which the Apartheid regime officially denied, had undermined the position of the FNLA and UNITA. In the eyes of African governments, the two movements were perceived as collaborating with an oppressive and racist white minority regime. Emphasising the Southern African dimension of the conflict, the ambassadors advised that the West - they included Switzerland in this bloc—should avoid identification with South Africa's actions. ${ }^{53}$ This implied keeping a distance from the FNLA and UNITA. Third, the Swiss government lost confidence in the ability of the US to influence the outcome of the war in Angola. The Swiss embassy in Washington reported that even the US State Department admitted that the MPLA was gaining the upper hand and that the US seemed to watch the actions of the Eastern bloc in Angola with "powerless resignation". ${ }^{44}$ The Ford administration was facing domestic criticism of its handling of the Angolan situation and its perceived collaboration with the South African intervention. On 19 December 1975, the US Senate refused further funding for the CIA mission in Angola. ${ }^{55}$ Finally, FPD leaders started to see the MPLA in a more positive light. The good impression made by the MPLA delegation in early November was confirmed by an FPD employee who had spent two months in Angola as an ICRC delegate and who stated, in a report to the department, that this movement enjoyed widespread popular support: "Aside from all political sympathy or antipathy, one has to concede to the MPLA that the administration and infrastructure in its territory work best and that real efforts are being made to solve the problems [...] caused by the war". ${ }^{56}$

$5^{2} \quad$ Gleijeses, Conflicting Missions, pp. 317-321, 370-371; Westad, The Global Cold War, pp. $235^{-236 .}$

53 PR no 16 by Théodore Curchod, Swiss ambassador in South Africa, "LAfrique du Sud et l'Angola", o2.12.1975, pp. 3-4, SFA E2001E-o1\#1987/78\#1687*; PR no 21 by Richard Pestalozzi, "Worum es in Angola geht", 05.12.1975, pp. 4, 6-7, ibid. See also Jamie Miller, An African Volk, pp. 191-192.

54 See PR no 7o by Alfred Reinhard Hohl, "La situation en Angola vue de Washington", 03.12.1975, SFA E2300-01\#1977/3O\#88*.

55 Gleijeses, Conflicting Missions, pp. 331-332.

56 Jürg Streuli, STC, report, "Die politische und militärische Lage in Angola Ende November 1975", no date, confidential, pp. 2-3, attached to the letter from François de Ziegler, chief of the DIO, to the Swiss Embassy in Portugal, "Die politische und militärische Lage in Angola Ende November 1975”, o8.12.1975, confidential, sFA E20o1E-o1\#1987/78\#1687*. 
Facing a trade-off between US pressure and a growing number of African and Third World states that recognised the PRA, FPD leaders chose to follow the lead of the OAU. On 10-13 January 1976, OAU chairman Idi Amin of Uganda convened the first extraordinary session of the organisation's Assembly, in Addis Ababa, in order to make one last push at resolving the Angolan conflict. ${ }^{57}$ A few days before the OAU summit, Hansjakob Kaufmann addressed a note to Federal Councillor Graber in which he discussed the political benefits of recognising Angola if the OAU should decide to support the MPLA government. It is remarkable how far the author was willing to go in order to improve Switzerland's image in Southern Africa, even though the MPLA had not yet gained control over the whole of Angola's territory. Kaufmann argued that military and ideological alliances were irrelevant to Swiss policy and never even mentioned the attitude of the US or other European states. Switzerland's national interest alone justified the recognition of Angola: "If the OAU recognises the MPLA, but Switzerland continues to wait, this could further impair our 'image', which is already not spotless in Africa. This would undoubtedly be contrary to our interests." 58 In this matter, the DPA prioritised African aspects over Cold War alliances. But, as the OAU vote on this subject ended in a tie, the decision was, for the time being, postponed.

Kaufmann's note shows that the Swiss authorities' recognition policy was essentially pragmatic. He presented a nuanced, albeit condescending, view of the MPLA, arguing that it was well known that "Western ideological categories have a different significance in Africa than in our country. (This means that the 'socialist' orientation of an African state or the fact that it is supported by the USSR cannot a priori be equalled with alignment with Moscow)." ${ }^{59}$ FPD leaders did not believe that recognition of the PRA would mean accepting Soviet dominance in Angola. Although they continued to observe US policy on Angola, they did not trust that the Ford administration would be able to prevent an MPLA victory. In a report to the FPD in mid-January, the Swiss chargé d'affaires in Washington considered the rather optimistic prognosis of William E. Schaufele, Assistant Secretary of State for African Affairs, to be "possibly partly wishful thinking." 60

\footnotetext{
57 Amate, Inside the $O A U$, p. 253; Walraven, Dreams of Power, p. 253.

$5^{8}$ Note from Hansjakob Kaufmann to the head of the FPD, "Angola: Frage der Anerkennung", o8.01.1976, p. 2, SFA E2001E-01\#1988/16\#19०7*.

59 Ibid.

6o PR no 2 by Alfred Hohl, "Angola", 14.01.1976, p. 2, SFA E230o-o1\#1988/91\#80*; see also Susan M. Klingaman, European Bureau, memorandum of conversation with Alfred Hohl on 13 January 1976, "Angola", no date, NARA, RG 59, P-Reel Printouts 1976, P76ooo7-1930, box 7D.
} 
The possible economic benefits of collaborating with the MPLA regime strengthened the FPD's willingness to recognise the PRA. In late January 1976, the MPLA's public relations man in Europe, Arsalan Humbaraci, who claimed to enjoy good relations with Swiss banks and aviation and industrial companies, called on the DPA. He assured the DPA that, despite receiving Soviet support, his movement was keen to establish contact with Western countries and hoped to win their recognition. ${ }^{61}$ In the following month, Humbaraci continued advocating recognition of the PRA by giving several interviews to the Swiss press, in which he underlined that the MPLA was well disposed towards Switzerland and had good relations with the Swiss private sector. ${ }^{62}$ This economic argument did not fall on deaf ears. Only a few days after Humbaraci's visit, the DPA started to draft a letter of recognition to the MPLA's foreign minister. ${ }^{63}$

Despite the fact that even the Swedish government was unwilling to recognise the PRA in January 1976, ${ }^{64}$ the OAU's recognition of Angola on 11 February 1976 represented a turning point for Western European states. The French government immediately decided to follow suit and announced its decision to recognise the PRA very soon to African governments, the US, and its EEC allies. Although critical of French unilateralism, the EEC countries made great efforts to agree a coordinated recognition of Angola. While the French government justified its decision by pointing to the pressure of its moderate African allies, observers believed it to be an attempt to compensate for its former support of the FNLA. ${ }^{65}$ Once the OAU paved the way, Western European capitals showed themselves willing to act independently of the US government, which was still set on preventing recognition of the PRA. Scholars generally perceive the Angolan War to be a negative episode in the OAU's history due to of the organisation's inability to unite the contending liberation movements and because

$61 \quad$ Hansjakob Kaufmann, memorandum, "Vorsprache Arsalan Humbaraci (H.), 'persönlicher Beauftragter' Netos (MPLA)", 26.01.1976, SFA E2001E-o1\#1988/16\#1907*.

62 See the note from Claude Huguenin to Jürg Iselin, "Arsalan Humbaraci", o1.o6.1976, SFA E2001E-o1\#1988/16\#1907*.

63 Draft letter by Pierre Graber to José Eduardo dos Santos, Angolan foreign minister, 28.01.1976, SFA E2001E-o1\#1988/16\#1907*.

64 Bernard Turettini, Swiss Ambassador in Sweden, to the DPA, "Représentants du MPLA en Suède", 22.01.1976, SFA E2001E-o1\#1988/16\#1907*.

65 Circular telegram no 108 from [?] Georgy to French embassies in Africa, 11.02.1976, CAD 200QO/213; telegram no 39-43 from [?] Dienesch, Luxembourg, to the French foreign ministry, 13.02.1976, ibid.; Norman Aspin, Assistant Under-Secretary of State, FCO, memorandum, "Angola: Recognition of the MPLA", 12.02.1976, TNA FCO 45/1884; telegram no 18 from Walter Jaeggi, Swiss ambassador in Denmark, to the FPD, 18.02.1976, SFA E2001E-o1\#1988/16\#1907*; telegram no 18 from Auguste Hurni, Swiss ambassador in Belgium, to the FPD, 24.02.1976, SFA E2OO1E-o1\#1988/16\#1907*. 
the conflict highlighted discord among its member states. ${ }^{66}$ In the case of recognition of the PRA, however, the African organisation was considered to have a certain moral authority that the Western European capitals, including Switzerland, were inclined to follow.

In a statement to the Foreign Policy Committee of the Council of States on 12 February, Federal Councillor Pierre Graber argued that, for political and mainly economic reasons, Switzerland should not wait too long before recognising the PRA, so as not to repeat the mistakes made in Mozambique. ${ }^{67}$ The OAU's decision and the belief that Angola's recognition by other Western European states was imminent gave the DPA enough leeway to resist US pressure. When Nathaniel Davis, US ambassador in Bern, protested that this step was "premature" and "hasty", Iselin assured him that "Switzerland would not be among the first in Europe to recognize Luanda and would in fact try to be among the 'middle states." But, he argued, if the EEC decided to recognise the PRA, Switzerland would "find it difficult not to follow suit." 68

The timing of Switzerland's recognition was closely coordinated with the EEC and the other European neutrals. Not wanting to be overtaken by an expected wave of recognitions, DPA leaders requested Swiss ambassadors in the Western European capitals to report on their host country's plans and those of the EEC. ${ }^{69}$ In the following days, telegrams went back and forth between Bern and its embassies. On 16 February 1976, the Eec's Political Committee discussed Angola's recognition. ${ }^{70}$ On the following day, France independently recognised the PRA, thereby thwarting the EEC and the Nordic countries' wish for a synchronised recognition. Competition to be among the first European countries to recognise Angola ensued. "In the case of Angola, the Western states hesitated to take the front seat in the recognition train. But as soon as France had taken this place, everybody rushed at the next places", Iselin recalled in September $1976 .{ }^{71}$

66 Walraven, Dreams of Power, pp. 251-257; Amate, Inside the OAU, pp. 249-254.

67 Statement by Pierre Graber, minutes of the meeting of the Council of States' Foreign Policy Committee on 12 February 1976, 28.02.1976, p. 22, SFA E1050.12\#1995/512\#10*.

68 Telegram from Nathaniel Davis, US Ambassador in Switzerland, to the Secretary of State, 12.02.1976, NARA, RG 59, AAD, CF PF, Electronic Telegrams 1976, 1976BERNoo665.

69 Telegram no 5029 from Jürg Iselin to the Swiss embassies in Stockholm, Oslo, Vienna, Lisbon, and Madrid, 13.02.1976, SFA E2001E-o1\#1988/16\#1907*; telegram no 5030 from Iselin to the embassies in Brussels, London, Paris, Rome, Cologne, The Hague, Copenhagen, and Dublin, 13.02.1976, ibid.

70 Telegram no 1 from Hansjakob Kaufmann to the Swiss embassy in Luxembourg, 16.02.1976, SFA E2OO1E-o1\#1988/16\#1907*.

71 Presentation by Jürg Andreas Iselin held on 3 September 1976, "Die bilateralen Beziehungen der Schweiz zum Südlichen Afrika", appendix no 20 of the minutes of the Annual Conference of Swiss Ambassadors 1976, p. 6, SFA E2010-01A\#199o/5\#9*. 
On 18 February 1976, DPA leaders urged their chief to convince his fellow government members to recognise Angola. At noon, Iselin informed Graber that Sweden had just recognised the PRA and other Western European countries planned to do so that day. A Swiss businessman had told him that the MPLA's leader was disappointed that Switzerland had not recognised Angola and that "the Swiss economy might miss out on interesting business opportunities if we wait too long". ${ }^{72}$ The Secretary General of the FPD, Albert Weitnauer, echoed these fears for Switzerland's economic interests and urged haste: "The race has become a matter of hours." If Switzerland sent a telegram to the MPLA that same afternoon, it could still fulfil its goal: "to be, in the matter of recognition, within the first third of the Western countries of the world." 73 The Federal Council agreed with this reasoning. That same day, Graber addressed a telegram to Angola's Foreign Minister informing him of Switzerland's recognition of the PRA, its wish to establish diplomatic relations, and his hope that Angola would soon find peace and prosperity. ${ }^{74}$

Reactions to Switzerland's recognition of the PRA generally ranged from non-committal to positive. In Secretary of State Henry Kissinger's absence from Washington, the Department of State did not comment on Bern's decision, although the US would not recognise Angola until 1993. The strongly antiCommunist Swiss ambassador to Zaire qualified Switzerland's recognition as "reasonably quick and, fortunately, only just not premature." ${ }^{75}$ While Swiss solidarity movements welcomed the news, the national press showed little interest. Right-wing National Councillor James Schwarzenbach criticised Switzerland's recognition of the PRA in a parliamentary question in early March 1976. Yet, for the Swiss government, this limited domestic criticism was offset by the positive reaction of the MPLA. A Swiss businessman reported that the Angolan government greatly appreciated Switzerland's recognition. ${ }^{76}$ By early

72 Note from Jürg Iselin to Pierre Graber, “Anerkennung von Angola", 18.02.1976, p. 2, SFA E2001E-o1\#1988/16\#1907*.

73 Notefrom AlbertWeitnauer, F PD Secretary General, to Pierre Graber,18.02.1976,SFA E20o1Eol\#1988/16\#1907*.

74 Telegram from Pierre Graber to José Eduardo dos Santos, 18.02.1976, SFA E2001E-o1\#1988/ $16 \# 1907^{*}$.

75 PR no 6 by Jean-Pierre Weber, Swiss ambassador to Zaire, "Rapprochement Mobutu-Neto", o1.o3.1976, p. 5, SFA E230o-o1\#1988/91\#39*. See also telegram no 128 from Raymond Probst, Swiss Ambassador to the US, to the FPD, 19.02.1976, p. 1, SFA E2001E-o1\#1988/16\#1907*; US Department of State, Office of the Historian, "A Guide to the United States' History of Recognition, Diplomatic, and Consular Relations, by Country, since 1776: Angola", https://history.state.gov/countries/angola (13 January 2021).

76 Erwin Bischof, FPD, press review, "Die Anerkennung der Volksrepublik Angola durch die Schweiz", 24.02.1976, SFA E2003A\#1990/3\#633*; "Dringliche Einfache Anfrage Schwarzenbach vom 2. März 1976 (76.614). Anerkennung Angolas - Reconnaissance de 
March 1976, the Angolan War was over. The MPLA controlled Angola's central regions and the FNLA had given up the fight. With UNITA's retreat to the Southeast of the country, the hostilities ended for a time. The withdrawal of South Africa's troops was complete by late March. ${ }^{77}$

Recognition of the PRA was the most crucial foreign policy decision that the Swiss government faced in sub-Saharan Africa during the whole period under consideration. By supporting a major ICRC relief mission and modelling its recognition policy on that of the OAU, Swiss foreign policymakers successfully manoeuvred through the Angolan War without endangering the image of Swiss neutrality or alienating African leaders. Early recognition, before the official end of hostilities and in coordination with other neutral and Western European states, laid the foundation for cordial relations with the victorious MPLA regime without creating tensions with the US, which was strongly opposed to a Communist government in Angola.

\section{Unfulfilled Expectations: Relations with the MPLA Government}

After the end of the Angolan War, Swiss foreign policymakers were keen to strengthen their political and economic relations with the MPLA government, irrespective of ideological differences. However, continuing political and military instability limited the opportunities for cooperation. In Angola, Jonas Savimbi resumed UNITA's armed struggle against the MPLA government. In the northern exclave of Cabinda, the Frente para a Libertação do Enclave de Cabinda (Front for the Liberation of the Enclave of Cabinda, FLEC) stepped up its struggle for the secession of the province. In addition, the Angolan government's relations with South Africa and Zaire remained tense. ${ }^{78}$ Once FPD leaders had, by recognising the PRA, implicitly accepted the MPLA as Angola's rulers, they were careful to distance themselves from any movement or person that challenged Luanda. Consequently, they were hesitant to readmit former Angolan refugees that had returned to their home country after the Carnation Revolution but fled back to Switzerland during and after the war. In March 1976, Federal Councillor Kurt Furgler of the FDJP agreed to grant permission

l'Angola", Amtliches Bulletin der Bundesversammlung 1976, Frühlingssession Nationalrat, 24.03.1976, pp. 410-411; Claude Huguenin, memorandum, "Angola", o9.04.1976, p. 1, SFA E2001E-o1\#1988/16\#1920*.

77 Westad, The Global Cold War, pp. 237, 390-392.

78 See David Birmingham, "Angola" in Chabal, A History of Postcolonial Lusophone Africa, pp. 137-184. 
to return to a number of UNITA members and their families. Worried about the political implications of sheltering members of a movement engaged in armed conflict with a government recognised by Switzerland, the Swiss immigration authorities warned the Swiss embassy in Zaire that all applications for readmission had to be submitted to the Swiss Immigration Police and were to be checked carefully. ${ }^{79}$ By mid-1976, 37 Angolans, among them members of all three liberation movements, had returned to Switzerland. ${ }^{80}$

The FPD's first order of business was the establishment of diplomatic relations with the PRA. This proved to be less difficult than it had been in Mozambique. In early April 1976, a Swiss businessman (and husband of the former MPLA representative in Sweden), informed the DPA that the leaders of Angola were well disposed towards Switzerland. After this meeting, Claude Huguenin of the DPA suggested a more proactive Swiss policy than established practice demanded. A few days before Swiss-Mozambican relations were finally formalised, he proposed that all diplomatic efforts should focus on Angola, whose government was friendlier and whose potential richness presented important business opportunities for Swiss economic actors. ${ }^{81}$ Following his suggestion, the FPD reminded the Secretary General of the Angolan foreign ministry of the Swiss offer to establish diplomatic relations and asked the Swiss ambassadors to Ethiopia, Portugal, and Yugoslavia to contact MPLA representatives if they deemed this helpful. ${ }^{82}$

Apart from a general will to improve Switzerland's image in Southern Africa, the FPD's urgency to formalise relations with Angola was largely dictated by economic interests. Swiss business circles considered Angola an important future market. In the first half of 1976, the Trade Division was faced with numerous information requests about economic opportunities in the former Portuguese colonies and therefore insisted on the quick opening of diplomatic representations in Angola and Mozambique. ${ }^{83}$ Economic actors facilitated

79 Letter from Federal Councillor Kurt Furgler to Rosa Thulin-Krebs, 11.03.1976, SFA E2001E-o1\#1988/16\#1913*; letter from Guido Solari, director of the Swiss Immigration Police, to the Swiss embassy in Zaire, "Cadres du movement de libération de l'Angola UNITA réfugiés au Zaïre", 18.05.1976, ibid.; letter from Jean-Pierre Weber to the DPA, 22.03.1976, SFA E2001E-o1\#1988/16\#433*.

8o Kurmann, 'Affaires angolaises', pp. 171-172.

81 Claude Huguenin, memorandum, "Angola", o9.04.1976, SFA E20o1E-o1\#1988/16\#1920*.

82 Telegram from Albert Weitnauer to the Secretary-General of the Angolan foreign ministry, 28.04.1976, SFA E2001E-o1\#1988/16\#1907*; telegram no 5092 from Alfred Glesti, AD, to the Swiss embassies in Ethiopia and Portugal, 28.04.1976, ibid.; telegram no 92 from Gérard Franel, Swiss embassy in Yugoslavia, to the FPD, 31.05.1976, ibid.

83 Note from Emilio Moser, Vice-Director of the Trade Division, to the AD, "Relations diplomatiques avec l'Angola et le Mozambique", 14.05.1976, SFA E2004B\#199o/219\#344*. 
bilateral negotiations. Through the intermediary of the Trade Division, FPD representatives met the Angolan delegation to the International Labour Conference in Geneva in early June. On this occasion, both sides agreed, in principle, to establish diplomatic relations on a date to be suggested by the Angolan government. ${ }^{84}$ The Angolan foreign ministry backed this agreement in early July but insisted that negotiations continue in Luanda. ${ }^{85}$ After some prevarication, Federal Councillor Pierre Graber agreed in mid-September 1976 to send an ambassador to Angola. The following day, however, the Angolan government relented and suggested the establishment of diplomatic relations on 30 September $1976 .{ }^{86}$ Prior to the opening of the Swiss embassy in Angola and the arrival of chargé d'affaires Hans Freiburghaus in February 1977, Swiss business circles played an important intermediary role. They provided Bern with information on the situation in Angola and relayed messages between the two governments. In particular, the Swissair representative in Luanda was important for the DPA. ${ }^{87}$

The relative ease with which Switzerland and Angola established diplomatic relations is explained by a mutual wish for political and economic collaboration. The MPLA valued Switzerland's humanitarian contributions during the Angolan War and wished to strengthen economic cooperation. Angolan nationalists had never been particularly vocal in condemning Switzerland's selective policy of neutrality, probably due to rivalry for the Swiss authorities' favour that had begun during the independence war. Although the MPLA came out on top in the Angolan War and gained widespread diplomatic recognition, the US government was still powerfully opposed to the MPLA government.

84 Note from Ernst Henri Léchot, responsible for relations with Portugal within the Trade Division, to Jürg Andreas Iselin and Aregger, Federal Air Office, "Angola - Visite du Ministre du travail et de la Sécurité sociale", 31.05.1976, attached to the note from Albert Weitnauer to Pierre Graber, "Diplomatische Beziehungen mit Angola", 31.05.1976, SFA E2004B\#1990/219\#344*; Rudolf Emil Stauch, DPA, memorandum, "Angola. Besuch einer Delegation des angolanischen Arbeitsministers bei Herrn Botschafter Iselin vom 4. Juni 1976", o9.06.1976, ibid.

85 Letter from the Angolan foreign ministry to the FPD, 01.07.1976, SFA E2004B\#199o/219\#344*.

86 Note from Hansjakob Kaufmann to Albert Weitnauer, 14.09.1976, SFA E2001E-o1\#1991/17_ Bd610, B.15.21; telegram from the Angolan foreign ministry to the FPD, 15.09.1976, E2004B\#199o/219\#344*.

87 See notably Hans Freiburghaus, Swiss consul in Angola, memorandum, "Notiz über Besprechung vom 11.12.1976 mit Herrn René Grosjean, Swissairdelegierter in Luanda", 14.12.1976, SFA E2004B\#199o/219\#344*; letter from M. Hottinger, Vice-Director of Swissair, to Jürg Andreas Iselin, "Angola", 13.07.1976, SFA E20o1E-o1\#1988/16\#1920*; letter from Freiburghaus to the AD, "Eröffnung Schweizerische Botschaft Luanda", 14.02.1977, SFA E2004B\#199O\#199O\#219\#344*. 
More needful of cordial relations with Western and neutral states, Angola's leaders were less assertive than FRELIMo had been after Mozambique's independence. On their part, FPD officials were more considerate and forthcoming in their dealings with the MPLA, both because of lessons learned in Mozambique and thanks to pressure by Swiss business circles.

Consequently, Switzerland was one of the first Western and neutral states to establish diplomatic relations with Angola. In late July 1976, the MPLA regime had only formalised its links with Sweden, Denmark, Italy, and Brazil. By October, Switzerland, Belgium, the Netherlands, and Portugal had followed. ${ }^{88}$ The big Western powers were noticeably absent. While the Ford administration had not even recognised the PRA, British and French efforts to establish diplomatic relations were hindered by bilateral difficulties. The MPLA criticised France's support for the FNLA and UNITA during the Angolan War and its economic relations with South Africa. In early 1977, the French government succeeded in formalising its links with Angola. Shortly afterwards, however, the French airlift of Moroccan troops to bolster the troops of Mobutu Sese Seko during the first invasion of the Zairean province of Shaba (formerly Katanga), from March to May 1977, destroyed all remaining Angolan goodwill. The invading so-called Katangese gendarmes were Angola-based Katangese exiles of the Front de Libération Nationale Congolaise (Congolese National Liberation Front, FLNC). ${ }^{89}$ Owing to tensions caused by the activities of British mercenaries that had joined the FNLA's ranks in January 1976 and were subsequently tried and condemned by the Angolan authorities, British-Angolan relations were only established in October $1977^{90}$

Angola's independence raised the hopes of Swiss investors who wanted to gain access to economic sectors formerly controlled by the colonial power.

88 Report from H. C. Byatt, British Diplomatic Observer at the Mercenary Trial in Angola, to the Secretary of State for Foreign and Commonwealth Affairs, "Six Weeks in Angola", 30.07.1976, p. 10, TNA FCO 45/2212; H.M.S. Reid, CSAD, memorandum, "Angola", 29.10.1976, p. 1 , TNA FCO $45 / 1885$.

89 No author, DAM, memorandum, "Relations franco-angolaises", 20.12.1976, CAD 310QONT6; JG, DAM, memorandum, "Relations franco-angolaises", 20.04.1978, ibid. On the Shaba crises, see Piero Gleijeses, "Truth or Credibility: Castro, Carter, and the Invasions of Shaba", The Transnational History Review 18:1 (1996), pp. 70-108; Erik Kennes, Miles Larmer, The Katangese Gendarmes and War in Central Africa, Bloomington: Indiana University Press, 2016, pp. 119-144; Miles Larmer, "Local Conflicts in a Transnational War: the Katangese Gendarmes and the Shaba Wars of 1977-78", Cold War History 13:1 (2013), pp. 89-108; Nathaniel Kinsey Powell, "La France, les Etats-Unis et la Force interafricaine au Zaïre (19781979)", Relations internationales 150:2 (2012), pp. 71-83.

$90 \quad$ Note from H. M. S. Reid to Mansfield, "Further recruitment of British mercenaries in Angola", 24.01.1978, secret, TNA FCO 45/2215; see also Hughes, "Soldiers of Misfortune". 
Despite the disruptive effect of the Angolan War, the situation for Swiss economic circles in the second half of the 1970 s was, in many ways, similar to that in Mozambique. Big Swiss export firms continued to do good business, although the MPLA asserted its control over foreign trade. Ciba-Geigy, for example, whose activities during the war were limited to the Luanda area and whose workforce of more than 40 people dropped by more than $50 \%$, maintained its presence and made good sales by the end of the decade..$^{91}$ In early 1976 , the MPLA issued a nationalisation decree. Compared to the significant Swiss losses in Mozambique, in Angola, the DPA only learned of the nationalisation of a few small farms. These cases were closed by the early 1980 os. $^{92}$ Consequently, the new government's nationalisation policy did not have a noticeable dissuasive effect. The General Director of the engineering consultant firm Société Générale pour l'Industrie (SGI), Geneva, for example, was convinced that Angola was a very promising market for Swiss business. SGI began consulting in the fields of telecommunications and airport construction in February 1976, once the MPLA's victory in the Angolan War was apparent. ${ }^{93}$

In some cases, Swiss business people were able to benefit from close links to the new Angolan regime. The manager of De Chambrier Aviation SA, Geneva, a firm that sold aircraft including the North American Rockwell, was an acquaintance of Agostinho Neto's public relations man in Europe. In early 1976, while the fighting in Angola was still ongoing, the firm sold Neto a French Mystère jet as a presidential airplane, and put a team of Swiss pilots at his disposal. It was also involved in the sale of two Boeing 737 aircrafts to Angola, whose export had been authorised by the US authorities. ${ }^{94}$ The Swiss aviation industry was particularly interested in Angola's economic potential.

91 R. Pargätzi, minutes no $7 / 75$ of the Regional Services meeting on 19 September 1975, p. 3, Novartis archives, Ciba-Geigy company archives, Regional Services, minutes, box RD 1, 14/72-9/77; R. Pargätzi, minutes no 9/75 of the Regional Services meeting on 21 November 1975, p. 4, ibid. See also chapter 6.

92 Note from Hermann Jossen to the DPA and the DPIL, "Nationalisierungen in Angola und Mozambique - Geltendmachung schweizerischer Ansprüche”, 02.06.1976, SFA E2200.167\#1991/284\#51*; Christian Dunant, DPA, memorandum, "Verstaatlichungen Angola", o6.07.1981, SFA E2001E-o1\#1991/17_Bd.610, B.34.66.

93 Hans Freiburghaus, memorandum, "Notiz über Besuch bei der SG I - Société Générale pour l'Industrie, Ingénieurs-Conseils, Genève, vom 7.1.77", 20.01.1977, SFA E2025A\#1991/168\#684*.

94 Hansjakob Kaufmann, memorandum, "Vorsprache Arsalan Humbaraci (H.), 'persönlicher Beauftragter' Netos (MPLA)”, 26.01.1976, SFA E2001E-o1\#1988/16\#1907*; note from Kaufmann to Jürg Andreas Iselin, "Anruf Dr. Hottinger (Swissair)/Angolabesuch", 12.03.1976, SFA E2001E-o1\#1988/16\#1920*; telegram from Robert Stephen Ingersoll, US Deputy Secretary of State to the US embassy in Nigeria, O3.03.1976, NARA, RG 59, AAD, CFPF, Electronic Telegrams 1976, 1976STATEo5115o. 
Between July and October 1975, Swissair had operated up to five weekly flights to Angola to repatriate Portuguese citizens, under a contract with the Portuguese national airline TAP. This experience and the contacts established during these flights convinced the company of the great opportunities presented by an independent Angola. In March 1976, a Swissair delegation discussed the possibility of bilateral cooperation with the Angolan air transport organisation in Luanda. On this occasion, the Angolan authorities raised the possibility of negotiating an aviation agreement with Switzerland. Encouraged by the DPA, Swissair subsequently concluded a cooperation treaty for the training of Angolan ground staff and sent a representative to Luanda to observe developments on the spot. ${ }^{95}$ Although a Swiss-Angolan aviation agreement was initialled in mid-1977, the Angolan authorities repeatedly postponed its signature and it seems that the agreement was never ratified. ${ }^{96}$

By late 1979, the Swiss export industry's belief in Angola's economic potential had diminished, despite the Angolan government's efforts to strengthen its economic collaboration with Western states. In November 1978, the head of the Trade Division doubted the sincerity of Angolan advances towards the European neutrals. The following month, the Swiss authorities decided to maintain their restrictive policy on ERG covers for exports to Angola, as the political and economic situation was deemed too unstable. ${ }^{97}$ In February 1979, Ismael Gaspar Martins, Angolan Minister of Finance and former refugee in

95 [Hansruedi Karlen, Swiss consul in Angola], "Angola: Tätigkeit des IKRK. Einsatz der SWISSAIR und BALAIR", o2.10.1975, attached to the letter from Karlen to the AD, "Mission in Angola: Schlussbericht", 02.10.1975, SFA E2001E-o1\#1987/78\#4650*; Ernst Aebi, head of the international relations section of the Federal Air Office, report, "Bericht über die Luftverkehrsverhandlungen mit Angola vom 9. - 17. August 1977 in Luanda", 29.08.1977, attached to the note from Aebi to the FDEA, "Luftverkehrsverhandlungen mit Angola", 06.09.1977, SFA E711O\#1988/12\#1335*; note from Hansjakob Kaufmann to Jürg Andreas Iselin, 13.04.1976, SFA E2004B\#199o/219\#344*.

96 Hans Freiburghaus, report, "Schlussbericht. Schweizerische Botschaft Luanda", 25.10.1979, p. 2, SFA E2OO1E-o1\#1991/17_Bd.610, B.15.21.

97 Note from Paul Rudolf Jolles, head of the Trade Division, to Jürg Andreas Iselin and Emilio Moser, "Kontakt mit Herrn Arslan Humbaraci, Emissär des Präsidenten von Angola", personal and strictly confidential, 20.11.1978, SFA E2010A\#1995/313\#4175*; note from Jolles to Moser and Iselin, "Oesterreichische Beurteilung der Annäherungsversuche Angolas an die europäischen Neutralen”, 24.11.1978, ibid; note from Ernst Henri Léchot to Hans-Ulrich Greiner, Trade Division, “Angola: Garantie contre les risques à l'exportation”, 25.09.1978, SFA E711O\#1989/32\#1395*; letter from Hans Freiburghaus to the Trade Division, "vR Angola - Wirtschaftslage Ende 1978”, 18.11.1978, SFA E7110\#1989/32\#1390*; note from Hermann Hofer to Léchot, "Ihre Notiz vom 12. Dezember 1978", 13.12.1978, SFA E711O\#1989/32\#1395*; Hans Freiburghaus, report, "Schlussbericht Schweizerische Botschaft Luanda", 25.10.1979, p. 3, SFA E2001E-o1\#1991/17_Bd.610, B.15.21. 
Switzerland, made a private visit to Switzerland and Austria, during which he met with representatives of banks and companies. During a visit to Federal Councillor Georges-André Chevallaz, the minister reiterated Angola's wish to assert its economic independence by deepening its economic relations with the three neutrals Switzerland, Austria, and Sweden, and to some extent with the EEC. ${ }^{98}$ In July of the same year, the Angolan authorities promulgated an investment law adapted to Western standards in order to attract foreign investment. Yet, this law seems to have had little effect. The political insecurity in Angola saw investment projects by Nestlé, Alusuisse, and Motor Columbus that had been much talked about in early 1979 being shelved two years later. ${ }^{99}$

Humanitarian and development aid played only a small role in bilateral relations between Switzerland and Angola. The STC stood by its decision not to start development projects in Angola because of the country's natural resources. Humanitarian aid dropped from approximately CHF 2 million in the second half of 1975 to about CHF 1 million in 1976 and CHF 40O,OoO in 1977. Following the MPLA victory, aid was granted mainly in the form of material donations to Swiss and international charities and financial contributions to UNHCR and UNICEF programmes. ${ }^{100}$

In the late 1970s, Switzerland's political relations with Angola were low-key, yet cordial. The MPLA's Soviet links and the continuing presence of Cuban troops in Angola may have contributed to Bern's decision to keep a low profile, but the continuing armed conflicts and political instability in the Southern African state were probably more important factors. In May 1977, disagreements between different factions of the M PLA erupted in a coup attempt led by Nito Alves. Although it was quickly quelled by Cuban troops, the MPLA government responded in the form of violent reprisals against suspected rebels in its ranks and adopted a more authoritarian style of leadership. At the same time, guerrilla activities by UNITA and the FLEC undermined the Angolan government's attempts at reconstruction. ${ }^{101}$ Consequently, when the kidnapping

98 No author, "République populaire d'Angola. Visite privée du Ministre des finances Martins", 22.02.1979, p. 1, attached to the decree of the Federal Council, "République populaire d'Angola. Visite privée du Ministre des finances Martins", 05.03.1979, SFA E1004.1\#1000/9\#865*.

99 Letter from Emanuel Dubs, chargé d'affaires a.i. of the Swiss embassy in Angola, to the Trade Division, "Wirtschaftslage Angolas", o7.08.1981, p. 3, SFA E20o1E-o1\#1991/17_Bd.611, C.41.Angola.10o.o; see also Robert Bärfuss, Trade Division, memorandum, "MIMETA SA Lausanne", o9.08.1979, SFA E7115A\#199o/6o\#1377*.

100 LV, memorandum, "Aide humanitaire de la Confédération en Angola", 03.01.1977, SFA E2003A\#199o/3\#633*; note from Pierre Barbey to Arthur Bill, 21.12.1977, ibid.

101 Birmingham, "Angola", pp. 150-153. 
of a Swiss missionary nurse of the Alliance missionnaire évangélique, formerly Mission philafricaine, demanded a response from the FPD, its leaders acted with great discretion and took care to avoid any association with the conflicts in Angola.

In December 1977, the missionary nurse was abducted by UNITA troops during a raid on her dispensary. This was the first time a European had been kidnapped since the end of the Angolan War. ${ }^{102}$ The Swiss embassy in Luanda immediately informed the Angolan government, in order to ensure the nurse's safety if she were to be found in the company of UNITA troops. Meanwhile, the FPD mobilised the ICRC and Swiss Protestant and Catholic missionaries in Angola to inform the abductors of the negative consequences of the kidnapping on UNITA's image in Switzerland. ${ }^{103}$ Either these indirect appeals to UNITA bore fruit, or the movement's leadership was anxious to rectify a mistake made by overzealous troops. In mid-February 1978, UNITA's information service declared that the missionary would be repatriated at the movement's expense. After marching more than 3,000 km in the company of UNITA soldiers, the missionary reached the Zambian border, from where she was able to return to Switzerland. ${ }^{104}$ This episode highlights the difficult situation of Swiss missionary stations in Angola. They were caught between the belligerents; while the Angolan government disapproved of religious groups and criticised missionary hospitals for providing medical care to UNITA troops, the latter condemned them for stabilising the MPLA's rule. Nevertheless, in a country severely lacking in healthcare infrastructure, the missionary stations were generally tolerated. ${ }^{105}$

102 Telegram no 18 from [?] Peyronnet, chargé d'affaires a.i. of the French embassy in Angola, to the French foreign ministry, 10.01.1978, CADN 89PO/2002021/66o.

103 Letter from Hans Freiburghaus to the DPA, "Entführung Marinova Lazaria Gandhi", 03.01.1978, SFA E2001E-o1\#1988/16\#1914*; letter from Freiburghaus to the DPA, "Entführung Marinova Lazaria Gandhi”, 09.01.1978, and handwritten notes on this document, ibid.; letter from Rolf Heinis to the Swiss Province of the La Salette missionaries, 13.04.1978, ibid.; note from Hermann Jossen to Hansjörg Renk, head of the FPD's Information and Press Service, "Rückkehr der entführten Schwester Marinova Ghandi Lazaria”, o2.08.1978, ibid.

104 Pierre Pittet, "Enlevée en décembre dernier en Angola. Gandhi Marinova, infirmière vaudoise est rentrée hier après-midi au pays", 24heures, o2.08.1978, p. 2; [?] Pijac, "3200 Km dans la brousse angolaise. La longue marche de Gandhi Marinova enlevée par les rebelles de l'UNITA", Tribune de Lausanne/Le Matin, 21.08.1978, p. 7; [?] Pijac, "3200 Km dans la brousse angolaise. La longue marche de Gandhi Marinova enlevée par les rebelles de l'UNITA", Tribune de Lausanne/Le Matin, 22.08.1978, p. 5 .

105 Letter from Hans Freiburghaus to the DPA, "Entführung Marinova Lazaria Gandhi", 03.01.1978, SFA E2001E-o1\#1988/16\#1914*; Freiburghaus, memorandum, "Notiz über Gegenwartsfragen der Missionen", 07.08.1978, attached to the report from Freiburghaus to the DPA, “VR Angola - Besuch der Schweizerkolonie”, o7.08.1978, sFA E2001E-o1\#1988/16\#1920*. 
Bern's wish to preserve its cordial relations with the MPLA government explains why the DPA was unwilling to grant political asylum to Holden Roberto of the FNLA. On 11 November 1979, four years after Angola's independence, Roberto was forced to leave his exile in Zaire. This was probably a symbolic gesture by President Mobutu, who wished to improve relations with neighbouring Angola. After Shaba II, a second invasion by the Katangese gendarmes in May 1978, which was rebuffed by French and Belgian troops aided by the Carter administration, Zaire and Angola established diplomatic relations and agreed to terminate support for movements hostile to their respective governments. ${ }^{106}$ In late November 1979, Holden Roberto demanded political asylum at the Swiss embassy in Paris. The French government did not wish to welcome Roberto due to its delicate relations with the MPLA and deemed it advantageous if the former guerrilla leader were admitted to Switzerland. D PA leaders also considered it politically inopportune to host Roberto and were relieved that the former Angolan leader had made similar requests to other governments and did not follow up on his request for political asylum in Switzerland. ${ }^{107}$ On the whole, although Bern succeeded in creating and maintaining cordial relations with the MPLA government, Swiss economic actors' hoped for opportunities after independence and the end of the Angolan War did not materialise.

\section{$4 \quad$ Towards a Swiss Policy Position on Southern Africa}

In late February 1976, the OAU Council of Ministers warmly congratulated "the heroic people of Angola who under the leadership of the MPLA have resisted South African aggression thus shattering the myth of the superiority and invincibility of the white fascist military regime and its allies". ${ }^{108}$ The MPLA's victory in the Angolan War and its regional and geopolitical consequences drew

106 Larmer, "Local Conflicts in a Transnational War", pp. 107-108; Gleijeses, Visions of Freedom, pp. 55-6o; Birmingham, "Angola”, pp. 154-155.

107 Deputy Director of the Immigration Police, memorandum, 28.11.1979, SFA E2001Eol\#1991/17_Bd.610, B.41.21; telegram no 579 from François de Ziegler, Swiss ambassador in France, to the FPD, 30.11.1979, ibid.; telegram no 5417 from Alfred Rüegg, DPA to the Swiss embassies in Zaire and Senegal, 04.12.1979, ibid.; telegram from Rüegg to the Permanent Observer in New York and the Swiss embassy in Portugal, 04.12.1979, ibid.; Rüegg, memorandum, "Asylgesuch Holden Roberto", 14.03.1980, ibid.; telegram no 214 from [?] Georgy, DAM, to the French embassy in Bern, 13.12.1979, CAD 1929INVA/4683.

108 Resolution CM/Res 455 (XXVI) of the OAU Council of Ministers' 26th Ordinary Session from 23 February to 1 March 1976, "Resolution on Southern Africa", https://au.int/sites/ default/files/decisions/9591-council_en_23_february_1_march_1976_council_ministers_ twenty_sixth_ordinary_session.pdf (13 January 2021). 
the attention of Swiss foreign policymakers to Southern Africa. The failure of South Africa's intervention in the Angolan War invigorated the liberation struggles in this region. In January 1976, the Rhodesian liberation movements ZANU and Zimbabwe African People's Union (ZAPU) increased their activities. Two months later, the FRELIMO government, supportive of the Rhodesian liberation struggle, closed its border with its minority-ruled neighbour, thereby cutting the Smith regime's access to the sea. After the end of the Angolan War, the Namibian SWAPO transferred its headquarters from Zambia to Angola, where it obtained support and military training from the USSR and Cuba. The presence of a hostile government on the northern border of Namibia-occupied by South Africa since the end of the First World War-represented a risk to the latter's national security. Pretoria was humiliated by the defeat of its troops in Angola and felt abandoned by its US allies. On 31 March 1976, its intervention was singled out in a UN Security Council resolution condemning the Apartheid regime's aggression in Angola. South Africa's image suffered further when reports went out around the world of its violent suppression of the riots that followed the killing of protesting schoolchildren in the township of Soweto in June $1976 .{ }^{109}$

The Angolan War increased tensions between the superpowers. The Ford administration's covert involvement was a fiasco. In the eyes of allies and enemies, the failure of IAFEATURE made the US look weak and incapable of ensuring the victory of its protégés. US prestige was further hurt by its association with the Apartheid regime. At home, the CIA's activities in Southern Africa gave rise to anti-interventionism. The defeat of US allies also fuelled domestic criticism of Détente, perceived to be an ineffective policy in the face of Soviet expansionism. This was particularly damaging in an election year. ${ }^{110}$ For the USSR, the Angolan War was a political success. After the end of the conflict, bilateral meetings between Soviet and MPLA officials were stepped up. In October 1976, the two states signed a Treaty of Friendship and Cooperation. The USSR aimed to transform the MPLA into a Marxist—Leninist party and

109 While Sweden supported the UN resolution of 31 March 1976, the US, France, the UK, Italy, and Japan abstained and China did not participate in the vote. See Gleijeses, Conflicting Missions, pp. 340-346; Sue Onslow, "We Must Gain Time': South Africa, Rhodesia and the Kissinger Initiative of 1976", South African Historical Journal 56 (2006), pp. 123-153; Gleijeses, Visions of Freedom, pp. 30-34, 89-90; Chris Saunders, Sue Onslow, "The Cold War and Southern Africa", in Melvyn P. Leffler, Odd Arne Westad (eds.), The Cambridge History of the Cold War. Volume III: Endings, Cambridge: Cambridge University Press, 2011, pp. 222-243.

110 Westad, The Global Cold War, p. 237; Garthoff, Détente and Confrontation, pp. 577-582, 592; Hanhimäki, The Flawed Architect, p. 422-426. 
established a military mission in Angola to arm and train the regime's troops. At the Soviet leadership's request, the Cuban government agreed, in early 1976, to withdraw a large number of the 36,ooo Cuban soldiers stationed in Angola at the end of the war. Nevertheless, Cuba would maintain a military presence in the Southern African state until 1991. ${ }^{111}$

Although Swiss foreign policymakers were set on establishing cordial relations with the MPLA government, they worried about the after-effects of the Angolan War. On the one hand, they were profoundly unsettled by their perception of US weakness. On the other hand, the continuing presence of Cuban troops in Angola gave rise to fears that Soviet influence might further grow in Southern Africa and endanger Swiss economic interests and citizens in the region. After years of muddling along without any clear policy, the possibility that the whole region might turn into a Cold War battleground compelled Bern to make efforts, starting in early 1976, to determine a clear and coherent Swiss policy on Southern Africa.

In a meeting of the Foreign Policy Committee of the Council of States in mid-February 1976, the majority of MPs were alarmed and disconcerted by the events in Angola, which they considered dangerous. While Raymond Broger (Christian Democratic Party) foresaw the installation of numerous new Soviet bases in "red" black Africa, Peter Hefti (Liberal Democratic Party) argued that the Soviet Union had shown its true colours in Angola and that Switzerland should be wary of Détente. For Guy Genoud (Christian Democratic Party), the Angolan War raised doubts about the reliability of the US as an ally for Europe: would the superpower continue to protect the continent from the USSR or would it drop Western Europe as it had dropped Vietnam and Angola? Federal Councillor Pierre Graber did his best to calm these fears by insisting that the new MPLA regime sought contact with all governments and deserved a chance. ${ }^{112}$ He agreed, however, that the US retreat from Vietnam and the defeat of its allies in the Angolan War could be explained by the "(partial) relapse of the United States as a global power".13

In March 1976, Albert Weitnauer, who took over as Secretary General of the FPD in January 1976, ordered a review of Switzerland's policy in Southern Africa. A trade diplomat, adherent to a selective understanding of neutrality

\footnotetext{
111 Shubin, The Hot 'Cold War', pp. 66-67; Westad, The Global Cold War, pp. 238-241; Gleijeses, Visions of Freedom, pp. 70-73.

112 Minutes of the meeting of the Council of States' Foreign Policy Committee on 12 February 1976, 28.02.1976, pp. 19-23, SFA E1050.12\#1995/512\#10*.

113 Pierre Graber's speech at the meeting of the Council of States' Foreign Policy Committee on 12 February 1976, "Tour d'horizon", no date, p. 1, SFA E1050.12\#1995/512\#10*.
} 
in the sense of non-interference who was sceptical of any possibility of fundamental change in East-West relations, the new Secretary General soon became one of the most influential voices in the elaboration of Switzerland's foreign policy guidelines. ${ }^{114}$ Weitnauer tasked the Political Secretariat, a support division within the FPD responsible for developing political studies and the coordination of study groups on foreign policy, with analysing Swiss policy objectives in Southern Africa. The Secretariat was also ordered to formulate measures the Swiss government might adopt as a result of political and military developments in the region. ${ }^{115}$ Considering Bern's general reactivity and long-standing unwillingness to envisage profound policy changes in this area, the assignment is highly significant and attests to the alarm caused by the 'arrival of the Cold War in Africa'.

In the course of the following months, this mandate was divided. The Political Secretariat remained in charge of drafting a report on the situation in Southern Africa and its consequences on Swiss and international policy. In parallel, the chief of the Political Secretariat headed up a newly constituted working group of high-ranking officials from the different sections of the FPD (DPA, DIO, STC, DPIL, and the Financial and Economic Service) responsible for developing policy instruments. ${ }^{116}$ The working group's reflections were based on a pessimistic scenario of developments in Southern Africa that would have serious consequences for Swiss investments, trade, and emigrated citizens; a major deterioration of the political, military, and economic situation in the coming five years, including armed conflicts at South Africa's borders, increased guerrilla activities, economic boycotts by the OAU and the $\mathrm{G}_{77}$, and the collapse of state structures. ${ }^{117}$

114 See Fischer, Grenzen der Neutralität, pp. 205-209.

115 Letter from Jean Cuendet, head of the Political Secretariat, to selected Swiss embassies in Africa, Europe, and the US, and the Swiss missions in New York and Brussels, "Situation en Afrique australe", confidential, 24.03.1976, SFA E2010-o1A\#199o/5\#198*.

116 Note from Jean Cuendet to Jean Monnier, Vice-Director of the DPIL, Jean Zwahlen, head of the Financial and Economic Service of the FPD, Thomas Raeber, deputy head of the STC, Hansjakob Kaufmann, Franz Muheim, chief of the Dio's United Nations and International Organisations Section, "Afrique australe. Groupe de travail 'moyens d'action", 28.05.1976, confidential, pp. 1-2, SFA E2001E-o1\#1988/16\#497*; working group "moyens d'action", draft report, "Afrique australe", confidential, 27.12.1976, p. 1, attached to the note from Cuendet to Monnier, Zwahlen, Raeber, Kaufmann, Muheim, "Afrique australe. Groupe de travail 'moyens d'action", 30.12.1976, SFA E2005A\#1991/16\#541*.

117 Note from Jean Cuendet to Jean Monnier, Jean Zwahlen, Thomas Raeber, Hansjakob Kaufmann, Franz Muheim, "Afrique australe. Groupe de travail 'moyens d'action", 28.05.1976, confidential, SFA E2Oo1E-o1\#1988/16\#497*. 
Unfortunately, neither the minutes of the working group's several meetings in the middle of 1976, nor drafts of the Political Secretariat's report could be located. ${ }^{118}$ Available documents show, however, that from the point of view of the DPA, at least, there was little interest in pursuing a fundamentally different policy in Southern Africa. As Jürg Andreas Iselin suggested to Albert Weitnauer in June 1976, "our relations to the black African states should be reinforced wherever possible, those with South Africa continued with the necessary caution."119 Deepening Switzerland's relations with black African states, notably with Angola and Mozambique, would render its commitment to human rights and its rejection of Apartheid more credible. Although Iselin judged it politically opportune to reduce Switzerland's economic and financial cooperation with South Africa, he discounted this possibility, as it might cause economic difficulties. Instead, he suggested four policy instruments to improve the country's image in Africa: increased support for liberation movements; participation in international programmes to help Zambia and Mozambique deal with the consequences of their economic action against Rhodesia; the issuance of a new statement against racial discrimination; and an emphasis on the negative consequences that South Africa's isolation would have on black workers. ${ }^{120}$ Iselin suggested nothing that had not been discussed, and in some cases carried out, for years.

Bern's reappraisal of its foreign policy in Southern Africa in 1976 was part of a general effort to improve Switzerland's image in the Third World and to participate actively in the North-South dialogue. Switzerland was one of the eight representatives of industrialised countries at the CIEC negotiations that opened in December 1975 in Paris. ${ }^{121}$ In March 1976, FPD leaders decided to seek an invitation to the fifth NAM Summit in Colombo in August of the same year. Intended mainly as a gesture of Switzerland's sympathy with Third World states, an official presence at this summit also enabled Swiss diplomats to make contact with non-aligned leaders and obtain first-hand infor-

118 The study of Swiss policy-making on Southern Africa in 1976 and early 1977 is decidedly hampered by a lack of sources. Despite repeated enquiries by the author and by members of the Dodis research group, it was impossible to locate several key files of the Political Secretariat. They do not seem to have been forwarded to the SFA and are either still located at the FPD or were destroyed. This notably concerns the files of the working group moyens d'action (policy instruments), file number B.58.o6: Email by Yves Steiner, Dodis Africa specialist, to the author, 29 January 2018.

119 Note from Jürg Andreas Iselin to Albert Weitnauer, “Südliches Afrika”, p. 7, o8.o6.1976, SFA E2001E-o1\#1988/16\#497*.

120 Ibid., pp. 7-8.

121 Newsletter of the FPD's Information and Press Service, "Schweizerische Aussenpolitik", o6.02.1976, dodis.ch/50064. 
mation about their political objectives. ${ }^{122}$ In the run-up to the fourth session of UNCTAD, held in Nairobi in May 1976, the FDEA insisted on the need to reduce North-South tension and to seek compromise with the Third World, which absorbed more than one-fifth of Switzerland's total exports and supplied essential raw materials. Bern's readiness to negotiate and to reform some aspects of the international economic order to improve the situation of developing powers is also explained by its desire to maintain liberal market economy principles. ${ }^{123}$ The assertive stance of Third World governments in the international arena spurred the Swiss authorities to speed up development of their active foreign policy, and, in the words of the British ambassador in Bern in June 1976, "to make policies where before they had none."124

Yet, political realities in Switzerland limited this increased openness towards the Third World. In June 1976, Swiss voters rejected a loan of CHF 200 million to the IDA. Many politicians were sceptical of the Third World's political goals and opposed even moderate changes in Switzerland's position on Southern Africa. In August 1976, the Foreign Policy Committee of the Council of States discussed Switzerland's neutrality policy in Southern Africa and the Third World. The conservative majority of committee members remained attached to a selective interpretation of neutrality based on the principle of non-interference. They insisted that the media in a neutral state should not judge the Apartheid regime by calling it a minority government and that Switzerland should not join UN and OAU campaigns against Rhodesia. Perturbed by the radical rhetoric of some NAM member states, they even questioned Bern's decision to attend the Colombo summit. ${ }^{125}$

After the hostilities in Angola came to an end, Swiss foreign policymakers' doubts about the ability of the US to protect the Western bloc's interests lingered. The presidential elections, which introduced an element of insecurity about the future direction of Washington's Africa policy, reinforced these

122 Letter from Albert Weitnauer to the Swiss embassy in Sri Lanka, "5. Gipfelkonferenz der Blockfreien Staaten in Colombo”, 04.03.1976, SFA E20o1E-o1\#1988/16\#936*; Jürg Andreas Iselin, information dispatch to all diplomatic posts and interested services of the FPD and the FDEA, "Gipfelkonferenz 1976 Blockfreier Staaten in Colombo", 07.05.1976, ibid.

123 Proposal of the FDEA to the Federal Council, "4e session de la Conférence des NationsUnies sur le commerce et le développement (Nairobi, 3 au 28 mai 1976)", no date, pp. 5-7, attached to the Decree of the Federal Council, "4e session de la Conférence des NationsUnies sur le commerce et le développement (Nairobi, 3 au 28 mai 1976)", 28.04.1976, dodis. $\mathrm{ch} / 40898$.

124 John Wraight, British ambassador in Switzerland, valedictory despatch, o1.06.1976, p. 3, TNA FCO 33/3046.

125 Minutes of the meeting of the Council of States' Foreign Policy Committee on 19 August 1976, pp. 11-18, citation p. 18, SFA E1050.12\#1995/512\#10*. 
doubts. Fearing that Cuban troops might intervene in the Rhodesian conflict and bring about another USSR victory in Southern Africa, Secretary of State Henry Kissinger undertook great diplomatic efforts to convince Ian Smith's regime to agree to majority rule in a negotiated settlement. He even travelled to Africa in April 1976. Kissinger's campaign was run in close cooperation with James Callaghan's Labour government in the UK. He also got South African Prime Minister Balthazar Johannes Vorster to persuade the Rhodesian regime to cooperate. Until mid-1976, the new Swiss ambassador to the US, Raymond Probst, and his staff met at least once a month with State Department officials for briefings on US policy in Angola and Southern Africa. In a rare comment in May 1976, Probst expressed his scepticism that the controversial Secretary of State would manage to realise the Ford administration's ambitious political programme and contribute to a peaceful solution to the Southern African conflicts in an election year. ${ }^{126}$

Despite, or possibly because of, Swiss feelings of uncertainty, leading Swiss foreign policymakers made some effort to intensify foreign policy consultations with the US government. In a meeting with William E. Schaufele, Assistant Secretary of State for African Affairs, on 11 August 1976, Raymond Probst showed some openness follow the US on Southern African issues. Asked about the role that European states, apart from the UK, might play in the negotiations to end white minority rule, Schaufele replied that the US preferred to restrict participation to African countries. He did not comment on Swiss policy in Southern Africa, stating simply that the US government "appreciates Switzerland's unique position and that we would hesitate to give advice to the Swiss." ${ }^{127}$ Thus, FPD leaders had some reassurance that they were free to pursue

126 PR no 46 by Raymond Probst, "Afrikareise Kissingers", 07.05.1976, SFA E2300-01\#1988/ 91\#80*. See also PR no 17 by Probst, "Weiterungen des Angolakonflikts", o3.03.1976, ibid., PR no $5^{2}$ by Probst, "Retrait des Cubains d'Angola", 26.05.1976, ibid.; PR no 56 by Probst, "Politique américaine à l'égard de l'Afrique", o2.06.1976, ibid.; PR no 63 by Probst, "Rencontre Kissinger/Vorster", 18.06.1976, ibid.; PR no 73 by Probst, "Les relations entre le Zaire et l'Angola et la politique de Washington à leur égard", o9.07.1976, ibid.; PR no 88 by Alfred Reinhard Hohl, Swiss embassy in Washington, "Kissingers Afrikamission", 16.og.1976, ibid.; Susan M. Klingaman, European Bureau, memorandum of conversation between William E. Schaufele, Assistant Secretary of State for African Affairs, and Probst on 1 June 1976, "The Secretary's African Trip, South Africa, Rhodesia, Angola, Sahel Plan, UnCTAD IV", no date, NARA, RG 59, P-Reel Printouts 1976, P76oo85-o676, box 85B; Klingaman, memorandum of conversation between Schaufele and Probst on 11 August 1976, "Angola, Transkei, Rhodesia, South Africa, Namibia, Nyerere", no date, NARA, RG 59, P-Reel Printouts 1976, P76o130-0354, box 130A; Mitchell, Jimmy Carter in Africa, pp. 37-85; Onslow, "We Must Gain Time"', pp. 132-142.

127 Susan M. Klingaman, memorandum of conversation between William E. Schaufele and Raymond Probst on 11 August 1976, "Angola, Transkei, Rhodesia, South Africa, Namibia, 
their own policy in the region. During an informal trip to Washington in September 1976, FPD Secretary General Albert Weitnauer expressed Switzerland's appreciation of US initiatives in Southern Africa to State Department officials. He also suggested the introduction of regular biannual high-level foreign policy consultations between Switzerland and the US, which would allow the former to be more directly informed on major world issues. "Since the Swiss are a friendly democratic people of significant economic and military importance to our interests", the Ford administration was willing to pursue this idea. ${ }^{128}$

Six months after the end of the Angolan War, the conflict and its consequences were some of the main issues on the agenda of the annual conference of Swiss ambassadors. Angola was the second topic of Pierre Graber's tour d'horizon speech, after the US elections. The head of the FPD viewed the conflict through a 'Cold War lens'; although he clearly blamed Soviet support of the MPLA for the escalation of what had initially been a civil war, he did not spare the Ford administration, either. While he considered the latter's decision to back the FNLA precipitate, Graber's main criticism was of Washington's "incapacity" to prevent its allies' defeat in Angola. This, he argued, had led to the demoralisation of those African states that wished to resist Soviet advances on the continent. Despite his disquiet at Soviet activism and the continuing presence of large numbers of Cuban troops in Africa, the Federal Councillor noted the UssR's cautious behaviour in the rest of the world. Referring to the ongoing revision of Switzerland's policy on Southern Africa, Graber underlined that the region had been the focus of the FPD's attention in $1976 .{ }^{129}$

Several Swiss ambassadors echoed this disaffection with Washington's role in the Angolan War. Yet, they never questioned Switzerland's own foreign policy during the conflict. Jean Pierre Weber, Swiss ambassador to Zaire, was one of few diplomats to even mention Switzerland in connection with Angola. The staunch anti-Communist - who had formerly been in charge of the Swiss consulate in Saigon, had — as he told his colleagues, had to "assist at the Western world's loss of strategic positions" for the second time in his career. Weber argued that Switzerland had done well to follow "its traditional policy

Nyerere", no date, p. 4, NARA, RG 59, P-Reel Printouts 1976, P760130-0354, box 13oA; see also the telegram no 678 from Probst to the FPD, 13.08.1976, SFA E2O1O-O1A\#199o/5\#9*. State, "Swiss Proposal for Regular Bilateral", 28.og.1976, NARA, RG 59, P-Reel Printouts 1976, P76o16o-287o, box 16oD; telegram from the US State Department to the Secretary of State, "Daily Activity Reports, Monday, September 20, 1976", 21.09.1976, pp. 1-2, NARA, RG 59, AAD, CFPF, Electronic Telegrams 1976, 1976STATE233210.

129 Speech held by Pierre Graber on 1 September 1976, "Exposé liminaire", pp. 5, 9, 15, appendix no 7 of the minutes of the Annual Conference of Swiss Ambassadors 1976, SFA E201Oo1A\#1990/5\#9*. 
of restraint" during the Angolan War. ${ }^{130}$ As he had elaborated in a report two months previously, Weber considered the containment of Communism to be the responsibility of big powers and organisations such as NATO and the EEC. Switzerland's attitude, in contrast, should be marked by "consideration, understanding, and discretion": "as far as we are concerned, I do not at all endorse a hardening of Switzerland's attitude in Africa. Our behavior, as a small, observing state, is wise". ${ }^{131}$ Weber put it rather bluntly, but as Switzerland's role during the Angolan War was almost undisputed within the FPD, his understanding of Switzerland's role throughout the Cold War in Africa, and this delegation of responsibility, was widely shared by Swiss foreign policymakers.

If the vague policy outlines sketched by Iselin in June 1976 are discounted, the attempt to create a coherent Swiss policy position in Southern Africa failed. By the end of the year, the regional approach had been abandoned and FPD leaders preferred to deal with each Southern African state separately again, from a bilateral point of view. Relations with the new Angolan and Mozambican governments developed to Bern's satisfaction; those with Namibia were not significant. Therefore, the first version of the working group's report, dated late December 1976, focused almost exclusively on South Africa and, to a smaller extent, Rhodesia - the two states where Switzerland's interests were most significant and its economic role most heavily criticised. In the case of Rhodesia, FPD leaders felt the need to adapt their policy, as international pressure on the regime started to show results. On 24 September 1976, Ian Smith agreed to the principle of majority rule in a televised statement. Two weeks later, the Swiss government consented to host a constitutional conference in Geneva that would bring together the Smith regime and the African nationalist movements under British chairmanship. As the end of the Smith regime seemed likely, the FPD drafted a proposal to the Federal Council to charge the FDEA with preparing the necessary legislation to ban triangular trade, limit Swiss exports, and restrict the movement of Swiss capital to Rhodesia. However, the Rhodesia conference soon broke down and was adjourned in December $1976 .{ }^{132}$ Exactly one year later, pressure from African states, as well as the UK and the

130 Statements by Jean-Pierre Weber, minutes of the Annual Conference of Swiss Ambassadors on 1-3 September 1976, SFA E2010-o1A\#199o/5\#9*, pp. 8o-81. See also the statement by Raymond Probst, ibid., p. 84 .

131 PR no 11 by Jean-Pierre Weber, "Rapport final de Kinshasa", 30.07.1976, p. 9, SFA E230oO1\#1988/91\#39*.

132 Jürg Andreas Iselin, memorandum, "Rhodesien-Konferenz”. 07.10.1976, SFA E2003A\#199o/ $3^{\# 1584 *}$; no author, draft proposal to the Federal Council, "Die Schweiz und die Rhodesien-Sanktionen", 20.10.1976, SFA E2001E-o1\#1988/16\#5213*; Onslow, "We Must Gain Time"', pp. 147-152; Mitchell, Jimmy Carter in Africa, pp. 95-116. 
US, would be strong enough that the Federal Council introduced a regulation which prohibited trade with Rhodesia, even if the goods never touched Swiss soil, as well as financial transactions on behalf of people living in Rhodesia. This regulation was heavily criticised by Swiss economic and financial elites. ${ }^{133}$ With regard to South Africa, the working group's draft report of December 1976 contained no fundamentally new policy instruments. It was essentially defensive and focused on the protection of Swiss interests and investments in this state. ${ }^{134}$ The final, untraceable report was completed in April 1977. Whether because of bureaucratic delays, or because it was regularly overtaken by events, the Political Secretariat's analysis of the situation in Southern Africa was still unfinished. ${ }^{135}$ Thus, even after the shock of the Cuban intervention in Angola - that would be referred to for years to come - the Swiss government's foreign policy in Southern Africa continued to be the result of crisis management and contingency planning rather than strategy.

133 Letter from Adrian V. Hill, British embassy in Bern, to John C. Harrison, Rhodesia Department of the FCO, "Rhodesia sanctions", no date, but received on 15 December 1977, TNA FCO $36 / 2088$; letter from A. Jetzer, first secretary of the Vorort, and P. Brügger, legal assistant, to the FPD, "Rhodesia", 25.01.1978, ASBA folder L. 182 Afrique, 1975-1978; letter from J.-P. Chapuis, sBA, to W. de Capitani, legal assistant Crédit Suisse, B. Hartmann, legal assistant Société de Banque Suisse, F. Lusser, Director of the uBs, "Transactions avec la Rhodésie du Sud", o8.02.1978, ASBA folder L. 182 Afrique, 1975-1978.

134 Working group "moyens d'action" draft report, "Afrique australe", confidential, 27.12.1976, attached to the note from Jean Cuendet to Jean Monnier, Jean Zwahlen, Thomas Raeber, Hansjakob Kaufmann, Franz Muheim, "Afrique australe. Groupe de travail 'moyens d'action"', 30.12.1976, SFA E2005A\#1991/16\#541*.

135 CJ, BJN, summary, "Australafrika. Arbeitsgruppe 'moyens d'action'. (Zusammenfassung des Berichts vom 28.4.1977)", confidential, o9.06.1977, p. 2, attached to the note from Jean Cuendet to Albert Weitnauer, Jean Monnier, Jean Zwahlen, Thomas Raeber, Hansjakob Kaufmann, Franz Muheim, “Afrique australe. Groupe de travail 'moyens d'action”, 10.06.1977, SFA E2O1O-O1A\#1990/5\#199*. 


\section{Retaining Western Influence in Africa: The Ogaden War}

While FPD officials were still finishing their report on Switzerland's Southern Africa policy that had been mandated after the Angolan War, tensions between the two socialist neighbours in the Horn of Africa were about to escalate. In an attempt to unite all ethnic Somalis in one state, the Somali army invaded the Ethiopian Ogaden region in July 1977, starting the only conventional war between two African states during the Cold War. The peasant liberation movements Western Somali Liberation Front (WSLF) and Somali-Abo Liberation Front (SALF), trained, armed, and commanded by the Somali state, had been fighting for more than a year in this desert area. By the time they were joined by regular Somali troops, the liberation movements were in control of most of the Ogaden region, except for the bigger towns. In July 1977, the Somali army quickly conquered the rest of the Ogaden lowlands before starting to attack the towns on the Harar plateau in mid-August. Fierce Ethiopian resistance soon brought the Somali offensive to a halt and stalemate began. ${ }^{1}$ The Good Offices Committee of the OAU, chaired by the Nigerian head of state, reaffirmed its central tenet of the inviolability of colonial borders and called for the respect of territorial sovereignty, thereby diplomatically backing Ethiopia's side in the conflict. Over the course of the following months, the OAU's repeated attempts to mediate a negotiated settlement failed. ${ }^{2}$

This conflict, between two of Africa's poorest states, would probably have raised little international interest, had it not been accompanied by a reversal of superpower alliances. In December 1976, the USSR and the Ethiopian PMAC had signed a military cooperation agreement. During a shootout in February 1977, Lieutenant Colonel Mengistu Haile Mariam eliminated his political rivals within the Ethiopian regime and was elected chairman of the Derg. Exasperated by the Somali invasion and its government's refusal to abandon its nationalist quest, the Soviet leadership increased military deliveries to Ethiopia in September 1977 and stopped providing Somalia with arms. In a desperate bid for Western support, the Somali head of state, Mohammad Siad Barre, abrogated the 1974 friendship treaty with the USSR on 13 November 1977, expelled

1 Gebru Tareke, "The Ethiopia-Domalia War of 1977 Revisited", pp. 638-651.

2 Amate, Inside the $O A U$, pp. $415^{-418}$ 
all Soviet experts from Somalia, and closed the Soviet bases in Berbera and Mogadishu. ${ }^{3}$

The Carter Administration, however, refused to grant overt, large-scale military aid to the aggressor for the duration of the Ogaden War. The conflict in the Horn of Africa was one of the Democratic administration's first foreign policy challenges. Jimmy Carter put a strong emphasis on human rights in foreign policy and called for a regionalist, long-term approach to Third World crises. He inherited a wait-and-see policy towards Ethiopia. Despite the Derg's antiAmerican rhetoric, the Ford administration had hoped to maintain its longstanding alliance with Ethiopia and had even increased military aid after the fall of Emperor Haile Selassie. ${ }^{4}$ The Derg's arms deal with the UssR, together with its human rights abuses, rendered this policy untenable to the Carter administration. The independence struggles in Ethiopia's peripheral regions, notably in Eritrea, were echoed by power struggles between competing Ethiopian Marxist-Leninist organisations and the Derg in the centre. Purges and assassinations began in mid-1976 and escalated after Mengistu's takeover in early 1977. It is estimated that about half a million Ethiopians lost their lives during the 'Red Terror' of 1977 and $1978 .{ }^{5}$

The growing US distance towards the PMAC in early 1977 was accompanied by a rapprochement with Somalia. The Saudi Arabian government, which was keen to entice Somalia, a fellow Muslim state, away from the Soviet Union, supported this. Somali leaders and their Arab allies pressed Western governments to provide alternative arms supplies if Somalia broke with the USSR. Rather than granting direct military aid to this regime, the Carter administration preferred to work through a Western consortium, an idea explored during talks with British, French, and West German diplomats. Siad Barre's well-known expansionist designs rendered arms deals problematic. This was particularly true for the UK and France, as the Somali government made claims to the territory of their allies Kenya, and Djibouti, whose independence from France was set for July 1977. Nevertheless, in June 1977, the UK, France, and the FRG agreed to provide

3 Westad, The Global Cold War, pp. 261-272; Yordanov, The Soviet Union and the Horn of Africa, pp. 138-162; 182-187.

4 Jackson, Jimmy Carter and the Horn of Africa, pp. 47-49; Woodroofe, 'Buried in the Sands of the Ogaden', pp. 47-49. Between 1974 and 1976, US military aid to Ethiopia amounted to an estimated \$197 million (CHF 492.3 million), more than half of all aid granted since 1953: Mitchell, Jimmy Carter in Africa, p. 178. The sum has been converted using the exchange rates for 1976 indicated in Officer, "Exchange Rates Between the United States Dollar and Forty-one Currencies".

5 Gebru Tareke, The Ethiopian Revolution, pp. 40-41; Andrew, Mitrokhin, The World Was Going Our Way, p. 457. 
small arms deliveries that were financed by Saudi Arabia. The so-called Safari Club also seems to have delivered some military aid to Mogadishu. This shadowy, informal intelligence alliance, created in the mid-1970s at France's behest as a result of the perceived weakness of the CIA, was aimed at containing Communism, mainly on the African continent. Its members included Saudi Arabia, Iran, Egypt, Morocco, and France. Somalia was also supported by Iran, Iraq, and other Middle Eastern and Northern African states. ${ }^{6}$

The Carter administration did not openly condemn the Somali invasion of July 1977, thereby following Mogadishu's line that its army was not fighting in the Ogaden. Since his open violation of the OAU principle of respecting the borders inherited from colonial times discredited his cause, Siad Barre insisted that the conflict in this region was a non-international fight for self-determination led by Ethiopian citizens. In early September, the US government publicly stated that US arms supplies to the Somali regime would not be forthcoming for the duration of the conflict. Behind the scenes, however, Washington encouraged its NATO allies and conservative Arab states to discreetly send arms to Somalia. ${ }^{7}$

After Siad Barre's break with the USSR in mid-November 1977, the Soviet leaders decided to massively back their remaining ally in the Horn of Africa. They increased deliveries of military equipment to Ethiopia via an air bridge and sent more than 1,0oo generals and military advisors to lead the Ethiopian defence. On 25 November 1977, Fidel Castro decided to accede to Ethiopian aid demands. Over the following months, up to 12,00o Cuban soldiers and 6,ooo advisors participated in a concerted operation under Soviet leadership to drive back the Somali invasion. According to Arne Westad, this was the "most important Soviet-led military operation outside the area of the Warsaw Pact since the Korean War". In early March 1978, Somali troops were forced to withdraw and the conventional war ended, although guerrilla resistance would continue for several years. ${ }^{8}$ A peace accord between Ethiopia and Somalia would only be signed in April 1988. ${ }^{9}$

The Ogaden War had few direct consequences for Switzerland's political and economic interests in the Horn of Africa. Swiss commercial exchanges with and

6 Mitchell, Jimmy Carter in Africa, pp. 191-194; 254-28o; on the Safari Club, pp. 172, 291-301.

7 Ibid., pp. 286-298.

8 Yordanov, The Soviet Union and the Horn of Africa, pp. 188-199; Westad, The Global Cold War, pp. $276-278$, citation p. 277 .

9 See Belete Belachew Yihun, "Ethiopian Foreign Policy and the Ogaden War: The Shift from 'Containment' to 'Destabilization', 1977-1991', Journal of Eastern African Studies 8:4 (2014), pp. 677-691; Flavia Gasbarri, "From the Sands of Ogaden to Black Hawk Down: The End of the Cold War in the Horn of Africa", Cold War History 18:1 (2018), pp. 73-89. 
investments in Somalia were almost non-existent and diplomatic relations had been de facto interrupted in 1975. Although Switzerland's political relations with the Derg had improved somewhat after the controversy surrounding the former Emperor's Swiss bank accounts died down, they remained distant. The Ethiopian government had a bad reputation in Bern. Apart from its nationalisation of Swiss interests and its Eastern bloc ties, the extensive human rights abuses of its 'Red Terror' also contributed to this. The internal conflicts in Ethiopia rendered the situation for foreigners so dangerous that ambassador Fritz Bohnert requested a hazard bonus for Swiss embassy personnel in March $1977 \cdot{ }^{10}$ The employees of private Swiss aid projects, missionaries, and business people left the country. By early August, shortly after the outbreak of the Ogaden War, only about ten Swiss citizens remained in Ethiopia. ${ }^{11}$

The Swiss government saw no need to deviate from a policy of non-interference, for several reasons; Switzerland had few interests in Ethiopia and Somalia, the stigma of its close economic and financial relations with South Africa was far less important than in Southern Africa, and Swiss non-state actors do not seem to have taken much notice of events in the Horn of Africa. Accordingly, its role during the Ogaden War was largely passive. Bern's decision-making during and after the Ogaden War was determined by Cold War considerations. Swiss foreign policymakers saw the Soviet-Cuban intervention in favour of the Ethiopian government as further proof of Soviet expansionism. In order to contribute to the containment of Soviet influence in Africa through Western efforts to provide African governments with an alternative to an alliance with the USSR, the Swiss authorities subsequently took some minor steps to deepen their relations with African states.

FPD leaders were not overly concerned about the outbreak of the Ogaden War. If anything, Federal Councillor Pierre Graber's opening speech at the annual

\footnotetext{
10 Telegram no 26 from Fritz Bohnert, Swiss ambassador in Ethiopia, to the FPD, 25.03.1977, SFA E2OO1E-o1\#1988/16\#3188*.

11 Letter from Fritz Bohnert to the DPA, "Ausländer in Aethiopien, Hilfe, Handelsvertreter", 29.04.1977, SFA E2001E-o1\#1988/16\#319o*; letter from Bohnert to the DIO and the stC, "Missionen, Rotes Kreuz, Terre des Hommes und Helvetas", 30.05.1977, SFA E2005A\#1991/16\#527*; letter from Bohnert to the DPA, "Jari: Helvetas und TdH. Diplomatischer Schutz ausländischer Hilfswerke", 31.07.1977, SFA E2005A\#1991/16\#520*; letter from Bohnert to the AD, "Addis Abeba: Diplomatische Missionen und ihre Aktionsmöglichkeiten”, o8.o8.1977, SFA E2001E-o1\#1988/16\#3188*.
} 
conference of Swiss ambassadors in early September 1977 shows a certain satisfaction that "the UssR lost control of events" in the Horn of Africa and was "in a very delicate [...] situation". ${ }^{12}$ As he told the Council of States' Foreign Policy Committee a few days later, this "direct clash between two Soviet protégés" meant that the Soviet strategy to remain on good terms with both of its allies in the Horn of Africa was "close to complete failure". Graber concluded: "there seems to be no imminent danger of a relapse into the Cold War."13 Following Somalia's break with the USSR on 13 November 1977, the FPD's Political Secretariat considered the USSR's loss of one of its most important allies in subSaharan Africa to be of more interest than the outcome of the war. ${ }^{14}$ The Swiss government's role during the Ogaden War was very low-key. It adopted a position of impartiality and granted financial support to the ICRC relief mission, as it had done during the Angolan War. However, Ambassador Fritz Bohnert's reports from Addis Ababa reveal a certain pro-Somali bias. In mid-October, he still talked of civil war in the Ogaden rather than international conflict between Ethiopia and Somalia, thereby backing Mogadishu's line. ${ }^{15}$

Somalia's rapprochement with the Western bloc led to the re-establishment of diplomatic relations between Mogadishu and Bern. As a result of the Somali government's cavalier treatment of the Swiss ambassador to Tanzania, the FPD had, in early 1975, decided not to accredit another ambassador to Somalia. In April 1977, since it appeared likely that Siad Barre's government would turn away from the USSR, the Swiss authorities reconsidered. The Somali regime reacted positively to the Swiss suggestion of renewing diplomatic relations, probably out of a general willingness to diversify its foreign relations and convince more powerful potential Western donors of Somalia's readiness for a change in alliances. ${ }^{16}$ The practical advantages of a diplomatic representa-

12 Opening speech held by Pierre Graber, Federal Councillor and head of the FPD, on 1 September 1977, "exposé liminaire", pp. 10-11, appendix no 5 of the minutes of the Annual Conference of Swiss Ambassadors 1977, SFA E2010-01A\#1990/5\#10*.

Pierre Graber's speech at the meeting of the Foreign Policy Committee of the Council of States on 8 September 1977, "Tour d'horizon", no date, pp. 2O-21, SFA E1050.12\#1995/512\#11*. Note from Jean Cuendet, head of the Political Secretariat of the FPD, to the head of the FPD, "Corne de l'Afrique: le ton monte à Mogadiscio", 14.11.1977, SFA E2010-01A\#1990/5\#201*. PR no 21 by Fritz Bohnert, "Aethiopien vor dem Verlust der Hälfte seines Gebietes, gute Dienste der OAU”, 08.08.1977, SFA E2300-01\#1988/91\#100*; letter from Bohnert to the DIO, "Aethiopien: Hilfsgesuche", 17.10.1977, SFA E2001E-o1\#1991/17_Bd. 759, B.55.4O.

16 Telegram no 68 from Hansjakob Kaufmann, deputy chief of the DPA's African, Asian, Middle Eastern and Latin American Division, to the Swiss embassy in Kenya, 20.04.1977, SFA E2001E-o1\#1991/17_Bd. 1096, B.15.21; note from Alfred Glesti, AD, to the DPA, "Somalie", 20.05.1977, SFA E2004B\#199o/219\#381*; letter from Hans Miesch, Swiss ambassador 
tion for the protection of Swiss citizens are insufficient to explain the Swiss government's change of mind. It was, however, consistent with the principle of the universality of diplomatic relations, an integral part of Switzerland's conception of neutrality since the Second World War. Nevertheless, between 1975 and early 1977, concern about neutrality had not prevented the Swiss government from infringing the principle of universality in the case of Somalia, a state with little political and economic importance for Switzerland whose government was allied to the USSR and had been less than friendly towards the Swiss ambassador. It was the possibility that the war with Ethiopia might motivate Somalia to turn towards the West that spurred Swiss efforts to normalise relations with this state. In late October 1977, the FPD renewed contact with the Somali government, which had been temporarily halted in July. As a result, the Federal Council decided, in February 1978, to nominate the Swiss ambassador to Tanzania to represent Switzerland in Somalia. ${ }^{17}$ The re-establishment of diplomatic relations with Somalia can thus be interpreted as a low-cost and low-risk means of contributing to efforts to wean the Somali government off the USSR and to contain Communism in the Horn of Africa.

During and after the Ogaden War, Ambassador Fritz Bohnert repeatedly underlined that there was no opportunity to offer Switzerland's good offices, as Africans preferred to resolve their own disputes. ${ }^{18}$ Even if the OAU had not claimed the role of mediator, the fact that the Swiss government did not have diplomatic relations with both belligerents through most of the conflict made it an unlikely candidate to play an active role. There was no opportunity to act as an intermediary to the superpowers, either. In a telegram to the State Department in December 1977, the US Chief of Mission in Addis Ababa excluded the possibility of entrusting Bern with the protection of American interests in the case of a rupture between the US and Ethiopia. According to him, not only was the staff of the Swiss embassy in Addis Ababa too small but Bohnert's personality was also unsuited to handling such a task: "present ambassador is frightened for his own safety (having evacuated family) and shows no natu-

in Kenya, to the DPA, "Akkreditierung eines schweizerischen Botschafters in Somalia", 17.05.1977, SFA E2004B\#1990/219\#381*.

17 Letter from Hans Miesch to the AD, "Relations diplomatiques avec la Somalie", 15.09.1977, SFA E2004B\#1990/219\#381*; telegram no 92 from Alfred Glesti to the Swiss embassy in the FRG, 31.10.1977, ibid.; letter from Glesti to Michael Gelzer, Swiss ambassador in the FRG, secret, 14.02.1978, ibid.

18 Telegram no 124 from Fritz Bohnert to the FPD, 30.09.1977, SFA E2001E-o1\#1988/16\#3190*; letter from Bohnert to the DPA, "Aethiopien: Vermittlung und Gute Dienste", confidential, 16.o3.1978, ibid. 
ral rapport with Ethiopians. If ambassador had choice, he would close Swiss embassy entirely."19

While the Swiss government had neither the will nor the opportunity to play a political role during the Ogaden War, the field of humanitarian aid provided possibilities for action, notably through the intermediary of the ICRC. In mid1977, the ICRC launched a relief mission to aid the victims of the conflict in the Ogaden. The Swiss government supported this mission, yet its role was more discreet than in Angola. The two belligerents' different views on the nature of the war-an international armed conflict where international humanitarian law applied (Ethiopia) vs insurgents fighting for self-determination (Somalia)-hampered the ICRC's activities. The PMAC even called the ICRC's neutrality into question, because the Geneva-based organisation accepted the Somali government's refusal to consider itself a party to the conflict. Thus, there was a risk that Switzerland's neutrality might suffer due to its association with the ICRC. ${ }^{20}$

In early August 1977, a few weeks after the outbreak of the Ogaden War, the ICRC sent emergency aid to the Horn of Africa. The organisation made an appeal to the conflicting parties as well as the OAU, calling for international humanitarian law in armed conflicts to be respected. The DPA approved of the ICRC's activities. Its deputy director Jürg Iselin sent diplomatic reports from the Swiss embassies in Ethiopia and the US to his former colleague as Ambassador to Kenya, Richard Pestalozzi, who had joined the ICRC in $1976 .{ }^{21}$ The ICRC also sent delegates to Addis Ababa and Mogadishu in order to offer its services. The Ethiopian PMAC consented to let the ICRC visit prisoners of war and organise relief for civilians. The Somali government, however, refused to be considered a party to an international conflict and declined to discuss the application of the Geneva Conventions. Nevertheless, it authorised the ICRC to collaborate with the Somali Red Crescent Society to aid refugees. The ICRC also managed to establish contacts with the WSLF fighting in the Ogaden. This gave rise to considerable diplomatic tension between the ICRC and the Derg

19 Telegram by Richard Matheron, Chief of Mission of the US embassy in Ethiopia, to the Secretary of State, 23.12.1977, NARA, RG 59, AAD, CFPF, Electronic Telegrams 1977, 1977 ADDISo70o6.

20 The analysis of Switzerland's humanitarian role during the Ogaden War is subject to a double bias. As the ICRC archives have not yet released any documents dated after 1975, the study relies on the organisation's published annual reports and SFA documents. In addition, the information in the latter is decidedly one-sided, as the FPD had no direct source of intelligence in Somalia.

21

Letter from Jürg Andreas Iselin, deputy chief of DPA and chief of its African, Asian, Middle Eastern and Latin American Division, to Richard Pestalozzi, ICRC, 04.08.1977, SFA E2001E-o1\#1988/16\#319o*. 
and hampered the former's mission for several months. In its official appeal for donations to its relief effort on 8 September, the ICRC mentioned having been in contact with the WSLF and did not name the Somali government as aggressor. Ethiopian officials and the Soviet ambassador in Addis Ababa strongly criticised this. ${ }^{22}$

While the ICRC attempted to resolve its difficulties with the Derg, the Swiss authorities had to decide on whether to participate in a UNDP project to provide trucks for the Ethiopian government, mainly to be used for emergency aid in famine areas and agricultural projects. Ambassador Bohnert and the STC agreed that the risk that these trucks might be repurposed for military use was too great. This would have undermined the credibility of Switzerland's policy of neutrality if not balanced with aid to the other warring party. Therefore, it was decided to channel Swiss aid through the ICRC. ${ }^{23}$ The decision not to contribute to the UNDP project was judicious. After the end of the Ogaden War, it transpired that the Ethiopian authorities had frequently used vehicles donated for humanitarian purposes for military ends. ${ }^{24}$

In January 1978, the ICRC achieved a breakthrough. After talks with an ICRC representative, the PMAC authorised the resumption of aid distributions that had stalled for months. This was to be done "jointly and in consultation with the Ethiopian Red Cross Society."25 The limited cooperation from the Ethiopian and Somali governments left the ICRC unable to fully develop its

22 Letter from Fritz Bohnert to the DIO and the DPA, "IKRK-Aktion in Aethiopien", 03.10.1977, SFA E2001E-o1\#1988/16\#319o*. See also Jean-Pierre Hocké, Director of the ICRC's Operations Department, copy of the ICRC's appeal to main donors on 8 September 1977, 09.09.1977, "International Committee of the Red Cross Appeal for Victims of Ogaden Conflict", attached to the letter from Fritz Bohnert to the DPA, "Das IKRK in Aethiopien, August 1977-Juli 1978", 17.07.1978, SFA E2003A\#1990/3\#679*; ICRC, Annual Report 1977, Geneva: ICRC, 1978, pp. 13-14.

23 Letter from Fritz Bohnert to the DIO, "Aethiopien: Hilfsgesuche", 17.10.1977, SFA E20o1E-o1\#1991/17_Bd. 759, B.55.40; letter from Bohnert to the sTC, "Hilfe für Aethiopien: Aufruf für Nottransport-Flotte von 125 Lastwagen”, 12.12.1977, SFA E2005A\#1991/16\#520*; letter from Rudolf Dannecker, head of the STC's Eastern Africa Section, to the Swiss embassy in Ethiopia, "Hilfe für Aethiopien: Aufruf für Nottransport-Flotte von 125 Lastwagen”, 13.01.1978, SFA E2005A\#1991/16\#521*.

24 Letter from Fritz Bohnert to the Trade Division, the STC, and the DPA, "Wirtschaftsbeziehungen mit und Hilfe an Aethiopien. Besuch Cheysson EG. Besprechung mit Planungschef und MFA“, 12.06.1978, p. 6, SFA E2005A\#1991/16\#521*.

25 Letter from Teferra Wonde, Ethiopian Minister of Health, to Eddi P. Leemann, head of the ICRC mission in Ethiopia, 06.02.1978, attached to the letter from Fritz Bohnert to the DPA, "Das IKRK in Aethiopien, August 1977-Juli 1978", 17.07.1978, SFA E2003A\#199o/3\#679"; see also the letter from Bohnert to the STC, "IKRK: Mission Prof. Fleiner in Addis Abeba", 30.01.1978, SFA E2OO1E-o1\#1988/16\#319o*. 
activities. Its delegates in the two states focused mainly on the distribution of relief goods to refugees. For this, the organisation received donations in cash and kind amounting to CHF 4.1 million by the end of the war in late March 1978. After the end of hostilities, the ICRC supported medical projects in both Ethiopia and Somalia and continued the distribution of relief goods for some months, until UN specialised agencies took over. ${ }^{26}$ The Swiss government's exact contribution to the ICRC relief mission in the Ogaden is not known. In 1977, its total humanitarian aid to Ethiopia and Somalia, distributed by different national and international charities, amounted to CHF 2 million and CHF 0.5 million, respectively, which was $2.6 \%$ and $0.6 \%$ of Switzerland's overall budget for humanitarian aid. The contributions were lower in the following year, amounting to CHF 315,000 (Ethiopia) and CHF 370,00o (Somalia) up to October $1978 .{ }^{27}$ In Ethiopia, a part of this contribution probably went to other conflict zones, notably Eritrea.

In a long letter to the FPD four months after the end of the Ogaden War, Ambassador Fritz Bohnert strongly criticised the ICRC's role during the conflict. His list of the organisation's blunders was long: insufficient examination of the wording of the international appeal for aid; bad handling of the Ethiopian complaints; and a lack of insistence on respect of the Geneva Conventions. The biggest problem was the ICRC's collaboration with the Ethiopian Red Cross, which was, according to Bohnert, in the full control of the Derg; since the two organisations shared offices in Addis Ababa, Bohnert claimed that the ICRC delegates' work was controlled by the Ethiopian organisation, which had access to ICRC records. Furthermore, the delegation from Geneva received few travel permits and was thus unable to control the distribution of relief funds. For the ambassador, the ICRC's dependence on a body controlled by a totalitarian government threatened the credibility of the Geneva organisation. This was even more galling as "any activity of the ICRC is seen by the relevant parties here as 'Swiss' and as an expression of our neutrality." 28

26 Telegram from [?] Santschy, ICRC, to delegate [?] Jäckli in Ethiopia, 31.03.1978, attached to the letter from Fritz Bohnert to the DPA, "Das IKRK in Aethiopien, August 1977-Juli 1978", 17.07.1978, SFA E2003A\#199o/3\#679*; ICRC, Annual Report 1978, Geneva: ICRC, 1979, pp. 18-19. Letterfrom ArthurBill, theFederal Council's Delegate for Disaster Relief Abroad, to theSwiss embassy in Ethiopia, "Ethiopie: demande d'aide", o2.11.1977, SFA E2005A\#1991/16\#520*; letter from Alfred Rüegg, DPA, to the Swiss Permanent Mission in Geneva, "Athiopischschweizerische Freundschaftsgesellschaft", o8.02.1979, SFA E2001E-o1\#1991/17_Bd. 759, B.38.21.Eth.1.; telegram no 129 from Hansjakob Kaufmann to the Swiss embassy in Tanzania, 09.10.1978, SFA E2001E-o1\#1991/17_Bd. 1096, B.15.21; Swiss Federal Council, Bericht des Bundesrates über seine Geschäftsführung im Jahre 1977, 06.03.1978, p. 29. 
Nevertheless, Switzerland's role as host country of the ICRC, one of Ethiopia's main potential future aid donors, was probably behind the dubious honour conferred on Bohnert of being the only neutral and Western European participant in a propaganda visit to the Ogaden organised by the Ethiopian foreign ministry in April 1978. The visit to the war zone had two main goals: first, to convince foreign observers of Somali brutality in order to counter allegations that the Ethiopian troops were committing genocide against the Somali population of the Ogaden; second, to strengthen Ethiopian demands for international humanitarian aid in order to repair the war damages. It was arranged for about thirty selected representatives of international organisations and diplomats, mainly from African and Third World states, but also Eastern European countries. As the Western press was highly critical of Ethiopia, only the Swiss and the Dutch ambassadors were invited. The invitation to the latter was subsequently withdrawn, however, as he did not immediately confirm. Although the Swedish government had just granted aid to Ethiopia amounting to CHF 70 million, its ambassador was not welcome on the tour. The propaganda visit did not have the desired impact on the Swiss government. It confirmed Bohnert's conviction in the Ethiopian regime's brutality and failed to stimulate substantial Swiss humanitarian assistance. ${ }^{29}$

After the end of hostilities in the Ogaden, Switzerland's foreign policy in the Horn of Africa remained low-key. Swiss economic interests in Ethiopia and Somalia were negligible and neither government was deemed politically stable or reliable enough to launch long-term development cooperation projects. ${ }^{30}$ Nevertheless, the Swiss government continued to grant limited humanitarian aid. According to Fritz Bohnert, this would help maintain a minimal Swiss political presence in Ethiopia, which he considered advisable in order to react to possible export opportunities. ${ }^{31}$

29 Fritz Bohnert, report, "Besuch im Ogaden in einer diplomatischen fact-finding mission, 5.-6- April 1978”, 10.04.1978, p. 1, SFA E2OO1E-01\#1988/16\#319o*. See also telegram by Richard Matheron to the Secretary of State, 11.04.1978, NARA, RG 59, AAD, CFPF, Electronic Telegrams 1978, 1978ADDISo1659.

30 See the letter from Rolf Wilhelm, Vice-Director of the STC, to the Swiss embassy in Ethiopia, "Aethiopien Finanzhilfe", 24.01.1979, SFA E2O25A\#1991/168\#652*; No author (STC), memorandum, "deux possibilités", 07.03.1979, and the attached memorandum by CA [?], 22.01.1979, SFA E2O25A\#1991/168\#1648*.

$31 \quad$ Fritz Bohnert, report, "Besuch im Ogaden in einer diplomatischen fact-finding mission, 5-6- April 1978", 10.04.1978, p. 1, SFA E2001E-o1\#1988/16\#319o*; letter from Bohnert to the Trade Division, the STC, and the DPA, "Wirtschaftsbeziehungen mit und Hilfe an Aethiopien. Besuch Cheysson EG. Besprechung mit Planungschef und MFA", 12.06.1978, SFA E2005A\#1991/16\# $521^{*}$. The sums indicated in US\$ have been converted to CHF using the exchange rates for 1976 and 1978 indicated in Officer, "Exchange Rates Between the United States Dollar and Forty-one Currencies". 


\section{"Sources of Infection": Contributions to the Containment of Soviet Power in Sub-Saharan Africa}

For Swiss foreign policymakers, the Ogaden War mattered mainly because of its implications for global East-West relations. Ever since the arrival of Cuban troops on Angolan soil in November 1975, growing Soviet influence in Africa had been a source of worry. A number of crises in 1977 and 1978 heightened this sense of a Soviet menace on the continent. After the first invasion of the Shaba province in Zaire by the Angola-based Katangese gendarmes in early 1977, the large-scale Soviet-Cuban intervention during the Ogaden War, which was swiftly followed by the second Shaba crisis in May 1978, was seen as a further, huge advance in Soviet plans to dominate Africa. In mid-March 1977, as tensions in the Horn of Africa increased and the Katangese gendarmes invaded the Shaba province, the head of the Political Secretariat, Jean Cuendet, addressed a note on the "African crisis" to Federal Councillor Pierre Graber. This crisis consisted in a growing number of armed conflicts fuelled by the Soviet Union, which might spread out from the four main "sources of infection": Southern Africa, the Horn, Shaba, and Western Sahara. ${ }^{32}$ Dismissing the strategic benefits of the UssR's presence in Angola, Mozambique, and Somalia, the author struggled to understand the aims of Moscow's strategy on the continent. Its policy seemed, to him, motivated by a vague desire to "create trouble for the West" and to get retribution for setbacks that the UssR had suffered elsewhere on the globe. Washington's role in Africa did not fill Cuendet with optimism. He saw no fundamental difference in the arrival of Jimmy Carter in the White House: "The United States still do not have an Africa policy. They are just more receptive to the Africans' complaints". ${ }^{33}$

Pierre Graber's May 1977 tour d'horizon speech to the parliamentary Foreign Policy Committees presented the Shaba crisis and the UssR's growing influence in Ethiopia as a clear escalation in the new era of great power competition for Africa, which had started after the Cuban invasion in Angola. As the US seemed unable to counter these advances and the OAU appeared completely paralysed, the politically and economically weak African continent appeared to be at the USSR's mercy. The French government's willingness to step into the breach was seen as a rare ray of hope. Graber seems to have welcomed the French airlift of Moroccan troops to Zaire, which ended the first invasion of Shaba. According to him, this dispelled the danger of Zaire, and other moderate African states,

\footnotetext{
32 Note from Jean Cuendet to Pierre Graber, "La crise africaine", 21.03.1977, p. 1, SFA E2010ol\#199o/5\#197*.

33 Ibid., p. 3.
} 
falling to the Soviet Union. ${ }^{34}$ This image of passive African governments and a powerless OAU contrasts markedly with the importance that FPD leaders had ascribed to these actors when it came to Switzerland's relations with the white minority regimes in Southern Africa, most importantly concerning Swiss recognition of the PRA. While African states had the means to cause embarrassment for Switzerland on the matters of image and economic interests on the continent, they were not judged powerful enough to significantly influence the East-West struggle-or even to resolve their own problems. The tour d'horizon also provided an explanation of Soviet aims in Africa: "Unfortunately, one has to fear that the first objective of this policy currently consists in harming the West and cutting it off from its economic positions in Africa." ${ }^{35}$ Graber argued that, according to the Kremlin, Western imperialism relied on the neocolonial exploitation of this continent. He therefore concluded that the USSR intended to separate its enemies from the roots of their power. Although this perceived attack on Western economic interests extended to Switzerland, Swiss foreign policymakers did not deem it urgent enough to warrant action. This would change after the Soviet-Cuban intervention in the Ogaden.

FPD leaders initially saw the Ogaden War between two Soviet allies as a setback for the USSR. In late 1977, rather than focusing on the Horn, their attention was on Southern Africa - a region where their interests were far more substantial. In addition, US, British, and African pressure would shortly result in the introduction of a Swiss regulation to prohibit trade and financial transactions with Rhodesia. ${ }^{36}$ The Soviet-Cuban intervention in support of the PMAC as 1977 turned to 1978, however, caused much consternation in Bern. It reinforced worries about the US government's seeming inability to counter the USSR's advances in Africa and raised the fear that other African actors might attempt to achieve their political goals by calling on Soviet military power. ${ }^{37}$

34 Pierre Graber's speech at the meetings of the Foreign Policy Committees of the National Council on 24 May 1977 and of the Council of States on 25 May 1977, "Tour d'horizon", no date, pp. 24-32, SFA E1050.12\#1995/512\#11*.

35 Ibid., p. 29.

36 See Opening speech held by Pierre Graber on 1 September 1977, "exposé liminaire", pp. 6-11, appendix no 5 of the minutes of the Annual Conference of Swiss Ambassadors 1977, SFA E2010-o1A\#1990/5\#10*. On the Carter administration's efforts to end white minority rule in Rhodesia, see Andrew J. Deroche, "Standing Firm for Principles: Jimmy Carter and Zimbabwe", Diplomatic History 23:4 (1999), pp. 657-685; Mitchell, Jimmy Carter in Africa; Sue Onslow, "South Africa and the Owen/Vance Plan of 1977", South African Historical Journal 51 (2004), pp. 130-158.

37 See notably PR no 7 by Fritz Bohnert, "Aethiopien: Erfolg des neuen sowjetischen Interventionsmodells und Folgen für Afrika", 13.03.1978, p. 3, SFA E230o-o1\#1988/91\#196*. 
The new head of the FPD dedicated most of his May 1978 tour d'horizon speech to the Horn of Africa. In early 1978, the newly elected Federal Councillor Pierre Aubert had taken over from his fellow Social-Democrat, Pierre Graber, who stepped down after having led the department for eight years. Aubert continued and sought to intensify the active foreign policy of his predecessors. With a stronger emphasis on human rights and development cooperation with the Third World, he aimed to render Switzerland's foreign policy more dynamic and move beyond a position beholden to a conception of neutrality based on non-interference. ${ }^{38}$ In his speech to the foreign policy specialists, Aubert underlined that Soviet policy in Africa "is at odds with the spirit, at least, of Détente" and caused considerable embarrassment to the US. Since in the wake of the Vietnam War, it would be unthinkable to commit American troops, the Carter administration was compelled to adopt a policy of abstention. This damaged its credibility in Africa. At the same time, the Federal Councillor was convinced that Africa had no intrinsic importance for the USSR: "In the eyes of the Soviet Union, Africa is mainly a source of raw materials for the West."39 At the meeting of the Council of States' Foreign Policy Committee on 19 May 1978, the day that the first French troops landed in the Zairean city of Kolwezi to liberate European expatriates taken hostage during the second invasion of Shaba, the conservative committee members worried that the US underestimated the Soviet danger in Africa. While the FPD leaders present attempted to restore the committee's confidence in the Western superpower, Jean Cuendet voiced the department's main fear; that "certain African states, whose mining and agricultural production is crucial for Europe and the United States, might fall into the hands of regimes that are hostile to them". 40 The potential danger to their economic interests in Africa, which seemed more critical after the Ogaden War, spurred FPD leaders into action.

In the middle of 1978, FPD leaders frequently raised the issue of the Soviet penetration of Africa in bilateral meetings with Western and international

38 On Federal Councillor Pierre Aubert's conception of Swiss foreign policy and the conflicts this generated within the FPD, most prominently with Secretary-General Albert Weitnauer, adherent of a foreign policy strictly based on a selective understanding of neutrality, see Fischer, Die Grenzen der Neutralität, pp. 268-285. Fischer argues that their different conceptions of Switzerland's international role played a major part in the conflict that led to Weitnauer's early retirement in early 1980. States on 19 May 1978, "Tour d'horizon", no date, p. 28, SFA E1050.12\#1995/512\#12*.

40 Statement by Jean Cuendet, minutes of the meeting of the Council of States' Foreign Policy Committee on 19 May 1978, no date, p. 12, SFA E1050.12\#1995/512\#12*. 
leaders and diplomats. ${ }^{41}$ During a lunch meeting with the US ambassador in Bern in late June 1978, Pierre Aubert applauded Jimmy Carter's speech of 7 June at the US Naval Academy in Annapolis. In this speech, the President had criticised the Soviet intervention by proxy in the Ethiopian conflict and called on the USSR to choose between confrontation or cooperation with the US. Aubert expressed Switzerland's and Western Europe's relief at the firm American response to Soviet moves in Africa. In a telegram to the Department of State, Ambassador Marvin Leon Warner pointed out that Aubert had repeatedly insisted on the "importance of US strength for independence of weaker nations" - the Federal Councillor even referred to the US as "big St Bernard".42 Whether or not Aubert included Switzerland in the ranks of states needful of US protection, his reference to the Catholic saint - and founder of travel shelters in the Alps - can be read as an appeal to the US to assume its leadership role in a harsh international climate. FPD leaders wished for a more forceful US role on the African continent. Although they did not go as far as to claim that Détente was "buried in the sands of the Ogaden", as US National Security Advisor Zbigniew Brzezinski did in his memoirs, ${ }^{43}$ they were of the opinion that the events in the Horn of Africa undermined Détente—and that the USSR was responsible for this.

After the Ogaden War, Swiss foreign policymakers started to think about what the West-and Switzerland-might do to prevent further opportunities for Soviet interventions. The UssR's growing influence in Africa prompted intelligence bodies within the Swiss federal administration to embark on a detailed analysis of the continent's role in the Cold War, Western states' possibilities to influence the situation to their advantage, and Switzerland's role in this context. In a widely circulated report, Erwin Hofer of the Political Secretariat insisted in September 1978 that Africans had no deep-rooted attachment to socialism. They only turned to the USSR if they were unable to find other

See notably Sylvie Michl-Keller, Political Secretariat, speaking notes, "Visite à Rome 10/11 juillet. Corne de l'Afrique”, 29.o6.1978, SFA E2O1O-o1A\#19o/5\#2O2*; KR, Michl-Keller, Hansjörg Renk, Political Secretariat, "Visite Waldheim 6/7 juillet. Afrique", o5.07.1978, SFA E2O1O-O1A\#19o/5\#197*.

Telegram by Marvin Leon Warner, US ambassador in Switzerland, to the Secretary of State, 29.06.1978, NARA, RG 59, AAD, CFPF, Electronic Telegrams 1978, 1978BERNo3125; see also US President Jimmy Carter's address at the commencement exercises at the United States Naval Academy on 7 June 1978, in Gerhard Peters, John T. Woolley, The American Presidency Project, https://www.presidency.ucsb.edu/documents/address-thecommencement-exercises-the-united-states-naval-academy (13 January 2021). A detailed analysis of this speech can be found in Mitchell, Jimmy Carter in Africa, pp. 440-442.

Cited in Westad, The Global Cold War, p. 282. 
allies to attain their goals. Consequently, once Soviet and African interests were no longer aligned, new alliances would become possible. As things stood, Western and African governments were on opposite sides with regard to the latter's two major international goals: the decolonisation of Southern Africa and the redistribution of economic wealth to the global South. Nevertheless, the author concluded that the African continent remained mostly tied to the West. This was explained, in a simplistic and patronising way, by the Africans' attachment to Western values and religion and the fact that the continent's economic development depended mainly on Western states. ${ }^{44}$ Although this report did ascribe African actors a certain room for manoeuvre in their choice of alliances, Hofer still portrayed them as largely passive and easily influenced by one side or the other.

This view was also taken up by the Security Conference, a coordination unit within the FMD responsible for the exchange of strategic and security policy information among the federal administration's different departments. Its head decided in October 1978 to dedicate one of its monthly meetings to Africa. ${ }^{45}$ A report of more than forty pages, written by Erwin Hofer, which summarised contributions by the FPD, the Trade Division, and the FMD, served as a basis for the discussion, held in early December. As the meeting's minutes have not been declassified, this report provides fascinating insights into Swiss policymakers' perception of the threat to Swiss interests and their strategies to counter them. With regard to Africa's role in global East-West relations, it argued that, as Western "intellectual, cultural, and economic resources" were superior and the USSR and Cuba had only been able to gain a foothold in Africa during conflicts, Western states needed to prevent and limit local and international crises. Also, they should deepen their ties with African governments. ${ }^{46}$

44 Erwin Hofer, Political Secretariat, memorandum, "Afrika als eigenständiger Faktor der internationalen Politik. Eine Analyse bisheriger Entwicklungen und möglicher Zukunftsaussichten", confidential, 28.09.1978, SFA E2010-O1A\#19o/5\#197*.

45 Letter from Richard Ochsner, FMD, chairman of the Conference, to Jean Cuendet and Fritz Rothenbühler, Trade Division, "Westlicher Einfluss und spezifisch schweizerische Interessen in Afrika", 19.10.1978, attached to the note from Cuendet to the STC, DPA, Financial and Economic Service of the FPD, Service for Consular Protection, "Lagekonferenz: Westlicher Einfluss und schweizerische Interessen in Afrika”, 25.10.1978, confidential, SFA E2005A\#1991/16\#543*.

46 Erwin Hofer, report, "Die Möglichkeiten der westlichen Präsenz und die schweizerischen Interessen in Afrika”, 22.12.1978, pp. 3-4, citation p. 4, attached to the letter from Richard Ochsner to the people invited to the Conference, and from Jean Cuendet to all FPD section heads, the leaders of the Trade Division, and selected Swiss embassies, "Die Möglichkeiten der westlichen Präsenz und die schweizerischen Interessen in Afrika", 22.12.1978, SFA E2O10-O1A\#19o/5\#197*. 
Despite Switzerland's policy of neutrality, the country was considered part of the West. Consequently, Swiss foreign policymakers felt the need to participate in efforts to contain Soviet advances.

According to the report, Switzerland had not exhausted the limited means of a small state to help retain the allegiance of African states to the West. In particular, it could increase economic and development cooperation and strengthen its political, cultural, and scientific dialogue with Africa. ${ }^{47}$ With regard to bilateral relations, the biggest potential threat to Swiss interests on the continent was identified as Southern Africa. On the one hand, armed conflicts in this region might cut trade and financial relations, destroy investments, and endanger Swiss citizens in South Africa and Rhodesia. On the other hand, a Swiss refusal to apply sanctions against South Africa might endanger its economic interests in other African states. ${ }^{48}$ The few actions proposed to protect Swiss interests reveal a certain helplessness, as Switzerland's political, economic, and financial relations with South Africa again limited its government's policy options. While a credible policy of neutrality was judged useful, the author had to admit that the Swiss government's verbal condemnation of Apartheid alongside Swiss economic and financial circles' support for South Africa did raise "occasional doubts" about Switzerland's neutrality in Africa. While economic measures were considered to be of limited use, active participation in the North-South dialogue might indirectly protect Swiss interests. ${ }^{49}$ The report had no new strategies to offer, and only suggested reinforcing policy instruments that were already in use: economic and development aid as well as political dialogue with African leaders. Pierre Aubert's January 1979 trip to Western Africa was an occasion to put these conclusions into practice.

\section{A Federal Councillor's Africa Trip, or the Limits of a More Active Foreign Policy}

The initiative for Federal Councillor Pierre Aubert's 1979 Africa trip went back to mid-1978. After the Soviet-Cuban intervention in the Ogaden, FPD leaders started to think about how Switzerland might help prevent further opportunities for Soviet intervention in Africa. Although it is not quite clear when and in what context the idea originated, by mid-July 1978 Aubert had decided to go on a goodwill mission to Western Africa. He seems to have insisted on

\footnotetext{
47 Ibid., pp. 8-9.

48 Ibid., pp. 20-22.

49 Ibid., pp. 23-25, citation p. 23.
} 
this trip even though his staff considered that his travel programme in 1979 was already overloaded. The Federal Councillor's original goals were to foster goodwill towards Switzerland, exchange ideas on key issues of world politics, and resolve bilateral issues. ${ }^{50}$ Aubert's two-week trip to Nigeria, Senegal, the Ivory Coast, Cameroon, and Burkina Faso in January 1979 has been described as extraordinary and novel, both for its geographical focus and scope. ${ }^{51}$ It was uncommon for members of Switzerland's collective government go on a state visit. Aubert's insistence on Africa testifies to the importance he ascribed to the continent in the East-West confrontation and to the perceived need to reinforce Switzerland's bilateral relations with African states. Yet, the domestic controversy caused by his trip illustrates the limits on a more active Swiss foreign policy in the late 1970s.

For the Federal Councillor's visit, the FPD chose African states that were "close to our own", meaning they were states with which Switzerland had important economic links or particularly cordial political relations, or where it supported development cooperation projects. ${ }^{52}$ This limited the political risks of the trip. As "Africa's leading nation", Nigeria was selected for its political importance. ${ }^{53}$ It had chaired the OAU's Good Offices Committee during the Ogaden War. The fact that Nigeria had been, in 1977, Switzerland's main trade partner on the African continent, surpassing even South Africa, certainly did not hurt, either. ${ }^{54}$ Switzerland's political links with the Ivory Coast and Senegal were qualified as very cordial, while economic relations were characterised as

50 Note from Jürg Andreas Iselin to Marcel Heimo, Delegate for Technical Cooperation, and Jimmy Martin, head of the AD, 14.07.1978, SFA E2Oo1E-o1\#1988/16\#499*; Rudolf Emil Stauch, DPA, memorandum of conversation "Westafrikareise des Departementchefs", ol.09.1978, ibid.

Urban Kaufmann, Auslandreisen der Schweizer Bundesräte 1919-1993. Die Gewöhnung an das Aussergewöhnliche, unpublished Master thesis, University of Fribourg, 1996, pp. 83-84. No author, FPD, report, "Premier bilan du voyage du Chef du Département politique au Nigéria, au Cameroun, en Haute-Volta, en Côte d'Ivoire et au Sénégal (14 au 28 janvier 1979)", 30.01.1979, pp. 1-2, citation p. 2, SFA E2001E-o1\#1991/17_Bd. 106, B.15.22.3.

53 Rudolf Emil Stauch, memorandum of conversation "Westafrikareise des Departementchefs", 01.09.1978, p. 2, SFA E2001E-o1\#1988/16\#499*. See also the note from Jürg Andreas Iselin to Marcel Heimo and Jimmy Martin, 14.07.1978, ibid.

54 In 1977, Swiss imports from Nigeria amounted to CHF 193.1 million, 19.7\% of all Swiss imports from Africa, and $0.4 \%$ of total Swiss imports, followed by South Africa (CHF 127 million) and Algeria (CHF 125 million). Swiss exports to Nigeria amounted to CHF 391 million (17.4\% of Swiss exports to Africa and 0.9 worldwide), compared to 350 million (South Africa) and 336 million (Algeria): Erwin Hofer, Political Secretariat, report, "Die Möglichkeiten der westlichen Präsenz und die schweizerischen Interessen in Afrika", 22.12.1978, p. 36, attached to the letter from Richard Ochsner to the people invited to the Conference, and from Jean Cuendet to all FPD section heads, the leaders of the Trade 
substantial. Cameroon and Burkina Faso were chosen as examples of "typical poor developing countr[ies]".55

Although bilateral economic interests played a role in the selection of states to visit, economic motives were not a priority for Aubert's trip. They seem to have been added to the agenda to 'sugar the pill' and make the trip palatable to a Swiss public highly critical of 'travelling diplomacy'. The Federal Councillor embarked on his tour to foster goodwill in Africa towards Switzerland and to discuss the continent's role as an arena of the global Cold War with African leaders. According to the speaking notes prepared for Aubert in December 1978 , he wished to encourage the peaceful settlement of local and regional conflicts by African actors and warn his interlocutors that appeals to a superpower presented a risk to Détente. The notes were not only paternalistic but also decidedly one-sided. Although the French and Belgian interventions in Shaba were briefly mentioned, Aubert's hint at the neocolonial designs of external powers and his wish that African states might preserve the biggest possible marge de manoeuvre in international affairs were clearly directed against the USSR. ${ }^{56}$ Aubert and his department applied different standards to foreign interventions on the African continent. Only those seemingly supported by the USSR were considered harmful and dangerous to regional and global stability. The mention of France, rather than the US, hints that Bern's concerns about growing Soviet influence in Africa and the seeming inability of the US to counter this were assuaged to some extent by the more active French role on the continent. FPD leaders seem to have approved of the French interventions in Zaire's Shaba province, as a sign that the French government was willing to assume responsibility for the defence of Western interests and to check what they considered aggressive Soviet behaviour.

In Switzerland, the planned Africa trip was controversial. First, Swiss business circles worried that the trip might draw negative attention to Switzerland's economic and financial relations with South Africa. This was particularly true in Nigeria, whose government was known for its outspoken position on white minority rule. Therefore, in December 1978, high-ranking representatives of Switzerland's leading export firms (Sulzer, ввс, Ciba-Geigy, and Nestlé), including prominent members of the SSAA, intervened twice in person to

Division, and selected Swiss embassies, "Die Möglichkeiten der westlichen Präsenz und die schweizerischen Interessen in Afrika”, 22.12.1978, SFA E2010-o1A\#19o/5\#197*. E2Oo1E-ol\#1988/16\#499*.

56 CJ, Sylvie Michl-Keller, speaking notes, "Voyage en Afrique occidentale du Chef du Département (14 au 30 janvier 1979). L'Afrique comme champ de confrontation des grandes puissances (URSS, USA, Chine)", 11.12.1978, SFA E2001E-o1\#1988/16\#499*. 
insist on maximum discretion regarding Apartheid. ${ }^{57}$ Second, the Trade Division and Federal Councillor Fritz Honegger of the FDEA insisted that greater priority should be attached to bilateral economic issues. ${ }^{58}$ Finally, large parts of the Swiss public and the press were very sceptical of the usefulness of 'travelling diplomacy', especially if they could not perceive a clear political or economic benefit that justified a state visit. Thanks to a misleading translation of an interview Aubert had granted to a Nigerian magazine in November 1978, some Swiss journals criticised the Federal Councillor for choosing relations with black-ruled Africa over those with South Africa. This was seen as contrary to Switzerland's policy of neutrality. ${ }^{59}$

During Aubert's trip to Western Africa, the controversy in Switzerland escalated. It focused on a short passage in a four-page communiqué published on 17 January 1979 on the occasion of the visit to Lagos. Aubert and the Nigerian Foreign Minister "condemned the violation of human rights all over the world and apartheid in particular." 60 Considered by many Swiss observers to be incompatible with Swiss neutrality because it singled out human rights abuses in South Africa, the Lagos statement was another bone of contention, alongside the ambition and cost of the programme, the information policy surrounding the visit, and Aubert's impulsive style of leadership. The more than 200

57 Georg Sulzer was the president of the SSAA, while Erwin Bielinski of ввС represented his firm in its committee. Ciba-Geigy and Nestlé also participated in this association: Gygax, La Suisse-South African Association, pp. 245-246, 291-292. Hansjakob Kaufmann, memorandum, 05.12.1978, SFA E2Oo1E-o1\#1991/17_Bd. 107, B.15.22.3; NF, memorandum, "Note sur l'entretien à Berne, chez le Chef du Département, avec MM. Georg sulze R, Sulzer Frères Sa, Erwin bielinski, bBC, WAldvogel, Ciba-Geigy, daniel, Nestlé, le 19 décembre 1978", 29.12.1978, p. 1, SFA E2001E-o1\#1991/17_Bd. 107, B.15.22.3.

58 Decree of the Federal Council, "Westafrika Reise des Departementschefs", 13.o9.1978, SFA E2001E-ol\#1988/16\#499*; note from John Clerc, FPD, to Pierre Aubert, "Séance du Conseil federal du 10.1.1979. Voyage en Afrique occidentale”, o9.01.1979, SFA E2001E-o1\#1991/17_Bd. 107, B.15.22.3; Page, Le Nigeria et la Suisse, pp. 295-296.

59 On the subject of Swiss criticism of 'travelling diplomacy', see Kaufmann, Auslandreisen der Schweizer Bundesräte. Aubert's Africa trip is discussed on pp. $83^{-87}$, and, with a focus on the Nigerian stage, by Page, Le Nigeria et la Suisse, pp. 294-300.

6o Emphasis in original. Major-General H.E.O. Adefope, Nigerian Commissioner for External Affairs, and Pierre Aubert, "Joint communiqué on the official visit to Nigeria of the Honourable Swiss Foreign Minister, His Excellency, Mr. Pierre Aubert”, 17.01.1979, SFA E2001E-01\#1991/17_Bd. 106, B.15.22.3. The wording of this communiqué had been the subject of intense diplomatic exchange before the departure of the delegation: see the note from Hansjörg Renk, head of the FPD's Information and Press Service, "Nigéria. Communiqué commun", 12.01.1979, ibid., and the attached draft statements; No author, FPD, report, "Premier bilan du voyage du Chef du Département politique au Nigéria, au Cameroun, en Haute-Volta, en Côte d'Ivoire et au Sénégal (14 au 28 janvier 1979)", 30.01.1979, p. 5, SFA E2OO1E-o1\#1991/17_Bd. 106, B.15.22.3. 
editorials in Swiss journals that focused on the trip to Western Africa were also an expression of a certain unease about the active Swiss foreign policy propagated by Aubert. ${ }^{61}$

Assessments of Aubert's Western Africa trip varied greatly. Despite, and probably also because of, widespread criticism, the FPD insisted that the voyage had been largely successful. The department's first, internal report after the delegation's return maintained that the talks on economic issues had exceeded expectations. The visit had succeeded in fostering goodwill towards Switzerland and a deeper understanding of Switzerland's neutral status, which had a "not insignificant prophylactic value" for the protection of Swiss economic interests in Southern Africa. FPD leaders were also reassured that their interlocutors seemed well aware of the risk of further Soviet - Cuban interference in African affairs. ${ }^{62}$ Nevertheless, Aubert's Western Africa trip raised more profound questions about public acceptance of a dynamic Swiss foreign policy. On his return, the Federal Councillor had to justify his policy to the members of the parliamentary Foreign Policy Committees and to representatives of the Swiss export industry. The trip even triggered an important foreign policy debate in the Swiss parliament in March $1979 .{ }^{63}$

While domestic reactions to Aubert's visit reveal a deep-seated scepticism of Switzerland's active foreign policy, many external observers welcomed the trip as an expression of the country's willingness to play a more dynamic role in international affairs. In Africa, Aubert's visit generated positive headlines. ${ }^{64}$ The governments of the US, France, and the UK welcomed a more active Swiss foreign policy on the African continent. Even before Aubert's trip, the British

61 Mentioned in Hansjörg Renk, FM, Serge Salvi, DPA, press review, "Reise des Departementsvorstehers nach Westafrika" 14.02.1979, SFA E2001E-01\#1991/17_Bd. 107, B.15.22.3.

62 No author, FPD, report, "Premier bilan du voyage du Chef du Département politique au Nigéria, au Cameroun, en Haute-Volta, en Côte d'Ivoire et au Sénégal (14 au 28 janvier 1979)", 30.01.1979, citation p. 3, SFA E2001E-01\#1991/17_Bd. 106, B.15.22.3; see also the attached appendix no 1 by Jürg Andreas Iselin, "Erörterung politischer Fragen mit den Staatspräsidenten oder Aussenministern Nigerias, Kameruns, Obervoltas, der Elfenbeinküste und Senegals", 30.01.1979, p. 4.

63 See the minutes of the meeting of the National Council's Foreign Policy Committee on 5 February 1979, no date, SFA 1050.12\#1995/511\#23*; minutes of the meeting of the Council of States' Foreign Policy Committee on 6 Febuary 1979, no date, SFA 1050.12\#1995/512\#13*; Amtliches Bulletin der Bundesverfassung 1979, Frühlingssession Nationalrat, 14.03.1979, pp. 203-248; Amtliches Bulletin der Bundesverfassung 1979, Frühlingssession Ständerat, 21.03.1979, pp. 137-154; Rudolf Emil Stauch, memorandum of conversation, 19.03.1979, E20o1E-o1\#1991/17_Bd. 106, B.15.22.3; Fischer, Die Grenzen der Neutralität, pp. 274-276.

64 See Hansjörg Renk, FM, Serge Salvi, press review, "Reise des Departementsvorstehers nach Westafrika" 14.02.1979, pp. 11-12, SFA E2001E-o1\#1991/17_Bd. 107, B.15.22.3. 
ambassador in Bern was convinced that it would be to the Western world's advantage if Aubert were able to develop a foreign policy more attuned to Third World interests, despite the hesitancy of the Swiss population. ${ }^{65}$ Convinced "that Switzerland, too, could contribute to the 'depolarisation' of Africa", as Alfred Rüegg of the DPA put it in a memorandum in February 1979, the French government encouraged Switzerland's opening up towards African states. ${ }^{66}$ The US embassy in Bern advised the State Department in early February 1979 to facilitate Aubert's first official visit to the US, scheduled for May 1979, as much as possible. It was argued that the head of the FPD was in need of a political success in order to continue his active foreign policy: "If his US visit is not successfful [sic], there will be much 'schadenfreude' in the hearts of Swiss 'isolationists'. This would be detrimental to our own objectives of greater Swiss participation, [in] bilateral cooperation, and in solution of pol[itical]/ mil[itary] problems." ${ }^{67}$

Nevertheless, the novelty of Aubert's January 1979 trip should not distract from the fact that there was little fundamental change in Swiss policy towards Africa. The trip was an opportunity for dialogue and a show of respect. However, much as during the April 1972 OAU visit to Bern, the political gesture concealed the fact that, with regard to specific economic matters, there was no will to change. Following the Soviet—Cuban intervention in the Ogaden War, FPD leaders adopted a slightly more active policy on Africa. Switzerland's role during this conflict was largely passive. As there were few Swiss economic interests and citizens in the Horn of Africa, Bern's view of developments in this region was shaped by broader considerations - mainly the perceived threat of growing Soviet influence that was fuelled by the extensive military intervention. Presuming that the USSR's main objective on the continent was to drive a wedge between Western states and their economic interests in Africa, which potentially endangered Switzerland's own investments on the continent, Swiss foreign policymakers considered ways of participating in efforts to keep African states tied to the West. Concluding that African alliances with the Soviet Union were not founded on deep-rooted ideological convictions and that the

65 Alan K. Rothnie, British ambassador in Switzerland, report, "Swiss Foreign Policy (or Graber Plus)", 01.11.1978, p. 5, TNA FCO 33/3802.

66 Alfred Rüegg, memorandum, "Sowietische [sic] Einflussnahme in Afrika", 16.02.1979, SFA E2001E-o1\#1991/17_Bd. 111, B.15.22.4. See also the French embassy's report on Aubert's African trip: Letter from Claude Lebel, French ambassador in Switzerland, to Jean-François Poncet, French foreign minister, "Des résultats et des incidences du voyage de M. Aubert en Afrique", 07.02.1979, CAD 1929INVA4683.

67 Telegram from [?] Crowley, US embassy in Switzerland, to the Secretary of State, O2.02.1979, NARA, RG 59, AAD, CFPF, Electronic Telegrams 1979, 1979BERNoo658. 
West was a more attractive partner for economic cooperation, they argued that stronger political, economic, and development cooperation relations would reduce Soviet influence in Africa. Although the Swiss authorities realised, in late 1978, that their economic and financial relations with South Africa and Rhodesia represented the biggest threat to their interests on the African continent, they did not envisage taking any steps to limit them.

The controversy generated by Aubert's African visit, and especially by his Lagos statement on Apartheid, shows that even limited steps to strengthen the ties between Switzerland and Africa were a hard sell in Switzerland. The trip, seen as an expression of Aubert's attempts to render Swiss foreign policy more dynamic, revealed great resistance to an active Swiss foreign policy, in both parliament and public opinion. Many politicians, economic leaders, and a significant conservative segment of the Swiss public considered his limited openness to the Third World incompatible with a foreign policy based on neutrality. While influential voices in Switzerland demanded, in early 1979, that the country's economic and financial interests in South Africa be protected, the danger of Soviet influence in Africa was side-lined. When the Ogaden War was not followed by further Soviet-Cuban interventions, fear of a domino effect in Africa abated. This explains why, even though the Swiss government realised that the main risks to Swiss interests on the continent-on an economic, financial, and human level — were either located in Southern Africa or linked to Switzerland's policy in this region, the situation did not appear urgent enough to warrant fundamental change. Swiss foreign policymakers hid behind a rhetoric that insisted on the limited means of a small state to bring about change in Africa. They thereby concealed the fact that, given Switzerland's important economic and financial role in South Africa, its government certainly had some leverage. 


\section{Conclusion to Part 3}

[T] he deployment of Cuban armed forces controlled by Moscow [has] put a damper on American-Soviet Détente. Therefore, 1976 has a good chance of going down as the 'year of Africa' in the history of international politics. Consequently, in recent months, the Directorate of Political Affairs' activities focused [...] on Southern Africa. ${ }^{1}$

As Jürg Andreas Iselin, deputy director of the DPA and head of its African, Asian, Middle Eastern and Latin American Division, told his colleagues at the annual conference of Swiss ambassadors in September 1976, the shock of the Cuban invasion in Angola had focused Bern's attention on Africa. The victory of the Soviet-allied forces during the Angolan and Ogaden Wars increased the Swiss policymakers' loss of confidence in the capacity of the US to protect the interests of the Western bloc and undermined their belief in Détente. They also saw their commercial exchanges and investments on the African continent threatened as a consequence of the intensification of liberation struggles in Southern Africa after the MPLA victory in Angola and by the possibility of further Soviet-Cuban interventions in Africa. As a result, efforts were made within the Swiss federal administration to analyse the situation, take steps to prevent damage to Swiss interests, and consider ways to contribute to the containment of Soviet influence in Africa.

Although Switzerland's foreign policy was shaped more by the East-West conflict after the Angolan War, regional concerns continued to be decisive in its government's position during both the Angolan and Ogaden conflicts. The FPD publicly adopted an impartial attitude. However, the will to improve Switzerland's image and win the respect of African leaders, in order to safeguard economic interests in Southern Africa and on the continent as a whole, was the determining factor for Swiss foreign policy decisions. This is seen most clearly in the recognition of the PRA. Once FPD leaders realised that the MPLA was likely to win the Angolan War and that the OAU was considering recognising the PRA, concern about Switzerland's image in Southern Africa trumped apprehension about the MPLA's ideological orientation or a possibly negative US reaction. The weakened superpower was unable to prevent the almost

1 Emphasis in original. Presentation by Jürg Andreas Iselin, deputy chief of DPA and chief of its African, Asian, Middle Eastern and Latin American Division, held on 3 September 1976, "Die bilateralen Beziehungen der Schweiz zum Südlichen Afrika", appendix no 20 of the minutes of the Annual Conference of Swiss Ambassadors 1976, p. 3, SFA E2010-01A\#199o/5\#9*. 
universal recognition of the PRA in early 1976. In this context, the voices of Swiss business people who demanded recognition in order to create new economic opportunities strengthened a policy that was already set in motion.

While Swiss foreign policymakers did not hold back their criticism of American policy on Africa, they never questioned their own low-key role during the Angolan and Ogaden Wars. Although it is doubtful that the Swiss government could have made a positive contribution to mediation between the warring parties or easing East-West tensions, their pragmatic wait-and-see policy and, particularly, the early recognition of the PRA might be considered opportunistic. To defuse such criticism, Swiss diplomats employed a rhetoric of smallness and insisted on their position as a small European state with limited geopolitical influence. In addition, the ICRC relief missions in Angola and the Ogaden presented the Swiss government with an opportunity to show solidarity with the war's victims in a highly visible and, at the same time, ostensibly non-political way. In Angola, Bern's considerable financial and organisational support for the humanitarian organisation allowed it to benefit from the ICRC's high moral standing, earn the gratitude of all belligerents, and improve the image of Swiss neutrality. In the Ogaden, however, the ICRC's role was controversial. While there is no sign that Bern benefited politically from its association with the ICRC in Ethiopia and Somalia, its image did not suffer from it, either.

The years between 1975 and 1979 saw, both the culmination of the Swiss government's efforts to lead a more active foreign policy on the African continent, and the failure of these attempts. By the mid-197os, most FPD officials were convinced of the need to deepen Switzerland's relations with the Third World and to participate in the North-South dialogue. The victories of the Sovietbacked forces in Angola and the Ogaden added urgency to this. Yet, any real change in Switzerland's foreign policy in sub-Saharan Africa would have necessitated downgrading the country's economic and financial ties with South Africa. Against the background of a strong domestic lobby that prioritised relations with South Africa over those with the rest of the African continent, and a weakened Third World solidarity movement, the FPD's attempts to create a coherent Africa policy did not succeed. 


\section{Conclusion}

"Swiss foreign policy [...] evolves at about the speed of those glaciers for which this country is rightly famous."1 Alan K. Rothnie, British ambassador in Bern, thus opened his November 1978 analysis of Switzerland's foreign policy. Looking at the country's role in sub-Saharan Africa from the late 196os to the late 1970s, it is indeed tempting to conclude that the rise and demise of superpower Détente and the growth and erosion of the Third World's political power had little impact on the foreign policy of this small, Western European, neutral state. In 1967, as in 1979, a selective interpretation of neutrality that prioritised the principle of non-interference in the internal affairs of other states and the separation of political and economic affairs guided the Swiss government's foreign policy decisions on the African continent. There were no dramatic changes or spectacular initiatives - although some Swiss observers did consider Federal Councillor Pierre Aubert's January 1979 Western Africa trip to be a departure from Switzerland's habitual low-key foreign policy. Aubert's visit did not herald a new era of special relations between Switzerland and Africa. It indicated, however, that Switzerland's foreign policy in sub-Saharan Africa had indeed evolved, although it was more a change in form than in content. During the OAU April 1972 visit to Bern, Swiss foreign policymakers had focused on defending their position and deflecting criticism of Switzerland's economic and financial role in Southern Africa. In 1979, though, it was the Swiss Foreign Minister who sought out African leaders. He intended to exchange views on the leaders' role in East-West relations and improve Switzerland's image on the continent. His trip was an expression of a more active and dynamic approach to foreign policy; yet this approach remained restricted to the diplomatic level in Africa.

The two Social Democratic Federal Councillors, Pierre Graber and Pierre Aubert, who led the FPD from 1970 and from 1978, respectively, pursued a more active foreign policy than their predecessors had in the early Cold War. During their term of office, the Swiss government took steps towards joining the UN and participated actively in the CSCE negotiations. When it came to subSaharan Africa, however, this drive, which had already set in under Federal Councillor Willy Spühler (Social Democratic Party) in the late 196os, was frustrated. Faced with an international campaign to end white minority rule in Southern Africa and to guarantee racial equality and human rights, the Swiss

1 Alan K. Rothnie, British ambassador in Switzerland, report, "Swiss Foreign Policy (or Graber Plus)", o1.11.1978, p. 1, TNA FCO 33/3802. 
government adopted a non-committal attitude so as not to endanger Switzerland's close economic and financial links with Apartheid South Africa. After the fall of the Portuguese colonial empire and the Ethiopian Revolution in 1974, the need to improve Switzerland's image and show its support for independent African governments spurred Swiss foreign policymakers to seek cordial relations with these new rulers. However, it was the victories of Soviet-allied parties in the Angolan and Ogaden wars, the resulting renewal of superpower tension, and fears for Switzerland's economic interests in the event of growing Soviet influence in Southern Africa and on the continent as a whole that prompted a reconsideration of Switzerland's Africa policy. Whether this limited drive to take a more active Swiss role on the continent survived the shift of the Cold War's battlegrounds to the Middle East and the fragmentation of the Third World's challenge to the world economic order in the late 1970s, or whether it stalled, as indicated by the controversy over Aubert's Africa trip, merits further research.

From 1967 to 1979, the need to improve Switzerland's image and the credibility and respectability of its neutrality in sub-Saharan Africa was at the core of its government's decision-making on the continent, thanks to the harm done by its economic and financial elites' close relations with the Apartheid regime, the Swiss government's non-participation in the UN sanctions against Rhodesia, and its refusal to take a stand against Portuguese colonialism. During the regime changes and armed conflicts in Angola, Mozambique, Ethiopia, and Somalia, Bern attempted to preserve its political and economic interests on the ground, weather Afro-Asian disapproval of its neutrality, and preserve cordial relations with the Western bloc. Yet, in the deeply polarised context of the late 1960s and 1970s, as the East-West and North-South conflicts overlapped, its actions and even its attempts to keep out of the action invited criticism from one side or the other. It thus became clear that Switzerland's conception of neutrality was poorly adapted to the situation in the Third World.

Neutrality is, essentially, a principle applicable to armed conflicts. A legal discussion of whether it applied, or not, to the different conflicts chosen for this study-liberation wars, an internationalised civil war, and an inter-state conflict - would not be expedient. The Swiss government referred to neutrality when avoiding taking a stance during these wars and adopting a policy of impartiality, and observers judged it by that. Switzerland was not militarily involved in the independence wars in Angola and Mozambique, or the wars in Angola and the Ogaden. There was no risk of it being dragged into these conflicts and there were comparatively few economic interests or Swiss citizens present in these territories that its government needed to protect. 
During the independence wars in the Portuguese colonies, the Swiss government restricted arms sales, refused to comment on Portuguese colonialism, and represented Portuguese interests in Senegal, citing its policy of neutrality. At the same time, Swiss business circles strengthened their economic cooperation with the colonial power and their activities in the colonies. Unwilling to accept the Swiss insistence on the separation of economic and political affairs, African leaders considered Swiss business activities in Portugal and Portuguese Africa a clear show of favour to the colonial power and thus incompatible with neutrality. Moreover, the admittance of Angolan refugees to Switzerland and very limited efforts to increase the aid provided to the African population of the colonies were insufficient to foster goodwill among African nationalist movements - or to seriously impair Swiss-Portuguese relations. For the parties to conflict, it was evident which side the Swiss government was on, irrespective of protestations of neutrality. The fear of creating a precedent for relations with South Africa partly explains Bern's one-sided attitude; the unease of many Swiss foreign policymakers with this type of war also contributed, however. No Swiss diplomat denied, either that armed conflicts took place in the Portuguese colonies, or that they would eventually lead to the colonies' independence. Nevertheless, the Swiss government never accepted the liberation movements as belligerents on a par with the Portuguese colonial authorities. Bern was wary of these non-state actors and fundamentally treated the independence wars as an internal affair of the Portuguese state.

Switzerland's neutrality policy was more successful during the wars in Angola and the Ogaden. The Swiss government treated the three Angolan liberation movements fighting for control of the newly independent state equally. Its neutrality during this conflict was never called into question. On the contrary, its government's support of the ICRC relief mission convinced observers of the positive contribution of neutrality during armed conflict. During the Ogaden War, Bern's discreet attitude averted the possible negative fallout from its association with the ICRC. Conscious that its invasion of the Ethiopian Ogaden region violated its neighbour's territorial integrity and thus the OAU's central tenet, the Somali government insisted that the conflict was an uprising of Ethiopian peasants, rather than a conventional war between two African states. In its official appeal for donations, the ICRC did not name the Somali government as a party to the conflict, thereby accepting the Somali point of view. This led the Ethiopian government to question the humanitarian organisation's neutrality. Given the Swiss government's support for the ICRC mission in the Ogaden and the multiple entanglements between these two bodies, this might have undermined Switzerland's neutrality. 
When looking at neutrality's political dimension and Switzerland's foreign policy during the regime changes in Angola, Mozambique, Ethiopia, and Somalia, it emerges that the Swiss government strove to uphold, or establish, relations with all four states, despite its Western ties and anti-Communist stance. The fact that the regimes that took over in Angola, Mozambique, and Ethiopia, and the Somali military government that came to power in 1969 (and formalised its links with the USSR in July 1974) all adopted Marxist rhetoric, nationalised foreign assets, and reorganised their national economies was certainly remarked upon in Bern. It did not, however, decisively influence the FPD's policy.

In order to judge how Switzerland's neutrality policy performed during the selected conflicts and regime changes in sub-Saharan Africa, it is useful to consider the specific components of its conception of neutrality and the resulting policy instruments its government had at its disposal. The principle of universality called for relations with all states irrespective of their government's political couleur. As shown above, Bern largely conformed to this principle. There was but one exception; the de facto suspension of diplomatic relations with Somalia between early 1975 and early 1978. This was a result of mutual disinterest, however, rather than a matter of political will, and relations were re-established as soon as the Somali government showed interest in doing so. In Mozambique, Bern undertook considerable efforts to overcome the FRELIMO government's criticism of its neutrality policy and establish diplomatic relations. The same was true in Angola. By deciding to recognise the PRA in February 1976, before the end of the internationalised civil war and regardless of the Ford administration's censure of such a step, Bern prioritised its relations with independent sub-Saharan African states. At the height of the North-South conflict, the Swiss government was keen to strengthen its relations with Third World governments in order to improve its image and protect its political and economic interests. The fact that most Western European governments showed a similar openness towards the new regimes strengthened this policy.

The principle of solidarity had a more mixed record. The provision of aid to the victims of armed conflicts was one way of demonstrating the benefits of a neutral stance. When assessing the usefulness of this principle, it is necessary to differentiate between the independence wars in the Portuguese colonies and the conflicts in Angola and the Ogaden. In the first case, the effectiveness of Switzerland's humanitarian and development aid to improve its image was very limited—not least because the aid itself was limited. This was mainly due to the difficulty in making Swiss aid to the Angolan and Mozambican populations appear non-political and disinterested. Since development 
aid was organised on a government-to-government basis, aid to Angola and Mozambique would have had to be organised in cooperation with the colonial authorities. African leaders would then have considered it further proof of Swiss collaboration with a white minority regime. At the same time, FPD officials were highly sceptical of multilateral aid programmes organised by the UN, as they considered them too politicised-read critical of white minority rule-and preferred to remain in control of their donations.

During the wars in Angola and the Ogaden, however, the ICRC provided the Swiss government with an ideal opportunity to demonstrate Swiss goodwill. Nominally independent from the Swiss government, despite ongoing financial, personnel, and operational links, the Geneva-based humanitarian organisation arranged relief missions for the victims of these conflicts. In Angola, Bern was able to benefit from the goodwill fostered by the humanitarian action during the independence wars. By supporting the relief mission, Bern was able to play for time with respect to the recognition of Angola, without alienating any of the warring parties. As the ICRC's role during the Ogaden War was controversial, it was less successful in cultivating goodwill towards the Swiss government. On the whole, the ICRC was an asset to Switzerland's foreign policy in sub-Saharan Africa. However, it cannot be called a foreign policy instrument of the Swiss government. Although there were exchanges of information between the leaders of the two bodies, in the cases under consideration there are no discernible attempts by the Swiss government to influence the ICRC, which acted independently in sub-Saharan Africa.

Humanitarian aid was routinely granted during the decolonisation of the Portuguese colonies in the interests of seeking amicable relations with the new governments. The results were most remarkable in Mozambique. While FRELIMO was highly critical of Switzerland's selective neutrality policy in Southern Africa after it took over in 1974-1975, the establishment of a bilateral development cooperation relationship led to cordial relations by the end of the decade. Swiss foreign policymakers routinely suggested the use of aid when faced with a situation that required a goodwill gesture, thereby belying their own rhetoric of the non-political nature of Switzerland's aid policy.

The Swiss conception of neutrality emphasised the principle of availability. This was of little use during the armed conflicts in sub-Saharan Africa, as there were no opportunities for Swiss mediation in any of the wars analysed in this book. Swiss foreign policymakers regularly, almost automatically, evoked the possibility of offering Switzerland's good offices to the belligerents in internal communications. However, African leaders preferred regional mediation, notably through the OAU. Even if external mediation had been sought, Bern was not in a position of special trust that made it a likely candidate for the 
role of mediator. During the independence wars in the Portuguese colonies, the Swiss government was, in the eyes of African observers, too closely allied to one side of the conflict. In Angola, Bern had few contacts among the warring liberation movements and no diplomatic personnel on the spot. During the Ogaden War, the Swiss government had no diplomatic relations with one belligerent, while, with respect to the other, the tension created by the controversy surrounding the Ethiopian Emperor's Swiss bank accounts still lingered in the minds of Swiss foreign policymakers. Switzerland's reputation as a mediator could not overcome these disadvantages, and the Swiss government made no efforts in that regard.

Although, on the whole, the Swiss government managed to manoeuvre rather successfully through the armed conflicts and regime changes in subSaharan Africa, the Swiss conception of neutrality had little to offer in the Third World context. In the late 196os and 1970s, Afro-Asian leaders' main objectives were the reorganisation of global economic relations and the end of white minority rule. These issues were framed in terms of justice, such that standing apart appeared highly immoral. On the North-South front, Switzerland was an industrialised state and, in the eyes of Third World observers, part of the capitalist camp. On the end of white minority rule, Afro-Asian leaders demanded more than an abstract, verbal commitment to human rights. Neutrality in itself, and the Swiss government's insistence on non-interference in what it considered the internal affairs of third states and on the separation of political from economic issues, had nothing to recommend it to political leaders in the global South. In addition, none of the policy instruments discussed above-mediation, aid, and political recognition-were unique to Switzerland or restricted to neutral states. Neutrality was no precondition to pursue a humanitarian agenda, to mediate during a conflict, or to adopt a position of impartiality during a specific conflict. Thus, Switzerland was in competition not only with the other neutrals but also other powers, small and big.

Many Swiss foreign policymakers do not seem to have realised, or wanted to realise, the limits of their neutrality in sub-Saharan Africa and continued to insist on the usefulness of this principle. The Political Secretariat's 1978 report on Bern's policy options in this region reflected this idea that neutrality in and of itself was a positive value and that Africans would come to understand this if proper efforts were made to explain it. Most policymakers remained attached to the European outlook in which neutrality had been developed and made no effort to adapt it to the changing international system following decolonisation. They expected Third World leaders to conform to their own view and showed little understanding of the desire to change the political and economic system that had worked to the advantage of the colonisers. It is tempting to 
conclude, as a senior OAU official hinted in mid-1974, that, if Swiss diplomats had insisted less on the special nature of their neutrality, they would have given African leaders less grounds for criticism: "by time and again referring to its 'established humanitarian traditions' and adopting a moralistic position in the world, Switzerland downright invites attack." ${ }^{2}$

At the very least, by insisting less on the benefits of neutrality in their contact with African leaders, Swiss foreign policymakers might have avoided the comparison with Sweden that could, in the African context, only be to Switzerland's disadvantage. When compared to Swedish humanitarian support for national liberation, Swiss aid in Southern Africa appeared even more paltry. The Swedish example showed African leaders that neutrality was not incompatible with taking a stand on racial oppression. Thus, in the eyes of Third World observers, Switzerland was the 'bad neutral'. In the polarised context of the 'long 1970s', however, gains in credibility and respectability in the global South almost inevitably came at the cost of losses in the North. The neutrals were faced with a trade-off and had to choose whether to please the newly independent countries in the Third World and the liberation movements, or the main Western powers. Foreign policymakers in Sweden and Switzerland made different choices. Western diplomats criticised Sweden's outspoken position on Third World issues. But, they saw Switzerland as a politically stable and economically powerful state, whose alliance to the West, despite its policy of neutrality, was never questioned. They welcomed Switzerland's more active foreign policy, particularly in the context of growing North-South polarisation. In their eyes, Switzerland occupied the position of 'good neutral'.

The presence of two different, competing models of a neutral foreign policy in sub-Saharan Africa invites the question of which one was better adapted to the situation in this region. At the height of the North-South conflict in the mid-1970s, the Swedish model seemed to win the day. Looking at the period from 1967 to 1979, however, it appears that the Swiss government managed to manoeuvre rather well through the different conflicts and crises. To be sure, Switzerland's political and economic relations with the white minority regimes in Southern Africa did undermine the credibility and respectability of its neutrality in the eyes of Afro-Asian leaders. While this was undoubtedly worrying and disagreeable, the Swiss government succeeded in waiting out their criticism. When faced by situations in these four African states that demanded a response, the Swiss government tended to prevaricate and play for time. In addition, it strategically granted humanitarian aid and focused on low-cost

2 Cited in the letter from Heinz Langenbacher to the Dıo, "Beziehungen Schweiz - Südafrika; UNO-Dokument”, 29.07.1974, p. 5, SFA E2OO3A\#1988/15\#1508*. 
political gestures of goodwill, such as permitting the opening of an OAU office in Geneva. This pragmatic foreign policy approach was, on the whole, successful. Despite repeated threats, the OAU did not introduce blacklists of firms active in Southern Africa and there are no signs that Switzerland's economic position in sub-Saharan Africa suffered as a result of its image problem on the continent. This was certainly aided by the fact that critical Afro-Asian voices were silenced in the late 1970s in a context of growing East-West tension and the Third World political movements' loss of strength.

Switzerland's smallness also helped overcome Third World censure. Although it had considerable investments in sub-Saharan Africa, Switzerland was but one industrialised state that engaged in controversial economic activities in the Third World. Away from the elite discussions of the UN, the OAU, and other international organisations, the former colonial powers and especially the Western superpower were much easier targets. Switzerland's foreign policy only had a direct, bilateral, negative impact during the regime changes in Mozambique and Ethiopia. The new FRELIMO government was unwilling to overlook the former lack of Swiss support for national liberation in Southern Africa and refused to establish diplomatic relations for several months after Mozambique's independence. Yet, FRELIMo's leadership was similarly dismissive of the major Western powers. It seems unlikely that they consciously intended Switzerland to be the last state previously represented in colonial Mozambique with which they established diplomatic relations.

In Ethiopia, however, Switzerland was singled out for criticism. After a committee of army officers toppled Emperor Haile Selassie's government in September 1974, the controversy surrounding the assets of the deposed Emperor in Swiss banks not only damaged Switzerland's standing with the new regime but also led to public protests and attacks against Swiss citizens in Ethiopia. The contrast between the highly visible Duke of Harar Memorial Hospital project in the capital, Addis Ababa, and the highly publicised reception of Ethiopian state funds by Swiss banks was striking. It probably reinforced the image of Switzerland using monies misappropriated in Third World countries to pay for humanitarian activities in these same states, adding hypocrisy to accusations of exploitation. At a time when Third World governments called for a NIEO and it seemed possible that the OAU might follow the example of the OPEC states' 1973 oil embargo and introduce economic sanctions against firms dealing with the South African and Rhodesian governments, African criticism of Switzerland's banking secret and its links with the Apartheid regime were politically, and potentially also economically, damaging. Whether this would have led the Swiss government to make concessions if the Ethiopian regime had been able to sustain its campaign remains open to speculation. 
By contrasting Switzerland's foreign policy in sub-Saharan Africa with that of other small Western European states, this study underlines the leeway of small states to act independently of bloc interests during Détente. This was particularly true during the independence wars in the Portuguese colonies. Faced by the problem of white minority rule in Southern Africa, there was no cohesion within the Western bloc-no unified Western position. The governments of small states, such as the Scandinavian countries and the Netherlands, condemned racial discrimination, gave diplomatic and, in some cases, humanitarian support to African liberation movements, and advocated putting pressure on Portugal, notably through the EEC and NATO. The example of NATO member Norway, whose government lobbied for the liberation movements to be able to participate in the $1974 \mathrm{IHL}$ conference in Geneva is a case in point. These small Western European states reached out to Afro-Asian leaders and helped delegitimise white minority rule. Within the group of small states, Switzerland was an outlier. Its government was careful to adopt a low profile, refrained from condemning colonialism, and did not restrict Swiss business activities in Southern Africa. When it came to white minority rule in subSaharan Africa, Bern's position was closer to that of the major Western powers than that of most other small states. Even so, Swiss foreign policymakers rarely referred to the position of the Nixon and Ford administrations on sub-Saharan Africa. Switzerland's economic and financial role in this region, which, particularly in South Africa, bore no relation to the small size of its territory, gave its government a vested interest in maintaining the status quo. This supports, to some extent, the claims of scholars that call for the inclusion of Switzerland among the middle powers due to the strength of its economy and financial centre. As most small states had few interests in sub-Saharan Africa, they had little to lose from an end to white minority rule.

Nevertheless, when it came to specific foreign policy choices in the mid1970s, such as the recognition of the new Angolan and Mozambican governments, the positions of big and small Western governments were similar. They all recognised the new states, despite the Soviet ties of their new leaders-with the notable exception of the Ford administration with respect to the recognition of the PRA. On this issue, there was a gulf between the US and the rest of the Western bloc. The Swiss government's frame of reference for its relations with sub-Saharan Africa was, in the 1970s, Western European. The FPD coordinated its policies with neutrals Sweden and Austria, but also with the EEC. Department leaders closely observed the Swedish government's position on African issues and sometimes consulted it. This was also true with regard to Austria, even though the Austrian government was less invested in sub-Saharan Africa. After checking with Stockholm and Vienna, the FPD also 
routinely asked its ambassadors in the EEC member states to report on their host governments' position.

Compared to the crucial role played by neutral and Western European governments in Swiss decision-making in sub-Saharan Africa, the influence of the US appears more muted. Until the mid-197os, the Nixon and Ford administrations showed little interest in Africa, focusing rather on the establishment of triangular diplomacy, the wars in Vietnam and the Middle East, the collapse of the Bretton Woods system, and the fallout from the Watergate scandal. Swiss policymakers viewed the US State Department's interpretations of the Ethiopian Revolution and the decolonisation of Mozambique and Angola with some scepticism. For Bern, Washington's position became important once the Cold War escalated on the African continent. The Cuban and Soviet interventions in Angola in 1975-1976 and, two years later, in the Ogaden, raised fears that the USSR would continue to expand its influence in Africa. Swiss foreign policymakers were deeply worried about the 'inability' of the US to ensure their allies' victories in these conflicts. This spurred them to consider ways in which they could contribute to the containment of Cuban and Soviet influence in Africa by strengthening Switzerland's relations with sub-Saharan African states. During the global Cold War in sub-Saharan Africa, the Swiss government clearly perceived Switzerland to be part of the Western bloc.

However, the Swiss government was no monolith. Analysis of the country's foreign policy on sub-Saharan Africa has exposed the departmental logics and individual convictions warring behind the scenes, which echoed broader disagreements within Swiss civil society. In the late 196os, the leaders of newly independent Afro-Asian states and a heterogeneous domestic solidarity movement started to participate in the debate surrounding Switzerland's foreign policy in sub-Saharan Africa, alongside business leaders with long-standing influence in Bern. Whether more or less openly, many Swiss foreign policymakers rejected their criticism outright and denied that these new actors were entitled to contribute to policy formation. They were distrustful of and condescending towards 'leftist' Swiss youth movements and 'excitable' African leaders.

Nevertheless, Afro-Asian and domestic criticism gave rise to disagreements about the future direction of Switzerland's foreign policy on sub-Saharan Africa within the FPD. From the late 196os, a small number of diplomats started to advocate a reorientation. Some of them were stationed at the centres of international debate in New York and Addis Ababa and therefore regularly confronted Third World criticism. These men repeatedly criticised the government's continuing refusal to constrict the activities of Swiss banks and firms in Southern Africa and questioned its selective policy of neutrality in the region. 
They argued that collaborating with the white minority regimes in Southern Africa was not only morally reprehensible but also economically short-sighted, as it jeopardised business opportunities on the rest of the African continent. These debates gained momentum in the 1970s and culminated in the years between 1974 and 1976. Although the voices calling for a fundamental change in Switzerland's foreign policy on Southern Africa remained in the minority and often went unheard, the department as a whole became more attentive to the demands of Afro-Asian leaders. This is most clearly underlined by FPD leaders' willingness to restrict triangular trade with Rhodesia in early 1974. This example also highlights the conflict of interest between the FPD and the Trade Division. Intent on export promotion and closely tied to Switzerland's business community — which had extensive links to South Africa - the latter service opposed any steps that restricted economic freedom. Faced with this resistance and a business-friendly government, the FPD's policy options were limited.

The direct impact of private economic actors on Switzerland's foreign policy in Angola, Mozambique, Ethiopia, and Somalia is more muted. Switzerland's economic interests in these countries were few and business leaders rarely contacted the government to influence its policy. They did not need to do so, as economic considerations traditionally held great weight in Bern. During the independence wars in the Portuguese colonies, the FPD took next to no steps to restrict Swiss trade and investment so as not to set a precedent that might undermine Switzerland's commercial and financial relations with South Africa. FPD leaders habitually made vague references to economic interests in order to validate policy decisions. The maintaining of a political presence in the four states was always justified, in part, by the need to protect Swiss investments or to obtain information about the markets. In the rare cases in which business leaders got in touch directly with the federal administration, notably in the case of the recognition and establishment of diplomatic relations with Mozambique and Angola in 1974-1976, their suggestions were immediately taken up. Intervention by these economic actors only strengthened policy decisions that had already been made, however.

Between 1967 and 1979, Swiss civil society actors played an active role in the formation of Switzerland's foreign policy on sub-Saharan Africa. Religious organisations, anti-imperialist groups, students, intellectuals, peace activists, and Third World solidarity groups contributed to delegitimising white minority rule, put the issue of the Swiss government's collaboration with these regimes on the political agenda, and pressured Bern to strengthen its relations with independent African states. On the occasion of Portugal's invitation to the Comptoir Suisse trade fair in 1973, they even convinced Federal Councillor 
Pierre Graber that Switzerland had better keep its distance from the Estado Novo regime, although he was eventually outvoted by his fellow government members. This episode also highlights the differences in impact between specific groups of non-state actors. While student and Third World groups were generally viewed with suspicion in Bern, FPD officials had great respect for established churches and missionary organisations and took them much more seriously. Such actors were valued partners in the implementation of the Swiss government's humanitarian and development policy and were thought to contribute to the cultivation of goodwill towards Switzerland in the Third World. Swiss missionary organisations were active in many African states and had experience and expertise that the government lacked, particularly in regions where its diplomatic network was small. Missionaries were less likely to be suspected of ulterior motives than Swiss business people on the ground. In peripheral regions, non-state actors played an important role for the Swiss government, particularly in the transitional period during the decolonisation of the Portuguese colonies. Private actors represented in sub-Saharan Africa served as intermediaries and facilitated Bern's contact with local leaders at various points, as has been shown in the cases of the DM missionaries in Mozambique and the Swissair office in Angola.

The controversy surrounding Federal Councillor Pierre Aubert's January 1979 trip to Western Africa underlines that the FPD's efforts to render Switzerland's foreign policy more active and to reach out to the Third World were hampered by the resistance from a significant part of Switzerland's population. There was also domestic resistance to increasing Switzerland's foreign aid budget and to its attendance as an observer at NAM summits. Much of Switzerland's population remained attached to the selective and restrictive interpretation of neutrality developed during the early Cold War. Despite the limits of Switzerland's conception of neutrality in sub-Saharan Africa, the attachment to this guideline united all actors involved in developing foreign policy. Neutrality meant different things to different people, however; it was cited both by Swiss anti-imperialist groups that accused Bern of infringing on neutrality by prioritising the white minority regimes over African nationalists in the liberation wars in Southern Africa in the early 1970s, and by conservative MPs and business leaders to criticise the government's statements against Apartheid later in the same decade. Neutrality thus constituted an extremely malleable concept in foreign policy. 


\section{Bibliography}

\section{Unpublished Sources}

\section{Switzerland}

1 Swiss Federal Archives (SFA), Bern

1.1 Federal Council

E1004.1*, minutes of Federal Council resolutions

$1.2 \quad$ Federal Assembly

E1050.12*, Foreign Policy Committees

1.3

Federal Political Department (FPD), from 1979 Federal Department of Foreign Affairs (FDFA)

E2001E*, Directorate of Political Affairs (DPA): central repository (1960-1973)

E2001E-O1*, DPA: central repository (1973-1981)

E2010A*, DPA: central repository (1982-1984)

E2001-O9*, DPA: political documentation (1967-1980)

E2010-01A*, DPA: political documentation (1976-1984)

E2003-06*, DPA: foreign interests (1973-1985)

E20o3 $A^{*}$, Directorate for International Organisations (DIO): central repository (19551972)

E2004B*, Administration Division (AD) (1973-1979)

E2024A*, AD (1980-1984)

E2005 $A^{*}$, Delegate for Technical Cooperation: central repository (1964-1979)

E2025A*, Delegate for Technical Cooperation: central repository (1979-1984)

E2200.36*, Swiss embassy in Washington

E2200.54-03*, Swiss embassy in Lisbon

E2200.70*, Swiss embassy in Addis Ababa

E2200.167*, Swiss consulate in Lourenço Marques

E2200.185-O2*, Swiss embassy in Nairobi

E2200.307 $A^{*}$, Swiss embassy in Maputo

E2300-O1*, political and military reports of diplomatic missions (1966-1978)

E240\%*, annual reports of diplomatic missions

$1.4 \quad$ Federal Department of Justice and Police (FDJP)

E426oC-o1*, Federal Office of Police Matters

$\mathrm{E}_{428 \mathrm{oA}}$, Delegate for Refugees 
1.5 Federal Military Department (FMD)

$\mathrm{E}_{5} \mathrm{OO}_{\mathrm{G}} \mathrm{G}^{*}$, Directorate of the Federal Military Administration: central repository

1.6 Federal Department of Finance (FDF)

E610oB-o2*, Federal Finance Administration: central repository

1.7 Federal Department of Economic Affairs (FDEA)

E70o1C* ${ }^{*}$, General Secretariat of the FDEA: central repository

E7110*, Trade Division: general repository (1967-1979)

E7115A*, Trade Division: general repository (1979-1984)

2

Archiv für Zeitgeschichte (Archives for Contemporary History, AfZ), Zurich

2.1

IB Vorort-Archiv (Archives of the Swiss Federation of Commerce and Industry, Vorort)

377.20.1, country files Mozambique

Minutes of the meetings of the Vorort (1968-1979)

3 Archives of the Swiss National Bank (ASNB), Zurich

Minutes of the SNB directorate's meetings, 1967-1979

4 Archives of the Swiss Bankers Association (ASBA), Basel

Minutes of the meetings of the SBA's Committee

Folder L. 182 Afrique 5.1.71 au 14.7.75

Folder L. 182 Afrique, $1975^{-1978}$

5

ICRC Archives (ACICR), Geneva

B AG, Archives générales (1966-1975)

6

Basler Afrika Bibliographien. Namibia Resource Centre \& Southern Africa Library (BAB), Basel

AA.5, Archives of the solidarity group Medic' Angola / Kämpfendes Afrika, (Zurich, 1971-1988)

Archives of the Département missionnaire des églises protestantes de Suisse romande (ADM), Lausanne

Central repository

Folder Conseil 1973-1978 
$8 \quad$ Novartis Archives, Basel

8.1 Ciba company archives

REFA/CIBA Léopoldville, 1955-1969, box KGK2, Kon 3

8.2 Ciba-Geigy company archives

Minutes of the Group Executive Committee

Minutes of the regional committees

Minutes of the regional services

Minutes: various documents, box KL 1.o1, Aug 1976 - Dez. 1979

$9 \quad$ Historical Archives Авв (НААвВ), Baden

Minutes of the meetings of Brown Boveri \& Cie (B BC)'s directorate

Minutes of the meetings of BвC's Board of Directors

\section{United States}

10 National Archives and Record Administration, College Park, Maryland, (NARA)

10.1 General Records of the Department of State, Record Group 59

Subject-Numeric Files 1967-1969, 1970-1973

Records Relating to Angola 1974-1975

Records Relating to Portuguese Guinea, Mozambique 1975

P-Reel Printouts 1975-1976

\section{United Kingdom}

11 The National Archives, Kew, (TNA)

11.1 Records of the Foreign and Commonwealth Office (FCO)

31: East Africa Department

33: Western European Department

36: Rhodesia Political Department

45: Southern African Department

61: United Nations (Economic and Social) Department

106: Central African Department

12 Bodleian Library, Oxford

Archives of the Anti-Apartheid Movement (1956-1998)

\section{France}

13 Centre des Archives diplomatiques, La Courneuve/Paris (CAD)

200QO, Portugal

206QO, Switzerland 
1929INVA, Switzerland, 1976-1980

310QONT, Angola

342QONT, Mozambique

14 Centre des Archives diplomatiques, Nantes (CADN)

$89 \mathrm{PO} / 2002 \mathrm{O} 21$, French embassy in Bern

37oPO/B, French embassy in Lisbon

\section{Portugal}

15

Arquivo Histórico Diplomático (AHD), Lisbon

EEA files

PAA files

PEA files

Archives of the Gabinete dos Negócios Políticos (Office of Political Affairs, GNP)

16

Arquivo Nacional Torre o Tombo (ANTT), Lisbon

Archives of the Portuguese secret service PIDE/DGS

Mozambican Service for the Centralisation and Coordination of Information (SCCIM)

\section{Official Publications}

\section{Amtliches Bulletin der Bundesverfassung}

Bundesblatt

Ciba-Geigy annual reports

ICRC annual reports

Nestlé annual reports

Swiss Directorate General of Customs, Jahresstatistik des Aussenhandels der Schweiz, 1967-1979

Swiss Federal Council, Berichte des Bundesrates über seine Geschäftsführung

\section{Online Resources}

"Abkommen zwischen der Schweizerischen Eidgenossenschaft und der Demokratischen Bundesrepublik Äthiopien über die Förderung und den gegenseitigen Schutz von Investitionen", concluded on 26 June 1998 and in force since o7 December 1998, https://www.admin.ch/opc/de/classified-compilation/200106o6/index.html (13 January 2021)

Access to Archival Databases (AAD), website of the NARA: https://aad.archives.gov/ aad/index.jsp (13 January 2O21) 
Data Portal of the SNB, Interest Rates, Yields and Foreign Exchange Market, Historical Exchange Rates of Selected Euro Member Countries, https://data.snb.ch/en/topics/ ziredev\#!/cube/devkuhism (13 January 2021)

Diplomatic Documents of Switzerland 1848-1975 (Dodis) Online, https://www.dodis.ch/en (13January 2021)

Federal Council, press release, "Switzerland and Mozambique discuss peace and sign an international cooperation agreement", 28.02.2018, https://www.admin.ch/gov/ en/start/documentation/media-releases.msg-id-69945.html (13 January 2021)

Foreign Relations of the United States (FRUS) Online, https://history.state.gov/ historicaldocuments (13 January 2021)

General Assembly of the United Nations, documents, http://www.un.org/en/ga/ documents/index.shtml (13January 2021)

Historical Dictionary of Switzerland (HLS) Online, http://www.hls-dhs-dss.ch (13January 2021 )

Historical Statistics of Switzerland Online (HSSO) database, developed under the supervision of the Swiss Society for Economic and Social History in collaboration with the Universities of Zurich, Geneva and the Federal Institute of Technology Lausanne, https://hsso.ch/en (11 August 2021)

Lawrence H. Officer, "Exchange Rates Between the United States Dollar and Forty-one Currencies", Measuring Worth, 2018, https://www.measuringworth.com/datasets/ exchangeglobal/ (13 January 2021)

"Laws of War: Rights and Duties of Neutral Powers and Persons in Case of War on Land (Hague V)", 18.10.1907, Yale Law School, The Avalon Project, Documents in Law, History and Diplomacy, http://avalon.law.yale.edu/2oth_century/hagueo5.asp, (13 January 2021)

Organization of African Unity (OAU), decisions and declarations of the Assembly and the Council of Ministers, https://au.int/en/decisions/assembly (13 January 2021); https://au.int/en/decisions/council (13 January 2021)

The American Presidency Project, https://www.presidency.ucsb.edu (13 January 2021)

United Nations (UN), "Growth in United Nations membership", https://www.un.org/ en/about-us/growth-in-un-membership (11 August 2021)

US Department of State, Office of the Historian, "A Guide to the United States' History of Recognition, Diplomatic, and Consular Relations, by Country, since 1776: Angola", https://history.state.gov/countries/angola (13 January 2021)

\section{Press}

24heures

Tribune de Lausanne/Le Matin

Mozambique Revolution 


\section{Books and Articles}

Alexander, Amanda, "A Short History of International Humanitarian Law", The European Journal of International Law 26:1 (2015), pp. 109-138

Almada e Santos, Aurora, "The Role of the Decolonization Committee of the United Nations Organization in the Struggle Against Portuguese Colonialism in Africa: 1961-1974", The Journal of Pan-African Studies 4:10 (2012), pp. 248-26o

Almada e Santos, Aurora; Capanga André, Bernardo; Tornimbeni, Corrado; Vasile, Iolanda (eds.), Afriche e Orienti. International Solidarities and the Liberation of the Portuguese Colonies 19:3 (2017)

Amate, C. O. C., Inside the OAU. Pan-Africanism in Practice, New York: St. Martin's Press, 1986

Andargachew Tiruneh, The Ethiopian Revolution 1974-1987. A Transformation from an Aristocratic to a Totalitarian Autocracy, Cambridge: Cambridge University Press, 1993

Andrew, Christopher; Mitrokhin, Vasili, The World Was Going Our Way. The KGB and the Battle for the Third World, New York: Basic Books, 2005

Aunesluoma, Juhana, Britain, Sweden and the Cold War, 1945-54. Understanding Neutrality, Basingstoke: Palgrave Macmillan, 2003

Bahru Zewde, A History of Modern Ethiopia, 1855-1991, Oxford: James Currey, 2nd edition 2001

Baudendistel, Rainer, Between Bombs and Good Intentions. The Red Cross and the ItaloEthiopian War, 1935-1936, New York: Berghahn Books, 2006

Belete Belachew Yihun, "Ethiopian Foreign Policy and the Ogaden War: The Shift from 'Containment' to 'Destabilization', 1977-1991", Journal of Eastern African Studies 8:4 (2014), pp. 677-691

Bernecker, Walther L.; Fischer, Thomas (eds.), Unheimliche Geschäfte. Schweizer Rüstungsexporte nach Lateinamerika im 20. Jahrhundert, Zurich: Chronos, 1991

Birmingham, David, "Angola" in Patrick Chabal, A History of Postcolonial Lusophone Africa, Bloomington: Indiana University Press, 2002, pp. 137-184

Birri, Marisa, "Der Kalte Krieg war in Afrika ein Heisser. Die Schweiz und der Kongokonflikt 196o-1963", in Sandra Bott, Janick Marina Schaufelbuehl, Sacha Zala (eds.), Itinera. Die internationale Schweiz in der Zeit des Kalten Krieges/Relations internationales de la Suisse durant la Guerre froide, Basel: Schwabe, 2011, pp. 65-79

Birri, Marisa, Die Schweiz und der Kongo in den ersten Jahren der Unabhängigkeit 196o1963, unpublished Master thesis, University of Bern, 2007

Bischof, Günter, Austria in the First Cold War, 1945-1955. The Leverage of the Weak, Basingstoke: Palgrave Macmillan, 1999

Bjereld, Ulf; Ekengren, Ann-Marie, “Cold War Historiography in Sweden”, in Thorsten B. Olesen (ed.), The Cold War - and the Nordic Countries: Historiography at Crossroads, Odense: University Press of Southern Denmark, 2004, pp. 143-175 
Boeglin, Philippe, La coopération entre la Suisse et le Burkina Faso. Continuité en régime révolutionnaire (1983-1987), unpublished Master thesis, University of Fribourg, 2010

Borstelmann, Thomas, Apartheid's Reluctant Uncle. The United States and Southern Africa in the Early Cold War, New York: Oxford University Press, 1993

Borstelmann, Thomas, The Cold War and the Color Line. American Race Relations in the Global Arena, Cambridge, MA: Harvard University Press, 2001

Bott, Sandra, La Suisse et l'Afrique du Sud. Marché de l'or, finance et commerce durant l'apartheid, Zurich: Chronos, 2013

Bott, Sandra; David, Thomas; Lützelschwab, Claude; Schaufelbuehl, Janick Marina (eds.), Suisse-Afrique (18e-20e siècles). De la traite des Noirs à la fin du régime d'apartheid, Münster: LIT Verlag, 2005

Bott, Sandra; Guex, Sébastien; Etemad, Bouda, Les relations économiques entre la Suisse et l'Afrique du Sud durant l'apartheid (1945-1990), Lausanne: Antipodes, 2005

Bott, Sandra; Hanhimäki, Jussi M.; Schaufelbuehl, Janick Marina; Wyss, Marco, "Introduction. Le rôle international de la Suisse dans la Guerre froide globale: un équilibre précaire", Relations internationales 163:3 (2015), pp. 3-13

Bott, Sandra; Hanhimäki, Jussi M.; Schaufelbuehl, Janick Marina; Wyss, Marco, (eds.), Neutrality and Neutralism in the Global Cold War. Between or Within the Blocs? London: Routledge, 2016

Bott, Sandra; Schaufelbuehl, Janick Marina, "Switzerland and Détente: A Revised Foreign Policy Characterized by Distrust", in Martin Klimke, Reinhild Kreis, Christian F. Ostermann (eds.), Trust, but Verify. The Politics of Uncertainty and the Transformation of the Cold War Order, 1969-1991, Washington, DC: Woodrow Wilson Center Press, 2016, pp. 259-278

Bott, Sandra; Schaufelbuehl, Janick Marina; Zala, Sacha (eds.), Itinera. Die internationale Schweiz in der Zeit des Kalten Krieges/Relations internationales de la Suisse durant la Guerre froide, Basel: Schwabe, 2011

Bradley, Mark Philip, "Decolonization, the global South, and the Cold War, 1919-1962", in Melvyn P. Leffler, Odd Arne Westad (eds.), The Cambridge History of the Cold War. Volume I: Origins, Cambridge: Cambridge University Press, 2011, pp. 464-485

Brazinsky, Gregg A., Winning the Third World. Sino-American Rivalry during the Cold War, Chapel Hill: The University of North Carolina Press, 2017

Breitenmoser, Christoph, Sicherheit für Europa. Die KSZE-Politik der Schweiz bis zur Unterzeichnung der Helsinki-Schlussakte zwischen Skepsis und aktivem Engagement, Zürich: ETH, 1996

Breitenmoser, Christoph, Strategie ohne Aussenpolitik. Zur Entwicklung der schweizerischen Sicherheitspolitik im Kalten Krieg, Bern: Peter Lang, 2002

Brückner, Thomas, Hilfe schenken. Die Beziehung zwischen dem IKRK und der Schweiz, 1919-1939, Zürich: NZZ Libro, 2017 
Brunner, Franziska, Die Beziehungen Schweiz-UNO im Kontext des Rhodesienkonflikts. Eine Neubewertung der multilateralen Zusammenarbeit, unpublished Master thesis, University of Bern, 2011

Buclin, Hadrien, "Swiss Intellectuals and the Cold War: Anti-Communist Policies in a Neutral Country", Journal of Cold War Studies 19:4 (2017), pp. 137-167

Bugnion, François, Le Comité international de la Croix-Rouge et la protection des victimes de la guerre, 2nd ed., Geneva: Comité international de la Croix-Rouge, 2000

Byrne, Jeffrey James, “Africa's Cold War", in Robert J. McMahon (ed.), The Cold War in the Third World, New York: Oxford University Press, 2013, pp. 101-123

Carron, Damien, La Suisse et la guerre d'indépendance algérienne (1954-1962), Lausanne: Éditions Antipodes, 2013

Castaño, David, “'A Practical Test in the Détente': International Support for the Socialist Party in the Portuguese Revolution (1974-1975)", Cold War History 15:1 (2015), pp. $1-26$

Centre d'investigation sur le colonialisme portugais (CISCOP) in collaboration with the Centre Europe-Tiers Monde (сетім), Suisse-Portugal. De l'Europe à l'Afrique, Geneva: Editions CETIM, 1973

Chabal, Patrick, A History of Postcolonial Lusophone Africa, Bloomington: Indiana University Press, 2002

Chichava, Sérgio Inácio, "Unlike the Other Whites? The Swiss in Mozambique under Colonialism" in Eric Morier-Genoud, Michel Cahen (eds.), Imperial Migrations. Colonial Communities and Diaspora in the Portuguese World, Houndsmills: Palgrave Macmillan, 2012, pp. 149-167

Clarence-Smith, Gervase, The Third Portuguese Empire, 1825-1975. A Study in Economic Imperialism, Manchester: Manchester University Press, 1985

Connelly, Matthew, "Rethinking the Cold War and Decolonization. The Grand Strategy of the Algerian War for Independence", Journal of Middle East Studies 33:2 (2001), pp. 221-245

Correia, Paulo; Verhoef, Grietjie, "Portugal and South Africa: Close Allies or Unwilling Partners in Southern Africa during the Cold War?", Scientia Militaria: South African Journal of Military Studies 37:1 (2009), pp. 50-72

Cruz e Silva, Teresa, Protestant Churches and the Formation of Political Consciousness in Southern Mozambique (1930-1974), Basel: P. Schlettwein Publishing, 2001

Dalsjö, Robert, “The Hidden Rationality of Sweden's Policy of Neutrality during the Cold War", Cold War History 14:2 (2014), pp. 175-194

David, Thomas; Etemad, Bouda, "Introduction”, Les Annuelles 5 (1994), pp. 7-17

David, Thomas; Etemad, Bouda "Un impérialisme suisse? Introduction”, Traverse 5 (1998), pp. 7-16

David, Thomas; Etemad, Bouda; Schaufelbuehl, Janick Marina, La Suisse et l'esclavage des Noirs, Lausanne 2005 
David, Thomas; Schaufelbuehl, Janick Marina, "Swiss Conservatives and the Struggle for the Abolition of Slavery at the End of the Nineteenth Century", Itinerario 34:2 (2010), pp. 87-103

De Fischer, Beat, Contributions à la connaissance des relations suisses-égyptiennes (d'environ 100 à 1949) suivies d'une esquisse des relations suisses-éthiopiennes (jusqu'en 1952), Lisbon: Ramos, Afonso \& Moita, Ltd, 1956

De Meneses, Filipe Ribeiro; McNamara, Robert, "Exercise ALCORA: Expansion and Demise, 1971-4", The International History Review 36:1 (2014), pp. 89-111

De Meneses, Filipe Ribeiro; McNamara, Robert, "The Origins of Exercise ALCORA, 196o-71", The International History Review 35:5 (2013), pp. 1113-1134

De Souto, Amélia Neves, Caetano e o Ocaso do Império'. Administração e Guerra Colonial em Moçambique durante o Marcelismo (1968-1974), Porto: Edições Afrontamento, 2007

Debrunner, Hans Werner, Schweizer im kolonialen Afrika, Basel: Basler Afrika Bibliographien, 1991

Del Pero, Mario, “'Which Chile, Allende?' Henry Kissinger and the Portuguese Revolution", Cold War History 11:4 (2011), pp. 625-657

Del Pero, Mario, "A European Solution for a European Crisis. The International Implications of Portugal's Revolution" Journal of European Integration History 1 (2009), pp. 15-34

Deroche, Andrew J., "Standing Firm for Principles: Jimmy Carter and Zimbabwe", Diplomatic History 23:4 (1999), pp. 657-685

Dhada, Mustafah, "The Wiriyamu Massacre of 1972: Its Context, Genesis, and Revelation", History in Africa 40 (2013), pp. 45-75

Dhada, Mustafah, "The Wiriyamu Massacre of 1972: Response to Reis and Oliveira", Civil Wars 15:4 (2013), pp. 551-558

Dhada, Mustafah, The Portuguese Massacre of Wiriyamu in Colonial Mozambique, 19642013, London: Bloomsbury, 2016

Dieng, Alioune, A l'ombre de la France. Les relations entre le Sénégal et la Suisse au lendemain de l'indépendance (1960-1964), unpublished Master thesis, University of Neuchâtel, 2008

Dieng, Alioune, La Suisse et l'Afrique aux lendemains des indépendances: le cas de la Côte d'Ivoire, unpublished Master thesis, The Graduate Institute, Geneva, 2010

Dietrich, Christopher R. W., Oil Revolution. Anticolonial Elites, Sovereign Rights, and the Economic Culture of Decolonization, Cambridge: Cambridge University Press, 2017

Dinkel, Jürgen, “'Third World Begins to Flex its Muscles'. The Non-Aligned Movement and the North-South Conflict during the 197os", in Sandra Bott, Jussi M. Hanhimäki, Janick Marina Schaufelbuehl, Marco Wyss (eds.), Neutrality and Neutralism in the Global Cold War. Between or Within the Blocs? London: Routledge, 2016, pp. 108-123

Dirlewanger, Dominique; Guex, Sébastien; Pordenone, Gian-Franco, La politique commerciale de la Suisse de la Seconde Guerre mondiale à l'entrée du GATT (1945-1966), Zurich: Chronos, 2004 
Dreier, Marcel, "Afrikanische Befreiungsbewegungen und die antiimperialistische Solidaritätsbewegung in der Schweiz", in Janick Marina Schaufelbuehl (ed.), 1968-1978. Ein bewegtes Jahrzehnt in der Schweiz, Zürich: Chronos, 2009, pp. 161-176

Eichenberger, Pierre; David, Thomas; Haller, Lea; Leimgruber, Matthieu; Schär, Bernhard C.; Wirth, Christa, "Beyond Switzerland. Reframing the Swiss Historical Narrative in Light of Transnational History", Traverse 24:1 (2017), pp. 137-152

El Ammari, Sakina, Les autorités politiques suisses face aux réclamations d'avoirs illicites déposés dans les banques suisses: le cas du 'blood money' de l'empereur éthiopien Haïlé Sélassié (1974), de Ferdinand Marcos aux Philippines (1986) et de Jean-Claude Duvalier en Haïti (1986), unpublished Master thesis, University of Lausanne, 2017.

Elmer, Sara; Kuhn, Konrad J.; Speich Chassé, Daniel, Itinera. Handlungsfeld Entwicklung. Schweizer Erwartungen und Erfahrungen in der Geschichte der Entwicklungszusammenarbeit/Le champ d'action "développement". Attentes et expériences suisses dans le travail de développement, Basel: Schwabe, 2014

Eriksen, Tore Linné (ed.), Norway and National Liberation in Southern Africa, Stockholm: Nordiska Afrikainstitutet, 2000

Eriksen, Tore Linné, "The Origins of a Special Relationship: Norway and Southern Africa 1960-1975", in Tore Linné Eriksen (ed.), Norway and National Liberation in Southern Africa, Stockholm: Nordiska Afrikainstitutet, 200o, pp. 9-89

Erni, Paul, Mariage à la bâloise. Histoire de la fusion Ciba-Geigy, Zürich: Nzz Verlag, 1979 Etemad, Bouda; Humbert, Mathieu, "La Suisse est-elle soluble dans sa 'postcolonialité?” Schweizerische Zeitschrift für Geschichte 64:2 (2014), pp. 279-291

Evans, Gareth, "The Great Simplifier: The Cold War and South Africa, 1948-1994", in Alan P. Dobson (ed.), Deconstructing and Reconstructing the Cold War, Aldershot: Ashgate, 1999

Fanzun, Jon A., Die Grenzen der Solidarität: schweizerische Menschenrechtspolitik im Kalten Krieg, Zürich: NZZ, 2005

Farquet, Christophe, "Au-delà des affaires, de la corruption et de la spéculation. Analyse de la fuite de capitaux vers le nord au temps de la décolonisation au travers des sources diplomatiques suisses", Economic History Working Papers 4 (2017)

Farquet, Christophe, La défense du paradis fiscal suisse avant la Seconde Guerre mondiale: une histoire internationale. Analyse de la politique helvétique dans les négociations sur la double imposition et l'évasion fiscale durant l'entre-deux-guerres, Neuchâtel: Éditions Alphil-Presses universitaires, 2016

Fässler, Hans, Reise in schwarz-weiss: Schweizer Ortstermine in Sachen Sklaverei, Zürich: Rotpunktverlag, 2005

Ferguson, Niall, et al. (eds.), The Shock of the Global. The 1970s in Perspective, Cambridge MA: The Belknap Press of Harvard University Press, 2010

Ferrari, Lorenzo, Sometimes Speaking with a Single Voice. The European Community as an International Actor, 1969-1979, Bruxelles: P.I.E. Peter Lang, 2016 
Ferrari, Lorenzo, "The European Community as an Opposer of the Portuguese Colonial Rule: Debates and Initiatives, 1970-1974" Afriche e Orienti 19:3 (2017), pp. 69-84

Fischer-Tiné, Harald, "The Other Side of Internationalim. Switzerland as a Hub of Militant Anti-Colonialism, c. 1910-1920", in Patricia Purtschert, Harald Fischer-Tiné (eds.), Colonial Switzerland. Rethinking Colonialism from the Margins, Basingstoke: Palgrave Macmillan, 2015, pp. 221-258

Fischer, Rahel, 'Die Solidarität in den Strukturen'. Entwicklungspolitische Konzepte, Aktionen und Lebenswelten der Arbeitsgruppe Dritte Welt Bern, 1968-1976, unpublished Master thesis, University of Bern, 2007

Fischer, Thomas, "From Good Offices to an Active Policy of Peace: Switzerland's Contribution to International Conflict Resolution" in Jürg Martin Gabriel, Thomas Fischer (eds.), Swiss Foreign Policy, 1945-2002, Houndsmills: Palgrave Macmillan, 2003, pp. 74-104

Fischer, Thomas, Die Grenzen der Neutralität. Schweizerisches KSZE-Engagement und gescheiterte UNO-Beitrittspolitik im kalten Krieg 1969-1986, Zürich: Chronos, 2004

Fischer, Thomas, Neutral Power in the CSCE. The N+N States and the Making of the Helsinki Accords 1975, Baden-Baden: Nomos, 2009

Fischer, Thomas; Möckli, Daniel, "The Limits of Compensation: Swiss Neutrality Policy in the Cold War", Journal of Cold War Studies 18:4 (2016), pp. 12-35

Fleury, Antoine, "La Suisse: petite ou moyenne puissance?" in Jean-Claude Allain (ed.), La moyenne puissance au XXème siècle: recherche d'une définition, Paris: FE DN-IH CC, 1989, pp. 217-230

Fonseca, Ana Mónica, "The Federal Republic of Germany and the Portuguese Transition to Democracy (1974-1976)", Journal of European Integration History 15 (2009), pp. $35^{-5}$

Fonseca, Ana Mónica; Marcos, Daniel, "Cold War Constraints: France, West Germany and Portuguese Decolonization”, Portuguese Studies 29:2 (2013), pp. 209-226

Forster, Jacques, "Die öffentliche Entwicklungshilfe sechs kleiner europäischer Länder: Dänemark, Finnland, Norwegen, Oesterreich, Schweden, Schweiz. Grundlagen für eine vergleichende Analyse", Entwicklung/Développement 8 (1981), pp. 2-14

Forsythe, David P., The Humanitarians. The International Committee of the Red Cross, Cambridge: Cambridge University Press, 2005

Fracheboud, Virginie, "La Suisse au service des intérêts américains à Cuba ou le succès de la politique de neutralité et solidarité (1961-1963)", Relations internationales 163:3 (2015), pp. 47-62

Franc, Andrea, Wie die Schweiz zur Schokolade kam: Der Kakaohandel der Basler Handelsgesellschaft mit der Kolonie Goldküste (1893-1960), Basel: Schwabe, 2008

Friedman, Jeremy, Shadow Cold War. The Sino-Soviet Competition for the Third World, Chapel Hill: The University of North Carolina Press, 2015 
Gabriel, Jürg Martin, "Switzerland and Economic Sanctions: The Dilemma of a Neutral", in Marko Milivojevic, Pierre Maurer, Swiss Neutrality and Security. Armed Forces, National Defence and Foreign Policy, New York: Berg, 1990

Gabriel, Jürg Martin, The American Conception of Neutrality After 1941, Basingstoke: Palgrave Macmillan, 2002 (Updated and Revised Edition)

Gabriel, Jürg Martin; Fischer, Thomas (eds.), Swiss Foreign Policy, 1945-2002, Houndsmills: Palgrave Macmillan, 2003

Gaffino, David, Autorités et entreprises suisses face à la guerre du Viêt Nam, 1960-1975, Neuchâtel: Alphil, 2006

Găinar, Maria, Aux origines de la diplomatie européenne. Les neuf et la coopération politique européenne de 1973 à 1989, Bruxelles: P.I.E. Peter Lang, 2012

Garavini, Giuliano, “Completing Decolonization: The 1973 'Oil Shock' and the Struggle for Economic Rights", The International History Review 33:3 (2011), pp. 473-487

Garavini, Giuliano, "The Colonies Strike Back: The Impact of the Third World on Western Europe, 1968-1975", Contemporary European History 16:3 (2007), pp. 299-319

Garavini, Giuliano, After Empires. European Integration, Decolonization \& the Challenge from the Global South 1957-1986, Oxford: Oxford University Press, 2012

Garcia, Oscar Jose Martin, “The End of the Carnival': The UK and the Carnation Revolution in Portugal", Contemporary British History 29:2 (2015), pp. 199-221

Garthoff, Raymond L., Détente and Confrontation. American-Soviet Relations from Nixon to Reagan, Washington, DC: The Brookings Institution, revised edition 1994

Gasbarri, Flavia, "From the Sands of Ogaden to Black Hawk Down: The End of the Cold War in the Horn of Africa", Cold War History 18:1 (2018), pp. 73-89

Gasser, Hans Peter, "The International Committee of the Red Cross and its Development since 1945", in Jürg Martin Gabriel, Thomas Fischer (eds.), Swiss Foreign Policy, 1945-2002, Houndsmills: Palgrave Macmillan, 2003, pp. 105-126.

Gebru Tareke, "The Ethiopia-Domalia War of 1977 Revisited", The International Journal of African Historical Studies, 33:3 (2000), pp. 635-667

Gebru Tareke, The Ethiopian Revolution. War in the Horn of Africa, New Haven: Yale University Press, 2009

Gehler, Michael, "From Non-alignment to Neutrality: Austria's Transformation during the First East-West Détente, 1953-1958", Journal of Cold War Studies 7:4 (2005), pp. 104-136

Gehler, Michael; Steininger, Rolf, (eds.), Die Neutralen und die europäische Integration 1945-1995, Wien: Böhlau, 2000

George, Edward, The Cuban Intervention in Angola, 1965-1991. From Che Guevara to Cuito Canavale, London: Cass, 2005

Ghebali, Victor-Yves, La diplomatie de la détente: La CSCE, d'Helsinki à Vienne (19731989), Bruxelles: Emile Bruylant, 1989 
Gleijeses, Piero, "Truth or Credibility: Castro, Carter, and the Invasions of Shaba", The Transnational History Review 18:1 (1996), pp. 70-108

Gleijeses, Piero, Conflicting Missions. Havana, Washington, and Africa, 1959-1976, Chapel Hill: University of North Carolina Press, 2002

Gleijeses, Piero, Visions of Freedom. Havana, Pretoria, and the Struggle for Southern Africa, 1976-1991, Chapel Hill: The University of North Carolina Press, 2013

Glover, Nikolas, "Neutrality Unbound. Sweden, Foreign Aid and the Rise of the NonAligned Third World", in Sandra Bott, Jussi M. Hanhimäki, Janick Marina Schaufelbuehl, Marco Wyss (eds.), Neutrality and Neutralism in the Global Cold War. Between or Within the Blocs? London: Routledge, 2016, pp. 161-177

Gomes, Bernardino; de Sá, Tiago Moreira, Carlucci vs. Kissinger. The US and the Portuguese Revolution, Lanham: Lexington Books, 2011

Graber, Roger, Entwicklungshilfe und Exportförderung im Kalten Krieg: Interessen, Motive und Strategien der Schweizer Exportindustrie in Entwicklungsländern (19551965), Master thesis, University of Zurich, 2006

Graf, Christoph, "Die Schweiz und die Dritte Welt. Die Anerkennungspraxis und Beziehungsaufnahme der Schweiz gegenüber dekolonisierten aussereuropäischen Staaten sowie die Anfänge der schweizerischen Entwicklungshilfe nach 1945", Studien und Quellen 12 (1986), pp. 37-112

Guex, Sébastien, "Introduction. De la Suisse comme petit État faible: jalons pour sortir d'une image en trompe-l'oeil”, in Sébastien Guex (ed.), La Suisse et les Grandes puissances. 1914-1945. Relations économiques avec les États-Unis, la Grande-Bretagne, l'Allemagne et la France/Switzerland and the Great Powers. 1914-1945. Economic Relations with the United States, Great Britain, Germany and France, Genève: Librairie Droz, 1999, pp. 7-29

Guex, Sébastien, “The Origins of the Swiss Banking Secrecy Law and its Repercussion for Swiss Federal Policy”, Business History Review 74 (2000), pp. 237-266

Guex, Sébastien; Haver, Gianni, “James Bond contre - ou pour? - les gnomes de Zurich. L'image de la place financière suisse dans da série o07", in Françoise Hache-Bissette, Fabien Boully, Vincent Chenille (eds.), James Bond (2)007. Anatomie d'un mythe populaire, Paris: Bélin, 2007

Guex, Sébastien; Schaufelbuehl, Janick Marina, "Les vertus de l'ignorance. Enjeux et conflits autour des statistiques sociales et économiques en Suisse au XXe siècle", Économies et Sociétés 44:9 (2011), pp. 1555-1574

Guttmann, Aviva, The Origins of International Counterterrorism. Switzerland at the Forefront of Crisis Negotiations, Multilateral Diplomacy, and Intelligence Cooperation (1969-1977), Leiden: Brill, 2018

Gygax, David, La Suisse-South African Association (1956-200o). Un organe du capital helvétique en Afrique du Sud, Fribourg: Chaire d'histoire contemporaire de l'Université de Fribourg, 2001 
Hagen, Ruth, Expeditionen in den dunklen Kontinent: Die geografischen Gesellschaften der Schweiz und die wissenschaftliche Erforschung Afrikas, Saarbrücken: VDM, 2009

Häikiö, Martti, "Finland's Neutrality 1944-1994", in Michael Gehler, Rolf Steininger (eds.), Die Neutralen und die europäische Integration 1945-1995, Wien: Böhlau, 2000, pp. 199-217

Hakovirta, Harto, East-West Conflict and European Neutrality, Oxford: Clarendon Press, 1988

Halbeisen, Patrick; Straumann, Tobias, "Die Wirtschaftspolitik im internationalen Vergleich", in Patrick Halbeisen, Margrit Müller, Béatrice Veyrassat, Wirtschaftsgeschichte der Schweiz im 20. Jahrhundert, Basel: Schwabe, 2012, pp. 983-1075

Hanhimäki, Jussi M., "Détente in Europe, 1962-1975", in Melvyn P. Leffler, Odd Arne Westad (eds.), The Cambridge History of the Cold War. Volume II: Crises and Détente, Cambridge: Cambridge University Press, 2011, pp. 198-218

Hanhimäki, Jussi M., The Flawed Architect: Henry Kissinger and American Foreign Policy, Oxford: Oxford University Press, 2004

Hanhimäki, Jussi M., The Rise and Fall of Détente. American Foreign Policy and the Transformation of the Cold War, Washington, DC: Potomac Books, 2013

Harries, Patrick, Butterflies \& Barbarians. Swiss Missionaries \& Systems of Knowledge in South-East Africa, Oxford: James Currey, 2007

Haug, Hans, "Die Schweiz, die Rotkreuz- und Rothalbmondbewegung und das Internationale Komitee vom Roten Kreuz", in Alois Riklin, Hans Haug, Raymond Probst (eds.) Neues Handbuch der schweizerischen Aussenpolitik, Bern: Haupt, 1992, pp. $677-691$

Helgesson, Alf, Church, State and People in Mozambique. An Historical Study with Special Emphasis on Methodist Developments in the Inhambane Region, Uppsala: Swedish Institute of Missionary Research, 1994

Henrichson, Dag, Registratur AA.5. The Archive of the Solidarity Group Medic'Angola / Kämpfendes Afrika (Zurich, 1971 - 1988), Basel: Basler Afrika Bibliographien. Namibia Resource Centre \& Southern Africa Library, 2002

Henze, Paul B., Layers of Time. A History of Ethiopia, London: Hurst \& Company, 2000 Hofmann, Ursin, La politique d'aide au développement suisse pour le Tiers-monde. La relation entre la Confédération helvétique et la Banque africaine de développement entre intérêts propres et altruisme (1964-1975), unpublished Master thesis, University of Lausanne, 2011

Hohler, Stefan, Hans Ulrich Lenzlinger. Fluchthelfer, Abenteurer und Lebemann, Bern: Stämpfli, 2013

Holenstein, Anne-Marie; Renschler, Regula; Strahm, Rudolf, Entwicklung heisst Befreiung. Erinnerungen an die Pionierzeit der Erklärung von Bern (1968-1985), Zürich: Chronos, 2008

Holenstein, René, Was kümmert uns die Dritte Welt. Zur Geschichte der internationalen Solidarität in der Schweiz, Zürich: Chronos, 1998 
Holenstein, René, Wer langsam geht, kommt weit. Ein halbes Jahrhundert Schweizer Entwicklungshilfe, Zürich: Chronos, 2010

Hug, Peter, "Steuerflucht und die Legende vom antinazistischen Ursprung des Bankgeheimnisses. Funktion und Risiko der moralischen Überhöhung des Finanzplatzes Schweiz", in Jakob Tanner, Sigrid Weigel (eds.), Gedächnis, Geld und Gesetz. Vom Umgang mit der Vergangenheit des Zweiten Weltkrieges, Zürich:vdf Hochschulverlag AG an der ETH Zürich, 2002

Hug, Peter; Mesmer Beatrix, (eds.), Von der Entwicklungshilfe zur Entwicklungspolitik, Bern: SFA, 1993

Hughes, Geraint, "Soldiers of Misfortune: The Angolan War, the British Mercenary Intervention, and UK Policy towards Southern Africa, 1975-6", The International History Review 36:3 (2014), pp. 493-512

Humair, Cedric, "Commerce extérieur et politique commerciale aux 19e et 20 e siècles", Traverse 17:1 (2010), pp. 184-202

Humbert, Mathieu, "L'expansionnisme suisse en Afrique sub-saharienne au cours du XIXe siècle. Un aperçu”, Schweizerische Gesellschaft für Wirtschafts- und Sozialgeschichte/Société suisse d'histoire économique et sociale 29 (2015), pp. 145-161

Humbert, Mathieu, "Une défense discrète et flexible des intérêts économiques suisses. Les cas du Ghana et du Congo au début de leur indépendance", Relations internationales 163:3 (2015), pp. 63-79

Independent Commission of Experts Switzerland - Second World War (ed.), Switzerland, National Socialism and the Second World War. Final Report, Zurich: Pendo, 2002

Jackson, Donna R., "The Carter Administration and Somalia", Diplomatic History 31:4 (2007), pp. 703-721

Jackson, Donna R., "The Ogaden War and the Demise of Détente", The Annals of the American Academy of Political and Social Science 632:1 (2010), pp. 26-40

Jackson, Donna R., Jimmy Carter and the Horn of Africa. Cold War Policy in Ethiopia and Somalia, Jefferson, NC: McFarland, 2007

Jackson, Steven F., "China's Third World Foreign Policy: The Case of Angola and Mozambique, 1961-93", The China Quarterly 142 (1995), pp. 388-422

Jeannerat, Caroline; Morier-Genoud, Eric; Péclard, Didier, Embroiled. Swiss Churches, South Africa and Apartheid, Münster: Lit-Verlag, 2011

Jerneck, Magnus, "Sitting on the Balcony: American Responses, Strategic Dilemmas, and Swedish Criticism of the Vietnam War", Diplomacy \& Statecraft 24:3, pp. 404-426

Jerónimo, Miguel Bandeira; Pinto, António Costa, “A Modernizing Empire? Politics, Culture, and Economy in Portuguese Late Colonialism", in Miguel Bandeira Jerónimo, António Costa Pinto (eds.), The Ends of European Colonial Empires. Cases and Comparisons, Houndsmills: Palgrave Macmillan, 2015, pp. 51-80

Jerónimo, Miguel Bandeira; Pinto, António Costa, (eds.), The Ends of European Colonial Empires. Cases and Comparisons, Houndsmills: Palgrave Macmillan, 2015 
Jost, Hans Ulrich, "Origines, interprétations et usages de la 'neutralité helvétique", Matériaux pour l'histoire de notre temps 93 (2009), pp. 5-12

Jost, Hans Ulrich, "Switzerland's Atlantic Perspectives", in Marko Milivojevic, Pierre Maurer (eds.), Swiss Neutrality and Security:Armed Forces, National Defence and Foreign Policy, New York: Berg, 199o, pp. 110-121

Jost, Hans Ulrich, Politik und Wirtschaft im Krieg. Die Schweiz 1938-1948, Zürich: Chronos, 1998

Jost, Hans Ulrich; Ceni, Monique; Leimgruber, Matthieu, (eds.), Relations internationales et affaires étrangères suisses après 1945, Lausanne: Éditions Antipodes, 2006

Kälin, Walter, "Schweizerische Kriegsmaterialausfuhr im Spannungsfeld von Menschenrechten und Entwicklungszusammenarbeit", in Walther L. Bernecker, Thomas Fischer, (eds.), Unheimliche Geschäfte. Schweizer Rüstungsexporte nach Lateinamerika im 20. Jahrhundert, Zurich: Chronos, 1991, pp. 73-91

Kalt, Monica, Tiersmondismus in der Schweiz der 196oer und 1970er Jahre. Von der Barmherzigkeit zur Solidarität, Bern: Peter Lang, 2010

Kanet, Roger E., "The Superpower Quest for Empire: The Cold War and Soviet Support for 'Wars of National Liberation', Cold War History 6:3 (2006), pp. 331-352

Karlsson, Birgit, "Neutrality and Economy: The Redefining of Swedish Neutrality, 194652", Journal of Peace Research 32:1 (1995), pp. 37-48

Karsh, Efraim, Neutrality and Small States, London: Routledge, 1988

Katzenstein, Peter, Small States in World Markets. Industrial Policy in Europe, Ithaca: Cornell University Press, 1985

Kaufmann, Lyonel, "Guillaume Tell au Congo. L'expansion suisse au Congo belge (1930-196o)", Les Annuelles 5 (1994), pp. 43-94

Kaufmann, Urban, “'Nicht die ersten sein, aber vor den letzten handeln'. Grundsätze und Praxis der Anerkennung von Staaten und Regierungen durch die Schweiz (1945-1961)", in Antoine Fleury, Horst Möller, Hans-Peter Schwarz (eds.), Die Schweiz und Deutschland 1945-1961, Munich: R. Oldenbourg, 2004, pp. 69-87

Kaufmann, Urban, Auslandreisen der Schweizer Bundesräte 1919-1993. Die Gewöhnung an das Aussergewöhnliche, unpublished Master thesis, University of Fribourg, 1996

Keller, Edmond J., Revolutionary Ethiopia: From Empire to People's Republic, Bloomington: Indiana University Press, 1991

Keller, Florian, Botschafterporträts. Schweizer Botschafter in den "Zentren der Macht" zwischen 1945 und 1975, Zürich: Chronos, 2017

Kennes, Erik; Larmer, Miles, The Katangese Gendarmes and War in Central Africa, Bloomington: Indiana University Press, 2016

Klarer, Heinz, Die schweizerische Praxis der völkerrechtlichen Anerkennung, Zürich: Schulthess Polygraphischer Verlag, 1981

Klimke, Martin; Scharloth, Joachim, (eds.), 1968 in Europe. A History of Protest and Activism, New York: Palgrave Macmillan, 2008 
Kouvibidila, Gaston-Jonas, Histoire de la construction de l'Afrique, Paris: L'Harmattan, 2011

Kreis, Georg (ed.), Staatsschutz in der Schweiz. Die Entwicklung von 1935-1990. Eine multidisziplinäre Untersuchung im Auftrage des schweizerischen Bundesrates, Bern: Paul Haupt, 1993

Kreis, Georg, Die Schweiz und Südafrika 1948-1994. Schlussbericht des im Auftrag des Bundesrates durchgeführten NFP 42+, Bern: Haupt, 2005

Kuhn, Konrad J., “'Der Kampf der Entrechteten dort ist unser Kampf hier!' Entwicklungspolitisches Engagement und internationale Solidarität in der Schweiz", in Janick Marina Schaufelbuehl (ed.), 1968-1978. Ein bewegtes Jahrzehnt in der Schweiz, Zürich: Chronos, 2009, pp. 113-123

Kuhn, Konrad J., "Liberation Struggle and Humanitarian Aid: International Solidarity Movements and the 'Third World' in the 196os", in Samantha Christiansen, Zachary A. Scarlett (eds.), The Third World in the Global 196os, New York: Berghahn Books, 2013, pp. 69-85

Kuhn, Konrad J., Entwicklungspolitische Solidarität: die Dritte-Welt-Bewegung in der Schweiz zwischen Kritik und Politik 1975-1992, Zürich: Chronos, 2011

Kuhn, Konrad J.; Ziegler, Béatrice, “Die Schweiz und die Sklaverei: Zum Spannungsfeld zwischen Geschichtspolitik und Wissenschaft”, Traverse 16:1 (2009), pp. 116-130

Kurmann, Eliane, 'Affaires angolaises'. Die angolanischen Studenten in der Schweiz während dem Unabhängigkeitskampf 1961-1975, unpublished Master thesis, University of Fribourg, 2008

Laitin, David D.; Samatar, Said S., Somalia. Nation in Search of a State, Boulder: Westview Press, 1987

Larmer, Miles, "Local Conflicts in a Transnational War: the Katangese Gendarmes and the Shaba Wars of 1977-78", Cold War History 13:1 (2013), pp. 89-108

Latham, Michael E., "The Cold War in the Third World, 1963-1975" in Melvyn P. Leffler, Odd Arne Westad (eds.), The Cambridge History of the Cold War. Volume II: Crises and Détente, Cambridge: Cambridge University Press, 2011, pp. 258-280

Lefebvre, Jeffrey A., Arms for the Horn. U.S. Security Policy in Ethiopia and Somalia 19531991, Pittsburgh: University of Pittsburgh Press, 1991

Leffler, Melvyn P.; Westad, Odd Arne (eds.), The Cambridge History of the Cold War. Volume I: Origins, Cambridge: Cambridge University Press, 2011

Leffler, Melvyn P.; Westad, Odd Arne (eds.), The Cambridge History of the Cold War. Volume II: Crises and Détente, Cambridge: Cambridge University Press, 2011

Leffler, Melvyn P.; Westad, Odd Arne (eds.), The Cambridge History of the Cold War. Volume III: Endings, Cambridge: Cambridge University Press, 2011

Lenzin, René, 'Afrika macht oder bricht einen Mann': Soziales Verhalten und politische Einschätzung einer Kolonialgesellschaft am Beispiel der Schweizer in Ghana (19451966), Basel: Basler Afrika Bibliographien, 1999 
Lenzin, René, "Schweizer im kolonialen und postkolonialen Afrika. Statistische Übersicht und zwei Fallbeispiele", Studien und Quellen 28 (2002), pp. 299-324

Letsch, Rudolf, Rhodesien, die Vereinten Nationen und die Schweiz. Konzepte und Inkonsistenzen der Rhodesienpolitik, Herisau: Druck Schläpfer + Co. AG, 1983

Lewis, Ioan M., A Modern History of the Somali. Nation and State in the Horn of Africa, Oxford: James Currey, 4th edition, 2002

Linder, Adolphe, Die Schweizer in Mosambik 1721-1990, Capetown: Rondebosch, 1998

Little, Douglas, "The Cold War in the Middle East: Suez Crisis to Camp David Accords" in Melvyn P. Leffler, Odd Arne Westad (eds.), The Cambridge History of the Cold War. Volume II: Crises and Détente, Cambridge: Cambridge University Press, 2011, pp. 305-326

Lopes, Rui, "Accommodating and Confronting the Portuguese Dictatorship within NATO, 1970-4", The International History Review 38:3 (2016), pp. 305-326

Lopes, Rui, West Germany and the Portuguese Military Dictatorship, 1968-1974. Between Cold War and Colonialism, Basingstoke: Palgrave Macmillan, 2014

Lorenzini, Sara, "East-South Relations in the 1970s and the GDR Involvement in Africa: Between Bloc Loyalty and Self-interest", in Max Guderzo, Bruna Bagnato (eds.), The Globalization of the Cold War: Diplomacy and Local Confrontation, 1975-1985, London: Routledge, 2010, pp. 104-115

Lützelschwab, Claude, La Compagnie Genevoise des Colonies Suisses de Sétif (1853-1956): Un cas de colonisation privée en Algérie, Bern: Lang, 2006

MacQueen, Norrie, "Belated Decolonisation and UN Politics against the Backdrop of the Cold War. Portugal, Britain, and Guinea-Bissau's Proclamation of Independence", Journal of Cold War Studies 8:4 (2006), pp. 29-56

MacQueen, Norrie, "Portugal's First Domino: 'Pluricontinentalism' and Colonial War in Guiné-Bissau, 1963-1974”, Contemporary European History 8:2 (1999), pp. 209-230

MacQueen, Norrie, The Decolonization of Portuguese Africa. Metropolitan Revolution and the Dissolution of Empire, London and New York: Longman, 1997

MacQueen, Norrie; Oliveira, Pedro Aires, “'Grocer meets Butcher': Marcello Caetano's London Visit of 1973 and the Last Days of Portugal's Estado Novo", Cold War History 10:1 (2010), pp. 29-50

Magnin, Chantal, "Entwicklungshilfe für die Schweizer Wirtschaft. Der lange Weg zur Investitionsrisikogarantie, 196o-1970", in Peter Hug, Beatrix Mesmer (eds.), Von der Entwicklungshilfe zur Entwicklungspolitik, Bern: SFA, 1993, pp. 363-379

Makko, Aryo, "Sweden, Europe, and the Cold War: A Reappraisal", Journal of Cold War Studies 14:2 (2012), pp. 68-97

Malmborg, Mikael af, Neutrality and State-Building in Sweden, Basingstoke: Palgrave Macmillan, 2001

Mantovani, Mauro, Schweizerische Sicherheitspolitik im Kalten Krieg (1947-1963). Zwischen angelsächsischem Containment und Neutralitäts-Doktrin, Zürich: Orell Füssli, 1999 
Marcum, John A., The Angolan Revolution. Volume I: The Anatomy of an Explosion (1950-1962), Cambridge, MA: MIT Press, 1969

Marcum, John A., The Angolan Revolution. Volume II: Exile Politics and Guerrilla Warfare (1962-1976), Cambridge, MA: MIT Press, 1978

Mateus, Dalila Cabrita, A PIDE/DGS na Guerra Colonial (1961-1974), Lisbon: Terramar, 2004

Matter, Dominik, “'SOS Biafra'. Die Schweizerischen Aussenbeziehungen im Spannungsfeld des nigerianischen Bürgerkriegs 1967-1970", Bern: Diplomatische Dokumente der Schweiz (DDS), 2015

Matusevich, Maxim (ed.), Africa in Russia, Russia in Africa. Three Centuries of Encounters, Trenton: Africa World Press, 2007

Maxwell, Kenneth, The Making of Portuguese Democracy, Cambridge: Cambridge University Press, 1995

Mazower, Mark, Governing the World. The History of an Idea, London: Allen Lane, 2012, pp. 299-304

McMahon, Robert J. (ed.), The Cold War in the Third World, New York: Oxford University Press, 2013

McMahon, Robert J., "Introduction", in Robert J. McMahon (ed.), The Cold War in the Third World, New York: Oxford University Press, 2013, pp. 1-10

Meier, Lukas, Swiss Science, African Decolonization and the Rise of Global Health, 19402010, Basel: Schwabe, 2014

Meister, Magnus, Les Trente Glorieuses et la crise des années 1970 en Suisse. Une politique conjoncturelle et économique au service de l'internationalisation de l'économie suisse, unpublished Master thesis, University of Geneva, 2013

Meister, Magnus, Swiss Economic and Political Relations with Israel, Egypt and Syria During the Arab-Israeli Conflicts (1967-1983), unpublished PhD thesis, University of Lausanne, 2019

Middlemas, Keith, Cabora Bassa. Engineering and Politics in Southern Africa, London: Weidenfeld and Nicolson, 1975

Milivojevic, Marko; Maurer, Pierre (eds.), Swiss Neutrality and Security: Armed Forces, National Defence and Foreign Policy, New York: Berg, 1990

Miller, Jamie, An African Volk. The Apartheid Regime and its Search for Survival, New York: Oxford University Press, 2016

Miller, Jamie, "Yes, Minister. Reassessing South Africa's Intervention in the Angolan Civil War, 1975-1976", Journal of Cold War Studies 15:3 (2013), pp. 4-33

Minder, Patrick, La Suisse coloniale. Les représentations de l'Afrique et des Africains en Suisse au temps des colonies (1880-1939) Bern: Peter Lang, 2011

Misteli, Samuel, "Der UNCTAD-Moment. Die Entstehung des Nord-Süd-Konflikts und die Politisierung des Schweizer Entwicklungsdiskurses", in Sara Elmer, Konrad J. Kuhn, Daniel Speich Chassé, Itinera. Handlungsfeld Entwicklung. Schweizer Erwartungen und Erfahrungen in der Geschichte der Entwicklungszusammenarbeit/ 
Le champ d'action "développement". Attentes et expériences suisses dans le travail de développement, Basel: Schwabe, 2014, pp. 185-211

Mitchell, Nancy, Jimmy Carter in Africa. Race and the Cold War, Washington DC: Woodrow Wilson Center Press, 2016

Möckli, Daniel, European Foreign Policy during the Cold War. Heath, Brandt, Pompidou and the Dream of Political Unity, London: I.B. Tauris, 2009

Möckli, Daniel, Neutralität, Solidarität, Sonderfall. Die Konzeptionierung der schweizerischen Aussenpolitik der Nachkriegszeit, 1943-1947, Zurich: Forschungsstelle für Sicherheitspolitik und Konfliktanalyse der ETH Zürich, 2000

Monnier, Nicolas, Stratégie missionnaire et tactiques d'appropriation indigènes. La mission romande au Mozambique 1888-1896, Lausanne: Le Fait missionnaire, 1995

Moores, Simon, “Neutral on our Side': US Policy towards Sweden during the Eisenhower Administration", Cold War History 2:3 (2002), pp. 29-62

Moosmann, Reto, "Die Verwässerung des 'generellen Ausfuhrverbots' im Dienste von Armee und Rüstungsindustrie. Zur Kriegsmaterialausfuhrpolitik des Bundesrates in den 195oer und 6oer Jahren", Schweizerische Zeitschrift für Geschichte 56:2 (2006), pp. $15^{2-167}$

Morgenstierne, Christopher Munthe, Denmark and National Liberation in Southern Africa. A Flexible Response, Uppsala: Nordiska Afrikainstitutet, 2003

Morier-Genoud, Eric, Of God and Caesar. The Relation Between Christian Churches and the State in Post-Colonial Mozambique, 1974-1981, Lausanne: Le Fait Missionnaire, 1996

Morier-Genoud, Eric, The Catholic Church, Religious Orders and the Making of Politics in Colonial Mozambique: The Case of the Diocese of Beira, 1940-1974, Ann Arbor: UMI, 2006

Muehlenbeck, Philip E., Betting on the Africans. John F. Kennedy's Courting of African Nationalist Leaders, New York: Oxford University Press, 2012

Mueller, Wolfgang, "The US and Permanent Neutrality in the Cold War", Journal of Cold War Studies 18:4 (2016), pp. 148-179

Mueller, Wolfgang, A Good Example of Peaceful Coexistence? The Soviet Union, Austria, and Neutrality, 1955-1991, Wien: Verlag der Österreichischen Akademie der Wissenschaften, 2011

Neff, Stephen C., The Rights and Duties of Neutrals: A General History, Manchester: Manchester University Press, 2000

Neval, Daniel Alexander, 'Mit Atombomben bis nach Moskau'. Gegenseitige Wahrnehmung der Schweiz und des Ostblocks im Kalten Krieg 1945-1968, Zürich: Chronos, 2003

Newitt, Malyn, "Mozambique", in Patrick Chabal, A History of Postcolonial Lusophone Africa, Bloomington: Indiana University Press, 2002, pp. 185-235 
Nguyen, Lien-Hang T., "The Vietnam Decade: The Global Shock of the War", in Niall Ferguson et al. (eds.), The Shock of the Global. The 1970s in Perspective, Cambridge MA: The Belknap Press of Harvard University Press, 2010, pp. 159-172

Nilsson, Mikael; Wyss, Marco, "The Armed Neutrality Paradox: Sweden and Switzerland in US Cold War Armaments Policy", Journal of Contemporary History 51:2 (2016), pp. 335-363

O'Sullivan, Kevin, Ireland, Africa and the End of Empire. Small State Identity in the Cold War 1955-1975, Manchester: Manchester University Press, 2012

Oliveira, Pedro Aires, "Live and Let Live: Britain and Portugal's Imperial Endgame (1945-75)", Portuguese Studies 29:2 (2013), pp. 186-208

Oliveira, Pedro Aires, "O Flanco Sul sob Tensão. A NATO e a Revolução Portuguesa, 1974-1975”, Relações Internacionais 21 (2013), pp. 61-78

Onslow, Sue, “'We Must Gain Time': South Africa, Rhodesia and the Kissinger Initiative of 1976", South African Historical Journal 56 (2006), pp. 123-153

Onslow, Sue, "South Africa and the Owen/Vance Plan of 1977", South African Historical Journal 51 (2004), pp. 130-158

Onslow, Sue, "The Cold War in Southern Africa. White Power, Black Nationalism and External Interventions", in Sue Onslow (ed.), Cold War in Southern Africa. White Power, Black Liberation, London: Routledge, 2009, pp. 9-34

Page, Steve, La Suisse et le Ghana de Nkrumah: une présence économique et diplomatique à l'épreuve de la décolonisation (1950-1970), unpublished Master thesis, University of Fribourg, 2006

Page, Steve, Le Nigeria et la Suisse, des affaires d'indépendance. Commerce, diplomatie et coopération 1930-1980, Bern: Peter Lang, 2016

Patman, Robert G., The Soviet Union in the Horn of Africa. The Diplomacy of Intervention and Disengagement, Cambridge: Cambridge University Press, 2009 (1990)

Payton, Gary D., "The Somali Coup of 1969: The Case for Soviet Complicity", The Journal of Modern African Studies 18:3 (1980), pp. 493-508

Péclard, Didier, Ethos missionnaire et esprit du capitalisme. La Mission philafricaine en Angola 1897-1907, Lausanne: Le Fait missionnaire, 1995

Pellaux, Jean-Marie, L'affaire Pilatus. Les milieux engagés et la Suisse officielle face aux exportations d'armes (1978-1985), Fribourg: Université de Fribourg, 2008

Pereira, Nuno, "Le mouvement suisse de 1968 et le Portugal: de la dictature à la révolution (1962-1975)", in Janick Marina Schaufelbuehl (ed.), 1968-1978. Ein bewegtes Jahrzehnt in der Schweiz, Zürich: Chronos, 2009, pp. 147-16o

Pereira, Nuno, Anti-impérialisme et nouvelle gauche radicale dans la Suisse des années 1968, unpublished PhD thesis, University of Lausanne, 2015

Perrenoud, Marc, “La place financière suisse en tant qu'instrument de la politique étrangère helvétique", Relations internationales 121 (2005), pp. 25-42 
Perrenoud, Marc, "Léconomie suisse et la neutralité à géometrie variable", Matériaux pour l'histoire de notre temps 93 (2009), pp. 77-86

Perrenoud, Marc, "Les relations de la Suisse avec l'Afrique lors de la décolonisation et des débuts de la coopération au développement", Revue internationale de politique de développement, 1 (2010), pp. 81-98

Perrenoud, Marc, "Politique économique et relations extérieures", Traverse 17:1 (2010), pp. 171-183

Perrenoud, Marc, "Guerres, indépendances, neutralité et opportunités: quelques jalons historiques pour l'analyse des relations économiques de la Suisse avec l'Afrique (des années 1920 aux années 1960)", in Sandra Bott et al. (ed.), Suisse - Afrique (18e - 20e siècles): De la traite des Noirs à la fin du régime de l'apartheid, Münster: Lit Verlag 2005, pp. 85-104

Pitcher, M. Anne, Transforming Mozambique. The Politics of Privatization, 1975-2000, Cambridge: Cambridge University Press, 2002

Powell, Nathaniel Kinsey, "The UNHCR and Zimbabwean Refugees in Mozambique, 1975-1980", Refugee Survey Quarterly 32:4 (2013), pp. 41-65

Powell, Nathaniel Kinsey, "La France, les Etats-Unis et la Force interafricaine au Zaïre (1978-1979)", Relations internationales 150:2 (2012), pp. 71-83

Prasad, Vijay, The Darker Nations. A People's History of the Third World, New York: The New Press, 2007

Purtschert, Patricia; Fischer-Tiné, Harald (eds.), Colonial Switzerland. Rethinking Colonialism from the Margins, Basingstoke: Palgrave Macmillan, 2015

Purtschert, Patricia; Fischer-Tiné, Harald, "Introduction. The End of Innocence: Debating Colonialism in Switzerland”, in Patricia Purtschert, Harald Fischer-Tiné (eds.), Colonial Switzerland. Rethinking Colonialism from the Margins, Basingstoke: Palgrave Macmillan, 2015, pp. 1-25

Purtschert, Patricia; Lüthi, Barbara; Falk Francesca, "Eine Bestandesaufnahme der postkolonialen Schweiz", in Patricia Purtschert, Barbara Lüthi, Francesca Falk (eds.), Postkoloniale Schweiz. Formen und Folgen eines Kolonialismus ohne Kolonien, Bielefeld: Transcript, 2012, pp. 13-63

Reis, Bruno Cardoso, "Portugal and the UN: A Rogue State Resisting the Norm of Decolonization (1956-1974)", Portuguese Studies 29:2 (2013), pp. 251-276

Reis, Bruno Cardoso; Oliveira, Pedro Aires, "Cutting Heads or Winning Hearts: Late Colonial Portuguese Counterinsurgency and the Wiriyamu Massacre of 1972", Civil Wars 14:1 (2012), pp. 80-103

Reis, Bruno Cardoso; Oliveira, Pedro Aires, "Reply to Mustafah Dhada", Civil Wars 15:4 (2013)

Rentola, Kimmo, "From Half-Adversary to Half-Ally: Finland in Soviet Policy, 19531958", Cold War History 1:1 (2000), pp. 75-102 
Rial, Jacques, Le bicorne et la plume. Les publications de diplomates suisses de 1848 à nos jours. Un essai de bibliographie, Malta and Geneva: DiploFoundation, Graduate Institute of International and Development Studies, 2008

Ribeiro, Tiago, L'attitude de la Confédération suisse vis-à-vis des mouvements indépendantistes angolais (1960-1975), unpublished Master thesis, University of Lausanne, 2011

Riklin, Alois; Haug, Hans; Probst, Raymond (eds.), Neues Handbuch der schweizerischen Aussenpolitik, Bern: Haupt, 1992

Rodrigues, Luís Nuno, “The International Dimensions of Portuguese Colonial Crisis", in Miguel Bandeira Jerónimo, António Costa Pinto (eds.), The Ends of European Colonial Empires. Cases and Comparisons, Houndsmills: Palgrave Macmillan, 2015, pp. $243^{-267}$

Rodrigues, Luís Nuno, “The United States and Portuguese Decolonization”, Portuguese Studies 29:2 (2013), pp. 164-185

Rohrbasser, Charles, L'œuvre sociale de la Mission Suisse au Mozambique, unpublished Master thesis, University of Lausanne, 1991

Rosin, Philip, Die Schweiz im KSZE-Prozess 1972-1983. Einfluss durch Neutralität, München: Oldenbourg Verlag, 2014

Ross, John F. L., Neutrality and International Sanctions. Sweden, Switzerland and Collective Security, New York: Praeger, 1989

Rossinelli, Fabio, "Sociétés de géographie et impérialisme suisse au 19e siècle. Un tour d'horizon et deux exemples représentatifs", Schweizerische Zeitschrift für Geschichte 67:1 (2017), pp. 1-19

Ruddy, Michael T., "European Integration, the Neutrals, and U.S. Security Interests: From the Marshall Plan to the Rome Treaties", in Michael Gehler, Rolf Steininger, (eds.), Die Neutralen und die europäische Integration 1945-1995, Wien: Böhlau, 2000, pp. $13^{-28}$

Ruggenthaler, Peter, The Concept of Neutrality in Stalin's Foreign Policy, Latham: Lexington Books, 2015

Sandoz, Yves, "La Suisse et le droit international humanitaire, en particulier les conventions de Genève pour la protection des victimes des conflits armés", in Alois Riklin, Hans Haug, Raymond Probst (eds.), Neues Handbuch der schweizerischen Aussenpolitik, Bern et al.: Verlag Paul Haupt, 1992, pp. 247-263

Sargent, Daniel J., "The United States and Globalization in the 1970s", in Niall Ferguson et al. (eds.), The Shock of the Global. The 1970s in Perspective, Cambridge, MA: The Belknap Press of Harvard University Press, 2010, pp. 49-64

Saunders, Chris; Onslow, Sue, "The Cold War and Southern Africa”, in Melvyn P. Leffler, Odd Arne Westad (eds.), The Cambridge History of the Cold War. Volume III: Endings, Cambridge: Cambridge University Press, 2011, pp. 222-243 
Schaller, André, Neutralität im West-Ost Handel: Das Hotz-Linder Agreement vom 23.Juli 1951, Bern: Haupt, 1987

Schär, Manuel, "Wie entwickeln wir die 'Dritte Welt'? Kontinuitäten und Brüche im Entwicklungsverständnis um 1968 in der Schweiz”, in Janick Marina Schaufelbuehl (ed.), 1968-1978. Ein bewegtes Jahrzehnt in der Schweiz, Zürich: Chronos, 2009, pp. 99-111

Schaufelbuehl, Janick Marina (ed.), 1968-1978. Ein bewegtes Jahrzehnt in der Schweiz, Zürich: Chronos, 2009

Schaufelbuehl, Janick Marina, La France et la Suisse ou la force du petit. Évasion fiscale, relations commerciales et financières (1940-1954), Paris: Presses de Sciences Po, 2009

Schaufelbuehl, Janick Marina; König Mario (eds.), Traverse. Schweiz-USA im kalten Krieg/Suisse-USA dans la guerre froide, 16:2 (2009)

Schaufelbuehl, Janick Marina; Wyss, Marco; Bott, Sandra, "Choosing Sides in the Global Cold War: Switzerland, Neutrality, and the Divided States of Korea and Vietnam", The International History Review 37:5 (2015), pp. 1014-1036

Scherer, Christian, Durch die tiefsten Tiefen des Wellentals. Die äthiopische Revolution in den Politischen Berichten der Schweizerischen Botschaft in Addis Abeba, 1970-1975, unpublished Master thesis, University of Bern, 2009

Schmid, Patrick, Medicine, Faith and Politics in Agogo. A History of Health Care Delivery in Rural Ghana, ca. 1925 to 1980, Zürich: LIT Verlag, 2018

Schmidl, Erwin A., "Lukewarm Neutrality in a Cold War? The Case of Austria", Journal of Cold War Studies 18:4 (2016), pp. 36-50

Schneidman, Witney W., Engaging Africa. Washington and the Fall of Portugal's Colonial Empire, Dallas: University Press of America, 2004

Schulzinger, Robert D., "Détente in the Nixon-Ford Years, 1969-1976", in Melvyn P. Leffler, Odd Arne Westad (eds.), The Cambridge History of the Cold War. Volume II: Crises and Détente, Cambridge: Cambridge University Press, 2011, pp. 373-394

Schümperli, Catherine, La politique suisse de solidarité internationale. De la coopération au développement global, Lausanne: Presses polytechniques et universitaires romandes, 2007

Schuwey, Jérôme, La Suisse et la Guinée de Sékou Touré. Les enjeux de la Coopération technique au lendemain de l'indépendance (1958-1974), unpublished Master thesis, University of Lausanne, 2011

Schwager, Laure, La Suisse et ses liens politiques et économiques avec l'Angola pendant la Guerre froide (1974-1979), unpublished Master thesis, University of Lausanne, 2014

Seleti, Yonah N., "The Development of Dependent Capitalism in Portuguese Africa", in Zbigniew A. Konczacki, Jane L. Parpart, Timothy Shaw (eds.), Studies in the Economic History of Southern Africa. Volume I: The Front-Line States, London: Frank Cass, 1990, pp. 30-74 
Sellström, Tor, Sweden and National Liberation in Southern Africa. Volume I: Formation of a Popular Opinion (1950-1970), Uppsala: Nordiska Afrikainstitutet, 1999

Sellström, Tor, Sweden and National Liberation in Southern Africa. Volume II: Solidarity and Assistance 1970-1994, Uppsala: Nordiska Afrikainstitutet, 2002

Shiferaw Jammo, "An Overview of the Economy 1941-74", in Shiferaw Bekele, An Economic History of Ethiopia, Vol. I: The Imperial Era 1941-74, Dakar: CODE SRIA, 1995

Shubin, Vladimir, "Unsung Heroes: The Soviet Military and the Liberation of Southern Africa", Cold War History 7:2 (2007), pp. 251-262

Shubin, Vladimir, The Hot 'Cold War'. The USSR in Southern Africa, London: Pluto Press, 2008

Skenderovic, Damir; Späti, Christina, Die 1968er-Jahre in der Schweiz. Aufbruch in Politik und Kultur, Baden: Hier + jetzt, 2012

Soiri, Iina; Peltola, Pekka, Finland and National Liberation in Southern Africa, Stockholm: Nordiska Afrikainstitutet, 1999

Stauffiger, Rahel, 'Behind the Scenes'. Die Gesellschaft Schweiz-Rhodesien zwischen diskreter Beziehungspflege und offizieller Schweizer Rhodesienpolitik, unpublished Master thesis, University of Fribourg, 2018

STC, Trade Division (eds.), Schweiz-Mozambique. 30 Jahre bilaterale Zusammenarbeit von 1979 bis 2009, Bern: STC, 2009

Steinemann, Andrea, Medic’Angola und Komitee Südliches Afrika. Über das Entstehen, die Veränderung und das Verschwinden einer Schweizer Solidaritätsgruppe in den 1970er Jahren, unpublished Master thesis, University of Zurich, 2014

Stettler, Niklaus; Haenger, Peter; Labhardt, Robert, Baumwolle, Sklaven und Kredite: die Basler Welthandelsfirma Christoph Burckhardt \& Cie. In revolutionärer Zeit (17891815), Basel: Merian, 2004

Stone, Glyn, "Britain and Portuguese Africa, 1961-65", The Journal of Imperial and Commonwealth History 28:3 (2000), pp. 169-192

Stone, Glyn, "Britain and the Angolan Revolt of 1961", The Journal of Imperial and Commonwealth History 27:1 (1999), pp. 109-137

Storkmann, Klaus, Geheime Solidarität: Militärbeziehungen und Militärhilfen der DDR in die 'Dritte Welt', Berlin: Ch. Links Verlag, 2012, pp. 243-384

Stössel, Gian-Luca, Kriegsmaterial und Solidarität - Die Schweiz und der Biafrakrieg. Die Bemühungen der Schweiz um Linderung der humanitären Auswirkungen des Biafrakriegs und die Bührle-Affäre, Saarbrücken: VD M Verlag Dr. Müller, 2011

Suri, Jeremy, Power and Protest. Global Revolution and the Rise of Détente, Cambridge, MA: Harvard University Press, 2005

Telepneva, Natalia, Our Sacred Duty: The Soviet Union, the Liberation Movements in the Portuguese Colonies, and the Cold War, 1961-1975, PhD thesis, Open Access, The London School of Economics and Political Science, 2014 
Thomson, Alex, U.S. Foreign Policy Towards Apartheid South Africa, 1948-1994. Conflict of Interests, New York: Palgrave Macmillan, 2008

Tobler, Ruedi, "Wenn Schweizer Kanonen auf IKRK-Flugzeuge schiessen. Der Bührle Skandal”, in Heinz Looser et al. (eds)., Die Schweiz und ihre Skandale, Zürich: Limmat Verlag, 1995, pp. 93-106

Trachsler, Daniel, "Neutralität, Solidarität und Kalter Krieg: Die Entwicklungshilfe als aussenpolitisches Instrument in der Ära Petitpierre, 1945-1961" in Sara Elmer, Konrad J. Kuhn, Daniel Speich Chassé, Itinera. Handlungsfeld Entwicklung. Schweizer Erwartungen und Erfahrungen in der Geschichte der Entwicklungszusammenarbeit/ Le champ d'action "développement". Attentes et expériences suisses dans le travail de développement, Basel: Schwabe, 2014, pp. 167-183

Trachsler, Daniel, Bundesrat Max Petitpierre. Schweizerische Aussenpolitik im Kalten Krieg 1945-1961, Zurich, NZZ, 2011

Trachsler, Daniel, Neutral zwischen Ost und West? Infragestellung und Konsolidierung der schweizerischen Neutralitätspolitik durch den Beginn des Kalten Krieges, 19471952, Zürich: Forschungsstelle für Sicherheitspolitik und Konfliktanalyse ETH, 2002

Ulrich, Mathias, 'Die Sache Rhodesiens in der Schweiz vertreten'. Funktion und Netzwerk der Gesellschaft Schweiz-Rhodesien, 1965-1980, unpublished Master thesis, University of Zurich, 2019

Van Dongen, Luc, «La Suisse dans les rets de l'anticommunisme transnational durant la Guerre froide: réflexions et jalons", in Sandra Bott, Janick Marina Schaufelbuehl, Sacha Zala (eds.), Itinera. Die internationale Schweiz in der Zeit des Kalten Krieges/ Relations internationales de la Suisse durant la Guerre froide, Basel: Schwabe, 2011, pp. $17-30$

Van Dongen, Luc; Roulin, Stéphanie; Scott-Smith, Giles (eds.), Transnational Anti-Communism and the Cold War. Agents, Activities, and Networks, Basingstoke: Palgrave Macmillan, 2014

Varsori, Antonio, "Crisis and Stabilization in Southern Europe during the 1970s: Western Strategy, European Instruments", Journal of European Integration History 1 (2009), pp. 5-14

Villaume, Poul; Mariager, Rasmus; Porsdam, Helle (eds.), The 'Long 1970s'. Human Rights, East-West Détente and Transnational Relations, Farnham: Ashgate, 2016

Villaume, Poul; Westad, Odd Arne (eds.), Perforating the Iron Curtain. European Détente, Transatlantic Relations, and the Cold War, 1965-1985, Copenhagen: Museum Tusculanum Press, 2010

Vonèche Cardia, Isabelle, Neutralité et engagement. Les relations entre le Comité international de la Croix-Rouge (CICR) et le Gouvernement suisse 1938-1945, Lausanne: SHSR, 2012

Wagner, Tilo, "Portugal and the German Democratic Republic during the Carnation Revolution", Portuguese Journal of Social Science 7:1 (2008), pp. 37-47 
Waldburger, Daniele; Zürcher, Lukas; Scheidegger, Urs, 'Im Dienst der Menschheit'. Meilensteine der Schweizer Entwicklungszusammenarbeit seit 1945, Bern: Haupt, 2012 Walraven, Klaas van, Dreams of Power. The Role of the Organization of African Unity in the Politics of Africa, 1963-1993, Aldershot: Ashgate Publishing, 1999

Westad, Odd Arne, The Global Cold War: Third World Interventions and the Making of Our Times, Cambridge: Cambridge University Press, 2005

Widmer, Sabina, "D’une “neutralité abstentionniste” à une solidarité instrumentalisée: L'établissement de relations diplomatiques entre la Suisse et le Mozambique", Relations internationales 163:3 (2015), pp. 81-94

Widmer, Sabina, "Neutrality challenged in a Cold War Conflict: Switzerland, the International Committee of the Red Cross, and the Angolan War", Cold War History 18:2 (2018), pp. 203-220

Widmer, Sabina, "Switzerland's Neutrality Policy in Southern Africa on the Defensive: The Swiss Government's Reactions to Non-State Actors' Solidarity with the Independence Struggles in the Portuguese Colonies, 1968-1974", Afriche e Orienti 19:3 (2017), pp. 101-114

Widmer, Thomas; Hirschi, Christian, Stabilität im Wandel. Gestaltung der schweizerischen Südafrikapolitikvon 1968 bis 1994, Zürich: Verlag Rüegger, 2005

Wirz, Albert, "Die humanitäre Schweiz im Spannungsfeld zwischen Philanthropie und Kolonialismus: Gustave Moynier, Afrika und das IKRK", Traverse 5 (1998), pp. 95-110 Woodroofe, Louise, 'Buried in the Sands of the Ogaden'. The United States, the Horn of Africa, and the Demise of Détente, Kent, Ohio: The Kent State University Press, 2013

Wylie, Neville, "Switzerland: a neutral of distinction?" In Neville Wylie (ed.), European Neutrals and Non-Belligerents during the Second World War, Cambridge: Cambridge University Press, 2002, pp. 331-354

Wylie, Neville; Wyss, Marco, "Neutrality 'de jour': Switzerland and the Italo-Abyssinian War of 1935-6" in Frank McDonough (ed.), The Origins of the Second World War. An International Perspective, London: Continuum, 2011

Wyss, Marco, "Neutrality in the Early Cold War: Swiss Arms Imports and Neutrality", Cold War History 12:1 (2012), pp. 25-49

Wyss, Marco, Arms Transfers, Neutrality and Britain's Role in the Cold War: Anglo-Swiss Relations 1945-1958, Leiden: Brill, 2013

Wyss, Marco; Hanhimäki, Jussi M.; Bott, Sandra; Schaufelbuehl, Janick Marina, "Introduction. A Tightrope Walk - Neutrality and Neutralism in the Global Cold War", in Sandra Bott, Jussi M. Hanhimäki, Janick Marina Schaufelbuehl, Marco Wyss (eds.), Neutrality and Neutralism in the Global Cold War. Between or Within the Blocs? London: Routledge, 2016, pp. 1-14

Yordanov, Radoslav A., The Soviet Union and the Horn of Africa during the Cold War. Between Ideology and Pragmatism, Lanham: Lexington Books, 2016

Zeller, Christian, Globalisierungsstrategien - Der Weg von Novartis, Berlin: Springer, 2001 
Zubok, Vladislav M., "The Soviet Attitude towards the European Neutrals during the Cold War", in Michael Gehler, Rolf Steininger (eds.), Die Neutralen und die europäische Integration 1945-1995, Wien: Böhlau, 2000, pp. 29-43

Zürcher, Lukas, „So fanden wir auf der Karte diesen kleinen Staat': Globale Positionierung und lokale Entwicklungsfantasien der Schweiz in Rwanda in den 196oer Jahren“, in Hubertus Büschel, Daniel Speich (eds.), Entwicklungswelten. Globalgeschichte der Entwicklungszusammenarbeit, Frankfurt: Campus Verlag, 2009, pp. 275-309

Zürcher, Lukas, Die Schweiz in Ruanda. Mission, Entwicklungshilfe und Nationale Selbstbestätigung (1900-1975), Zurich: Chronos, 2014 


\section{Index}

24 Heures 134

Abegg Pharma 63

Action Portugal et Afrique australe

(APAA) 136, 141-142

Administration Division (AD) 35, 93, 223

Advisory Commission on Switzerland's

Relations with the UN 188, 217

Africa Institute 134

African Solidarity Insurance Co. 179-180

Afrika Komitee Basel $112 \mathrm{n}$

Ageca 181

Agreement on the Prevention of Nuclear War 149

aid (foreign) 4, 6, 10, 14, 16, 18, 25-26, 29-33,

35 , 37-40, 46, 49, 66, 73-75, 77-78, 81-

$82,87,89-92,94,109-110,117-118,126$,

$128,130,137,139,143,145,154,157,159$,

165-167, 174, 176, 178, 180, 183-184, 189,

191, 194-196, 198-203, 205, 207, 109-211,

216, 219, 224-229, 238, 240-241, 246,

251-258, 261, 272, 287, 290-293, 296,

299-300, 305, 310-314, 319

Aldrich, George W. 102, 106

Algeria 1 1, 29-30, 42, 45, 88, 173-174, 30on

Algerian War 29-30, 42, 47

Alliance missionnaire évangélique 273

Almeida, António de 64

Alpina Investments AG 64

Alusuisse 272

Alves, Nito 272

Alvor Agreement ～204-205, 247

Aman Mikael Andom $\quad$ 153, 161, 165, 168-169,

$$
\text { 171, } 173
$$

Amin, Idi 262

Amnesty International 129

Amstein, André 112

Andargachew Tiruneh 178

André \& Cie $\quad 51-52,58-59,181$

André, Jean 59, 181

Andrié, Georges 127-128, 130

Angola 2-4, 12, 15-19, 24-26, 33, 40-43, $46-53,55^{-66,72,74,78,83,93-94,}$ 107, 110-112, 114, 116, 118, 121, 133, 143, 145-146, 148, 156, 186-187, 189-19o,
192, 196-198, 200, 204-208, 211-214, 216, 219, 221-223, 225, 230, 232-237, 242, 244-276, 278-281, 283, 290, 294, 3०6-307, 309-313, 317-319

Angolan War 14, 16-18, 26, 49, 148, 154, 157, 197, 211-212, 217, 223, 225, 242, 244-286, 288, 306-307, 309-314

Anti-Apartheid Movement 92 in Geneva 110-111, 121 in Switzerland 90, 111, 188, 190-191 in the UK 111

Anti-Colonialism, see colonialism

Anti-Communism 6, 157-158, 204

Apartheid regime, see South Africa

Arab League 104

Arbeitsgruppe Dritte Welt ( $\left.\mathrm{AG}_{3} \mathrm{~W}\right)$ 111-112, 136

Archiv für Zeitgeschichte (AfZ) 23

Armed Forces Committee (Ethiopia), see Derg

arms sales $36,42,68,161,18$ o, 247-248, 26o, 284-286

Switzerland $18,65,79,113-119,143$, 248-249-310

Artho, Walter 48

ASEA 122-123

Aubert, Pierre ２6-27, 296-297, 299-304, 3०8-309, 319

Austria $5,8,11,26,32,87,93,111,162$, 199-200, 202, 214, 224, 242, 272, 316

Availability (principle of) $6,75,251,312$, see also good offices

Awash Dam 59

Azores 42,69

Balair 255

Banco de Portugal 195

Bandung 70

Bank for International Settlements (BIS) 196

banking secret $\quad 164-176,184,315$

Basler Afrika Bibliographien. Namibia Resource Centre \& Southern Africa Library (ВАВ) 24

Beira Trading Co. Ltd 63 
Belgium 9-10, 29, 93, 269, 274, 301

Berlin Crisis 69

Biafra War 109, 116-117, 143, 252, 254

Bilate Agricultural Estate $\quad 59,160,181$

Boeing 270

Bohnert, Fritz $\quad$ 228, 287-293

Bott, Sandra 11

Brandt, Willy 69

Brazil 4O, 44, 71, 198, 223n, 269

Bréchet, Rodolphe 133

Bretton Woods system 10, 245, 317

Brezhnev, Leonid 70,149

Brzezinski, Zbigniew $\quad$ 245, 297

Bridler \& Co 63,132

Britain, see United Kingdom

British Somaliland Protectorate, see Somalia

Broger, Raymond 244, 276

Brown Boveri \& Cie (BBC) 24, 62, 120,

122-125, 143, 230-231

ввC Mannheim 120, 122, 125, 301-3O2

Brown, Gillian G. 136

Brunner, Edouard 86

Bugalho, Eduardo Manuel Fernandes 88, 130, 139-140

Bühler 230

Bühler, Hans $\quad 81,122$

Bührle scandal 116-117, 119, 143

Bührle, Emil 36, 168

Bureau for the Placement and Education of African Refugees (BPEAR) 91-92

Burkina Faso 300-301

Cabinda 266

Cabora Bassa Dam $\quad 62,83,85,111,113$,

$$
119-125,128,143,231
$$

Caetano, Marcello $\quad 72,76,131-133,135^{-136}$, 186

Cafex Private Ltd. Co $\quad 59,182$

Callaghan, James 280

Camenzind, Robert $\quad 35,155^{-157}$

Cameroon 1, 85n, 88, 300-301

Cape Verde $40,72,187$

Caritas 49

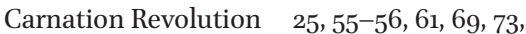
$77,87,91,107,111,124,143,146,187-197$, 200, 230, 232, 235, 250, 266

Carter administration $\quad 17-18,183,244-245$, 274, 285-286, 295-296

Carter, Jimmy $\quad 285,294,297$
Castro, Fidel $\quad 286$

Catholic Church 125-126, 220

Celio, Nello $\quad$ 1-2, 38-39, 88, 107-108, 139

Central Intelligence Agency (CIA) 161, 169, $261,275,286,247,250$

Centre Europe-Tiers Monde (CETIM) 188

Chaney, Louis 137,190

Chevallaz, Georges-André $\quad$ 138, 140, 174, 272

Chichava, Sérgio Inácio $\quad 65,126$

Chile 142

China see People's Republic of China, Republic of China

Chissano, Joaquim 221-222, 237

Christian Peace Service $121,136,138,144$

Ciba-Geigy $\quad 24,58,62,181,230-232,234-237$, 250, 270, 301-302

City Stores Ltd 63

Coordinating Committee of the Armed Forces, Police, and Territorial Army, see Derg

Coelho, Gonçalo Caldeira 77, 112

Collectif Europe-Afrique 190

Colonialism 20, 25, 30, 42, 47, 50, 65, 68, $72-73,78,83,87,93,102-103,105$, 109, 119-120, 133, 140, 143-144, 146, 19o, 245, 309-310, 316, see also decolonisation

Communism 195, 282, 286, 289

Compagnie commerciale et agricole S.A. 63

Companhia de Boror $\quad 62-63,232-233$, 235-236

Companhia de Culturas de Angoche (CCA) 62-63, 233

Companhia Mineira do Lobito $\quad 63-64$

Comptoir suisse $113,124,133-143,318-319$

Confederation of Ethiopian Labour Unions 153

Conference on International Economic Cooperation (CIEC) $\quad 245,278$

Conference on Security and Co-operation in Europe (CSCE) 22, 70-71, 149, 213, 308

Congo Crisis $\quad 29,42$

Congo 41-42, 53, 62, 85n, see also Zaire

Congress of Vienna in $1815 \quad 5$

Conrad Zschokke 62

Council of States (Switzerland) 189, 244, 264, 276, 279, 288, 296

Cruz e Silva, Teresa 128 
Cuba $\quad 16-18,26,43,69,148,183,211,244$, 247-250, 252, 255-256, 26o-261, 272, 275-276, 28o-281, 283, 286-287, 294-295, 298-299, 3०3-306, 317

Cuendet, Jean 294, 296

Cunha, Alexandre Ribeiro da 77

Daddah, Moktar Ould $\quad$ 1, 88-89

Davis, Nathaniel 264

De Chambrier Aviation SA 270

De Gaulle, Charles 69

Decolonisation $\quad 3-4,7,14-16,19,24-25$, 29-3o, 33, 42, 50-51, 66, 70, 72-73, 78-79, 82, 94, 144, 146, 148, 150, 187, 189-19o, 192-193, 196-198, 200-201, 204, 212-213, 215, 232, 234, 236, 242, 247-248, 298, 312-313, 317, 319, see also national liberation

Defence Technology Division (DTD) 114

Demaurex, Jean 59, 181-182

Democratic People's Republic of Angola (DPRA) 256-257

Denmark 9-10, 32, 69, 93, 111, 137, 144, 209-210, 220, 229, 259, 269

Département missionnaire des églises protestantes de Suisse romande (DM) 24, 126-134, 139, 205, 210-211, 227,319

Derg 153, 16o-18o, 182-185, 241, 284-285, $287,290-292,295$

Détente $3-4,10-11,15,21-22,24,70-71,149$, 197, 244-245, 26o, 275-276, 296-297, 301, 306, 308, 316

development cooperation, see aid (foreign)

Diez, Emanuel 171-172

Directorate for International Organisations

(DIO) 23, 31, 34, 73-75, 79-83, 90-92, 94, 97, 100-104, 106-107, 146, 191-192, 199, 202, 215, 226, 253, 277

Directorate of Political Affairs (DPA) 23, $45,74-75,82,85,87-89,93-94,112,122$, 131-133, 136-137, 140, 144, 146, 155, 157, $159,166,169,172-173,175,179-182$, 190191, 2O2, 204-207, 209-211, 214-217, 223, 225, 233, 249-250, 257-258, 262-265, 267-268, 270-271, 274, 277-278, 290, 304, 306

Directorate of Public International Law (DPIL) 171, 277
Directorate General of Security (DGS), see PIDE

Disaster Relief Corps (Switzerland) 159

Division of Police (Switzerland) $\quad 47-50$

Djibouti $\quad 34-35,285$

Dos Santos, Marcelino $\quad$ 208-209, 211, 224, 226

Dow Banking Corporation 66

Duke of Harar Memorial Hospital 38-40,

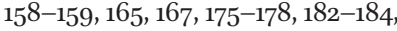
315

Eanes, António Ramalho 196

Eastern bloc $\quad 6,14-16,25,30,68,70,159$, $182,191,197,202,210,219-220,229$, 236-237, 256, 261, 287

Egal, Mohammad $\quad 151$

Egypt 35, 44-45, 149, 151, 154-156, 235, 286

Eritrea $\quad 36-37,152,173,176,178,182,285,292$ Erklärung von Bern (EvB) 111, 134, 136

Escher Wyss 120

Estado Novo regime, see Portugal

Ethiopia $3-4,12,15,17-18,24-25,27,33-38$, 40, 51-53, 55-59, 66, 84-85, 91-92, 100-101, 103, 107, 148, 151-155, 158-185, 188, 191, 197, 219, 223, 226-227, 232-233, 237, 241-242, 244-246, 252, 267, 284-294, 307, 309, 311, 315, 318

Ethiopian Herald $\quad 165$

Ethiopian Revolution $\quad 17-19,25,39,57-59$, $148,15^{2-154}, 156,15^{8-164}, 176,183,201$, 235, 309, 317

European Economic Community (EEC) 11, 26, 6o, 79, 146, 162, 179-18o, 194, 200, 202, 210, 242, 26o, 263-264, 272, 282, 316-317

European Free Trade Association (EFTA) 4O, 42, 6o, 65, 79, 118, 140, 144, 146, 193-195

European Integration 11, 71, see also EEC

Exchaquet, Olivier $\quad 161,174,185,200-201$, 223,228

Exercise Alcora 72

export risk guarantees (ERG) 31, 62, 65, 122-123, 192n, 231-232, 238, 271

famine $152,157,159,165^{-166,173,184, ~ 203,}$ 291

Farquet, Christophe $\quad 164,167,174$ 
Federal Council 13-14, 31, 34, 38-39, 79, 9०, 98-100, 114-118, 121-124, 133-135, 137-140, 144, 156, 162-163, 172, 188, 190, 192, 199-200, 202-203, 208, 253, 257, 259, 265, 282-283, 289

Federal Department of Economic Affairs (FDEA) 23, 65, 86, 123, 181, 194, 239, 279, 282, 302

Federal Department of Finance (FDF) 23, $38,61,174$

Federal Department of Justice and Police (FDJP) 47-48, 170, 266

Federal Military Department (FMD) 23, 114, 118, 298

Federal Police $\quad 46,49-50,112,206$ Federal Republic of Germany (FRG) 13, $38,42,69-70,73,80,111,119,124,146$, 187, 193-194, 210, 216, 223, 248-249, 285-286

Fédération horlogère suisse $(\mathrm{FH}) \quad 135$

Fincha Dam 59

Finland 2, 5, 8, 32, 79, 142, 144, 200, 214, 229

First National City Bank 64

Fischer, Thomas 22, 213

Food and Agriculture Organization (FAO) 205, 226, 228

Ford administration $\quad 26,161,197,201$, 209-210, 242, 250, 26o-262, 269, 275, 28o-281, 285, 311, 316

Ford, Gerald 149, 211

France $13,23-24,29-30,34,41-42,47$, 69, 73, 76-77, 8०, 93-94, 101, 106, 119, 124-125, 16o, 162, 187, 193-195, 210, 216, 223, 248, 259-26o, 263-264, 269, 274-275, 285-286, 294, 296, 301, 303

Franco, Francisco 44

Freiburghaus, Hans 268

French Somaliland, see Djibouti

Frente de Libertação de Moçambique

(FRELIMO) 45, 47, 87, 99, 105, 107, 119, 125-129, 131-132, 137-138, 143, 148, 154, 190-191, 197, 201-203, 205, 208-211, 218-224, 226-234, 236-242, 251, 269, 275, 311-312, 315

Frente Nacional para a Libertação de Angola (FNLA) 41, 48, 205-208, 211, 247-248, 251-253, 255-258, 26o-261, 263, 266, $269,274,281$
Frente para a Libertação do Enclave de Cabinda (FLEC) 266

Frey, Hans Karl 83

Front de Libération Nationale (Algeria, FLN) 30, 47, 174

Front de libération nationale congolaise (FLNC) $\quad 269$

Furgler, Kurt $\quad 266-267$

$\mathrm{G}_{7} \quad 15 \mathrm{O}$

G77 70, 277

Gadimpovi, Pedro 75

Gailloz, René 49-50, 206-207

Garthoff, Raymond $\quad 244$

Gaye, Karim 77

Gebru Tareke 18

Gelzer, Michael 93, 131, 202-203, 214

Geneva Conventions 95-96, 98-102, 104-105, 252, 290, 292

Genoud, Guy $\quad 276$

German Democratic Republic (GDR) 18, 198n, 203, 248

Germany 5, 70, 198, see also Federal Republic of Germany, German Democratic Republic

Ghana 29, 45, 53

Good Offices 6, 29-30, 73, 75, 77, 145, 210, 251, 289, 312, see also availability

Mediation $\quad 5^{-6}, 18,75,252,307,312-313$

Protecting power mandates $43-44,47$, $76-77,252$

Goodwill Fund 132

Governo Revolucionário de Angola no Exílio (GRAE) 75

Graber, Pierre $\quad 89-90,94,130,136,138-139$, $172,177-178,189,211-214,217,222$, 248, 251, 258-259, 262, 264-265, 268, 276, 281, 287-288, 294-296, 308, 318-319

Greece 193,198

Groupe de travail Afrique australe et Portugal 112n

Guélat, Marcel 208

Guex, Sébastien 11

Guinea $\quad 118$

Guinea-Bissau 40, 43, 55n, 72, 76-77, 87, 104, 110, 118, 133, 186-187, 19o, 197-200, 205, 225 
Hague Conventions of 1907 4, 96, 113

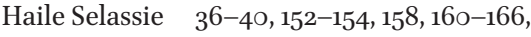
$168-171,173-176,184-185,285,315$

Hakovirta, Harto 5

Hamid, Mohammed $\quad$ 171, 173

Hastings, Adrian $\quad$ 135-136

Hefti, Peter $\quad 276$

Hilfswerk der Evangelischen Kirchen Schweiz

$$
\text { (HEKS) 47, } 49
$$

Hocké, Jean-Pierre 104

Hofer, Erwin $\quad$ 297-298

Hofer, Walther 212

Hohl, Alfred 204

Honegger, Fritz 302

Huguenin, Claude $\quad 257,267$

Human Rights League, Swiss $\quad 136$

humanitarian aid, see aid (foreign)

Humbaraci, Arsalan 263

Humbert, Jean 101-103, 105

IAFEATURE 247,275

Iceland 229

Igreja Presbiteriana de Moçambique (IPM) 126-131, 134, 143, 201, 220-221, 227

Ilg, Alfred $\quad 35$

Immigration Police (Switzerland) 48, 267

Imperialism 20, 103, 105, 295

independence wars in the Portuguese

colonies $2,12,15^{-16}, 24-25,40-50$,

55, 6o-66, 68, 72-78, 87, 89, 91, 95, 107,

$110,115,118,126,133,149,186-187,191$,

199, 209, 218-220, 224, 231, 237-238,

247, 254, 268, 275, 3०6, 3०9-313, 316, 318

India 74

Industrie- und Handelsbank Zürich $\quad$ 168, 175

Instituto de Crédito de Moçambique (ICM) 64

Instituto dos Cereais de Moçambique 64

International Commission of Jurists 129

International Committee of the Red Cross

(ICRC) 13-14, 24, 26, 78, 95-106,

$116-117,162,199,213,246,25^{2-257, ~ 261, ~}$

266, 273, 288, 290-293, 307, 310, 312, see

also Red Cross

International Development Association

(IDA) 12, 195

International Energy Agency (IEA) $\quad 216$ international humanitarian law (IHL) 95, 97-99, 102-103, 105-106, 213, 316

International Labour Organization (ILO) 102

investment risk guarantee (IRG) $\quad$ 181-182

Iran $\quad 286$

Iraq 286

Ireland $5,8,18,101,144$

Irish Republican Army (IRA) 101

Iselin, Jürg Andreas $\quad 217,223,264-265,278$, 282, 290, 306

Israel 114, 149, 217

Italian Somaliland, see Somalia

Italy $34-36,111,119,123,162,179,203,210$, $269,275 n$

Ivory Coast $\quad 103,300$

Jaccaud, Paul Etienne $\quad$ 211, 221-223

Japan 2, 8o, 85, 179, 216, 275n

Jerónimo, Miguel Bandeira 61

Jolles, Paul Rudolf $\quad 140$

Jost, Hans Ulrich 7

Kagnew base 37

Kämpfendes Afrika, see Medic'Angola

Katanga, see Shaba

Katzenstein, Peter 9-10

Kaufmann, Hansjakob $\quad$ 157, 250, 258, 262

Kaunda, Kenneth 85

Keller, René 103

Kennedy administration $\quad 41-42$

Kennedy, John F. 42

Kenya $1,35,80,83,88,157,188,225,261$, 285

КG В (Committee for State Security, USSR) $15 \mathrm{in}$

Kissinger, Henry $\quad$ 70, 193, 197, 258, 265, 280

Komitee Südliches Afrika (KSA) 110, 136

Korea 8, 198, see also North Korea

Korean War 286

Kuhn, Konrad 122

La vie protestante 134

Lajes airbase 69

Langenbacher, Heinz $\quad 37,39,84-85,88-91$, 103, 158-161, 163, 165-169, 171-176, 178-179, 191-192, 197

Lavoro Bank AG 63 
League of Nations $\quad 35^{-36}$

Lesotho 81, 225

liberalism 1, 10, 88

liberation struggle, see independence wars

Liberia $\quad 41,79$

Libya 235

Lindt, August 83

Lopes, Rui 12

Luciri, Pierre $\quad 216$

Lusaka Agreement 201

Lusaka Manifesto $\quad 83-84$

Machel, Samora $\quad$ 45, 209-211, 220, 237-239

Madagascar 225

Malawi 81, 123

Mali $\quad 1,88$

Manganhela, Zedequias $\quad$ 128-130, 132-133

Markees, Curt Alfred 170

Marshall Plan 31

Martins, Ismael Gaspar $\quad$ 271-272

Mauritania $\quad 1,88$

Medic'Angola 24, 110-111, 259

Menelik 35

Mengistu Haile Mariam $\quad$ 27, 173, 284-285

mercenaries 203, 260, 269

Micheli, Pierre $\quad 42-43,46$

Mission philafricaine $\quad 46,133,273$

Mitchell, Nancy 18

Mobutu Sese Seko 207, 269, 274

Mogadishu Declaration 84

Mondlane, Eduardo $\quad 45-47,126,128$

Mondlane, Janet $128 \mathrm{n}$

Monteiro, José Oscar $\quad$ 99, 107

Morier-Genoud, Eric $\quad 126$

Morocco 286

Mossaz, Lucien A. $\quad$ 156-157, 191

Motor Columbus 272

Mouvement de soutien aux peuples de l'Angola et des autres colonies portugaises 112n

Movimento das Forças Armadas (Portugal, MFA) 186, 189-19o, 192-195

Movimento Popular de Libertação de Angola (MPLA) 16-17, 26, 41, 48-50, 87, 94, 110-111, 125, 148, 154, 157, 197, 205-207, 211, 222-223, 236, 244, 246-248, 250-251, 255-263, 265-270, 272-276, $281,292,306$

Mozambican National Resistance

(MNR) 218-219, 229
Mozambique 2-4, 12, 15-19, 24-25, 33, 40, $43,45^{-47}, 5^{\circ}-53,55^{-66}, 72,74,78,8$, $83,85,93-94,105,107,110-111,113,116$, 118-120, 122, 124-133, 136-137, 139, 142$143,145^{-146,148,150,154, ~ 156, ~ 186-19 o, ~}$ 192-193, 196-198, 200-205, 208-214, 216-242, 249, 251, 264, 267, 269-270, 278, 294, 309, 311-312, 315, 317-319

Mozambique Revolution 105

Muheim, Franz 202, 215

Mulcahy, Edward William 161, 200-201, 249

Müller, Charles 140

Müller, Maurice $\quad 38-39$

Mumenthaler, Hans 49

Muret, Marc-Antoine $\quad$ 134, 139

Mussolini, Benito 36

Mystère 270

N'Delé, José $\quad 206$

N'Delé, Theresia $\quad$ 250-251

Namibia $\quad 2,15,72,80,85,215,255,275,282$

Nasser, Gamal Abdel $\quad 44$

National Bank of Ethiopia 170, 174

National Council (Switzerland) 121, 209, 212, $214-215,251$

national liberation 2, 9, 18, 68-69, 87, 91, 95, 99, 144-146, 184, 188, 219, 224-225, 314-315, see also decolonisation

nationalisation $4,25,148,155,160,176$, $178-183,185,201,208,221,227,232-236$, 27 O, 287,311

Natural, Albert $\quad 75,83$

Nestlé $\quad 51,62,83,272$, 301-302

Netherlands $\quad 5,9,69,93,136,144,179,193$, 199, 203, 210, 215, 222n, 255, 259, 269, 293, 316

Neto, Agostinho 189n, 248, 270

Neutrality $4-5,7$, see also universality, solidarity, availability, good offices

Austrian 8

Non-interference $1,9,73,88,136,144$, $215,277,279,287,296,308,313$

Swiss $1-2,4-10,21-22,25-26,30-31$, 44, 47, 68-69, 71, 73-75, 82, 85-90, 94, $96,107,113,118,138,145,15$ O 187,191 , 197, 205, 207-209, 212-216, 218-220, 224, 228, 241-242, 248, 254, 266, 268, 276-277, 279, 289-292, 296, 299, 302, $305,307-315,317,319$

Swedish $\quad 5,8-10,87-88,209-210,314$ 
New International Economic Order

(NIEO) 1O, 15O, 213, 245, 315

Nigeria $\quad 53-54,116-117,254,300-302,341$

Nixon administration $\quad 70,73,76,245$, 316-317

Nixon, Richard $\quad$ 70, 149, 197

Nkrumah, Kwame 45

Non-Aligned Movement (NAM) 70, 214, 216-217, 278-279

Algiers summit of $1973 \quad$ 149, 214

Colombo summit of $1976 \quad 278-279$

Non-alignment 30, 214

North American Rockwell 270

North Atlantic Treaty Organization (NATO) 2, 10, 16, 69, 84-86, 98-99, 106-107, 110, 114-115, 146, 193, 213, 282, 286, 316

North Korea 71, 198n-199

North Vietnam $\quad 71,149,198 \mathrm{n}-199$

North-South conflict $3,7,10,66,187,242$, 3०9, 311, 314

North-South dialogue $\quad$ 149, 245, 278, 299, 307

Norway 9, 32, 69, 93, 99-100, 106-107, 144, 193, 210, 220, 229, 259, 316

Novartis 24, 234, see also Ciba-Geigy

Nyerere, Julius $\quad 45,156$

October War of $1973 \quad$ 149, 212

Oerlikon Bührle $\quad 36,116-117,168$

Office of the Attorney General of Switzerland 48, 203

Office of the Permanent Observer of Switzerland to the United Nations $\quad 68,79$

Ogaden War, 14, 17-18, 24, 26, 183, 185, 244-246, 284-297, 299-300, 304-307, 3०9-313, 317

Oil Shock of $1973 \quad 10,149,213$

Omega 168

Organisation for Economic Co-operation and Development (OECD) 10, 32, 216

Organization of African Unity (OAU) $\quad 1-2$, 11-12, 30, 37, 43, 68, 78, 83-94, 100-104, $107,119,154,163,167,169,172,197-198$, 204, 213, 245, 247, 251-252, 258-26o, 262-264, 266, 277, 279, 284, 286, 289-29o, 294-295, 304, 3०6, 3०8, 310, $312,314-315$

Council of Ministers 84n, 92, 99, 100-101, 120-121, 188, 216, 274
Executive Secretariat of the OAU in Europe $\quad 92-93,315$

Liberation Committee 30,89

Good Offices Committee 284, 300

Organization of the Petroleum Exporting Countries (OPEC) 149, 188, 315

Ostpolitik 69

Pahud, Jean-Louis $\quad$ 130-131, 137, 189

Palestine Liberation Organization (PLO) 104

Parodi, André $\quad$ 154-156

Partido Africano da Independência da Guiné e Cabo Verde (PAIGC) 43, 76, 87, 104, 125, 186, 197-200, 205

Partido Comunista Português (PCP) 193-195 Partido Socialista (Portugal, Ps) 193, 195-196 Paul vi (Pope) 125

People's Republic of Angola (PRA), see Angola People's Republic of China (PRC) 15-16, 68, $7 \mathrm{O}, 111,161,242,247-248,25^{1}$

Pereira, Nuno 141

Pestalozzi, Richard $\quad$ 148, 157-158, 188, 191-192, 202, 241, 290

Petitpierre, Max 30, 48

Piachaud, Claude-Louis $\quad 226,238$

Pictet, François $\quad$ 100, 103-104

PIDE (International and State Defence Police, Portugal) 41, 112, 125, 128-129, 190

Pilatus Porter aircraft 249

Pilloud, Claude $\quad 98$

Pinto, António Costa $\quad 61$

Political Secretariat (Switzerland) 23, 85-86, 277-278, 283, 288, 294, 297, 313

Portugal $4,12,15^{-16}, 23^{-24}, 30,33,40-51$, 55,6 o-66, 69, 71-81, 83-84, 86-88, 9०, 93-94, 99, 101, 104-105, 109-110, 112-116, 118-120, 123-149, 16o, 186-19o, 192-205, 208, 210, 218, 220, 222, 224-225, 228, 23०, 247, 251, 254, 256, 261, 267-269, 271, 309-310, 316, 318-319

Portuguese Revolution, see Carnation Revolution

Potter, Philip A. 127

Probst, Raymond 45, 28o

Programme to Combat Racism $\quad$ 126-127

Progressive Organisationen der Schweiz (POCH) 258

Protestant Church of Geneva 139 
Provisional Military Administrative Council (PMAC), see Derg

Provisional Revolutionary Government of South Vietnam (PRG) 102

Red Cross 89, 165, 252, 255, see also International Committee of the Red Cross

Angolan Red Cross $\quad 256$

Ethiopian Red Cross 291-292

International Red Cross Conference in Istanbul, $1969 \quad 97-98$

Portuguese Red Cross $\quad 256$

Somali Red Crescent 290

Swiss Red Cross (SRC) 157

refugees $47,82,89-92,226,290,292$

Angolan refugees in Switzerland 19, 46-5o, 112, 206, 266, 271-272, 310

Republic of China $\quad 41$

Reserve Bank of Rhodesia 79

Resistência Nacional Moçambicana (RENAMO) 218, 229, 240

Rhodesia $1-2,15,21,24,50-51,53-55,66$, $72-73,79-81,83-85,87,110,114,116,123$, 144, 167, 187-188, 191-192, 203, 209, 213, 215-216, 218-219, 225-228, 235, 239, 242, 275, 278-28o, 282-283, 295, 299, $305,309,315,318$

Richard, Jean $\quad 76-77$

Rist, Gilbert 188

Roberto, Holden $\quad 41,48,211,247,274$

Rothnie, Alan K. 308

Roux, Jacques 124-125

Rüegg, Alfred 304

Rumania 248

Rwanda 74, 225

Sadat, Anwar $\quad 151$

Safari Club $\quad 286$

Sahlfeld-Singer, Hanna 209

Salazar, António de Oliveira $\quad 72,78$

sanctions- $21,36,54-55,73,79,83-87,154$, 188, 242, 299, 309, 315

São Tomé e Príncipe $\quad 40,72,187$

Sarasin, Alfred E. $\quad 64,169-170$

Saudi Arabia $\quad 285^{-286}$

Saurer $230-232$

Savimbi, Jonas $\quad 48,206-207,251,266$

Schärer, Hans $\quad 165,168$

Schaufele, William E. $\quad 262,28$ o
Schnyder, Felix $\quad 145^{-146}$

Schwarb, H. 236

Schwarzenbach, James 265

Schweizerische Arbeitsgruppen für

Entwicklungspolitik(SAFEP) 111-112

Schweizerische Evangelische Kirchenbund

(SEK) 121-122

Schweizerische Industriegesellschaft

Neuhausen (SIG) 36, 115

Schweizerische Metallwerke Selve \& Co 115

Sellström, Tor 9

Senegal $43-44,47,76-77,300-301,310$

Senghor, Léopold Sédar $\quad 76-77$

Service for Technical Cooperation (sTC, Switzerland) $23,31-32,37-39,74-75$, $81-82,155,177,182-183,205,225-226$, 228-229, 238-240, 272, 277, 291

Shaba 269, 274, 294, 296, 301

Shermarke, Ali $\quad 151$

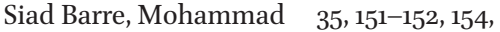
$156-157,185,284-286,288$

small states $\quad 4,9-12,224,299,305,316$

Smith, Ian $54,226,276,280,282$

Socialism 4, 148, 152, 156, 297

Sociedade Technica de Equipamentos Industriais \& Agricolas Lda $64 \mathrm{n}$

Société Générale pour l'Industrie (SGI) 270

Solidarity (principle of) 6, 30-31, 46, 74, 311-312, see also aid (foreign).

Somali Youth League (SYL) 34

Somali-Abo Liberation Front (SALF) 284

Somalia $3-4,12,15,17-18,24-25,33-35$, $37,40,51^{-53}, 55^{-}-57,59,66,11^{-158}$, 161, 183-185, 219, 244-245, 284-29o, 292-294, 307, 309, 311, 318

SONEFE $\quad 62,64 \mathrm{n}, 66$

South Africa $1-2,11-12,15-16,21,24-26$, 3 o, $33,43,46,50-51,53-54,62,66,68$, 71-74, 79-84, 86-87, 89-91, 110, 114, 116-117, 119, 121, 126-127, 132, 144-146, 167, 187-189, 192, 198, 203-204, 209, 211, 215, 217-219, 223-224, 235, 239, 242, $244-245,248,25$ o, 255-256, 26o-261, 266, 269, 274-275, 277, 280, 282-283, 287, 299-302, 247-305, 307, 309-310, $315-316,318$

South Vietnam 149, 249

South West Africa People's Organisation (sWAPO) 255, 275

Soviet Union, see UssR 
Soweto 275

Spain 44, 193, 198

Spínola, António de 186

Spühler, Willy $\quad 82,117,308$

Stöckli, Bruno $\quad$ 208, 220-224

Strategic Arms Limitation Talks (SALT) 70

SüdafrikaMission 209

Sudan 235

Sulzer $57,62,120,230-232,301-302$

Sweden 2, 5, 8-11, 25-26, 32, 71, 87-88, 93, 107, 117, 119-120, 122, 136-137, 144-145, 162, 193, 197, 199-200, 207, 209, 214$215,220,224,228-229,242,259,263$, 265, 267, 269, 272, 275n, 293, 314, 316

Swiss Bankers Association (SBA) 23, 64, 165, 169-170

Swiss Federal Archives (SFA) 23, 164

Swiss Federation of Commerce and Industry, see Vorort

Swiss Mission $\quad$ 19, 46-47, 74, 113, 125-133

Swiss National Bank (SNB) 23, 63, 79, 82, 195-196

Swiss National Science Foundation (SNF) $21 \mathrm{n}$

Swiss Re 59, 179-180

Swiss-South African Association (sSAA) 54, 301-302

Syria 149

Tana Plantation Co. $\quad$ 59, 181

Tanda, Albert 206

Tanzania $\quad 45,81,83,118,154,156,190-191,201$, 2o8-211, 222-223, 225, 288-289

TAP (Portugal) 271

Teferi Bante $\quad 178$

Tehran International Conference on Human Rights $\quad 83,96-97$

Telli, Boubacar Diallo $\quad 85-87$

Tewodros 35

Thalmann, Ernesto $\quad 73,80,97,138-139$

Third World $\quad 2-3,7-10,13-16,20-26,29-32$, $46,54,68-74,78-79,81,83,86,94-95$, 97, 103, 106-107, 109-111, 113-114, 116, 119-122, 124, 127-128, 141, 143-146, 149-150, 156-157, 164-165, 169-170, $175,187-188,191,195,200,202,212-215$, 217-219, 231, 239, 241-242, 244-245, 248-249, 256, 262, 278-279, 285, 293, 296, 304-305, 307-309, 311, 313-315, $317-319$
Times 135

Trade Division (Switzerland) 23, 31, 59, 62, $80-81,122,138,140,146,192,194,217$. 267-268, 271, 298, 302, 318

Truman, Harry S. $\quad 31$

Turrettini, Bernard $\quad 68,79,82,85$

UBS 232

Uganda 262

União dos Povos de Angola (UPA) 41, 48

União Nacional para a Independência Total de Angola (UNITA) 48, 110, 205-207, 211, 247-251, 255-257, 259-261, 266-267, 269, 272-273

Union of Socialist Soviet Republics

(USSR) $\quad 3-4,6,15^{-17}, 26,35,38$, 40-41, 49, 68-70, 87, 106, 110, 145, 148-149, 151-155, 157, 159, 161, 176, 183, 185, 187, 189, 199, 201, 204-205, 207, 212, 219, 242, 244-251, 256, 26o, 262-263, 272, 275-276, 28o-281, 284-289, 291, 294-299, 301, 303-307, 309, 311, 316-317

United Kingdom (UK) 13, 21, 23-24, 29, 34, $3^{6-38,41-42,46,54,61,69,72-73,77}$, 79-8o, 93, 95, 98-99, 101-102, 106-108, $111,119,123,136,142,146,16 \circ, 162,166$, 169, 171, 179, 187, 193, 198, 209-210, 216, 221, 234, 248, 259-26o, 269, 279-28o, 282, 285, 295, 303-304, 308

United Nations (UN) 8, 12, 21-22, 29, 31, 34, $42,54,68,71,73,78-85,92-93,96-97$, $100,107,115,119,145,149,152,162,188$, 20O, 212, 215, 217, 242, 252, 275n, 279, 308-309, 312, 315

Children's Fund (UNICEF) 205, 272

Conference on Trade and Development (UNCTAD) 70, 279

Development Programme (UNDP) 31, 155,291

General Assembly (UNGA) 2, 34, 36, 65, $68,78-83,90,97-98,102,114,136,15$ O, 162, 171, 198, 217, 221

High Commissioner for Refugees (UNHCR) 82, 91-92, 272

Security Council 41, 79, 88, 114, 200, 275 Training Programme for South Africans 81

Trust Fund for South Africa $\quad 81,89-90$ Unit on Apartheid 188 
United States (US) $\quad 3,6,11,13,23-24,26,33$, 37-38, 41-43, 69-70, 76-77, 8०, 95, 98, 101-106, 109, 119, 130, 132, 142, 145-146, 149-153, 158-159, 161-163, 166, 169, 171, 175, 179-180, 183, 185, 187, 189, 194, 197-198, 200-201, 208-210, 216, 219221, 244-247, 249-252, 255, 257-258, 261-263, 265-266, 268, 270, 275-276, 279-281, 285-286, 289-29o, 294-297, 301, 303-304, 306-307, 316-317

Universality (principle of) $6,157,198,257$, 289, 311

\section{Verein Schweizer Freunde Angolas}

(VSFA) 48-49

Vieira, Sergio $\quad 238$

Vietnam War 9, 109, 245-246, 296, 317

Vietnam 8, 10-11, 98, 149, 198, 246, 276, see also North Vietnam, South Vietnam

Vincent, Jean 199

Vonnez, Marcel 129

Vorort 23, 194

Vorster, Balthasar Johannes $\quad 280$

Walker, Peter C. 209

Warner, Marvin Leon 297

Warsaw Pact 70, 286

Watergate scandal $\quad 11,149,197,317$

Weber, Jean-Pierre $\quad$ 207, 281-282

Weitnauer, Albert $\quad 265,276-278,281$

West Germany, see Federal Republic of Germany
Westad, Odd Arne $\quad$ 14, 286

Western bloc 2, 4, 9, 14, 30, 68, 95, 157-158, 166, 185, 193, 279, 288, 3०6, 3०9, 316-317

Western Sahara 294

Western Somali Liberation Front (WSLF) 284, 290-291

White Fathers 127

Wiriyamu Massacre 135-136, 143

World Council of Churches (WCC) 49, 69, 119, 126-127

World Energy Conference (WEC) 150

World Health Organization (wHO) 38, 253

World University Service 49

Xelor Invest AG 64

Yugoslavia $\quad 38,248,267$

Zaire 118, 204, 207, 211, 247-248, 251, 257, 26o, 265-267, 269, 274, 281, 294, 301

Zambezi River 119

Zambia $\quad 1,81,88,116,118,275,278$

Zamco 120, 123

Ziegler, Jean $\quad 121-123,135,138-140,172,174$, 251

Zimbabwe African National Union (ZANU) 226, 275

Zimbabwe African People's Union (ZAPU) 275

Zimbabwe, see Rhodesia

Zwahlen, Jean 170 